UNIVERSIDADE DE SÃO PAULO

FACULDADE DE FILOSOFIA, LETRAS E CIÊNCIAS HUMANAS

DEPARTAMENTO DE GEOGRAFIA

PROGRAMA DE PÓS-GRADUAÇÃO EM GEOGRAFIA HUMANA

\title{
SHINHITI OSANAI
}

REDES SOCIAIS E COMÉRCIO: identificação das centralidades em consequiência da mobilidade e acessibilidade determinadas pelo sistema de transporte urbano de massa para os moradores de baixa renda do Distrito de Pedreira no Município de São Paulo

São Paulo

2009 


\title{
UNIVERSIDADE DE SÃO PAULO \\ FACULDADE DE FILOSOFIA, LETRAS E CIÊNCIAS HUMANAS \\ DEPARTAMENTO DE GEOGRAFIA \\ PROGRAMA DE PÓS-GRADUAÇÃO EM GEOGRAFIA HUMANA
}

\begin{abstract}
REDES SOCIAIS E COMÉRCIO: identificação das centralidades em consequiência da mobilidade e acessibilidade determinadas pelo sistema de transporte urbano de massa para os moradores de baixa renda do Distrito de Pedreira no Município de São Paulo
\end{abstract}

\section{Shinhiti Osanai}

Tese apresentada ao Programa de

Pós-Graduação em Geografia Humana

do Departamento de Geografia da

Faculdade de Filosofia, Letras e Ciências

Humanas da Universidade de São Paulo, para a

obtenção do título de Doutor em Ciências

Orientadora: Profa. Dra. Claudette Barriguela Junqueira

São Paulo 
AUTORIZO A REPRODUÇÃO E DIVULGAÇÃO TOTAL OU PARCIAL DESTE TRABALHO, POR QUALQUER MEIO CONVENCIONAL OU ELETRÔNICO, PARA FINS DE ESTUDO E PESQUISA, DESDE QUE CITADA A FONTE.

Serviço de Biblioteca e Documentação da Faculdade de Filosofia, Letras e Ciências Humanas da

Universidade de São Paulo

Osanai, Shinhiti

Redes sociais e comércio: identificação das centralidades formadas em conseqüência da mobilidade e acessibilidade determinadas pelo sistema de transporte urbano de massa para os moradores de baixa renda do Distrito de Pedreira no Município de São Paulo / Shinhiti Osanai; orientadora Claudette Barriguela Junqueira. -- São Paulo, 2009.

$467 \mathrm{f}$.

Tese (Doutorado - Programa de Pós-Graduação em Geografia Humana Departamento de Geografia) - Faculdade de Filosofia, Letras e Ciências Humanas da Universidade de São Paulo.

1. Transporte urbano - Pedreira (SP) - Aspectos socioeconômicos. 2. Geografia de mercado. 3. Geografia urbana. 4. Centros comerciais - Hierarquia. 5. Análise espacial. 6. Redes sociais. 7. Sistema de Informação Geográfica. I. Título. II. Junqueira, Claudette Barriguela. 


\section{DEDICATÓRIA}

A Dalila Garcia Osanai, minha esposa e Guilherme Garcia Osanai, meu filho, com gratidão e muito carinho pela paciência, compreensão e apoio ao longo do período de elaboração deste trabalho. 


\title{
AGRADECIMENTO
}

\begin{abstract}
À Professora Doutora Claudette Barriguela Junqueira que aceitou o desafio de levar a um aluno, que não possui formação em Geografia, por meio da sua atenção e dedicação, os conhecimentos sobre o espaço e que muito me ensinou contribuindo para o meu crescimento científico e profissional ao proporcionar uma nova visão espacial sobre o mercado e o comércio.
\end{abstract}




\section{Epígrafe}

"Não é pelo facto de um indivíduo estar mais próximo de um núcleo comercial que o frequentará. Pode preferir um outro mais afastado, mas que lhe "convenha" mais - e neste termo podem entrar situações complexas: preço, hábitos, percepções mais favoráveis, agrupamentos de certas actividades... O consumidor não é um autómato económico e, se as grandes leis de atracção proporcional relativa existem, devem ser controladas e, eventualmente, corrigidas, em função do comportamento social e psicológico da clientela".

Jacqueline Beaujeu-Garnier 


\section{RESUMO}

\section{OSANAI, S. Redes sociais e comércio: identificação das centralidades formadas em conseqüência da mobilidade e acessibilidade determinadas pelo sistema de transporte urbano de massa para os moradores de baixa renda do Distrito de Pedreira no}

Município de São Paulo. 2009. 452 f. Tese (Doutorado) - Faculdade de Filosofia, Letras e Ciências Humanas, Universidade de São Paulo, São Paulo, 2009.

O tema central deste trabalho tem como o escopo a identificação das centralidades formadas em conseqüência da mobilidade e acessibilidade determinadas pelo sistema de transporte urbano de massa para os moradores de baixa renda do Distrito de Pedreira no município de São Paulo. A autonomia de cada município na gerência do seu próprio sistema de transporte coletivo urbano condiciona muitos moradores, para as compras, a se dirigirem a locais mais distantes de suas residências, por exemplo, o Largo 13 de Maio em Santo Amaro, apesar da disponibilidade de um comércio bem estruturado nas proximidades, no município vizinho de Diadema. Para alguns moradores, a distância para Santo Amaro é de $18 \mathrm{~km}$ enquanto Diadema se localiza a menos de $2 \mathrm{~km}$. A escolha do centro habitual para as compras, em algumas situações, pode ser irracional em termos de distância e tempo. Alguns modelos racionais de localização do comércio, como o de Christaller, não se verificam no Distrito de Pedreira em conseqüência das características do sistema de transporte de massa. A estrutura da rede social dos moradores do Distrito de Pedreira possibilitou a determinação dos níveis hierárquicos de cada um dos centros de comércio objetos deste estudo. Com base em uma amostra de 135 moradores as medidas de centralidade grau, posicionamento e proximidade forneceram os parâmetros necessários para a identificação dos centros de níveis hierárquicos mais elevados os quais foram o Largo 13 de Maio, Shopping Center Interlagos e Diadema. Os resultados de equivalência estrutural possibilitaram a identificação das principais áreas de influência e a maioria delas se localiza fora dos limites geográficos do Distrito. Os produtos de baixa frequiência de demanda são os determinantes para o estabelecimento dos níveis hierárquicos mais elevados. Existe uma forte relação entre os padrões de distribuição do comércio e os níveis hierárquicos dos centros. A análise espacial, realizada com a ajuda dos recursos do sistema de informações geográficas, foi utilizada para o estudo desses padrões. Após o georeferenciamento dos pontos de comércio objetos deste trabalho, os resultados das estatísticas globais Moran's I e Getis Ord G indicaram a existência de formação de grupos ou "clusters", bem como, da dependência espacial em relação ao padrão de distribuição do comércio. O uso das estatísticas locais Moran's I e Getis Ord Gi* permitiram a identificação dos principais centros que mais contribuem para a caracterização dos padrões de agrupamento do comércio e também indicaram as grandes semelhanças existentes entre todos os centros secundários analisados. Dentro do perímetro de um raio de $3 \mathrm{~km}$ a partir do centro médio dos moradores, notamos que existe somente o comércio de vizinhança, que atende apenas as compras de frequiência baixa ou diária, obrigando os moradores a deslocarem alguma distância significativa, para efetuarem as compras de produtos de demanda de baixa freqüência, como exemplo, no Largo 13 de Maio. 


\begin{abstract}
OSANAI, S. Social network and commerce: centralities as consequence of poor people mobility and accessibility in reason São Paulo city Pedreira district urban transport system. 2009. 452 f. Thesis (Doctoral) - Faculdade de Filosofia, Letras e Ciências Humanas, Universidade de São Paulo, São Paulo, 2009.
\end{abstract}

The main purpose of this study is the analysis of centralities regarding the mobility and the accessibility as a consequence of urban transport system in Pedreira's district, São Paulo, therefore the focus of attention is on peripheral poor residents. Each city is autonomous, to manage its urban transport system, then bus users residents go shopping in far trade center area, as Largo 13 de Maio in Santo Amaro's district, instead of purchasing in a well structured commercial center in the neighborhood as Diadema's city. The distance from Pedreira to Santo Amaro is $18 \mathrm{~km}$, for many residents, on the contrary the distance to Diadema is up to 2 $\mathrm{km}$. Sometimes the normal trade centers used by the consumers are irrational in terms of time and distance. Some rational trade center localization model, as Christaller's central place theory, does not work in Pedreira's district because of this distinct urban transport system between São Paulo and Diadema. Pedreira's district social network, built with a sample of 135 residents, has been used to obtain the hierarchical level of each target trade areas. The centrality positions as degree, betweeness and proximity permitted the identification of hierarchical levels, the most important are Largo 13 de Maio, Shopping Center Interlagos and Diadema. The areas of influence have been defined by social network equivalence's results and the localization of most of them is outside Pedreira's district boundaries. The low frequency demand goods are fundamental to determine the higher hierarchical levels. Strong relationship between the trade area cluster patterns and their correspondence hierarchical levels has been obtained. The spatial analysis has been developed using geographical information system techniques. After geocoding the target trade points, general Moran's I and Getis Ord $\mathrm{G}$ indexes indicate the commercial activities cluster patterns spatial dependence evidence. Local Moran's I and Getis Ord Gi* statistics have shown the most important trade areas, that are more significant to explain their cluster patterns, it also indicated that all of the secondary trade areas are similar. In a $3 \mathrm{~km}$ perimeter from the residents' mean center point, the business structure attends mainly high or daily demand frequency. Therefore residents travel significant distance, as to Largo 13 de Maio, to purchase their durable goods. 


\section{Lista de mapas}

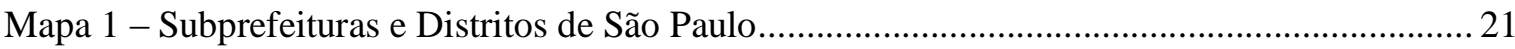

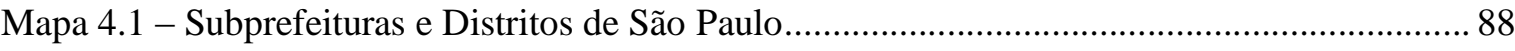

Mapa 4.2 - Localização do Distrito de Pedreira na Grande São Paulo ...........................................89

Mapa 4.3 - Principais bairros do Distrito de Pedreira.................................................................... 91

Mapa 4.4 - Principais acessos ao Distrito de Pedreira...................................................................... 92

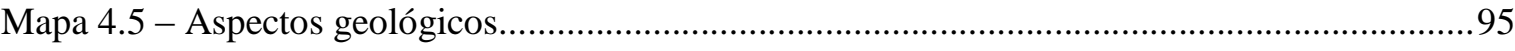

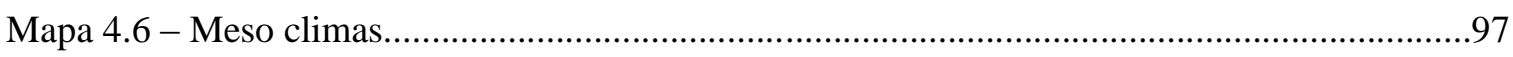

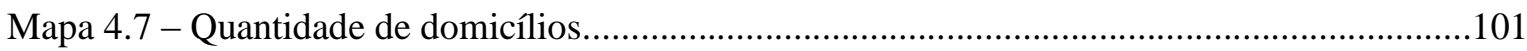

Mapa 4.8 - Quantidade de habitantes por domicílio........................................................................102

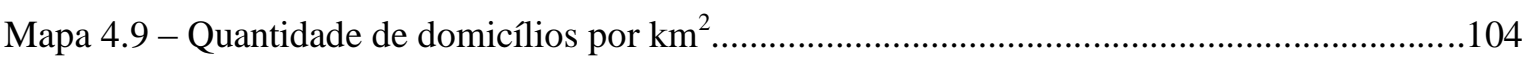

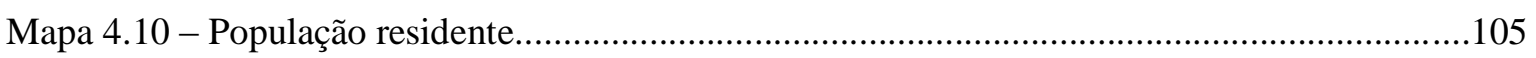

Mapa 4.11 - Densidade demográfica - habitantes por $\mathrm{km}^{2}$........................................................107

Mapa 4.12 - Renda per capita do ou da chefe de família em reais...................................................108

Mapa 4.13 - Tempo médio de estudo do ou da chefe de família em anos.......................................110

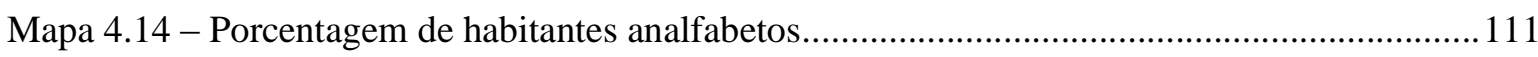

Mapa 4.15 - Ocupação do solo período de 1950 a 2002 .................................................................. 113

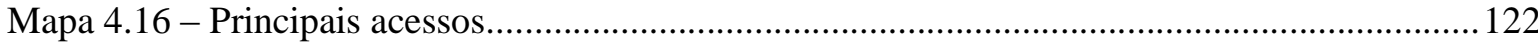

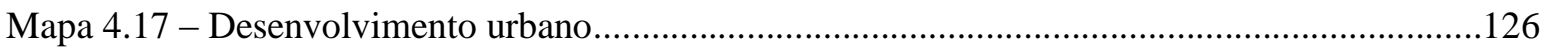

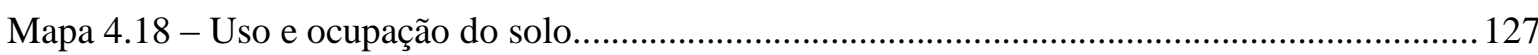

Mapa 4.19 - Transporte urbano - sistema radioconcêntrico...........................................................138

Mapa 4.20 - Principais cotas sobre o nível do mar em metros.................................................... 146

Mapa 5.1 - Rede social do comércio - centros principais............................................................. 152

Mapa 5.2 - Rede social do comércio - centros principais............................................................ 154

Mapa 5.3 - Rede social do comércio - centros secundários.............................................................157

Mapa 5.4 - Rede social do comércio - equivalência estrutural - grupo 1 ........................................160

Mapa 5.5 - Rede social do comércio - equivalência estrutural - grupo 2...................................... 161

Mapa 5.6 - Rede social do comércio - equivalência estrutural - grupo 3 ........................................162

Mapa 5.7 - Rede social do comércio - equivalência estrutural grupo 4............................................ 164

Mapa 5.8 - Rede social do comércio - equivalência estrutural - grupo 5......................................165

Mapa 5.9 - Rede social do comércio - equivalência estrutural - grupo 6 ………...........................167

Mapa 5.10 - Rede social do comércio - equivalência estrutural - grupo 7 ......................................168

Mapa 5.11 - Rede social do comércio - equivalência CONCOR - grupo 1 ..................................... 170

Mapa 5.12 - Rede social do comércio - equivalência CONCOR - grupo 2 2................................... 172

Mapa 5.13 - Rede social do comércio - equivalência CONCOR - grupo 3 …….......................... 173

Mapa 5.14 - Rede social do comércio - equivalência CONCOR - grupo 4 ................................... 175

Mapa 5.15 - Rede social do comércio - equivalência automórfica - grupo 1..................................177 
Mapa 5.16 - Rede social do comércio - equivalência automórfica - grupo 2 parte A......................178

Mapa 5.17 - Rede social do comércio - equivalência automórfica - grupo 2 parte B..................... 180

Mapa 5.18 - Rede social do comércio - equivalência automórfica - grupo 3..................................181

Mapa 5.19 - Rede social do comércio - equivalência automórfica - grupo 4 parte A.....................184

Mapa 5.20 - Rede social do comércio - equivalência automórfica - grupo 4 parte B..................... 185

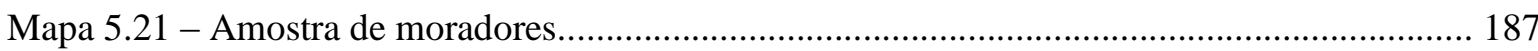

Mapa 5.22 - Participação nas compras - Largo 13 de Maio............................................................ 195

Mapa 5.23 - Participação nas compras - Diadema...........................................................................197

Mapa 5.24 - Participação nas compras - Shopping Center Interlagos............................................ 199

Mapa 5.25 - Centralidades - medida de grau - valores globais.................................................... 202

Mapa 5.26 - Centralidades - medida de grau - bens de demanda baixa.......................................... 203

Mapa 5.27 - Participação nas compras - Estrada do Alvarenga........................................................207

Mapa 5.28 - Participação nas compras - Parque Santa Amélia.......................................................... 209

Mapa 5.29 - Participação nas compras - Supermercado Pedreira....................................................210

Mapa 5.30 - Participação nas compras - Jardim Rubilene...........................................................214

Mapa 5.31 - Participação nas compras - Av. Yervant Kissajikian................................................. 217

Mapa 5.32 - Centralidades - medida de proximidade - valores médios globais.............................. 224

Mapa 5.33-Centralidades - medida de proximidade - bens de demanda baixa............................ 225

Mapa 5.34 - Centralidades - medida de posicionamento - valores globais.................................... 236

Mapa 5.35 - Centralidades - medida de posicionamento - bens de demanda baixa....................... 237

Mapa 5.36 - Equivalência estrutural - distância euclidiana - regiões de influência......................... 252

Mapa 5.37 - Equivalência estrutural - CONCOR - regiões homogêneas........................................ 265

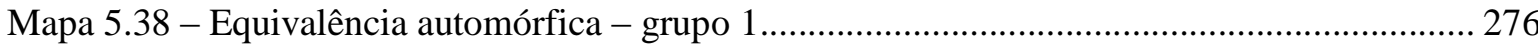

Mapa 5.39 - Equivalência automórfica - grupo 2 2.................................................................. 278

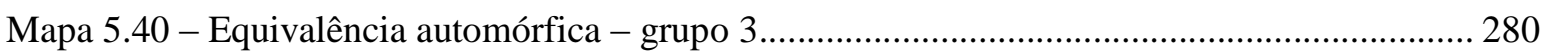

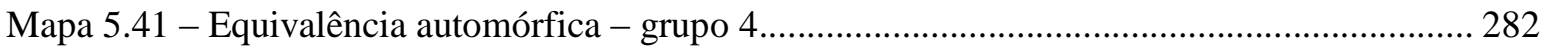

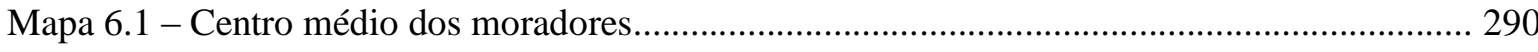

Mapa 6.2 - Localização de centros principais e secundários...................................................... 292

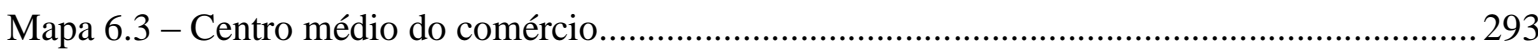

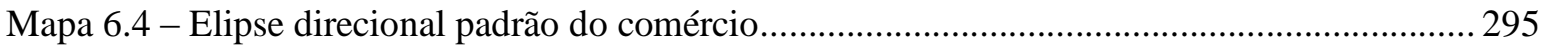

Mapa 6.5 - Padrão de concentração do comércio - estatística local Moran's I............................... 301

Mapa 6.6 - Padrão de concentração do comércio - estatística local Moran’s I................................ 302

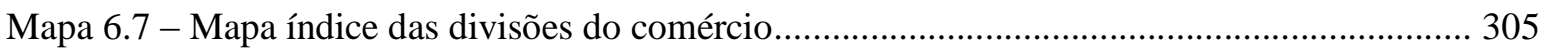

Mapa 6.8.1 - Estatística local Moran's I - Largo 13 de Maio.......................................................... 315

Mapa 6.8.2 - Estatística local Getis Ord Gi* - Largo 13 de Maio....................................................... 316

Mapa 6.9.1 - Estatística local Moran's I - Diadema..................................................................... 321

Mapa 6.9.2 - Estatística local Getis Ord Gi* - Diadema................................................................ 322

Mapa 6.10.1 - Estatística local Moran’s I - Shopping Center Interlagos.........................................327 
Mapa 6.10.2 - Estatística local Getis Ord Gi* - Shopping Center Interlagos............................... 328

Mapa 6.11.1 - Estatística local Moran's I - Shopping Center SPMarket......................... 336

Mapa 6.11.2 - Estatística local Getis Ord Gi* - Shopping Center SPMarket..................... 337

Mapa 6.12.1 - Estatística local Moran's I - Estrada do Alvarenga....................................................339

Mapa 6.12.2 - Estatística local Getis Ord Gi* - Estrada do Alvarenga........................................... 340

Mapa 6.13.1 - Estatística local Moran's I - Jardim Rubilene........................................................... 344

Mapa 6.13.2 - Estatística local Getis Ord Gi* - Jardim Rubilene ......................................................345

Mapa 6.14.1 - Estatística local Moran’s I - Parque Santa Amélia......................................................352

Mapa 6.14.2 - Estatística local Getis Ord Gi* - Parque Santa Amélia............................................353

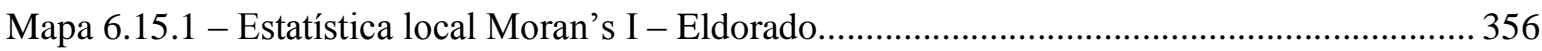

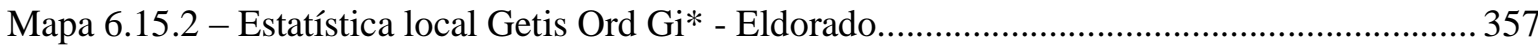

Mapa 6.16.1 - Estatística local Moran's I - Av. Yervant Kissajikian................................................ 361

Mapa 6.16.2 - Estatística local Getis Ord Gi* - Av. Yervant Kissajikian ........................................362

Mapa 6.17.1 - Estatística local Moran’s I - Jardim Miriam......................................................... 367

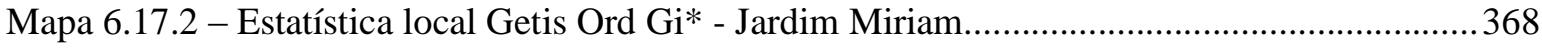

Mapa 6.18.1 - Estatística local Moran's I - Av. Nossa Senhora do Sabará.................................... 372

Mapa 6.18.2 - Estatística local Getis Ord Gi* - Av. Nossa Senhora do Sabará............................. 373

\section{Lista de figuras}

Figura 1.1 - Exemplo de uma rede social com 3 centros e 8 famílias.............................................38

Figura 1.2 - Exemplo de rede para o cálculo da distância geodésica.................................................. 45

Figura 1.3 - Exemplo de uma rede social com 3 centros e 8 famílias ............................................49

Figura 1.4 - Exemplo de uma rede social em forma de uma estrela............................................... 49

Figura 1.5 - Exemplo de uma rede social em forma de um círculo...................................................50

Figura 1.6 - Exemplo de uma rede social em linha reta................................................................. 50

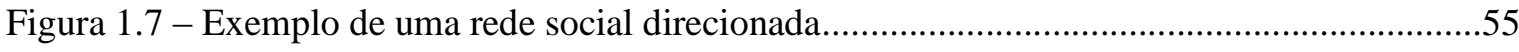

Figura 2.1- Representação gráfica dos critérios de agrupamento, dispersão e randômico................67

Figura 4.1 - Representação das declividades conforme o perfil AB do mapa 4.20.........................147

Figura 4.2 - Representação das declividades conforme o perfil CD do mapa 4.20..........................147

Figura 4.3 - Representação das declividades conforme o perfil EF do mapa 4.20.......................... 148

Figura 5.1 - Rede de moradores sob influência do Largo 13 de Maio............................................ 194

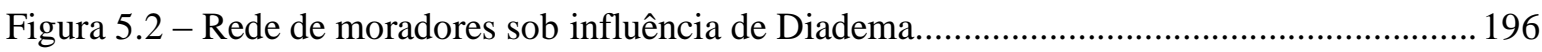

Figura 5.3 - Rede de moradores sob influência do Shopping Center Interlagos............................... 198

Figura 5.4 - Rede de moradores sob influência do comércio da Estrada do Alvarenga....................208

Figura 5.5 - Rede de moradores sob influência do Parque Santa Amélia........................................ 211

Figura 5.6 - Rede de moradores que preferem o Supermercado Pedreira......................................2212

Figura 5.7 - Rede de moradores sob influência do Jardim Rubilene............................................. 215 
Figura 5.8 - Rede de moradores conforme a equivalência estrutural - grupo 1 ...............................253

Figura 5.9 - Rede de moradores conforme a equivalência estrutural - grupo 2...............................25

Figura 5.10 - Rede de moradores conforme a equivalência estrutural - grupo 3............................256

Figura 5.11 - Rede de moradores conforme a equivalência estrutural - grupo 4.............................257

Figura 5.12 - Rede de moradores conforme a equivalência estrutural - grupo 5............................259

Figura 5.13 - Rede de moradores conforme a equivalência estrutural - grupo 6............................. 260

Figura 5.14 - Rede de moradores conforme a equivalência estrutural - grupo 7 f............................ 261

Figura 5.16 - Rede de moradores conforme a equivalência CONCOR - grupo 1 1.............................266

Figura 5.17 - Rede de moradores conforme a equivalência CONCOR - grupo 2......................... 267

Figura 5.18 - Rede de moradores conforme a equivalência CONCOR - grupo 3 3...........................268

Figura 5.19 - Rede de moradores conforme a equivalência CONCOR - grupo 4........................... 269

Figura 5.21 - Rede de moradores conforme a equivalência automórfica - grupo 1 1...................... 277

Figura 5.22 - Rede de moradores conforme a equivalência automórfica - grupo 2....................... 279

Figura 5.23 - Rede de moradores conforme a equivalência automórfica - grupo 3........................ 281

Figura 5.24 - Rede de moradores conforme a equivalência automórfica - grupo 4........................ 283

Figura 6.1.1 - Estatística local Moran's I - Largo 13 de Maio..........................................................310

Figura 6.1.2 - Estatística local Getis Ord Gi* - Largo 13 de Maio.....................................................312

Figura 6.2.1 - Estatística local Moran’s I - Diadema................................................................... 314

Figura 6.2.2 - Estatística local Getis Ord Gi* - Diadema................................................................ 319

Figura 6.3.1 - Estatística local Moran's I - Shopping Center Interlagos........................................ 320

Figura 6.3.2 - Estatística local Getis Ord Gi* - Shopping Center Interlagos..................................... 325

Figura 6.4.1 - Estatística local Moran's I - Shopping Center SPMarket...........................................329

Figura 6.4.2 - Estatística local Getis Ord Gi* - Shopping Center SPMarket...................................... 331

Figura 6.5.1 - Estatística local Moran's I - Estrada do Alvarenga....................................................... 332

Figura 6.5.2 - Estatística local Getis Ord Gi* - Estrada do Alvarenga.............................................334

Figura 6.6.1 - Estatística local Moran's I - Jardim Rubilene ...........................................................338

Figura 6.6.2 - Estatística local Getis Ord Gi* - Jardim Rubilene .....................................................343

Figura 6.7.1 - Estatística local Moran's I - Parque Santa Amélia .......................................................346

Figura 6.7.2 - Estatística local Getis Ord Gi* - Parque Santa Amélia...............................................348

Figura 6.8.1 - Estatística local Moran's I - Eldorado.......................................................................... 349

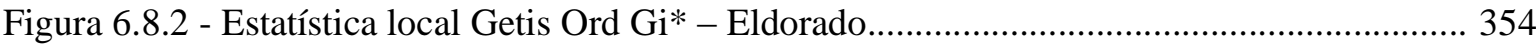

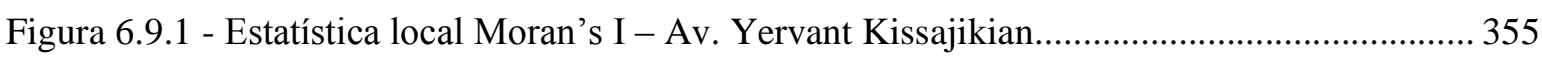

Figura 6.9.2 - Estatística local Getis Ord Gi* - Av. Yervant Kissajikian..................................... 359

Figura 6.10.1 - Estatística local Moran’s I - Jardim Miriam.......................................................... 363

Figura 6.10.2 - Estatística local Getis Ord Gi* - Jardim Miriam................................................... 365

Figura 6.11.1 - Estatística local Moran’s I - Av. Nossa Senhora do Sabará...................................... 366

Figura 6.11.2 - Estatística local Getis Ord Gi* - Av. Nossa Senhora do Sabará.............................370 


\section{Lista de fotos}

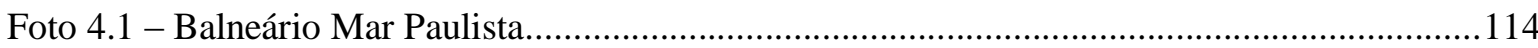

Foto 4.2 - Área de declividade acentuada - Av. Alda.................................................................. 116

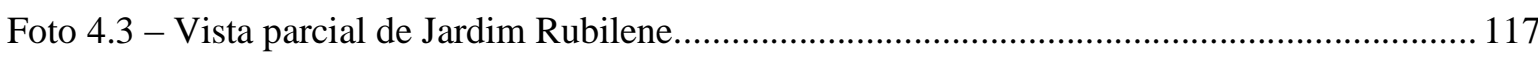

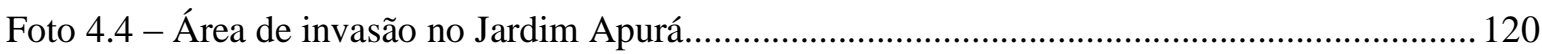

Foto 4.5 - Um dos acessos para a favela Itatinga - R. Guaicuri...................................................... 141

Foto 4.6 - Área de declividade acentuada - R. 20 - Eldorado......................................................... 144

\section{Lista de dendogramas e matriz}

Dendograma 5.15 - Dendograma dos moradores - equivalência estrural ....................................262

Dendograma 5.20 - Árvore dos moradores - equivalência estrutural - CONCOR.........................271

Dendograma 5.25 - Dendograma dos moradores - equivalência automórfica............................... 286

Matriz 1.1 - Representação matricial da rede social da figura 1.1 .................................................. 39

\section{Lista de Tabelas}

Tabela 2.1 - Parâmetros do índice médio da vizinhança mais próxima............................................ 69

Tabela 5.1 - Centralidades medida de grau - resultado global......................................................200

Tabela 5.2 - Centralidades medida de grau - produtos de demanda baixa.................................... 201

Tabela 5.3 - Centralidades medida de grau - produtos de demanda mediana................................... 205

Tabela 5.4 - Centralidades medida de grau - outros produtos de demanda baixa............................ 205

Tabela 5.5 - Centralidades medida de grau - Estrada do Alvarenga, Parque Santa Amélia e Jardim

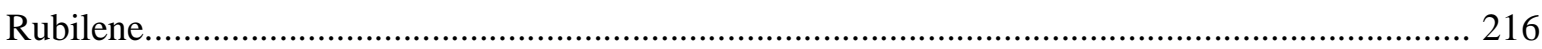

Tabela 5.6 - Centralidades medida de grau - Av. Yervant Kissajikian e Av. N. S. do Sabará....... 218

Tabela 5.7 - Centralidades medida de grau - Centro Histórico, Brás e Bom Retiro........................ 219

Tabela 5.8 - Centralidades medida de proximidade - valores globais médios............................... 222

Tabela 5.9 - Centralidades medida de proximidade - produtos de demanda baixa...........................223

Tabela 5.10 - Centralidades medida de proximidade - produtos de demanda mediana...................226

Tabela 5.11 - Centralidades medida de proximidade - outros produtos de demanda baixa............227

Tabela 5.12 - Centralidades medida de proximidade - Estrada do Alvarenga, Parque Santa Amélia e Jardim Rubilene.

Tabela 5.13 - Centralidades medida de proximidade - Av. Yervant Kissajikian e Av. N. S. do Sabará

Tabela 5.14 - Centralidades medida de proximidade - Centro Histórico, Brás, Bom Retiro........... 231

Tabela 5.15 - Centralidades medida de posicionamento - valores globais.....................................233

Tabela 5.16 - Centralidades medida de posicionamento - produtos de demanda baixa................. 234 
Tabela 5.17 - Centralidades medida de posicionamento - produtos de demanda mediana............ 235

Tabela 5.18 - Centralidades medida de posicionamento - outros produtos de demanda baixa.......238

Tabela 5.19 - Centralidades medida de posicionamento - Estrada do Alvarenga, Parque Santa Amélia e Jardim Rubilene

Tabela 5.20 - Centralidades medida de posicionamento - Av. Yervant Kissajikian e Av. N. S. do

Sabará.

Tabela 5.21 - Centralidades medida de posicionamento - Centro Histórico, Brás e Bom Retiro... 242

Tabela 5.22 - Centralidades medidas de grau, proximidade e posicionamento - bens duráveis.....244

Tabela 5.23 - Centralidades medidas de grau, proximidade e posicionamento - alimentícios........246

Tabela 5.24 - Centralidades medidas de grau, proximidade e posicionamento - outros produtos.. 247

Tabela 5.25 - Centralidades medidas de grau, proximidade e posicionamento - resumo geral...... 248

Tabela 5.26 - Quantidade de estabelecimentos em torno das residências......................................... 274

Tabela 5.27 - Equivalência automórfica - formação de grupos..................................................... 275

Tabela 6.1.1 - Resultados da estatística local Moran's I - Largo 13 de Maio...................................309

Tabela 6.1.2 - Resultados da estatística local Getis Ord Gi* - Largo 13 de Maio........................... 312

Tabela 6.2.1 - Resultados da estatística local Moran's I - Diadema................................................ 314

Tabela 6.2.2 - Resultados da estatística local Getis Ord Gi* - Diadema..........................................318

Tabela 6.3.1 - Resultados da estatística local Moran’s I - Shopping Center Interlagos................... 320

Tabela 6.3.2 - Resultados da estatística local Getis Ord Gi* - Shopping Center Interlagos.......... 324

Tabela 6.4.1 - Resultados da estatística local Moran's I - Shopping Center SPMarket................. 326

Tabela 6.4.2 - Resultados da estatística local Getis Ord Gi* - Shopping Center SPMarket........... 330

Tabela 6.5.1 - Resultados da estatística local Moran's I - Estrada do Alvarenga............................ 332

Tabela 6.5.2 - Resultados da estatística local Getis Ord Gi* - Estrada do Alvarenga...................... 334

Tabela 6.6.1 - Resultados da estatística local Moran’s I - Jardim Rubilene..................................... 338

Tabela 6.6.2 - Resultados da estatística local Getis Ord Gi* - Jardim Rubilene............................. 342

Tabela 6.7.1 - Resultados da estatística local Moran's I - Parque Santa Amélia............................ 346

Tabela 6.7.2 - Resultados da estatística local Getis Ord Gi* - Parque Santa Amélia......................348

Tabela 6.8.1 - Resultados da estatística local Moran's I - Eldorado................................................349

Tabela 6.8.2 - Resultados da estatística local Getis Ord Gi* - Eldorado...................................... 354

Tabela 6.9.1 - Resultados da estatística local Moran's I - Av. Yervant Kissajikian........................355

Tabela 6.9.2 - Resultados da estatística local Getis Ord Gi* - Av. Yervant Kissajikian.................359

Tabela 6.10.1 - Resultados da estatística local Moran's I - Jardim Miriam..................................... 363

Tabela 6.10.2 - Resultados da estatística local Getis Ord Gi* - Jardim Miriam........................... 365

Tabela 6.11.1 - Resultados da estatística local Moran’s I - Av. Nossa Senhora do Sabará.......... 366

Tabela 6.11.2 - Resultados da estatística local Getis Ord Gi* - Av. Nossa Senhora do Sabará....370 


\section{Lista de apêndices e anexos}

Apêndice A - Resultados dos cálculos da medida de grau.....................................................................390

Apêndice B - Resultados dos cálculos da medida de proximidade .......................................................401

Apêndice C - Resultados dos cálculos da medida de posicionamento..................................................412

Apêndice D - Resultados das estatísticas locais Moran's I e Getis Ord Gi*.......................................423

Apêndice E - Códigos da atividade do comércio..............................................................................439

Apêndice F - Resultado do modelo de regressão entre linha de ônibus e quantidade de

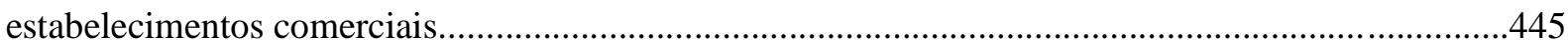

Apêndice G - Quantidade de estabelecimentos comerciais e linhas de ônibus.....................................44

Apêndice H - Síntese da distribuição dos ramos de comércio por região................................................449

Apêndice I - Síntese dos resultados da rede social e da estatística espacial..........................................452

Apêndice J - Cálculos da distância das estatísticas globais....................................................................454

Apêndice $\mathrm{K}$-Formulário de aplicação dos inquéritos com os moradores............................................458

Apêndice L -Formulário do levantamento dos dados de comércio........................................................462

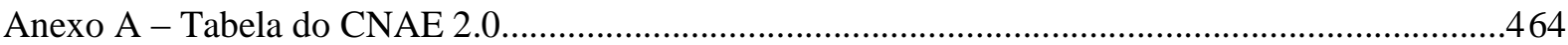




\section{Sumário}

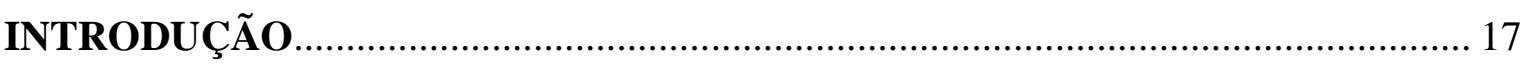

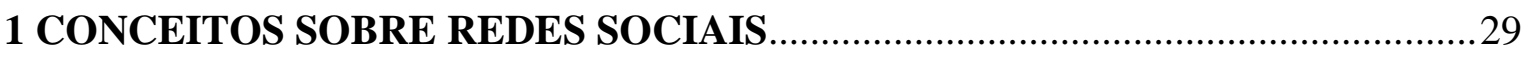

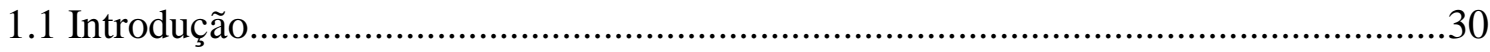

1.2 Alguns conceitos básicos sobre redes sociais (na ótica dos norte-americanos)......... 37

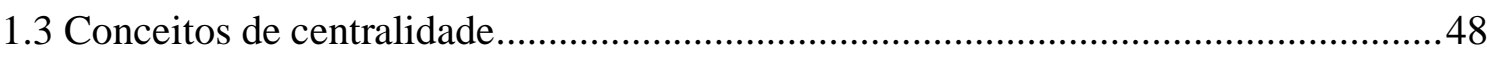

1.4 Medidas de centralidade para grafos não direcionados............................................51

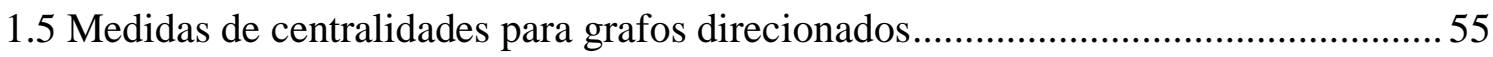

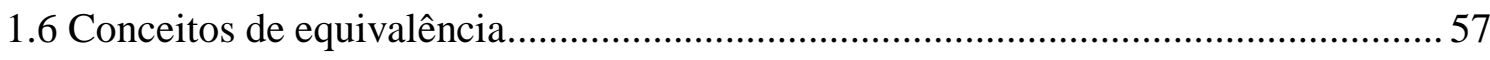

2 CONCEITOS SOBRE ANÁLISE E ESTATÍSTICA ESPACIAL ............................ 61

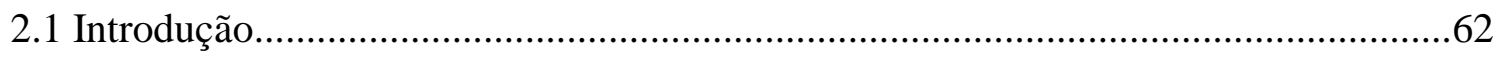

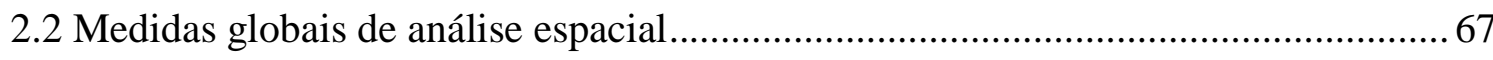

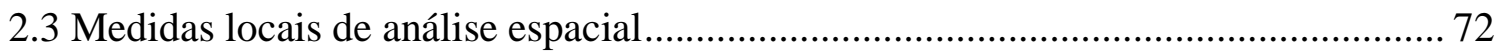

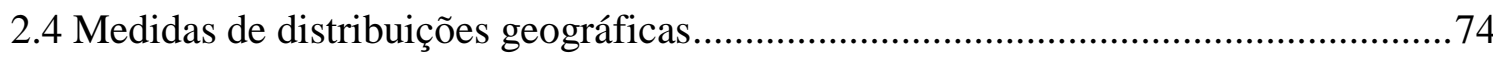

3 CONCEITOS SOBRE REDE URBANA, CENTRALIDADE E MOBILIDADE....76

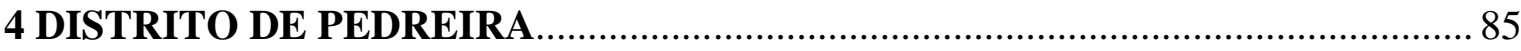

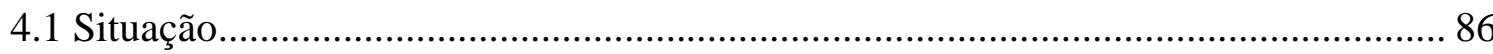

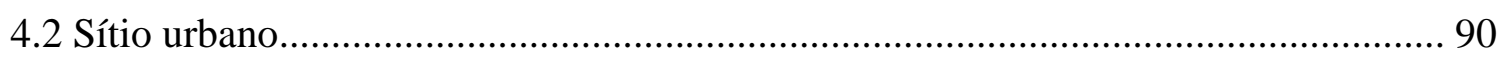

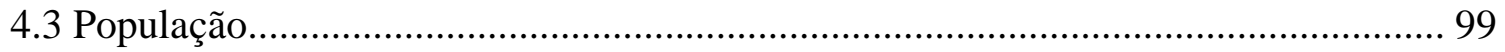

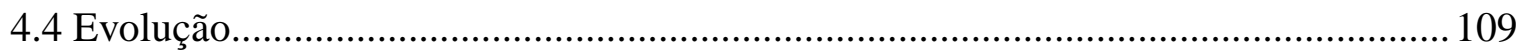

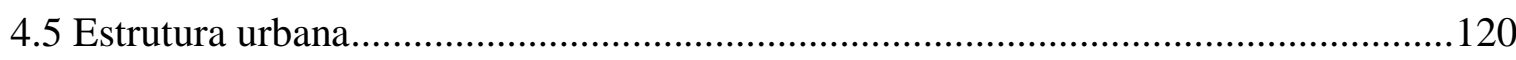

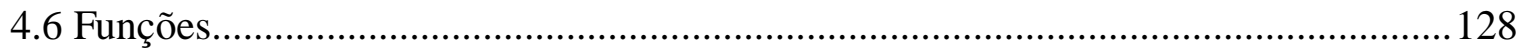

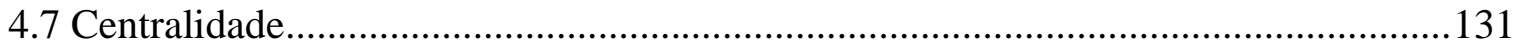

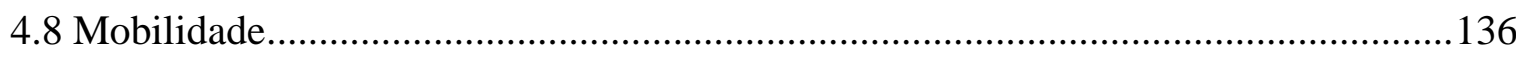

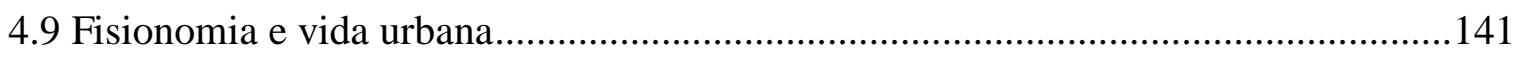

5 A REDE SOCIAL DO COMÉRCIO E DOS MORADORES DO DISTRITO DE PEDREIRA NO PROCESSO DE SATISFAÇÃO DAS SUAS NECESSIDADES DE

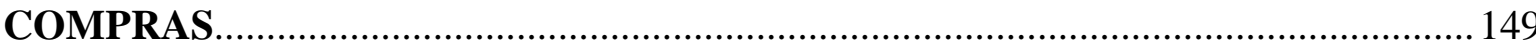

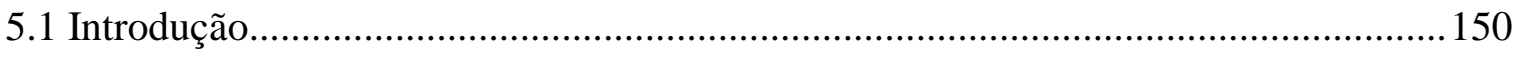

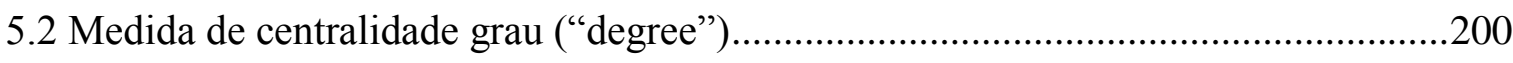

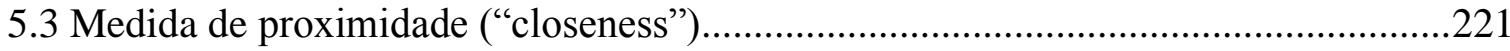

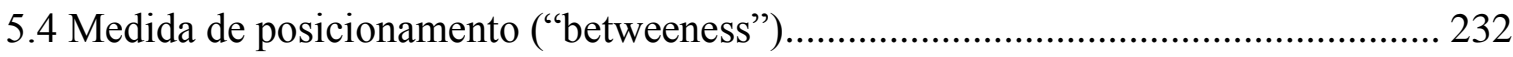


5.5 Equivalência estrutural e automórfica.

5.6 Equivalência estrutural - método de distância euclidiana 250

5.7 Equivalência estrutural - método CONCOR (CONvergence of interated CORrelations) 263

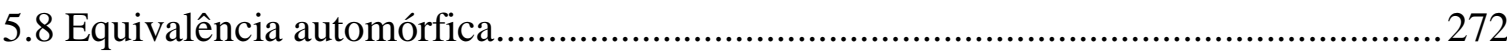

6 TÉCNICAS DE ANÁLISE ESPACIAL DOS CENTROS COMERCIAIS..............287

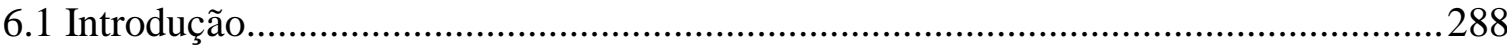

6.2 Região do Largo 13 de Maio, em Santo Amaro................................................................ 309

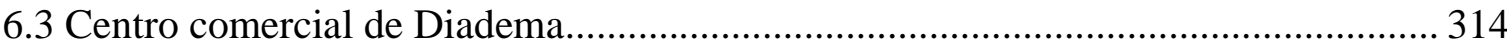

6.4 Shopping Center Interlagos e Shopping Center Interlar..........................................320

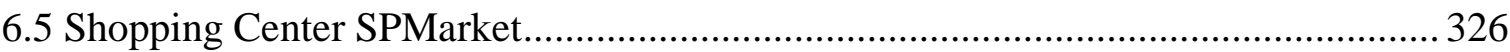

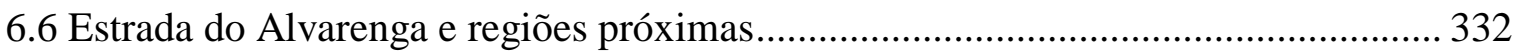

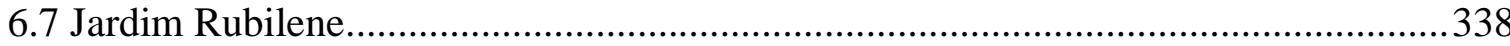

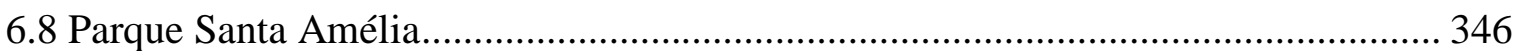

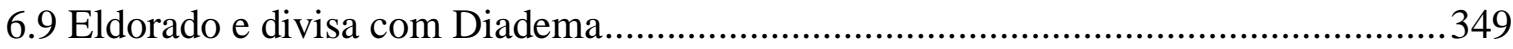

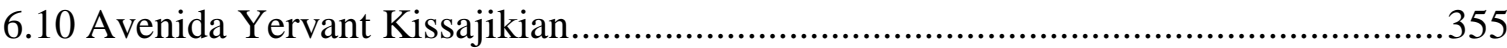

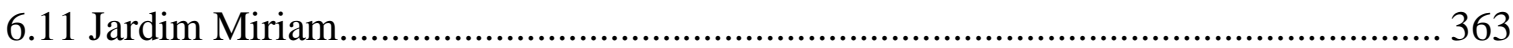

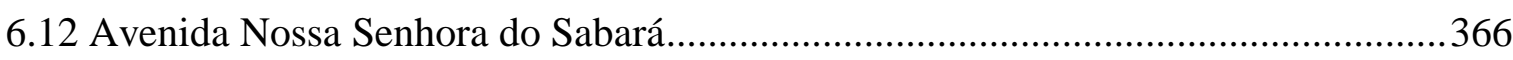

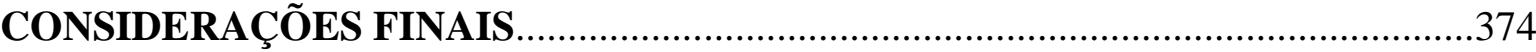




\section{INTRODUÇÃO}


O objetivo deste trabalho é estudar a estrutura do comércio em função das condições de mobilidade e acessibilidade dos moradores do Distrito de Pedreira. Sendo a satisfação das necessidades de compras fruto de relação entre os moradores e o comércio, a análise morfológica da rede de relacionamentos do comércio, através da aplicação de técnicas de redes sociais, proporciona resultados sustentáveis na identificação de centros principais e secundários com os seus respectivos níveis hierárquicos e indicadores de acessibilidade e de dependência.

Em um modelo de rede social pode-se dispensar dados sobre a distância que separa o morador do comércio, bem como, os custos de transporte. O levantamento de campo sobre os locais habituais de compras dos moradores e o sistema de transporte urbano são suficientes. O estudo morfológico da rede social obtida foi desenvolvido com a ajuda e aplicação da teoria dos grafos.

O tema central tem como escopo a identificação de uma das causas que torna um local distante das residências o centro comercial mais importante e de nível hierárquico elevado, apesar da existência de centros mais próximos, em conseqüência da mobilidade e acessibilidade determinadas pelo sistema de transporte urbano de massa em relação aos moradores de baixa renda do Distrito de Pedreira, Município de São Paulo.

No Distrito de Pedreira considera-se que a maioria dos moradores seja de baixa renda. No ano de 2000 a renda média do ou da chefe de domicílio era $\mathrm{R} \$ 766,03$, classificado em $285^{\circ}$ lugar dentre o total de 454 unidades de desenvolvimento humano do Município de São Paulo. Em primeiro lugar encontra-se Cidade Jardim com o valor de $\mathrm{R} \$ 7098,43$. No Distrito de Pedreira, o quinto mais rico, em 2000, está com a renda per capita média de $\mathrm{R} \$ 1067,63$, em $253^{\circ}$ lugar, e o quinto mais pobre mantém a renda per capita média de $\mathrm{R} \$ 42,03$, em $350^{\circ}$ lugar. Estão classificados em primeiro lugar Cidade Jardim, que apresenta o quinto mais rico com a renda per capita média no valor de $\mathrm{R} \$ 10979,36$, e Moema cujo quinto mais pobre se encontra com a renda per capita média de $\mathrm{R} \$ 643,83$.

A rede social do comércio, que apresenta as relações de compras e abastecimento dos moradores do Distrito, foi utilizada para o estudo e análise do espaço. Essa rede está delimitada apenas ao relacionamento entre os compradores e o comércio, portanto, as fontes de suprimento dos estabelecimentos comerciais não foram contempladas. As considerações finais sobre o espaço, objeto deste estudo, têm como base os resultados obtidos pela rede 
social e foram complementadas com algumas técnicas de análise espacial que estão disponíveis em um sistema de informações geográficas.

Conceitualmente, neste trabalho adota-se como baixa renda, os hábitos de compras observados, independentemente dos seus níveis de renda, com maior freqüência entre a maioria da população de renda baixa. A população do Distrito de Pedreira é constituída por um número significativo de migrantes, muitos procedentes de algumas regiões mais pobres do nordeste do país. Muitos obtiveram sucesso, porém, apesar de receberem atualmente uma boa renda, continuam com os mesmos hábitos de compras das pessoas de renda baixa. Certos proprietários de automóveis ainda utilizam o serviço de ônibus para se locomoverem a determinados locais, como o Largo 13 de Maio. Entretanto, podem existir situações particulares quando as compras são feitas pelas esposas, que utilizam os serviços de entregas dos supermercados, pelo fato do automóvel ser utilizado pelos maridos para a sua locomoção ao local de trabalho.

O Distrito de Pedreira está localizado na região sul do Município de São Paulo, conforme o mapa número 1, constituído a partir do ano de 1992 de acordo com a lei municipal de número 11220. Desde 1996, pertence à Subprefeitura de Cidade Ademar, responsável, também, pelo Distrito de Cidade Ademar. Constitui-se a divisa, a leste e sudeste com o Município de Diadema, ao norte com o Distrito de Cidade Ademar, a noroeste com o Distrito de Campo Grande (Subprefeitura de Santo Amaro), a oeste com o Distrito de Cidade Dutra e a sudoeste com o Distrito de Grajaú (esses dois últimos pertencentes à Subprefeitura de Capela do Socorro). Até 1996 pertenceu à Administração Regional de Santo Amaro.

A parte empírica deste trabalho foi desenvolvida e fundamentada numa amostra de 135 moradores do Distrito de Pedreira e um total de 2033 estabelecimentos de comércio disponíveis nos centros que foram pesquisados. O termo "moradores" refere-se aos participantes da amostra e não necessariamente à população do Distrito de Pedreira.

Será utilizada, no que se refere a um centro, um nome de uma via principal. Por exemplo, a menção do Largo 13 de Maio corresponde ao centro constituído pelo comércio da região do Largo 13 de Maio. Na maioria das vezes, a referência do comércio de Diadema, corresponde ao centro comercial de Diadema. 
O núcleo deste trabalho está dividido em 6 capítulos. Nos três primeiros, de 1 a 3 , encontramse as compilações dos conceitos básicos necessários para o embasamento da parte empírica, apresentada nos capítulos 4 a 6 .

Os principais conceitos teóricos do capítulo 1, conceitos sobre redes sociais, foram compiladas da obra de Wasserman e Faust (1997), Social Network Analysis.

Muitos artigos e trabalhos sobre o assunto redes sociais estão disponíveis em diversas publicações. Alguns desses artigos são mencionados por Wasserman e Faust (1997) no livro Social Network Analysis, anteriormente referido. Dentre alguns dos principais autores destacam Stanley Wasserman (1994, 1997), Katherine Faust (1997), Barry Wellman (1988), John Scott (2006), Vladir Batagelj (2005), J. Clyde Mirchell (2005), Michel Forsé (2004) e Frank Harary $(1965,1971)$.

O sucesso obtido pelas idéias da aplicação da teoria dos grafos em redes sociais deve ser atribuído a Harary (1965), ao introduzir muitas das valiosas contribuições inovadoras atualmente utilizadas.

As principais medidas de centralidade de uma rede social são: grau, posicionamento e proximidade. A medida grau indica a quantidade de relacionamentos. A força e o poder de um determinado nó estão diretamente relacionados com o valor da medida grau desse nó que serve para indicar o seu nível de hierarquia, caso o nó represente um centro ou uma determinada atividade comercial. Quanto menor for o valor da medida de proximidade, maior é a proximidade de um nó em relação aos seus vizinhos adjacentes e serve como um indicador de facilidade de acesso a um centro ou uma atividade comercial.

A medida de posicionamento representa o poder de intermediação, ou seja, quanto mais alto for o valor dessa medida, maior é a sua influência para o sucesso do relacionamento entre os nós mais próximos, além de servir para indicar o nível de dependência dos compradores em relação a um determinado centro ou atividade comercial. A palavra original para a medida posicionamento é "betweeness", todavia Michel Forsé (2004) adota a palavra "intermediarité" em língua francesa, bastante adequada quando utilizada em ciências sociais. Neste trabalho adota-se como sendo o foco principal a função comércio, portanto, julga-se mais adequada a palavra posicionamento, em vez de intermediação, com o objetivo de denotar a intensidade de atração exercida por um determinado centro ou ponto comercial. 
MAPA 1

Subprefeituras e Distritos

do Município de São Paulo

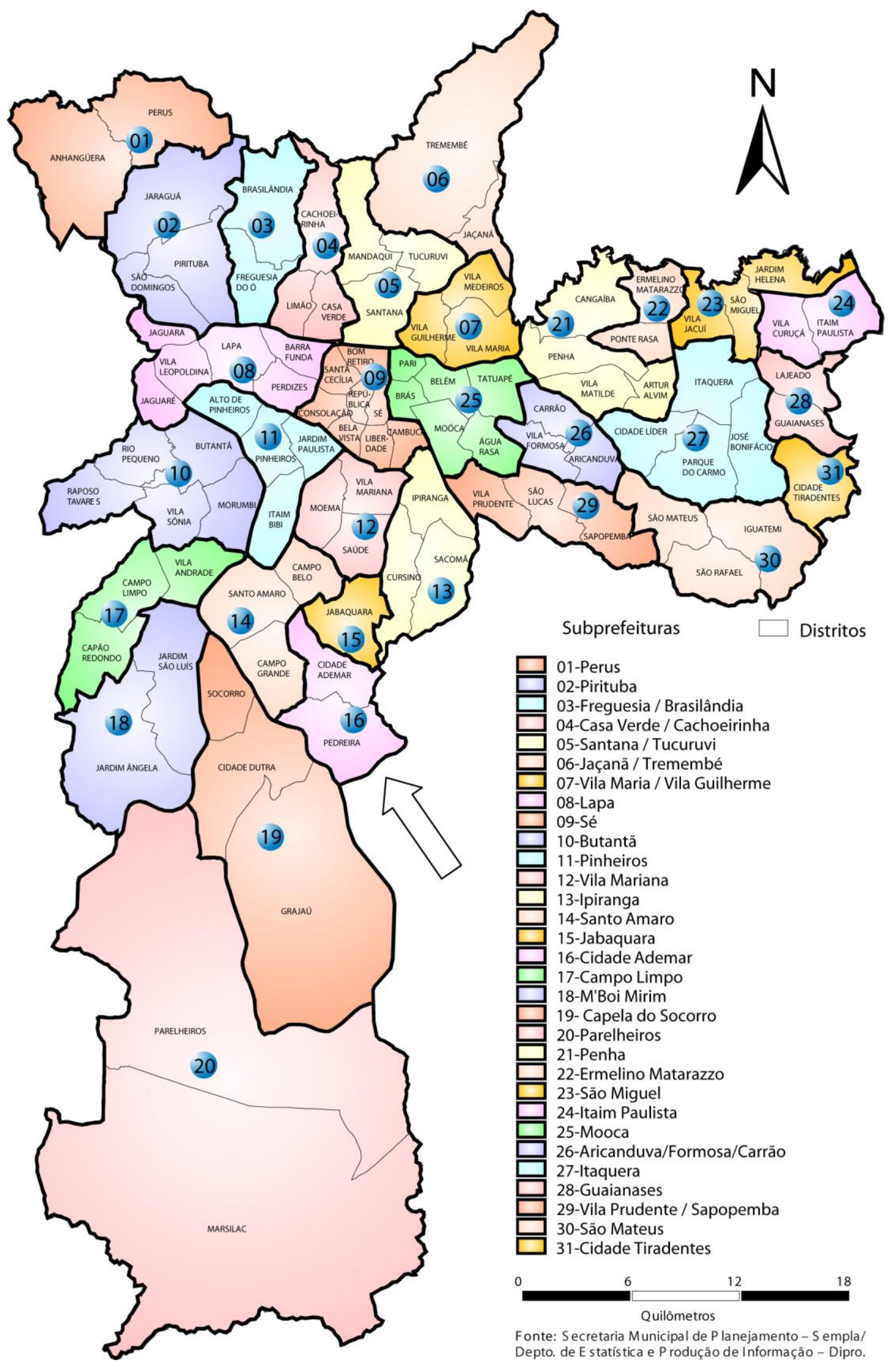


As propriedades de equivalência estrutural da rede social ajudaram a organizar os grupos de moradores em conseqüência da identificação de determinados centros de influência.

No capítulo 2, conceitos sobre análise e estatística espacial, estão compiladas as idéias de alguns autores responsáveis pela publicação de trabalhos sobre o tema análise e estatística espacial. Apresentamos a seguir os resumos dos principais pontos objetos desse capítulo.

As primeiras idéias sobre autocorrelação espacial sugiram com Michael F.Goodchild, cujo conceito se baseia na proximidade entre as feições. Seus fundamentos se baseiam no uso implícito da lei de Tobler": "Everything is related to everything else, but near things are more related than those far apart." (LONGLEY et al, 2002, p. 61). As principais técnicas, as mais utilizadas em análise espacial, adotam o critério de proximidade. Constata-se a dependência espacial (GOODCHILD; JANELLE, 2004), caso seja possível a identificação de cluster ou agrupamentos. Numa situação de dispersão não se verifica a existência de dependência espacial.

Dentre alguns dos principais autores, sobre análise espacial, estão Michael F Goodchild (2004), David J. Maguire (1991, 2001), S. Openshaw (1991), P. A. Burrough (1990) e Paul A. Longley (2002).

O autor Andy Mitchell (2005) é a fonte da compilação para todos os conceitos referentes aos cálculos de estatística espacial, constantes neste trabalho. As principais técnicas, empregadas em análise espacial, as quais servem também para a indicação da existência de dependência espacial, utilizam as estatísticas Moran's I, Getis Ord G e Getis Ord Gi*, próprias para a avaliação dos padrões globais e locais de agrupamento.

Classificam-se os padrões em três categorias: agrupado, disperso e randômico. Os valores das estatísticas indicam o padrão agrupado diante da ocorrência de formação de grupos, todavia o padrão pode ser disperso desde que não se verifique a existência de grupos. Quando não for possível, por meio dos valores da estatística, a identificação de um desses dois extremos estabelece-se o padrão randômico.

No capítulo 3, conceitos sobre rede urbana, centralidade e mobilidade, estão compiladas algumas idéias publicadas sobre redes urbanas, centralidades e mobilidade. A seguir, apresentam-se os resumos do conteúdo desse capítulo.

\footnotetext{
${ }^{1}$ Tradução do autor: "no mundo, todas as coisas se parecem; mas as coisas mais próximas são mais parecidas que aquelas mais distantes"
} 
As idéias de Castells $(1983,2005)$ abrangem os conceitos de centralidade, da análise de relações e articulações entre os elementos da estrutura urbana, os quais são consumo (C), produção $(\mathrm{P})$, troca $(\mathrm{T})$ e gestão $(\mathrm{G})$, bem como, a representação da centralidade em nós de uma rede. Uma das suas contribuições mais importantes é a idéia do espaço como expressão da sociedade, que está construída em torno de fluxos, e as suas definições sobre o espaço de lugar e o espaço de fluxos. A distinção entre esses dois tipos de espaços ajuda no entendimento dos fenômenos espaciais. Por exemplo, um morador pode realizar as compras em um centro muito distante da sua residência, pois na ótica do espaço, o custo da tarifa do transporte de passageiros pode ser o seu determinante e deixam de ser importantes tanto o tempo de percurso quanto a sua proximidade métrica.

Um dos autores a pensar sobre a estrutura de um centro foi Burgess, trazendo os conceitos de CBD - Central Business District -, posteriormente criticado por Castells em seu livro A Questão Urbana. O trabalho de Christaller, a teoria dos lugares centrais, é um dos assuntos mais citados sobre o referido tema. Todos eles mencionam a existência de diversos níveis hierárquicos em decorrência da importância de cada centro.

Mobilidade e acessibilidade são freqüentemente mencionadas por muitos autores, tais como Beaujeu-Garnier (1997), Pierre George (1966, 1971) e Rochefort (1998). Obteve-se nos trabalhos de Dupuy (1985) alguns dos conceitos de rede urbana e sistema urbano.

As três classes de comércio em relação à freqüência de demanda, consideradas neste capítulo, podem ser alta, quando diária ou semanal; menor (mediana) demanda, se for mensal, ou baixa diante de um período bastante longo entre uma compra e outra.

Muitos autores escreveram sobre a evolução da cidade de São Paulo. Dentre eles, destacam-se Aroldo de Azevedo ([1958]), Pasquale Petrone (1963), Juergen Richard Langenbuch (1971) e, mais recentemente, Regina Maria Prosperi Meyer (2004).

O objetivo do capítulo 4, Distrito de Pedreira, é descrever e caracterizar o Distrito de Pedreira, no Município de São Paulo. O modelo adotado para o seu desenvolvimento está baseado no livro coordenado por Pasquale Petrone com o título de Pinheiros - Aspectos Geográficos de um Bairro Paulistano. Os dados sobre o sítio urbano foram extraídos da carta geotécnica do Município de São Paulo, de 1992, disponível na Secretaria Municipal de Planejamento SEMPLA. As características populacionais, por setor censitário, foram obtidas do censo demográfico do ano de 2000 divulgado pelo Instituto Brasileiro de Geografia e Estatística - 
IBGE. A descrição da evolução do Distrito foi baseada no mapa de expansão da área urbanizada da região metropolitana de São Paulo preparada pela Empresa Metropolitana de Planejamento da Grande São Paulo - EMPLASA, publicado no ano de 2002, também disponível na SEMPLA. A feição foi elaborada levantando as informações nos mapas do sistema cartográfico metropolitano - levantamento aerofotogramétrico de 1996, e igualmente, na carta de classes de declividades da região metropolitana da grande São Paulo de 1980, todos fornecidos pela EMPLASA. A estrutura urbana foi desenvolvida por meio de levantamentos feitos nos diversos locais do Distrito, está fundamentada no Plano Regional Estratégico de 2004, da Subprefeitura de Cidade Ademar, no tocante às centralidades polares, desenvolvimento urbano e uso e ocupação do solo. As funções foram baseadas nos levantamentos locais e, finalmente, os assuntos sobre a centralidade e mobilidade foram desenvolvidos em conformidade com as informações fornecidas pela São Paulo Transporte S.A. - SPTrans e Empresa Metropolitana de Transportes Urbanos - EMTU sobre o sistema de transportes coletivos. Também foi possível extrair informações do PRE em relação ao planejamento futuro para o transporte coletivo do Distrito de Pedreira.

Observa-se, nas proximidades da divisa com Diadema, a existência do comércio carente. Todavia, mesmo perante alguma deficiência de transporte coletivo, alguns dos moradores são obrigados a satisfazerem as suas necessidades de compras nesse município vizinho.

O PRE manifesta alguma preocupação em tentar amenizar os danos ecológicos ocorridos, pelo não cumprimento da legislação anterior de proteção das áreas de mananciais. Perante a função social da cidade, estabelecida em lei no Estatuto da Cidade e também no PRE, a criação da Zeis - zona especial de interesse social - permite a regularização dos imóveis irregulares, por parte da Prefeitura, dentro do perímetro da área de preservação ambiental. Conseqüentemente, na área preservada, a densidade ocupacional continua elevada e, enquanto as autoridades sanitárias não apresentarem alguma solução para o problema do tratamento de esgotos, a represa Billings permanece ameaçada.

No capítulo 5, rede social do comércio e dos moradores do Distrito de Pedreira, apresentamos a rede social, que contempla as relações de compra e abastecimento dos moradores do Distrito de Pedreira, e foi estruturada por meio de entrevistas com 135 residentes, sendo a amostra formada por um morador de cada setor censitário. O foco principal dessa rede social foi, por meio da análise das ligações entre os nós, apresentar o padrão de relacionamento de cada morador da amostra com o comércio. 
Os resultados das ligações dos nós dessa rede social entre os moradores e o comércio possibilitaram a avaliação dos respectivos níveis hierárquicos dos principais centros. Os centros, segundo Beaujeu-Garnier (1997), podem ser classificados em centro principal, centros secundários, quarteirões de comércio de vizinhança e centros comerciais periféricos.

O nível hierárquico superior de um centro principal em relação a um centro secundário ou comércio de vizinhança pode ser comprovado por meio dos resultados das ligações entre os nós de uma rede social. Os centros de níveis hierárquicos mais elevados são aqueles que oferecem os produtos de demanda de freqüência baixa de compras, em conseqüência da necessidade de estarem localizados em pontos comerciais de elevada circulação. Ao contrário, todo o comércio estruturado para atender a demanda de freqüência alta de compras apresenta níveis hierárquicos baixos. Além dos níveis hierárquicos, os resultados dos relacionamentos permitiram a obtenção da intensidade de atração de determinados centros, sendo possível analisar os centros mais diferenciados. Foi possível, ainda, por meio dos resultados dessas ligações, determinar a organização de grupos de moradores em conseqüência de seus hábitos de compras, algumas vezes decorrentes do sistema de transporte urbano. Para cada um desses grupos foi possível a identificação dos seus respectivos centros de influência.

Esta rede social determina maior ou menor dependência dos moradores, em relação à localização, para alguns tipos específicos de comércio.

Em geral, os modelos que analisam a localização dos centros utilizam as variáveis de população, distância e custos de transporte. Todavia, a população e a distância entre a moradia e os centros comerciais podem ser, às vezes, as variáveis menos relevantes para a determinação dos centros mais importantes. Segundo Beaujeu-Garnier (1997), um morador nem sempre utiliza um núcleo comercial localizado mais próximo de sua residência, ele pode preferir outro mais afastado, desde que seja mais conveniente. Em modelo de redes sociais, apesar das conclusões sobre os impactos do sistema de transportes urbanos serem implícitos, torna-se possível a identificação dos centros mais preferidos pelos moradores, sem a necessidade do uso das informações sobre distâncias e nem dos custos de transporte, em relação à localização desses moradores. Apenas as informações sobre os relacionamentos são suficientes para estruturar uma rede social.

Uma das alternativas para a análise de uma rede social é através da teoria de grafos, cujos teoremas garantem os seus resultados exatos. Muitos dos cálculos, por exemplo, os de 
centralidade, são exatos. Entretanto, muitas vezes os relacionamentos entre as pessoas e o comércio não são racionais. Já as equivalências, conceitualmente quantitativas e exatas, pois como são provenientes da teoria de grafos, não podem funcionar perfeitamente em ciências humanas. Diante disso, os algoritmos utilizados nos programas computacionais de redes sociais estão preparados para apresentarem resultados aproximados para os cálculos de equivalência todas as vezes que for necessário, em função de determinadas características estruturais e particulares de cada rede social.

O modelo de redes sociais é estático apresenta a fotografia de um determinado momento. Apesar disso é possível representar de maneira estática os fluxos de pessoas à procura da satisfação de suas necessidades de compras, os quais são dinâmicos. Podem-se identificar situações de inclusão e exclusão social em função da mobilidade e acessibilidade permitida pelo sistema de transporte urbano. Também se podem analisar as vulnerabilidades de determinados centros comerciais diante de alterações radicais no sistema de transporte de passageiros.

A aplicação dos conceitos de rede social foi desenvolvida para o estudo de uma população ou especificamente de uma determinada amostra. Não foram encontradas publicações sobre a análise de erros estatísticos aplicados a rede social estruturada a partir de uma amostra. Portanto, caso os resultados da rede social do Distrito de Pedreira sejam utilizados para uma inferência, não existem, ainda, conhecimentos divulgados para o cálculo de seus erros amostrais.

No capitulo 6, técnicas de análise espacial dos centros comerciais, consta a análise dos padrões de agrupamento e distribuição espacial das atividades de comércio, decorrentes dos resultados de levantamento de campo dos principais centros de comércio indicados pelos participantes da amostra de moradores. Foram georeferenciados 2033 estabelecimentos comerciais e obteve-se a média de 1,76 lojas.

Além do comércio de vizinhança, estruturado para atender a demanda de compras de freqüência alta e disponível regularmente pelo Distrito de Pedreira, exceto nas proximidades da divisa com Diadema, foi contemplado, também, o comércio dos centros principais e secundários. Os principais centros considerados são: a região do Largo 13 de Maio em Santo Amaro, centro comercial de Diadema e os Shoppings Centers Interlagos/Intelar e SPMarket. 
Quanto ao comércio instalado no eixo das vias de elevada circulação, correspondendo aos centros secundários, parte está localizada nos Distritos de Campo Grande e Cidade Ademar, na Avenida Nossa Senhora do Sabará e Avenida Yervant Kissajikian, respectivamente. Em Diadema os principais centros secundários estão instalados na Avenida Rotary, no bairro de Serraria, e na Avenida Nossa Senhora dos Navegantes, no bairro de Eldorado, também conhecido entre a população como Navegantes. No Distrito de Pedreira, o principal está localizado na Estrada do Alvarenga e os menos importantes na Rua Professor Cardozo de Mello Neto, Rua Dr. José Silvio de Camargo, Avenida Alda e Rua Dr. Carlos de Rezende Enout. Ficam em destaque alguns estabelecimentos isolados, por exemplo, o Supermercado Pedreira e o Depósito 5 Irmãos.

Os resultados da análise espacial, obtidos por meio da ajuda dos recursos de um sistema de informações geográficas para os cálculos das estatísticas espaciais, identificaram alguns centros diferenciados os quais são o Largo 13 de Maio e os Shopping Centers Interlagos/ Interlar e SPMarket. Todos os centros secundários apresentam padrões muito semelhantes, inclusive o centro comercial de Diadema, embora não seja um centro secundário.

As estatísticas locais Moran's I e Getis Ord Gi* apresentam resultados relevantes para a análise dos centros mais importantes para a definição do padrão global de agrupamento ou cluster e sendo possível, dessa maneira, a identificação dos centros mais diferenciados.

O padrão dos centros secundários, instalados no eixo de algumas das vias principais, é caracterizado pela constatação de 1 ou 2 lojas, em cada ramo de negócio, em suas vizinhanças mais próximas. Diante disso, sob a ótica da estatística espacial, verificam-se dois tipos de padrões quantitativos de agrupamento: um deles em torno da média, caracterizando baixa concentração, decorrente de um tipo de distribuição constituído por 1 ou 2 lojas nas vizinhanças; e o segundo, apresentando um padrão mais significativo de concentração quando se constata a existência acima de 3 a 4 estabelecimentos, por ramo de comércio, nas proximidades.

Os padrões de agrupamento do comércio, obtidos por meio da análise espacial, estão coerentes em relação aos resultados apresentados pela rede social quanto à preferência e hábitos dos locais de compras. Essas duas técnicas distintas mostraram consistência nos resultados apresentados. 
Os cálculos da estatística espacial mostram algumas evidências sobre a existência de dependência espacial na determinação dos padrões de agrupamento do comércio, igualmente, a constatação de alguma similaridade entre os centros secundários.

Aproximadamente $46 \%$ das lojas estão instaladas dentro do raio de $3 \mathrm{~km}$ a partir do centro médio dos moradores. Embora os resultados observados sejam significativos, muitos moradores continuam satisfazendo as suas necessidades em centros mais distantes.

Em consequiência do sistema de transportes urbano, muitas vezes, os moradores necessitam realizar as suas compras em locais mais distantes, por exemplo, o Largo 13 de Maio em Santo Amaro. O modelo de Christaller, cujos centros são distribuídos de maneira racional e próximos das residências, não se verifica no Distrito de Pedreira.

Obteve-se uma correlação significativa de 74\%, entre a quantidade de linhas de ônibus e o seu correspondente número de lojas instaladas nos logradouros, o qual mostra a importância da disponibilidade de ônibus na constituição dos centros comerciais (vide apêndice F).

Questões meramente administrativas, envolvendo a autonomia de cada município na gerência do sistema de transporte coletivo, condicionam os moradores a se deslocarem a locais mais distantes de suas residências, por exemplo, o Largo 13 de Maio, para as suas compras, apesar da disponibilidade do comércio bem estruturado nas proximidades, como Diadema. A localização do centro habitual para as compras pode se tornar irracional em termos de distância e tempo. 
1 CONCEITOS SOBRE REDES SOCIAIS 


\subsection{Introdução}

O espaço geográfico pode ser observado sob vários aspectos distintos em função de cada uma das atividades, que estejam sendo realizadas, tais como extração de recursos naturais, pecuária, agricultura, silvicultura; da disponibilidade de instalações, algumas para finalidades industriais, outras para o armazenamento da safra agro pecuária, combustíveis ou insumos diversos; de áreas utilizadas para o comércio, plantas de geração de energia, centros de distribuição, shopping centers; bem como, dos padrões de aglomerações de moradias, edifícios, lojas e indústrias, fazendo que se estabeleçam povoados, vilas ou cidades.

Portanto, no espaço geográfico se inscreve a organização espacial das relações sociais, a organização dos meios de consumo coletivo, e todas as atividades econômicas de produção, consumo e troca, quando ocorre a divisão funcional do espaço. As relações espaciais são dependentes da competição econômica, da centralização e descentralização das decisões políticas e administrativas, conseqüentemente, ocorrendo o desenvolvimento desigual dos padrões espaciais.

O espaço é também produzido pelo sistema de organização social em decorrência do esforço da sociedade para satisfazer as necessidades, freqüentemente diárias, e envolve ações de natureza política, como decisões sobre o sistema de transporte urbano de massa e o seu correspondente custo, ao setor público e para a população em geral, em conseqüência da localização das moradias, em particular, na periferia das grandes cidades, por causa da predominância de moradores de renda mais baixa. Neste processo de produção de espaço, acontecem determinadas aglomerações dentro de uma cidade, diante da divisão funcional do espaço, por meio da constituição de lugares, que se relacionam em rede, havendo a possibilidade de identificação de níveis hierárquicos de determinados pontos dessa rede. Por exemplo, um pequeno comércio instalado nas proximidades das áreas residenciais para o atendimento das necessidades mais imediatas.

Segundo Mark Gottdiener (1993), durante a produção de formas espaciais, os processos estruturais do seu desenvolvimento mantém uma estreita relação entre a estrutura de uma organização espacial e o seu correspondente padrão espacial. Em outras palavras, pode-se estudar, de um lado o papel da ação e, de outro, o da estrutura na produção de fenômenos e formas espaciais. 
A procura e a busca do espaço, por uma multidão de atores e instituições, segundo Lefebvre, produziram uma "explosão de espaços" por meio da articulação múltipla das relações sociais estratificadas com o espaço. Entretanto, para Castells, ocorre apenas um desdobramento e especificação da teoria da estrutura social, ou seja, não existe uma teoria específica do espaço, cujo objetivo é explicar as articulações do espaço com outras forças e processos pertinentes numa forma social particular (GOTTDIENER, 1993).

Vários estudos sobre a produção de espaço foram publicados. Um deles desenvolvido por Robert E. Park, Ernest W. Burguess e Roderick D. McKenzie, nos anos de 1925, teve como objetivo explicar os padrões do uso da terra. Burguess, ao criar o modelo da zona concêntrica, apresentou os conceitos de hierarquia de localizações, a qual é dominada pela localização central e noções de centralidade.

Nos anos 50, Amos Hawley citou, como sendo um fato espacial, gerando as complexas formações sociais modernas, a qualidade do movimento em termos de tecnologias de transporte e de comunicação. Fundamentado nas idéias de McKenzie de 1933, trabalhou os conceitos de rede funcional interdependente de organização espacial, de importância da posição da localização, igualmente, de concepções de forças centrípetas e centrífugas.

Lösch, em 1954, seguindo as idéias de Christaller, voltou a mencionar as teorias do lugar central e interdependência funcional. $\mathrm{O}$ autor também desenvolveu as idéias de economia regional como sendo uma espécie de hierarquia de lugares urbanos, compreendendo uma matriz funcional de rede de comércio, de transporte e de administração. Isard em 1956 e Berry em 1968, igualmente trabalharam com esses mesmos conceitos.

Em 1956, Walter Isard escreveu que as cidades representam os nós funcionais numa sociedade concebida tal qual um grande sistema social, realizando tarefas essencialmente econômicas, cujos arranjos em rede dependem dos custos de transporte.

Berry, em 1968, divulgou outras idéias sobre lugares centrais, constituindo a base econômica, onde em torno deles se aglomeram outras atividades urbanas. O autor também comentou sobre a noção de diferenciação e interdependências econômicas funcionais devidas ao comércio. 
Segundo Castells, as relações sócio espaciais são dominadas pela estrutura econômica e, na sociedade moderna, o espaço abrange as relações sociais e produzem a organização espacial das relações.

Em outras palavras, observa-se um conjunto de locais geográficos organizados em forma de rede e interconectados. Eles podem ser representados graficamente por meio de nós (vértices) e conexões (linhas), formando um sistema de rede de relações sociais, econômicas e até eventualmente políticas.

Esta morfologia das formas de ocupação do espaço, que mostra as articulações das suas respectivas ligações, que representam as relações, e também a organização das relações entre as pessoas no espaço ocupado, pode ser identificada, analisada, estudada, estruturada mediante a aplicação das técnicas de redes sociais. O que permite o entendimento dos padrões das estruturas das relações entre as diversas entidades sociais de natureza política, econômica ou social.

Em resumo, um conjunto de nós interconectados podem formar redes. Manuel Castells (2005) em seu livro A Sociedade em Rede, menciona algumas características de um sistema de redes sociais, tais como:

"Uma estrutura social com base em redes é um sistema aberto altamente dinâmico suscetível de inovação sem ameaças ao seu equilíbrio". (CASTELLS, 2005, p. 567).

"Empresas comerciais, e, cada vez mais, organizações e instituições são estabelecidas em redes de geometria variável cujo entrelaçamento suplanta a distinção tradicional entre empresas e pequenos negócios, atravessando setores e espalhando-se por diferentes agrupamentos geográficos de unidades econômicas”. (CASTELLS, 2005, p. 567).

As relações entre as entidades sociais e o seu correspondente padrão ou modelo de organização dessas relações sociais fazem parte de redes sociais. É possível, dessa maneira, construir modelos de redes envolvendo temas políticos, econômicos ou de outros tipos de estrutura social. Conforme mencionado anteriormente, Castells analisa localidades como sendo nós de uma rede. Por meio dos padrões de relacionamento entre os diversos pontos da rede, ou nós, pode-se analisar a importância de cada um deles em relação às necessidades de circulação das pessoas. A aplicação dos conceitos teóricos e das propriedades utilizados em 
redes sociais pode indicar os níveis de hierarquia de cada uma das centralidades envolvidas no dia a dia dos moradores de determinados lugares.

Existem informações, quanto ao início do desenvolvimento de interesse por redes sociais, atribuídas aos anos 30 na área de Psicologia Social por meio de trabalhos publicados por Kurt Lewin, Jacob Moreno, Fritz Holder, sob a influência "gestalt" da psicologia social. Kurt Lewin, em Massachusetts e Michigan, desenvolveu os conceitos de percepção social e estrutura de grupo. Ainda aparecem trabalhos de Wolfgang Köhler, igualmente, na ótica de "gestalt" - psicologia social e cognitiva - sobre estrutura de grupo, fluxo de informações e idéias sobre grupos. Da mesma forma, em Harvard, pesquisadores desenvolveram estudos de relações interpessoais e formações de grupos de interesse, quando surgiram as primeiras idéias sobre "cliques" ou organização de grupos informais.

A idéia de sociograma começou com Moreno em 1934, por meio da representação das propriedades formais das configurações sociais e da aplicação dos conhecimentos de geometria espacial, pontos e linhas, tendo como objetivo a identificação de líderes. Nesta mesma época, em 1936, Lewin, ao estudar a constituição de grupo social por meio da propriedade estrutural do espaço social, utilizou técnica matemática para determinar a interdependência entre o grupo e o meio ambiente num sistema de relações.

Em Harvard, o antropólogo inglês Radcliffe-Brown estudou os fenômenos informais e relação interpessoal em sistema social. Em Manchester, ao se basearem nas idéias de RadcliffeBrown, foram desenvolvidas as análises de conflitos e contradições numa sociedade tribal africana e em pequenas cidades rurais da Inglaterra. Ainda, em Manchester, os antropólogos John Barnes, Clyde Mitchell, Elizabeth Bott, sob influencia de Radcliffe-Brown, trabalharam com integração, coesão, conflito e mudanças, igualmente, Max Gluckman com negociação, barganha e coerção.

Heider, em 1946, iniciou trabalhos na área da Psicologia Social tendo preocupações voltadas para atitudes, percepção e equilíbrio. A teoria de grafos passou a ser utilizada, a partir de 1953, pelo emprego dos trabalhos de Cartwright e Harary, na área de comportamento de grupo, por meio da aplicação de grafos direcionados e também sinalizados. No período entre 1952 e 1958, Rapoport criou modelos preditivos de contágio epidemiológico ao estudar difusão de doenças. 
Significativos desenvolvimentos, mediante novas idéias, surgiram em 1957, quando Siegfried Nadel conceituou a estrutura como sendo a articulação ou arranjo dos elementos para formar um todo, ou seja, a estrutura social de um sistema total, rede ou padrão de relações entre indivíduos. Disso, uma estrutura social compreende as estruturas de relacionamentos, igualmente, os seus relacionamentos mantidos por meio dos seus respectivos conjuntos de relacionamentos, que são definidos por meio de redes de atividades interdependentes.

Mitchell em 1969, seguindo as idéias de Nadel e de Barnes, trouxe o conceito de esfera de relações interpessoais correspondendo a uma ordem pessoal, comunicação, transferência de informação entre os indivíduos, estabelecimento das normas sociais e criação do grau de consenso. Considerou, inclusive, a transferência de mercadorias e serviços entre as pessoas, o fluxo de informações, a transferência de recursos e serviços, bem como, algumas relações envolvendo transação ou troca.

Mais recentemente, Boyd, Lorrain e White trabalharam o conceito de relacionamento em estrutura social, o "block modeling" ou modelos de blocos, e também pelo emprego de técnicas estatísticas multivariadas do tipo MDS - "Multidimentional Scaling".

A aplicação de redes sociais é bastante ampla, é freqüentemente utilizada em várias áreas distintas sendo algumas delas a Geografia, Antropologia, Sociologia, Psicologia Social. Uma das mais importantes aplicações da metodologia de redes sociais na Geografia está no campo de estudo da produção de espaço. Vários focos distintos podem ser observados, tais como o estudo de um conjunto de localizações geográficas interconectadas num sistema de rodovias; o estudo de centralidades em relação a bairros, distritos e cidades; relações econômicas entre países, regiões ou cidades; acessibilidade e mobilidade da população de determinadas regiões.

Na Geografia Física, a metodologia de redes sociais pode ser utilizada para a representação de uma bacia hidrográfica; ou desenvolvimento de modelos de simulação do comportamento de uma bacia hidrográfica, entre outros.

Antropólogos habitualmente dirigem a atenção para sistemas culturais de padrões sobre os direitos e deveres, ao estudarem o comportamento próprio de grupos definidos como tribos, vilas, e unidade de trabalho. Para alguns analistas, uma rede é um conjunto de conexões interligando membros de um sistema social por meio de categoria social e grupos definidos. 
Uma das principais atividades dos sociólogos é estudar a estrutura social. A maneira mais direta de estudar uma estrutura social pode ser a análise dos padrões das conexões interligando os seus membros. A sua descrição é fundamentada no conceito de rede social por meio das conexões, as quais interligam os nós de um sistema social, cujas conexões interligam pessoas, grupos, organizações, ou agrupamentos ou clusters de pessoas.

Os analistas de redes desejam saber de que maneira as propriedades estruturais afetam o comportamento, diante dos efeitos das imposições padronizadas, atitudes pessoais e relações duais. Eles se concentram em estudar o modo que os padrões das conexões na rede proporcionam as oportunidades significantes e também as coerções, pois eles afetam o acesso de pessoas e instituições para os recursos como, informação, saúde e poder. Portanto, os analistas de rede atribuem a um sistema social o tratamento de redes de relações de dependência, resultante do diferencial entre a posse de recursos escassos, em cada um dos nós, e a estrutura de alocação desses recursos nas conexões.

$\mathrm{Na}$ ótica da análise estrutural fundamentada em redes sociais, a estrutura social consiste num conjunto de elementos relacionados entre si por determinados padrões de relações. Os conceitos de redes sociais podem ajudar a descrever a estrutura social de uma cidade, são muito úteis para mostrar os conceitos normativos, ao explicarem cada processo social chave, tais como acesso ao trabalho, ao comércio e atividades políticas.

A partir dos anos de 1960, modelos matemáticos denominados redes, passam a ser utilizados de maneira mais intensiva, tendo a finalidade de mapear os padrões de relacionamentos entre as partes de uma estrutura social complexa, por meio de uma adaptação das técnicas e teorias quantitativas para representar formatos globais ou morfológicos de uma estrutura social.

Nos meados dos anos 70, houve avanços metodológicos a partir do surgimento de um novo paradigma: a análise estrutural. Vários ramos da Ciência Social surgiram, em particular, o desenvolvimento de técnicas de pequenos grupos, teoria dos jogos, teoria de sistemas gerais, epidemiologia, estudos inter-organizacionais e sociometria. Estruturalistas norte-americanos trabalharam no desenvolvimento de ferramentas, construíram e testaram novas técnicas para modelar as relações entre os elementos dentro de uma estrutura social. Trata-se de uma metodologia de estudo de relacionamento entre as partes elementares de um sistema social, determinando os inter-relacionamentos entre uns e outros, e mostra o estabelecimento de padrões de comportamento envolvidos. O ponto central da abordagem da análise estrutural é a 
morfologia de um conjunto de relacionamentos, determinando ou condicionando a efetiva demarcação entre um conjunto de atores, ou uma delimitação de ações, as quais identificam, sob várias circunstâncias, os habituais ou recorrentes tipos de trocas ou outros comportamentos, os quais devem ser mais coerentes e compatíveis.

Por meio da análise estrutural, é possível mapear as relações de corporações, estados e sistemas internacionais e estudar a natureza estrutural de um sistema social. O seu objetivo é enfocar as relações, que constituem a sua unidade básica da estrutura social, e o agrupamento de similaridade dos atores sendo o seu resultado. A análise estrutural descreve a rede de relações de maneira mais completa possível, extrai os padrões proeminentes dessas redes, traça o fluxo de recursos por meio dessas redes, identifica quais são os efeitos existentes entre os indivíduos, que estão ou não conectados em situações específicas. Essas informações permitem analisar a coerência entre a estrutura e o comportamento para cada um dos vários níveis analíticos dentro de uma determinada organização de rede social.

Portanto, torna-se importante a atenção para as implicações dos padrões de relacionamento entre os vários elementos dentro de uma estrutura social. Uma das vantagens, quanto à abordagem total da rede, é a possibilidade da visão simultânea do sistema social como um todo, e também das partes formando o sistema, igualmente, a análise de mobilização de recursos para explicar o comportamento político, econômico e social. As análises estruturais, por conseguinte, são capazes de traçar fluxos de informação, identificar origem e destino, e detectar regras e normas estruturais operando nos fluxos dos recursos.

Por meio da análise estrutural, podem-se entender as relações de trocas e dependência entre grupos de interesse e estados nações. É possível, ao mesmo tempo, verificar uma estrutura de coalizão, divisões e relação de competição, e também os modos das relações diretas e indiretas conectando diferentemente indivíduos e grupos em função dos recursos disponíveis.

Por conseguinte, pode-se analisar a distribuição espacial das atividades econômicas e sociais, que se estabelecem para a satisfação das necessidades da população, na forma de um sistema de redes sociais, no qual cada um dos nós possa representar as pessoas, e também os estabelecimentos comerciais, onde toda a população possa resolver os seus problemas de abastecimento de alimentos, vestuário, higiene pessoal e do lar, bem como, de produtos duráveis, tais como eletrodomésticos, ou então, de serviços de saúde, de educação, de lazer, bancários, etc. As interconexões entre esses nós podem representar as relações estabelecidas 
entre a população e as correspondentes fontes de abastecimento ou os locais para a satisfação das suas necessidades. Ainda, o estabelecimento dessas interconexões pode representar, também, algumas características de mobilidade e acessibilidade da população, em decorrência de um sistema de transporte urbano de massa, caso seja do tipo radioconcêntrico.

Pode-se estabelecer, em conseqüência de um determinado sistema de transporte urbano de passageiros e também em função do fluxo de locomoção das pessoas, uma estrutura espacial organizada para atender as necessidades específicas da população. Em decurso disso, surgem as mais diversas formas de ocupação do espaço, responsáveis pela concentração ou dispersão espacial dos centros, exercendo as funções de suprimento de bens e serviços, decorrentes das relações dessas pessoas com o comércio.

A análise morfológica, por meio das técnicas de redes sociais, se baseia em alguns recursos quantitativos provenientes da aplicação da teoria de grafos, estatística descritiva e estatística multivariada.

\subsection{Alguns conceitos básicos sobre redes sociais (na ótica dos norte-americanos)}

A representação gráfica de uma rede social é feita por meio de grafos, principalmente utilizando dos conhecimentos apresentados por Hage e Harary, em 1983; e Harary, Norman e Cartwright, em 1965 (WASSERMAN; FAUST, 1997). Em rede social, todo o conceito matemático, utilizado na teoria de grafos e, igualmente, os conhecimentos da estatística descritiva e multivariada, se aplica na análise e representação das propriedades de uma estrutura social. Conseqüentemente, torna-se possível a apresentação de determinados modelos de uma organização espacial, se baseando em relacionamentos das pessoas com os seus respectivos fornecedores de bens e serviços. Por meio de pontos, que podem representar as famílias e também os fornecedores de bens e serviços, que correspondem aos nós de uma rede, ao mesmo tempo, o uso de linhas representando as ligações, ou seja, as relações entre esses nós, consegue-se produzir um modelo de uma rede de relacionamentos, de maneira relativamente simples.

Os cálculos, correspondentes a determinada representação gráfica de uma rede social, são feitos por meio da utilização de matrizes denominadas sociomatrizes, nas quais as informações sobre cada um dos nós e as suas correspondentes ligações com outros nós, adjacentes ou não, são representadas na forma de linhas e colunas. Isso possibilita a aplicação das técnicas matemáticas empregadas em cálculos matriciais, para a obtenção dos resultados 
quantitativos individuais de cada nó, também, obter os resultados descritivos globais de uma rede como um todo, e, finalmente, havendo sempre a possibilidade de uso de técnicas estatísticas multivariadas.

Encontra-se, na figura 1.1, a representação hipotética de 3 centros comerciais e 8 famílias. Os centros comerciais estão representados pelos nós C1, C2 e C3 e cada uma das famílias pelos nós M1, M2, M3, M4, M5, M6, M7 e M8. As linhas interligando cada um dos nós representam as ligações estabelecidas entre todos esses nós. Todas as famílias podem satisfazer as suas necessidades no centro $\mathrm{C} 1$, todavia apenas as famílias M1 ao M5 mantêm contato com o centro C3 e somente as famílias M6 ao M8 se relacionam com o centro C2. Todas as famílias, quando entram em contato com $\mathrm{C} 1$, por ser um centro mais diversificado, podem satisfazer todas as suas necessidades em termos de bens e serviços. Entretanto os centros C2 e C3, sendo menos diversificados e disponibilizando menos opções de serviços em relação a $\mathrm{C} 1$, atendem somente parte dessas 8 famílias. Isso ocorre em decorrência de algumas vantagens estratégicas de localização e não pela diversificação maior de seus serviços oferecidos.

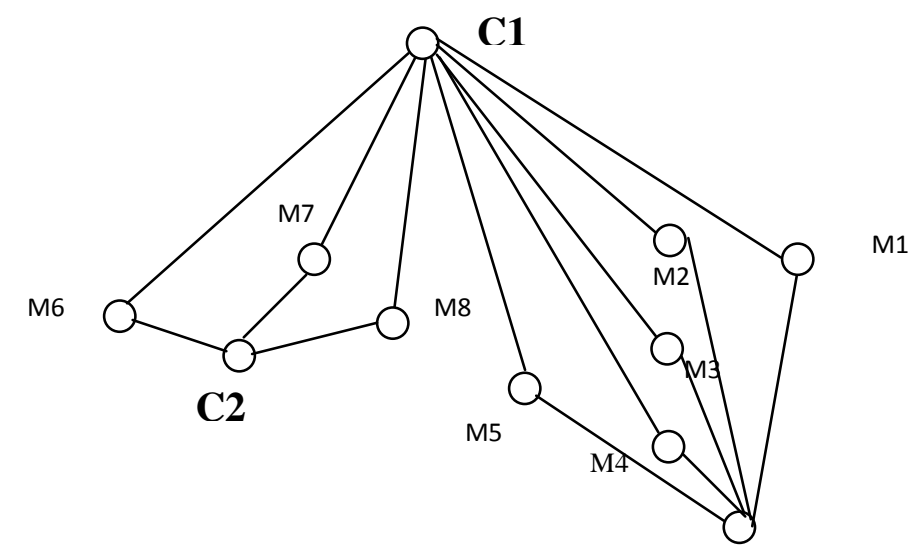

C3

Figura 1.1 - Exemplo de uma rede social com 3 centros e 8 famílias

A forma matricial, representando as relações de interação mútua entre os indivíduos mostradas na figura 1.1, é uma sociomatriz composta de 11 linhas e 11 colunas conforme a matriz 1.1.

Neste momento, no exemplo hipotético da figura 1.1, o foco está voltado apenas para os conceitos de ligação, sem entrar em detalhes sobre as características de um grafo direcionado 
ou não direcionado. Numa sociomatriz, os dados de origem da ligação são representados na linha e os de destino são apresentados na coluna. $O$ valor 0 significa que não existe ligação entre os nós e o valor 1 corresponde a uma ligação estabelecida. Examinando a linha M1 e a coluna $\mathrm{C} 1$, contendo o valor igual a 1, entende-se que a família M1 (a linha M1 como origem) mantém ligação com o centro $\mathrm{C} 1$ (a coluna $\mathrm{C} 1$ como destino). Esse mesmo raciocínio vale para as demais linhas M2 a M8 da coluna $\mathrm{C} 1$, cujos valores correspondem a 1. Em relação à linha M6 e coluna C2, o valor 1 significa a existência de ligação entre a família M6 e o centro C2. Examinando a linha M1 e a coluna C3, observa-se a permanência da ligação entre a família M1 e o centro C3.

DESTINO

\begin{tabular}{|c|c|c|c|c|c|c|c|c|c|c|c|}
\hline & $\mathrm{C} 1$ & $\mathrm{C} 2$ & C3 & M1 & M2 & M3 & M4 & M5 & M6 & M7 & M8 \\
\hline $\mathrm{C} 1$ & 0 & 0 & 0 & 1 & 1 & 1 & 1 & 1 & 1 & 1 & 1 \\
\hline $\mathrm{C} 2$ & 0 & 0 & 0 & 0 & 0 & 0 & 0 & 0 & 1 & 1 & 1 \\
\hline C3 & 0 & 0 & 0 & 1 & 1 & 1 & 1 & 1 & 0 & 0 & 0 \\
\hline M1 & 1 & 0 & 1 & 0 & 0 & 0 & 0 & 0 & 0 & 0 & 0 \\
\hline M2 & 1 & 0 & 1 & 0 & 0 & 0 & 0 & 0 & 0 & 0 & 0 \\
\hline M3 & 1 & 0 & 1 & 0 & 0 & 0 & 0 & 0 & 0 & 0 & 0 \\
\hline M4 & 1 & 0 & 1 & 0 & 0 & 0 & 0 & 0 & 0 & 0 & 0 \\
\hline M5 & 1 & 0 & 1 & 0 & 0 & 0 & 0 & 0 & 0 & 0 & 0 \\
\hline M6 & 1 & 1 & 0 & 0 & 0 & 0 & 0 & 0 & 0 & 0 & 0 \\
\hline M7 & 1 & 1 & 0 & 0 & 0 & 0 & 0 & 0 & 0 & 0 & 0 \\
\hline M8 & 1 & 1 & 0 & 0 & 0 & 0 & 0 & 0 & 0 & 0 & 0 \\
\hline
\end{tabular}

MATRIZ 1.1 - Representação matricial da rede social da figura 1.1

Fonte: adaptado de WASSERMAN; FAUST, 1997, p. 151

Observando-se a linha $\mathrm{C} 1$ e a coluna M1, de valor igual a 1, compreende-se que o centro C1 atende a família M1. O valor 1 da linha C2 e coluna M6 mostra a existência de ligação entre o centro C2 e a família M6. O mesmo ocorre, também, para a linha C3 e coluna M1, indicando outra ligação entre esse centro C3 e a família M1.

Além dos nós, denominados de pontos ou vértices na teoria de grafos, e das linhas estabelecendo as ligações, também designadas como arcos ou lados na referida teoria, a seguir apresentam-se algumas definições chaves e mais relevantes em redes sociais. 
Atores correspondem às entidades sociais formadas por pessoas, empresas ou por unidades sociais coletivas, compreendendo as pessoas num determinado grupo, os departamentos numa empresa, as agências de serviços públicos numa cidade, os países existentes em todo o mundo. Constituem a parte mais importante de uma rede social e são representados por nós nos grafos. No exemplo hipotético da figura 1.1 os centros de consumo $\mathrm{C} 1$ a $\mathrm{C} 3$ e as famílias M1 a M8 constituem os atores. São os pontos básicos para o estabelecimento das ligações entre os vários nós.

As ligações estabelecem a conexão entre os vários atores, tais como o relacionamento entre as pessoas por meio de amizade, contatos profissionais, transações entre empresas do tipo fornecimento e recebimento de materiais, empréstimos, prestação de todos os tipos de serviços, associação ou afiliação, por exemplo, possuir o registro no Conselho Regional de Medicina, fazer parte de um determinado partido político, relações sociais com os moradores do mesmo condomínio residencial, colegas de trabalho de uma empresa, mobilidade em situações do tipo migração interna ou, então, imigração para um país estrangeiro, conexão física através de uma rede de rodovias, sistema fluvial ou aeroviário, relações formais de autoridade e poder, por exemplo, ser um político atuante e influente, relação de natureza biológica envolvendo a constituição de uma família, etc.

Díade corresponde a ligações por meio do relacionamento entre dois atores. A análise dual enfoca as propriedades das interligações entre dois pares de atores, e serve de base nas formulações das premissas básicas dos modelos de análise estatística utilizados em rede social.

Tríade corresponde a ligações que ocorrem entre três atores, tornando útil quando uma determinada análise estiver sendo feita sob a ótica de aplicação da propriedade transitória. A idéia é relativamente antiga quando, em 1908, Simmel $^{2}$ declarava:

"[...] the fact that two elements [in a triad] are each connected not only by a straight line - the shortest - but also by a broken line, as it were, in an enrichment from a formal-sociological standpoint.” (SIMMEL, 1950, apud WASSERMANN; FAUST, 1997, p.19).

Subgrupo é um subconjunto de atores e as suas correspondentes ligações que podem ser tanto diádicas quanto triádicas. Corresponde à identificação dos vários tipos de agrupamentos de

\footnotetext{
${ }^{2}$ Tradução do autor: “... o fato que dois elementos (em uma tríade) estão conectados não somente por uma linha reta - a mais curta - mas também por uma linha descontínua, como, fosse um enriquecimento de um ponto sociológico formal"
} 
atores, apresentando características semelhantes ou idênticas, existindo vários algoritmos específicos para determinadas situações particulares, tais como "cliques", "N-cliques", "Nclan", "K-plex", "Lambda Set", "Factions" e "f-groups". Sob determinadas condições de mobilidade e acessibilidade de uma população, pode-se identificar a organização de grupos de pessoas, que possuem necessidades semelhantes, em relação à preferência de escolha dos locais onde os bens e serviços são oferecidos.

O critério básico de análise de um grupo como um todo, consiste em modelar as ligações entre os membros desse grupo. Para redes sociais, o conceito de grupo consiste na coleção de todos os atores, cujas ligações possam ser mensuradas. Em outras palavras, o grupo pode ser organizado por um conjunto finito de atores, os quais sob o critério teórico, empírico ou conceitual, estão confinados dentro de determinados limites pré-estabelecidos. Conseqüentemente, em termos amostrais, os resultados são válidos e pertinentes ao grupo, não sendo possíveis, as inferências estatísticas, para a população na sua totalidade.

O seu resultado é dependente da ocorrência dos diferentes tipos de relações, que se observam entre os pares de atores.

Conseqüentemente, uma rede social não é simplesmente um conjunto de díades, tríades e subgrupos, mas uma habilidade para modelar o relacionamento entre os diversos sistemas de atores, dentro de um finito conjunto de atores, e seus respectivos relacionamentos são constituídos de ligações entre esses atores.

Variáveis estruturais são mensuradas entre os pares de atores, medindo as relações de um tipo específico entre esses pares de atores. Podem ser transações comerciais entre empresas, amizade entre pessoas, comércio entre países, etc.

Existem vários tipos distintos de redes sociais, principalmente, em função do conjunto de atores e das suas respectivas propriedades desses nós.

Relações são estabelecidas por diversas opções distintas, que podem ocorrer ao nível das pessoas, por exemplo, amizade; transações ou transferência de recursos materiais, igualmente, compras e vendas, empréstimos e aluguéis; transferência de recursos não materiais envolvendo comunicações, o envio e recebimento de informações; interações; mobilidade de natureza física, do tipo migração de um lugar para o outro, ou de natureza social, abrangendo mudança de status social e de posição ocupacional; relacionamentos formais; estrutura familiar, através de casamento e filhos. 
Podem ser adotadas, várias maneiras distintas, para classificar os diferentes tipos de redes sociais:

a) Um dos critérios é estabelecido por um conjunto de atores e nas propriedades das relações entre eles. $\mathrm{O}$ conceito do modo de uma rede corresponde à quantidade de conjuntos de entidades, nos quais as variáveis estruturais são mensuradas. A rede social, sendo do tipo modo único, o tipo mais predominante de redes sociais, estuda um único conjunto de atores.

As relações podem ser constituídas por vários tipos distintos:

- Avaliação individual: constituída por relações de amizade, afinidades pessoais, respeito, etc.;

- Transação ou transferência de material e recursos: o seu conteúdo contém valores de empréstimos ou aluguéis, vendas e compras;

- Transferência de recursos não materiais: envolve um sistema de comunicação, envio e recebimento de informações;

- Interações;

- Movimentos: pode ser físico quando se trata de processos de migração, ou sociais quando envolvem movimentos de ocupação e de status;

- Agrupamentos formais;

- Laços familiares: casamento, descendência.

b) Dois conjuntos de atores: trata-se de uma rede social diádica, de modo duplo, desde que a relação ocorra entre o ator do primeiro conjunto e o ator do segundo conjunto, de maneira diádica. Ou então, pode ser estabelecido por um conjunto de atores e outro conjunto de eventos: muito utilizado em redes sociais do tipo afiliação, quando o evento é atribuído ao ator. Possui a característica de uma rede social não diádica. Cada modo pode ser organizado pelo emprego de dados sobre pessoas, subgrupos, organizações, comunidades, estados nação, etc. Os subgrupos são formados por pessoas ou arranjos de subgrupos de pessoas. Comunidades e estados nação podem ser entidades grandes, contendo muitas organizações e subgrupos.

Podem-se classificar os diferentes tipos de redes sociais em dois grandes grupos: redes sociais globais e rede social do tipo ego. Na categoria de redes sociais globais, são utilizados os 
conceitos de estrutura e de relacionamentos. Quanto aos conceitos estruturais, são adotadas as idéias de equivalência, quando as semelhanças são baseadas na morfologia da organização estrutural e determinadas por meio de técnicas estatísticas. Por exemplo, todas as famílias, que satisfazem as suas necessidades diárias nos mesmos centros de hierarquia mais baixa, podem ser consideradas equivalentes ou semelhantes, mesmo que certas famílias não mantenham o relacionamento com algumas lojas desses centros. Esses centros podem estar localizados em pontos diferentes e desde que o relacionamento se verifique nos centros de mesmo nível hierárquico não há necessidade do contato das famílias com todas as lojas desses centros. Na ótica relacional, existe a preocupação de se identificar certas características de relacionamentos, por exemplo, grupos informais ou "cliques", bem como, as medidas de centralidades obtidas mediante a ajuda das técnicas da teoria de grafos.

Na categoria do tipo ego, as redes sociais são constituídas por meio de focos em determinados atores, utilizando os conceitos de quase relacional (uma série de redes egos com a participação de egos não relacionados) e envolvendo o uso de técnicas probabilísticas. É muito utilizado por antropólogos, no estudo de benefícios sociais, quando concedidos pelos governos ou órgãos não governamentais, do mesmo modo, na análise de meio ambiente social e dos indivíduos objeto de estudo.

O modelo básico, em redes sociais, se baseia em grafos. Portanto, o grafo é constituído por um conjunto de nós e de linhas entre os pares de nós e parte-se do princípio que existe apenas uma linha entre um par de nós. Inicialmente, os conceitos estão fundamentados numa representação não direcionada, fazendo parte de uma relação dicotômica, ou seja, através da constituição de relações entre dois nós. Os nós representam os atores, e as linhas as relações entre esses atores. Na teoria de grafos os nós se referem aos vértices ou pontos, as linhas, aos arcos ou lados.

Dois nós são adjacentes quando se verifica uma linha (ligação) entre esses mesmos nós.

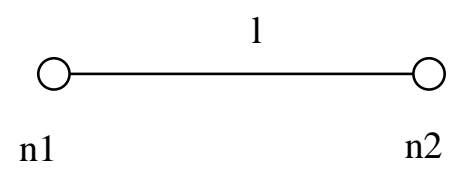

Notas:

- n1 e n2 são os nós;

- 1 é a linha. 
A rede social pode ser estudada sob vários aspectos: ator; díade; tríade; subgrupos ou grupo como um todo.

Subgrafos correspondem a uma parte ou um subconjunto de nós e linhas, derivados de um grafo maior.

O grau de um nó é a quantidade de linhas, pertencentes ou incidentes num determinado nó. O seu valor mínimo é 0 , quando não existem nós adjacentes ou ligações entre esses nós. O seu valor máximo é g - 1, sendo g a quantidade máxima de nós.

Exemplo:

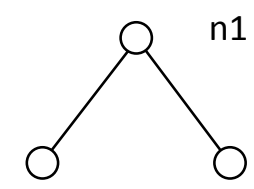

$\mathrm{g}=3 \quad(\mathrm{~g}-1)=2 \quad$ grau de $\mathrm{n} 1=2$

Fonte: WASSERMAN; FAUST, 1997, p. 98

O grau de um nó é uma das medidas mais importantes, pois indica a intensidade da atividade exercida por um determinado nó. Supondo que n1 seja um centro comercial, a sua maior ou menor importância é representada pelo seu maior ou menor valor de grau, quando os centros de hierarquia mais elevada devem apresentar o grau mais elevado em comparação aos centos de hierarquia menos importantes.

A densidade, de um grafo e de um subgrafo, é a proporção entre a quantidade de linhas presentes e a quantidade máxima de linhas possíveis. A densidade pode variar de 0 , quando não existem linhas, até 1 , quando todos os seus nós estão interligados.

O passeio é a seqüência de nós e linhas que inicia e termina em nós distintos. É a base para o cálculo da distância entre dois nós num grafo. Num passeio, em determinadas situações particulares, os mesmos nós e linhas podem ser contados várias vezes. O tamanho de um passeio é a quantidade de ocorrências de linhas. 


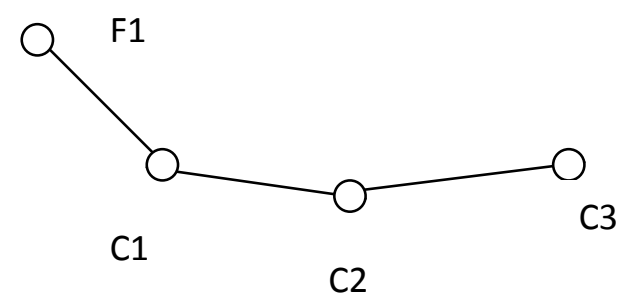

A família F1, para chegar ao centro $\mathrm{C} 3$, necessita realizar dois transbordos em C1 e C2. Portanto, a medida do passeio é 3, em conseqüência dessa família percorrer as três linhas, sendo $\mathrm{F} 1$ a origem e $\mathrm{C} 3$ o destino final.

Trilha é um tipo diferenciado de passeio, quando se utiliza cada linha apenas uma vez e é permitida a repetição de determinados nós.

Caminho é o passeio, quando todos os nós e linhas são utilizados apenas uma vez, sem a ocorrência de repetição de linhas ou nós. Portanto, o caminho é a medida mais curta entre o nó de origem e de destino.

Um determinado nó de destino é considerado alcançável, quando existe um caminho entre a origem e o destino.

Geodésico é o caminho mais curto entre dois nós. Distância geodésica ou simplesmente distância entre dois nós é definida como sendo a medida geodésica entre eles. (Vide aplicação na página 221 no tópico sobre medida de proximidade)

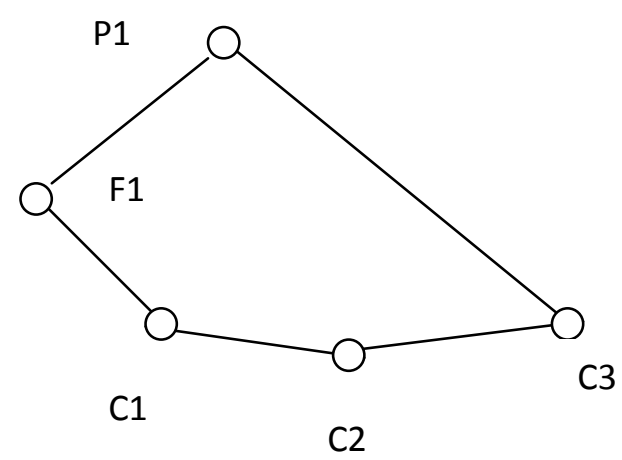

Figura 1.2 - Exemplo de rede para o cálculo de distância geodésica

A família F1, para chegar ao centro $\mathrm{C} 3$, possui duas alternativas. A primeira é passar por $\mathrm{C} 1 \mathrm{e}$ C2, necessitando de dois transbordos. A outra é passar por P1, realizando um único transbordo. A distância geodésica, a mais curta, é o caminho F1, P1, C3, sendo o seu valor igual a 2. O caminho F1, C1, C2 e C3 deixa de ser geodésico por ser o mais longo, pois obtém o valor igual a 3 . 
A excentricidade de um nó é a maior medida geodésica, que se verifica entre os nós mais distantes de um grafo. A excentricidade pode variar entre 1 e a quantidade máxima de linhas, calculada pela fórmula g-1, sendo g a quantidade de nós.

O diâmetro de um grafo é a maior distância geodésica entre os pares de nós, ou seja, é a maior excentricidade de um nó. $\mathrm{O}$ diâmetro de um grafo pode variar entre 1 e o máximo de $\mathrm{g}-1$, sendo g a quantidade de nós. No exemplo da figura 1.2 o diâmetro do grafo é igual a 2.

As relações são direcionais, quando são orientadas de um ator para outro. Consiste num conjunto de nós, correspondendo aos atores de uma rede, e um conjunto de arcos direcionados entre os pares de nós, que representa as relações direcionadas entre os atores. As linhas direcionadas formam os arcos e as suas direções são previamente especificadas.

Em grafos direcionados, o grau de um nó, que é a quantidade de linhas incidentes dentro de um nó, conforme apresentado anteriormente, em relação a um determinado nó pode ser de "entrada", quando esse nó estiver recepcionando uma relação, ou de "saída", quando esse nó estiver enviando uma relação. O grau de entrada é a quantidade de arcos, que terminam num nó. O grau de saída é a quantidade de arcos, que tem a origem nesse mesmo nó. O grau de saída mede as características de expansão, o grau de entrada corresponde à medida de receptividade ou de popularidade.

Existem vários tipos de nós: isolado, quando não existem arcos iniciando ou terminando no próprio nó; transmissor, quando existe somente grau de saída; receptor, quando há apenas grau de entrada; transportador, quando o seu grau de entrada ou de saída é igual a 1; ordinário, sempre que o seu grau de entrada ou de saída é acima de 1 .

Habitualmente as representações gráficas são feitas da seguinte maneira:

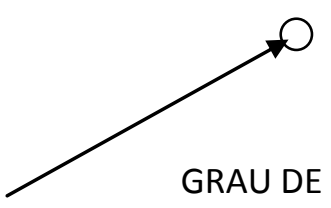

ENTRADA

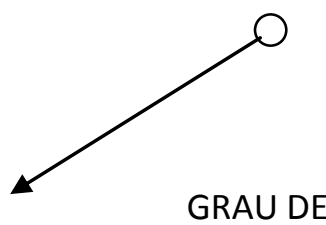

SAÍDA

Existem quatro tipos de conectividade num dígrafo, também denominado grafo direcionado: fraca, quando todos os seus pares de nós são formados por conexão de direções variadas e distintas; unilateral desde que todos os seus pares de nós sejam conectados seguindo uma única direção; forte caso todos os seus pares de nós consigam fechar um circuito completo; e 
recursiva numa situação que todos os seus pares de nós são conectados por grau de entrada e de saída ao mesmo tempo.

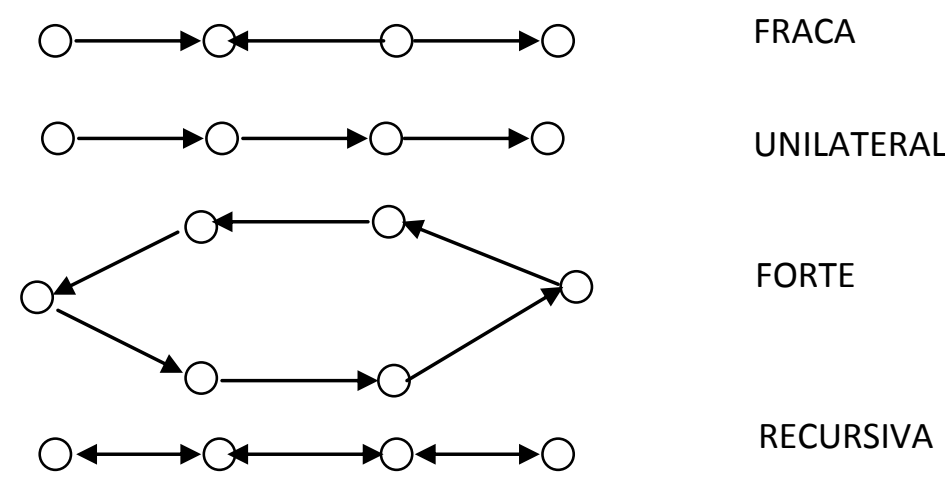

Fonte: WASSERMAN; FAUST, 1997, p.133

Em relação aos arcos, um díade ou par de nós, pode ser nulo na ausência de arcos; assimétrico, quando possuir apenas uma única direção; e mútuo ou recíproco diante da existência de dois arcos.

NULO

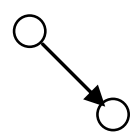

ASSIMÉTRICO

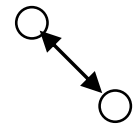

MÚTUO

Os grafos mais freqüentemente utilizados em redes sociais são os não direcionados e os direcionados ou dígrafos. Entretanto, existem outros tipos, tais como sinalizados, valorados, multígrafos e hipergrafos.

Os grafos sinalizados podem ser direcionados ou não direcionados. Em decorrência das características das relações entre os nós, as linhas recebem informações de sinais, negativos ou positivos. A título de exemplo, relações de maior intensidade recebem sinais positivos, já as de menor intensidade recebem sinais negativos.

Em grafos valorados, adiciona-se um valor ou magnitude em cada linha ou arco. Existem vários tipos diferentes de grafos valorados: grafos com pesos ponderados; grafos integrais; redes; cadeia de Markov; etc. Os seus correspondentes valores ficam associados a cada linha em grafos não direcionados ou em cada arco em dígrafos valorados ou direcionados valorados. Os grafos direcionados podem ser dos tipos ponderados ou integrais. Nesse caso, 
opcionalmente, a medida de grau de cada um dos nós pode corresponder à média dos valores de suas linhas ou arcos.

Grafos são simples quando existe, no máximo, uma linha ou relação entre um par de nós. Num multígrafo, e também num grafo direcionado multivariado, existe uma ou mais linhas conectando dois nós. Por exemplo, num multígrafo, descrevendo o relacionamento entre os funcionários de uma empresa, pode-se representar uma relação de amizade e outra relação formal de hierarquia funcional, num mesmo par de nós, entre um determinado chefe e o seu respectivo subordinado.

Hipergrafos são grafos utilizados em redes sociais de modo múltiplo ou duplo, próprios para rede de afiliação, contendo conjuntos distintos de atores.

\subsection{Conceitos de centralidade}

Dentre os vários tipos distintos de grafos, o foco encontra-se dirigido apenas a dois deles: o direcionado ou dígrafo e o não direcionado.

Em redes sociais, a centralidade envolve o conceito do papel estratégico de determinados atores dentro da rede. Em outras palavras, centralidade significa a identificação de atores mais importantes, ou seja, um nó ou ator central (o mais importante) é aquele que mantém o maior grau ou a maior quantidade de relacionamento com os demais atores da rede.

Um determinado centro comercial mais importante ou central, mantendo relacionamento com famílias, de elevado número de localidades periféricas, pode apresentar o índice de centralidade bastante significativo e alto. Por exemplo, o centro $\mathrm{C} 1$ da figura 1.3, que se relaciona com todas as famílias M1 ao M8. Todavia, outro centro mais periférico e menos importante apresenta o índice de centralidade bem mais baixo, em relação ao índice de centralidade do local mais importante ou central, tendo em vista a reduzida quantidade de relacionamentos, decorrente de um número inferior de famílias atendidas. Ainda, na figura 1.3, o Centro C2 por ser periférico, atende apenas as famílias M6 ao M8 e conseqüentemente, o seu índice de centralidade é relativamente baixo. 


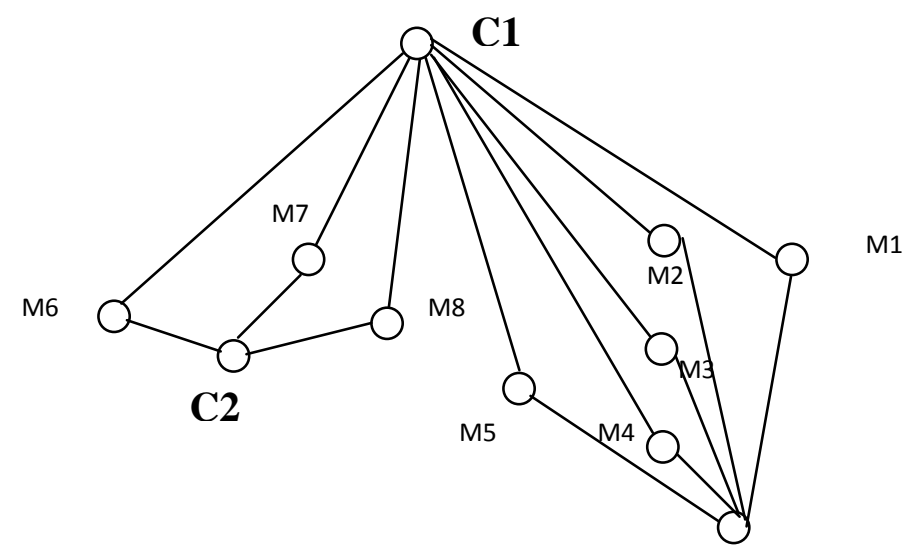

C3

Figura 1.3 - Exemplo de uma rede social com 3 centros e 8 famílias

Em grafos não direcionados, existe, para cada nó, apenas um único valor de cada tipo de medida de centralidade.

Em dígrafos, cada nó ou ator recebe dois tipos de valores. O primeiro de entrada, quando o ator estiver "recebendo" as relações dos demais atores. O segundo de saída, se o ator estiver "enviando" relações aos demais atores. O conceito de centralidade deve receber tratamentos distintos para grafos não direcionais e direcionais (dígrafos). (Vide grafos direcionados na página 46)

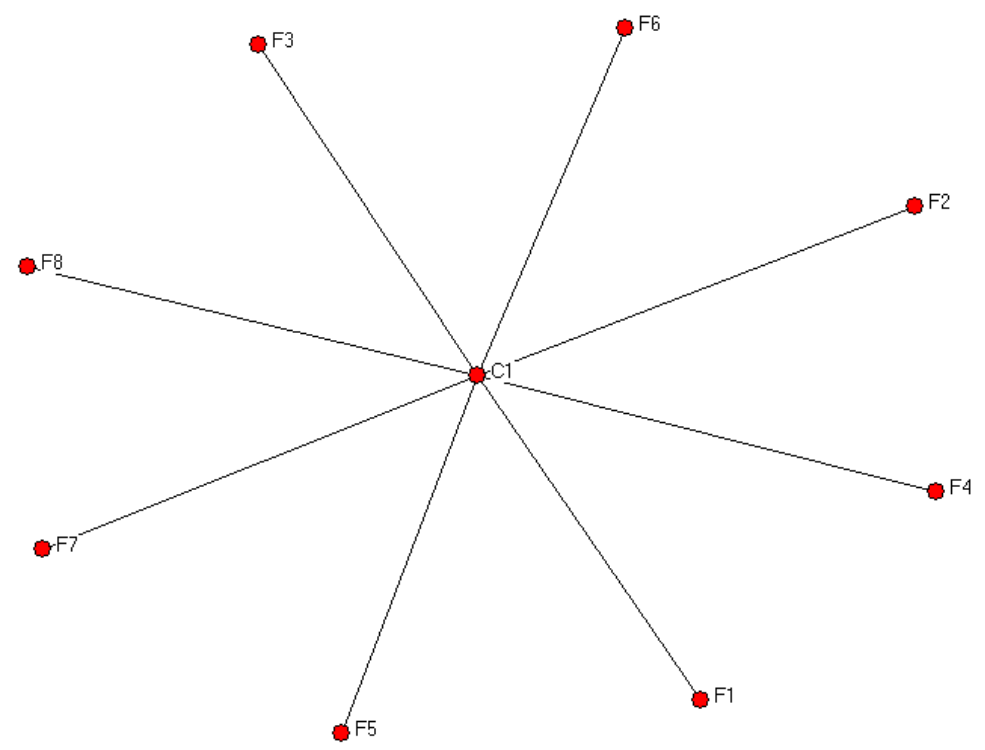

Figura 1.4 - Exemplo de uma rede social com 1 centro e 8 famílias em forma de uma estrela Fonte: adaptado de WASSERMAN; FAUST, 1997, p. 171 


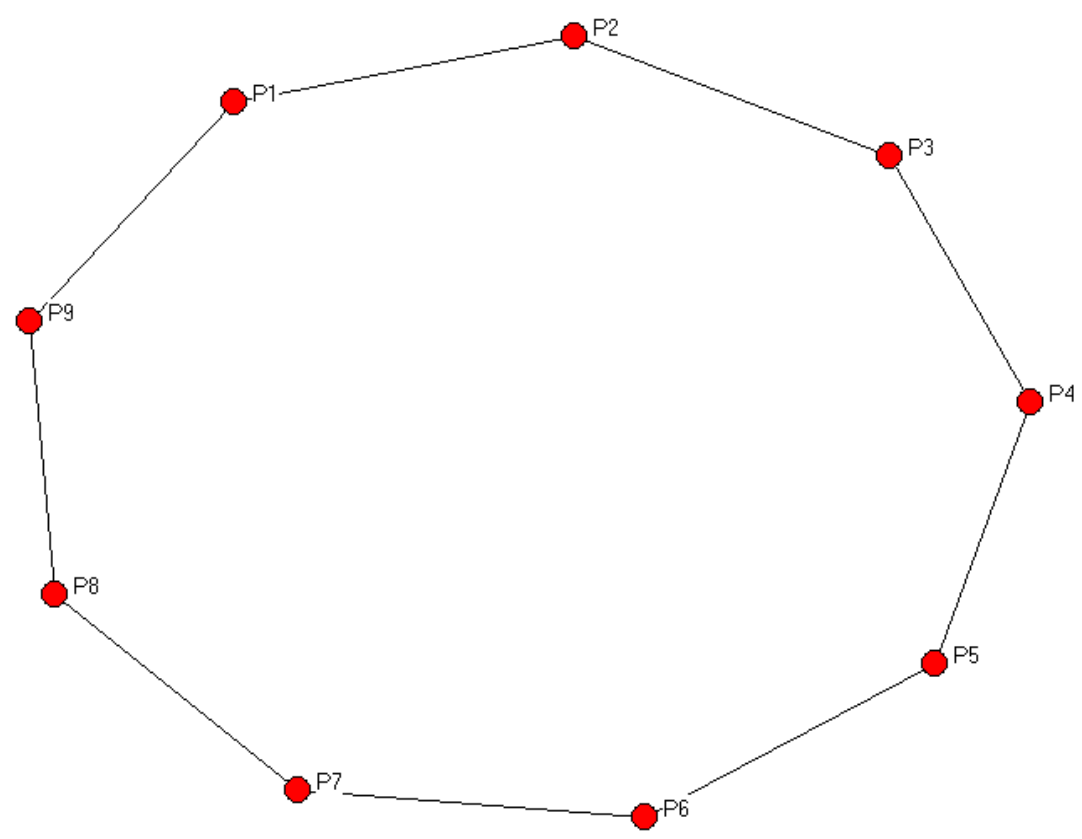

Figura 1.5 - Exemplo de uma rede social com 9 postos em forma de um círculo Fonte: adaptado de WASSERMAN; FAUST, 1997, p. 171

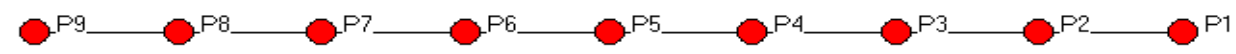

Figura 1.6 - Exemplo de uma rede social de 9 postos em linha reta Fonte: adaptado de WASSERMAN; FAUST, 1997, p. 171

A figura 1.4 é uma representação hipotética de um local central (C1), que relaciona com 8 famílias (F1 a F8), localizadas na periferia. A figura 1.5 representa, hipoteticamente, 9 postos de serviços (P1 a P9), localizados num anel viário sem acesso por outras vias. A figura 1.6 
corresponde a um exemplo hipotético de 9 postos de serviços, localizados num determinado trecho de uma rodovia sem acesso por outras vias.

As três principais medidas de centralidade são: grau, proximidade e posicionamento.

\subsection{Medidas de centralidade para grafos não direcionados}

A medida de centralidade grau indica a quantidade de relações, que um ator ou nó, mantém entre si (vide aplicação desse conceito na página 200).

Na figura 1.4, o centro C1 mantém relação com 8 famílias (atores) F1 a F8, localizados na periferia. Portanto, o valor de grau para o centro $\mathrm{C} 1$ é igual a 8 , que corresponde ao total de relações verificadas com todas as famílias F1 a F8, em relação a esse centro C1.

Para cada uma das famílias (atores F1 a F8) o seu valor de grau é igual a 1, em consequiência de cada uma delas manter o relacionamento com apenas o centro $\mathrm{C} 1$.

Portanto, o ator $\mathrm{C} 1$ é o mais importante por manter relações com todas as famílias da periferia, em conseqüência do seu valor de grau igual a 8 , o maior, em comparação ao valor de grau igual a 1, de cada um dos atores periféricos. $\mathrm{O}$ centro $\mathrm{C} 1$ constitui estrategicamente o local central dessa rede social.

O valor da medida global da centralidade grau, da rede da figura 1.4, é igual a 1 ou 100\%, pois existe apenas um nó central nessa rede social.

No exemplo da figura 1.5, cada um dos postos de serviços (nós P1 a P9) obtém o valor de grau igual a 2, pois cada um desses nós mantém relação com apenas 2 vizinhos. Sendo a medida de grau igual a 2 para cada um dos nós, todos eles detêm o mesmo grau de importância, e não há um ator central ou o mais importante.

O valor da medida global da centralidade grau, da rede da figura 1.5 , é igual a 0 ou $0 \%$. Não existe um ator ou posto de serviço central nessa rede, em conseqüência da localização num anel rodoviário, sendo assim, não há a possibilidade de identificar um determinado posto de serviços central.

Observando a figura 1.6, o valor da medida de grau é igual a 1 para todos os postos de serviços das extremidades (P1 e P9), por manterem relação com apenas 1 vizinho. Todavia, o 
valor da medida de grau é igual a 2, para cada um dos demais nós (P2 ao P8), logo o seu relacionamento é realizado com 2 outros vizinhos.

O valor da medida global da centralidade grau, da rede da figura 1.6, é igual a 0,0357 ou $3,57 \%$, relativamente baixo por causa da pequena possibilidade do ator central (P5) realizar algum papel central entre os seus vizinhos mais próximos. Entretanto, em conseqüência da sua localização numa rodovia, não possui tanto poder de influência entre os demais concorrentes mais distantes neste trecho de estrada. Em outras palavras, exceto os dois postos da extremidade, qualquer um dos postos pode exercer um pequeno papel de centralidade em relação aos seus dois vizinhos mais próximos.

De acordo com a medida de centralidade de 'proximidade', um determinado ator, sendo o mais próximo em relação aos demais atores de uma rede social, é considerado o "mais central". O critério é baseado no cálculo da distância geodésica da rede social, ou seja, o ator mais próximo é aquele com a menor distância geodésica em relação aos seus nós adjacentes. (vide aplicação desse conceito na página 221)

Na figura 1.4, o centro $\mathrm{C} 1$ é o mais próximo, em relação a todas as famílias F1 a F8, é, por causa disso, o mais central. $\mathrm{O}$ valor da medida de proximidade é igual a 8 para $\mathrm{C} 1$, sendo igual a 15, o valor para cada um dos demais pontos $\mathrm{F} 1$ a F8. O centro $\mathrm{C} 1$ é o ponto central, por apresentar o seu menor valor igual a 8, bem inferior ao valor 15 obtido pelos demais pontos.

O valor da medida global da centralidade proximidade, da rede da figura 1.4, é igual a 1 ou $100 \%$, pois existe apenas um ator ou um centro mais próximo de todos os demais pontos.

O resultado da medida de proximidade de cada um dos postos de serviços, do exemplo da figura 1.5, é igual a 20. Como todos os valores são iguais, não se pode identificar qual é o nó central ou mais próximo num anel rodoviário.

$\mathrm{O}$ valor da medida global da centralidade proximidade, da rede da figura 1.5, é igual a $0 \mathrm{ou}$ $0 \%$. Portanto, não existe um ator ou posto de serviço central nessa rede, em decorrência da localização num anel rodoviário. Sendo assim, não há a possibilidade de identificar qual é o posto de serviços central.

O exemplo da figura 1.6 apresenta o valor da medida de proximidade igual a 36 , o mais alto de todos, para os nós P1 e P9 localizados nas extremidades. O ator P5, cujo valor dessa 
medida é igual a 20, o mais baixo de todos, está localizado bem no centro da rede. Em seguida, os atores P4 e P6 adjacentes ao P5, mantêm o valor dessa medida igual a 21. Os atores P3 e P7, um pouco mais afastados, recebem o valor de proximidade igual a 24. Finalmente, os postos P2 e P8, bem mais afastados, obtêm o valor de proximidade igual a 29. À medida que os atores se afastam de P5 (central), os valores das medidas de proximidade aumentam atingindo o valor máximo igual a 36.

O valor da medida global da centralidade proximidade, da rede da figura 1.6, é igual a 0,2077 ou 20,77\%, relativamente baixo. Apesar do posto de serviço P5 ser o mais central, cada um dos demais postos, exceto os dois extremos, pode também exercer o papel de eventuais centros regionais em relação aos seus vizinhos mais próximos.

Conceitualmente, em redes sociais, na ótica da medida de centralidade de 'posicionamento' os atores intermediários são aqueles que possuem o poder de maior controle, entre os nós não adjacentes, no processo de relacionamento. O posicionamento torna-se relevante numa análise de atores não adjacentes numa rede. O relacionamento entre atores não adjacentes, desde que haja acessibilidade, pode depender da localização dos atores intermediários. A medida de posicionamento é feita, por meio da soma de todas as distâncias geodésicas de um determinado ator intermediário, em relação a outros nós não adjacentes. (vide aplicação desse conceito na página 232)

Por exemplo, muitos moradores da periferia chegam a um centro principal sem a necessidade de transbordo. Outros moradores, em consequiência do sistema de transporte urbano, necessitam de um ou mais transbordos para chegarem a um centro principal. Os que não necessitam de transbordo, independem de nós intermediários de uma rede. Já aqueles que necessitam de transbordo permanecem na dependência dos nós intermediários. Assim, quanto maior for a quantidade de transbordo, maior é o tempo necessário para a locomoção.

Na figura 1.4, o centro $\mathrm{C} 1$ é o único intermediário, dentre todos os demais nós, e, obteve o valor da medida de posicionamento igual a 28 , o que corresponde à quantidade máxima de combinações em relação às possibilidades de intermediação, com cada um dos nós F1 a F8. Cada uma das famílias F1 a F8 recebem o valor da medida de posicionamento igual a 0 por não serem intermediários. 
O valor da medida global da centralidade posicionamento, da rede da figura 1.4, é igual a 1 ou $100 \%$, pois existe somente um ator ou um centro, nessa rede, com poderes de intermediação. As demais famílias continuam na dependência desse único centro.

Observando a figura 1.5, cada um dos postos de serviço recebe o valor da medida de posicionamento igual a 6 , todos com o mesmo valor, por estarem localizados num anel viário. Dessa forma, cada posto pode ser intermediário dos demais 6 postos não adjacentes.

O valor da medida global da centralidade posicionamento, da rede da figura 1.5, é igual a 0 ou $0 \%$, porque não existe um ator ou posto de serviço central nessa rede. Conseqüentemente, por se tratar de um anel rodoviário, não há a possibilidade de definir o posto de serviços central que assume o papel de intermediário, pois todos eles podem executar a intermediação dos seus concorrentes não adjacentes.

No exemplo da figura 1.6, os postos de serviços das extremidades, P1 e P9, recebem o valor da medida de posicionamento igual a 0 por não serem intermediários. O nó P5, o mais central, por deter o maior potencial de intermediação, obtém o valor da medida de posicionamento igual a 16. Os demais nós, à medida que se afastam de P5, têm o seu poder de intermediação reduzido. P6 e P4 têm valores iguais a 15, P3 e P7 iguais a 12 e, finalmente, P2 e P8 iguais a 7.

O valor da medida global da centralidade posicionamento, da rede da figura 1.6, é igual a 0,2679 ou $26,79 \%$, relativamente baixo. Por conseguinte, não existem pontos centrais específicos e todos os postos, exceto os dois extremos, podem ser intermediários. 


\subsection{Medidas de centralidades para grafos direcionados}

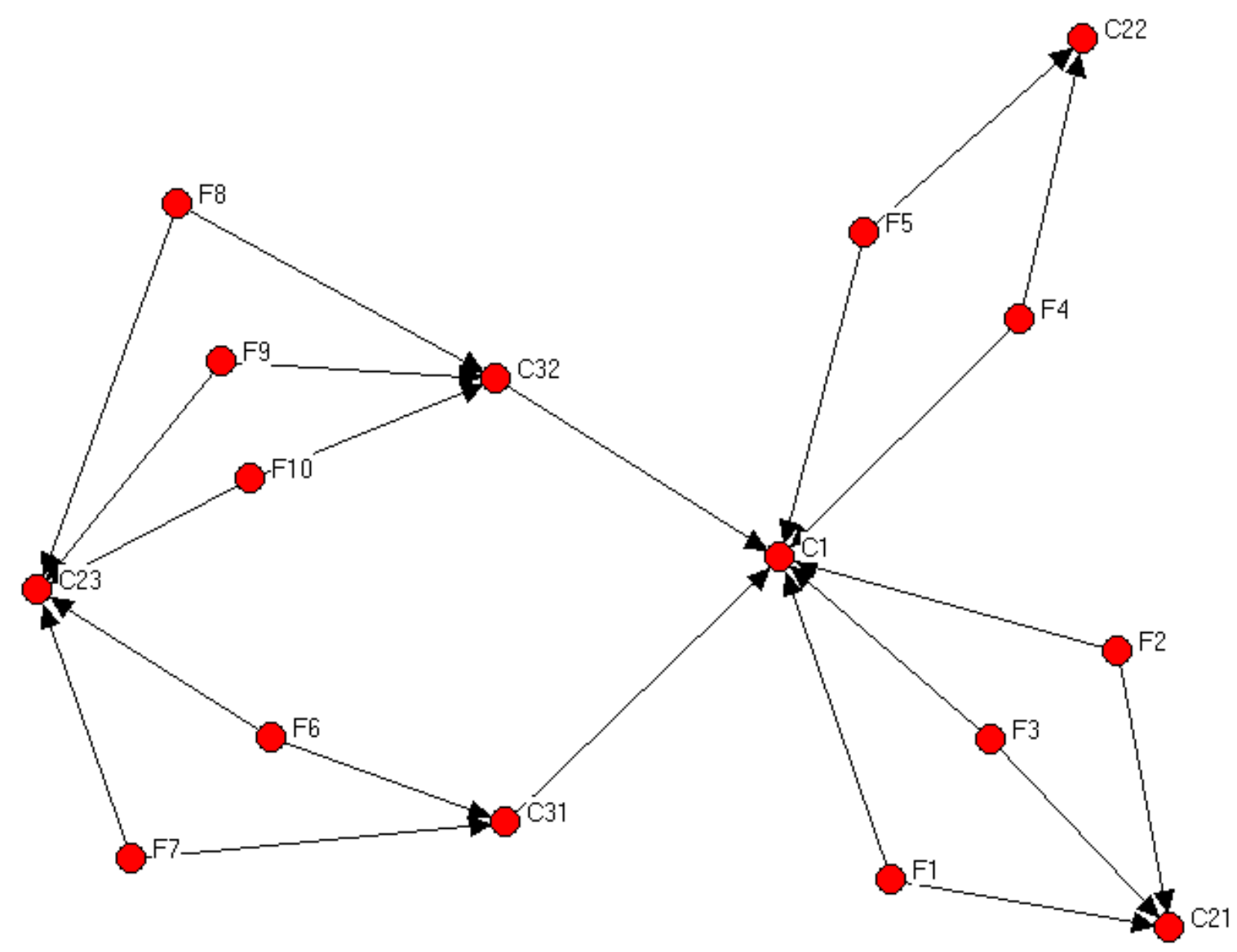

Figura 1.7 - Exemplo de uma rede social (direcionada) com 6 centros e 10 famílias

A figura 1.7 apresenta um exemplo hipotético, com participação de dez famílias. Cinco delas, representadas por F1 a F5, se relacionam diretamente com o centro $\mathrm{C} 1$, ou então, com os sub centros C21 (famílias F1 a F3) e C22 (famílias F4 e F5). A relação das outras cinco famílias se verifica diretamente com o sub centro C23 (famílias F6 a F10) e, também, com os sub centros C31 (famílias F6 e F7) e C32 (famílias F8 a F10). Essas últimas cinco famílias conseguem se relacionar com o centro principal $\mathrm{C} 1$, somente com a intermediação dos sub centros C31 e C32, que podem ser os pontos de baldeação do transporte coletivo, por não existir a opção de acesso direto ao referido centro $\mathrm{C} 1$.

O desenvolvimento dos conceitos de centralidades, para um grafo direcionado, está fundamentado no exemplo hipotético da figura 1.7.

Por se tratar de grafo direcionado, são apresentadas duas medidas de centralidade grau: a de entrada e a de saída. Os pontos, recepcionando as famílias, representados por C1, C21, C22, 
C23, C31 e C32, obtêm os valores de medidas de grau de entrada iguais a 7, 3, 2, 5, 2 e 3, respectivamente. Os centros $\mathrm{C} 31$ e $\mathrm{C} 32$, pontos de passagem para $\mathrm{C} 1$, obtêm o valor da medida de grau de saída igual a 1, ou seja, esses dois últimos nós, C31 e C32, mantêm as duas medidas, de entrada e de saída. Cada uma das famílias F1 a F10 permanecem com o valor da medida de grau de saída igual 2, pois se relacionam com 2 centros.

Na rede da figura 1.7, o valor da medida global de saída, da centralidade grau, é igual a $4,44 \%$, logo não existem famílias em posições centrais na rede. Os $40,0 \%$ de valor da medida global, de entrada, da centralidade grau, mostra que existem alguns pontos centrais significativos, por exemplo, o centro $\mathrm{C} 1$. Entretanto, não é o único diante da existência de alguns sub centros, tais como C21, C22 e C23, ou os pontos de transbordo, C31 ou C32.

Por se tratar de um grafo direcionado, aparecem duas medidas de centralidade de proximidade, de entrada e de saída. O ponto $\mathrm{C} 1$ é o mais central, o seu valor da medida de proximidade de entrada é igual a 65, seguido por C23, com o valor de proximidade entrada igual a 165 e C21 obteve o valor de proximidade de entrada igual a 195. Em consequiência da elevada quantidade de relações, o sub centro C23 equivale à distância geodésica, para as famílias F6 a F10, quando se dirigem a esse sub centro. O sub centro C22 é o "mais distante", entretanto os pontos de transbordo C32 e C31 apresentam os valores de proximidade de entrada iguais a 195 e 210, respectivamente. Nesse exemplo, quanto mais baixo for o valor de proximidade de entrada, mais fácil é o acesso para maior número de pessoas. Ou seja, os pontos mais centrais do tipo C1 são os locais onde podem ser oferecidas as mais variadas opções de produtos e de serviços.

A medida de centralidade de posicionamento, quanto à metodologia de cálculo, não apresenta diferenças entre grafos direcionados e não direcionados. Neste exemplo, as famílias com acesso direto aos centros ou aos pontos de transbordo apresentam os valores iguais a 0 . Os pontos de transbordo C32 e C31 apresentam valores diferentes de zero, iguais a 3 e 2 respectivamente, o que indica maior dependência das famílias F8 a F10 e menor dependência das famílias F6 e F7.

O valor da medida global da centralidade posicionamento, da rede da figura 1.7, é igual $1,37 \%$, bastante baixo. Portanto, nessa rede hipotética existe pouca dependência de transbordo para a maioria das pessoas chegarem a determinados destinos. 


\subsection{Conceitos de equivalência}

Observa-se numa rede social, uma série ou eventualmente um grupo de atores ou nós, com os mesmos valores de grau, proximidade e posicionamento, que mantém relações comuns com os mesmos nós ou então com os mesmos grupos de atores. Atores, que possam satisfazer essas condições, são considerados equivalentes e podem ser substituídos, entre si, sem trazer prejuízo nas propriedades de uma rede social. Um dos principais objetivos, aplicando-se os conceitos de equivalência, é identificar grupo de atores que apresentam características comuns. Portanto, o estudo do relacionamento das famílias com os centros, onde satisfazem as suas habituais necessidades de compras, ajuda a identificar os grupos de famílias com as mesmas necessidades em relação a determinados centros comerciais. (vide aplicação desse conceito na página 249)

Existem várias modalidades diferentes de equivalência, sendo algumas delas: equivalência estrutural; equivalência automórfica e equivalência regular.

$\mathrm{Na}$ equivalência estrutural, dois atores são estruturalmente equivalentes, quando esses mesmos atores estabelecem relações estruturais comuns com outros atores, que devem ser igualmente comuns a esses dois. Existem dois critérios básicos: a distância euclidiana, que apresenta vantagens na análise das características de cada nó ou ator; e a correlação de cada um dos nós da rede. (vide aplicação desses conceitos na página 250).

Adotando-se o exemplo da figura 1.7, sob o critério de distância euclidiana, os centros C1 e C21 constituem uma equivalência estrutural, pelas relações comuns existentes entre as famílias F1 a F3. A seguir, os centros C23 e C32, também são estruturalmente equivalentes por estarem relacionados com as famílias F8 a F10. O centro C31 faz parte de outra estrutura equivalente ao estar relacionado com as famílias F6 e F7. O centro C22 compõe o último grupo, em função da relação com as famílias F4 e F5.

Outros quatro grupos podem ser identificados, e estão constituídos pelas famílias F1, F2, F3; F4 e F5; F6 e F7; F8, F9 e F10. 
Em resumo, ao aplicar o método de distância euclidiana, obtêm-se os grupos abaixo:

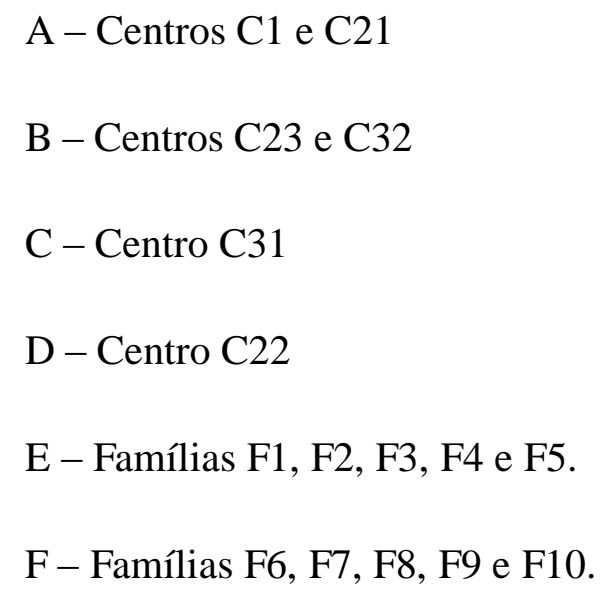

De acordo com o método de correlação, obtiveram-se quatro grupos estruturalmente equivalentes:

$\mathrm{I}$ - Centros C1, C21 e C22.

II - Centros C31, C32 e C23.

III - Famílias F1, F2, F3, F4 e F5.

IV - Famílias F6, F7, F8, F9 e F10.

Considerando-se o método de correlação mais apropriado para a análise de similaridade entre os atores, ao compararmos com o critério da distância euclidiana, cujo objetivo principal é obter as características de cada nó da rede social, nota-se o resultado um pouco diferente.

Pelo método de correlação, a relação com as famílias F1 a F5 torna os centros C1, C21 e C22 similares. No critério de distância euclidiana somente as famílias F1 a F3 estão mais próximas dos centros C1 e C21, exclui-se do grupo o centro C22. A relação das famílias F6 a F10 com os centros C31, C32 e C23 estabelece a similaridade desses três centros. Entretanto, apenas as famílias F8 a F10 estão mais próximas dos centros C32 e C23, exclui-se do grupo o centro C31 no critério de distância euclidiana.

A equivalência automórfica é mais abrangente que a estrutural. Vários atores apresentam a equivalência automórfica, quando as suas estruturas de relações forem equivalentes morfologicamente e não há a obrigatoriedade das relações estarem constituídas, necessariamente, com os mesmos atores tal qual ocorre na equivalência estrutural. 
No exemplo da figura 1.7, embora as famílias F4 e F5 não mantenham relações com o centro C21 e as famílias F1 a F3 não tenham relações com o centro C22, os centros C21 e C22 fazem parte de uma equivalência automórfica em decorrência das relações com as famílias F1, F2, F3, F4 e F5. Estes centros C21 e C22, em conseqüência do resultado do valor da medida de centralidade posicionamento ser, para ambos, igual a 0 , podem compor uma equivalência automórfica. Na equivalência estrutural existe a separação das famílias F1, F2, F3 das famílias F4 e F5 em conseqüência das relações (estruturas) distintas com os centros C21 e C22. O mesmo não acontece no critério da equivalência automórfica.

Os centros C31 e C32 participam de outro grupo de equivalência automórfica, por causa da relação com as famílias F6, F7, F8, F9 e F10. Pode-se, opcionalmente, incluir nesse grupo o centro C23, em decorrência da sua relação com as famílias F6 a F10. O ponto crucial da distinção, em comparação com os centros C21 e C22 do outro grupo, é a dependência das famílias F6 a F10 dos centros C31 e C32, quando for necessário o relacionamento com o centro C1.

Em resumo, obtêm-se para a equivalência automórfica, os seguintes grupos:

I - Centros C1, C21, C22, C23.

II - Centros C31, C32.

III - Famílias F1, F2, F3, F4 e F5.

IV - Famílias F6, F7, F8, F9 e F10.

A equivalência regular é a mais flexível de todas as três. Ao contrário do método da equivalência estrutural ou automórfica, não está necessariamente vinculada a uma estrutura rígida da morfologia das relações. O ponto chave, para a equivalência regular, é a posição de cada ator na rede social.

No exemplo da figura 1.7, o centro $\mathrm{C} 1$ faz parte de um grupo isolado por se relacionar diretamente com todas as cinco famílias F1 a F5 e, indiretamente, por meio dos centros C31 e C32, também com as demais famílias F6 a F10. Dessa forma, a sua posição a mais poderosa, já que se relaciona com todas as famílias presentes na rede social. Em seguida, os centros C21 e C22 constituem outro grupo, porém menos poderoso que $\mathrm{C} 1$, já que há divisão do relacionamento das famílias F1 a F5, pertencendo três famílias para C21 e duas famílias para C22. Em terceiro lugar, observa-se um grupo constituído pelo centro C23, com uma posição 
bastante forte, porém mais fraca que $\mathrm{C} 1$, ao relacionar diretamente com as cinco famílias $\mathrm{F} 6$ a F10. Finalmente, os centros C31 e C32 formam outro grupo de intermediários das famílias F6 a F10, fazendo parte do primeiro as famílias F6 e F7 e do segundo as famílias F8 a F10.

Em resumo:

I - Centro C1

II - Centros C21, C22.

III - Centro C23

IV - Centros C31 e C32

V - Famílias F1, F2, F3, F4 e F5.

VI - Famílias F6, F7, F8, F9 e F10.

Por meio da aplicação dos conceitos de equivalência em redes sociais, pode-se identificar e entender melhor as relações existentes numa organização espacial, que envolve o processo de satisfação das necessidades dos moradores de uma determinada região, no tocante ao suprimento de bens e serviços. Essa aplicação, das técnicas utilizadas na identificação da equivalência dos nós ou atores, pode ajudar a compreender melhor, as características das funções executadas por cada um dos centros, em relação às vantagens ou desvantagens proporcionadas pela mobilidade e acessibilidade da população. 
2 CONCEITOS SOBRE ANÁLISE E ESTATÍSTICA ESPACIAL 


\subsection{Introdução}

Um bom entendimento de todo espaço urbano bastante complexo, de uma maneira eficaz, pode ser realizado opcionalmente por meio do uso de instrumentos e ferramentas que permitam registrar e atualizar sistematicamente todas as informações mais relevantes para uma análise das potencialidades locais, diante de toda a dinâmica decorrente do crescimento e desenvolvimento econômico e urbano, de tal forma que possibilite o fornecimento de orientações consistentes para a tomada de decisões racionais.

Podemos entender decisões racionais na ótica filosófica de Habermas, a de universalização, com a solução racional dos conflitos diante da ética da responsabilidade solidária em respeito à legislação, principalmente a de proteção ambiental na região de mananciais. Desta maneira, as autoridades municipais poderiam evitar a invasão nas áreas de risco de deslizamento de encostas, ou às margens dos córregos e da represa Billings, o desmatamento das reservas naturais; os proprietários dos grandes imóveis deixariam de promover os loteamentos irregulares na ânsia de recuperarem o capital diante de uma possível desvalorização dessas propriedades, bem como, regulamentação da atividade de comércio através de legislação municipal específica na área de mananciais como existe no município de Diadema na Av. Nossa Senhora dos Navegantes.

Torna-se importante a identificação das soluções mais adequadas para a instalação de equipamentos urbanos de interesse econômico, por exemplo, centros comerciais, bem como, de interesse social que abrange escolas, hospitais, ou melhores soluções de transportes, sob a ótica da necessidade de circulação das pessoas e, assim evitar agressões ao meio ambiente.

O sistema de informações geográficas, por meio das ferramentas de geoprocessamento, pode ser uma das soluções alternativas, que ajuda a análise da organização do espaço urbano no tocante às relações sociais com o comércio, tendo em vista a acessibilidade e mobilidade das pessoas, em decorrência das características de um sistema urbano de transporte de massa o qual contribui para a determinação dos nós ou pontos que podem corresponder aos centros de influência.

Neste trabalho, na parte que se refere ao sistema de informações geográficas, a ênfase se refere à análise espacial da função comercial, observada no Distrito de Pedreira. Um dos seus focos principais é a descrição e a análise da sua localização geográfica. Igualmente, será desenvolvida a análise dos padrões de agrupamento do comércio de determinadas regiões, 
sendo as principais o Largo 13 de Maio em Santo Amaro e o centro comercial do Município de Diadema. Ao mesmo tempo, será mostrado o agrupamento de comércio em alguns logradouros, tais como Estrada do Alvarenga, Avenida Yervant Kissajikian e Avenida Nossa Senhora do Sabará, e também nos Shopping Centers Interlagos e Interlar. Esses locais foram indicados pelos moradores do Distrito de Pedreira e correspondem a algumas das opções para a satisfação das suas necessidades habituais de compras. Os estabelecimentos comerciais foram georeferenciados, por meio da aplicação da feição ponto, cujos atributos estão organizados em tabela vinculada ao mapa de logradouros, onde se localiza o comércio objeto do estudo.

A análise espacial está fundamentada em duas etapas. A primeira é quantitativa, baseada na aplicação de recursos de estatística espacial, pertinentes para o estudo de localização geográfica. Por meio da ajuda das funções estatísticas disponíveis e utilizadas num sistema de informações geográficas, uma das variáveis básicas adotadas é a distância entre os pontos. A segunda está baseada na análise qualitativa dos resultados obtidos, com o desenvolvimento da descrição e o estudo das características dos padrões de aglomeração ou dispersão dos estabelecimentos comerciais. O padrão da distribuição espacial do comércio, eventualmente, pode exercer uma força centrípeta atraindo os moradores de determinadas regiões, trata-se, muitas vezes, de uma das conseqüências da acessibilidade proporcionada pelo sistema radioconcêntrico de transporte urbano, ou decorrente do sistema das principais vias de acesso.

Segundo Goodchild a análise espacial ou análise de dados espaciais sugere uma ênfase na localização. Em análise espacial, os dados são estudados de maneira estática, todavia representam informações de determinadas localizações e também referentes a um determinado período de tempo (GOODCHILD; JANELLE, 2004). Por exemplo, pode-se analisar apenas a população residente do Distrito de Pedreira, do ano de 2000, pesquisando as informações no censo demográfico realizado naquele ano.

A elaboração de um mapa pode ser uma das formas mais intuitivas de se realizar uma análise espacial. Às vezes, pode ser muito difícil, a obtenção de explicações intuitivas de algumas causas. Ao mesmo tempo, uma análise espacial está sujeita a certas limitações, pois algumas vezes não se podem confirmar todas as teorias. Entretanto, a análise espacial, pode ser muito útil para elaborar questionamentos ou hipóteses quando estiver fundamentada numa pesquisa exploratória (GOODCHILD; JANELLE, 2004). Por exemplo, podem-se observar num mapa, as áreas do Distrito de Pedreira ocupadas pelo processo de loteamentos irregulares ou 
clandestinos, sendo uma das possíveis causas a promulgação da lei de proteção ambiental, que criou um interesse em lotear irregularmente as grandes áreas perante o risco de uma provável desvalorização desses grandes imóveis. Essas informações que mostram a realidade de um tipo diferenciado de ocupação do solo, não são suficientes para produzir generalizações por meio da criação de uma nova teoria que possa afirmar categoricamente que a lei de proteção ambiental incentiva os loteamentos irregulares.

Identificam-se, na análise espacial, os padrões de agrupamento ou de dispersão. Deste modo podem-se analisar os agrupamentos de comércio, onde os moradores do Distrito de Pedreira realizam as suas compras, com destaque para o Largo 13 de Maio em Santo Amaro, centro comercial do Município de Diadema ou alguns logradouros, a saber, Estrada do Alvarenga (Distrito de Pedreira), Avenida Yervant Kissajikian (Distrito de Cidade Ademar) ou Avenida Nossa Senhora do Sabará (Distrito de Campo Grande). Os pequenos estabelecimentos do tipo comércio de ração (pet shops) e bazares, que existem em grandes quantidades, apresentam um padrão significativo de dispersão por se encontrarem nas proximidades das residências. Ainda, por meio da análise espacial, podem-se perceber as possíveis causas de um determinado padrão de agrupamento ou de dispersão. Torna-se interessante a análise de algumas das principais causas que conduzem muitos moradores, inclusive próximos à divisa com Diadema, a efetuarem as compras em Santo Amaro, e incentivam apenas uma pequena parte, moradores da divisa, a realizarem compras em Diadema.

Uma questão importante envolve as possibilidades de determinados padrões, podendo ser eventualmente modelados por métodos quantitativos, por meio da aplicação das técnicas utilizadas em estatística espacial, desde que se verifique uma forte correlação entre os seus atributos espaciais pertinentes. Opcionalmente, o uso de algum modelo ou das técnicas de estatísticas espaciais pode ajudar no entendimento, quanto às semelhanças ou diferenças, por exemplo, entre o padrão de agrupamento do comércio do Largo 13 de Maio e o centro de Diadema, igualmente, entre algumas das principais vias de comércio.

Segundo Openshaw (1991) a análise espacial corresponde a uma descrição dos padrões espaciais e as suas relações por meio do envolvimento do uso das técnicas de análises univariadas ou multivariadas. Muitas vezes podem ser técnicas estatísticas, possibilitando as modelagens matematicamente ou em outras formas de análise geográfica. 
Sob a ótica quantitativa a análise espacial está sujeita a algumas limitações. É importante o conhecimento profundo dos dados espaciais utilizados, antes de validar os testes estatísticos de hipóteses, já que há necessidade desses dados apresentarem comportamentos conhecidos pela estatística paramétrica.

Conforme Goodchild (2004), a ajuda da análise espacial está na visualização dos padrões de relacionamento. Todavia, uma associação espacial deve ser considerada significante somente se for importante e pode perder toda a sua significância toda vez que seja irrelevante.

O principal instrumento da análise espacial é a autocorrelação espacial. Ela pode ser realizada por meio de algumas medidas, por exemplo, a distância entre os pontos. Também possibilita a descrição dos padrões dos processos espaciais. As suas técnicas estão baseadas no conceito de proximidade dos entes espaciais, permitindo o cálculo de medidas que correspondem aos seus indicadores locais e globais. Essas técnicas se baseiam nas idéias apresentadas na lei de Tobler" "Everything is related to everything else, but near things are more related than those far apart.” (LONGLEY et al, 2002, p. 61).

Quanto ao comércio do Largo 13 de Maio, embora tenha o foco principal voltado aos compradores de renda média e baixa, há uma significativa diversidade de oferta com muita variedade de mercadorias. Todos os estabelecimentos, encontrados nessa região, possuem a mesma característica em relação à diversidade dos produtos, e o mesmo foco quanto à classe de renda dos consumidores. Ou seja, todos os estabelecimentos agrupados no Largo 13 de Maio, por se localizarem na mesma área e estarem muito próximos, são muito semelhantes. Por outro lado, as lojas localizadas no agrupamento do comércio da Estrada do Alvarenga são muito semelhantes entre si, e por estarem na mesma região, apresentam as características próprias dessa área com poucas opções de escolha de marcas. Quando se comparam os estabelecimentos localizados no Largo 13 de Maio com os da Estrada do Alvarenga, notam-se grandes diferenças, principalmente no tocante à diversidade dos produtos oferecidos. De acordo com a Lei de Tobler, os estabelecimentos comerciais próximos ao Largo 13 de Maio são semelhantes, e são, igualmente, semelhantes os estabelecimentos comerciais localizados na Estrada do Alvarenga. Pelo fato da Estrada do Alvarenga estar relativamente afastada e distante do Largo 13 de Maio, pode-se observar a existência de significativas diferenças nas características do seu comércio em relação a Santo Amaro.

\footnotetext{
${ }^{3}$ Tradução do autor: "no mundo, todas as coisas se parecem; mas as coisas mais próximas são mais parecidas que aquelas mais distantes"
} 
Ao reunir, organizar e processar, por meio de técnicas computacionais, o inventário de feições de interesse, tais como os pontos de comércio, consumidores, rede de transporte, população, etc., o sistema de informações geográficas pode prestar um importante serviço para a realização da análise espacial com sucesso, mediante aplicação dos recursos de manipulação de dados e de visualização, com apoio na tecnologia de banco de dados, por meio dos seus recursos tecnológicos de desenhar e elaborar os mapas. Em decorrência das facilidades de acesso aos dados e do uso das técnicas espaciais de natureza estatística e analítica, o sistema de informação geográfica ajuda na integração dos dados referentes à concentração ou dispersão dos pontos de comércio, pelo emprego dos recursos que permitem a manipulação das informações constantes no banco de dados, e finalmente, apresentar na forma de um mapa, a visualização dos seus resultados estatísticos. A evolução do sistema de informação geográfica, verificada principalmente a partir dos anos 90, possibilitou um crescente desenvolvimento para o sistema de suporte de decisão. O sistema é capaz de proporcionar uma análise cada vez mais sofisticada, em particular, na operação de modelagem. Por exemplo, algumas de suas aplicações práticas podem ajudar na proposta de um roteiro ótimo para uma empresa transportadora, diante da informação do volume de mercadorias a serem transportadas, em função da localização de armazéns e dos consumidores, levando em consideração as características da rede de transportes. Outro exemplo, envolve uma avaliação de alternativas do padrão de uso do solo para o desenvolvimento de um novo bairro, ou então, possibilitar o acesso a informações sobre a geologia e o solo tendo em vista a obtenção de melhor solução para o uso do solo disponível.

Os significados dos padrões verificados num mapa e também as suas causas particulares podem ser analisados e estudados de duas maneiras: em primeiro lugar de modo global; e em segundo lugar em cada uma das suas posições, isoladamente, a partir dos indicadores locais de associação espacial. Em ambos os casos, podem ser desenvolvidos, utilizando os métodos explícitos quando a medida de distância é utilizada, ou alternativamente, implícitos quando outras medidas diferentes de distância, por exemplo, o quociente de localização de Ellison e Glaeser ou o coeficiente de localização de Duncan são aplicados. (GOODCHILD; JANELLE, 2004). Na análise local, podem-se identificar as propriedades e as características, diferenciando cada um dos lugares, dentro do contexto fornecido por uma visão geral. Desse modo, pode-se explicar se o padrão de agrupamento do comércio do Largo 13 de Maio, em Santo Amaro, é igual ou diferente do padrão do centro comercial de Diadema. A medida de padrão de agrupamento ou de dispersão, em decorrência das distâncias observadas, quando 
for de natureza global, é realizada a partir de medições simultâneas, de vários locais, das suas variadas medidas de associação espacial. Um padrão é espacialmente independente quando se observa uma distribuição homogênea em toda a área em estudo. Constata-se a dependência espacial quando se verificam distintos padrões locais de agrupamento ou de dispersão.

A seguir, encontram-se algumas medidas de distribuições geográficas e de análise espacial, a serem utilizadas neste trabalho:

Medidas globais de análise espacial

- Índice médio da vizinhança mais próxima;

- Autocorrelação espacial - estatística Moran's I global;

- Estatística Getis Ord - G geral.

Medidas locais de análise espacial

- Estatística Anselin Moran’s I local;

- Estatística "hot spot" Getis Ord Gi* local.

Medidas de distribuição espacial

- Localização do centro médio (“mean center”);

- Localização da orientação direcional - elipse do desvio padrão.

\subsection{Medidas globais de análise espacial}

As medidas globais de análise espacial indicam dois extremos de padrões, sendo um deles caracteriza agrupamento e o outro indica dispersão. Situações que não se enquadram num desses extremos são consideradas randômicas.

Exemplo:

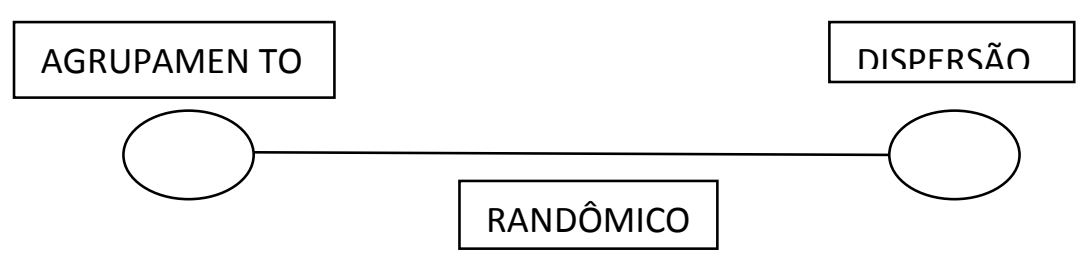

Figura 2.1 - Representação gráfica dos critérios de agrupamento, dispersão e randômico Fonte: MITCHELL, ANDY, 2005 
O índice médio da vizinhança mais próxima foi desenvolvido por Philip Clark e Frances Evans em 1950 para o estudo de padrão de distribuição de alguns espécimes de plantas. Seu objetivo principal é analisar a existência de agrupamentos ou de dispersão, cuja conclusão é obtida ao se comparar o valor do índice obtido com o valor teórico esperado. A sua vantagem é o uso da distância entre as feições. Entretanto, caso existam muitos elementos bem próximos junto ao limite geográfico da área em estudo, pode apresentar resultados enviesados.

Primeiro, calcula-se, para todos os elementos, a distância entre cada elemento e todos os seus vizinhos mais próximos. Em seguida, se obtém a média de todas as distâncias verificadas, conforme a fórmula 1 . O resultado final é o quociente entre o valor da distância média obtida (fórmula 1) e a distância média esperada (fórmula 2). Os valores desse quociente, o índice médio da vizinhança mais próxima (fórmula 3), quando são baixos, indicam a existência de grupos (Vide resultados obtidos na página 297).

$$
\begin{gathered}
\bar{d}_{0}=\frac{\sum c_{i}}{n} \text { (1) } \\
\mathrm{d}_{0}=\text { distância média } \\
\mathrm{c}_{\mathrm{i}}=\text { distancia do elemento em relação ao vizinho mais próximo } \\
\mathrm{n}=\text { total de elementos } \\
\bar{d}_{e}=\frac{0,5}{\sqrt{n / A}}(2) \\
\mathrm{d}_{\mathrm{e}}=\text { distância média esperada } \\
\mathrm{n}=\text { total de elementos } \\
\mathrm{A}=\text { área da região em estudo } \\
r=\frac{\overline{d_{0}}}{\overline{d_{e}}} \text { (3) }
\end{gathered}
$$

$\mathrm{r}=$ índice médio da vizinhança mais próxima 
Tabela 2.1 - PARÂMETROS DO ÍNDICE MÉDIO DA VIZINHANÇA MAIS PRÓXIMA

\begin{tabular}{cc}
\hline ÍNDICE OBTIDO & CARACTERÍSTICA \\
\hline MENOR QUE 1 & AGRUPADO \\
IGUAL A 1 & RANDÔMICO \\
MAIOR QUE 1 & DISPERSO
\end{tabular}

Fonte: MITCHELL ANDY, 2005 p.90

Esse índice, sendo inferior a 1, indica a existência de cluster ou agrupamento. Os valores acima de 1 são os indicadores de dispersão e valores iguais a 1 representam o padrão de distribuição randômica, quando não existe uma definição clara de agrupamento ou dispersão.

Quando se verificam as feições localizadas muito próximas umas das outras, podem causar alguma distorção no cálculo das distâncias médias, deste modo, é possível obter os valores da média um pouco abaixo da realidade. Existe o risco de se obter valores das distâncias médias um pouco acima da realidade quando se observam feições localizadas a distâncias mais afastadas.

A estatística Moran's I (global), que é um dos indicadores de autocorrelação espacial, tem como objetivo a identificação das características de agrupamento ou dispersão, fundamentada nas medidas que fornecem a indicação de similaridade entre as feições próximas. Foi desenvolvida por Patrick Moran em 1940. Em conseqüência da identificação de agrupamentos por meio de similaridades, possui alguma desvantagem, a impossibilidade de analisar os valores altos ou baixos de cada elemento pertencente ao agrupamento. Por exemplo, diante da existência de um agrupamento de lojas, do mesmo ramo de atividade, constituído por elevada quantidade de estabelecimentos numa determinada quadra e, nas quadras vizinhas um pequeno número de lojas, estatística global Moran's I indica apenas a similaridade ou a dissimilaridade. Torna-se impossível a avaliação do tamanho de cada grupo.

O intervalo dos valores da estatística Moran's I, quando for global, permanece entre -1 e 1 . Quando o resultado é positivo e acima de 0 , revela a situação da existência de valores similares agrupados. Porém, numa situação contrária, apresentando um resultado negativo e abaixo de 0 , denota a existência de valores dissimilares e dispersos. O resultado bem próximo de 1 se refere a intenso agrupamento, e um resultado mais próximo de -1 significa a intensa dispersão. Se o resultado é perto de 0 , pode ser uma situação da participação de diversos agrupamentos de tamanhos menores. 
O foco dessa estatística é identificar os agrupamentos através dos valores similares ou dissimilares em relação à média. Em região, quando existem várias classes de comércio que apresentam simultaneamente a quantidade de lojas acima e abaixo da média, os resultados podem ser dissimilares. Numa área constituída por uma classe de comércio mais homogênea, quando o número da maioria dos estabelecimentos é igual e próximo da média, os resultados podem ser similares.

Obtêm-se os resultados das diferenças ou igualdades, levando-se em consideração os atributos dos elementos vizinhos (Vide resultados obtidos na página 297).

$$
I=\frac{n \sum \sum w_{i j}\left(x_{i}-\bar{x}\right)\left(x_{j}-\bar{x}\right)}{\sum \sum w_{i j} \sum\left(x_{i}-\bar{x}\right)^{2}}
$$

numerador $=$ resultado da soma da multiplicação de 3 elementos: a diferença entre o elemento(i) em estudo e a média; a diferença entre o vizinho(j) e a média; e o peso, sendo que um dos critérios para o peso pode ser a distância entre os elementos (i) e (j); e n correspondendo ao total de elementos.

denominador $=$ resultado da soma da multiplicação entre a variância e os respectivos pesos atribuídos aos elementos.

Um dos critérios para a determinação dos pesos pode ser o inverso da distância.

Cálculo da média esperada

$$
I_{E}=\frac{-1}{n-1}
$$

$\mathrm{n}=$ quantidade de elementos

É bastante desejável que exista uma quantidade significativa de feições numa determinada área geográfica em estudo. Em áreas menores, contendo poucas feições, a existência, de alguns elementos vizinhos ou adjacentes dissimilares, pode distorcer os resultados e não mostrar a condição de agrupamento mesmo a maioria dos elementos sendo similar. Muitas 
vezes, pode surgir a necessidade de expandir a área geográfica em estudo para permitir a identificação de agrupamentos.

A estatística Getis Ord G (geral) foi desenvolvida em 1990 por Art Getis e Keith Ord. Mede apenas a constatação de agrupamentos, mas tem a vantagem de apresentar a característica do grupo e mostrar a sua constituição de valores altos ou baixos. Uma das desvantagens é a possibilidade de perder a precisão nos resultados, diante da participação simultânea de grupos estabelecidos por valores altos e baixos.

A título de exemplo, ao adotar a quantidade de lojas, pode-se avaliar através da estatística Getis Ord G geral, as características quantitativas dos vizinhos mais próximos. Torna-se possível a identificação de situações em que um determinado ramo de negócio possui como vizinhos outros ramos de negócios que são constituídos por uma quantidade inferior de lojas. $\mathrm{Ou}$, o seu inverso, em torno de uma determinada loja, uma vizinhança composta por uma quantidade superior de lojas. Quando o valor dessa estatística é alto, podem existir evidências de intensa concentração de lojas. O oposto, ao apresentar o seu valor baixo, pode revelar menor concentração de estabelecimentos, em termos quantitativos.

Em resumo, indica a existência de agrupamentos, cujos elementos apresentam valores muito elevados ou "hot spots" (bolsões de valores elevados), ao mesmo tempo valores muito baixos ou "cold spots" (bolsões de valores baixos). (Vide resultados obtidos na página 297)

$$
G(d)=\frac{\sum \sum w_{i j}\left(x_{i} * x_{j}\right)}{\sum \sum\left(x_{i} * x_{j}\right)}
$$

numerador $=$ soma do produto de 3 elementos: o peso dos elementos sendo que um dos critérios pode ser a distância entre os elementos (i) e (j); o elemento em estudo (i) e o seu vizinho mais próximo (j)

denominador $=$ soma do produto entre o elemento em estudo (i) e o seu vizinho mais próximo(j) 
O valor esperado da estatística $G$ geral é calculado do seguinte modo:

$$
\begin{gathered}
G_{E} \neq \frac{W}{n(n-1)} \\
\mathrm{W}=\text { soma dos pesos } \\
\mathrm{n}=\text { quantidade de elementos }
\end{gathered}
$$

Para o peso, o inverso da distância é uma das alternativas mais utilizadas.

Essa medida é bastante sensível em relação às distâncias e os valores entre as feições mais próximas. Caso exista numa área, um expressivo número de elementos muito próximos, mostrando valores elevados, ou pequena quantidade de elementos, apresentando valores baixos, igualmente bem próximos, em consequiência dessa proximidade dos elementos, os resultados podem mascarar o grupo de valores baixos, prevalecendo os resultados de um agrupamento de valores elevados para ambos os casos.

Os valores das feições também podem afetar os resultados. Quando em uma determinada região em estudo exista a concentração de alguns grupos, distribuídos em pequenas áreas, ao mesmo tempo de outros grupos, distribuídos em áreas maiores, desde que exista grande quantidade de participantes de valores altos em uma pequena área os resultados podem indicar a concentração de valores altos mesmo que haja a participação de elementos de valores baixos distribuídos em áreas grandes.

Quando se observam poucas feições, tendo valores muito elevados, os resultados podem indicar agrupamentos de valores altos, mesmo que exista grande quantidade de feições, apresentando valores mais baixos.

\subsection{Medidas locais de análise espacial}

A estatística local, Anselin Moran's I, mostra as características individuais, indicando a variação de cada um dos elementos em relação aos seus vizinhos, numa determinada aglomeração. O critério básico adotado para a comparação é a média dos valores de cada elemento. 
Obtém-se a análise das características individuais dos elementos em relação aos seus vizinhos mais próximos, quanto à sua similaridade ou dissimilaridade. Quando os vizinhos são semelhantes, ou seja, o elemento objeto de análise e, também, o seu vizinho mais próximo possuem valores acima da média, o sinal é positivo, e existem grandes possibilidades de formar um cluster, por serem similares. Igualmente, quando ambos possuem valores abaixo da média, o sinal da estatística é positivo, indicando a condição de serem similares. Se o resultado for de sinal negativo, o elemento objeto de análise pode apresentar o seu valor acima da média e o seu vizinho o valor abaixo da média, ou vice versa, esses dois elementos são dissimilares. Quando os valores das estatísticas são muito próximos, esses elementos podem se localizar nas proximidades, surgindo a oportunidade de formar um cluster. A quantidade de lojas por tipo de ramo de atividade é um exemplo sobre os valores das feições. (Vide mapas das páginas 315, 321, 327, 336, 339, 344, 352, 356, 361, 367, 372)

Numa situação de poucos vizinhos, o valor de Moran’s I local é sempre baixo.

$$
I=\frac{\left(x_{i}-\bar{x}\right)}{s^{2}} * \sum w_{i j}\left(x_{j}-\bar{x}\right)
$$

$I=$ estatística Moran’s I local

$\frac{\left(x_{i}-\bar{x}\right)}{s^{2}}$ é a divisão, da subtração entre a média e o valor do elemento objeto de análise, pela sua variância

$\sum w_{i j}\left(x_{j}-\bar{x}\right)$ é a soma resultante da multiplicação do peso dos elementos, sendo que um dos critérios pode ser a distância entre os elementos (i) e (j), pela subtração da média pelo elemento vizinho

O peso a ser adotado pode ser o inverso da distância.

São necessários pelo menos 30 elementos para a obtenção de resultados confiáveis e estatisticamente significativos.

Feições bem próximas aos limites geográficos de uma área em estudo podem apresentar resultados distorcidos, desde que existam elementos vizinhos além desses limites. 
Os resultados do índice Moran's I tendem a ser elevados quando se observam, simultaneamente, as feições bem próximas com valores elevados ou valores baixos.

A estatística local Getis Ord Gi* possibilita a análise da intensidade da ocupação do espaço e permite a identificação das características individuais dos elementos em estudo. Compara o valor de cada feição em relação ao valor de cada um dos seus vizinhos mais próximos. Adotando lojas como exemplo, o seu resultado é alto, quando os seus vizinhos mantêm a quantidade maior de estabelecimentos em comparação à loja objeto de estudo. O contrário, quando o resultado é baixo, denota que os seus vizinhos permanecem com quantidade inferior de estabelecimentos.

O critério básico é a comparação com os vizinhos em função das suas distâncias. (Vide resultados nos mapas das páginas 316, 322, 328, 337, 340, 345, 353, 357, 362, 368, 373)

$$
G *(d)=\frac{\sum w_{i j}(d) x_{j}}{\sum x_{j}}
$$

numerador $=$ soma do produto do peso de cada elemento, sendo que um dos critérios pode ser a distância entre os elementos (i) e (j), pelo valor de cada vizinho mais próximo (j)

denominador $=$ soma dos valores de cada vizinho $(\mathrm{j})$

Um dos critérios para o peso pode ser o inverso da distância.

\subsection{Medidas de distribuições geográficas}

$O$ centro médio é a localização representada pela média da coordenada $X$ e média da coordenada Y de todos os elementos encontrados na área em estudo.

$$
\begin{gathered}
\bar{X}=\frac{\sum X_{i}}{n} \\
\bar{Y}=\frac{\sum Y_{i}}{n} \\
\text { n = número de elementos }
\end{gathered}
$$


A comparação do centro médio dos moradores em relação ao centro médio do comércio permite a avaliação e identificação espacial de eventuais vantagens das localizações de determinados pontos comerciais. A localização de um agrupamento do comércio, bem próxima do centro médio dos moradores pode oferecer muitas vantagens, desde que exista facilidade de acesso aos moradores. Os principais agrupamentos de comércio, por exemplo, o Largo 13 de Maio, em Santo Amaro, ou o centro comercial de Diadema, se localizam fora dos limites do Distrito de Pedreira, portanto, verifica-se o deslocamento do centro médio do comércio para uma posição pouco vantajosa, em relação ao acesso da maioria dos moradores desse Distrito. (Vide resultados nos mapas das páginas 290 e 293)

O resultado da elipse do desvio padrão é uma elipse determinando a orientação direcional da distribuição dos elementos das feições. Estabelecem-se as dimensões dos eixos da elipse, fundamentadas na distância padrão calculada para os eixos x e y, separadamente. O centro dos eixos corresponde à localização do centro médio. A rotação da elipse é determinada por meio de cálculos trigonométricos, de tal maneira que a distância dos elementos elevada ao quadrado seja o mínimo em relação aos eixos da elipse. (Vide resultados no mapa da página 295)

$$
\begin{gathered}
S D_{X}=\sqrt{\frac{\sum(X-\bar{X})^{2}}{n}} \\
\mathrm{SD}_{\mathrm{X}}=\text { distância padrão do eixo x } \\
S D_{Y}=\sqrt{\frac{\sum(Y-\bar{Y})^{2}}{n}} \\
\mathrm{SD}_{\mathrm{y}}=\text { distância padrão do eixo y }
\end{gathered}
$$

Habitualmente o tamanho de cada eixo pode ser calculado, adotando-se duas ou três vezes, o valor de seu correspondente desvio padrão.

Determinados agrupamentos comerciais mais intensos, por exemplo, o Largo 13 de Maio, em Santo Amaro, e o centro comercial de Diadema, podem determinar a direção do eixo principal da elipse (eixo x). Outros centros localizados dentro dos limites do Distrito de Pedreira, um deles a Estrada do Alvarenga, podem determinar a direção do eixo secundário da elipse (eixo y). 
3 CONCEITOS SOBRE REDE URBANA, CENTRALIDADE E MOBILIDADE 
A preocupação e o interesse sobre o tema produção do espaço são relativamente antigos. Um dos primeiros estudos sobre a organização do espaço foi desenvolvido por Christaller em 1933 e pela Escola de Chicago na década de 1920, com a participação de Park, Burgess e McKenzie. Desde então, principalmente nos Estados Unidos, surgiram muitos estudiosos desse assunto, que, serem seguidores da Escola de Chicago, ficaram conhecidos como ecologistas. Os seguidores da Escola de Chicago acreditavam que a obtenção das explicações da ocupação do espaço se baseia nos conceitos da evolução humana de Darwin. Muitas críticas sobre a Escola de Chicago surgiram logo em seguida, já nos anos 30. Após a segunda guerra mundial houve a retomada da ecologia urbana contemporânea. Ainda, fundamentada na Escola de Chicago, surge um pouco mais tarde a teoria da localização, que apresenta algumas abordagens distintas, entre eles, em destaque, o estudo da centralidade, determinismo tecnológico com ênfase em transporte e uso do solo, teoria do equilíbrio, sistemas de cidades e a teoria da expansão metropolitana conceituando a relação centro-periferia.

Seguindo os fundamentos dos conceitos da Escola de Chicago, todos esses diferentes estudos proporcionaram diversos conhecimentos descritivos e morfológicos, em relação aos padrões de ocupação do espaço, nas regiões urbanas. Em decorrência das suas limitações, que não contemplam as ações e as dinâmicas responsáveis pela produção das formas de organização espacial, os resultados apresentados, de certa maneira, podem ser considerados superficiais, mesmo quando sofisticadas técnicas estatísticas são empregadas. Em outras palavras, apenas a morfologia dos padrões de ocupação do espaço é evidenciada, sem entrar no detalhe das causas estruturais determinantes das ações que levam aos padrões específicos de ocupação do espaço.

Castells (1983) trouxe outras contribuições por meio de novas idéias em relação à ocupação do espaço urbano. Ao publicar o seu livro A Questão Urbana, em relação à Escola de Chicago, apresenta vários de seus pontos fracos e deficiências conceituais, particularmente no tocante a ausência de uma análise estrutural. Manifesta a preocupação de que o espaço deve ser analisado como expressão da estrutura social em relação aos elementos do sistema econômico, do sistema político e do sistema ideológico. Embora a simples avaliação de certos resultados estáticos possa, muitas vezes, ser aceita como uma boa justificativa da relação entre causa e efeito, esses resultados estáticos podem ser insuficientes para uma explicação mais profunda e isenta de mistificação das suas referidas causas. 
Para Castells (1983) a centralidade pode ser um revelador bastante seguro quando se trata de analisar as relações e articulações entre os elementos da estrutura urbana os quais são consumo $(\mathrm{C})$, produção $(\mathrm{P})$, troca $(\mathrm{T})$ e gestão $(\mathrm{G})$. A sua definição de produção é um conjunto de atividades produtoras de bens, serviços e informações. Por consumo entende-se uma coleção de atividades relativas à apropriação social, individual e coletiva do produto. Troca é tudo o que ocorre no interior da produção e do consumo, tais como o comércio e a circulação. Gestão é o processo de regulação das relações entre produção, consumo e troca.

Neste trabalho, o foco principal abrange apenas a análise da centralidade do elemento $\mathrm{T}$ troca, por meio da utilização da ajuda de algumas das técnicas de redes sociais. Para o levantamento de dados, relacionados a determinados hábitos de compras, o ponto de partida é a amostra de moradores do Distrito de Pedreira que utilizam os serviços do comércio local, menos sofisticado, para as compras de freqüência alta, ou então, para as compras de frequiência baixa, do comércio mais distante e melhor estruturado localizado no Largo 13 de Maio, em Santo Amaro, ou do Município de Diadema.

Os conceitos de centralidade deste trabalho estão restritos apenas ao nível econômico, a centralidade que exprime a correlação dos diferentes elementos econômicos da estrutura urbana (produção, consumo, troca), bem como, as relações internas entre cada um desses elementos. O processo de troca urbana compreende, ao mesmo tempo, um sistema de fluxo, isto é, a circulação, e as placas giratórias de comunicação, isto é, os centros conforme a definição de Castells (2005). Portanto, a função comércio, fazendo parte do nível econômico, é o elemento básico para o desenvolvimento deste trabalho.

Às vezes, os centros podem não ser constituídos por lugares. Devem ser entendidos muito mais por um tipo de centro urbano-permutador, portanto, composto por uma organização espacial dos canais de troca entre os elementos de produção e o elemento de consumo, na ótica de uma organização social, inserido num aglomerado urbano. Exceto o Largo 13 de Maio, em Santo Amaro, ou o centro comercial do Município de Diadema, os quais podem ser ao mesmo tempo lugares e centralidades, a maioria dos pontos de comércio, por exemplo, o Supermercado Pedreira ou o Shopping Center Interlagos devem ser considerados apenas centralidades.

Pierre George (1971) comenta sobre a organização da distribuição e a sua diversidade do consumo, desde a aquisição cotidiana dos produtos perecíveis até os produtos de tempo de 
uso mais longo, cuja aquisição se verifica uma vez por ano, somente uma vez cada quatro ou cinco anos, ou uma única vez por geração. Faz parte de uma conduta de pensamento propriamente geográfico, conhecer a distribuição dos tipos e dos agrupamentos de consumo, em razão dos grupos sociais, na determinação dos melhores pontos de contato, para cada classe de comércio, entre o vendedor e o comprador.

Com fundamento nessas idéias, podem ser consideradas três classes de comércio:

- $\mathrm{O}$ comércio e serviço de apoio imediato à moradia de freqüência alta, diária ou semanal de utilização, e que possui um nível hierárquico baixo por ser local, por exemplo, a padaria, o açougue, a quitanda, o bar, a mercearia, etc.;

- O comércio e serviço de apoio à moradia de freqüência mediana ou intermediária de demanda e que possui um nível hierárquico médio por ser diversificado, por exemplo, um supermercado grande, uma farmácia, um bazar, etc.;

- O comércio e serviço de apoio à moradia e a outras atividades urbanas e que possui um nível hierárquico alto, sendo a frequêencia de demanda bastante baixa e apresentando maior diversificação possível, por exemplo, uma loja de eletrodomésticos, hipermercado de material de construção, etc.

O conceito de mobilidade, segundo TAGORE; SIKDAR (1995, apud RAIA JUNIOR, 2000, p. 61) é a capacidade dos indivíduos se moverem de um lugar para outro e depende do sistema de transportes, através da disponibilidade, freqüência, tempo de espera, bem como, das características do indivíduo, por exemplo, renda, veículo próprio, recursos disponíveis para o gasto em viagem.

Meyer (2004) também define mobilidade como sendo o deslocamento da população.

O Distrito de Pedreira pertenceu até algumas décadas atrás a Santo Amaro. Sua estrutura viária radioconcêntrica em direção ao centro desse bairro é bastante antiga e possivelmente deve ter sido estabelecida, ainda, na época que Santo Amaro ainda era município. Essa estrutura viária básica de Pedreira ajuda a fortalecer a centralidade desse último bairro,

\footnotetext{
${ }^{4}$ TAGORE, M.R; SIKDAR, P.K. A new accessibility measure accounting mobility parameters. In: paper presented at $7^{\text {th }}$ WORLD CONFERENCE ON TRANSPORT RESEARCH, 1995, Sydney, Australia . Sydney: The University of New South Wales, 1995.
} 
inclusive aos usuários de automóveis para a circulação. Novas centralidades poderão ser criadas quando as obras de intervenção, que facilitem o acesso da Estrada do Alvarenga para a Avenida Cupecê ou à Avenida Yervant Kissajikian, forem realizadas.

Para citar alguns exemplos, estão estruturadas, em direção a Santo Amaro, a Estrada do Alvarenga, a sua continuação Av. Nossa Senhora do Sabará e a Av. Yervant Kissajikian. Para o centro histórico a principal opção é a Av. Interlagos (Distrito de Campo Grande), que vai para o norte em direção ao aeroporto de Congonhas. As principais vias de acesso ao centro de Diadema são a Av. Alda e a R. Professor Cardozo de Mello Neto, ambos a partir da Estrada do Alvarenga. O sistema viário do Distrito de Pedreira permite alcançar a Estrada do Alvarenga a partir de qualquer bairro, conseqüentemente torna-se bastante fácil o deslocamento da população para Santo Amaro. Ao contrário, apesar da proximidade, a estrutura viária oferece poucas opções de deslocamento para o centro de Diadema. Para o metrô Jabaquara o deslocamento da população, a partir da Estrada do Alvarenga, tem como principal opção as vias locais mal estruturadas em direção ao Jardim Miriam, localizado no Distrito de Cidade Ademar.

Muitas vezes, a distribuição espacial do comércio não se estabelece em conseqüência de um resultado natural da organização das aglomerações da população. $O$ fato de o Distrito de Pedreira ter um sistema de transporte urbano sob a responsabilidade do Município de São Paulo e ser do tipo radioconcêntrico, constitui um dos principais fatores limitantes quanto ao acesso da população de renda mais baixa a determinadas áreas comerciais. A maioria das linhas se dirige ao Largo 13 de Maio, em Santo Amaro, embora existam algumas linhas para o Centro Histórico da nossa Cidade, metrô Jabaquara ou região sudeste ao atender os bairros de Itaim-Bibi ou Vila Olímpia. Diante da mobilidade e acessibilidade restrita sem muitas opções, devido ao sistema de transporte coletivo, o comércio do Largo 13 de Maio exerce uma atração centrípeta, mesmo em relação àqueles que moram na divisa com o Município de Diadema, apesar da distância aproximada de $18 \mathrm{~km}$. Embora a localização do centro de Diadema fique a $2 \mathrm{~km}$ da divisa do Distrito de Pedreira, muitos moradores preferem satisfazer as suas necessidades de compras de periodicidade mais longa em Santo Amaro. Uma das possíveis causas pode ser a deficiência do transporte coletivo de Pedreira para Diadema atendido por linhas intermunicipais administradas pela EMTU. Alguns residentes das proximidades da Avenida Alda, podem contar com a disponibilidade de linhas urbanas de Diadema e podem fazer as suas compras nesse município vizinho, muito provavelmente por causa da estrutura 
de comércio bastante precária nas regiões limítrofes com o Distrito de Pedreira. Os detalhes dessas conclusões serão apresentados no capítulo 5. O centro comercial de Diadema funciona como um pólo de mobilidade muito forte, em particular para os moradores próximos da divisa. Pelo contrário, o Largo 13 de Maio atrai a maioria dos moradores do Distrito de Pedreira, de maneira geral, inclusive aqueles que vivem na divisa. Segundo Regina Meyer (2004), os pólos de mobilidade são localizações urbanas precisas distribuídas no território urbano nos quais se articulam as funções urbanas muito fortemente correlacionadas ao transporte público de massa.

Para certos moradores do Distrito de Pedreira a mobilidade e acessibilidade são determinadas através de locomoção a pé. Os moradores da favela da Divisa, na Vila Guacuri, podem chegar ao centro de Diadema a pé, em poucos minutos, tendo em vista a sua proximidade. Os moradores da favela Eldorado, na falta de serviço de ônibus, caminham por um atalho, em poucos minutos, até a Av. Afonso Monteiro da Cruz, em Diadema, para utilizarem dos ônibus urbanos em direção ao centro desse município. O centro comercial mais próximo dos moradores de Eldorado e Mata Virgem é a Av. Nossa Senhora dos Navegantes em Diadema. Alguns moradores da Estrada da Água Santa, nas proximidades da Estrada do Alvarenga, caminham até o referido centro comercial de Diadema na falta de opção de serviços (intermunicipal ou urbano) de ônibus. Esses bairros Eldorado e Mata Virgem são muito carentes em serviços de ônibus e, conseqüentemente, muitos moradores necessitam caminhar percursos relativamente longos para chegarem até as vias servidas por transporte urbano, por exemplo, a Estrada do Alvarenga.

Segundo Rochefort (1998) o espaço físico é transformado pelas técnicas de transporte ativo e estruturação urbana sob as condições de funcionamento da economia. As condições de construção das vias de transporte constituem um elo importante para o funcionamento das relações entre o espaço e a economia. A partir do momento que uma via é criada, o seu eixo se impõe e torna um elemento estável para os produtos entre o espaço e as atividades econômicas.

Segundo a definição de Castells (2005), os fluxos são a expressão dos processos que dominam nossa vida econômica, política e simbólica. Ainda de acordo com o autor, nossa sociedade está construída em torno dos fluxos, os quais podem compreender os fluxos de capital, fluxos da informação, fluxos de tecnologia, fluxos de interação organizacional, fluxos de imagens, sons e símbolos. Disso propõe a idéia de formação da sociedade em rede, dentro 
de um espaço definido como o espaço de fluxos, onde os nós representam os centros de importantes funções estratégicas. Esta rede conecta lugares específicos, com características sociais, culturais, físicas bem definidas. Em muitos dos nós, que podem seguir uma hierarquia organizacional, encontram-se as funções estrategicamente importantes as quais constroem uma série de atividades e organizações locais em torno de uma função chave na rede.

A hierarquia espacial é uma especificação do sistema ou padrão nodal. O acesso físico usualmente define o ponto de melhor conveniência e, por meio da disponibilidade funcional, representa a necessidade concomitante de interação. Estrutura hierárquica e padrão nodal são conseqüências da divisão de trabalho e especialização territorial. O mercado, ambos perante o tamanho da população e distribuição de área, é dependente da disponibilidade de instituições de troca e meio de transporte e comunicação. Hierarquia e nodalidade, em sua vez, são dependentes e limitados pela natureza da malha de rotas e da multiplicidade da sua extensão. Torna-se óbvia, a necessidade da participação obrigatória de todos os três elementos, hierarquia, nodalidade e circulação, na análise de um sistema urbano (LLOYD, 1972).

Portanto, é possível, a representação, por meio dos nós de uma rede social, das funções comerciais encontradas no Largo 13 de Maio, centro comercial de Diadema, Shopping Center Interlagos e nos demais locais de comércio. A desconcentração da função comercial conduz à criação de centros de troca periféricos, dentro de uma rede de fluxos cotidianos do Distrito de Pedreira, cujos nós podem representar o Supermercado Pedreira ou uma pequena padaria localizada nos arredores da residência de um determinado morador.

De acordo com Dupuy (1985), a rede define, ao mesmo tempo, o espaço e o tempo. Ela estabelece entre ambos um novo produto fundamentado na circulação, no fluxo, na velocidade, estendendo à instantaneidade, o tempo real, conforme a terminologia dos especialistas da ciência da informação. Uma cidade é ou deveria ser uma forma derivada das necessidades de locomoção, que será perfeita quando a soma dos tempos empregados para andar de casa em casa for o mínimo. Ainda, ao mencionar I. Cerda, o autor afirma, que tudo é movimento, expansão e comunicação quando a hierarquia das vias e a multiplicação de cruzamentos visam a facilitar a acessibilidade generalizada. Ao citar M.-F. Rouge, comenta que o essencial de uma rede é encontrar as dimensões principais topológicas, cinéticas e adaptativas, já prontas e em evidência. A topologia da rede é resultante da necessidade de atender múltiplos pontos, mas também dentro da importância de consideráveis pontos nodais. As redes de diferentes categorias tendem a apoiar uns aos outros. É um sistema que inclui os 
pontos singulares do espaço, no seu conjunto, permite que cada nova parte não traga somente uma unidade adicional, mas valorize o todo.

A definição do sistema urbano conforme Castells (1983), em seu livro A Questão Urbana, é uma organização de um conjunto de relações entre os elementos da estrutura espacial: produção; consumo; intercâmbio; gestão e simbólico.

Para Dupuy (1985), uma rede, sob o ponto de vista sistêmico, mostra a realidade de um território. Deve representar todos os seus pontos de vista quando um geógrafo está preocupado em considerar vários elementos, tais como subsistemas, relações e processos, mostrando os diferentes aspectos da realidade territorial. É possível mostrar o local das atividades no território, inclusive os subsistemas de mão de obra, cuja localização é o fator essencial para a geração de fluxos, por exemplo, numa rede de transportes.

Ainda segundo Gabriel Dupuy (1985), as redes são constituídas de população e de suas atividades, por meio da constituição de um sistema de atividades humanas, cujo funcionamento desse sistema se verifica pela ligação entre unidades espaciais, povoados, cidades, regiões etc. O sistema de transporte urbano, ao estabelecer um fluxo de mobilidade das pessoas de renda mais baixa, pode determinar os centros, cuja hierarquia venha a depender do volume de freqüência dos compradores quanto à procura de bens e serviços. Quanto maior for a diversificação dos bens e serviços oferecidos, maior é a sua polaridade de atração, exercida pelo comércio e também pelos prestadores de serviços. Segundo Pierre George, esse tipo de fluxo de pessoas, é denominado freqüentação.

Rochefort (1998), ao questionar se a rede urbana pode ser definida na ótica da organização dos centros urbanos e de suas zonas de influência no interior de uma região controlada por um centro regional, responde afirmativamente ao desenvolver o seu conceito de arcabouço urbano.

A rede assegura, conforme idéias de Dupuy (1985), a conexão entre os pontos de espaço, independentemente de sua localização, indiferentemente das distintas barreiras e limites. Favorece a abertura do espaço urbano e a sua descentralização numa extensão espacial necessariamente descontínua ao unir os pontos. A rede substitui uma descontinuidade intrínseca através dos nós e das ligações e cria um espaço particular de rede. Dupuy (1985), ao mencionar as idéias de Hassmann, concebe uma idéia de rede estritamente hierarquizada, 
uma rede bem delimitada pelas fronteiras administrativas da cidade e que tem um interior e um exterior e, por meio das fortificações, formam o limite da cidade: o lugar. 
4 DISTRITO DE PEDREIRA 


\subsection{Situação}

A divisão política administrativa de São Paulo é constituída por 96 distritos e 31 subprefeituras distribuídos numa área geográfica de $1509 \mathrm{~km}^{2}$, ocupada por 10.789 .058 habitantes em 2006, e 85.885 estabelecimentos de comércio em funcionamento no ano de 2005.

O Distrito de Pedreira está localizado na região sul do Município de São Paulo, conforme o mapa número 4.1, constituído a partir do ano de 1992 de acordo com a lei municipal de número 11220. Desde 1996 pertence à Subprefeitura de Cidade Ademar, que é responsável também pelo Distrito de Cidade Ademar. A divisa a leste é com o Município de Diadema, ao norte com o Distrito de Cidade Ademar, a noroeste com o Distrito de Campo Grande (Subprefeitura de Santo Amaro), a oeste com o Distrito de Cidade Dutra e a sudoeste com o Distrito de Grajaú (esses dois últimos pertencentes à Subprefeitura de Capela do Socorro). Até 1996 pertenceu à Administração Regional de Santo Amaro. O Distrito de Pedreira, devido à sua localização na periferia, recebeu muito pouca atenção em relação aos investimentos públicos até os anos 80 .

Encontra-se ao sul da Grande São Paulo, de acordo com o mapa número 4.2, próximo a uma região bastante industrializada e bem desenvolvida, que é a do $\mathrm{ABC}$, formado pelos municípios de Santo André, São Bernardo do Campo, São Caetano do Sul e Diadema onde forma divisa como já foi mencionado no parágrafo anterior. A mobilidade para esses municípios vizinhos é relativamente precária pelo fato das principais vias de acesso estarem estruturadas em direção ao bairro de Santo Amaro. Para chegar a Santo André ou a São Bernardo do Campo, é preciso chegar primeiro a Diadema, na Av. Presidente Kennedy, continuação da Av. Cupecê, e assim ter acesso a algumas avenidas construídas em fundo de vale que fazem conexão com a Av. dos Estados em Santo André e cruzam a Rodovia dos Imigrantes e a Via Anchieta. Do Distrito de Pedreira o acesso a Diadema pode ser feito pela Av. Alda no bairro de Eldorado, R. Professor Cardozo de Mello Neto na Vila Guacuri, ou então, pelas vias locais e precárias que passam pelo bairro de Vila Missionária ou Parque Primavera. A Estrada do Alvarenga permite o acesso à periferia de São Bernardo do Campo na região de Acampamento dos Engenheiros. 
A Estrada do Alvarenga, atravessa o Distrito no sentido noroeste a sudeste, é, portanto o divisor entre, os bairros instalados na margem da represa Billings, e outros bairros localizados do seu lado oposto em direção a Diadema.

Os seus principais bairros são:

Ao norte, próximos à divisa com os Distritos de Campo Grande e de Cidade Ademar, estão os bairros Jardim Piratininga, Vila Paineira, Vila Aparecida, Conjunto Residencial Ingaí, Jardim Selma e Balneário Mar Paulista, esse último está localizado na margem da represa. Os seus principais acessos são a Estrada do Alvarenga, Rua Antonio do Campo e Rua José Vieira Martins.

A nordeste, próximos à divisa com Diadema, estão os bairros Vila Guacuri e Jardim Célia. O seu principal acesso é a Rua Professor Cardozo de Mello Neto.

Ao centro, na primeira península do Jardim Apurá, localizam-se os bairros Jardim Apurá, Balneário São Francisco e Parque Santa Amélia. Os seus principais acessos são a Estrada do Alvarenga, Avenida das Garoupas, Rua Davide Perez e Rua Salvador Dali.

Ao centro, do lado oposto da represa Billings, estão os bairros Parque Primavera, Refúgio Santa Terezinha, Parque Dorotéia e Jardim Rubilene. Seus principais acessos são a Estrada do Alvarenga, Rua Bento José Borba, Rua Professor Cardozo de Mello Neto e Rua Dr. Carlos de Rezende Enout.

Ao sul, na segunda península de Sete Praias, está o bairro Sete Praias. Os seus principais acessos são a Rua Professor Camillo Ashcar e Rua Dr. José Silvio de Camargo.

Ao sul, do lado oposto da represa Billings e em direção a Diadema, estão os bairros Jardim Monte Líbano, Jardim do Castelo e Eldorado. Seus principais acessos são a Avenida Alda, Rua Dr. José Silvio de Camargo e Estrada da Água Santa. 
MAPA 4.1

Subprefeituras e Distritos

do Município de São Paulo

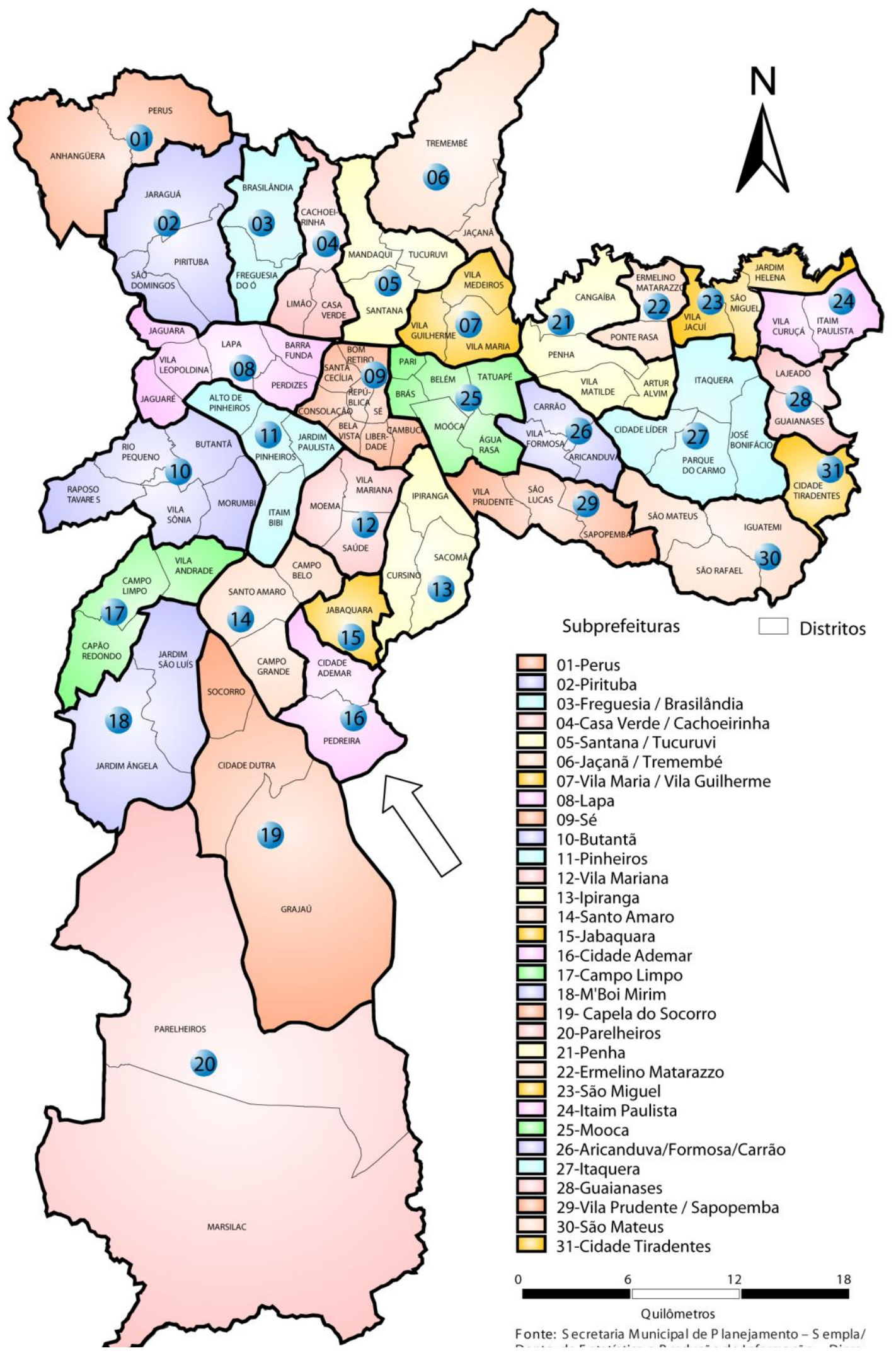




\section{LOCALIZAÇÃO DO DISTRITO DE PEDREIRA NA GRANDE SÃO PAULO}

MAPA NÚMERO 4.2
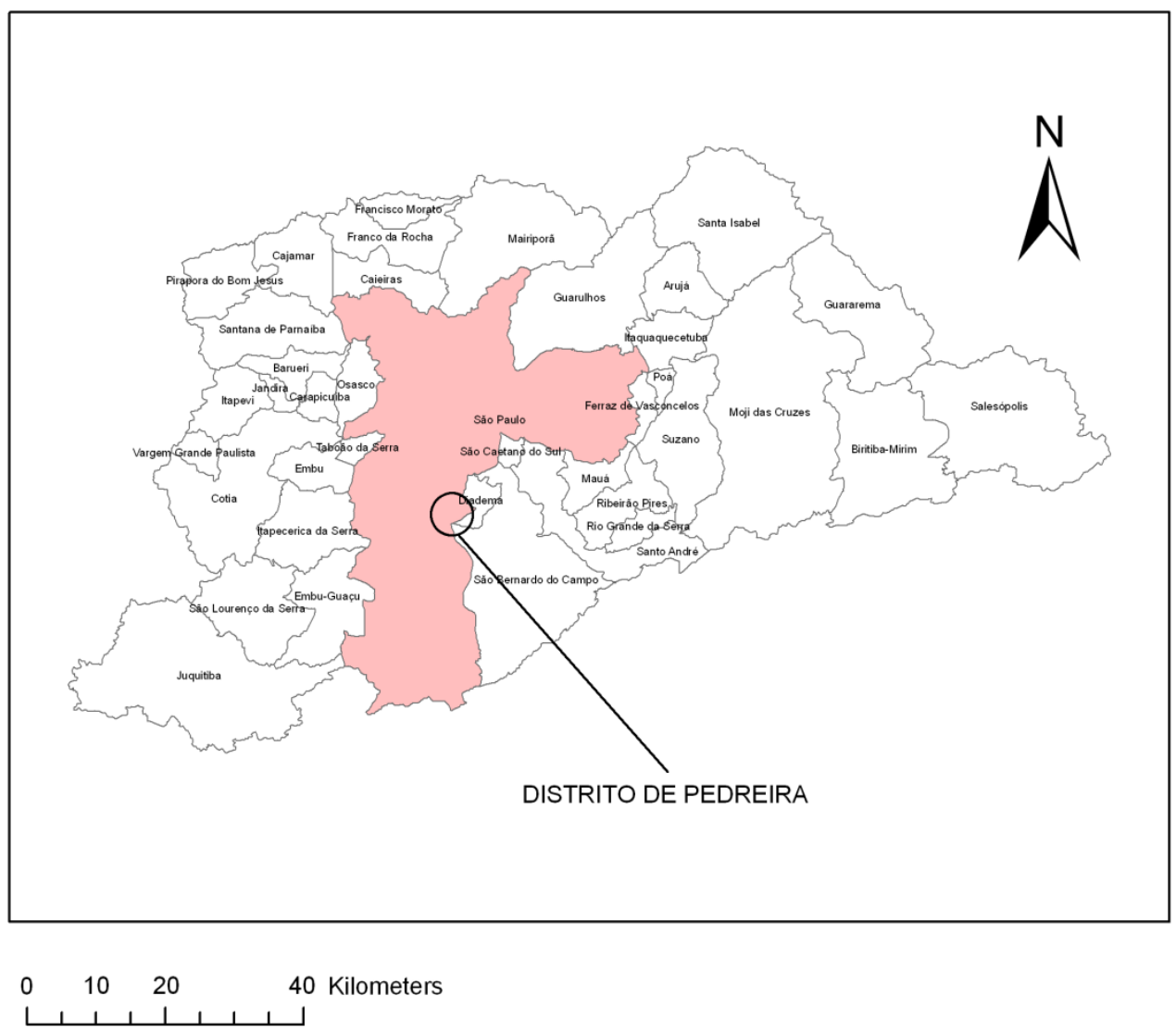

Fonte: IBGE

Autor: Shinhiti Osanai 


\subsection{Sítio urbano}

O Distrito de Pedreira está localizado no sul do planalto paulistano. Há presença de muitas colinas, sendo algumas altas na região de divisa com Diadema e outras apresentam topos aplainados nas proximidades da represa Billings, que predominam a caracterização do seu relevo. Muitos córregos, a maioria deles sem nome, correm entre algumas de suas colinas. O relevo é constituído principalmente por maciços e planícies aluviais.

Na região sul do Distrito, existe uma península à margem da represa Billings, cuja característica do solo se estende partindo da extremidade dessa península no sentido nordeste em direção a Diadema. Esse tipo de solo encontra-se entre a Rua Dr. José Silvio de Camargo e a Estrada da Água Santa, é formado por rocha xisto-micáceos (Xm), e corresponde ao conjunto de rocha e solo originados de xistos (rocha metamórfica rica em minerais micáceos, com estrutura foliada). Esses solos de alteração são bastante espessos, extremamente suscetíveis à erosão, apresentam dificuldades para cortes e aterros e também para compactação. Existe risco de escorregamento, dependendo da direção do corte, e de desplacamentos de porções de rocha. Estes solos se encontram nos bairros Sete Praias, na parte da península, chegando até os bairros Jardim Monte Líbano, Eldorado e Mata Virgem, até a divisa com Diadema. Esse mesmo tipo de solo também é encontrado em outra península (Jardim Apurá) localizada na parte central do Distrito, na sua extremidade, onde terminam os bairros Jardim Bandeirantes e Jardim Apurá, cujo limite fica entre a represa Billings e as Ruas Manoel Gutierrez Najera e Salvador Dali, em toda a sua extensão. Há um córrego denominado Ribeirão da Grota Funda que tem a sua foz na represa Billings e segue a linha de divisa com Diadema. 


\title{
PRINCIPAIS BAIRROS
}

\author{
DISTRITO DE PEDREIRA
}

MAPA NÚMERO 4.3

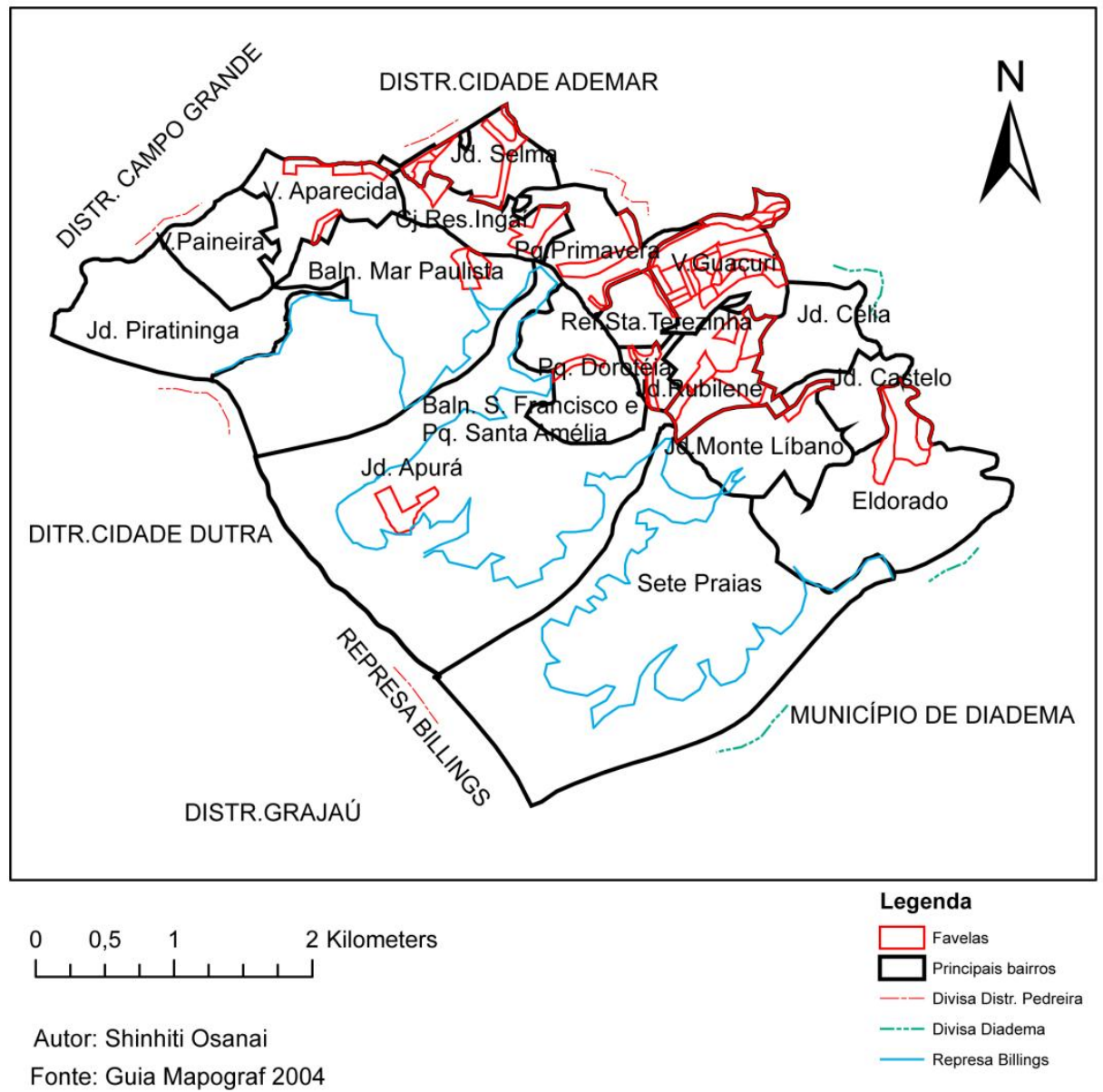




\section{PRINCIPAIS ACESSOS}

DISTRITO DE PEDREIRA

MAPA NÚMERO 4.4

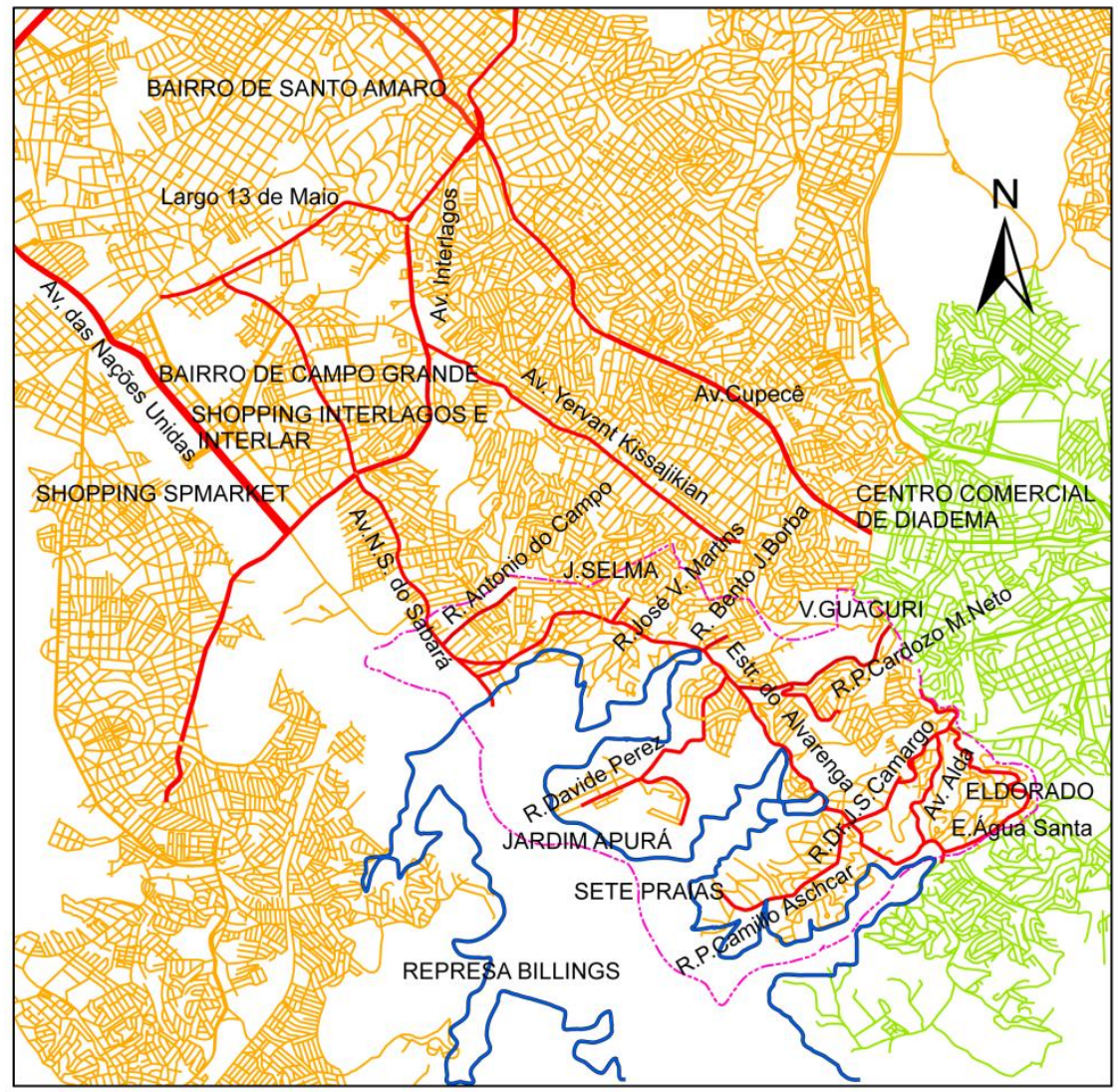

Legenda

$\begin{array}{lll}0 & 0,5 & 1\end{array}$ 2 Kilometers

Autor: Shinhiti Osanai

Fonte: Guia Mapograf 2004

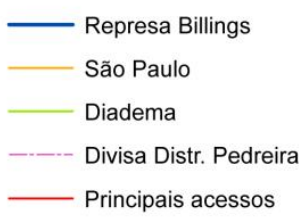


Partindo aproximadamente da metade da península da região central (Jardim Apurá), estendendo por toda parte central e nordeste do Distrito, onde ficam os bairros Jardim Apurá, na península, Balneário São Francisco, Jardim Rubilene, Vila Guacuri, Vila Missionária, encontram os solos de rocha graníticos $(\mathrm{Gr})$, constituídos por conjunto de rocha e solo originados da alteração, a partir da ocorrência de granitos (rocha magmática). Esses solos apresentam espessuras superiores a dez metros e textura areno-argilosa. Tal fato pode causar problemas geotécnicos semelhantes aos maciços gnáissicos, são agravados pela maior ocorrência de matacões correspondente a blocos de rocha arredondados, compreendendo dimensões métricas. Nesta área, na Vila Guacuri, chegou a operar uma pedreira, a Pedreira Itatinga, hoje desativada e transformada num aterro sanitário. Existe outra pedreira, a Pedreira Sete Praias, desativada e em fase de desapropriação pela Prefeitura de São Paulo para a construção de um parque.

A área formada por solos de rocha granítica $(\mathrm{Gr})$ é cortada por três faixas relativamente estreitas. Cada uma delas, separadas a uma distância não muito significativa, é constituída por uma planície aluvial (Al) de áreas de fundo de vale, que apresenta baixa declividade (menos de 5\%), com solos arenosos e argilosos, e lençol freático superficial. São áreas propensas a recalques, que podem danificar pavimentos, redes de infra-estrutura e edificações, além de estarem mais sujeitas a inundações. A primeira, mais ao centro, localiza-se numa região conhecida como Sete Campos no bairro Refúgio Santa Terezinha, bem próximo dos bairros Parque Primavera e Parque Santa Amélia, atualmente sem edificações e deve ser transformada em parque num futuro próximo. Trata-se da área onde se localizam a Rua dos Apiaris e Avenida Antonio Vieira Marcondes. Uma das suas extremidades, divididas em duas partes bastante estreitas, seguem para o norte, uma delas pela Rua do Guaicuri e a outra pelas Ruas Dom João dos Santos e Frei Francisco Ferreira. A segunda faixa, localizada mais para a região central, é delimitada pelas Ruas Miguel Fleta, Dr. Carlos de Rezende Enout e Avenida Aldo João Rinaldi, no bairro Jardim Rubilene. A terceira e última faixa está mais para o sul, na região das Ruas Vicente Strichalsky, Lúcia Parente Serra e Josefina Gianinni Elias - Dona Bimba, nos bairros Jardim das Laranjeiras e Praia Leblon. Nas duas primeiras faixas existe uma característica particular no solo, pois é formado pela deposição de sedimentos carregados por cursos água (solos aluviais), de consistência mole, compressíveis, apresentando a menor capacidade de suporte, afetados pelas oscilações do lençol freático e, portanto, mais suscetíveis a problemas de recalques. Nessas planícies correm vários riachos, e apenas um deles, na segunda planície, recebe o nome de córrego do Guaicuri. 
Ao extremo sul da península, onde se localiza o Jardim Apurá, com vistas em sua frente à outra península onde se situa o bairro Sete Praias, encontra-se solo de rocha xisto-quartzosos $(\mathrm{Xq})$, formados por conjunto de rocha e solos originados de xistos ricos em quartzo, que apresentam menor grau de estruturação (foliação) e menor potencial de erosão que os xistos micáceos. Possuem as características de facilidade e boa compactação como material para aterros. O maior problema deve-se à possibilidade de vazios (carsts) gerados por dissolução da rocha, quando intercalados com rochas carbonáticas. Nesta área estão as Ruas Independência, Portal Ecológico e Amad Massud.

Na região, mais ao centro e ao norte do Distrito, onde se localizam os bairros Jardim Selma, Balneário Mar Paulista, Balneário São Francisco, esses dois últimos à margem da represa Billings, encontram os solos característicos dos maciços mistos (Mst) formados por conjunto de rocha e solos provenientes da alteração de migmatitos (rocha mista com porções de rocha metamórfica e de rocha ígnea - granítica/ pegmatítica). São solos de alteração de composição arenosa a silto-arenosa. Os problemas estão relacionados à erosão intensa nos veios e bolsões de composição mais arenosa, em geral de coloração esbranquiçada, podendo ocorrer matacões. Nessa região nota-se a existência de duas faixas constituídas de planície aluvial (Al) de áreas de fundo de vale. A primeira faixa fica bem ao norte, na região dos bairros Vila Paineira e Vila Aparecida, entre as Ruas Zique Tuma e Antonio do Campo, onde passa o córrego da Olaria, determinando a divisa com o Distrito de Campo Grande. Essa faixa segue em direção às Ruas Brasil, Pontes de Morais e Avenida Eduardo Pereira Ramos. A segunda faixa, no bairro Balneário Mar Paulista, localiza-se entre a margem da represa Billings, Rua Rodrigues Medeiros e Rua do Sossego. Também, nessa segunda faixa, junto à beira da represa, pode-se encontrar o solo mole e compressível.

Esses solos característicos dos maciços mistos (Mst) também são encontrados na extremidade norte da península, onde se localiza o bairro Sete Praias, numa área delimitada pelas Ruas Dr. José Silvio de Camargo, Salvatore Marchesi, Lucília Marcel e Estrada do Alvarenga.

Seguindo em sentido norte, pelas Avenidas Emérico Richter e Nossa Senhora do Sabará, no lado esquerdo, na área ocupada pela usina termelétrica de Piratininga, encontra-se uma planície aluvial (Al), constituída por áreas de fundo de vale e baixa declividade (menos de $5 \%$ ), solos arenosos e argilosos, e lençol freático superficial. Essa área localiza-se à margem 


\title{
ASPECTOS GEOLÓGICOS DO DISTRITO DE PEDREIRA
}

\author{
DISTRITO DE PEDREIRA
}

MAPA NÚMERO 4.5

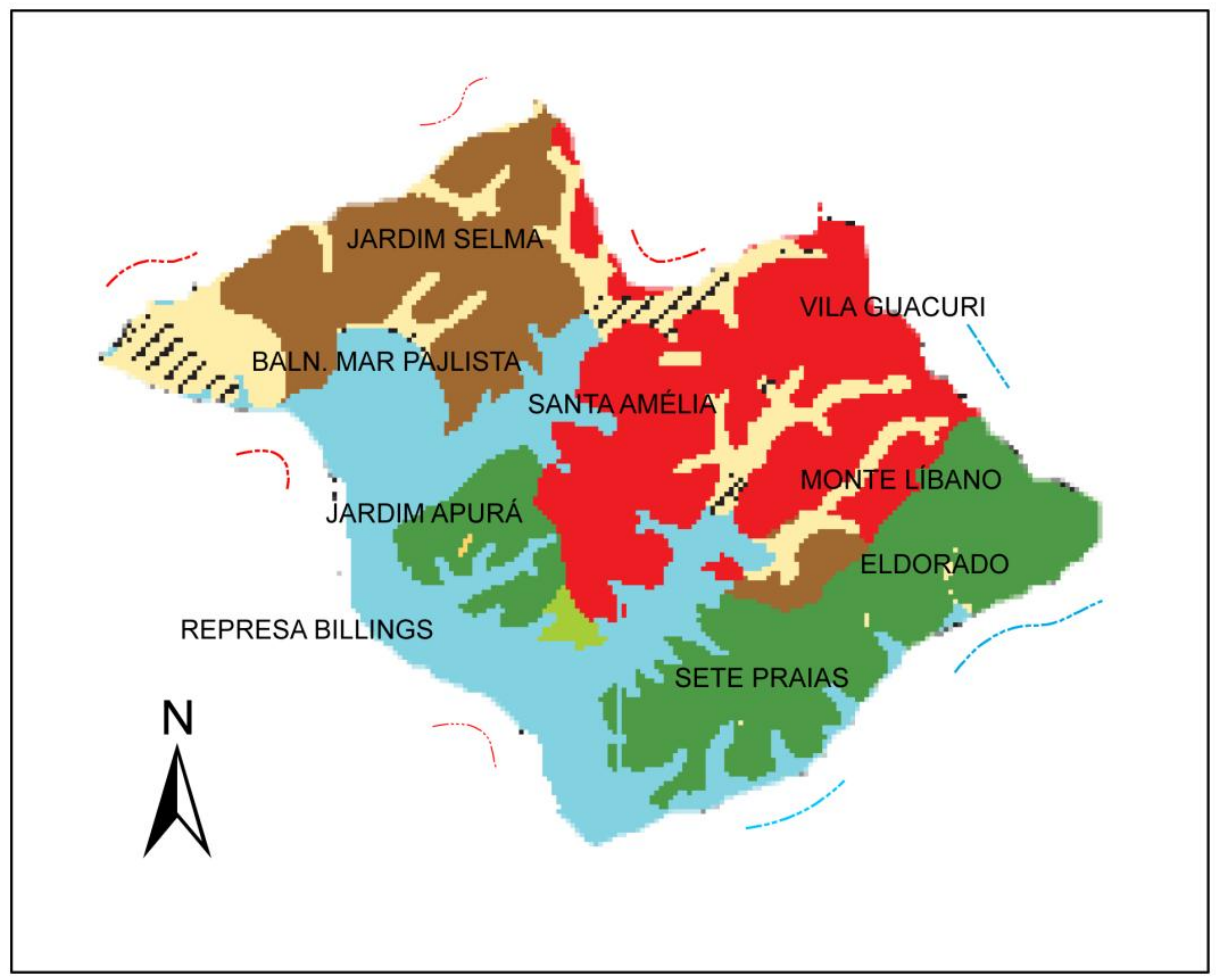

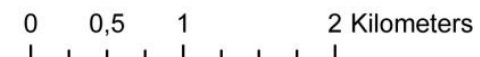

Autor: Shinhiti Osanai

Fonte: SEMPLA - Carta Geotécnica do Município de São Paulo - 1992

\section{Tipos de subsolos}

ROCHA XISTO-MICÁCEOS

ROCHA GRANITICOS

ROCHA XISTO-QUARTZOSOLOS

ROCHA MISTA METAMÓRFICA E ÍGNEA PLANÍCIE ALUVIAL

QZ SOLO MOLE E COMPRENSÍVEL

REPRESA BILLINGS

-_-- Divisa Distr. Pedreira Divisa Diadema 
do rio Jurubatuba (rio Pinheiros) e também apresenta a existência de solo mole e compressível cuja maior ocorrência se verifica ao longo dos rios Tietê e Pinheiros.

No Distrito de Pedreira o clima é do tipo tropical úmido de altitude do Planalto Atlântico e sendo três os seus mesoclimas. (TARIFA; ARMANI, 2000)

Apresentamos a seguir as classificações elaboradas por Tarifa e Armani (2000).

O primeiro mesoclima é classificado como IA2 e corresponde à região de relevo constituído por topos mais elevados dos maciços, referente à extremidade sul do Espigão Central localizado no Distrito de Pedreira. A temperatura média anual das máximas permanece em torno de $24,9^{\circ}$ e $24,8^{\circ} \mathrm{C}$ e a média anual das mínimas em torno de $15,5^{\circ}$ e $15,4^{\circ} \mathrm{C}$, sendo a média anual em torno de $19,3^{\circ}$ e $19,2^{\circ} \mathrm{C}$. As chuvas variam de 1350 a $1450 \mathrm{~mm}$ anuais. Em consequiência das altitudes mais elevadas possibilita uma boa dispersão de poluentes. Segue toda a divisa com o município de Diadema e localiza-se nos bairros de Vila Guacuri, Jardim Monte Líbano, Mata Virgem e Jardim do Castelo. Corresponde aos trechos de altitudes mais elevadas da Estrada da Água Santa com a cota de 865 m, Av. Alda e R. Dr. José Silvio de Camargo, ambos com a cota de 825 m e R. Professor Cardoso de Mello Neto com a cota de $840 \mathrm{~m}$.

O segundo tipo é denominado IB2, faz parte do mesoclima das colinas intermediárias, correspondendo às colinas, patamares e rampas do rio Pinheiros. A média anual das máximas varia de $25,2^{\circ}$ a $24,9^{\circ} \mathrm{C}$ e a média anual das mínimas de $15,8^{\circ}$ a $15,5^{\circ} \mathrm{C}$. A média anual oscila entre $19,6^{\circ}$ e $19,3^{\circ} \mathrm{C}$. Os índices pluviométricos são muito semelhantes do mesoclima IA2, apresentando valores de 1300 a 1400 mm pelo fato das colinas pertencerem à vertente dos topos mais altos em direção à Represa Billings. Sua condição topográfica intermediária favorece a drenagem noturna de ar frio e a dispersão dos poluentes é razoável, a qual pode variar em função da altura da camada de mistura e eventualmente pode ocupar apenas os setores rebaixados mais próximos da represa Billings. Nas áreas mais próximas à represa verificam-se presença freqüente de nevoeiros e névoas úmidas. Corresponde toda a extensão dos arredores da Estrada do Alvarenga, em média com a cota de $775 \mathrm{~m}$, sendo os principais bairros: Balneário São Francisco; Balneário Mar Paulista; Sete Praias; Parque Santa Amélia; Parque Dorotéia; Jardim Rubilene; Jardim Selma e Jardim Apurá. 


\section{MESO CLIMAS}

DISTRITO DE PEDREIRA

MAPA NÚMERO 4.6

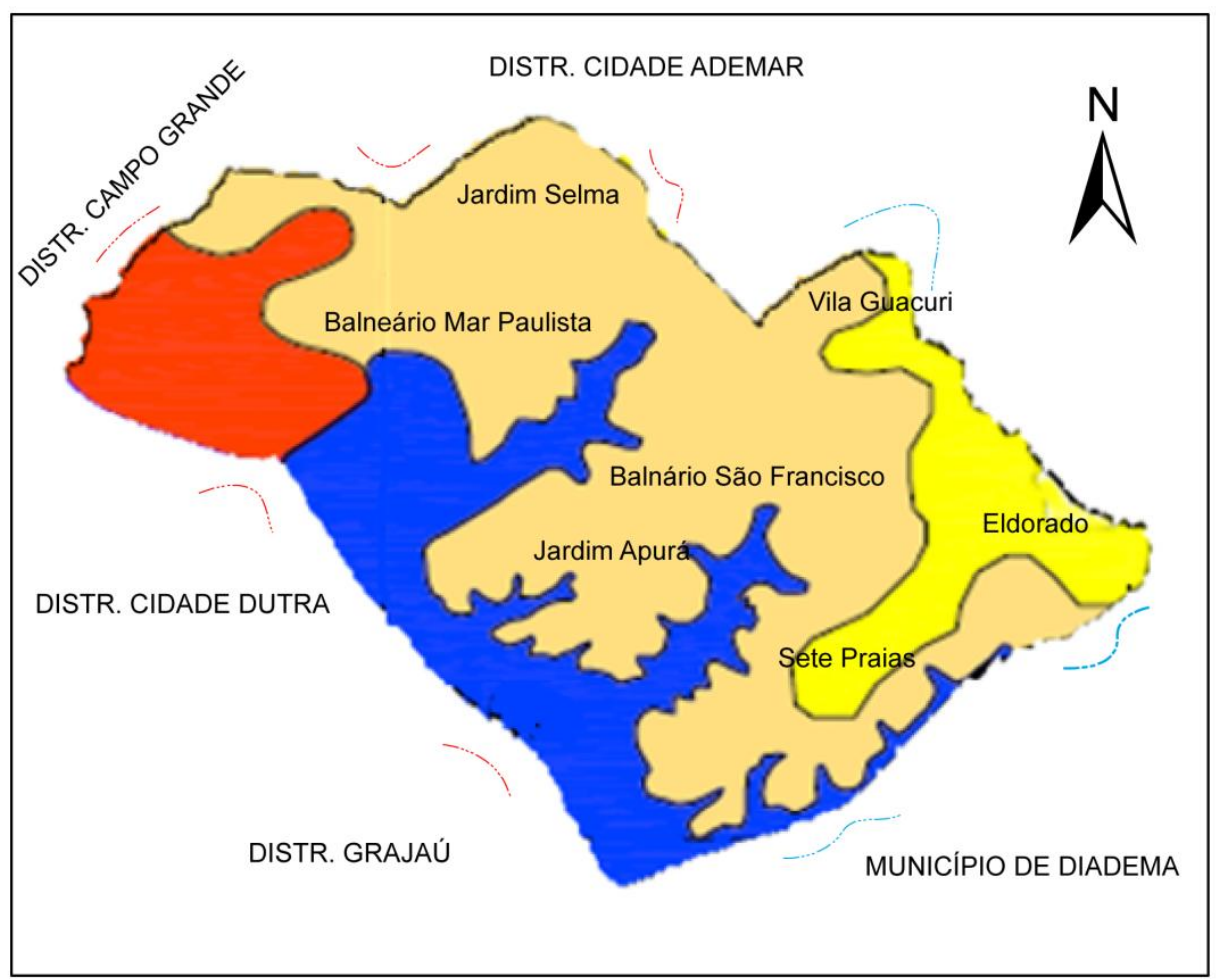

\section{$\begin{array}{llll}0 & 0,5 & 1 & 2 \text { Kilometers }\end{array}$}

Autor: Shinhiti Osanai

Fonte: Tarifa; Armani - 2001

Secretaria Municipal do Verde e Maio Ambiente

\section{Meso clima}

IC3 - Varzeas e baixos terraços do vale do rio Pinheiros

$\square$ IB2 - Colinas, patamares e rampas do rio Pinheiros

$\square$ IA2 - Altas colinas de cumeadas planas do Espigão Central

Represa Billings

--_ Divisa Distr. Pedreira

-.-- Divisa Diadema 
O terceiro tipo de mesoclima é o IC3 que corresponde a várzeas e baixos terraços do vale do rio Pinheiros. Em conseqüência da baixa altitude, as temperaturas são relativamente elevadas durante o dia e ocorrem as mínimas durante a noite, decorrente da drenagem e acumulação de ar frio nas partes mais baixas. A média anual das máximas se encontra de $25,3^{\circ}$ a $25,2^{\circ} \mathrm{C}$ e a média anual das mínimas de $15,9^{\circ}$ a $15,8^{\circ} \mathrm{C}$. A média anual varia de $19,7^{\circ}$ a $19,5^{\circ} \mathrm{C}$. Os totais pluviométricos anuais oscilam de 1240 a $1460 \mathrm{~mm}$. Por causa das freqüentes inversões térmicas as condições naturais para a dispersão de poluentes são ruins. Trata-se de uma área, com a cota de $750 \mathrm{~m}$, ocupada pela Usina Termelétrica de Piratininga, na divisa com o Distrito de Campo Grande, ao norte do Distrito de Pedreira, às margens do canal do rio Pinheiros.

O Distrito de Pedreira localiza-se em uma das margens da represa Billings. Ela foi inaugurada em 1926, com o objetivo de gerar energia elétrica pela Usina Henry Borden em Cubatão, cuja concepção foi desenvolvida pelo engenheiro Asa White Kenney Billings, para a concessionária de energia elétrica Light \& Power.

A represa Billings encontra-se na Grande São Paulo, nos municípios de São Paulo, São Bernardo do Campo, Diadema, Ribeirão Pires, Rio Grande da Serra e Santo André. Em São Paulo encontra-se no Distrito de Pedreira (Subprefeitura de Cidade Ademar), Distrito de Grajaú (Subprefeitura de Capela do Socorro) e Distrito de Parelheiros (Subprefeitura de Parelheiros).

Forma um lago com $130 \mathrm{~km}^{2}$, perímetro de $800 \mathrm{~km}$ com a capacidade de $1.200 .000 \mathrm{~m}^{3}$ correspondente a 2 bilhões de $\mathrm{kWh}$. Encontra-se a uma cota de $745 \mathrm{~m}$ acima do nível do mar, podendo atingir até $746,5 \mathrm{~m}$. (RADESCA, [1958])

No Distrito de Pedreira localiza-se a oeste constituindo a divisa com o Distrito de Grajaú. Forma duas penínsulas, a do Jardim Apurá na região central e a de Sete Praias mais a sul. Em suas margens funciona o Parque Mar Paulista, ao norte, com o seu início no rio Jurubatuba (canal do rio Pinheiros), acompanhando a Rua do Mar Paulista até a Rua Rodrigues Medeiros.

O PRE prevê a instalação de parques em toda a extensão da sua margem, até o Jardim Apurá, com a função de explorar o potencial turístico através da instalação de clubes náuticos e serviços de lazer aquático. O grande desafio é remover as favelas instaladas antes da execução das obras. Junto ao canal do rio Jurubatuba, no final da Av. Nossa Senhora do Sabará, está 
prevista a construção de um porto fluvial com o objetivo de aproveitar a represa Billings para o transporte de passageiros servindo os bairros, que margeiam a represa, como o Grajaú.

Na região do Distrito de Pedreira, foram aproveitadas as águas da bacia do rio Grande, por meio da construção de uma barragem com extensão de $1500 \mathrm{~m}$ e $25 \mathrm{~m}$ de altura, assentado diretamente sobre uma formação de granito através de aterro hidráulico e núcleo de concreto. (RADESCA, [1958])

Junto à barragem existe a Usina Elevatória de Pedreira, inaugurada em 1939, para bombear as águas do rio Tietê através da retificação e reversão do rio Pinheiros, com 8 bombas síncronas sendo que 7 delas podem funcionar como geradores quando o fluxo das águas for revertido da represa Billings para o rio Pinheiros. O objetivo do bombeamento é abastecer a represa para garantir a geração de energia elétrica em Cubatão.

Desde 1992 o bombeamento das águas do rio Tietê está suspenso e é permitido excepcionalmente para o controle das enchentes em épocas das chuvas. Isso reduziu a capacidade de geração de energia da Usina Henry Borden em 75\%.

Apesar da suspensão do bombeamento das águas do rio Tietê a qualidade das águas da represa Billings continua comprometida por causa da crescente ocupação irregular em suas margens. Todos os córregos com nascente no Distrito de Pedreira desembocam na represa transportando o esgoto de vários bairros.

A represa Billings ajuda a abastecer a represa Guarapiranga através da transposição de suas águas no braço de Taquacetuba, que tem sido motivo de discussões sobre a possibilidade da interferência na qualidade das águas de Guarapiranga, utilizadas para o abastecimento da população. As águas do braço de Riacho Grande são utilizadas para o abastecimento de água para o município de São Bernardo do Campo.

\subsection{População}

De acordo com censo demográfico de 2000 do IBGE, (mapas 4.7 e 4.8) verificam-se as maiores concentrações de domicílios no Jardim Apurá, à beira da represa Billings, e nos bairros Vila Aparecida, Parque Primavera, Refúgio Santa Terezinha, Vila Guacuri, Jardim Monte Líbano e Eldorado. Nesses bairros, geralmente, há um significativo número de áreas, 
que foram ocupadas por meio do processo de invasão, cujas moradias, muitas vezes, foram construídas em terrenos de declividade bastante acentuada. Exceto as áreas invadidas de Jardim Apurá, os bairros à beira da Represa contam com melhor padrão de urbanização. Observa-se significativa concentração de domicílios em muitas das áreas de favela.

Notam-se alguns índices habitacionais relativamente elevados em muitas favelas. Os bairros de Sete Praias, Balneário Mar Paulista e parte de Balneário São Francisco, são alguns dos bairros de melhor estrutura urbana e localizados à margem da represa Billings, que apresentam os índices mais baixos de habitantes por domicílio, exceto parte do Jardim Apurá nas suas áreas de invasão com uma das maiores concentrações de domicílios. As regiões, que sofreram invasão, também apresentam níveis mais elevados desse índice. Em relação ao Jardim Piratininga, esse índice é baixo, porque se trata de uma área ocupada pela Usina Termelétrica de Piratininga e apenas uma pequena área é ocupada pelos os moradores.

Nos setores censitários, onde se localizam os bairros Balneário Mar Paulista, Balneário São Francisco, Jardim Apurá e Sete Praias, às margens da represa Billings, parte dessa represa está incorporada no território de cada setor censitário, portanto, não representa as áreas territoriais efetivamente ocupadas. Esse fato pode trazer viés aos cálculos de densidade, eventualmente distorcendo os resultados em relação à realidade, toda vez que a área territorial for utilizada como base de cálculo de alguns índices, por exemplo, densidade populacional ou densidade de domicílios por $\mathrm{km}^{2}$.

As densidades mais elevadas, em domicílios por $\mathrm{km}^{2}$ (mapa 4.9), são observadas em dois conjuntos residenciais constituídos por vários blocos de prédios, localizados nos bairros Conjunto Residencial Ingaí e Jardim Monte Líbano. Em segundo lugar, as favelas de modo geral contam com quantidade bastante significativa de domicílios. Os bairros Balneário Mar Paulista, Balneário São Francisco e Sete Praias, por causa dos imóveis construídos em lotes de terreno de áreas maiores, apresentam densidades mais baixas. As áreas de invasão, freqüentemente, mesmo que não sejam de favelas, apresentam as densidades muito elevadas. No Jardim Paineira, encontram-se algumas indústrias, o que favorece a redução do número de residências e da densidade de domicílios. No Jardim Apurá, há uma grande propriedade utilizada para a atividade rural por meio de pastagem para o gado de leite, e isto colabora para a redução da densidade de domicílios. Todavia, no Jardim Apurá, às margens da represa Billings, há um número reduzido de residências de médio padrão construídas em lotes grandes. 


\title{
QUANTIDADE DE DOMICÍLIOS
}

\author{
DISTRITO DE PEDREIRA \\ POR SETOR CENSITÁRIO \\ CENSO 2000
}

MAPA NÚMERO 4.7
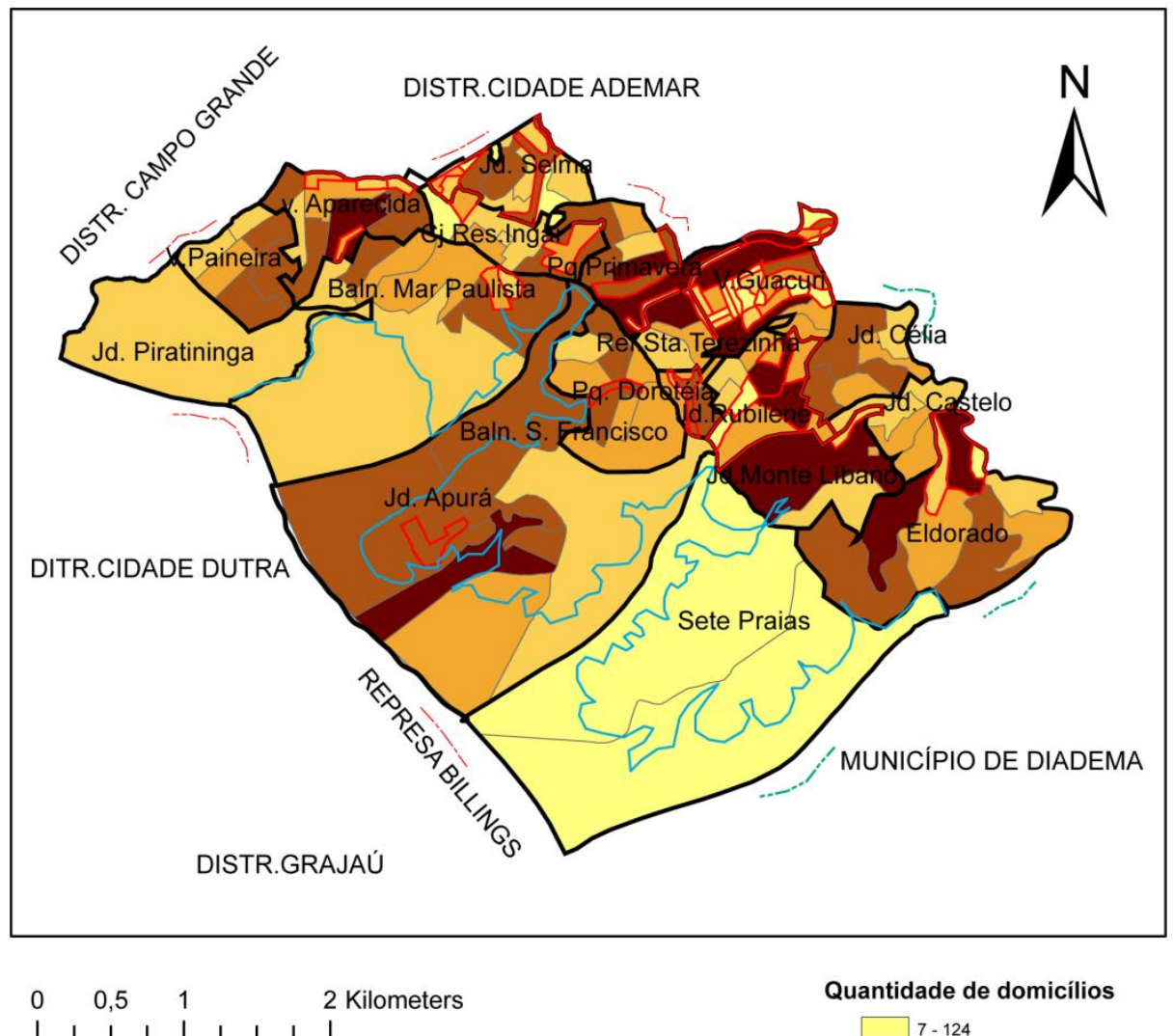

Autor: Shinhiti Osanai

Fonte: IBGE e Guia Mapograf 2004

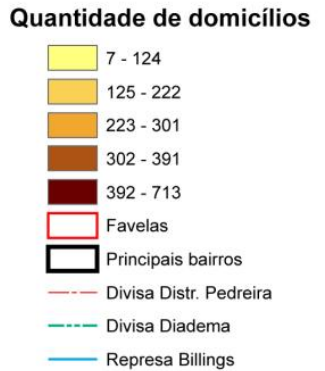




\section{QUANTIDADE DE HABITANTES POR DOMICÍLIO}

DISTRITO DE PEDREIRA

POR SETOR CENSITÁRIO

CENSO 2000

MAPA NÚMERO 4.8

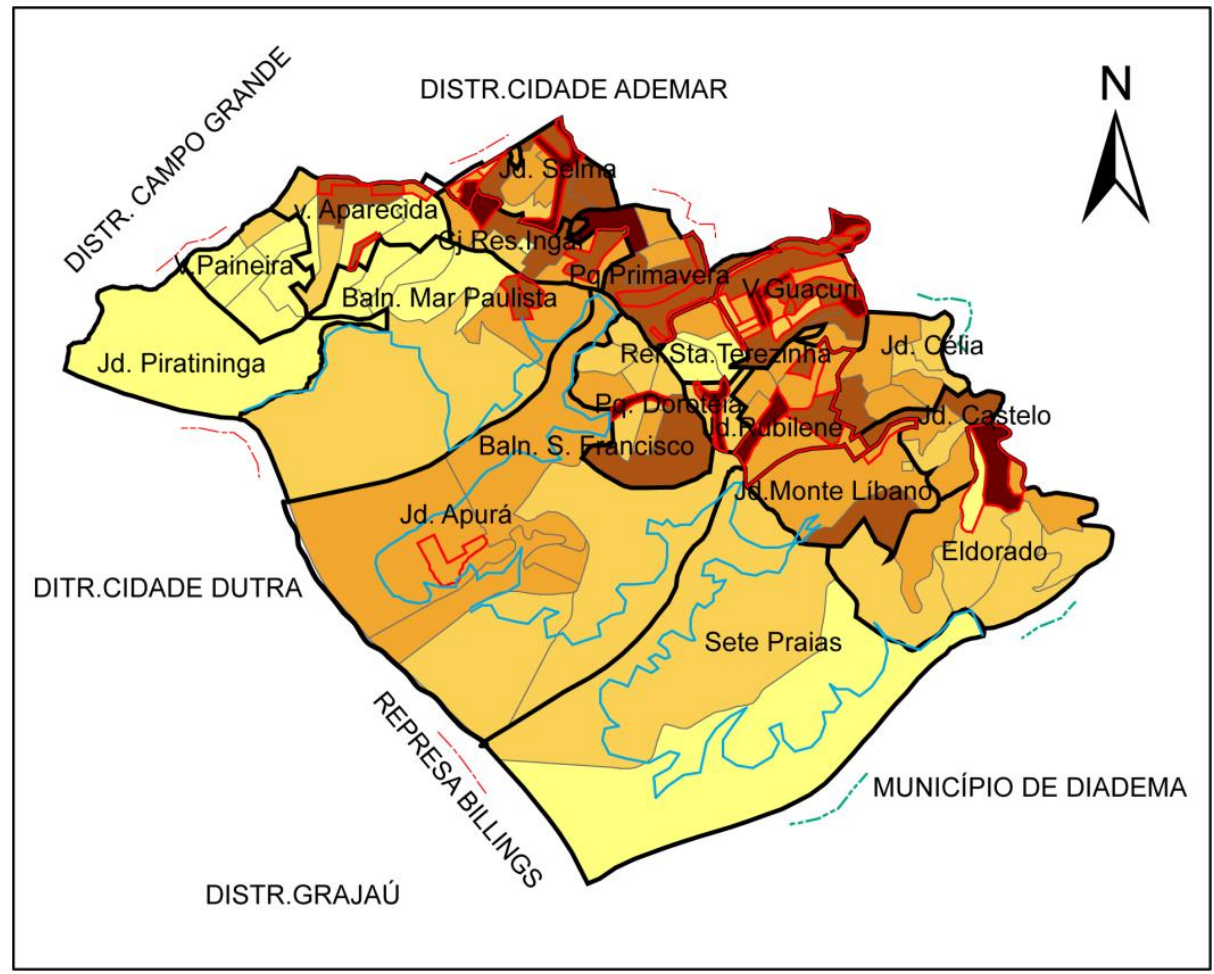

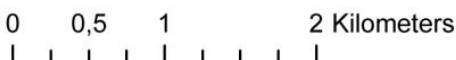

Autor: Shinhiti Osanai

Fonte: IBGE e Guia Mapograf 2004
Quant. de habitantes por domic.

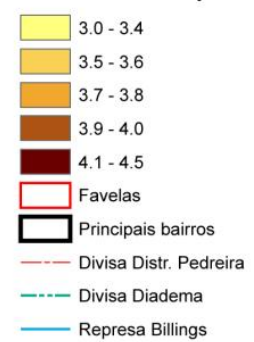


A população estimada do Distrito de Pedreira (mapa número 4.10) é de 133.148 habitantes em 2004 sendo a população em idade ativa de 111.691 habitantes. Em 2002 apenas 2.943 empregos formais foram constatados no próprio Distrito. Portanto, a maioria das pessoas está envolvida em atividades informais ou então trabalhando fora desse Distrito, o que dá a Pedreira a característica de um distrito dormitório.

Jardim Apurá, Vila Aparecida, Jardim Paineira, Parque Primavera, Jardim Célia, Jardim Rubilene e Eldorado são os bairros dotados de maior número de habitantes. Os bairros Balneário Mar Paulista e Sete Praias, localizados à margem da represa Billings, são os menos populosos. Nas favelas e nas áreas de invasão, geralmente, observa-se a concentração mais elevada de pessoas.

As maiores densidades demográficas sob o critério de habitante por $\mathrm{km}^{2}$, estão nos bairros Conjunto Residencial Ingaí e Jardim Monte Líbano, por causa dos conjuntos residenciais construídos em vários blocos de prédios de apartamentos (mapa 4.11). O resultado dessas densidades demográficas é relativamente baixo nos bairros que margeiam a represa Billings, mesmo no Jardim Apurá apesar a participação de uma área de invasão, em parte explicada pela área da represa que é incorporada na área territorial dos setores censitários.

As regiões de densidade demográfica elevada estão a nordeste da Estrada do Alvarenga, porque há muitas favelas e áreas de invasão. Nos bairros Eldorado e Jardim Monte Líbano, que são regiões de declividade acentuada, e apesar das invasões ocorridas em muitas das suas áreas não recomendadas para a construção de moradias, a densidade populacional ainda é relativamente baixa.

No Distrito de Pedreira existe um numeroso contingente de pessoas de renda baixa, justificando, em parte, a alta incidência de invasões. De acordo com o censo demográfico de 2000, 53,9\% dos domicílios recebiam uma renda familiar inferior a 5 salários mínimos e 28,6\% na faixa entre 5 e 10 salários mínimos. Nas favelas, $68,8 \%$ dos ou das chefes de domicílios recebiam uma renda inferior a 5 salários mínimos, apenas 7,8\% recebiam na faixa entre 5 e 10 salários mínimos e 22,5\% não possuíam rendimento. 


\title{
QUANTIDADE DE DOMICÍLIOS POR km²
}

\author{
DISTRITO DE PEDREIRA \\ POR SETOR CENSITÁRIO \\ CENSO 2000
}

MAPA NÚMERO 4.9

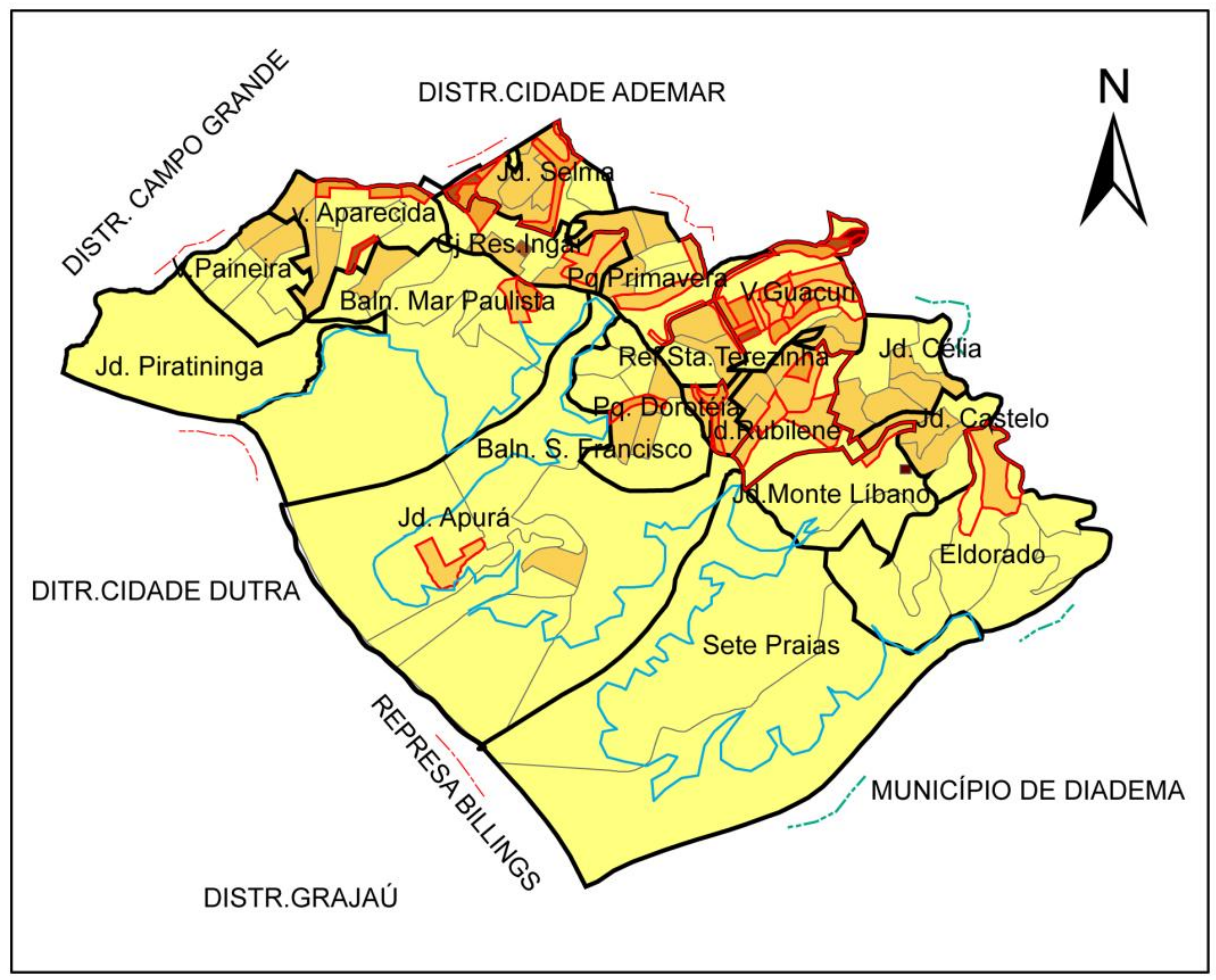

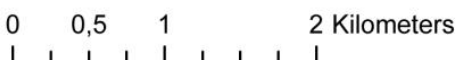

Autor: Shinhiti Osanai

Fonte: IBGE e Guia Mapograf 2004
Quant. domicílios por $\mathrm{km}^{2}$

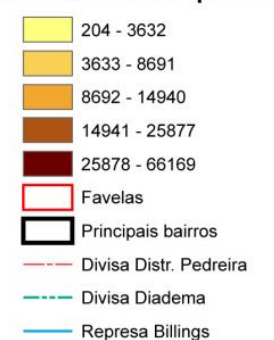




\title{
POPULAÇÃO RESIDENTE
}

\author{
DISTRITO DE PEDREIRA \\ POR SETOR CENSITÁRIO \\ CENSO 2000
}

MAPA NÚMERO 4.10
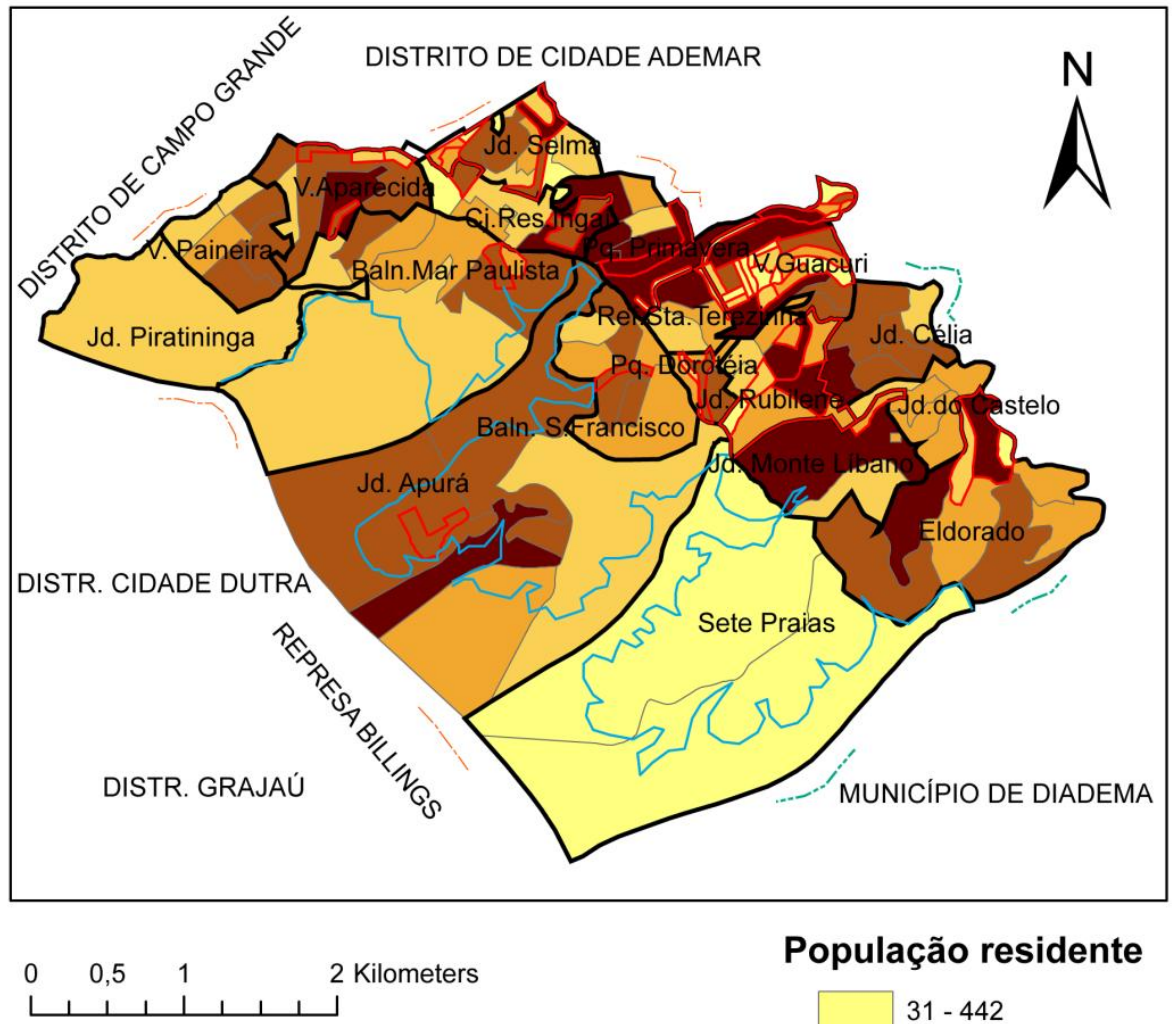

\section{População residente}

Autor: Shinhiti Osanai

Fonte: IBGE e Guia Mapograf 2004

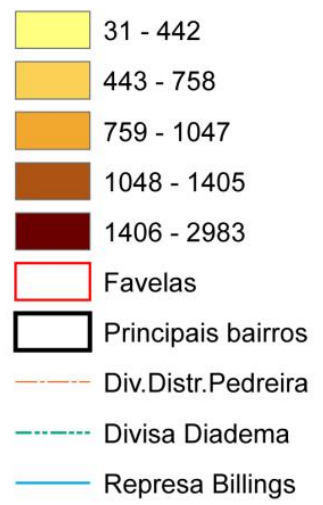


Os níveis mais baixos da renda per capita dos ou das chefes de família (mapa número 4.12) estão nas favelas. Entretanto, nas regiões de invasão, a renda é ligeiramente superior em comparação às favelas. Os níveis mais elevados estão localizados nos bairros de Jardim Paineira, Conjunto Residencial Ingaí, Balneário Mar Paulista, Balneário São Francisco e Sete Praias.

No bairro de Sete Praias, apesar da presença de chefes de família com rendimento entre 5 e 10 salários mínimos e também acima de 10 salários mínimos, existe uma parcela significativa de chefes de família com renda na faixa entre 1 e 2 salários mínimos.

Na maioria dos bairros, de renda per capita mais elevada, o resultado da remuneração encontra-se acima de 5 salários mínimos. A renda per capita da maior parcela dos ou das chefes de família, do Distrito de Pedreira, se classifica na faixa entre 2 e 5 salários mínimos.

Os índices mais baixos do tempo de estudo do ou da chefe de família (mapa número 4.13), com a média em torno de 5 anos, estão nas favelas. Em relação ao tempo de estudo, uma expressiva parcela dos ou das chefes de família do Distrito de Pedreira apresenta a média entre 5 e 7 anos e são muito poucos os bairros que apresentam a média acima de 7 anos. $\mathrm{O}$ mapa número 4.12, que apresenta a renda per capita, mostra um resultado muito semelhante em relação ao mapa número 4.13, referente ao tempo de estudo, no qual se observa maior tempo médio de estudo nas regiões de renda mais elevada.

Maior parte do Distrito de Pedreira apresenta o tempo médio de estudo entre 9 e 11 anos. Um número significativo de chefes de família, dos bairros Jardim Apurá e Eldorado, possuem escolaridade média de até 8 anos. O bairro Balneário Mar Paulista se destaca com o tempo médio de estudo entre 14 e 15 anos, embora existam, também, pessoas com a média na faixa entre 9 a 11 anos. Nas áreas de invasão, mesmo que não sejam de favela, as pessoas apresentam o tempo médio de estudo relativamente baixo, de até 8 anos. Chefes de família possuindo tempo médio acima de 16 anos de estudo são raros neste Distrito de Pedreira.

Há nas favelas uma significativa concentração de pessoas analfabetas (mapa número 4.14). Os bairros Parque Primavera e Jardim Rubilene, seguidos pelos bairros Jardim Apurá e Eldorado acomodam um elevado contingente da população analfabeta. 


\title{
DENSIDADE DEMOGRÁFICA - HABITANTES $/ \mathrm{km}^{2}$
}

\author{
DISTRITO DE PEDREIRA
}

POR SETOR CENSITÁRIO

CENSO 2000

MAPA NÚMERO 4.11

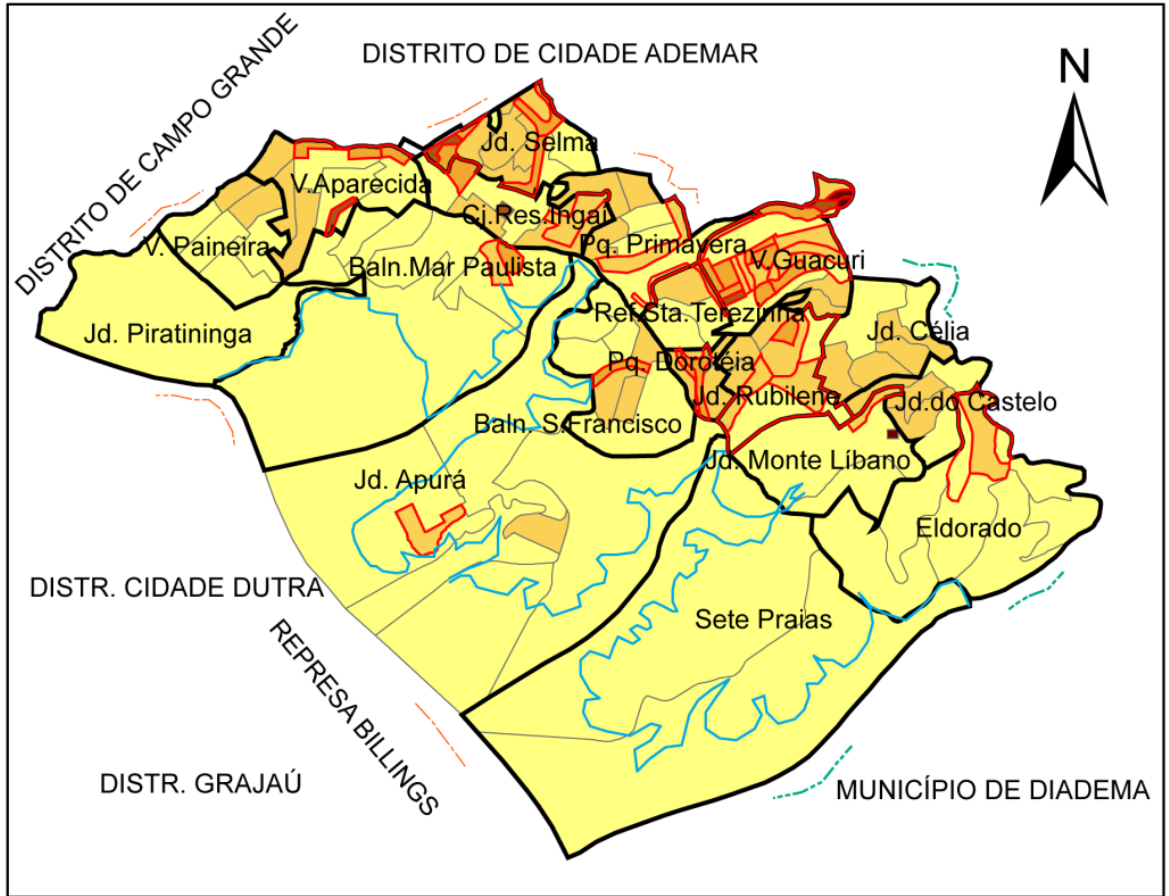

$\begin{array}{llll}0 & 0,5 & 1 & 2 \text { Kilometers }\end{array}$

Autor: Shinhiti Osanai

Fonte: IBGE e Guia Mapograf 2004
Densidade demográfica hab/km²

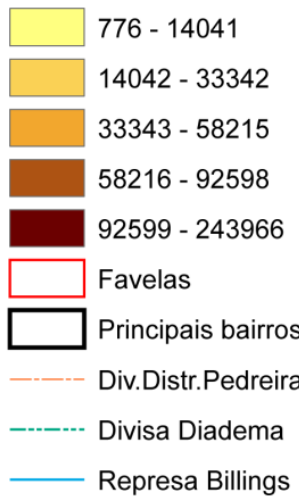




\section{RENDA PER CAPITA DO OU DA CHEFE DE FAMÍLIA EM REAIS}

DISTRITO DE PEDREIRA

POR SETOR CENSITÁRIO

CENSO 2000

MAPA NÚMERO 4.12

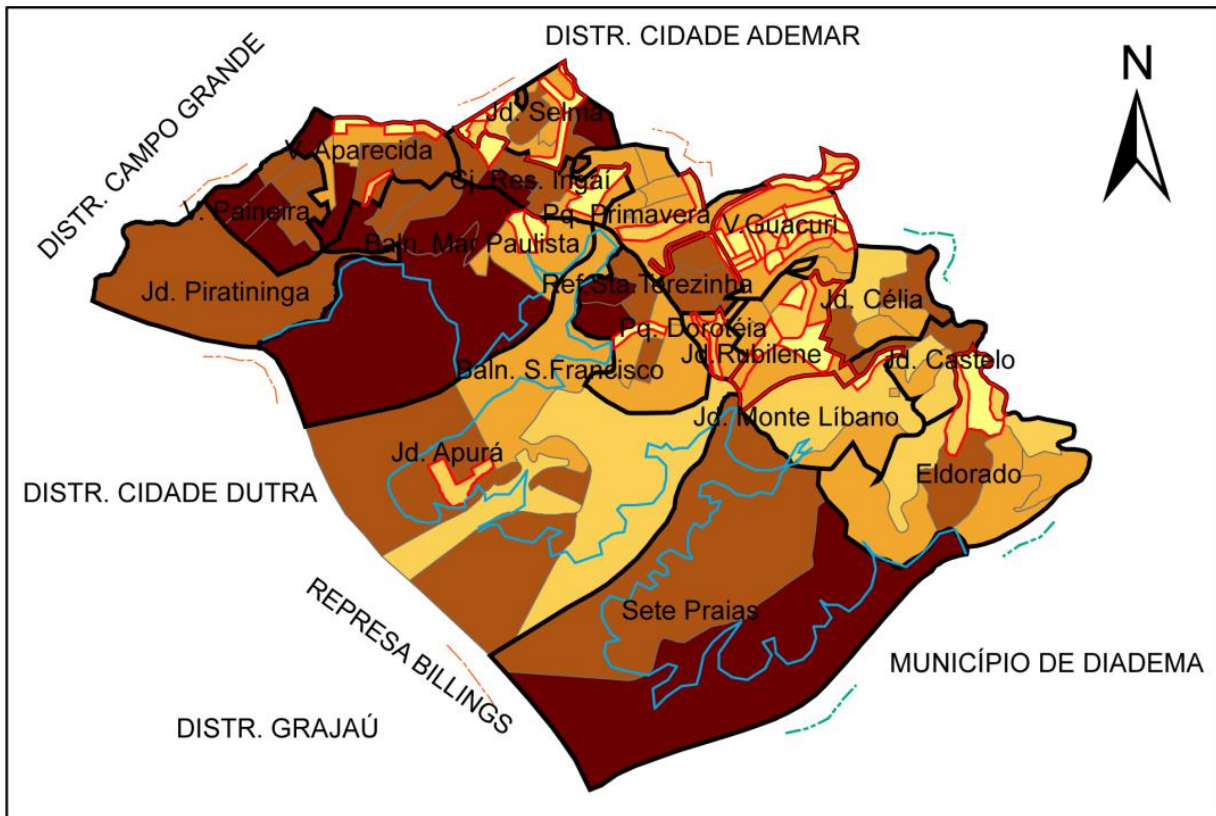

$0 \quad 0,5 \quad 1$ 2 Kilometers

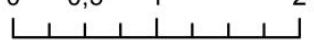

Autor: Shinhiti Osanai

Fonte: IBGE e Guia Mapograf 2004
Renda per capita do ou da ch. fam.

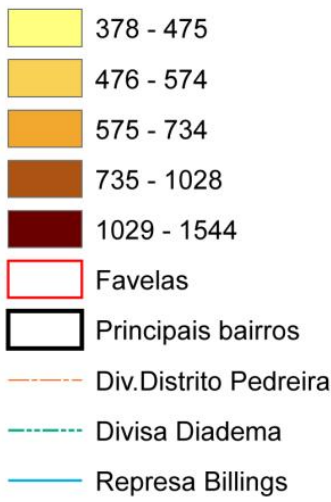


Segundo a Fundação Seade, em 2000 a faixa entre 30 a $40 \%$ da população de Pedreira é proveniente de outros estados. Diante disso existem muitos estabelecimentos comerciais especializados em produtos alimentícios típicos do nordeste, por exemplo, farinha d'água, carne de sol, feijão de corda, pinga de Santo Amaro (Bahia), entre outros.

\subsection{Evolução}

O desenvolvimento do Distrito de Pedreira transcorreu de forma desordenada, sem o cumprimento adequado das políticas de planejamento urbano, apesar da existência de leis de proteção das áreas de mananciais, bem como, das leis, que regulamentam o uso e o parcelamento do solo, antes da promulgação do Estatuto da Cidade de 2001 e do Plano Diretor Estratégico de 2002. Verifica-se alta densidade populacional e padrões precários de urbanização nas bacias tributárias da represa Billings.

Ao norte do Distrito de Pedreira, os principais bairros são Vila Paineira e Vila Aparecida. Na região central, à margem da represa Billings, localizam alguns dos principais bairros Jardim Piratininga, Balneário Mar Paulista e Balneário São Francisco. Ainda, na região central em direção oposta à represa, estão os bairros Conjunto Residencial Ingaí, Jardim Selma, Vila Missionária, Parque Primavera, Refúgio Santa Terezinha, Parque Dorotéia, Jardim Rubilene, Jardim Santa Lúcia do Guacuri. Os bairros Vila Guacuri, Jardim Célia e Jardim do Castelo, próximos da região centro, fazem divisa com o Município de Diadema. Nas penínsulas permanecem os bairros Jardim Apurá, Jardim Bandeirantes e Sete Praias. Mais para o sul estão os bairros Jardim Monte Líbano e Eldorado. 


\section{TEMPO MÉDIO DE ESTUDO DO OU DA CHEFE DE FAMÍLIA - ANOS}

DISTRITO DE PEDREIRA

POR SETOR CENSITÁRIO

CENSO 2000

MAPA NÚMERO 4.13
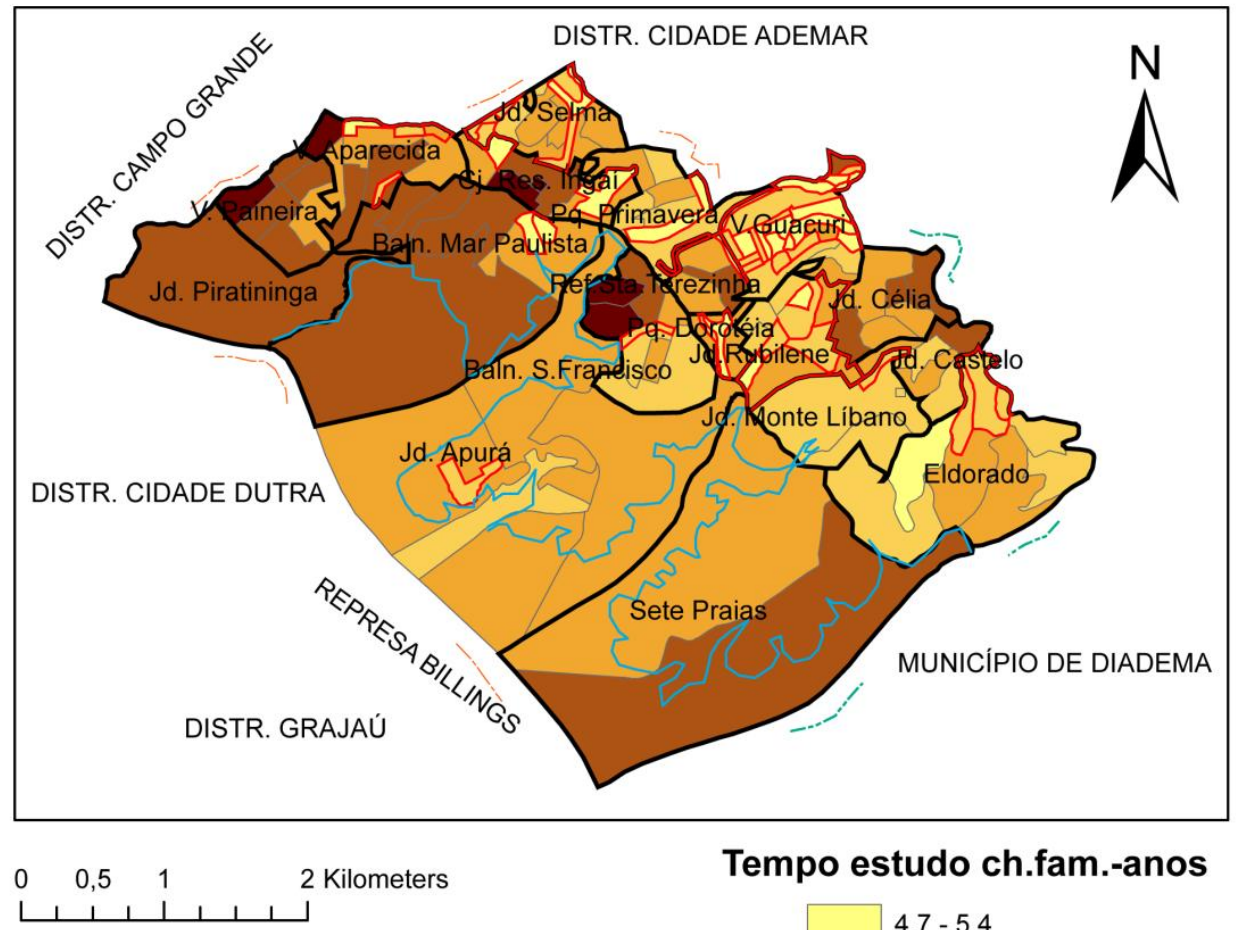

Tempo estudo ch.fam.-anos

Autor: Shinhiti Osanai

Fonte: IBGE e Guia Mapograf 2004

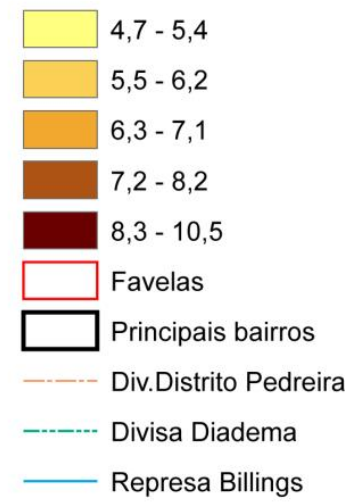




\title{
HABITANTES ANALFABETOS EM PORCENTAGEM
}

\author{
DISTRITO DE PEDREIRA \\ POR SETOR CENSITÁRIO \\ CENSO 2000
}

MAPA NÚMERO 4.14
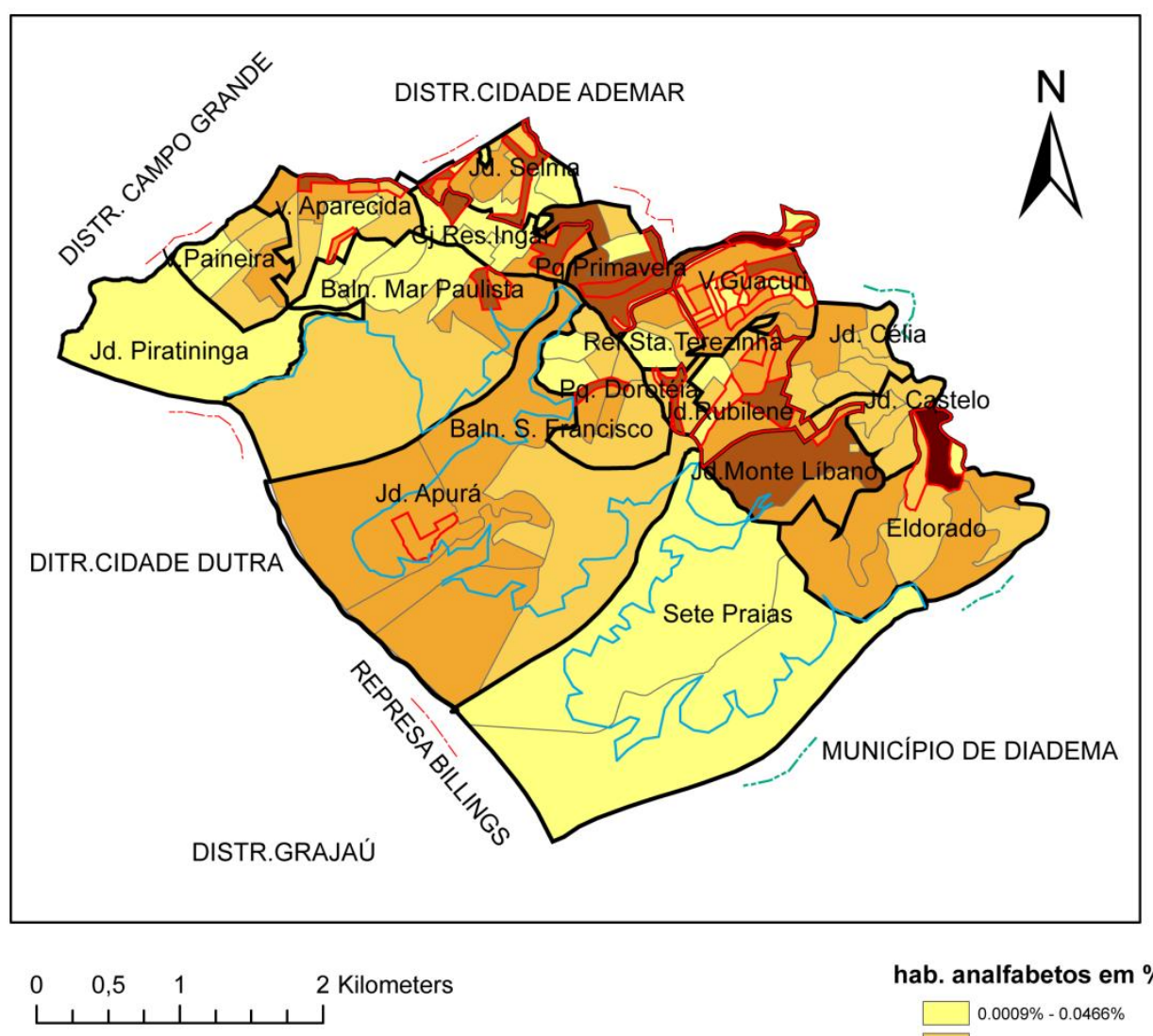

hab. analfabetos em $\%$

Autor: Shinhiti Osanai

Fonte: IBGE e Guia Mapograf 2004

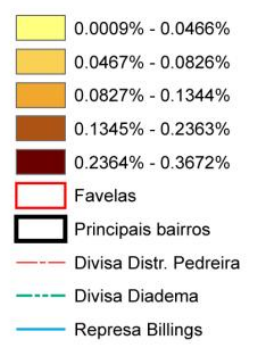


A urbanização do Distrito de Pedreira iniciou a partir de 1950 quando surge o bairro Balneário Mar Paulista, à beira da represa Billings. Está bastante próxima da barragem construída no rio Jurubatuba, conhecida com o nome de Pedreira, que é uma das barragens responsáveis pela formação a referida represa. Junto a essa barragem, se localiza a usina termelétrica de Piratininga no final da Avenida Nossa Senhora do Sabará. Neste mesmo período, entre 1950 e 1962, surgem aglomerações de residências em torno da Rua Antonio do Campo, igualmente, algumas aparecem nas áreas bem próximas à já referida usina termelétrica. Nessa mesma ocasião, um pouco mais distante, no sentido leste, em direção ao Município de Diadema, se instalam outras aglomerações, acompanhando o eixo da Rua Professor Cardozo de Mello Neto numa região oposta e afastada da represa. Nesse mesmo período surge o bairro Balneário São Francisco, à margem da represa Billings. Instala-se, também, do outro lado da Estrada do Alvarenga, o bairro Vila Missionária, localizado no sentido oposto da represa e próximo do bairro Balneário Mar Paulista.

Nos anos 60, uma das linhas de ônibus ligando Pedreira ao centro de São Paulo mantinha o ponto final nas proximidades da usina termelétrica de Piratininga. Havia muita pouca opção de transporte coletivo. Outra linha, partindo de Santo Amaro, fazia o ponto final um pouco mais adiante da usina, no Largo Nossa Senhora de Aparecida. Nessa mesma época, operava um serviço de transporte que partia do Vale do Anhangabaú até o bairro de Eldorado, porém com muita pouca freqüência.

O Jardim Pedreira e Balneário Mar Paulista (foto número 1) são um dos bairros mais antigos. Esse último bairro conta com uma boa estrutura urbana, lotes maiores e casas confortáveis, embora sejam de médio ou baixo padrão. Igualmente, o loteamento do Balneário São Francisco apresenta uma satisfatória estrutura urbana, porém lotes são menores e de padrões inferiores, de forma geral, em comparação ao Balneário Mar Paulista. 


\title{
OCUPAÇÃO DO SOLO - 1950 a 2002
}

\author{
DISTRITO DE PEDREIRA
}

MAPA NÚMERO 4.15
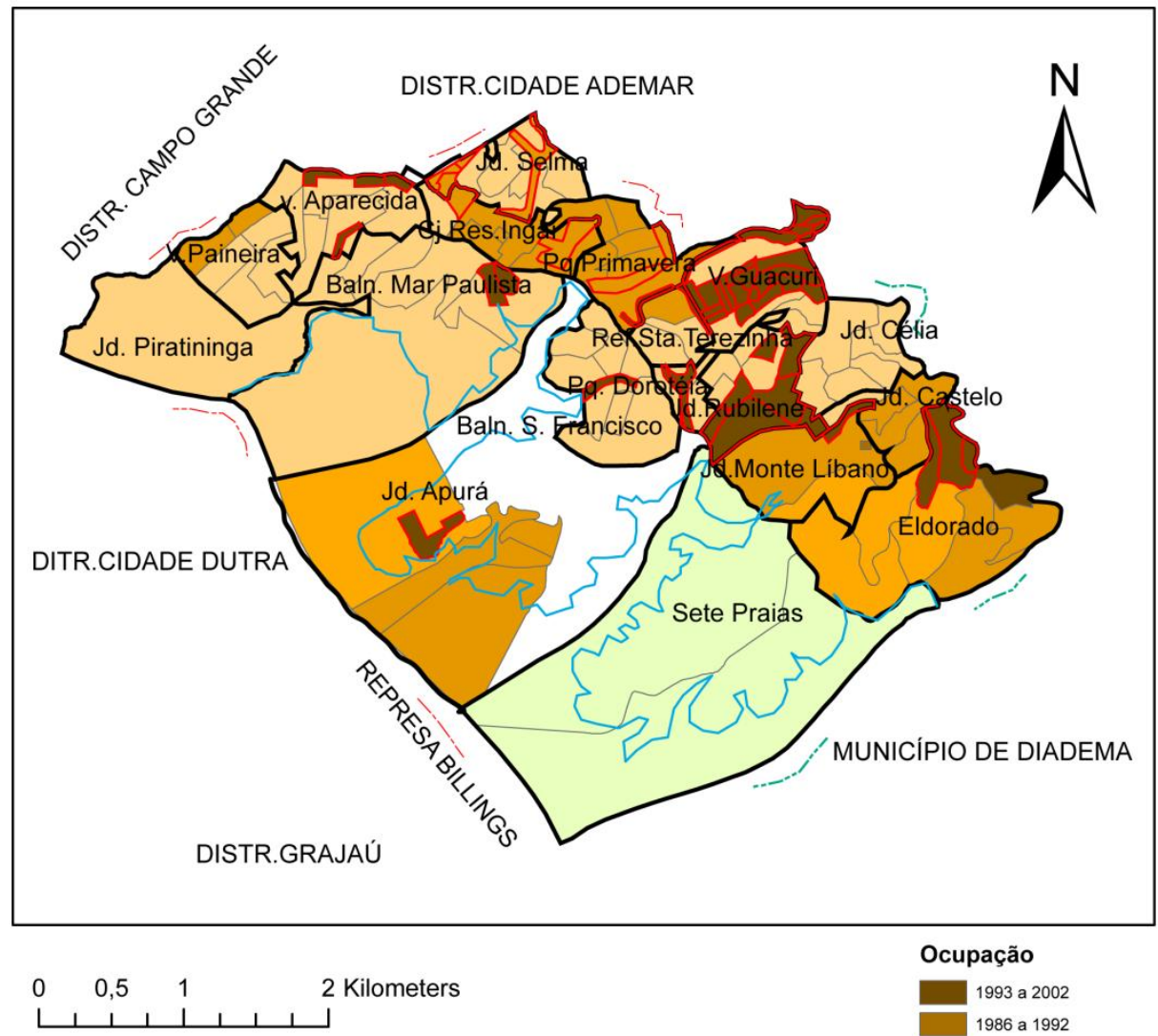

Ocupação

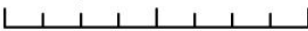 \\ Autor: Shinhiti Osanai \\ Fonte: SEMPLA - EMPLASA - Mapa de expansão \\ da área urbanizada da região metropolitana de}

São Paulo - 2002/2003

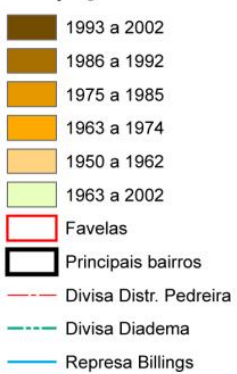




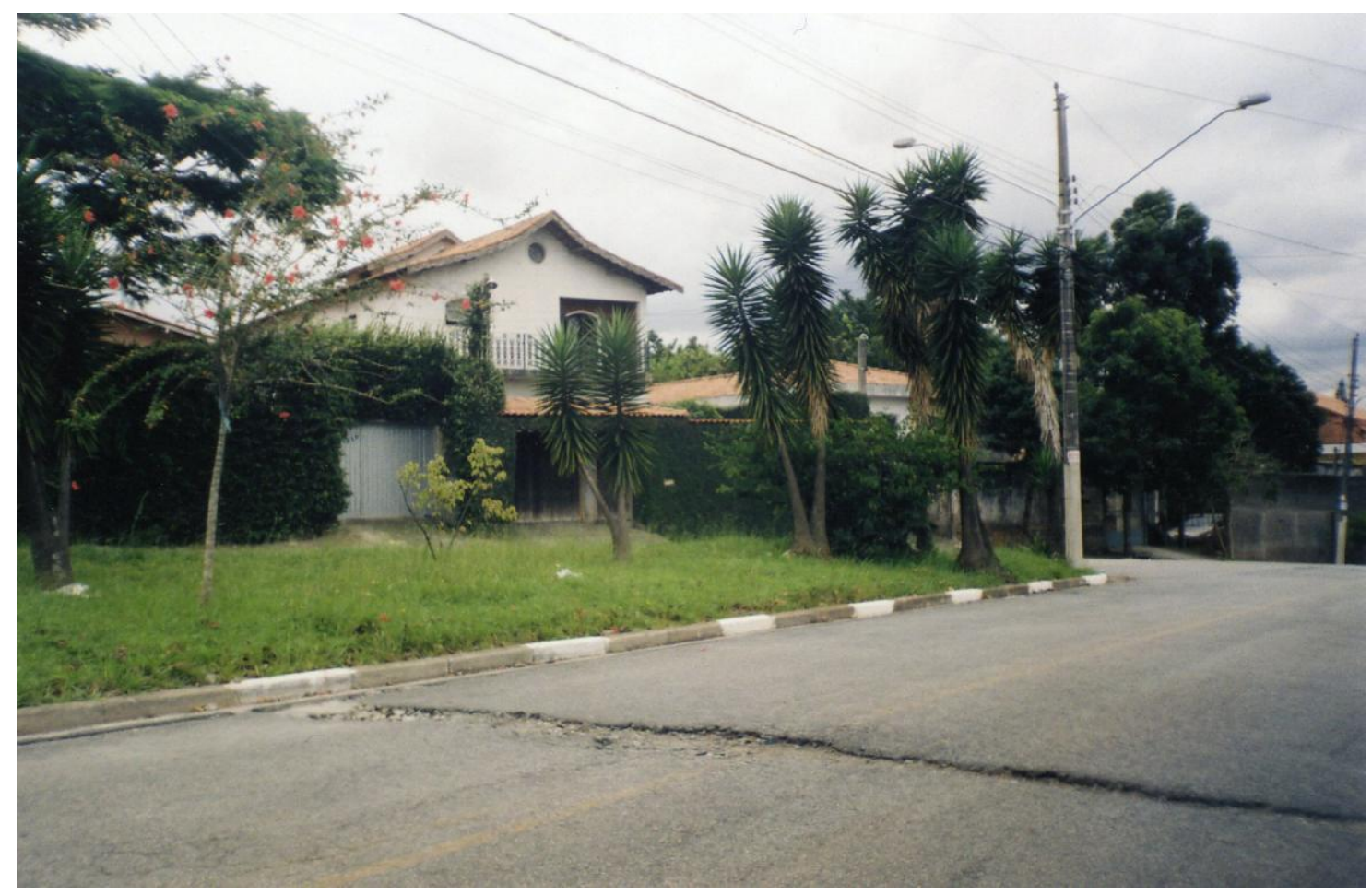

Foto número 4.1 - Balneário Mar Paulista

Fonte: acervo do autor

Entre 1963 e 1974, estabelece o Jardim Bandeirantes, com casas de um bom padrão, à margem da represa Billings, na península do Jardim Apurá, e o seu acesso pode ser feito pela Rua Davide Perez, passando por Balneário São Francisco. Instala-se o bairro Sete Praias, constituído de casas de bom padrão, na segunda península à margem da represa Billings, cujo acesso é feito pela Rua Professor Camillo Aschar e Rua Dr. José Silvio de Camargo. Verificam-se as primeiras aglomerações, que se transformam posteriormente no bairro Eldorado, no sentido oposto da represa Billings em direção à divisa com Diadema, seguindo o eixo da Avenida Alda. Surgem as primeiras aglomerações do bairro Jardim Monte Líbano, acompanhando o eixo da Rua Dr. José Silvio de Camargo, igualmente no sentido a Diadema.

O loteamento denominado Sete Praias, que hoje funciona como uma espécie de condomínio fechado, é a área de maior restrição, quanto à sua ocupação. A legislação de proteção de mananciais obriga a permanência de lotes grandes e as casas são de médio e alto padrão. 
Muitas chácaras, instaladas em lotes de área considerável, surgiram à margem da represa Billings, acompanhando uma boa extensão da Estrada do Alvarenga até a divisa com Diadema.

No período de 1975 a 1985 pode-se observar uma significativa expansão da ocupação do solo. Embora esta ocupação tenha sido feita, em parte, por meio de loteamentos regulares, observou-se ao mesmo tempo um intenso crescimento de loteamentos irregulares. Tal fato deve-se à especulação imobiliária e ao receio que os grandes lotes pudessem ser desvalorizados por causa da lei de proteção dos mananciais. As invasões e o crescimento da quantidade de favelas se fortaleceram nesse período. Simultaneamente ao surgimento de loteamentos irregulares, notam-se significativas ocupações no eixo da Rua Salvador Dali no Jardim Apurá, no eixo da Rua da Saúde no bairro de Mata Virgem, nas proximidades do número 4500 da Estrada do Alvarenga, e acontece a criação do bairro Praia Leblon, próxima à represa Billings. Outras aglomerações igualmente aparecem, tais como os bairros Jardim do Castelo e Jardim das Laranjeiras nas proximidades da Avenida Alda na região de divisa com Diadema. Apenas duas favelas constam nos registros da Secretaria de Bem Estar Social com datas anteriores a 1972. Este período, entre 1975 e 1985, é a referência do início das grandes concentrações de favelas do Distrito de Pedreira. Constam, nos registros da Prefeitura de São Paulo, as favelas das regiões do Balneário São Francisco, Parque Dorotéia, nas proximidades do número 3800 da Estrada do Alvarenga, Jardim Selma próxima à Rua Manuel Rodrigues Mexelhão, Parque Primavera junto à Rua Antonio Vieira Marcondes, Refúgio Santa Terezinha próxima à Rua Professor Cardozo de Mello Neto, e Vila Aparecida nas proximidades da Rua Brasil.

As invasões acontecem principalmente nas áreas de colinas com declividades mais acentuadas (foto 4.2), áreas que ainda não tinham sido loteadas e tampouco dispunham de energia elétrica e rede de água e esgoto. Essas invasões se intensificaram em direção às áreas de reserva natural chegando até as proximidades da divisa com Diadema.

Concomitantemente às invasões, vários loteamentos regulares foram comercializados, constituindo os bairros Jardim Itapura, Jardim Domitila, Jardim Nastari, Jardim Selma, Vila Missionária, Refúgio Santa Terezinha, Parque Dorotéia, Vila Guacuri e Jardim Rubilene (foto número 4.3) na região central do Distrito. 


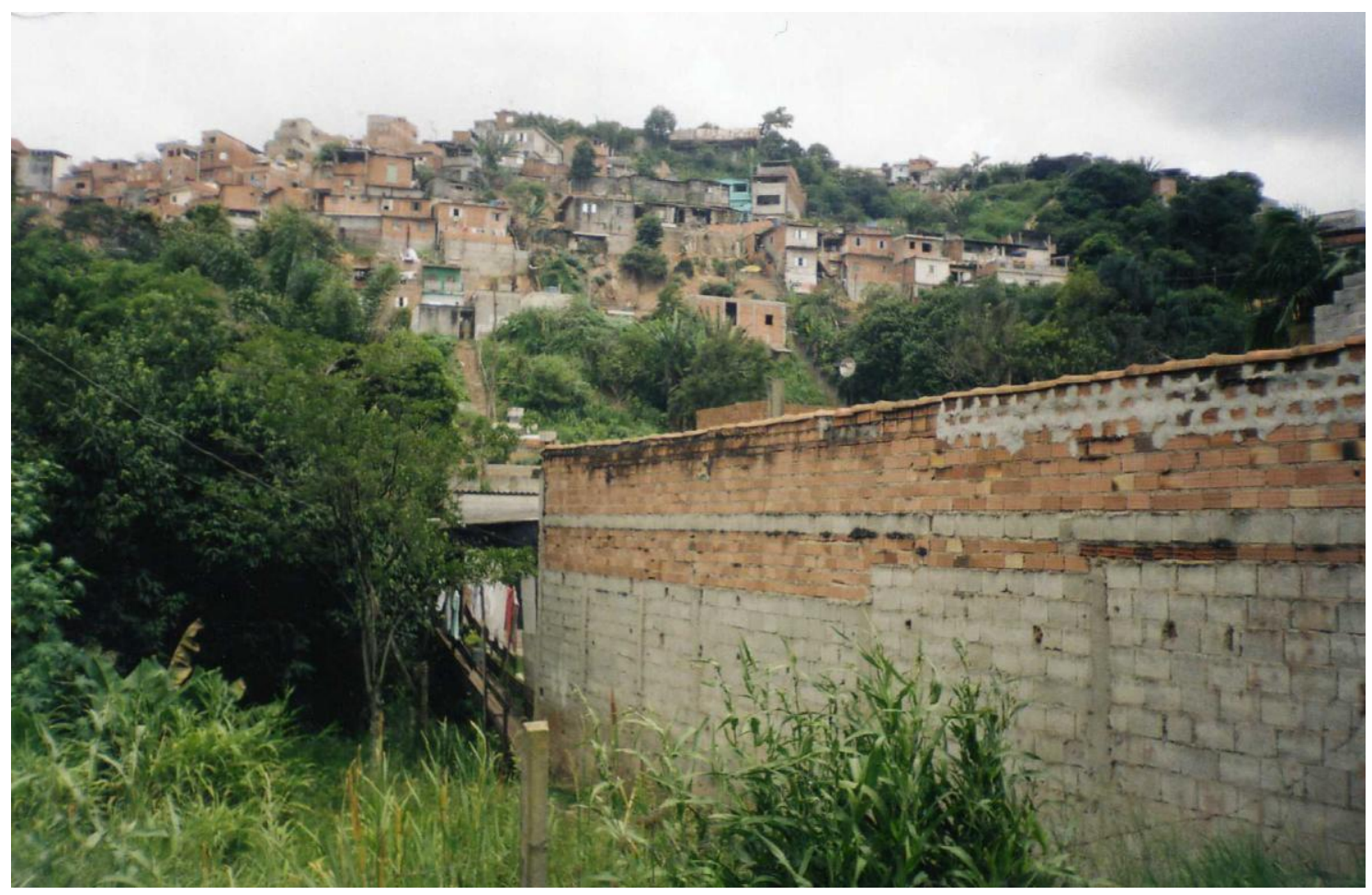

Foto número 4.2 - Área de declividade acentuada - Avenida Alda

Fonte: acervo do autor

Nos anos 80, houve expansão de várias linhas de ônibus, entretanto, pouco eficaz tendo em vista a localização dos pontos finais serem muito distantes de certas aglomerações. Tal fato obrigava as pessoas caminharem distancias significativas. Nessa ocasião, alguns bairros passaram a ser atendidos por ônibus até Santo Amaro, e foi o início dos primeiros serviços de integração com o metrô. As linhas até o centro eram as mesmas dos anos 60, com algumas alterações de itinerários, passavam pela Avenida 23 de Maio em vez da Avenida Santo Amaro e Avenida 9 de Julho. A quantidade da frota não era suficiente, para um atendimento adequado nos horários de pico. Os ônibus operavam com excesso de lotação e tempo de espera bastante longo. Em decorrência das declividades acentuadas e ruas muito estreitas, principalmente, nas regiões de invasão, a estrutura viária do Distrito de Pedreira é muito desfavorável para a operação de ônibus maiores.

No período de 1986 a 1992, praticamente se mantém as mesmas ocupações observadas até 1985. Observa-se um pequeno incremento das ocupações do Jardim Apurá e do Jardim Monte Líbano. Nesse período a ocupação ocorreu de maneira bastante lenta. 


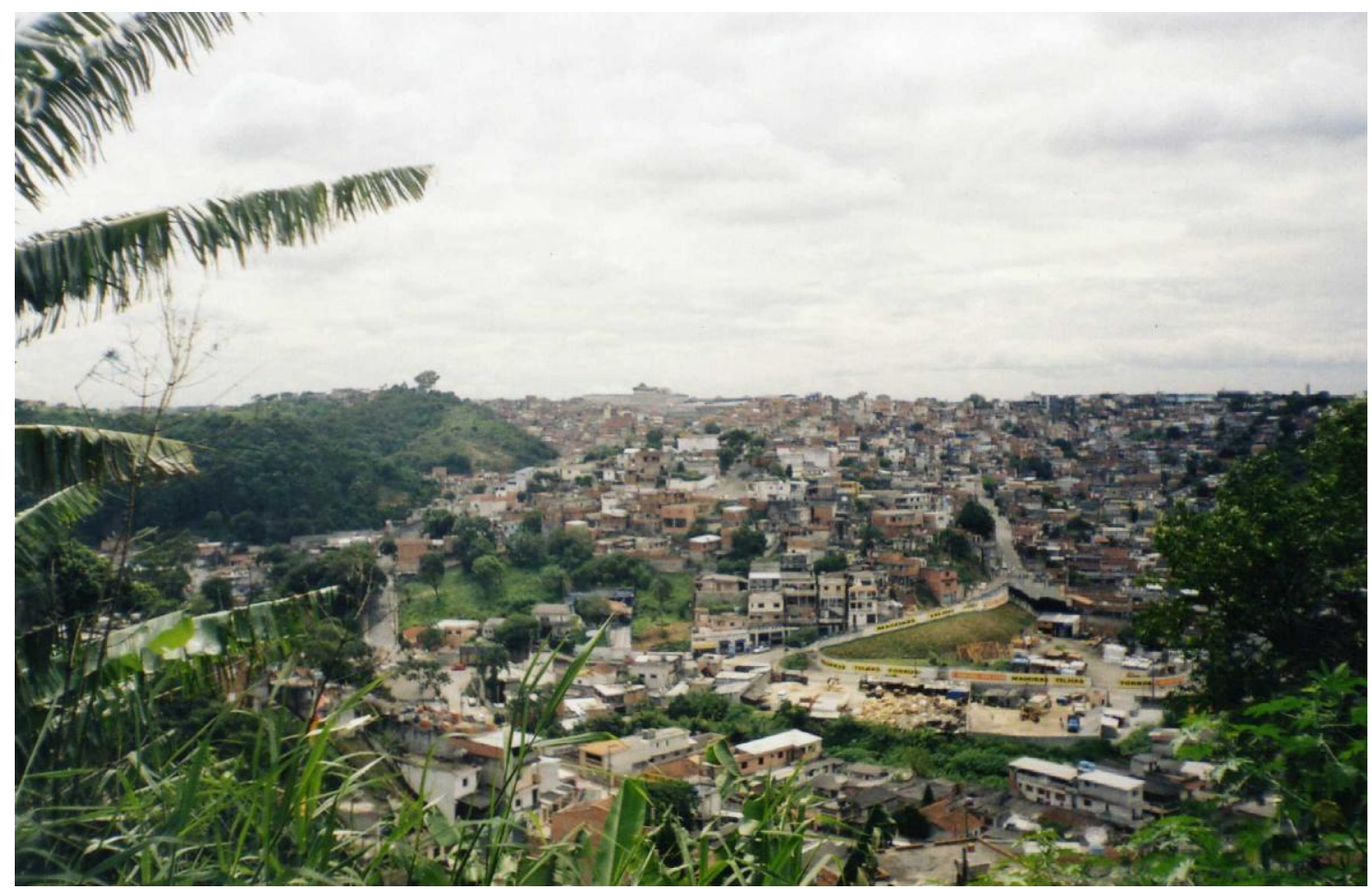

Foto número 4.3 - Vista parcial de Jardim Rubilene

Fonte: acervo do autor

No período de 1993 a 2002, houve a expansão do Jardim Monte Líbano na direção da Rua Josefina Gianinni Elias - Dona Bimba. Verificou-se, igualmente, o crescimento do bairro de Sete Praias por meio da ocupação de moradias de padrão inferior, em relação às áreas mais antigas ocupadas anteriormente a 1970. Houve o crescimento do bairro de Mata Virgem no eixo das vias Estrada da Água Santa, Rua Mata Virgem e Rua Francesco Mancini, contudo, ainda restam algumas áreas verdes. Nesse mesmo período surgem favelas nos bairros de Jardim Monte Líbano e Eldorado junto às vias Avenida Alda, Rua da Saúde, Rua Dr.José Silvio de Camargo e Estrada da Água Santa. Uma grande área, que pertenceu a uma empresa detentora de uma jazida de pedras britadas, conhecida na região como Pedreira Itatinga, foi quase totalmente invadida. Dessa invasão, instalaram-se das favelas do Pantanal, Santa Terezinha e Itatinga, acompanhando mais da metade de toda a extensão, do lado esquerdo para quem dirige a Diadema, da Rua Professor Cardozo de Mello Neto. Na área da Pedreira Itatinga formou-se uma cratera de grandes extensões, em consequiência da extração do granito, e tão logo as suas atividades foram extintas, a cratera transformou-se num depósito de 
lixo a céu aberto aproveitado depois como um aterro sanitário. Os primeiros invasores do local da favela do Pantanal exerciam a atividade econômica de coleta de resíduos de lixo, em particular sucata de papéis, plásticos e metais, atividade essa suspensa, tão logo essa área foi transformada num aterro sanitário. Atualmente esse aterro sanitário de Itatinga recebe apenas entulhos de demolição de construção civil e há muito tempo deixou de receber os resíduos domésticos.

A partir dos anos 90, novos loteamentos e invasões acontecem às margens da represa Billings, no Jardim Apurá, um bairro localizado numa península bem próxima de Balneário São Francisco.

À medida que as invasões cresceram, os movimentos populares se fortaleceram, muitas vezes com a ajuda do pároco local. Os invasores passaram a pressionar os órgãos públicos para receberem, inicialmente, energia elétrica, iluminação pública e rede de água, e posteriormente, rede de esgotos, pavimentação e, principalmente serviços de saúde e de educação, praticamente inexistentes no Distrito de Pedreira no início da sua ocupação desordenada.

Com exceção de Balneário São Francisco, Balneário Mar Paulista e Jardim Pedreira, que são áreas de declividade relativamente suaves e adequadas para um bom loteamento, os demais bairros de Pedreira se localizam em colinas, a maioria em regiões de declividade bastante acentuada. As invasões se verificam nas encostas de declividades mais acentuadas, nas margens da represa Billings e também de todos os córregos.

As invasões colaboraram para uma rápida redução da reserva ecológica, formada por matas nativas. Atualmente, existe um esforço da parte da Prefeitura de São Paulo na preservação das margens da represa Billings, pela conservação do parque Mar Paulista, e criação de outros, que ainda não foram construídos, tais como Bandeirantes, Apurá. Mais outros dois denominados parques Sete Campos e Aterro Itatinga, na área central, estão ainda na fase de projetos. Com o avanço das invasões, houve ampliação dos serviços de ônibus, interligando cada um dos diversos bairros ao centro de Santo Amaro e principalmente às linhas do metrô.

Mais recentemente, muitas linhas de ônibus de curta distância foram substituídas por micro ônibus, oferecendo algumas vantagens de maior facilidade para operarem em ruas mais estreitas. O transporte coletivo, quando realizado por micro ônibus, permite o atendimento mais próximo às residências, entretanto em conseqüência da sua menor capacidade, causam 
desconforto por causa da superlotação nos horários de pico. Houve redução no tempo de espera pela maior quantidade de veículos em operação, ou seja, nas linhas de curta distância, a quantidade de micro ônibus é muito superior a dos ônibus. Foram criadas várias opções diferentes de itinerários, muitas delas circulando nas entradas de favelas, que geralmente são constituídas por ruas muito estreitas e curvas bastante fechadas. Algumas linhas servem áreas mais remotas, localizadas em Mata Virgem ou Monte Líbano, as quais dispõem de estrutura viária bastante precária por causa das ruas muito estreitas e de declividade acentuada. São poucas as linhas até o centro. Entretanto, considerando-se um significado número de opções de acesso ao metrô, essas poucas linhas para o centro são suficientes devido ao sistema de integração proporcionada pelo bilhete único.

Dos 135 setores censitários do IBGE em 2000, 51 estão totalmente em favelas. Nos demais 12 setores uma parte dos domicílios localiza-se em áreas invadidas. Portanto, há favelas em 37\% dos setores censitários de Pedreira. O surgimento de grandes favelas, a partir dos anos 90, por meio do intenso crescimento populacional verificado nessas áreas consideradas subnormais, contribuiu de maneira significativa o crescimento populacional global do Distrito de Pedreira.

A parcela dos residentes de Pedreira, que moram em favelas, corresponde a 33,2\% da população do Distrito, ocupando uma área de $0,90 \mathrm{~km}^{2}$, e representam a quantidade de 32.859 habitantes, instalados em 8.165 domicílios. Pedreira abriga 2,68\% das favelas do Município de São Paulo.

O percentual dos domicílios, que em 2000 possuíam automóveis, equivale a 53,4\%. Sendo Pedreira um distrito dormitório e na situação de quase a metade dos domicílios não possuir automóvel torna-se expressiva a dependência da população em relação ao serviço de transporte coletivo. 


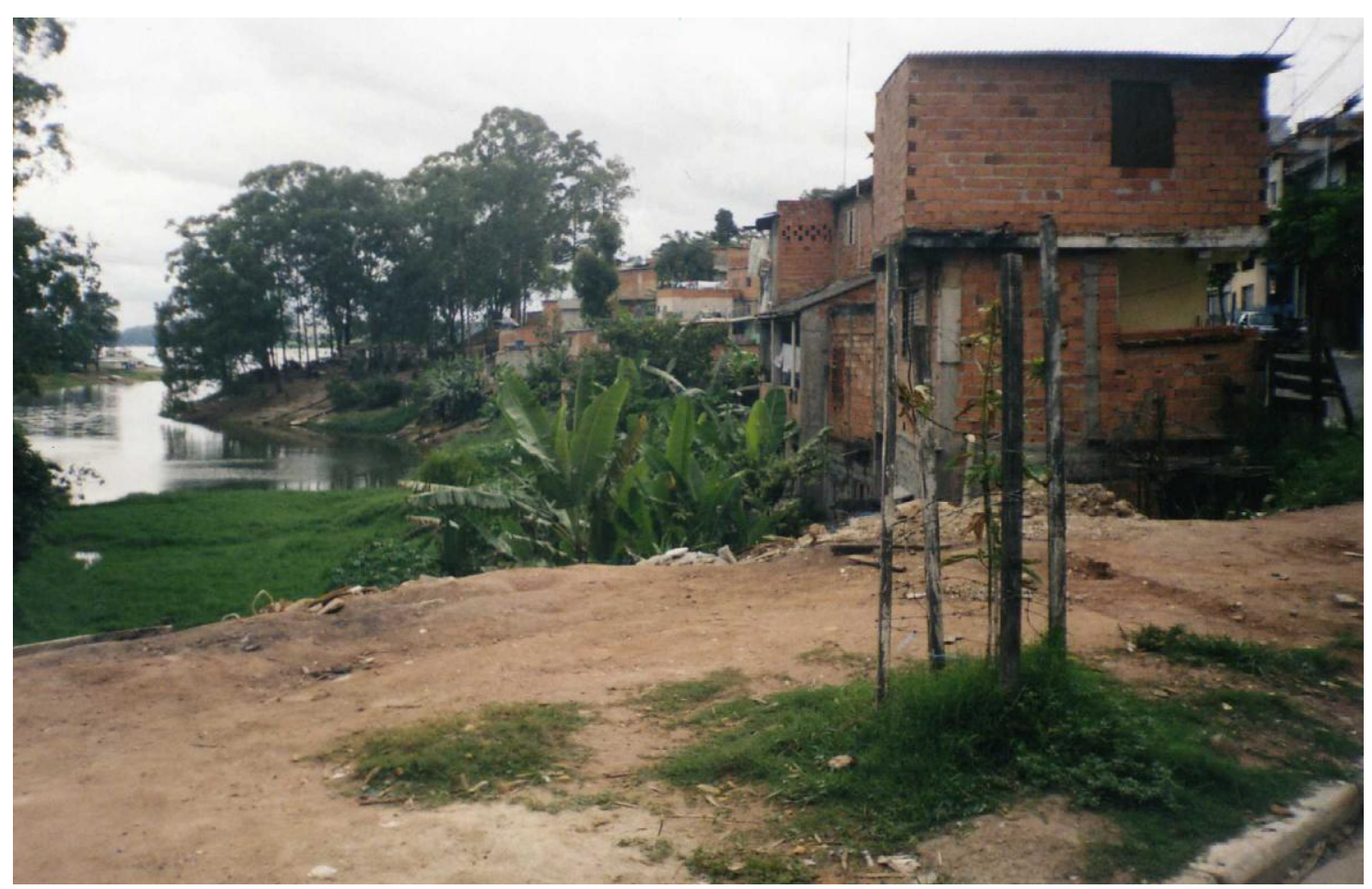

Foto número 4.4 - Área de invasão no Jardim Apurá - margens da represa Billings

Fonte: acervo do autor

\subsection{Estrutura urbana}

Existem duas vias principais de acesso ao Centro Histórico de São Paulo. Uma delas a Estrada do Alvarenga cuja continuação é a Avenida Nossa Senhora do Sabará, terminando em Santo Amaro na Avenida Washington Luis. A outra é a Avenida Cupecê, prosseguindo com os nomes de Avenida Vereador João de Lucca, Avenida Prof. Vicente Rao e Avenida Roque Petroni $\mathrm{Jr}$, essa última terminando nas proximidades da Avenida Engenheiro Luiz Carlos Berrini, bem próxima à Avenida das Nações Unidas (Marginal de Pinheiros). Existe outra opção alternativa, uma espécie de "bifurcação" da Avenida Cupecê, a Avenida Yervant Kissajikian, que cruza a Avenida Interlagos e termina na Avenida Nossa Senhora do Sabará. Em direção ao Município vizinho de Diadema, a via principal é a Avenida Cupecê cuja continuação é a Avenida Presidente Kennedy, no Município de Diadema. Igualmente, a Estrada do Alvarenga, passando por periferia de Diadema, e permite o acesso à periferia do 
Município de São Bernardo do Campo. A Avenida Alda é o principal acesso para o centro de Diadema a partir da Estrada do Alvarenga. (Vide o mapa número 4.16)

Uma referência importante para melhor entendimento do Distrito de Pedreira é a Estrada do Alvarenga, sendo uma espécie de um marco divisor entre os bairros, de certa maneira mais ricos, instalados na margem da Represa Billings, e aqueles, mais pobres, localizados em direção oposta à represa. (Vide mapa número 4.16). A Estrada do Alvarenga percorre todo o Distrito no sentido noroeste a sudeste.

A formalização mais recente quanto às políticas, que envolvem a estrutura do Distrito de Pedreira, é do ano de 2004, conforme a lei 13885, quando foi aprovado o Plano Regional Estratégico da Subprefeitura de Cidade Ademar, que faz parte integrante do Plano Diretor Estratégico do Município de São Paulo, em conformidade com a lei municipal número13430 de 13/09/2002. O Plano Diretor deve estar de acordo com o Estatuto da Cidade, a lei federal 10257 de 2001. Trata-se de uma proposta de solução para a deficiência de instrumentos de gestão do passado, em particular, para regularizar e conter o aumento de irregularidades no uso e parcelamento do solo em conseqüência do crescimento de favelas.

O Plano Regional Estratégico contempla as políticas de desenvolvimento de natureza urbana e ambiental, econômico e social, humano e de qualidade de vida, de maneira mais organizada. Manifesta a preocupação sobre a ocupação desordenada das áreas de proteção de mananciais, margens de córregos e encostas, oferece instrumentos para promover a regulação fundiária por meio da urbanização de áreas ocupadas por população de baixa renda. Prioriza os loteamentos clandestinos, irregulares e áreas de invasão, proteção, preservação e recuperação do meio ambiente. Compreende, igualmente, a urbanização de favelas e das áreas de loteamentos irregulares. No tocante à mobilidade e circulação, apresenta o desenvolvimento de estrutura viária, faixa livre para ônibus, atividades complementares próximas à moradia, por exemplo, escola e abastecimento doméstico. Procura algumas soluções para a redução de deslocamentos, em consequiência de melhor disciplina do uso do solo, de maneira mais adequada, em relação à circulação e o transporte urbano.

Estabelece as definições dos elementos estruturadores da cidade, que são rede viária estrutural, rede estrutural de transporte coletivo e rede estrutural de eixos e pólos de centralidades. Os elementos integradores são aqueles que preenchem os espaços, tais como habitação, equipamentos sociais, áreas verdes e espaços públicos. 


\section{PRINCIPAIS ACESSOS}

DISTRITO DE PEDREIRA

MAPA NÚMERO 4.16

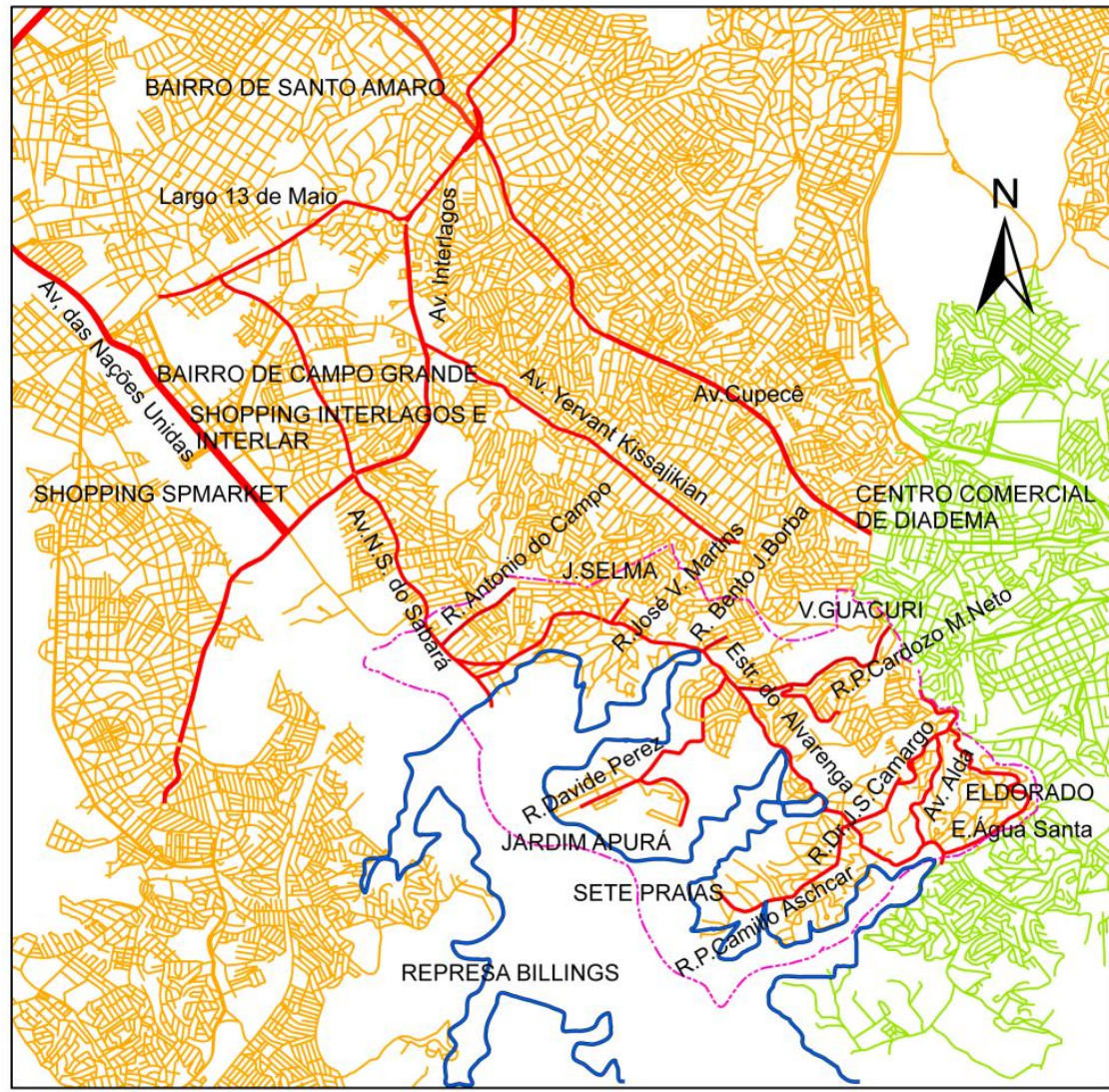

Legenda

$\begin{array}{lll}0 & 0,5 & 1\end{array}$

2 Kilometers

Autor: Shinhiti Osanai

— Represa Billings

São Paulo

Fonte: Guia Mapograf 2004

Diadema

Divisa Distr. Pedreira

- Principais acessos 
No Distrito de Pedreira, as vias estruturais previstas em lei, são da categoria de nível 3, responsáveis apenas para as ligações internas do município. São elas: Avenida Emérico Richter (acesso para o bairro de Santo Amaro); Estrada do Alvarenga (cruza todo o distrito no sentido noroeste-sudeste); Avenida Professor Araújo Lima (acesso para Avenida Cupecê); Avenida Alda e Rua Professor Cardozo de Mello Neto (acessos para Diadema). A não ser que sejam feitas melhorias na Avenida Professor Araújo Lima, essa via não apresenta as mínimas condições técnicas de ser uma via estrutural, pela sua topografia e largura muito estreita. Deste modo, em seu lugar utilizam-se para essa finalidade as ruas paralelas, Bento José Borba, Eduardo Cinelli e Berlamino Belisário de Araujo, as quais são vias coletoras nos termos da lei.

As vias coletoras, previstas em lei, são aquelas que interligam a Estrada do Alvarenga a alguns bairros, tais como a Rua Professor Camillo Ashcar, em Sete Praias, as Ruas Davide Perez e Luigi Mancinelli, que dão acesso ao Jardim Apurá e Jardim Bandeirantes, Rua Dr. José Silvio de Camargo, que permite o acesso ao Jardim Monte Líbano. Faz parte dessas vias coletoras, uma sequiência de ruas que têm início na Estrada do Alvarenga e chegam à Avenida Yervant Kissajikian, sendo uma delas a Avenida Augusto de Castro, que passa por Jardim São Jorge (Distrito de Cidade Ademar), ou então, a outra opção, a Rua do Roseiral, que continua pela Rua Papa Gregório Magno e passa por Vila Missionária. Finalmente a última alternativa, a Rua Bento José Borba, que atravessa o Parque Primavera, e permite o acesso para a Avenida Cupecê, por meio de várias ruas do Jardim Luso (Distrito de Cidade Ademar).

Os melhoramentos das vias coletoras constantes no PRE estão previstos para 2012. Os poucos planejados para 2006 ainda não foram executados, exceto a ligação da Avenida Nossa Senhora do Sabará com o Distrito de Grajaú passando pela Avenida Miguel Yunes. O acesso à Avenida Cupecê partindo da Estrada do Alvarenga é bastante difícil, é possível apenas seguindo as vias locais ou algumas coletoras, e estão previstas obras de melhoramentos para facilitar essa ligação e torná-la mais rápida, a partir de 2012. Igualmente, falta uma ligação rápida entre a Rua Professor Cardozo de Mello Neto e a Avenida Yervant Kissajikian, já prevista e deve ser executada no futuro, tão logo a abertura de uma nova via de ligação e melhoramentos na Rua do Guaicuri venha a ser realizada. Essas últimas ligações e muitos dos melhoramentos dependem de remoção de favelas, instaladas bem no meio dos seus traçados. O acesso do Distrito de Pedreira para o bairro de Santo Amaro é fácil, entretanto o trânsito 
para o Distrito vizinho de Cidade Ademar é feito por vias muito precárias, apesar de sua maior proximidade em relação a Santo Amaro.

O PRE, em relação à preservação do meio ambiente, prevê a construção de vários parques. Apenas a primeira metade do Parque Mar Paulista, que ocupa uma faixa de 150 metros e acompanha a margem da represa Billings desde o canal do Rio Jurubatuba até a Rua Rodrigues de Medeiros, está pronta.

Embora estivessem previstos para 2006, todos os demais parques planejados ainda não foram executados. É necessária a remoção de favelas das margens da represa Billings para a conclusão das obras do Parque Mar Paulista, Parque Bandeirante e Parque Apurá, esses dois últimos localizados na península do Jardim Apurá. Outros parques ainda dependem do domínio da área pela Prefeitura para a sua instalação os quais são o Parque da Pedreira no local de uma jazida de areia, já inativa, que pertence à empresa Porto de areia Sete Praias, o Parque Sete Campos e o Parque do Aterro Itatinga. Nas proximidades do canal do rio Jurubatuba, onde será construído um porto fluvial, haverá um parque linear e, também, nas margens do córrego do Olaria, que deverá ocupar uma faixa de $15 \mathrm{~m}$ em ambas as suas margens em relação ao eixo do rio. Caminhos verdes deverão ser construídos na Avenida Nossa Senhora do Sabará. Ciclovias e via ou caminho de pedestres poderão ser implementados nas proximidades dos parques projetados. As áreas dos parques pertencem à ZEPAM - Zona Especial de Preservação Ambiental, cujos objetivos são: recuperar as áreas de proteção ambiental, que sofreram intervenções antrópicas e estão degradadas; repor as áreas de mata ao longo das margens da represa Billings e requalificar os espaços ocupados impropriamente nas faixas de proteção ambiental, a fim de recuperar as bordas e as matas ciliares e assim restabelecer a qualidade das águas. Existem propostas para a transformação da Estrada do Alvarenga numa estrada parque e a construção de caminho verde na Avenida Nossa Senhora do Sabará, nas proximidades da represa Billings.

As áreas de invasão, de ocupação irregular e de favelas, fazem parte da ZEIS - Zona Especial de Interesse Social, cujos objetivos são: preservar os mananciais e recursos hídricos da Billings; recuperar as margens dos córregos e requalificar a ocupação existente; combater as moradias em áreas de risco por meio de construção de habitação de interesse social e complementar os equipamentos sociais, educação, saúde e transportes públicos. Há planos, para a recuperação urbanística, regularização fundiária, produção de habitação de interesse social HIS ou de mercado popular HMP. 
À medida que a Prefeitura cumprir a lei, os assentamentos habitacionais precários deverão estar dotados de infra-estrutura básica de saneamento ambiental, equipamentos sociais e culturais, espaços públicos, serviços e comércio de caráter local, com vistas à promoção da melhoria de qualidade de vida e da inserção urbana.

As duas zonas de interesse social do Distrito de Pedreira são:

ZEIS1 - constituída por população de baixa renda, favelas, loteamentos precários com o direito ao desenvolvimento de empreendimentos habitacionais de interesse social ou de mercado popular. Ocupa a maior e mais da metade da extensão do Distrito de Pedreira.

ZEIS4 - constituída por glebas ou terrenos não edificados, adequados à urbanização, localizados em área de proteção de mananciais ou de proteção ambiental e destinados a projetos de habitação de interesse social HIS. Possibilita o controle ambiental para o atendimento habitacional de famílias removidas de áreas de risco e de preservação permanente. Correspondem a duas áreas, uma delas na Vila Guacuri na Rua Professor Cardozo de Mello Neto e a outra no Jardim Apurá, atualmente utilizada para a pastagem de gado.

O bairro de Sete Praias é considerado ZERp - Zona Exclusivamente Residencial de Proteção Ambiental. Apresenta restrições em relação à área construída, principalmente quanto ao tamanho dos lotes, que devem ser grandes. O seu uso é exclusivamente para residências.

Dentro da área de proteção dos mananciais existe a preocupação de requalificar os espaços habitacionais de interesse social e reurbanizar as quadras destinadas ao uso habitacional. Encontra-se a ZMp, correspondente a Zona Mista de Proteção Ambiental, há a permissão para o comércio de pequeno porte, exceto nas vias coletoras onde não há restrições, também para as residências cujo tamanho mínimo do lote fica estabelecido em função das características das densidades, que podem ser de baixa ou média densidade. 


\title{
DESENVOLVIMENTO URBANO
}

\author{
PLANO REGIONAL ESTRATÉGICO - LEI 13885 - 2004
}

DISTRITO DE PEDREIRA

MAPA NÚMERO 4.17

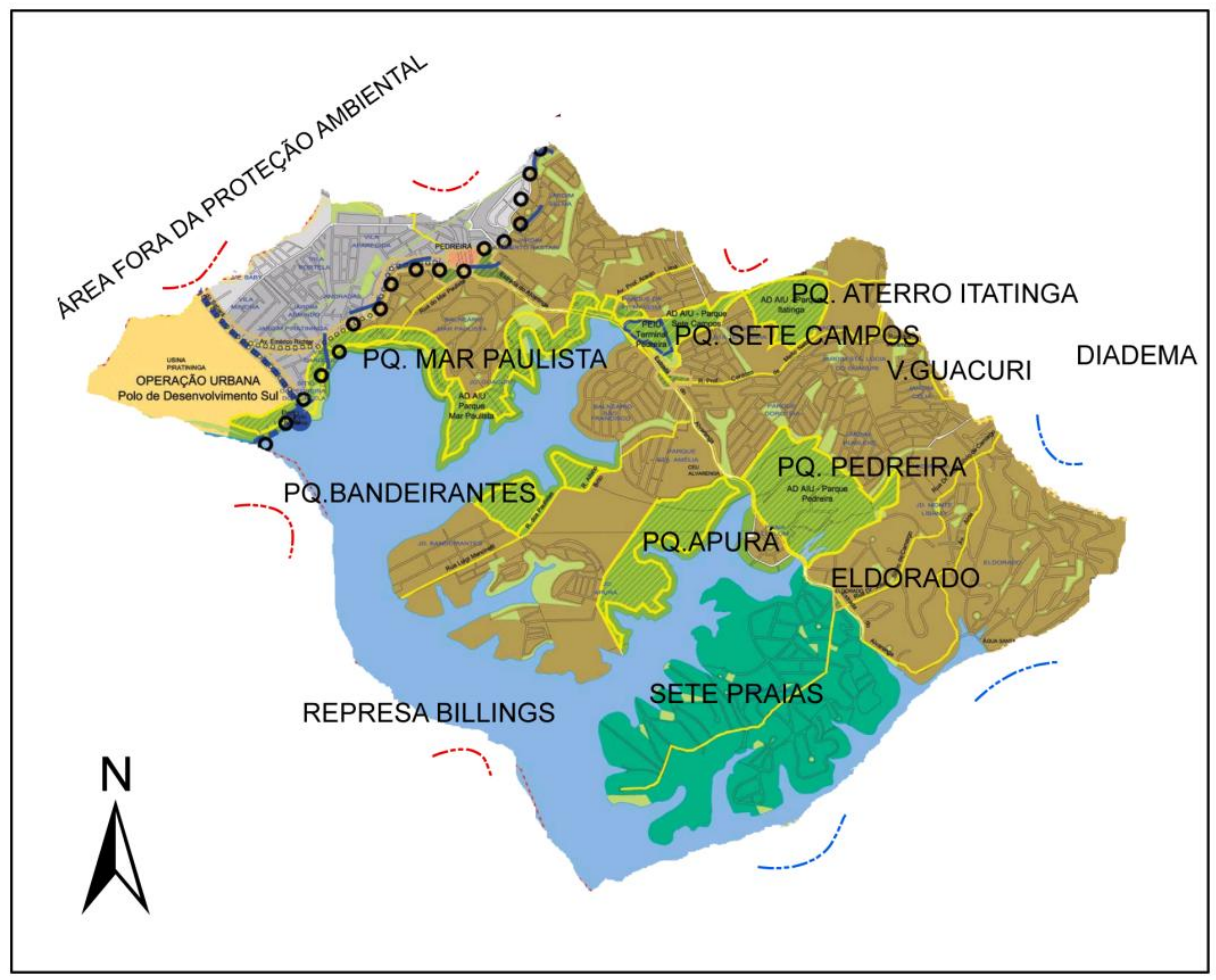

\section{$\begin{array}{llll}0 & 0,5 & 1 & 2 \text { Kilometers }\end{array}$}

Autor: Shinhiti Osanai

Fonte: SEMPLA - Plano Regional Estratégico Mapa 05 - 2004

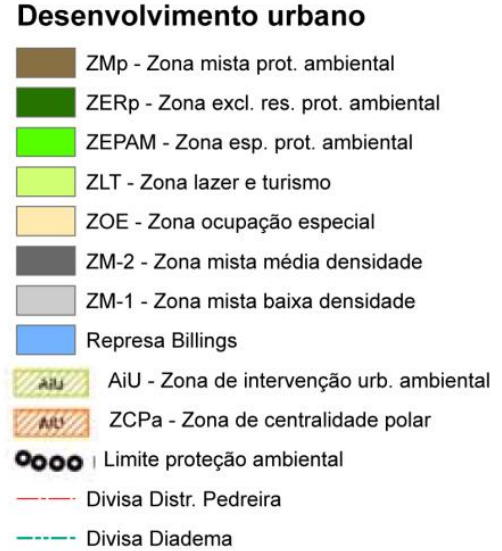

Desenvolvimento urbano ZEPAM - Zona esp. prot. ambienta

ZLT - Zona lazer e turismo ZCPa - Zona de centralidade pola

- - Divisa Distr. Pedreira Divisa Diadema 


\title{
USO E OCUPAÇÃO DO SOLO
}

\author{
PLANO REGIONAL ESTRATÉGICO - 2004
}

DISTRITO DE PEDREIRA

MAPA NÚMERO 4.18

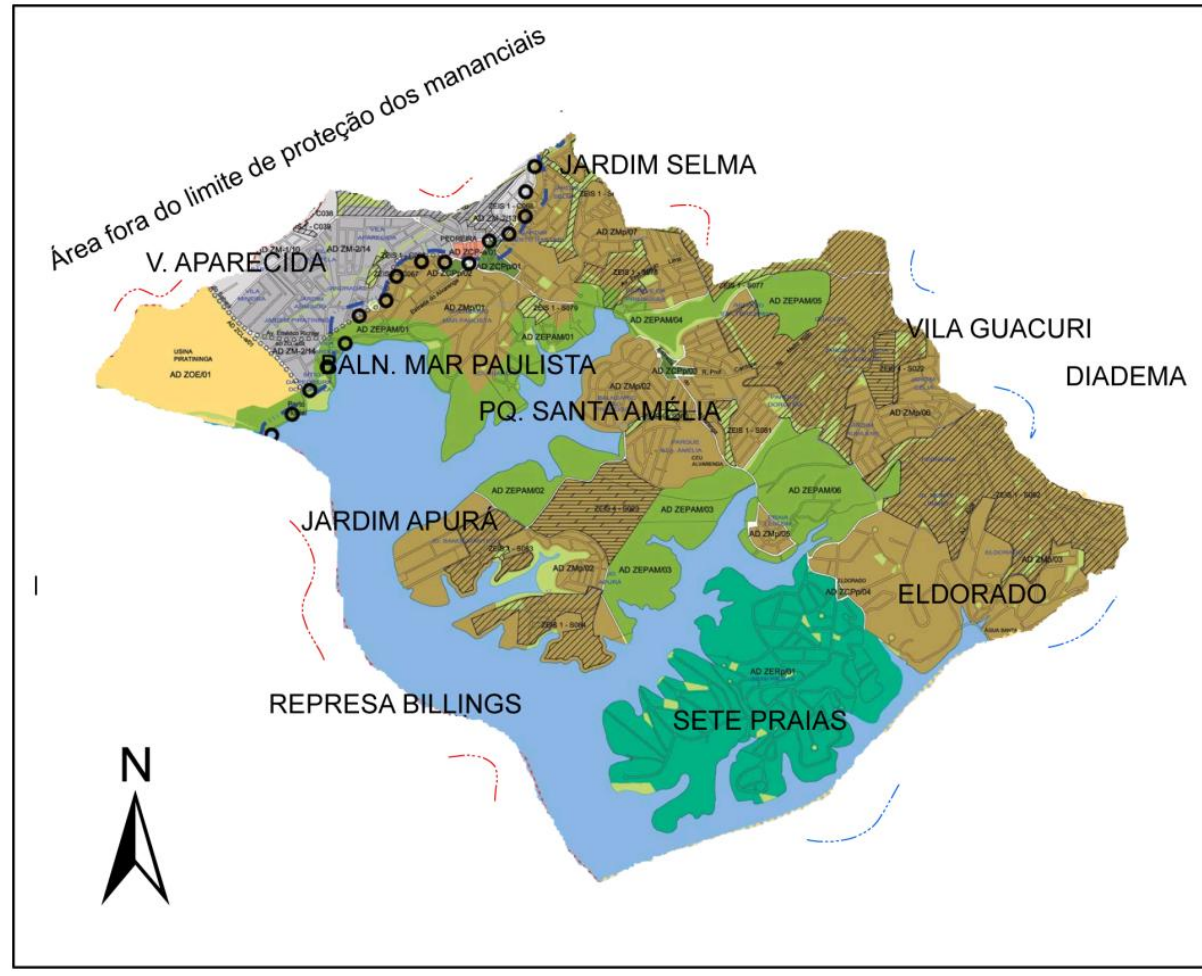

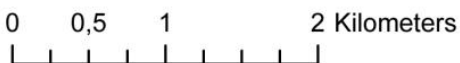

Autor: Shinhiti Osanai

Fonte: SEMPLA - Plano Regional Estratégico Mapa 04 - 2004

\section{Uso do solo}

ZMp- Zona mista prot. ambiental

ZERp-Zona excl. res. prot.ambiental ZEPAM-Zona esp. prot. ambiental

ZLT-Zona lazer e turismo

ZOE-Zona ocup. especial

ZM2-Zona mista média densidade

ZM1-Zona mista baixa densidade

Represa Billings

ZZIA ZEIS1-Zona esp. de inter. social

ZEIS4-Zona esp. de inter. social

000 । Limite proteção ambiental

_-_- Divisa Distr. Pedreira

-----. Divisa Diadema 
As áreas fora dos limites de proteção ambiental, ao norte do Distrito de Pedreira, são constituídas por zonas mistas com a permissão de instalação de indústrias, comércio e residências. Há duas zonas, a primeira a Zona Mista de Baixa Densidade - ZM-1 - com as características de densidade demográfica e construtiva baixa, onde se localiza parte do bairro Jardim Selma. A outra, a Zona Mista de Média Densidade - ZM-2 com as características de densidade demográfica e construtiva média, onde estão os bairros Jardim Domitila e Jardim Armindo.

\subsection{Funções}

A principal função do Distrito de Pedreira é a residencial.

O comércio, nas regiões ocupadas a partir dos anos 90, é muito deficiente mesmo com a significativa aglomeração de pessoas. Uma das causas pode ser a lei de proteção dos mananciais, que impõe muitas restrições a vários tipos de atividades. Os moradores próximos à divisa, por exemplo, da favela Eldorado, percorrem a pé alguns atalhos, e chegam muito rapidamente a uma região servida por ônibus urbano de Diadema com destino para o bairro de Serraria - centro mais próximo de comércio local -, bem estruturado, para aqueles que moram nessa região. Muitos moradores do bairro de Eldorado, próximos da Estrada do Alvarenga, caminham, e levam em média cerca de 50 minutos, até a Avenida Nossa Senhora dos Navegantes, que faz parte de um centro comercial local bem estruturado, localizado no Município de Diadema. Os moradores da favela da Divisa, ao nordeste do distrito, na Vila Guacuri, devido à proximidade da Avenida São José, em Diadema, fazem as compras no centro comercial do município vizinho, nessa mesma avenida. Na região de Vila Guacuri, o comércio melhor estruturado está em Diadema, bem no final da Rua dos Marimbas, na Rua Manoel da Nóbrega, logo após o cruzamento com a Avenida Alda, e há, inclusive, o serviço bancário. Embora as áreas limítrofes com a divisa, no Município de Diadema, pertençam igualmente à área de proteção de mananciais, aparentemente a legislação quanto à permissão de atividades de comércio em Diadema é menos rigorosa em relação a São Paulo. Existe uma legislação específica regulamentando o comércio da Avenida Nossa Senhora dos Navegantes.

Muitos dos moradores de Vila Guacuri, mesmo próximos da divisa, acabam satisfazendo muitas das suas necessidades de abastecimento no bairro de Santo Amaro, localizado a 18 km, e não no centro de Diadema, localizado a $2 \mathrm{~km}$. Tal fato deve-se à falta de opção de transporte intermunicipal, mais barato, para o município vizinho. Da mesma forma, os moradores de 
Mata Virgem, distante $16 \mathrm{~km}$ de Santo Amaro, não possuem acesso por meio de transporte coletivo, de custos mais baixos, a um pequeno centro comercial de Eldorado (Navegantes), em Diadema, localizado a 1,5 km de distância. Os moradores de Vila Guacuri e os de Mata Virgem, que eventualmente queiram locomover até Diadema de ônibus, fazem baldeação para as linhas de ônibus urbano do outro município, isso implica no custo de duas tarifas, portanto, é mais barato o deslocamento até Santo Amaro, apesar da distância. (Vide mapa número 4.16). Apenas os poucos, que moram nos arredores da Avenida Alda ou da Rua dos Marimbas, podem usufruir de um acesso mais fácil para Diadema pela disponibilidade do serviço de linhas de ônibus urbano do município vizinho.

A satisfação das necessidades de compras pode, muitas vezes, não ser atendida pelo pequeno comércio localizado em torno das residências, mesmo nas regiões próximas à divisa com Diadema. As compras semanais ou mensais podem ser efetuadas em pontos comerciais em regiões um pouco mais distantes das residências, em decorrência das lojas serem de maior porte e oferecerem maior variedade de opções de produtos e serviços. Finalmente as compras de bens de maior valor agregado podem ser feitas em centros mais distantes Largo 13 de Maio, Shopping Center Interlagos ou Shopping Center SPMarket que oferecem muitas opções de escolha.

Nos bairros mais antigos estão, em locais relativamente próximos das residências, cuja distância permite a locomoção a pé, os estabelecimentos que atendem as necessidades de freqüência diária ou semanal, tais como padarias, mercearias, bares, depósitos de material de construção, esse último principalmente nas proximidades das áreas de invasão, mesmo que não se enquadre na categoria de compras diárias. Farmácias, em quantidades bem menores, estão localizadas a certa distância, e nem sempre são possíveis de serem alcançadas a pé.

A região mais central do Distrito, cujo início de seu desenvolvimento aconteceu numa época anterior à lei de proteção dos mananciais, conta com o serviço de comércio melhor estruturado.

Na Estrada do Alvarenga, entre os números 600 e 2000 se observa uma aglomeração de prestação de serviços e também de comércio que atendem as necessidades de frequiência menor de demanda, por exemplo, supermercados de médio e grande porte, bazares/papelarias, farmácias, açougues, casas especializadas com produtos do nordeste, casas de aves vivas, lojas de móveis, quitandas, padarias, comércio de rações e produtos para animais, lojas de 
material de construção, sapatarias, lojas de confecção, autopeças, depósitos de revendas de GLP e de água mineral e revendas de veículos usados. Há, também, serviços de manutenção e reparos de automóveis, manutenção de computadores, aparelhos eletrônicos e eletrodomésticos, serviços jurídicos, de saúde com médicos e dentistas particulares, autoescolas e escolas de línguas. A Estrada do Alvarenga é uma das principais vias de acesso a Santo Amaro ou ao Centro Histórico de São Paulo, serve de passagem aos moradores da maioria dos bairros do Distrito de Pedreira, além de ser atendida por várias linhas de ônibus urbano.

$\mathrm{O}$ atendimento de necessidades de freqüência de demanda mais baixa e de maior diversificação é satisfeita fora do perímetro do Distrito de Pedreira, em lojas de eletrodomésticos, hipermercados ou lojas especializadas. As principais opções mais próximas do Distrito são a região do Largo 13 de Maio, Shopping Interlagos ou Shopping SPMarket, dentro do Município de São Paulo, e o centro comercial de Diadema. O acesso ao Shopping Interlagos de ônibus é bastante limitado, com poucas as opções de linhas. Significativa parcela da população não tem acesso direto ao Shopping SPMarket, por meio de ônibus urbano, a não ser que se realize um transbordo na Avenida Interlagos.

De qualquer parte do Distrito de Pedreira, é fácil o acesso a Santo Amaro, pois existe um número elevado de linhas de ônibus e o mesmo acontece em relação ao Centro Histórico.

O serviço de saúde, principalmente nas áreas mais carentes, é o serviço de médico da família. Há um sistema de visitas domiciliares mensais às residências feitos pelos agentes de saúde, que fazem o levantamento das necessidades de cada família e providenciam junto ao médico da UBS o agendamento da consulta ou encaminhamento aos ambulatórios de especialidades. Embora em frequiências menores, os agentes de saúde são acompanhados por auxiliares de enfermagem ou enfermeiros que providenciam o acompanhamento de pressão arterial e níveis de glicemia. Para as pessoas acamadas, idosos ou crianças recém nascidas, podem os agentes de saúde comparecem acompanhados por um médico. Existe um atendimento mensal, em grupo, dirigido para as pessoas moradoras em condomínios, com a participação de médico, enfermeiro ou auxiliar de enfermagem. Esse atendimento em grupo pode ser organizado nas instalações da UBS.

No tocante à educação, quase todas as crianças em idade escolar estão matriculadas. $\mathrm{O}$ Distrito de Pedreira dispõe de uma estrutura pública satisfatória para o atendimento das 
necessidades do ensino fundamental. Entretanto, existe grande deficiência em creches, préescola e ensino médio, na rede pública.

A função indústria do Distrito de Pedreira é muito pouco expressiva. Existe apenas uma indústria de médio porte que se instalou antes da promulgação da lei de proteção aos mananciais. As demais indústrias, em pouca quantidade, são de pequeno porte e se localizam ao norte do Distrito onde não há restrições de proteção ambiental.

Existe uma função de potencial bastante elevado, que ainda não é explorado, a do turismo, que poderia ter as funções de comércio de apoio ao lazer náutico e clubes esportivos. Existem propostas para a construção de praias na represa Billings. Essas funções poderão se desenvolver naturalmente quando todos os parques previstos na margem da represa Billings estiverem em funcionamento. Está previsto no PRE, para o Parque Mar Paulista, a instalação de estabelecimento de ensino de cunho ambiental, Universidade do Meio Ambiente e centro de pesquisas voltadas ao meio ambiente.

\subsection{Centralidade}

Santo Amaro foi constituído, como um povoado a partir do século XVI, tão logo foi estabelecida, a capitania de São Vicente, no início dos trabalhos de catequese dos índios que viviam na região da aldeia de Jeribatiba. Em 1686 foi promovido a freguesia, em 1832 foi transformado em município. O seu limite territorial estendia do córrego da Traição, onde atualmente passa a Avenida dos Bandeirantes, até a Serra do Mar, abrangendo as áreas hoje pertencentes aos Municípios de Itapecerica da Serra, Embu, Embu-Guaçu, Taboão da Serra, São Lourenço da Serra e Juquitiba, até a separação do Município de Itapecerica da Serra em 1877. Em 1938 deixou de ser município e passou a ser incorporado a São Paulo. Antes de serem desmembrados, redistribuídos e reorganizados em várias subprefeituras, os atuais Distritos de Pedreira, Cidade Ademar, Santo Amaro, Campo Grande, Campo Belo, Campo Limpo, Capão Redondo, Vila Andrade, Jardim Angela, Jardim São Luis, Socorro, Cidade Dutra, Grajaú, Parelheiros e Marsilac fizeram parte de Santo Amaro quando ainda era município.

No século XIX, na área rural, o sertão de Santo Amaro, D. Pedro I promoveu a colonização alemã, o atual bairro de Colonia, um empreendimento que na época teve fracasso por ser uma região muito afastada do centro e problemas de comunicação, e em 1847 restavam apenas 9 
famílias das 62 que chegaram inicialmente. Atualmente, nessa região, vivem descendentes dessa colonização com traços europeus de cabelos loiros e olhos azuis. Na época, o sertão de Santo Amaro tinha mais contato com São Bernardo do Campo e Itapecerica da Serra. Foi uma região importante na extração de madeira e produção de carvão vegetal.

No passado, Santo Amaro foi considerado um bairro de subúrbio (PENTEADO, [1958]). À beira da represa Guarapiranga surgiram chácaras de recreio, habitações de fins de semana e clubes náuticos. No bairro de Socorro formou-se uma indústria naval. Pensões e hotéis foram estabelecidos para atender o fluxo de turistas à procura de lazer na represa Guarapiranga. A expansão urbana ocorreu na direção noroeste com o surgimento de novos loteamentos a partir de 1920 e na década de 1935 a 1945 foi instalado o bairro de Brooklin Paulista.

A partir de 1945 houve a instalação de um centro industrial de destaque principalmente com a indústria têxtil e químico farmacêutica. No período de 1948 a 1950 houve a duplicação da Estrada Velha de Santo Amaro, atual Avenida Santo Amaro.

Sendo assim, o bairro de Santo Amaro é o centro histórico dessa vasta área, que no passado esteve sob a sua jurisdição política. O bairro até hoje exerce o importante papel de centro de influência de todo o seu espaço periférico, principalmente por estabelecer o nó central de circulação, exercer uma forte centralidade polar e atrair as pessoas pela oferta de comércio, serviços e equipamentos bastante diversificados. O seu parque industrial, apesar de ter sofrido uma significativa redução, ainda atrai a mão de obra, em conseqüência da facilidade de acesso a partir de todos esses locais periféricos. Exerce um poder de atração, por meio de uma hierarquia funcional superior em relação aos bairros mais periféricos, muitos deles dormitórios, localizados em seu redor, e gera fluxos centrífugos e centrípetos de pessoas e mercadorias. Muitas das vias de acesso apresentam algumas características radiais, em relação ao centro do bairro de Santo Amaro, por exemplo, a Estrada de Itapecerica, Estrada do M' Boi Mirim, Estrada do Campo Limpo, Avenida Robert Kennedy, Avenida Nossa Senhora do Sabará ou Avenida Cupecê. Tal fato gera um elevado fluxo de serviços de transporte coletivo com a origem nos locais periféricos vizinhos.

O PRE prevê a identificação de áreas, onde se pretende incentivar o desenvolvimento de pólos de comércio e serviços ou de equipamentos públicos. Pretende criar pólos de centralidades com o objetivo de estimular o desenvolvimento das atividades comerciais e de prestação de serviços de âmbito local e, assim gerar negócios e empregos, igualmente, estimular o 
desenvolvimento econômico local, que aumentam as possibilidades de ampliação do número de equipamentos públicos. As zonas de centralidade, segundo o PRE, são porções do território destinadas a abrigar maior diversidade e intensidade de usos não residenciais, com prevalência em relação aos usos residenciais, e podem ser:

-empreendimentos que concentrem atividades comerciais e de serviços (lojas diversas, shoppings, supermercados);

-equipamentos que abriguem serviços públicos (de saúde, de segurança, etc.);

-locais de encontro onde a população possa utilizar os espaços públicos e que sirvam como pontos de referência culturais, religiosos e de lazer.

A lei permite o estabelecimento de centralidades, também, em áreas de proteção ambiental. Existem dois tipos de centralidades: a primeira linear, quando ocorre ao longo de vias principais em forma de eixos; a outra polar, perante uma aglomeração estabelecida numa porção do território, ao ocupar vários quarteirões bem próximos e apresentar características de um centro local.

As zonas de centralidades polares, previstas em lei, ainda não existem de fato no Distrito de Pedreira e são quatro ao todo. A primeira, denominada de Pedreira ( $\mathrm{ZCPa} / 01)$, será instalada entre a Estrada do Alvarenga, Rua Professor Dantas Jr., Rua Felício Roscito e Rua Vicente de Paulo da Silva. Nesse local ainda não existe a constituição de um centro polar, de acordo com os conceitos do PRE, a não ser um grupo de várias atividades de comércio ao longo da Estrada do Alvarenga e da Praça do Acuri. Essa zona faz parte de uma área sujeita a intervenção urbana, no futuro, onde se espera a instalação de um centro que oferece, também, serviços de saúde. Ao seu lado, formando uma área contígua, está prevista a ZCPp/01 Jardim da Pedreira, na área delimitada pela Rua Vicente de Paulo da Silva, Rua Felício Roscito, Rua José Vieira Martins, Rua D. João Batista Nery, Rua Professora Irene Maurícia de Sá e Estrada do Alvarenga. O limite da área de proteção dos mananciais divide essa região de centralidade polar em duas partes, a ZCPa/01 fora da área e a ZCPp/01 dentro dessa área. Com exceção da Estrada do Alvarenga ou a Praça do Acuri, todas essas ruas possuem apenas imóveis residenciais, muito pouco adequados para a instalação de estabelecimentos comerciais, há, portanto, a necessidade de uma intervenção intensa para a sua transformação num pólo de centralidade. Tal mudança seria economicamente viável somente quando a renda da população crescer e assim justificar a expansão do comércio local. A não ser que a 
intervenção venha a alterar a largura das ruas estreitas, não será possível a instalação de grandes estabelecimentos comerciais, devido ao tamanho dos estabelecimentos serem proporcionais às larguras das suas respectivas ruas, conforme a lei do zoneamento.

Ainda, estão previstas duas zonas de centralidade linear, ao longo da Avenida Nossa Senhora do Sabará (ZCLa/01) entre a divisa do Distrito de Campo Grande até represa Billings, e na Avenida Emérico Richter/ Estrada do Alvarenga (ZCLa/02), entre Avenida Nossa Senhora do Sabará e Praça do Acuri. Futuramente, quando essa zona de centralidade linear for instalada, a idéia do PRE é disponibilizar o comércio e serviços numa extensão de um pouco mais de 2 $\mathrm{km}$ até a Praça do Acuri. Na Estrada do Alvarenga, em toda a extensão entre os números 600 e 2000, já existe um comércio bem estruturado. Em relação à zona ZCLa/01 talvez não atraia o interesse do comércio, de imediato, em decorrência das instalações da usina termelétrica de Piratininga, que ocupa uma significativa extensão da Avenida Nossa Senhora do Sabará num dos seus lados, a permanência de algumas indústrias e, também de muitos condomínios fechados. Seus moradores possuem um bom nível de renda, possivelmente, prefiram satisfazer as suas necessidades de compras no Shopping Center Interlagos, cuja localização é bem próxima.

Outras centralidades polares, sujeitas a intervenção urbana no futuro, estão previstas, a saber:

ZCPp/02 - Alvarenga - Localiza-se nas quadras delimitadas pelas ruas Eng ${ }^{\circ}$ Flávio da Costa, Estrada do Alvarenga, Rua do Sossego e Rua Dr. Juvenal Meyer. Estão no lado oposto das zonas ZCPa/01 e ZCPp/01 em relação à Estrada do Alvarenga. No futuro, pode ser uma espécie de expansão natural do comércio da Estrada do Alvarenga em direção às ruas paralelas. Neste momento ainda não se verifica tal necessidade, exigirá muita intervenção para a transformação dos imóveis residenciais em comerciais e adequar a largura das suas ruas. O estabelecimento dessas zonas, no futuro, poderá permitir a expansão do comércio de maneira mais ordenada em área de proteção ambiental.

ZCPp/03 - São Francisco - Localiza-se na área delimitada pela Estrada do Alvarenga, Travessa Maria J. da Conceição, Rua dos Aniquis, Rua dos Caratais, Rua das Baúnas, Rua Prof. Cardozo de Mello Neto, Estrada do Alvarenga, Rua dos Camuripins, Estrada do Alvarenga, Praça Francesco Manelly. Nessa região o pólo de atração do comércio é o 
Supermercado Pedreira e aos poucos, observa-se a instalação de alguns pequenos estabelecimentos de comércio em torno desse supermercado.

ZCPp/04 - Eldorado - A sua localização inicia-se na confluência da Travessa Mailho com a Estrada do Alvarenga, segue pela Estrada do Alvarenga, Rua Dr. José Silvio de Camargo, Travessa Mailho, até o ponto inicial. Poderá ser um concorrente, no futuro, do centro comercial bem estruturado da Avenida Nossa Senhora dos Navegantes, em Diadema, situado na divisa com o Distrito de Pedreira. Ainda é uma região de população de renda muito baixa, não existe comércio nas proximidades, e a população efetua as compras no comércio mais próximo localizado no município vizinho, ou então em Santo Amaro.

Apesar da distância entre Pedreira e Santo Amaro ser bem maior, em comparação da distância entre Pedreira e Diadema, por causa do sistema radioconcêntrico de ônibus, Santo Amaro torna-se um pólo de atração muito intenso. A população de baixa renda é muito dependente desse bairro. Locais do tipo Shopping Interlagos ou Shopping SPMarket, mesmo sendo mais próximos para os moradores de Pedreira em relação a Santo Amaro, em virtude das poucas opções de linhas de ônibus, acabam se transformando em pontos comerciais de menor importância, enquanto prevalecer o atual fluxo de pessoas para Santo Amaro.

Quase todos os tipos de comércio e serviços disponíveis no centro de Diadema também se encontram em Santo Amaro. Segundo Gabriel Dupuy, em seu livro Sistèmes, Réseaux et Territoires, existe uma repartição hierárquica dos pólos através de uma relação de atração resultante dos potenciais que eles representam, e existe uma ligação de concorrência entre os pólos. Em consequiência do sistema urbano de ônibus, a população de renda mais baixa, mesmo muitos dos moradores mais próximos de Diadema, precisam recorrer a Santo Amaro para satisfazerem as suas necessidades de compras, ou seja, o transporte coletivo torna-se um fator importante de atração da população para o comércio ou serviços, o que fortalece a manutenção de uma hierarquia superior desse pólo de Santo Amaro e constitui um forte concorrente para os demais pólos comerciais.

Apesar do centro de Diadema oferecer, em termos de comércio e serviços, as mesmas opções de Santo Amaro, na região do Largo 13 de Maio, somente os poucos moradores das proximidades da Avenida Alda são beneficiados pelo sistema de transporte intermunicipal ou urbano de Diadema para o centro desse Município. Disto, Santo Amaro constitui um ponto de atração mais intenso, apesar da distância em relação ao centro de Diadema, em decorrência do 
sistema de transporte urbano. A falta de opção de transporte coletivo, a custos mais baixos, em direção a Diadema para a maioria da população de renda mais baixa, beneficia Santo Amaro, mantendo o status de um centro de maior atração por causa da facilidade de acesso.

O acesso a Santo Amaro pode ser feito de maneira fácil de qualquer parte do Distrito de Pedreira existindo uma boa diversidade de linhas, o mesmo acontecendo em relação ao Centro Histórico de São Paulo. Os moradores dispostos a pagarem tarifa mais elevada podem se dirigir ao Município de Diadema.

Num futuro próximo, caso venha a ocorrer uma mudança bastante radical nos serviços de transporte coletivo ao oferecer novas opções de acesso, novos pólos podem surgir naturalmente ou poderão ser desenvolvidos, em locais mais próximos das aglomerações já existentes alterando a atual divisão hierárquica dos pólos liderada por Santo Amaro.

\subsection{Mobilidade}

O acesso ao centro e regiões sul e sudoeste de São Paulo é feito por um sistema de ônibus urbano cujo modelo é radioconcêntrico, de eficiência muito discutível, que apresenta muitas limitações e desvantagens quando se trata de atender as necessidades de acessibilidade a diversos outros locais da cidade.

Os serviços de ônibus estão distribuídos da seguinte forma:

Para o centro de São Paulo

- passando por Estrada do Alvarenga - 8 linhas;

- passando por Metrô Jabaquara - 2 linhas;

- passando por Avenida Cupecê ou Yervant - 4 linhas.

Para Santo Amaro

- passando por Estrada do Alvarenga - 7 linhas;

- passando por Avenida Cupecê ou Yervant - 5 linhas.

Para a região sudoeste

- passando por Estrada do Alvarenga - 4 linhas;

- passando por Avenida Cupecê ou Yervant - 7 linhas. 
Para o Metrô Jabaquara *

- passando por Estrada do Alvarenga - 8 linhas;

- passando por Avenida Cupecê ou Yervant - 5 linhas;

- passando por Avenida Angelo Cristianini - 10 linhas;

- outros itinerários - 1 linha.

* Algumas linhas seguem para outras estações da linha azul do metrô, e também para o bairro da Luz, passando pelo Metrô Jabaquara.

O acesso para o Município de Diadema, a partir de Pedreira ou Santo Amaro, é feito pelo sistema intermunicipal administrado pela EMTU. Na Avenida Alda, onde uma parte de seu traçado faz parte da linha divisória municipal, circulam, indistintamente, os ônibus urbanos de São Paulo e de Diadema.

Existem algumas linhas sendo:

- 1 linha intermunicipal, passando pela Estrada do Alvarenga, que atende o itinerário entre Diadema (Terminal Piraporinha) e Santo Amaro;

- 1 linha intermunicipal, passando pela Rua Dr. José Silvio de Camargo, que atende entre Terminal Diadema e São Bernardo do Campo até o local conhecido como Acampamento dos Engenheiros;

- 1 linha intermunicipal que liga o bairro Jardim Tiradentes em Diadema (divisa com o Jardim do Castelo no Distrito de Pedreira) ao bairro de Itaim Bibi em São Paulo;

- 1 linha intermunicipal e circular que perfaz o itinerário entre o Terminal Diadema e o bairro de Vila Guacuri no Distrito de Pedreira;

- 2 linhas urbanas de Diadema, que passam pelos bairros de Mata Virgem e Eldorado, circulam pela Avenida Alda até o centro de Diadema;

- 1 linha urbana de Diadema, que passa pela Rua dos Marimbas, segue em direção ao centro de Diadema. 
TRANSPORTE URBANO - SISTEMA RADIOCONCÊNTRICO

DISTRITO DE PEDREIRA

MAPA NÚMERO 4.19

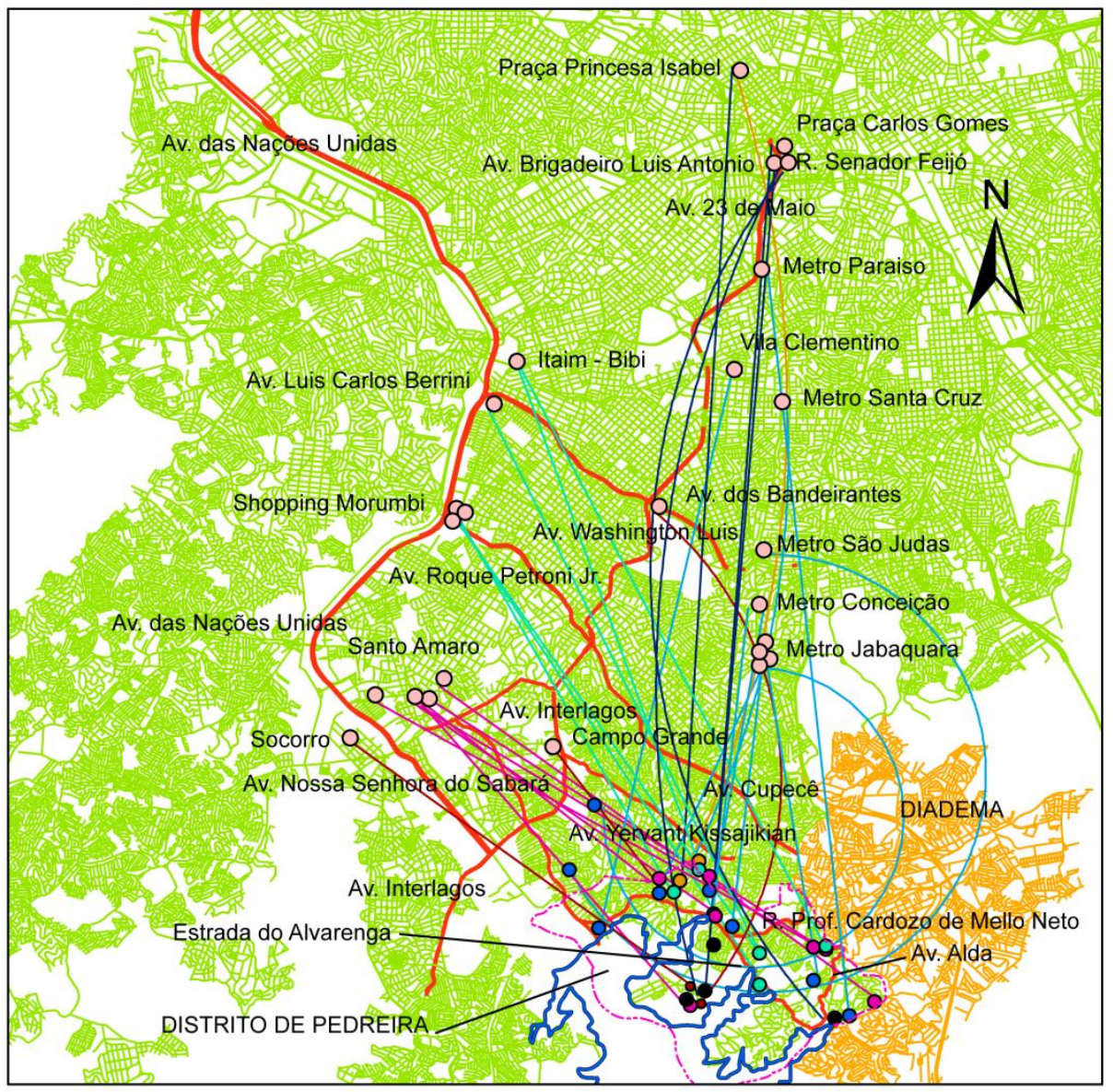

$\begin{array}{lll}0 & 1,5 & 3\end{array}$

6 Kilometers

Ônibus - destino

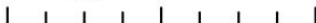

Autor: Shinhiti Osanai

Fonte: SPTrans
O Destino

- Santo Amaro

- Metrô

- Zona oeste

- Outros locais

- Centro via metrô

- Centro Represa Billings São Paulo

— Diadema

-.-D Divisa Distr. Pedreira 
Os bairros de Mata Virgem, Eldorado e Vila Guacuri, por se localizarem nas proximidades da divisa municipal, são bem mais próximos do centro do Município de Diadema em relação a Santo Amaro.

Somente os poucos moradores das proximidades da Avenida Alda podem usufruir do sistema de transporte urbano para o centro de Diadema. Portanto, Santo Amaro constitui um ponto de atração mais intenso pelo fato de oferecer mais opções de transporte urbano, apesar da distância em relação ao centro de Diadema. A falta de opção de transporte em direção a Diadema, para a maioria da população de renda mais baixa, beneficia Santo Amaro. Conseqüentemente, Santo Amaro é o centro de maior opção em termos de acesso.

As áreas mais carentes em termos de transporte coletivo estão nos bairros de Eldorado e Mata Virgem. Os moradores da favela Eldorado não dispõem de serviço de transporte urbano. O comércio melhor estruturado das proximidades é o do bairro Serraria em Diadema, esses moradores caminham, utilizando uma trilha, até a Avenida Afonso Monteiro da Cruz, na divisa com Diadema, para utilizarem o ônibus urbano de Diadema que passa por Serraria. Ou então, caminham até a Rua 20, nas proximidades do número 1300 da Estrada da Água Santa para tomarem o micro ônibus até Santo Amaro.

O bairro de Monte Líbano é muito carente de serviço de transporte urbano. Existe um serviço de micro ônibus, tendo o seu ponto inicial na Rua Nove, na altura do número 700 da Rua Dr. José Silvio de Camargo e faz o percurso para o metrô Jabaquara. Os usuários dessa linha, que necessitam chegar até Santo Amaro, são obrigados a uma baldeação na Vila Guacuri. Os moradores das proximidades da Rua Rust, podem caminhar até a Rua Vicente Strichalsky, onde existem ônibus para Santo Amaro ou para a região sudoeste da cidade. Muitos moradores da Rua Dr. José Silvio de Camargo, caminham até a Estrada do Alvarenga, diante de apenas uma opção de ônibus intermunicipal, que faz a ligação entre Diadema de São Bernardo do Campo.

Os moradores da favela da Divisa, nas proximidades da Rua Chico Mendes, contam com melhor estrutura de comércio no centro de Diadema, pela proximidade da Avenida São José, um dos principais eixos comerciais desse Município. Eles podem usufruir de uma linha de ônibus urbano de Diadema até o centro, apesar dessa Avenida se encontrar a poucos minutos a pé. 
Os moradores da favela Itatinga necessitam caminhar até a Rua Professor Cardozo de Mello Neto para utilizarem os ônibus para Santo Amaro, pois as poucas linhas de ônibus nas proximidades dessa favela realizam o itinerário em direção ao Jardim Luso e metrô Jabaquara.

O sistema de transporte urbano do Distrito de Pedreira conduz a maior parte dos moradores ao bairro de Santo Amaro, Centro Histórico, região sudoeste, ou metrô Jabaquara.

Nas proximidades do Largo 13 de Maio, na Av. Padre José Maria (continuação da Av. Adolfo Pinheiro), existe um terminal de integração de ônibus, o terminal Santo Amaro. Operam linhas provenientes de toda a região sul do município, tais como Grajaú e Jardim Angela. Funciona, também, como terminal de integração com a linha lilás do metrô, em fase de expansão, atualmente em operação no trecho entre Capão Redondo e Largo 13 de Maio. No futuro essa linha lilás estará integrada com a linha verde, em fase de expansão, neste momento funcionando entre Alto do Ipiranga e Vila Madalena. Ainda, existe uma integração da linha lilás com a linha esmeralda da Companhia Paulista de Trens Metropolitanos - CPTM, que opera entre Grajaú e Osasco, na estação Santo Amaro. No Distrito de Pedreira apenas uma linha de ônibus, que atende os moradores de Vila Guacuri e dos arredores da Estrada do Alvarenga, chega até o terminal Santo Amaro. Os micros ônibus não operam no terminal e os seus pontos finais se localizam nas Ruas Barão de Duprat e Desembargador Bandeira de Mello bem próximas do Largo 13 de Maio. Para os usuários dos micros ônibus, que não operam no terminal Santo Amaro, existe um acesso à linha lilás no Largo 13 de Maio.

A integração modal traz benefícios ao comércio permitindo o domínio do espaço pelo usuário.

Em relação às melhorias do transporte coletivo, constantes no PRE, de todas que estavam previstas para 2006, nenhuma delas foram executadas. Encontram-se planejadas, a via segregada para ônibus, o Passa Rápido, na Avenida Nossa Senhora do Sabará e a operação de preferência para os ônibus, a Operação Via Livre, na Estrada do Alvarenga entre a Avenida Augusto de Castro e Avenida Professor Araujo Lima. Qualquer melhoria, para dar prioridade ao ônibus na Estrada do Alvarenga, depende das obras de alargamento da pista, o que exigiria desapropriações. No local do Parque Sete Campos, deveria existir um terminal intermodal de ônibus, o Terminal Pedreira. O terminal, ainda não executado, está previsto desde 2003 conforme o decreto 42906. 


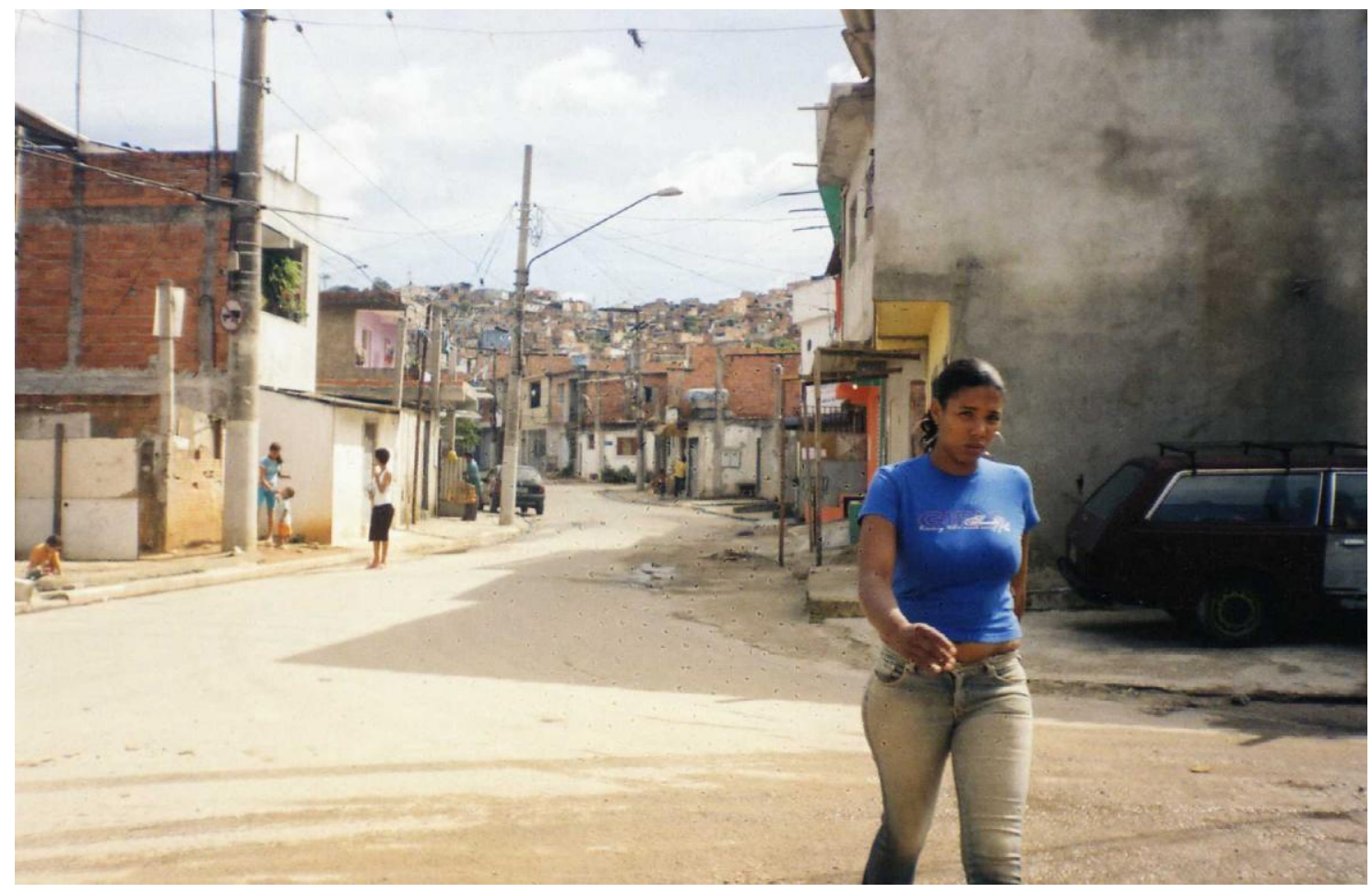

Foto número 4.5 - Um dos acessos para a favela Itatinga - Rua Guaicuri

Fonte: acervo do autor

Para 2012, consta no PRE planejamentos de muitos melhoramentos: a construção da via segredada para ônibus, o Passa Rápido, na Avenida Emérico Richter e Estrada do Alvarenga até a Avenida Augusto de Castro; a ligação entre a Estrada do Alvarenga e a Avenida Cupecê com o início na Avenida Augusto de Castro. Ainda, existe a previsão da construção, no final da Avenida Nossa Senhora do Sabará, de um porto fluvial junto ao Parque Mar Paulista, e de um terminal intermodal de ônibus, o que possibilitaria o aproveitamento da represa Billings para o transporte de passageiros e atenderia os bairros localizados as margens dessa represa.

\subsection{Fisionomia e vida urbana}

O Distrito de Pedreira é formado por muitas colinas. As declividades mais acentuadas se localizam, ao sul, nas regiões de divisa com Diadema, tais como Vila Guacuri, Eldorado e Mata Virgem, e mais ao centro, nas regiões compreendendo o Jardim Selma e Vila Missionária. A maioria dos córregos nasce no próprio Distrito e correm em fundos de vale entre as colinas, desembocando na represa Billings. Os córregos estão presentes na parte de planície, entretanto as suas nascentes se localizam nas áreas mais elevadas das colinas. São poucos os córregos que possuem nome. São eles: o córrego da Olaria, ao norte que demarca a 
divisa com o Distrito de Campo Grande; o córrego do Guaicuri, na região central de planície; o Ribeirão da Grota Funda, que demarca a divisa com Diadema. Todavia, a maioria dos córregos não possui nome.

Existem dois principais tipos de traçados de ruas no Distrito: um por meio do aproveitamento dos vales existentes entre as colinas; e outro acompanhando o eixo que passa pelo topo das colinas.

A Estrada do Alvarenga, que corta todo o Distrito de Pedreira no sentido noroeste-sudeste, foi aberta seguindo o eixo principal determinado pelos topos das colinas. Seu traçado se localiza, em muitos dos trechos, nas suas partes mais altas, exceto na região de planície na altura do bairro Balneário São Francisco ou quando passa próxima às margens da represa Billings, junto ao bairro de Eldorado quase na divisa com Diadema, onde contorna pela base de uma colina. Muitas das principais ruas são de fundo de vale, mesmo na região central, onde se encontra a planície, por exemplo, a Rua Carlos de Rezende Enout, Avenida Aldo João Rinaldi e Rua Vicente Strichalski, localizados no Jardim Rubilene. Nas regiões de declividades mais acentuadas, ao sul do Distrito, as principais ruas têm a origem na Estrada do Alvarenga. A Avenida Alda, que faz a ligação entre o bairro de Eldorado e o Município de Diadema, possui o seu traçado inicial em fundo de vale e, ao aproximar do bairro Jardim Monte Líbano, segue o eixo do topo das colinas, que acompanha as declividades acentuadas, até alcançar a região de divisa com o município limítrofe. No bairro de Mata Virgem, a Rua Mata Virgem e Rua da Saúde foram abertas num fundo de vale, acompanham a declividade das colinas, e formam subida em direção a Diadema. A Estrada da Água Santa, no bairro de Eldorado, tem o seu traçado inicial num fundo de vale, acompanha o Ribeirão da Grota Funda, que demarca a divisa com Diadema, prossegue pelas áreas de declividade acentuada ao acompanhar o eixo do topo das colinas a partir da Avenida Chico Mendes, até chegar bem próxima de Jardim do Castelo e termina na Avenida Alda. A Rua Dr. José Silvio de Camargo, em direção ao norte é a via de acesso ao Jardim Monte Líbano, e também ao sul é a entrada para o bairro Sete Praias, segue o traçado num fundo de vale em seu início e acompanha a declividade das colinas em forma de subida até terminar na Avenida Alda.

O acesso ao Jardim Bandeirantes e Jardim Apurá, localizados na primeira península, é feito a partir da Estrada do Alvarenga passando pela Rua Davide Perez e Rua Salvador Dali, as quais seguem o eixo da parte mais elevada dessa península. As ruas do Jardim Bandeirantes possuem o seu traçado em área relativamente plana e com pouca declividade. Todavia, no 
Jardim Apurá, as ruas transversais, em relação à rua principal Salvador Dali, foram abertas seguindo os eixos dos topos da península, apresentam, assim, uma declividade bastante considerável em direção às margens da represa Billings.

Existem algumas opções distintas de acesso ao bairro de Sete Praias, localizado na segunda península, todas elas mantêm cancelas diante do fato desse bairro ter uma estrutura de um condomínio fechado. Uma das alternativas é a partir da Estrada do Alvarenga, passar pela Rua Dr. José Silvio de Camargo e depois continuar pela Rua Professor Camillo Aschar, essa última segue o eixo da parte mais alta dessa península até atingir o seu extremo nas margens da represa Bilings. No bairro de Sete Praias as ruas transversais, de declividades acentuadas, que cruzam a via principal Rua Professor Camillo Aschar, foram abertas nos eixos dos topos das colinas dessa península, e são poucas as ruas em fundos de vale.

Na região central do Distrito, na Vila Missionária, a Rua Papa Gregório Magno começa em fundo de vale, forma descida a partir da Estrada do Alvarenga, continua numa subida pelo eixo do topo de uma colina e passa numa das partes mais altas do bairro. No Jardim Selma a Rua Maria Clotilde Martins segue o eixo do topo de uma colina.

Partindo da Estrada do Alvarenga, em direção às margens da represa Billings, no bairro Balneário Mar Paulista no centro do Distrito, as principais ruas foram abertas em fundo de vale, formando descida até alcançar as margens da represa. Podem-se destacar, entre outras, as Ruas Rodrigues de Medeiros, Córrego Azul e do Sossego.

Partindo da Estrada do Alvarenga, em direção à Vila Aparecida, ao norte do Distrito e para o lado oposto da represa, a Rua João de Araújo e a sua continuação a Avenida Batista Maciel acompanham um fundo de vale em forma de descida até chegar à Rua Antonio do Campo, que se localiza numa área de planície.

Nas faixas mais próximas às margens da represa Billings encontra-se a cota de $750 \mathrm{~m} \mathrm{e}$ predominam as declividades abaixo de $5 \%$.

Os pontos mais elevados do Distrito estão, ao sul, nos bairros Eldorado e Mata Virgem. Na Estrada da Água Santa, está o local mais elevado, na divisa com Diadema, com a cota de $865 \mathrm{~m}$. Nessa região, a Estrada da Água Santa atravessa os pontos mais altos, variando entre 840 e 865 m. A Rua Mata Virgem, nas proximidades da represa Billings, começa aos 750 m e termina nas imediações da Estrada da Água Santa aos 820 m. Nos bairros Eldorado e Mata 
Virgem encontram-se as declividades na faixa de 20 a 40\%, assim como, algumas áreas apresentando declividade acima de $40 \%$. Na região de divisa com Diadema prevalece a declividade na faixa de 20 a $40 \%$.

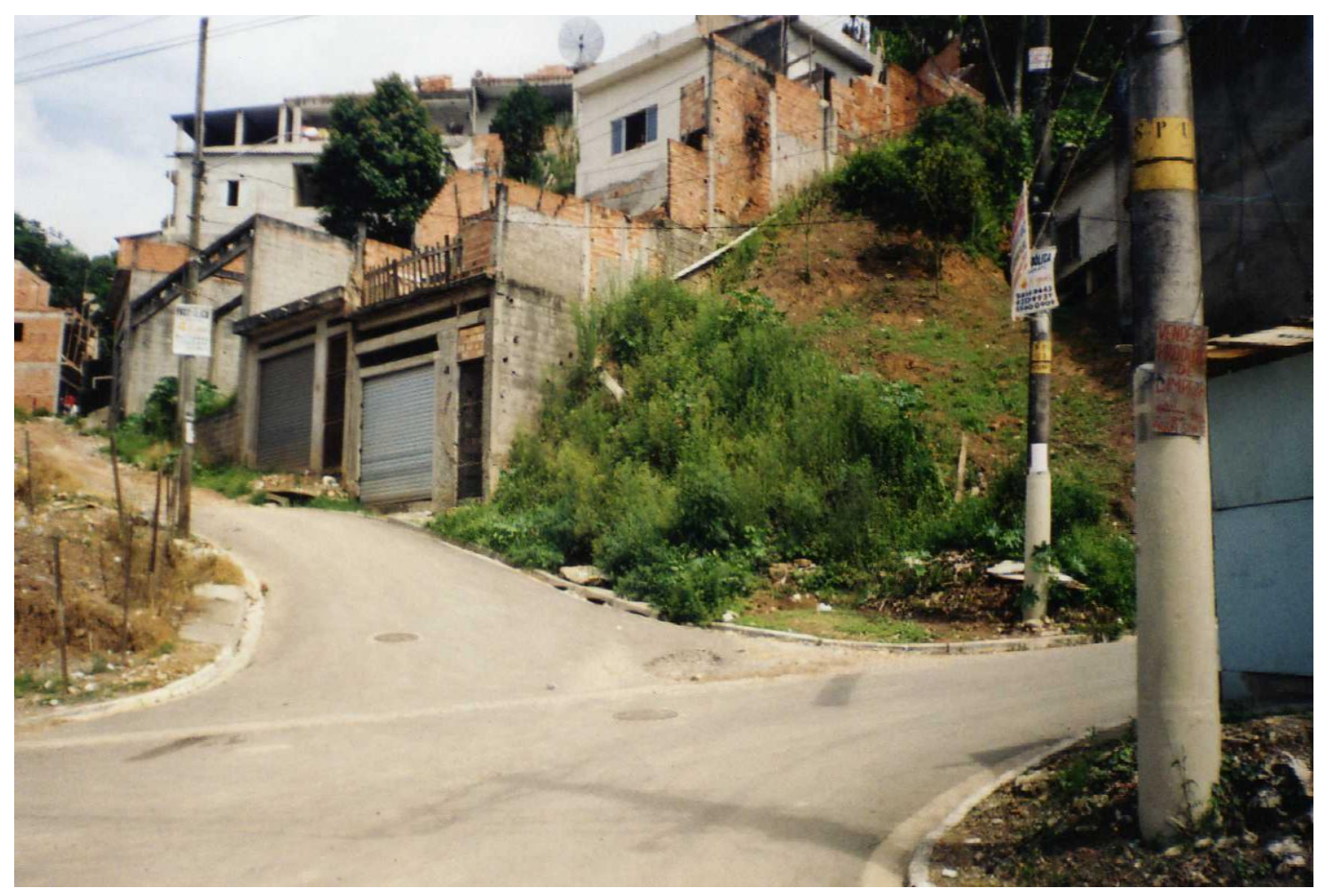

Foto número 4.6 - Áreas de declividade acentuada - Rua 20 - Bairro de Eldorado Fonte: acervo do autor

Entre a Avenida Alda e a Rua Dr. José Silvio de Camargo, próximo às margens da represa Billings, no sul do Distrito, localiza-se uma pequena colina cujo ponto mais alto corresponde a 800 m, é cortada pela Avenida Cidade Judaidei Marjayoum no seu ponto mais elevado.

A Rua Professor Cardozo de Mello Neto, na área central do Distrito, começa numa cota de 760 m nas proximidades do Balneário São Francisco. Uma boa parte do seu traçado segue por uma região de planície com declividade suave, ao se aproximar do seu final, em direção a Diadema, passa por um local de colinas, o que torna as suas declividades mais acentuadas. Nas imediações do Jardim Santa Lúcia do Guacuri percorre uma região de pontos mais elevados, com a cota $825 \mathrm{~m}$. Nessa rua, na região de planície, a sua declividade é menos de $5 \%$, os trechos intermediários atravessam áreas de declividade na faixa de 5 a $20 \%$, e o final, nas proximidades de Diadema, atinge uma região apresentando declividade na faixa de 20 a $40 \%$. 
Ao norte do Distrito as colinas são mais baixas, de declividade menos acentuada, os seus pontos mais altos variam entre 760 e 790 metros. Nos seus pontos mais altos, muitas vezes, no topo dessas colinas notam-se áreas planas onde se observam uma média entre 5 e 6 quarteirões. Nessa região as declividades são abaixo de $5 \%$.

Na área central do Distrito de Pedreira, as cotas variam entre 795 e 830 metros. Nas regiões correspondentes aos bairros Jardim Selma e Vila Missionária, verificam-se declividades medianamente acentuadas, na faixa de 5 a 20\%, todavia, em algumas regiões pode variar entre 20 e $40 \%$.

Na primeira península, a do Jardim Apurá, as cotas são muito semelhantes em relação às da região norte, variam entre 770 e $795 \mathrm{~m}$ em seus pontos mais altos, a sua declividade é menos de 5\%. As altitudes da segunda península, ao sul, onde se encontra o bairro de Sete Praias, são bem mais elevadas. Com ocorrência de declividades acentuadas, atingem nos seus pontos mais altos a cota de $820 \mathrm{~m}$. Nessa última península, nas imediações das margens da represa Billings, a declividade é abaixo de 5\%, contudo, na sua parte central a declividade passa a variar de 5 a 20\%. Nas proximidades da Estrada do Alvarenga a sua declividade pode atingir, níveis acima de $40 \%$, nos seus pontos mais elevados.

Dos 135 setores censitários, adotados pelo IBGE para o censo demográfico de 2000, 51 setores pertencem a áreas de favelas. Verifica-se a ocupação de favelas nas margens dos córregos, da represa Billings, em muitas das encostas de declividades acentuadas, em regiões de altos riscos de deslizamentos, ou em redor da cratera criada na área, que pertenceu à Pedreira Itatinga localizada na Vila Guacuri, posteriormente transformada num aterro sanitário.

Quanto à ocupação, em relação ao total da área construída do Distrito, 73\% é para o uso residencial. A predominância é por uso residencial horizontal de baixo padrão, o que corresponde a $42 \%$, ficando a parcela de $25 \%$ ao uso residencial horizontal de médio padrão. Habitações verticais ainda são poucas, correspondem apenas a 6\%. São aproveitados $15 \%$ para o uso comercial e são muito poucas as indústrias, que ocupa apenas $4 \%$, sendo a maioria de pequeno porte. As maiores indústrias localizam-se fora da área de proteção dos mananciais, ao norte, exceto a Empresa Valeo, instalada dentro do perímetro da área de proteção, por ser uma empresa construída antes da promulgação dessa lei. Ainda existem terrenos vagos que correspondem a $29 \%$ dos solos disponíveis para construção. 
PRINCIPAIS COTAS DE ALTITUDES EM METROS SOBRE O NÍVEL DO MAR

DISTRITO DE PEDREIRA

MAPA NÚMERO 4.20

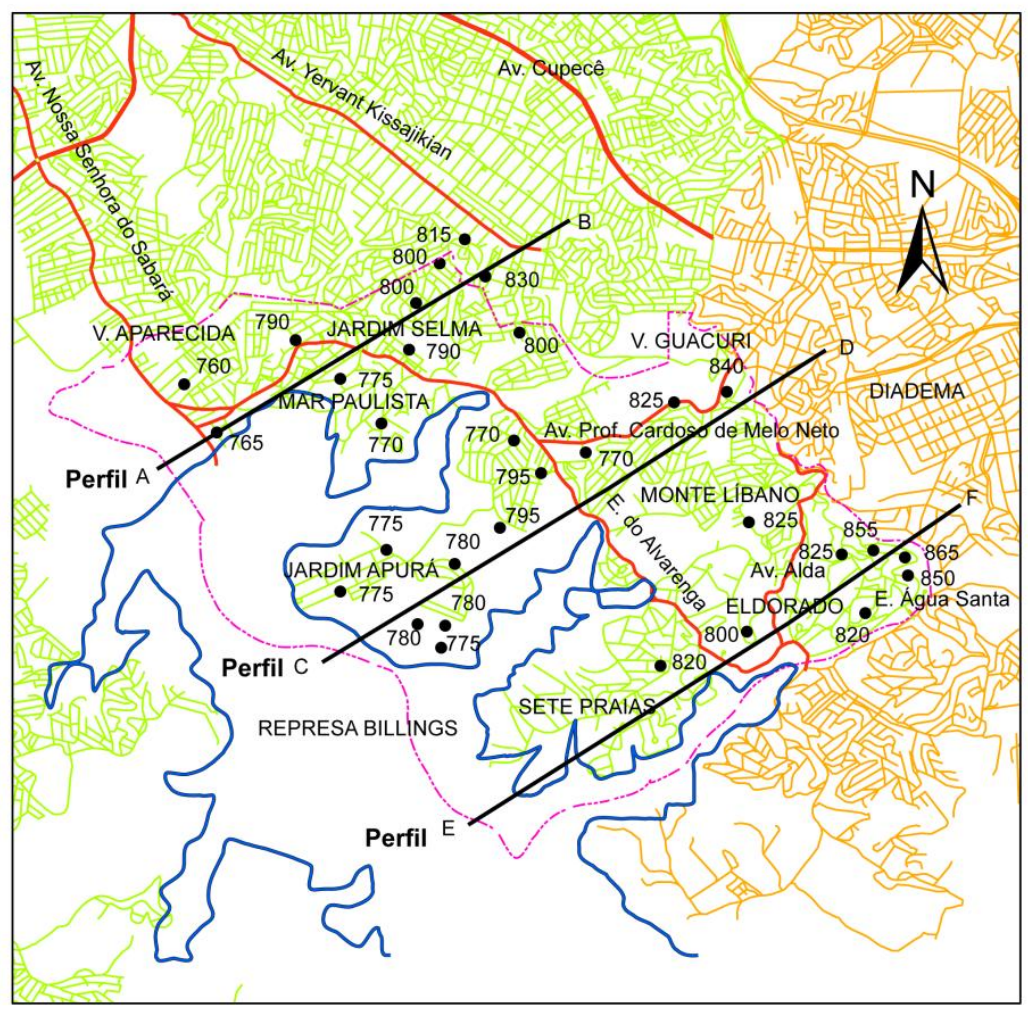

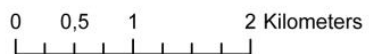

Autor: Shinhiti Osanai

Fonte: EMPLASA - Sistema Cartográfico Metropolitano
Principais cotas em metros

- cotas

- Săo Paulo - Diadema

-.- Divisa Distr. Pedreira

— Represa Billings 


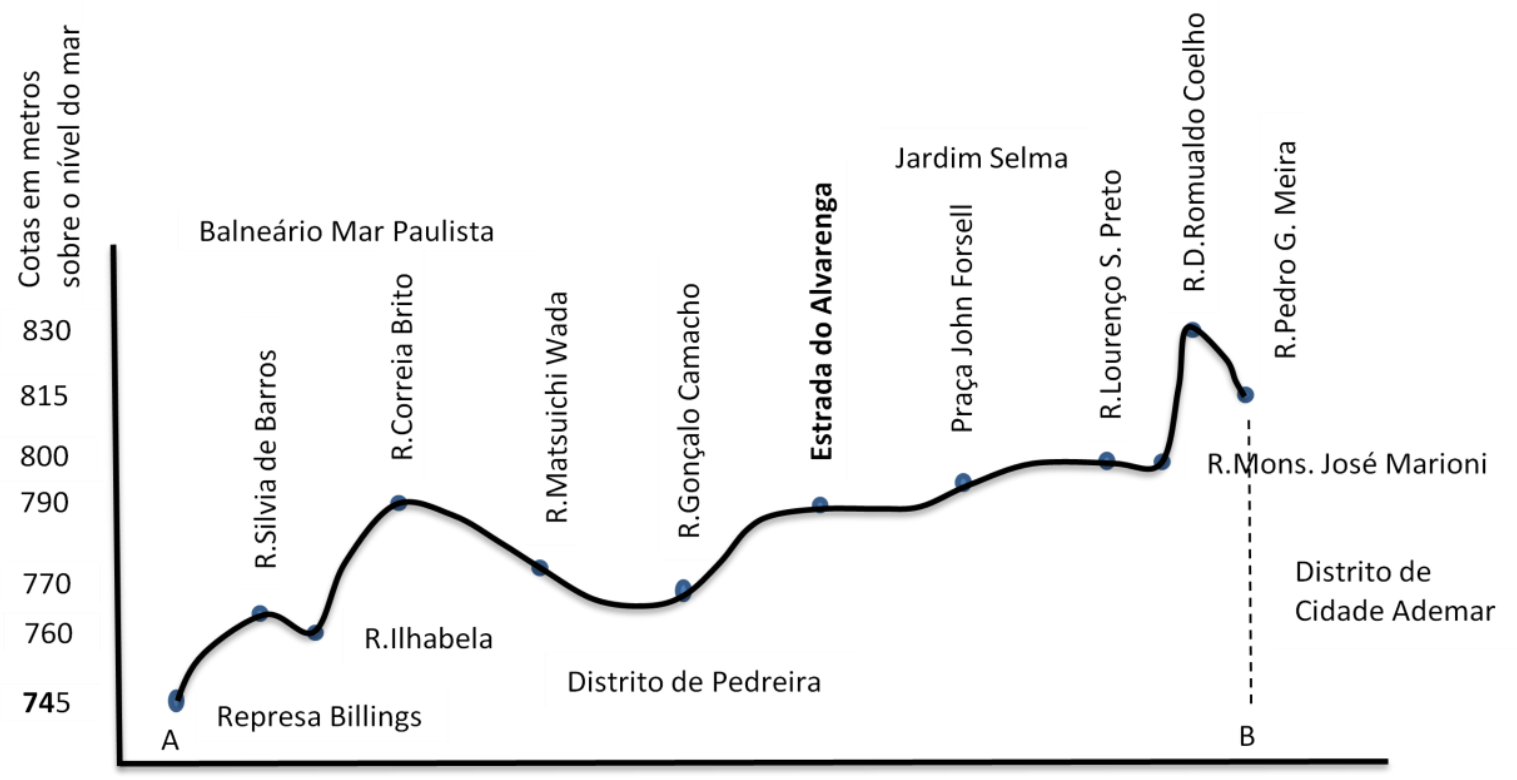

Figura 4.1 Declividades conforme perfil A B do mapa 4.20

Fonte: EMPLASA - sistema cartográfico metropolitano de 1996

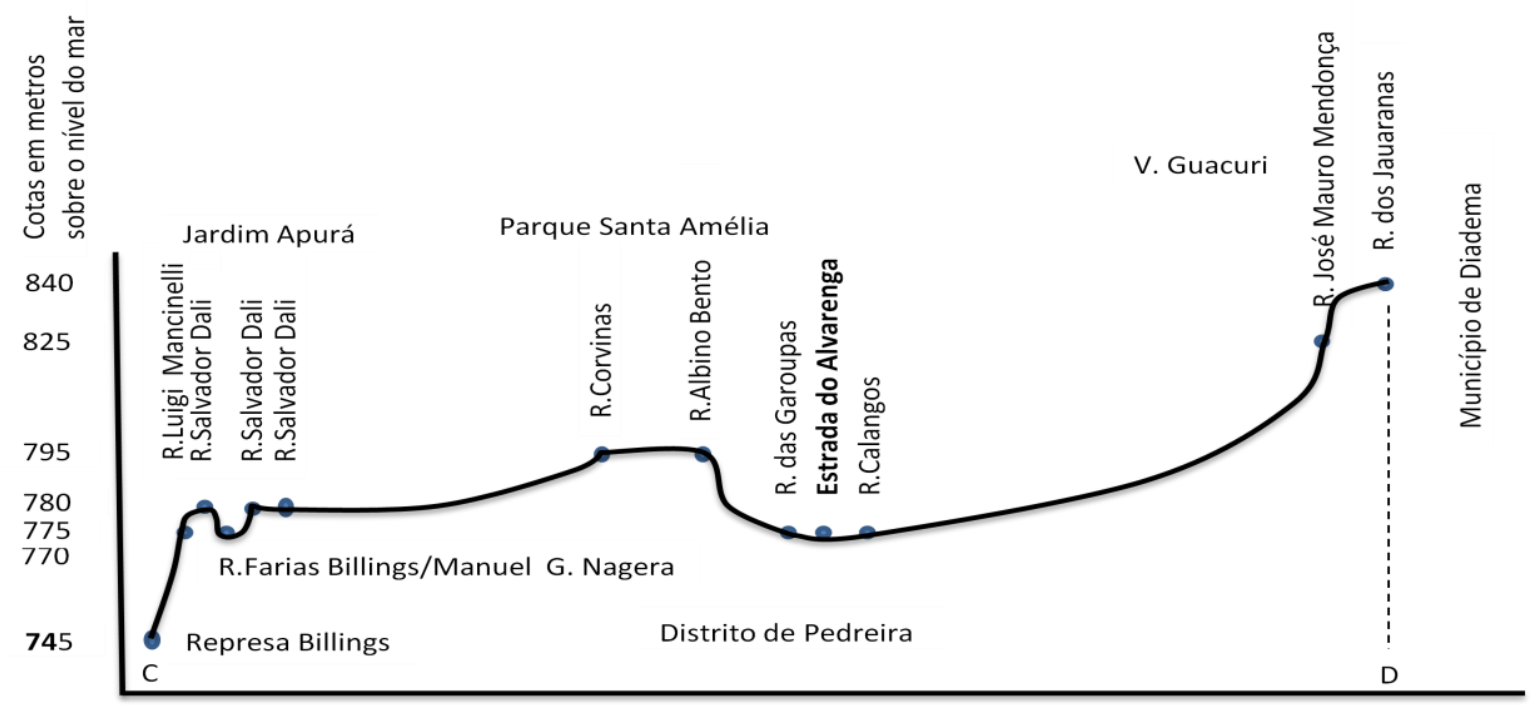

Figura 4.2 Declividades conforme perfil C D do mapa 4.20

Fonte: EMPLASA - sistema cartográfico metropolitano de 1996 


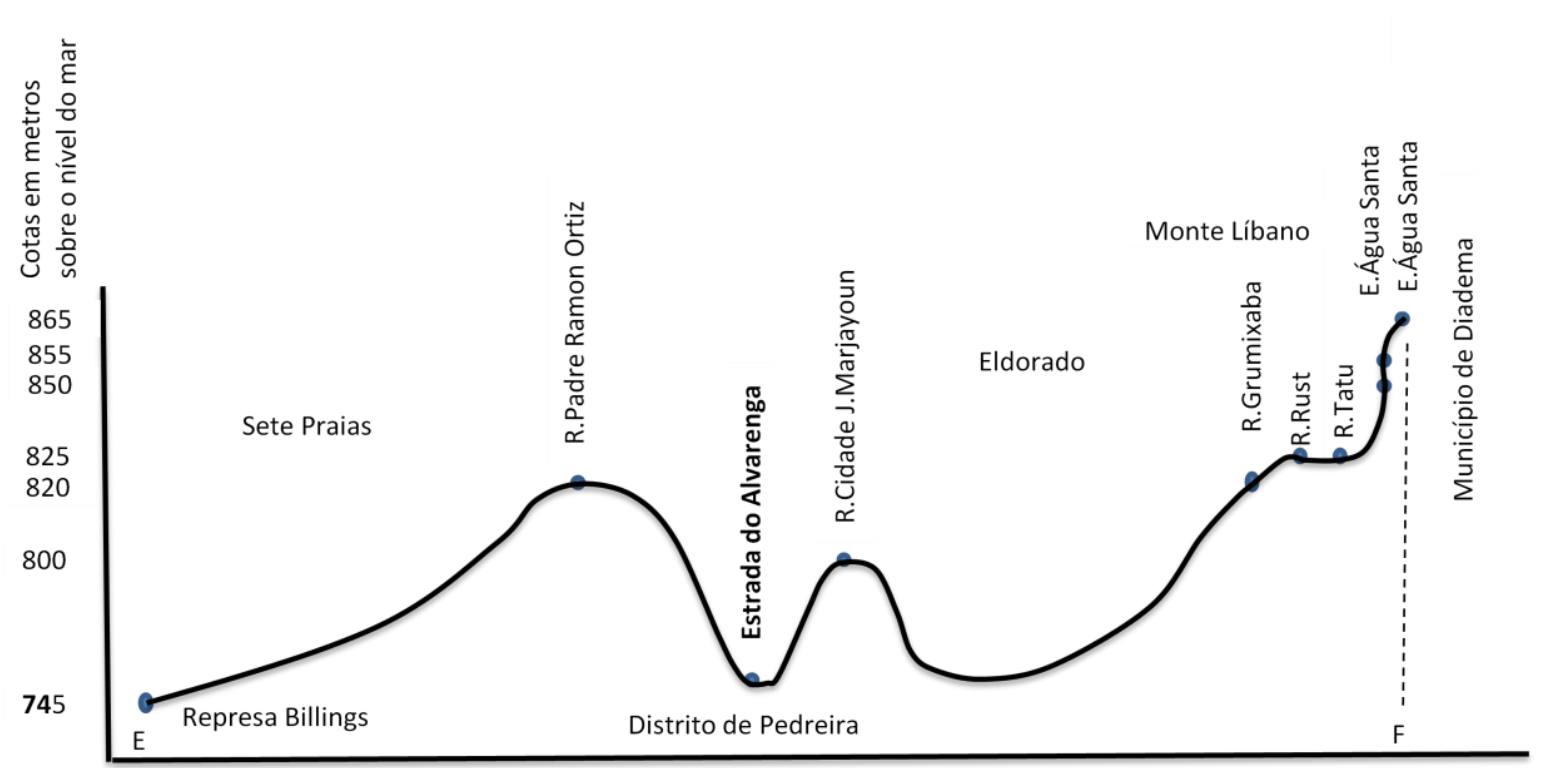

Figura 4.3 - Declividades conforme perfil E F do mapa 4.20

Fonte: EMPLASA - sistema cartográfico metropolitano de 1996

Analisando a classificação em relação aos 96 distritos do Município de São Paulo, a situação sócio-econômica do Distrito de Pedreira é nada privilegiada. Ficando em últimos lugares nos seus pontos fortes e, em primeiros lugares nos seus pontos mais fracos. Ocupa $81^{\circ}$ lugar no IDH, o seu índice é igual a 0,777. A taxa de alfabetização é de 92,67\%, ocupando $84^{\circ}$ lugar. Os $10 \%$ da população mais rica detém $35,55 \%$ da renda, ocupando $63^{\circ}$ lugar e os $80 \%$ mais pobres detém 47,04\%, obtendo $34^{\circ}$ lugar. Em relação à renda per capita, o $1^{\circ}$ quinto mais pobre se classifica em $85^{\circ}$ lugar, os $2^{\circ}$ e o $3^{\circ}$ quintos mais pobres em $84^{\circ}$ lugar, o $4^{\circ}$ quinto mais pobre em $82^{\circ}$ lugar e o quinto mais rico em $83^{\circ}$ lugar. A renda per capita dos $10 \%$ da população mais rica detém $83^{\circ}$ lugar. Quanto à população detentora da renda per capita abaixo de $\mathrm{R} \$ 75,50$ encontra-se em $12^{\circ}$ lugar. A taxa de crescimento populacional entre 1991 e 2000 foi de 4,51\% ocupando o $9^{\circ}$ lugar. A taxa de fecundidade está classificada em $13^{\circ}$ lugar com $2,22 \%$. A probabilidade de sobrevivência até aos 60 anos encontra-se em $75^{\circ}$ lugar, igual a 79,59\%. A taxa de analfabetismo entre as pessoas com mais de 25 anos é de 9,57\% ficando em $12^{\circ}$ lugar. A média do tempo de estudo entre as pessoas com mais de 25 anos é de 6,12 anos com a colocação de $81^{\circ}$ lugar. A taxa de desemprego entre a população na faixa etária de 18 a 24 anos é de 32,09\% e ocupa o $10^{\circ}$ lugar. Os domicílios que possuem carro obtiveram $82^{\circ}$ lugar equivalente a $36,15 \%$. Os proprietários de computador estão em $81^{\circ}$ lugar que corresponde a $11,80 \%$ e os proprietários de telefones fixos encontram em $88^{\circ}$ equivalente $42,93 \%$. 
5 A REDE SOCIAL DO COMÉRCIO E DOS MORADORES DO DISTRITO DE PEDREIRA NO PROCESSO DE SATISFAÇÃO DAS SUAS NECESSIDADES DE COMPRAS 


\subsection{Introdução}

A aplicação das técnicas de rede social no estudo do comércio apresenta alguns diferenciais em relação à capacidade de síntese dos resultados proporcionada através da análise das relações entre os compradores. Determinados modelos são dependentes diretamente da distância ou dos custos de transporte. Outros modelos são dependentes de população e da distância entre os centros, como por exemplo, o modelo gravitacional de Reilly. No caso de São Paulo, a tarifa dos ônibus urbano é única, independentemente da distância percorrida, e num estudo intra urbano a variável população deixa de ser pertinente, pois, as regiões periféricas mantêm populações elevadas em comparação às regiões mais centrais como Santo Amaro. A atração do comércio pode ser realizada pelos locais mais centrais de população mais reduzida. Um estudo fundamentado, em relações entre os moradores e o comércio, pode ser desenvolvido ao estruturar uma rede social onde os nós dos moradores e do comércio estão organizados em forma de uma rede. Basta obter informações sobre a morfologia das relações e não há a necessidade de dados, como custos de transporte ou população, exigidos por alguns dos modelos. A explicação, sobre a força de atração dos nós ou centros de comércio, pode ser a tarifa única e a mobilidade proporcionada pelo sistema de ônibus.

Os principais centros de influência estão localizados fora dos limites geográficos do Distrito de Pedreira, são o Largo Treze de Maio, em Santo Amaro, Shopping Center Interlagos, localizado na av. Interlagos no bairro de Campo Grande e o centro comercial do município de Diadema. Todos compreendem os locais de níveis hierárquicos mais elevados de conformidade com os resultados obtidos na medida de grau.

Constataram-se como centros secundários, exercendo alguma influência nos moradores das suas proximidades, a Estrada do Alvarenga, no bairro de Balneário Mar Paulista um pouco mais ao norte, Parque Santa Amélia e Jardim Rubilene, os dois últimos, localizados nos bairros do mesmo nome e situados na região central do Distrito. Ainda, restam mais dois centros secundários, fora do Distrito de Pedreira, os quais são a Av. Nossa Senhora do Sabará, no bairro de Campo Grande no Distrito de Santo Amaro e Av. Yervant Kissajikian, no bairro de Vila Joaniza no Distrito de Cidade Ademar. Os seus níveis hierárquicos obtiveram valores intermediários, caracterizando as condições de centros secundários.

Em Diadema existem os centros secundários no bairro de Serraria, no eixo da Av. Rotary e adjacências, e no bairro Navegantes na Av. Nossa Senhora dos Navegantes. 
A área norte do Distrito abrangendo os bairros Jardim Piratininga, Vila Paineira, Vila Aparecida, Conjunto Residencial Ingaí, parte de Jardim Selma e a região à margem da represa Billings, onde se localizam os bairros Balneário Mar Paulista e parte do Jardim Apurá, são um dos locais de renda mais elevada. A renda também é elevada, na região central, nos bairros Refúgio Santa Terezinha e parte do Balneário São Francisco. O mesmo se observa em alguns locais isolados, tais como partes de Jardim Célia e de Eldorado, nas proximidades da divisa, e igualmente ao sul, no bairro de Sete Praias. Em geral, essas áreas de renda mais privilegiada permanecem sob uma intensa influência do Largo 13 de Maio.

À medida que se dirige em direção ao sul, o nível de renda tende a reduzir, tomando como exemplo os bairros Eldorado, Jardim Monte Líbano, Jardim Célia e Vila Guacuri. Mesmo nessas regiões de renda mais baixa, o Largo 13 de Maio mantém uma forte influência apesar da concorrência exercida por Diadema devido a sua maior proximidade.

Os moradores da região norte são os que mantêm maior quantidade de contatos com os estabelecimentos comerciais, em particular aqueles que se encontram nos setores de renda mais elevada. À medida que se aproxima do sul, reduz o número de relacionamentos de cada morador com o comércio, em parte explicada pela renda mais baixa e por uma estrutura de comércio menos estruturada que se torna bastante precária nas proximidades da divisa com Diadema. O limite de influência do Largo 13 de Maio chega até a Av. Alda no bairro de Eldorado. Trafegam pela Estrada do Alvarenga, em toda a sua extensão, várias linhas de ônibus em direção a Santo Amaro, Centro Histórico e metrô Jabaquara, bem como, uma linha intermunicipal que liga Santo Amaro ao terminal Piraporinha, em Diadema. 


\section{REDE SOCIAL DO COMÉRCIO - CENTROS PRINCIPAIS}

DISTRITO DE PEDREIRA

MAPA NÚMERO 5.1

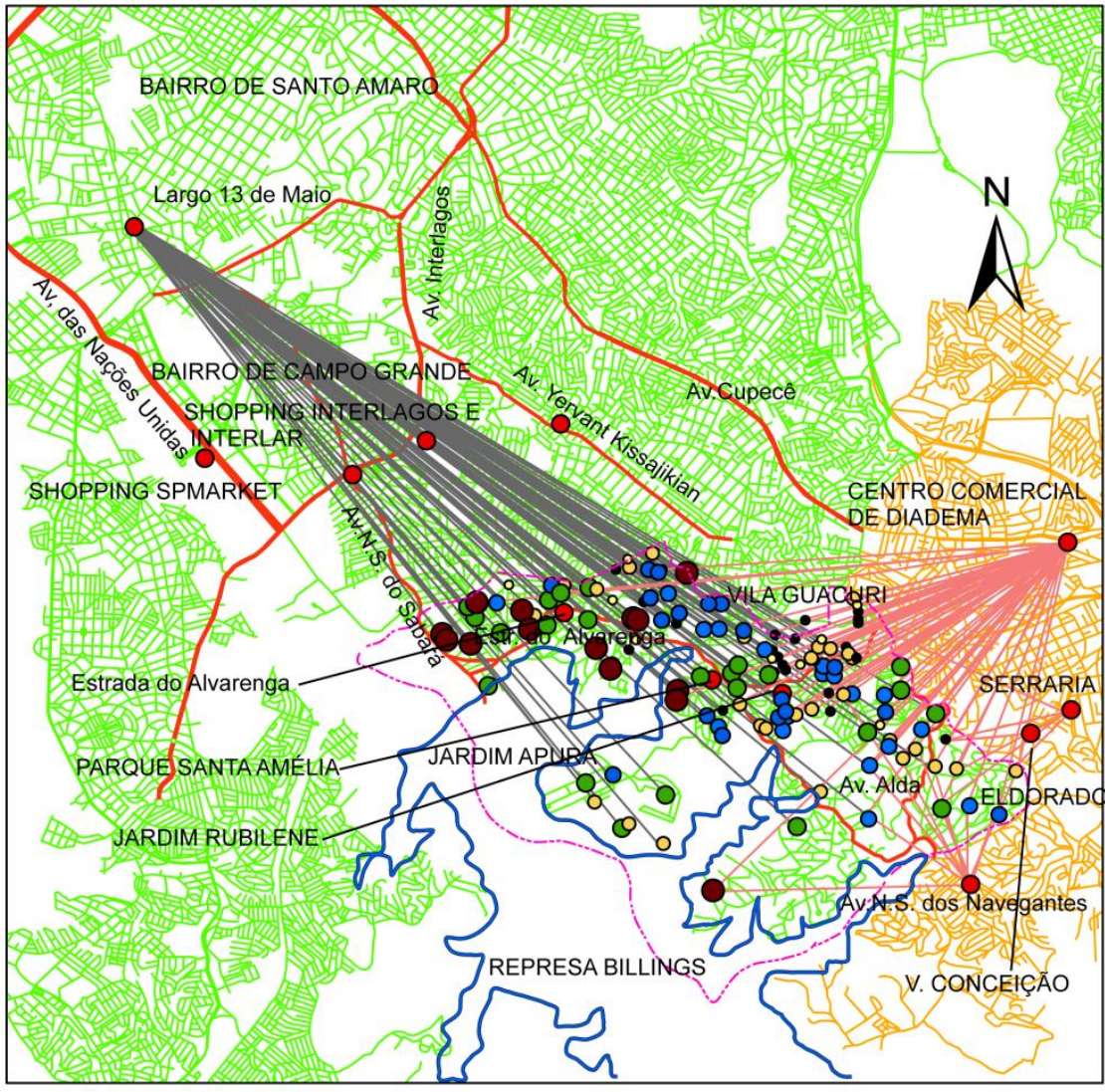

$\begin{array}{lll}0 & 0,5 & 1\end{array}$

2 Kilometers

\section{Autor: Shinhiti Osanai}

Fonte: pesquisa do autor; IBGE Censo 2000

A renda é representada sem escala

Renda chefe de família - reais

- $378-475$

O $476-574$

○ $575-734$

O $735-1028$

$1029-1544$

- Centros Relacionam. c/ Diadema

__ Relacionam. c/ L. 13 de Maio

Represa Billings

- São Paulo

_ Diadema

_-_. Divisa Distr. Pedreira 
Na região norte, os indicadores de facilidade de acesso ao comércio, medidos com base nos índices de proximidade, são mais vantajosos devido ao acesso a uma estrutura de comércio melhor estruturada. Esses indicadores pioram à medida que se aproxima do sul, tendo em vista eventuais estruturas mais precárias do comércio. Os locais que apresentam os índices de proximidade mais baixos são aqueles que apresentam maiores vantagens e facilidades de acesso ao comércio. Os índices de posicionamento são mais favoráveis na região norte em conseqüência do maior poder de barganha dos consumidores, já que há mais opções de acesso ao comércio. O que não acontece à medida que se aproxima do sul, devido ao número limitado de oferta de produtos e serviços e algumas limitações de poder aquisitivo. Os moradores que obtiveram os pontos mais baixos de posicionamento se localizam em áreas de renda mais baixa, em direção ao sul do Distrito, de estrutura do comércio menos desenvolvida, o que indica grande dependência em relação ao comércio localizado em áreas mais distantes das residências.

Quanto à renda populacional, os moradores sob influência do Largo 13 de Maio são bastante heterogêneos, com a participação de todos os níveis e há certa concentração de moradores de baixa renda na região da favela do Pantanal, na Vila Guacuri e em algumas favelas da região norte que se localizam no Jardim Selma e Vila Aparecida.

O Shopping Center Interlagos mantém influência mais intensa nos setores de renda mais alta, localizados próximos das regiões norte ou central. Apenas parte das áreas de renda mais elevada se relaciona com Santo Amaro, todavia, todos os setores de elevada renda fazem parte dos nós conectados a esse Shopping Center. Os bairros da região central, de nível de renda média, por exemplo, Balneário São Francisco, Parque Primavera, Parque Dorotéia, Jardim Rubilene, formam rede com esse Shopping Center. É mais rara a participação de bairros de renda mais baixa. Proporcionalmente, são poucos os moradores da favela do Pantanal relacionados com esse Shopping. O acesso por ônibus a partir da Estrada do Alvarenga ou da R. Professor Cardozo de Mello Neto é bastante facilitado pela disponibilidade de algumas linhas. 
REDE SOCIAL DO COMÉRCIO - CENTROS PRINCIPAIS

DISTRITO DE PEDREIRA

MAPA NÚMERO 5.2

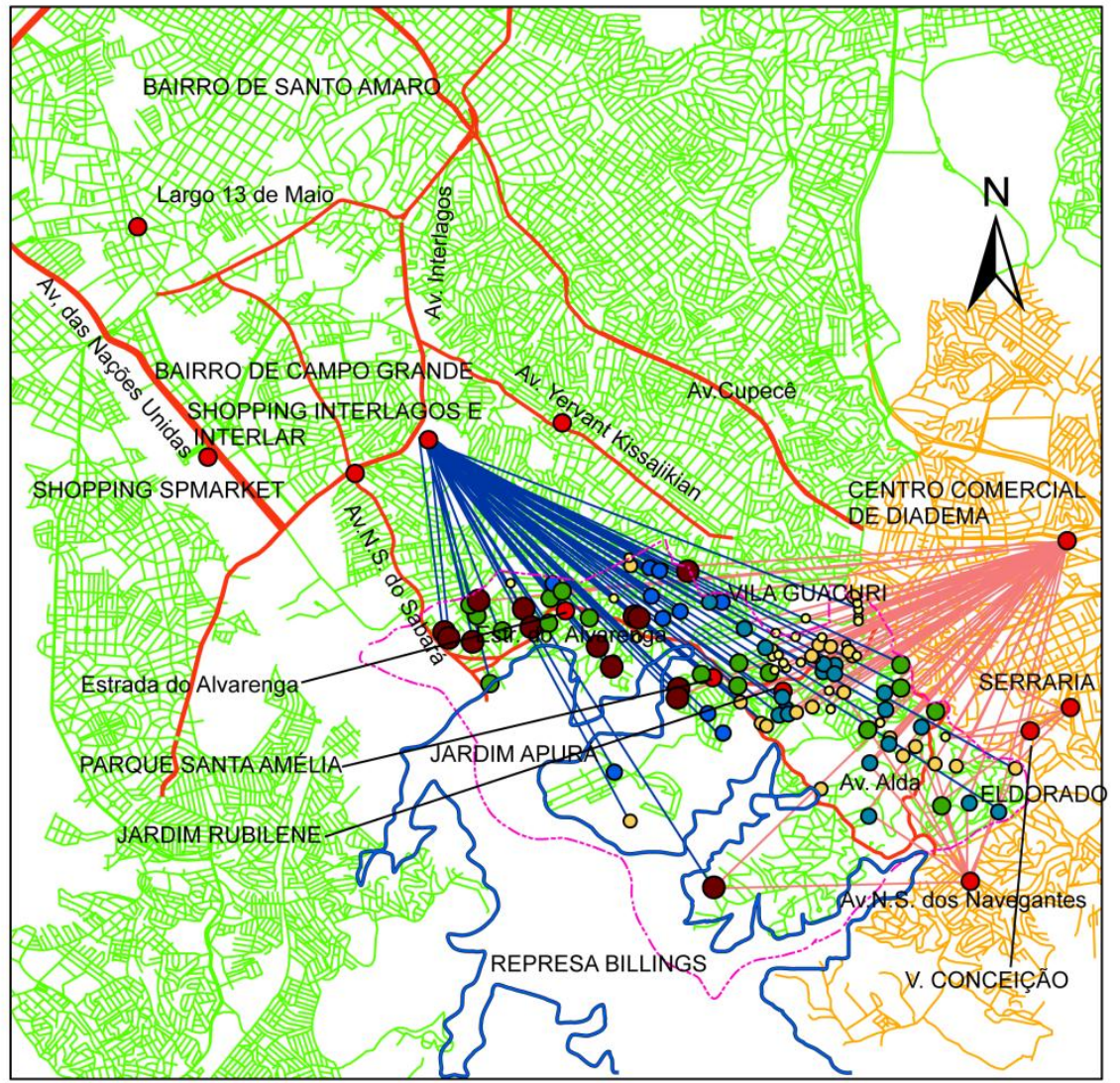

$\begin{array}{lll}0 & 0,5 & 1\end{array}$

2 Kilometers

Autor: Shinhiti Osanai

Fonte: pesquisa do autor; IBGE Censo 2000

A renda é representada sem escala

Renda chefe de família - reais

- $378-475$

O $476-574$

- $575-734$

O $735-1028$

$1029-1544$

- Centros

_ Relacionam. c/ Shop. Interlagos

__ Relacionam. c/ Diadema

—_ Represa Billings

- São Paulo

Diadema

___ Divisa Distr. Pedreira 
Diadema é um centro importante para os moradores da região sul, em particular da região mais próxima à divisa municipal. Setores de renda mais baixa, por exemplo, a favela do Pantanal na Vila Guacuri está fortemente conectada a Diadema. Existem dois centros secundários importantes que pertencem ao bairro de Serraria e de Eldorado. No bairro de Serraria, o comércio instalado no eixo da av. Rotary, atende muitos moradores da favela Eldorado, na região sudeste, bem próxima da divisa, na Estrada da Água Santa, diante da inexistência de comércio estruturado na região. Os moradores dessa favela chegam ao bairro de Serraria, caminhando por um atalho até a Av. Afonso Monteiro da Cruz, onde podem utilizar o ônibus urbano do município de Diadema em direção ao centro desse município. Esses mesmos moradores fazem as compras diárias nessa mesma avenida onde existem padaria, supermercado, farmácia e bazar. Os moradores de Eldorado, em torno da Estrada da Água Santa, que residem mais próximos da Estrada do Alvarenga, fazem as compras na Av. Nossa Senhora dos Navegantes, onde se localiza um centro secundário bem estruturado. $\mathrm{Na}$ falta de ônibus para Diadema, muitos caminham um percurso de até 50 minutos.

Em relação a estes três centros principais em primeiro lugar o Largo 13 de Maio leva vantagem de mobilidade pelo sistema radiconcêntrico das principais vias em direção ao centro de Santo Amaro e a farta disponibilidade de linhas de ônibus a partir de qualquer bairro do Distrito de Pedreira. A mobilidade para o Shopping Center Interlagos fica limitada por causa da menor opção de linhas de ônibus que apresenta vantagens apenas aos que residem nas proximidades da Estrada do Alvarenga, apesar de existir uma linha de ônibus com origem em Eldorado e que passa pela Av. Alda e R. Professor Cardoso de Mello Neto chegando na Estrada do Alvarenga. Diadema está com a maior desvantagem de mobilidade por falta de opção de ônibus intermunicipais com exceção para os que residem nas proximidades da Av. Alda. Parte das pessoas que moram nas proximidades da divisa municipal vão a pé para o centro de Diadema ou para a Av. Nossa Senhora dos Navegantes.

O centro secundário do Jardim Rubilene mantém como os principais pólos de atração o Depósito 5 Irmãos, Supermercado Ki Barato e Supermercado Mamb's. Atende uma região de renda média e baixa e o seu limite de atuação tem um raio aproximado de $1 \mathrm{~km}$ a partir do seu centro localizado no início da Rua Dr. Carlos de Rezende Enout. Esse centro não interfere na área de influência do centro da Estrada do Alvarenga.

O centro secundário do Parque Santa Amélia concorre fortemente com o centro do Jardim Rubilene por causa da sua proximidade. O seu limite de ação está num raio aproximado de 2 
km, a partir da Av. das Garoupas, por causa dos moradores de Jardim Apurá. O centro interfere na área de influência do centro da Estrada do Alvarenga por causa do Supermercado Pedreira, que atrai compradores de locais mais distantes. Muitos dos moradores sob a sua influência residem em setores de renda mais elevada.

O centro secundário da Estrada do Alvarenga possui o seu raio de ação aproximado, a partir do ponto central localizado na altura do número 1000 da referida via, de $1,5 \mathrm{~km}$. Localiza-se em uma área de renda média e alta, ao norte do Distrito, e sofre a concorrência do centro da Av. Nossa Senhora do Sabará cujo acesso é bastante facilitado pela disponibilidade de várias linhas de ônibus. A concorrência da Av. Yervant Kissajissian é menos intensa, pois atende principalmente os moradores do Jardim Selma e Vila Missionária, únicos locais que dispõem de ônibus em direção ao referido centro sem a necessidade de baldeação.

O limite de influência do centro secundário da Av. Nossa Senhora do Sabará chega até os moradores do bairro de Sete Praias, ao sul, em função da sua maior atração por causa do comércio de móveis e da Drogaria São Paulo. Todavia é mais intensa a sua atração junto aos moradores da região norte, próxima à divisa com o bairro de Campo Grande, por causa da sua maior proximidade. Apesar de não se observar restrições de acesso por ônibus, de qualquer parte do Distrito de Pedreira, o Largo 13 de Maio, embora mais distante, é o local mais preferido pelos moradores por causa do seu comércio muito mais diversificado e em consequiência de ser um centro principal.

O centro da Av. Yervant Kissajikian atende apenas os moradores do Jardim Selma e Vila Missionária, por causa da sua proximidade com a Vila Joaniza e o acesso por ônibus ser limitado para a maioria dos moradores do Distrito de Pedreira. Os ônibus que passam por essa via partem dos bairros Balneário São Francisco ou Jardim Selma, passando por Vila Missionária ou Parque Primavera, havendo a necessidade de baldeação na Estrada do Alvarenga para os que moram em outros bairros. 


\section{REDE SOCIAL DO COMÉRCIO - CENTROS SECUNDÁRIOS}

DISTRITO DE PEDREIRA

MAPA NÚMERO 5.3

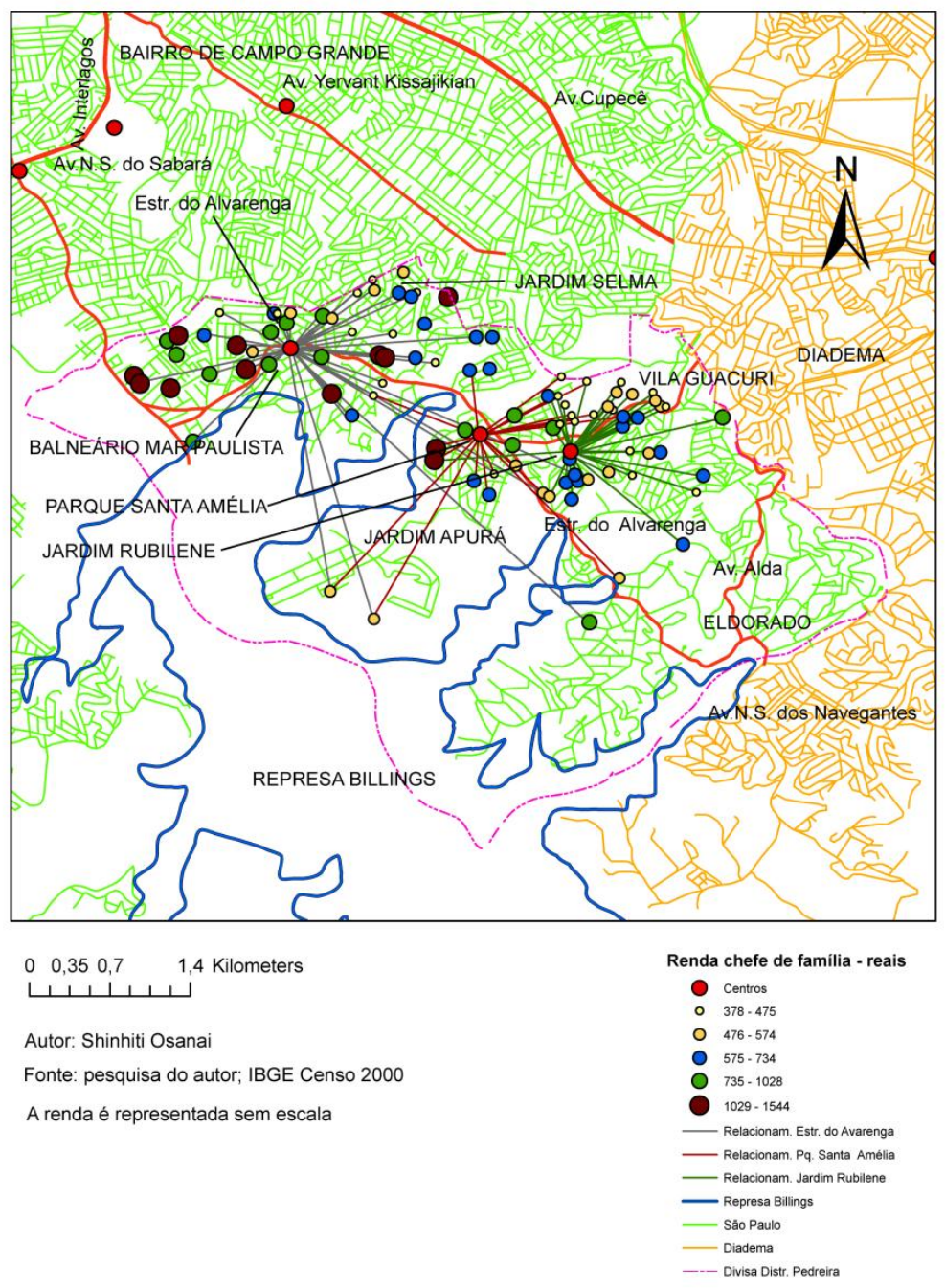


A rede social através das suas relações internas entre os moradores e o comércio ajuda na identificação das áreas de influência, bem como, da importância dos papéis dos centros secundários no suprimento dos bens de demanda de frequiência baixa. Os moradores das regiões mais periféricas e pobres, na falta de um centro comercial melhor estruturado nas proximidades, abastecem de produtos como pão e leite em estabelecimentos localizados em pontos relativamente distantes de suas residências. Portanto, as relações internas ajudam na identificação do espaço mal estruturado para muitos moradores, e, igualmente, na análise do espaço bem servido pelo comércio como se verifica nas áreas mais centrais do Distrito de Pedreira.

A análise da área de influência por grupos de moradores foi feita utilizando os métodos de equivalência estrutural, método concor e equivalência automórfica.

O método da equivalência estrutural ajuda na identificação de grupos homogêneos de moradores sob a influência de determinados centros principais ou secundários. Obtiveram-se sete grupos. Adotando-se o método de distância euclidiana, cujo critério básico é de caracterizar cada um dos grupos em relação a algumas das dissimilaridades inter grupais, tomando-se como base os hábitos de escolha dos locais de preferência, para a satisfação das suas necessidades de compras. Em cada grupo observou-se alguma diferença de intensidade exercida pelos principais centros Largo 13 de Maio, Shopping Center Interlagos e Diadema.

A maioria dos setores de renda alta se encontra na região norte, de ocupação mais antiga, os quais são o Jardim Piratininga, Vila Paineira, Vila Aparecida, Balneário Mar Paulista, Conjunto Residencial Ingaí e parte de Jardim Selma. Na região do centro predominam os setores de renda média que correspondem aos bairros Jardim Apurá, Balneário São Francisco, Parque Primavera, Refúgio Santa Terezinha, Parque Dorotéia e Jardim Rubilene. Os bairros próximos à divisa com Diadema, localizados na região nordeste, são Vila Guacuri, Jardim Célia e Jardim do Castelo. Na região sul, permanecem os bairros Sete Praias, de renda alta, bem como, Monte Líbano e Eldorado, de renda baixa, esse último, na divisa com o Município vizinho.

Foram organizados sete grupos a seguir descritos.

O grupo 1, organizado por apenas 3 elementos da amostra, apresenta características muito especiais, distintas e particulares, moradores da região norte, todos mantêm contato com Av. Yervant Kissajikian e nenhum deles está conectado com os centros locais Parque Santa 
Amélia e Jardim Rubilene. Apenas parte deles se relaciona, independentemente, com os centros da Av. Nossa Senhora do Sabará, Estrada do Alvarenga, Largo 13 de Maio ou Diadema. Pertencem aos setores que compreendem o Jardim Selma e Vila Aparecida. Cada um é completamente distinto em relação à renda do setor em que residem.

O grupo 2 é organizado por pessoas que mantêm número significativo de contatos com o comércio a maioria deles obteve resultados médios e altos da medida de grau. Trata-se de um grupo localizado em regiões de renda alta e média, ao norte e parte central do Distrito. A medida de proximidade obtida pelo grupo, relativamente baixa em termos médios, indica que o acesso das pessoas ao comércio é relativamente fácil pelo fato da maioria estar localizada na região norte sem dificuldades de acesso a quaisquer centros de comércio local ou principal. A média do valor de posicionamento relativamente baixa, indica a maior dependência para alguns ramos, do tipo roupa para cama mesa e banho, em relação a determinados centros, tais como Largo 13 de Maio. Esse grupo está sob uma intensa influência do Largo 13 de Maio, relaciona-se com todos os centros secundários exceto o Shopping Center SPMarket. Recebe menor influência do Shopping Center Interlagos em comparação a Santo Amaro. Apenas os moradores de Jardim Rubilene e Vila Guacuri, das regiões centro e nordeste, estão mais intensamente relacionados com Diadema, face à sua maior proximidade. Praticamente não existem restrições de acesso por ônibus a quaisquer dos centros mencionados, exceto Diadema.

O grupo 3 é formado por pessoas que residem na região norte, na região central, que correspondem aos bairros de Jardim Apurá, Parque Santa Amélia e Jardim Rubilene, bem como, de alguns da região sul, no bairro de Eldorado. São moradores de setores de renda média e baixa. Em particular, neste grupo os setores da região norte apresentam menor renda, mesmo assim a quantidade de contatos com o comércio continua relativamente elevada. Tal fato pode ser justificado pelas facilidades de acesso por causa da farta disponibilidade de linhas de ônibus. $\mathrm{O}$ valor médio de proximidade é relativamente baixo, pois o acesso das pessoas ao comércio é relativamente fácil, já que se trata de uma região com boa vantagem de acesso para a maioria dos principais centros comerciais, exceto o bairro de Eldorado. 
REDE SOCIAL DO COMÉRCIO - GRUPOS DE MORADORES - EQUIVALÊNCIA ESTRUTURAL

GRUPO 1

DISTRITO DE PEDREIRA

MAPA NÚMERO 5.4

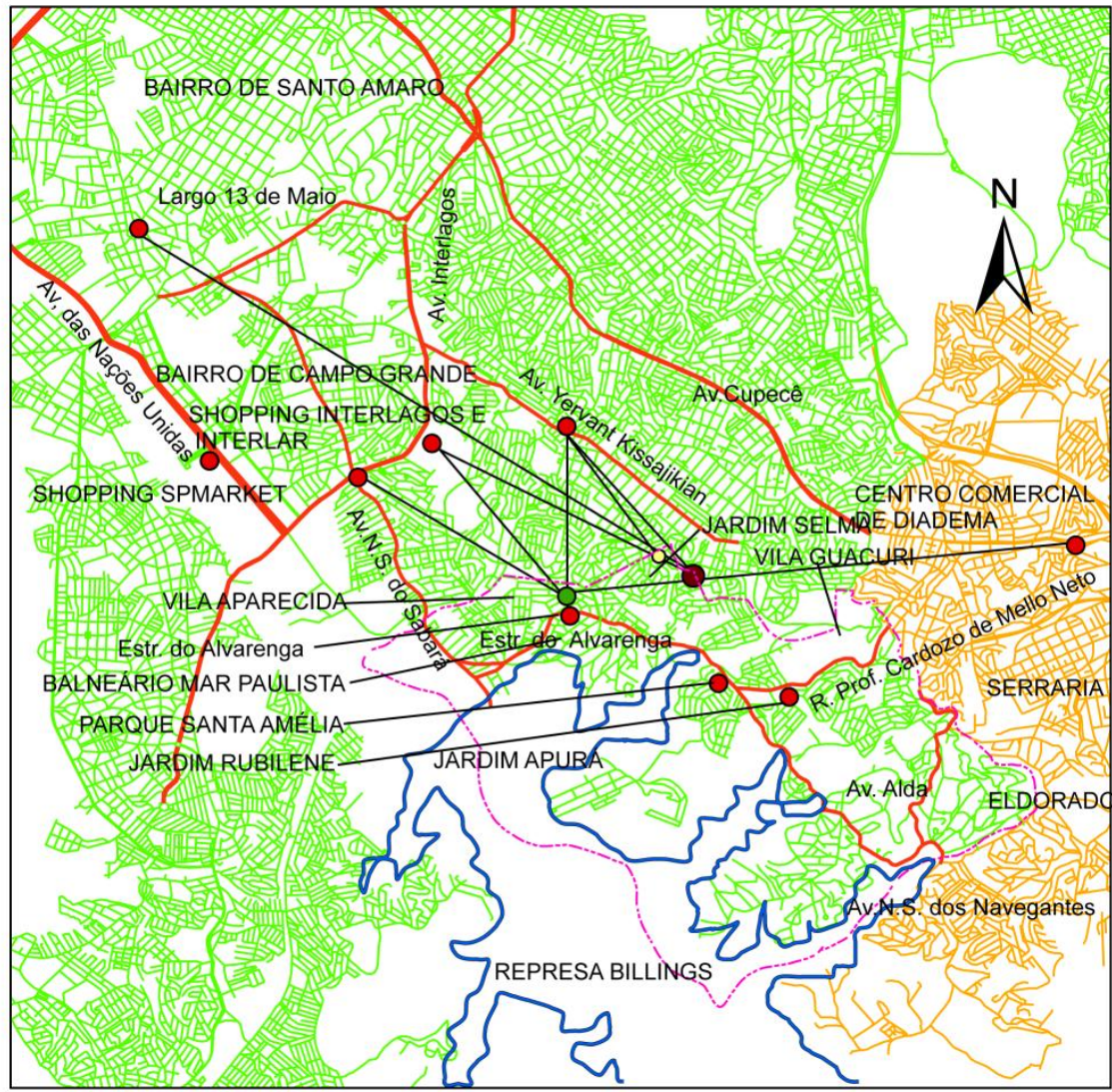

$\begin{array}{lll}0 & 0,5 & 1\end{array}$ 2 Kilometers

Autor: Shinhiti Osanai

Fonte: pesquisa do autor; IBGE Censo 2000

A renda é representada sem escala
Eq. estrutural - Renda ch. fam. - reais

$$
\begin{array}{ll}
\text { O } & 476-574 \\
0 & 735-1028 \\
0 & 1029-1544 \\
0 & \text { Centros } \\
\hline & \text { Relacionam. grupo } 1 \\
\hline & \text { Represa Billings } \\
\hline & \text { São Paulo } \\
\hline & \text { Diadema } \\
\hline & \text { Divisa Distr. Pedreira }
\end{array}
$$


REDE SOCIAL DO COMÉRCIO - GRUPOS DE MORADORES - EQUIVALÊNCIA ESTRUTURAL

GRUPO 2

DISTRITO DE PEDREIRA

MAPA NÚMERO 5.5

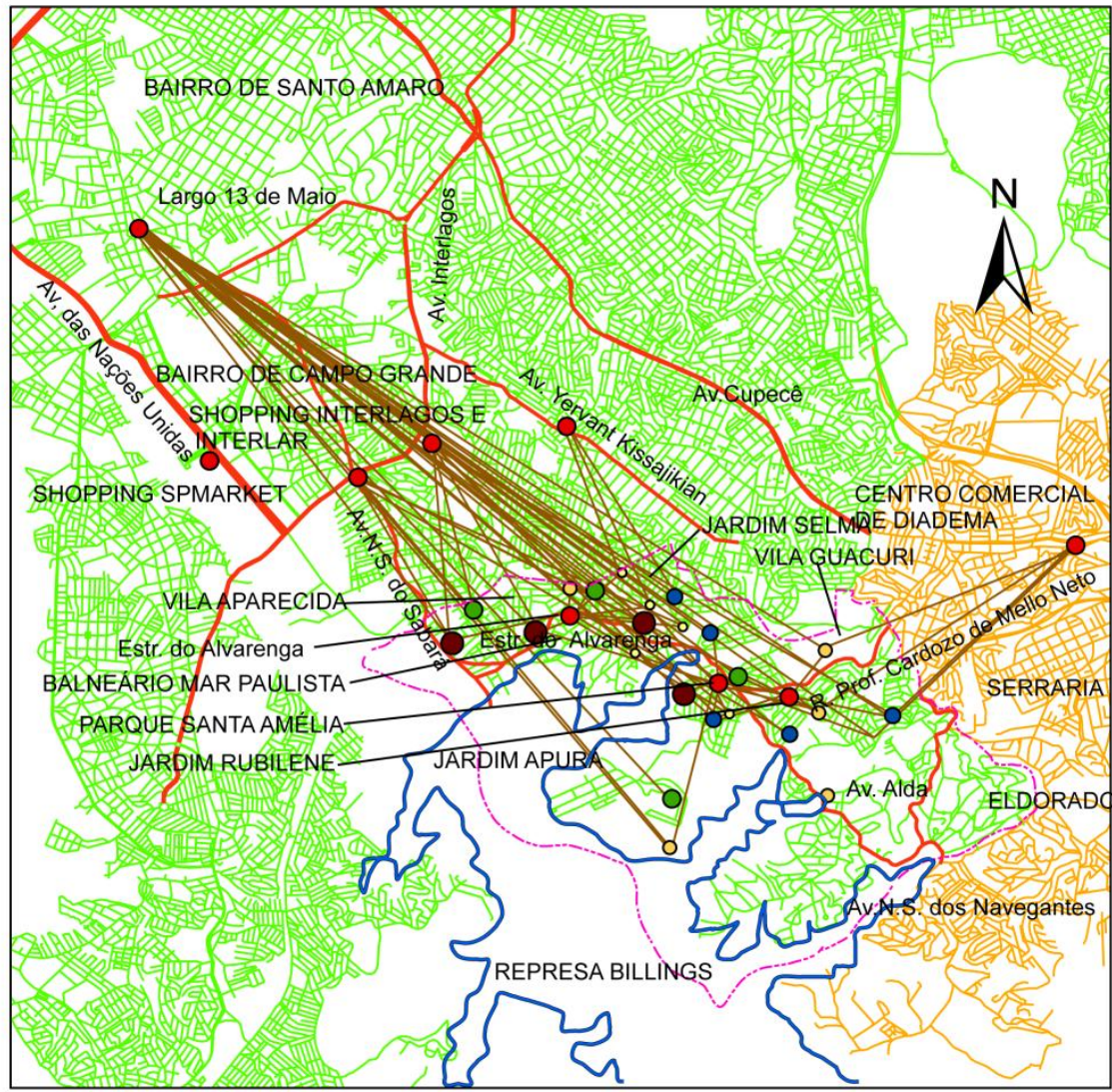

$\begin{array}{lll}0 & 0,5 & 1\end{array}$ 2 Kilometers

Autor: Shinhiti Osanai

Fonte: pesquisa do autor; IBGE Censo 2000

A renda é representada sem escala
Eq. estrutural - Renda ch. fam. - reais

$$
\begin{array}{ll}
\text { ○ } & 378-475 \\
\text { O } & 476-574 \\
\text { ○ } & 575-734 \\
\text { O } & 735-1028 \\
\text { O } & 1029-1544 \\
\text { C Centros } \\
\hline \text { Relacionam. grupo } 2 \\
\text { C Represa Billings } \\
\text { São Paulo } \\
\text { C Diadema } \\
\text { _- Divisa Distr. Pedreira }
\end{array}
$$


REDE SOCIAL DO COMÉRCIO - GRUPOS DE MORADORES - EQUIVALÊNCIA ESTRUTURAL

GRUPO 3

DISTRITO DE PEDREIRA

MAPA NÚMERO 5.6

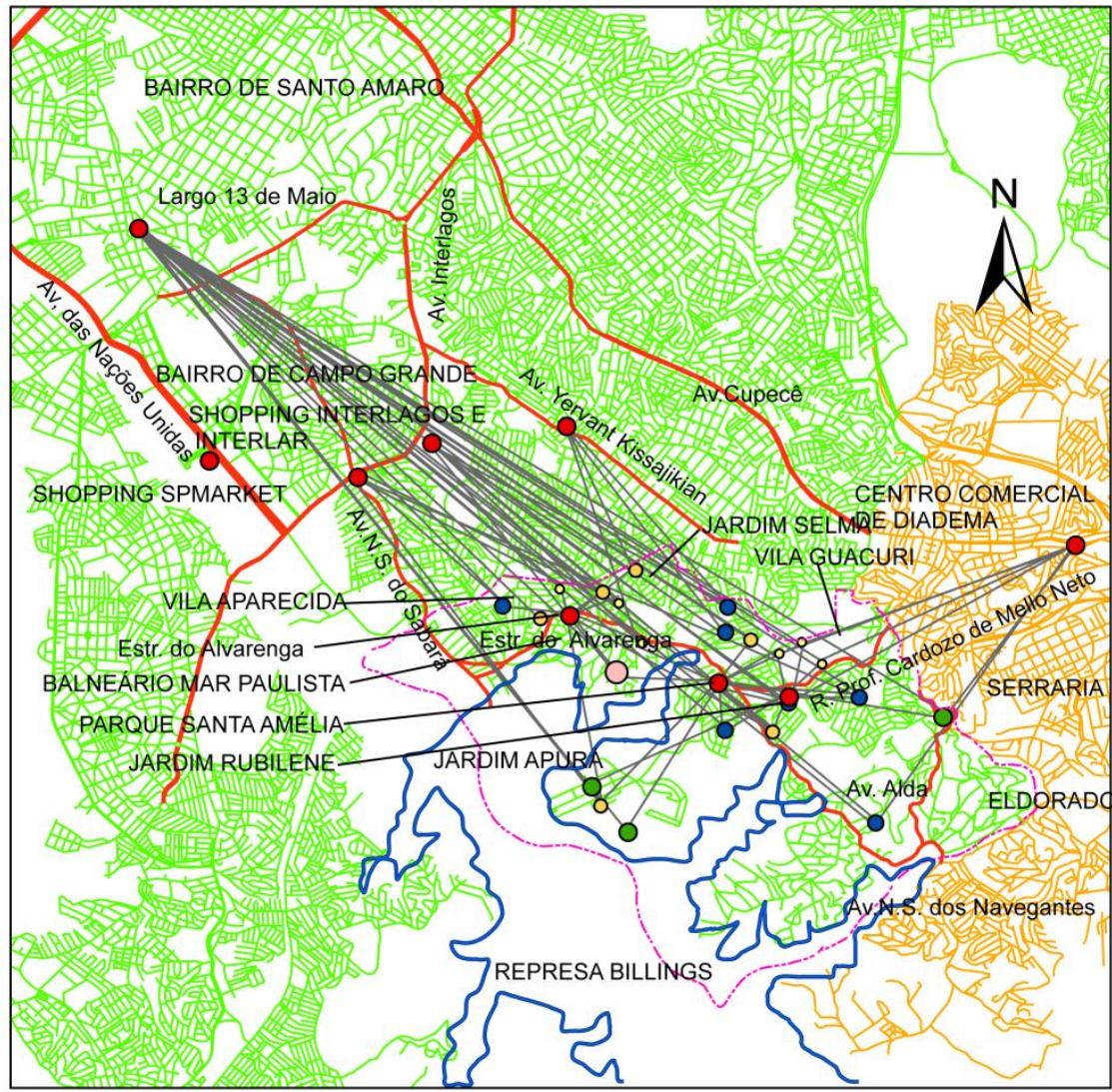

$\begin{array}{lll}0 & 0,5 & 1\end{array}$ 2 Kilometers

Autor: Shinhiti Osanai

Eq. estrutural - Renda ch. fam. - reais

Fonte: pesquisa do autor; IBGE Censo 2000

A renda é representada sem escala

$$
\begin{array}{ll}
\text { ○ } & 378-475 \\
\text { ○ } & 476-574 \\
\text { ○ } & 575-734 \\
\text { O } & 735-1028 \\
\bigcirc & 1029-1544 \\
\text { O } & \text { Centros } \\
\hline & \text { Relacionam. grupo } 3 \\
\hline & \text { Represa Billings } \\
& \text { São Paulo } \\
\hline & \text { Diadema } \\
\hline & \text { Divisa Distr. Pedreira }
\end{array}
$$


O valor médio de posicionamento, relativamente baixo, indica a dependência a determinados centros, tais como o Largo 13 de Maio em relação a alguns ramos de comércio, do tipo roupa para cama mesa e banho. Esse grupo está sob uma forte influência do Largo 13 de Maio, relaciona-se com todos os centros secundários, exceto o Shopping Center SPMarket. Recebe menos influência do Shopping Center Interlagos em comparação a Santo Amaro. Apenas os moradores de Jardim Rubilene e Vila Guacuri, das regiões centro e nordeste, bem como, Eldorado, da região sul, estão mais intensamente relacionados com Diadema, face à sua maior proximidade. Quanto à localização, é um grupo muito semelhante ao grupo anterior 2, com diferenças, principalmente, nos índices da medida de grau, ligeiramente inferiores.

O grupo 4 pertence aos moradores dos setores de renda mais elevada da região norte e central. Recebem intensa influência do Shopping Center Interlagos. Não mantêm contato com o centro da Av. Yervant Kissajikian e são menos importantes os demais centros secundários, exceto o centro da Av. Nossa Senhora do Sabará. São poucos os contatos com Largo 13 de Maio, Diadema e Shopping Center SPMarket. Apesar dos setores apresentarem renda elevada, a quantidade de relacionamentos com o comércio é mediana, podendo ser explicada pela preferência de compras em locais de maior concentração de lojas do tipo Shopping Center Interlagos. A medida de proximidade apresenta uma média mais elevada, em relação aos grupos 2 e 3, pelo fato da ausência dos centros secundários. O valor médio de posicionamento indica a dependência significativa em relação ao Shopping Center Interlagos pela reduzida participação de outros centros principais ou secundários.

O grupo 5 possui as características de maior concentração de moradores da região norte e central, com predominância de pessoas que residem em setores de renda média, em particular, localizadas nas áreas norte e Jardim Rubilene. É intensa a influência do Shopping Center Interlagos. Alguns moradores de setores de renda baixa, da favela do Pantanal, também participam do contato com o Shopping Center Interlagos. É pouco importante a influência de Diadema e se verifica a intensa participação de todos os centros secundários. A maioria das pessoas de setores de renda mais alta pode manter elevada quantidade de contado com o comércio. 
REDE SOCIAL DO COMÉRCIO - GRUPOS DE MORADORES - EQUIVALÊNCIA ESTRUTURAL GRUPO 4

DISTRITO DE PEDREIRA MAPA NÚMERO 5.7

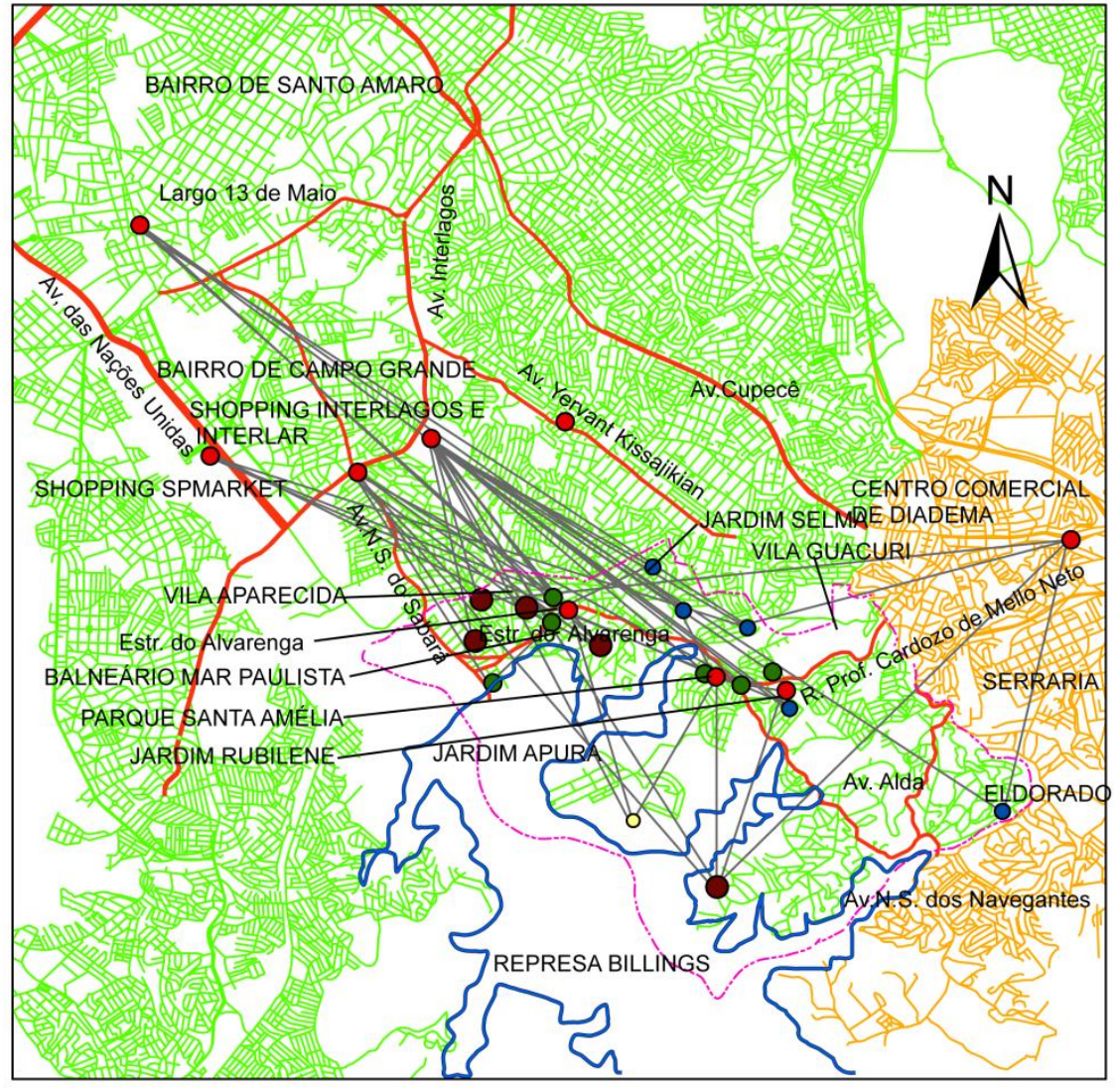

$\begin{array}{lll}0 & 0,5 & 1\end{array}$ 2 Kilometers

Autor: Shinhiti Osanai

Fonte: pesquisa do autor; IBGE Censo 2000

A renda é representada sem escala
Eq. estrutural - Renda ch. fam. - reais
○ $476-574$
- $575-734$
O $735-1028$
1029-1544
- Centros
- Relacionam. grupo 4
- Represa Billings
— São Paulo
— Diadema
___. Divisa Distr. Pedreira 
REDE SOCIAL DO COMÉRCIO - GRUPOS DE MORADORES - EQUIVALÊNCIA ESTRUTURAL GRUPO 5

DISTRITO DE PEDREIRA MAPA NÚMERO 5.8

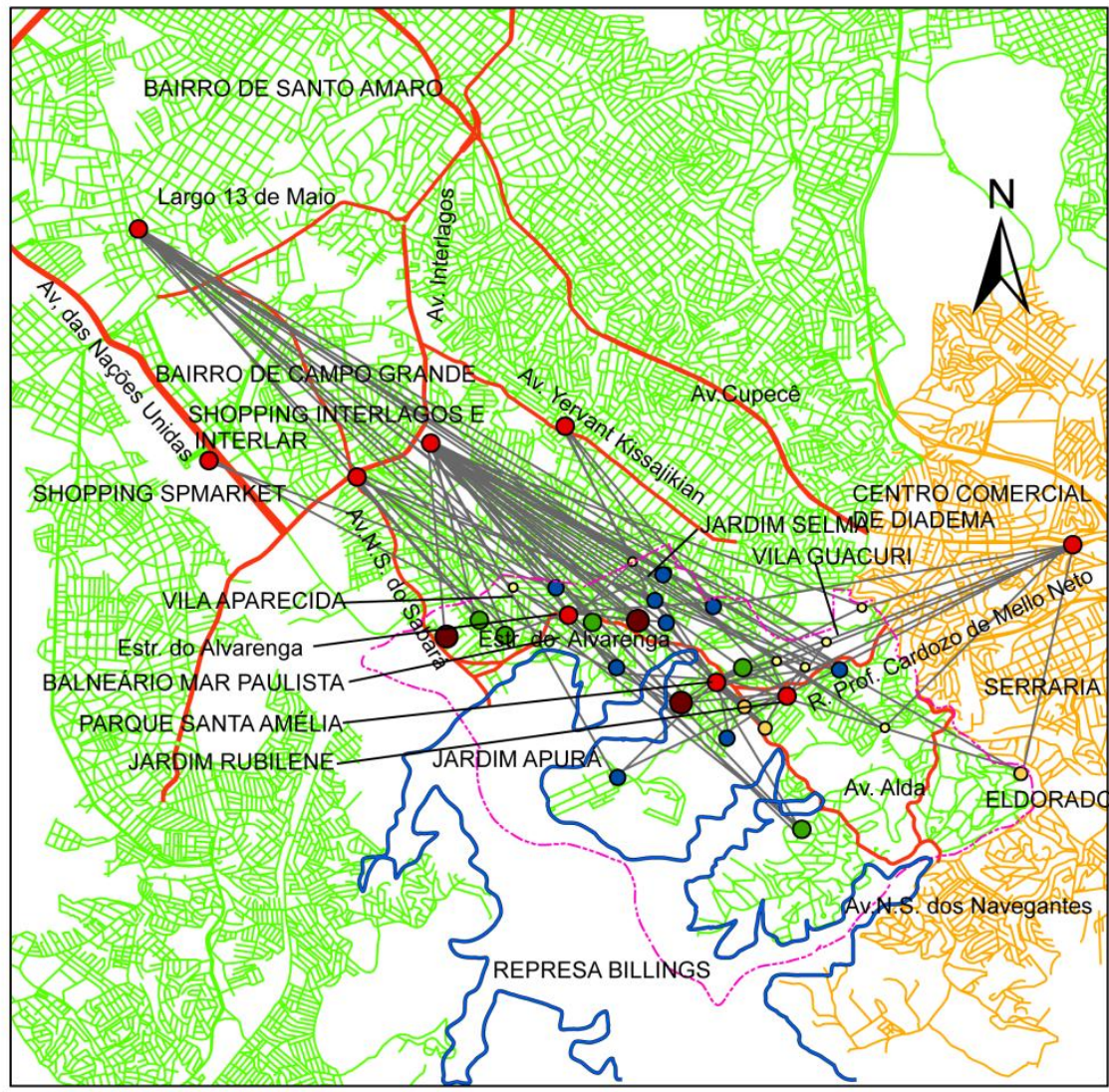

$\begin{array}{lll}0 & 0,5 & 1\end{array}$ 2 Kilometers

Autor: Shinhiti Osanai

Fonte: pesquisa do autor; IBGE Censo 2000 A renda é representada sem escala
Eq. estrutural - Renda ch. fam. - reais
- $378-475$
○ $476-574$
- $575-734$
O $735-1028$
$1029-1544$
- Centros
Relacionam. grupo 5
- Represa Billings
- São Paulo
— Diadema
--_- Divisa Distr. Pedreira 
O valor médio de proximidade é mais baixo, em relação ao grupo 4, pela oportunidade de realizarem as compras no Shopping Interlagos e nos centros secundários. O valor médio de posicionamento é mais elevado, em comparação ao grupo 4, em função da participação dos centros secundários que ajuda a reduzir a dependência pelo fato de oferecer maiores opções de locais de compras, bem como, a possibilidade de poder contar com o Shopping Center Interlagos e Largo 13 de Maio para os produtos que não são oferecidos nos centros secundários.

O grupo 6 corresponde aos moradores da região sul e nordeste que compõem os setores de faixa de renda média e baixa. Estão localizados nas proximidades da R. Professor Cardozo de Mello Neto e da Av. Alda. Compreendem os bairros de Vila Guacuri, Refúgio Santa Terezinha, Parque Dorotéia, Jardim Rubilene, Jardim Célia, Jardim do Castelo, Jardim Monte Líbano e Eldorado. Verifica-se uma intensa influência de Diadema sendo pouco importantes as influências de Largo 13 de Maio e Shopping Center Interlagos. Apenas dois centros secundários estão em contato com os moradores, os quais são Jardim Rubilene e Parque Santa Amélia, principalmente por causa do Depósito 5 Irmãos e Supermercado Pedreira. Em comparação aos grupos anteriores, a quantidade de opções de contatos com o comércio é bastante inferior. $\mathrm{O}$ valor médio de proximidade é relativamente baixo, em função dos contatos com os centros mais próximos, tais como Diadema, Jardim Rubilene e Parque Santa Amélia. O valor médio de posicionamento é mais alto em comparação aos outros grupos anteriores, por causa da maior proximidade com Diadema. Existe a oportunidade de reduzir a dependência, pois é possível obter produtos não disponíveis nos dois centros secundários. A quantidade de contatos dos moradores são inferiores em relação aos grupos anteriores, em função de uma renda mais baixa, e, também, por causa das características de comércio menos estruturado na região. As pessoas, que residem em torno da Av. Alda, contam com ônibus urbano para Diadema, Santo Amaro ou Centro de São Paulo.

O grupo 7 é organizado pelos moradores dos setores de renda média e baixa, localizados na região sul e nordeste do Distrito, a maioria nas proximidades da R. Professor Cardozo de Mello Neto, correspondendo aos bairros de Vila Guacuri, Jardim Rubilene, Parque Dorotéia e Refúgio Santa Terezinha, bem como, os que residem em torno da Av. Alda, nos bairros Eldorado e Jardim Monte Líbano. A quantidade de contatos com o comércio é relativamente baixa em função da renda e da estrutura menos desenvolvida do comércio. 
REDE SOCIAL DO COMÉRCIO - GRUPOS DE MORADORES - EQUIVALÊNCIA ESTRUTURAL GRUPO 6

DISTRITO DE PEDREIRA MAPA NÚMERO 5.9

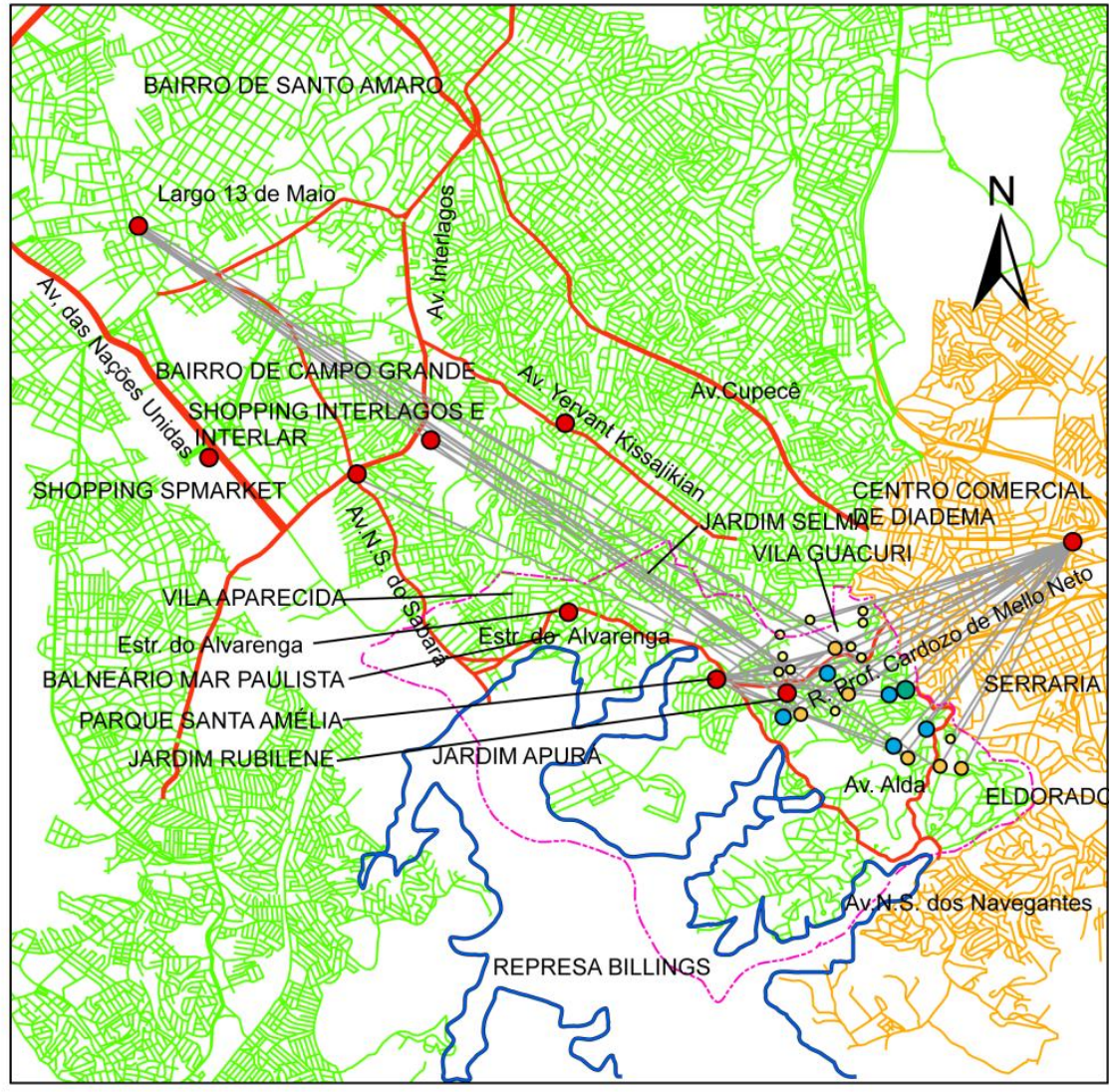

$\begin{array}{lll}0 & 0,5 & 1\end{array}$ 2 Kilometers

Autor: Shinhiti Osanai

Fonte: pesquisa do autor; IBGE Censo 2000

A renda é representada sem escala
Eq. estrutural - Renda ch. fam. - reais
- $378-475$
○ $476-574$
○ $575-734$
○ $735-1028$
- Centros
Relacionam. grupo 6
- Represa Billings
— São Paulo
— Diadema
-.-Divisa Distr. Pedreira 
REDE SOCIAL DO COMÉRCIO - GRUPOS DE MORADORES - EQUIVALÊNCIA ESTRUTURAL GRUPO 7

DISTRITO DE PEDREIRA

MAPA NÚMERO 5.10

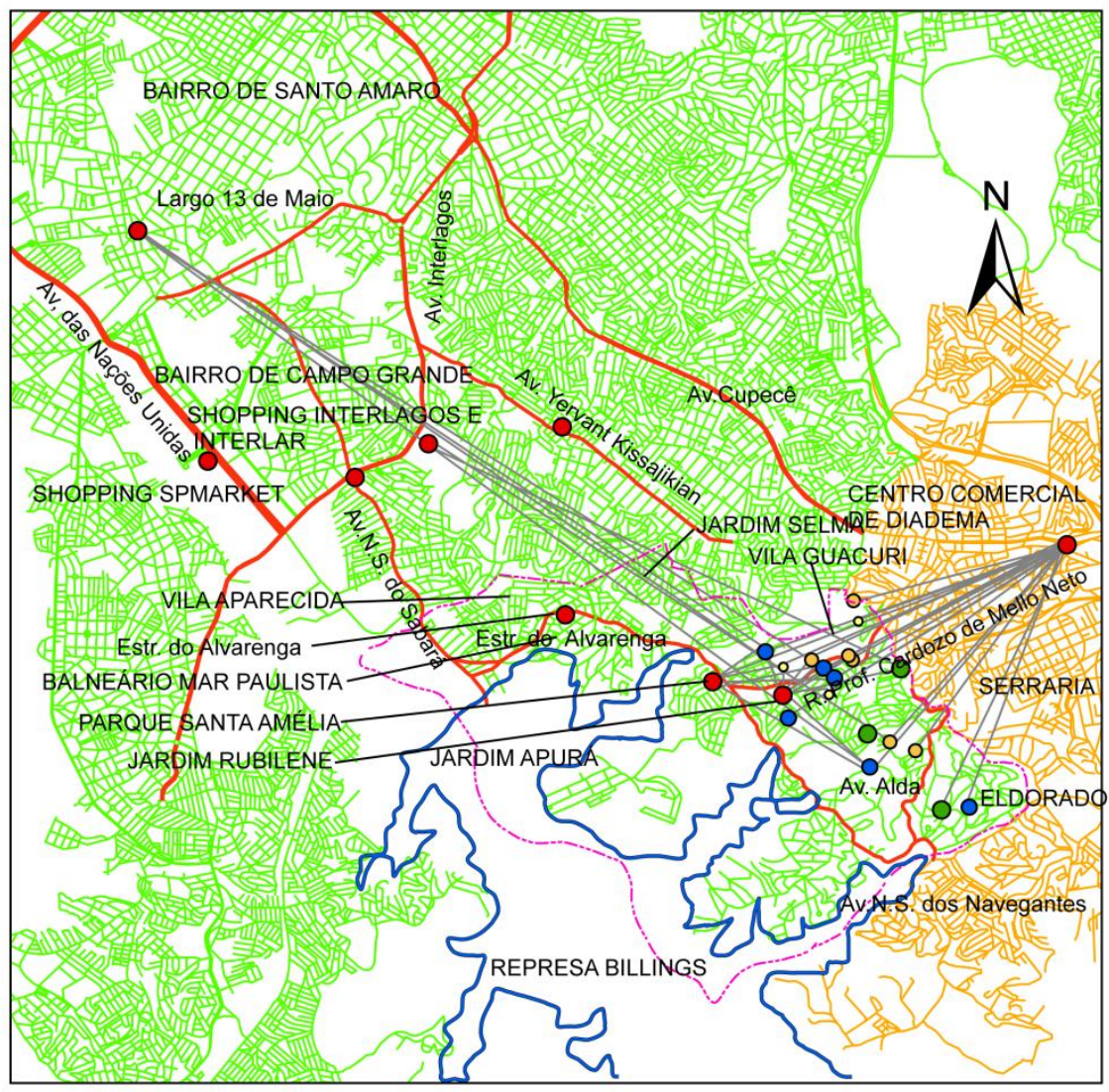

$\begin{array}{lll}0 & 0,5 & 1\end{array}$ 2 Kilometers

Autor: Shinhiti Osanai

Fonte: pesquisa do autor; IBGE Censo 2000

A renda é representada sem escala
Eq. estrutural - Renda ch. fam. - reais

$$
\begin{aligned}
& \text { - } 378-475 \\
& \text { ○ } 476-574 \\
& \text { - } 575-734 \\
& \text { O 735-1028 } \\
& \text { - Centros } \\
& \text { - Relacionam. grupo } 7 \\
& \text { — Represa Billings } \\
& \text { São Paulo } \\
& \text { - Diadema } \\
& \text { _._. Divisa Distr. Pedreira }
\end{aligned}
$$


Nota-se uma intensa influência de Diadema pela disponibilidade, na Av. Alda, de ônibus para esse Município. Apenas os centros secundários do Jardim Rubilene e Parque Santa Amélia participam do cotidiano dos moradores. O valor médio de proximidade é relativamente alto, pela deficiência da estrutura comercial local, e há a necessidade de satisfazer as necessidades de compras nos centros secundários Jardim Rubilene e Parque Santa Amélia relativamente distantes da Av. Alda. O valor médio de posicionamento é relativamente baixo, em função da maior dependência de alguns centros, por exemplo, Diadema, em conseqüência da estrutura comercial local muito deficiente.

O método CONCOR utiliza o critério básico de identificação de grupos. Baseando-se em semelhanças, obteve-se a organização de grupos fortemente identificados em relação à delimitação da localização geográfica dos moradores. Para as regiões norte e central, obtevese grupos geograficamente delimitados sob as influências predominantes do Largo 13 de Maio e Shopping Center Interlagos. Para a região sul formaram-se grupos sob forte influência de Diadema, apesar da concorrência do Largo 13 de Maio. Nem sempre os moradores da região sul se relacionam com o centro secundário da Estrada do Alvarenga e, igualmente os moradores da região norte, muitas vezes, não mantêm contato com o centro secundário do Jardim Rubilene. Alguns moradores próximos da divisa com Diadema não fazem compras no Largo 13 de Maio, nem no Shopping Center Interlagos. Obtiveram-se quatro grupos, com as suas delimitações geográficas bem definidas em consequiência das influências exercidas por cada um dos centros principais e secundários.

Foram organizados ao todo oito grupos, sendo quatro para moradores e o restante para o comércio.

O grupo 1 é constituído por moradores da área norte e central do Distrito, seguindo o eixo da Estrada do Alvarenga e início da R. Professor Cardozo de Mello Neto. É de pouca importância o centro de Diadema sendo intensa a influência dos centros principais do Largo 13 de Maio, Shopping Center Interlagos e os centros secundários da Av. Nossa Senhora do Sabará, Estrada do Alvarenga, Parque Santa Amélia e Jardim Rubilene. É pouco expressiva a influência da Av. Yervant Kissajikian e Shopping Center SPMarket. O grupo está delimitado geograficamente, ao norte, pelos bairros Vila Paineira, Vila Aparecida, Jardim Selma, Conjunto Residencial Ingaí; à margem da represa Billings por Balneário Mar Paulista, Jardim Apurá e Balneário São Francisco; e ao centro por Parque Dorotéia, Parque Santa Amélia e 
REDE SOCIAL DO COMÉRCIO - GRUPOS DE MORADORES - CONCOR GRUPO 1 DISTRITO DE PEDREIRA MAPA NÚMERO 5.11

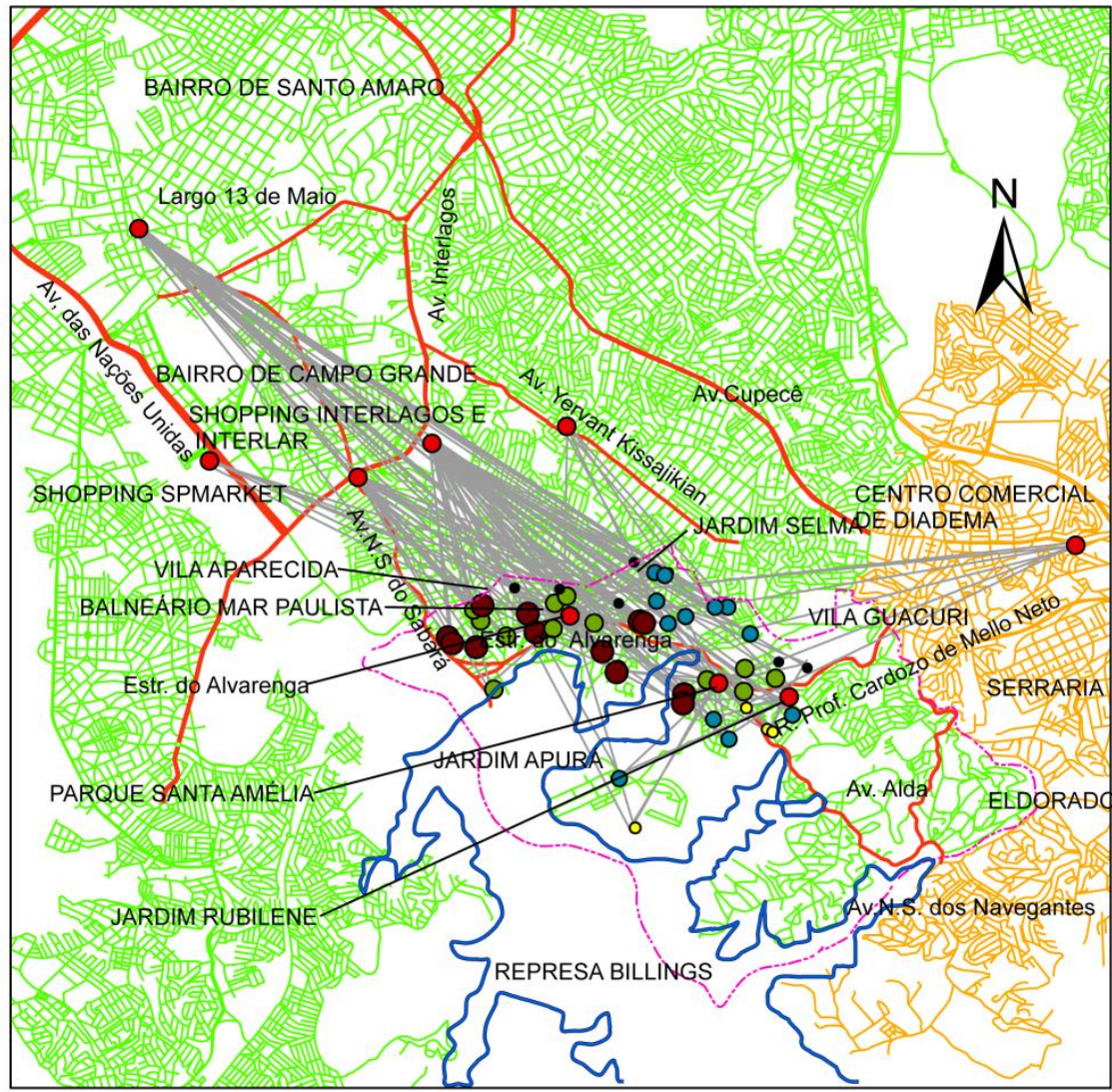

$\begin{array}{lll}0 & 0,5 & 1\end{array}$ 2 Kilometers

Autor: Shinhiti Osanai

Fonte: pesquisa do autor; IBGE Censo 2000

A renda é representada sem escala
CONCOR - Renda ch, fam - reais

- $378-475$

- $476-574$

○ $575-734$

O $735-1028$

$1029-1544$

- Centro hierarquia_CopyFeatur layer

Relacionam. grupo 1

Represa Billings

- São Paulo

- Diadema

_-_- Divisa Distr. Pedreira 
Jardim Rubilene. Predominam setores de renda alta e média, são poucos os moradores de setores de renda baixa que participam desse grupo. É uma região bastante privilegiada para o acesso por ônibus ao Largo 13 de Maio ou o Shopping Center Interlagos e está localizada bem próxima à Estrada do Alvarenga. Não existe linha de ônibus para o centro de Diadema.

O grupo 2 abrange predominantemente os moradores localizados em áreas de renda alta e média das regiões norte e central do Distrito, são poucos os setores de renda mais baixa. Abrangem, alguns bairros da região sul, por exemplo, o Jardim Monte Líbano. São intensas as influências do Largo 13 de Maio, Shopping Interlagos e Av. Nossa Senhora do Sabará. Podese considerar mediana a participação dos centros secundários Estrada do Alvarenga e Parque Santa Amélia. A área geográfica é muito semelhante ao do grupo 1, todavia a diferença está na quantidade menor de relacionamentos com o comércio. Não existem contatos com o centro Shopping Center SPMarket e é muito pouco expressiva a participação do centro secundário do Jardim Rubilene.

O grupo 3 pertence aos moradores da área geográfica da região sul e nordeste, com intensa influência de Diadema, correspondem aos bairros Refúgio Santa Terezinha, Vila Guacuri, Parque Dorotéia, Jardim Rubilene, Jardim Célia, Jardim Monte Líbano, Jardim do Castelo, Eldorado e Sete Praias. É expressiva a participação do Largo 13 de Maio que concorre com a área de influência de Diadema. É uma região de renda média e baixa, as rendas mais baixas se encontram na favela do Pantanal na Vila Guacuri. Nos setores mais pobres, verifica-se alguma tendência de quantidade menor de contatos com o comércio. Nas áreas de proteção dos mananciais, próximas à divisa com Diadema, a estrutura do comércio é muito precária, em parte, consistente na redução dos contatos com o comércio. A região sul, com muitas áreas de declividades acentuadas e sistema viário muito precário, pode trazer barreiras naturais para a instalação de um comércio melhor estruturado, sem contar que em regiões mais pobres a rentabilidade do comércio é mais baixa e não atraem interesse de investimento por parte de muitos empresários ou empreendedores. Os contatos locais são feitos nos centros de Jardim Rubilene e Parque Santa Amélia, localizados nas proximidades, é de muito pouca importância o centro da Av. Nossa Senhora do Sabará. Na Rua Dr. José Silvio de Camargo, não existe serviço de ônibus urbano de São Paulo, entre a Estrada do Alvarenga e o bairro de Monte Líbano. O único serviço é uma linha intermunicipal que atende o percurso entre o centro de Diadema e Acampamento dos Engenheiros, em São Bernardo do Campo. A única linha de ônibus urbano de São Paulo faz o trajeto do metrô Jabaquara, passando por algumas vias de 
REDE SOCIAL DO COMÉRCIO - GRUPOS DE MORADORES - CONCOR

GRUPO 2

DISTRITO DE PEDREIRA

MAPA NÚMERO 5.12

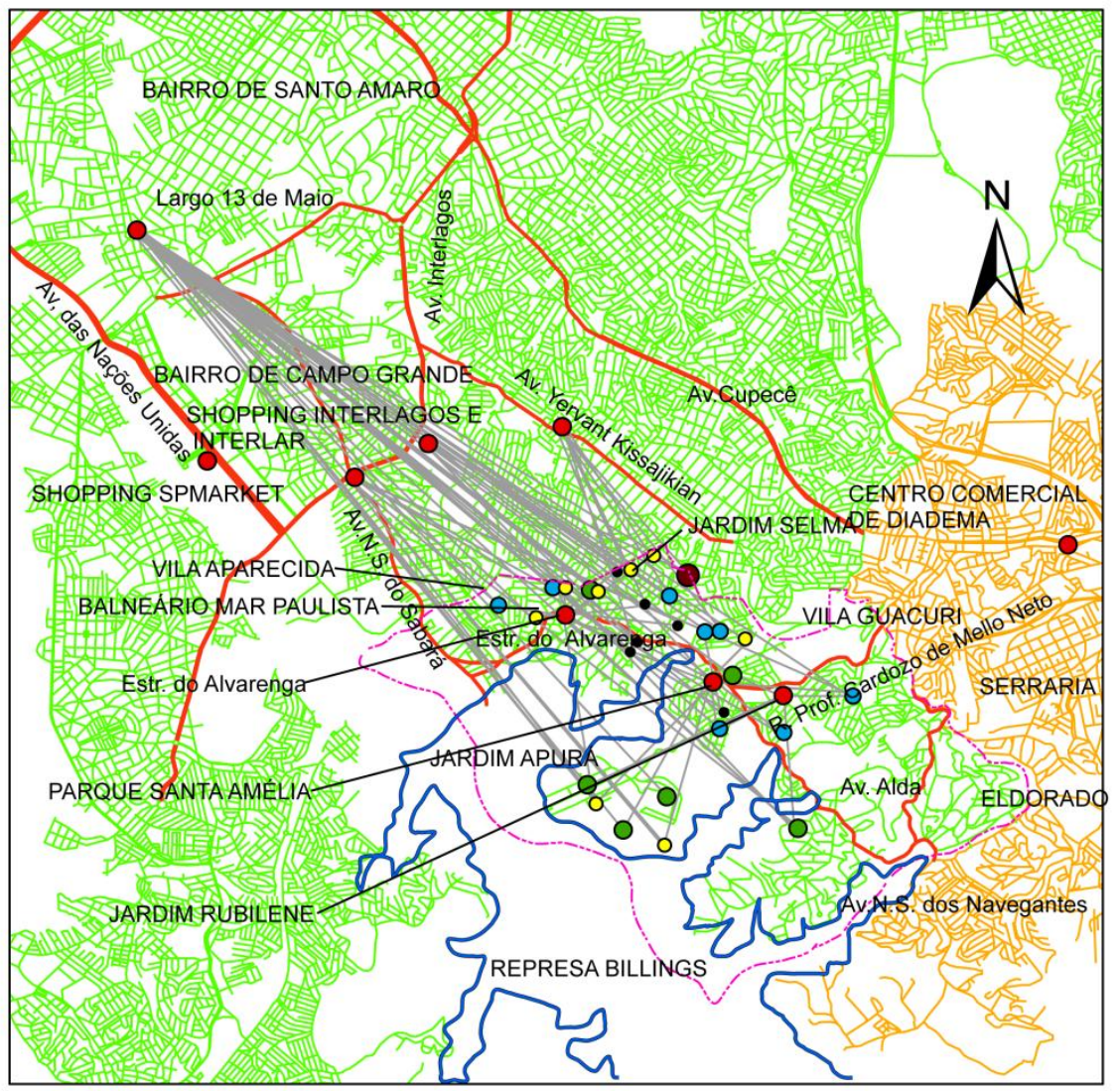

$\begin{array}{lll}0 & 0,5 & 1\end{array}$ 2 Kilometers

CONCOR - Renda ch. fam. - reais

Autor: Shinhiti Osanai

Fonte: pesquisa do autor; IBGE Censo 2000

$A$ renda é representada sem escala
- $\quad 378-475$

○ $476-574$

○ $575-734$

O $735-1028$

$1029-1544$

- Centros

Relacionam. grupo 2

_ Represa Billings

- São Paulo

Diadema

Divisa Distr. Pedreira 
REDE SOCIAL DO COMÉRCIO - GRUPOS DE MORADORES - CONCOR GRUPO 3

DISTRITO DE PEDREIRA MAPA NÚMERO 5.13

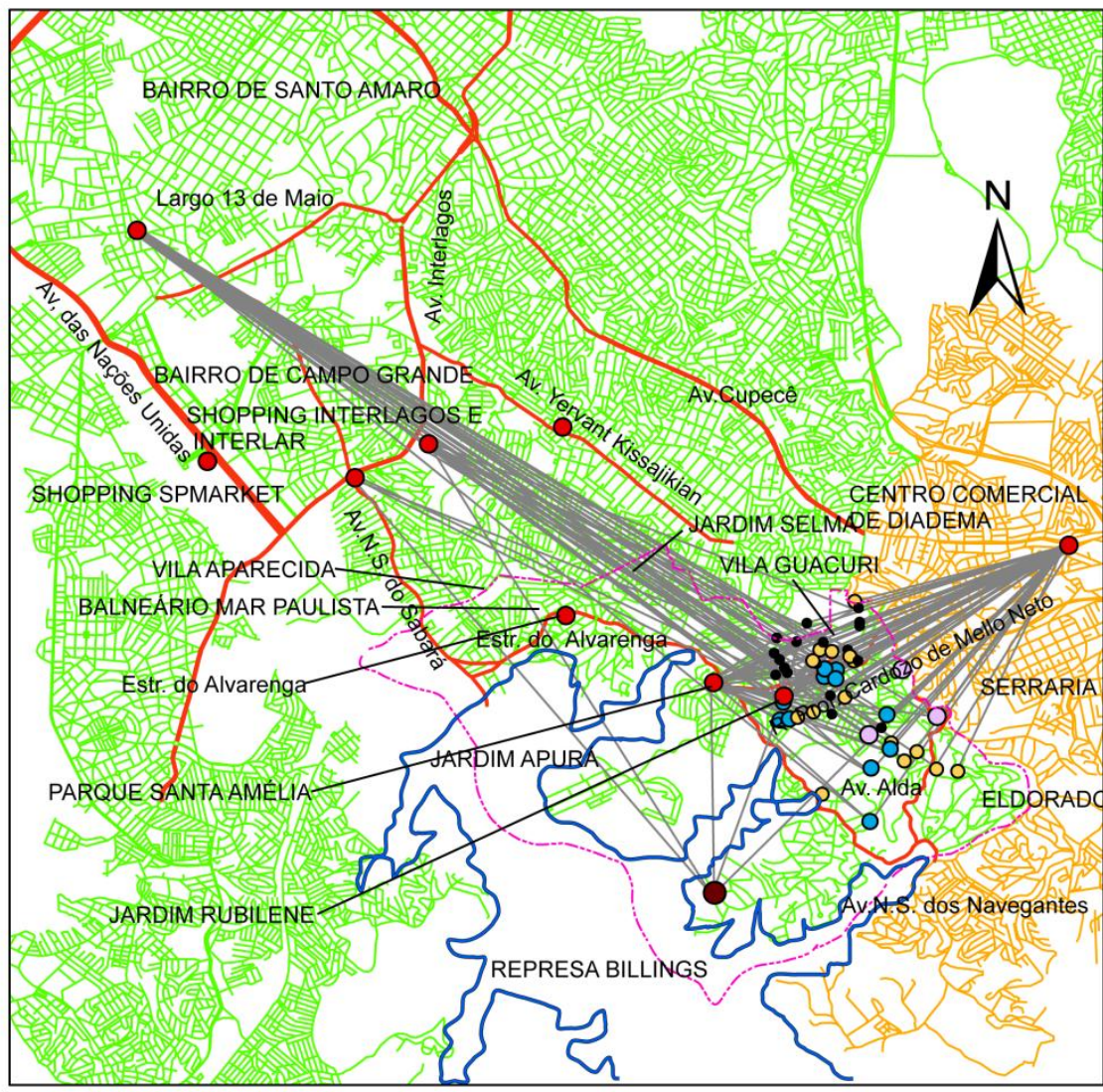

$\begin{array}{lll}0 & 0,5 & 1\end{array}$ 2 Kilometers

Autor: Shinhiti Osanai

Fonte: pesquisa do autor; IBGE Censo 2000

A renda é representada sem escala
CONCOR - Renda ch. fam. - reais

- $378-475$

○ $476-574$

O $575-734$

O $735-1028$

$1029-1544$

O Centro_hierarquia_CopyFeatur laye - Relaciona grupo 3

—_ Represa Billings

- São Paulo

- Diadema

- Divisa Distr. Pedreira 
Diadema, até o bairro de Monte Líbano e o seu ponto final está no início da R.Dr. José Silvio de Camargo. Os moradores de Monte Líbano contam com maior facilidade de acesso por ônibus para Diadema e realizam baldeação na Vila Guacuri sempre que se dirigem a Santo Amaro.

O grupo 4 é formado por moradores das regiões sul, sudeste e alguns da região nordeste, compreende os bairros mais próximos da divisa de Diadema que são Eldorado, Jardim do Castelo, Jardim Célia e Vila Guacuri de influência bastante intensa por parte de Diadema. Existem poucas exceções de contato com o Largo 13 de Maio ou o Shopping Center Interlagos. O relacionamento com os centros secundários do Parque Santa Amélia e Jardim Rubilene são pouco significativos. Não existe serviço de ônibus urbano na Estrada da Água Santa a partir da altura da Av. Chico Mendes. Os moradores da favela Eldorado, no final da Estrada da Água Santa, não dispõem de serviços de ônibus urbano e nem de comércio estruturado, se abastecem do comércio localizado em Diadema, no bairro de Serraria, ou na Av. Afonso Monteiro da Cruz. É possível chegar a essa última via, em poucos minutos a pé, percorrendo um atalho onde se utilizam do ônibus do município de Diadema em direção ao centro ou ao bairro de Serraria. Esses moradores da favela, quando necessitam chegar a Santo Amaro ou ao Centro de São Paulo, caminham um pouco mais de um quilometro até a Av. Alda onde existem serviços de ônibus do município de São Paulo e também de Diadema. Na falta de um comércio estruturado em Eldorado, muitos moradores da região sul da Estrada da Água Santa caminham um percurso de aproximadamente cinqüenta minutos até a Av. Nossa Senhora dos Navegantes, em Diadema, para realizarem as suas compras em conseqüência da não disponibilidade de ônibus para o município vizinho.

O método equivalência automórfica utiliza como critério básico a medida de centralidade grau de cada morador. É um dos indicadores de habituais relacionamentos com os seus principais locais de compras. Os moradores que dispõem de maior quantidade de opções de locais de compras tendem a apresentar valores mais elevados da medida de grau e podem corresponder aos residentes de bairros de renda mais alta, de densidade habitacional menos elevada, de níveis culturais mais altos, apresentando uma boa estrutura urbana, casas de médio padrão, construídos em lotes de tamanhos adequados, constituídos por bairros mais antigos, e instalados em uma região de topografia de declividade menos acentuada, os quais são Vila Paineira, Vila Aparecida, Balneário Mar Paulista, localizados na região norte do Distrito. Setores de renda alta também dividem o espaço em áreas de renda mediana e baixa, tais como 
REDE SOCIAL DO COMÉRCIO - GRUPOS DE MORADORES - CONCOR GRUPO 4

DISTRITO DE PEDREIRA MAPA NÚMERO 5.14

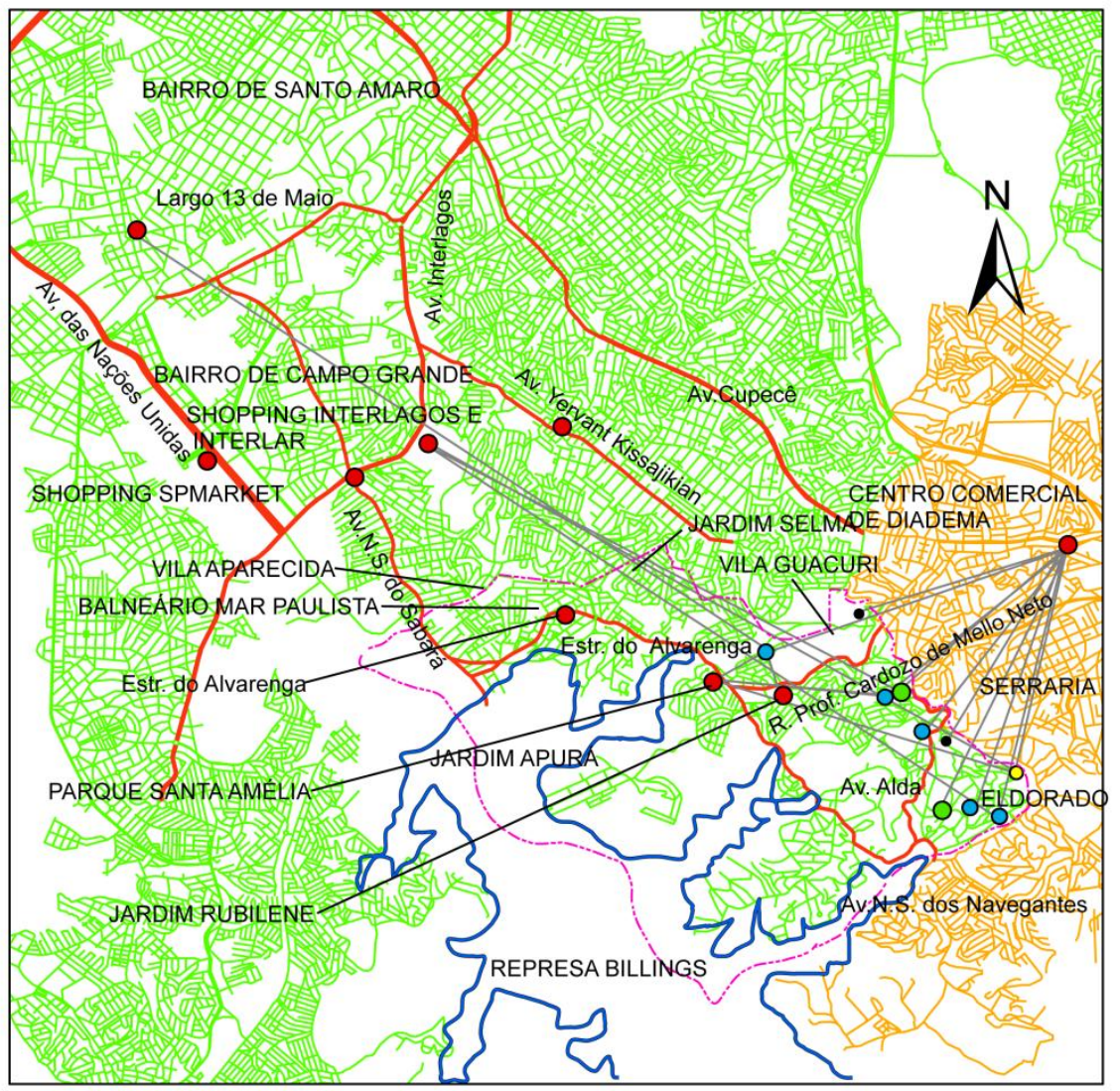

$\begin{array}{lll}0 & 0,5 & 1\end{array}$ 2 Kilometers

\section{Autor: Shinhiti Osanai}

Fonte: pesquisa do autor; IBGE Censo 2000

A renda é representada sem escala
CONCOR - Renda ch. fam. - reais

- $378-475$

○ $476-574$

○ $575-734$

O $735-1028$

- Centros

Relacionam. grupo 4 Represa Billings São Paulo - Diadema Divisa Distr. Pedreira 
os bairros Parque Primavera, na área central, e Eldorado, na região sul na divisa com Diadema.

O objetivo da equivalência automórfica é analisar e organizar grupos de moradores tomando como base a medida de grau. Os grupos formados, quando são equivalentes, devem apresentar os mesmos valores de grau ou muito próximos, levam em conta as características comuns dos relacionamentos entre os nós de uma rede social.

Os bairros localizados ao norte (mapas números 5.1 e 5.2 das páginas 152 e 154) sofrem forte influência do Largo 13 de Maio, Shopping Center Interlagos, Shopping Center SPMarket e Av. Nossa Senhora do Sabará. É menos intensa a influência do comércio da Av. Yervant Kissajikian e de Diadema. A Estrada do Alvarenga é o centro secundário mais próximo sendo utilizado com muita freqüência para a satisfação de compras de demanda baixa ou diária. Os moradores da região norte dispõe de muita facilidade de acesso por ônibus para Santo Amaro e Shopping Center Interlagos, pela proximidade da Estrada do Alvarenga, o que justifica as fortes intensidades de atração exercidas pelo comércio. A região norte é muito próxima do Shopping Center Interlagos e faz divisa com o bairro de Campo Grande onde se localiza o centro secundário da Av. Nossa Senhora do Sabará. Igualmente o acesso por automóvel a Santo Amaro e Shopping Center Interlagos é facilitado pelas vias estruturais de boas condições, pistas duplas e de rápida circulação. Para os moradores da região norte, os centros secundários do Parque Santa Amélia e Jardim Rubilene são menos importantes.

À medida que se desloca para o sul, (mapa número 5.13 da página 173) verifica-se uma tendência de redução nos valores da medida de grau dos moradores. Uma das causas pode ser a estrutura de comércio menos desenvolvida em função da renda populacional mais baixa, terrenos de declividades acentuadas, o que pode encarecer a construção de imóveis comerciais de tamanhos adequados, e a lei de proteção ambiental, que restringe os tamanhos dos imóveis. Os valores baixos dessa medida de grau podem ser encontrados entre os moradores das regiões mais remotas dos bairros Eldorado e Jardim Apurá.

A apresentação do grupo 2 está dividida em dois mapas. No mapa número 5.16 da página 178, observa-se uma significativa influência de Diadema nos moradores dos bairros Parque Dorotéia e Jardim Rubilene, que se encontram próximos da R. Professor Cardozo de Mello Neto. Justifica-se a redução na medida de grau por se tratar de uma área de renda mediana, principalmente entre os moradores das áreas de invasão. 
REDE SOCIAL DO COMÉRCIO - GRUPOS DE MORADORES - EQUIVALÊNCIA AUTOMÓRFICA GRUPO 1

DISTRITO DE PEDREIRA MAPA NÚMERO 5.15

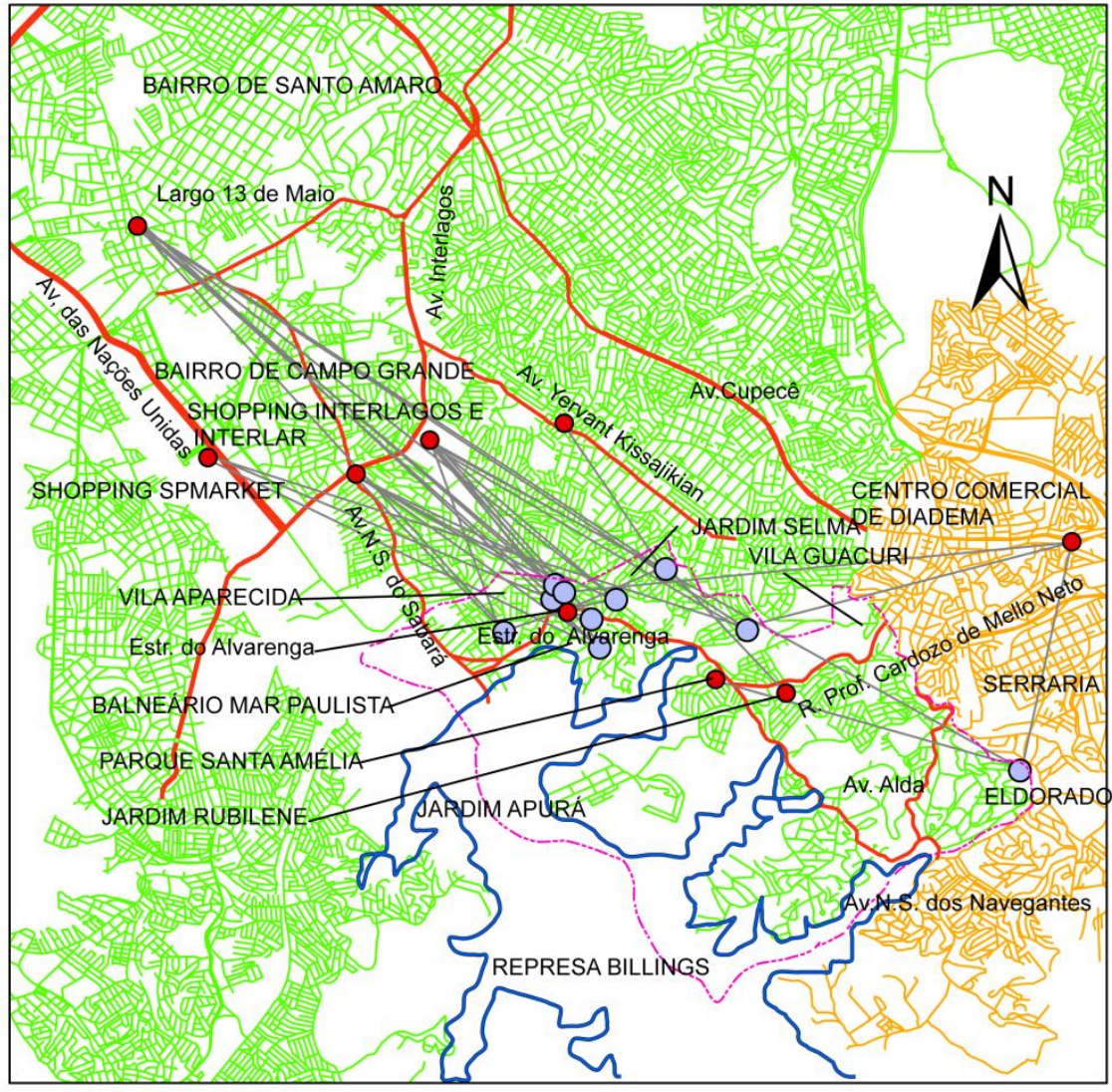

$\begin{array}{lll}0 & 0,5 & 1\end{array}$ 2 Kilometers

Autor: Shinhiti Osanai

Fonte: pesquisa do autor

A medida de grau é representada sem escala

\section{Moradores - Eq. automórfica}

Moradores - grau 18 - 24

- Centros

- Relacionam. grupo 1

_ Represa Billings

- São Paulo

— Diadema

_-_-_ Divisa Distr. Pedreira 
REDE SOCIAL DO COMÉRCIO - GRUPOS DE MORADORES - EQUIVALÊNCIA AUTOMÓRFICA GRUPO 2 - PARTE A

DISTRITO DE PEDREIRA MAPA NÚMERO 5.16

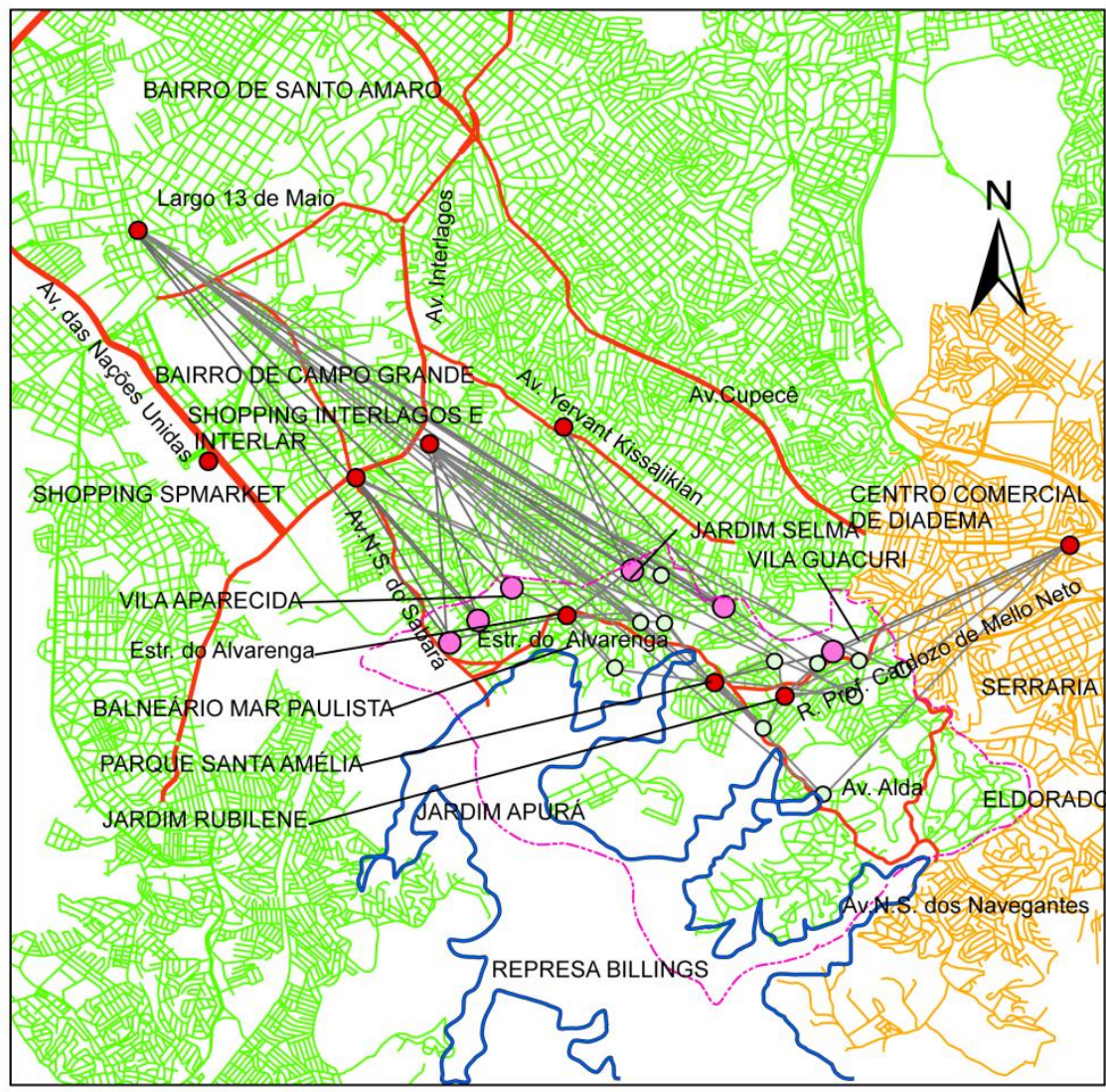

$\begin{array}{lll}0 & 0,5 & 1\end{array}$ 2 Kilometers

Autor: Shinhiti Osanai

Fonte: pesquisa do autor

A medida de grau é representada sem escala
Moradores - Eq. automórfica

Moradores - grau 17 e 18

O Moradores - grau 11 a 13

- Centros

- Represa Billings

- São Paulo

-- Divisa Distr. Pedreira 
Apesar da proximidade de Diadema, as dificuldades decorrentes do sistema de linhas intermunicipais para esse Município fortalecem a influência do Largo 13 de Maio, em consequiência da disponibilidade de acesso pelo transporte urbano que oferece muitas linhas e atende vários bairros. Existe a influência do Shopping Center Interlagos, todavia com menor intensidade, é possível o seu acesso por meio das linhas de ônibus que circulam na Estrada do Alvarenga em direção ao Centro Histórico. Trata-se de uma região ocupada a partir de 1985, exceto os bairros Balneário São Francisco, Refúgio Santa Terezinha e Jardim Célia, geralmente a estrutura viária é deficiente nas áreas de invasão, com as ruas estreitas, principalmente em algumas regiões de declividades mais acentuadas. Os centros secundários da Estrada do Alvarenga, Parque Santa Amélia e Jardim Rubilene exercem uma significativa influência, ficando em destaque o Supermercado Pedreira e Depósito 5 Irmãos. As influências da Av. Yervant Kissajikian, Av. Nossa Senhora do Sabará e Shopping Center SPMarket são menos importantes.

No mapa número 5.16 da página 178, nota-se uma fraca influência de Diadema nos moradores mais próximos ao Jardim Rubilene, das imediações da R. Professor Cardoso de Mello Neto. Alguns valores da medida grau são altos para os moradores de setores de renda média ou baixa. Verifica-se alguma influência do Shopping Center Interlagos e a influência do Largo 13 de Maio é mais significativa entre os moradores da região norte, que vivem em setores censitários de renda baixa ou mediana. Verifica-se no centro secundário do Parque Santa Amélia alguma influência, por causa do Supermercado Pedreira, seguido pelos centros do Jardim Rubilene, em função do Depósito 5 Irmãos e, finalmente pela Estrada do Alvarenga.

No mapa número 5.17 da página 180, os moradores de setores de renda média e baixa, alguns do Jardim Rubilene, Parque Dorotéia, Eldorado, Vila Guacuri e Parque Primavera, mantêm o valor da medida de grau relativamente alto. Aparecem em destaque os moradores da favela do Pantanal, na Vila Guacuri. Os centros da Av. Yervant Kissajikian, Av. Nossa Senhora do Sabará, Shopping Center SPMarket e Estrada do Alvarenga são de pouca importância na formação dos relacionamentos. São intensas as influências dos centros secundários do Parque Santa Amélia, pela preferência do Supermercado Pedreira, e Jardim Rubilene, em função da atração exercida pelo Depósito 5 Irmãos. 

GRUPO 2 - PARTE B DISTRITO DE PEDREIRA MAPA NÚMERO 5.17

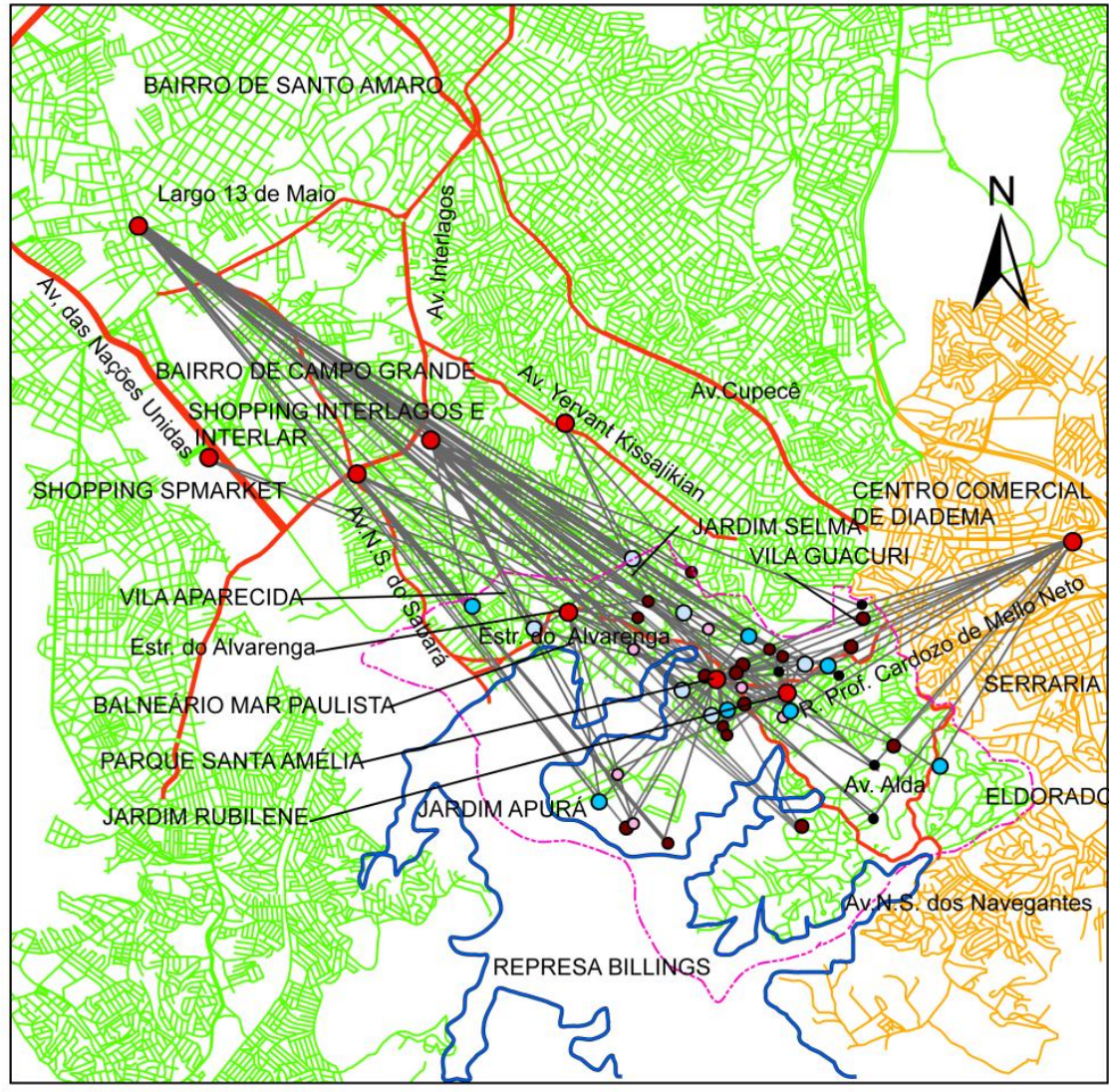

$\begin{array}{lll}0 & 0,5 & 1\end{array}$ 2 Kilometers

Autor: Shinhiti Osanai

Fonte: pesquisa do autor

A medida de grau é representada sem escala
Moradores - Eq. automórfica

O Moradores - grau 14 a 16

O Moradores - grau 15

- Moradores grau 13

- Moradores grau 14

- Moradores grau 12 e 13

- Moradores - grau 8 a 13

C Centros

- Represa Billings São Paulo - Diadema

-.- Divisa Distr. Pedreira 
REDE SOCIAL DO COMÉRCIO - GRUPOS DE MORADORES - EQUIVALÊNCIA AUTOMÓRFICA GRUPO 3

DISTRITO DE PEDREIRA MAPA NÚMERO 5.18

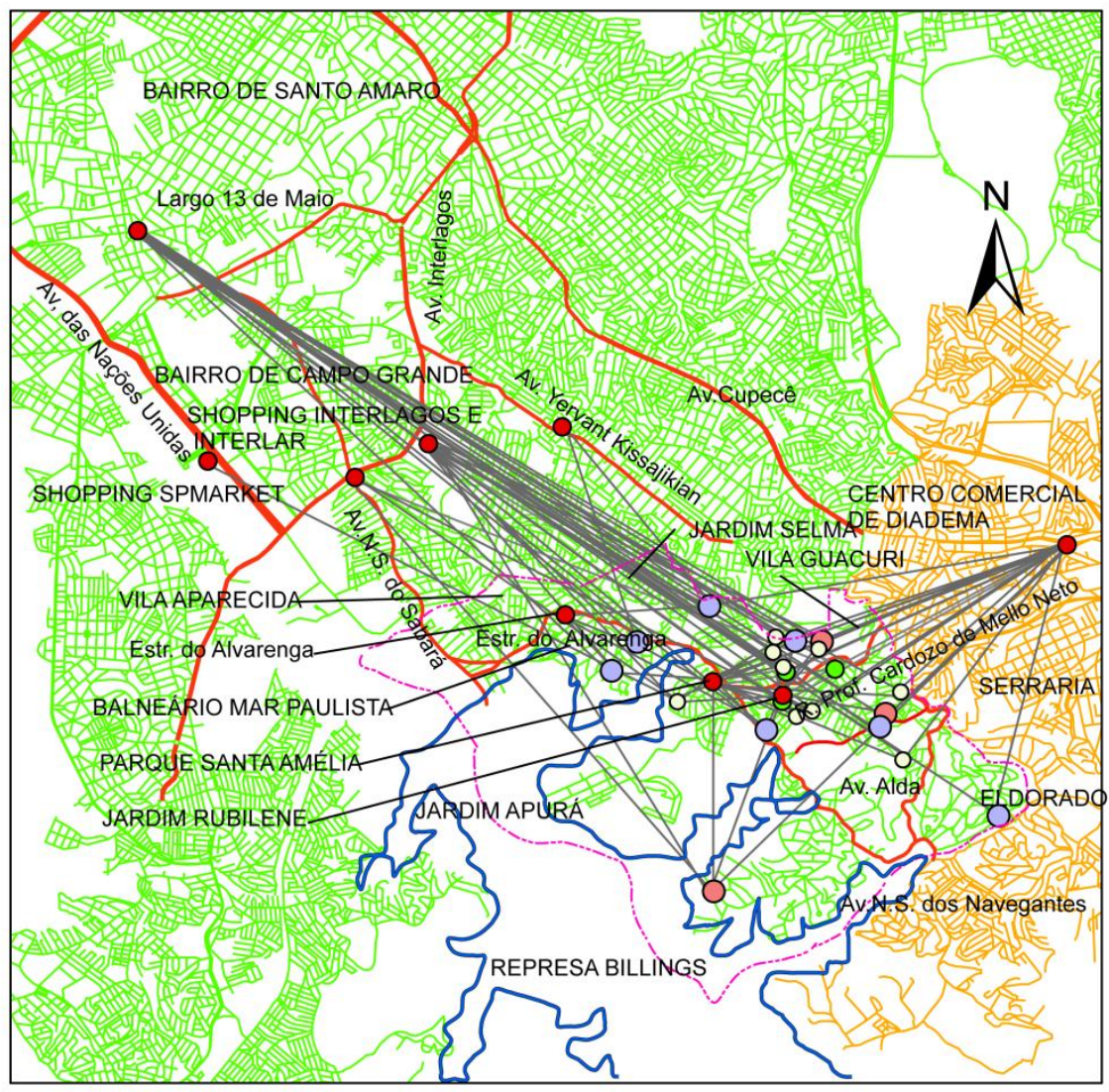

$\begin{array}{lll}0 & 0,5 & 1\end{array}$ 2 Kilometers

Autor: Shinhiti Osanai

Fonte: pesquisa do autor

A medida de grau é representada sem escala
Moradores - Eq. automórfica

Moradores - grau 18 e 19

O Moradores - grau 16 e 17

Moradores - grau 18 e 19

O Moradores - grau 14 a 16

- Centros

- Represa Billings São Paulo Diadema

_... Divisa Distr. Pedreira 
Neste grupo as intensidades entre Largo 13 de Maio, Shopping Center Interlagos e Diadema estão praticamente equilibrados. Existe, nessa região, disponibilidade de ônibus para o Largo 13 de Maio e também para o Shopping Center Interlagos através da linha para o Centro Histórico, que circulam pela R. Professor Cardozo de Mello Neto e Estrada do Alvarenga partindo do bairro Eldorado.

No mapa 5.18 da página 181 observam-se os valores de grau elevado entre os moradores de setores de renda baixa sob a influência de alguns dos centros principais Largo 13 de Maio, Shopping Center Interlagos ou Diadema. A maioria são moradores de Eldorado, Jardim Rubilene e Vila Guacuri. É forte a influência dos centros secundários Estrada do Alvarenga, Parque Santa Amélia e Jardim Rubilene devido aos moradores de setores de renda baixa que possuem o hábito de efetuarem as compras de bens de freqüência de demanda baixa no comércio mais próximo de suas moradias.

Dividiu-se a apresentação do grupo 4 em dois mapas. No mapa número 5.19 da página 184, observam-se os moradores da região norte e central do Distrito, cujo valor de grau está entre 12 e 16 pontos, relativamente baixo, exceto um único morador do Jardim Selma que obteve o valor de grau igual a 8. Alguns moradores, que mantêm índices baixos de relacionamentos com o comércio, residem em setores de renda alta da região norte. A maioria dos valores mais elevados da medida de grau, ao norte do Distrito, está nas áreas de renda mais alta. Na favela do Pantanal, a região de renda média e baixa, verifica-se valores elevados da medida de grau. Ao norte, no setor da favela da Vila Aparecida e do Jardim Selma observam-se os moradores com os valores mais baixos de grau. Na parte central do Distrito, estão os moradores que obtiveram os valores de grau intermediários e se localizam nas proximidades da R.Professor Cardozo de Mello Neto. A influência de Diadema é mais intensa nos moradores de Vila Guacuri, mais próximos à divisa municipal, pois onde existe a disponibilidade de ônibus para Diadema. Os que moram na região norte mantém relacionamento com o centro da Estrada do Alvarenga, o que não acontece com os demais moradores que não recebem influência dos centros secundários do Parque Santa Amélia e Jardim Rubilene.

No mapa número 5.20 da página 185, observam-se moradores dos bairros Eldorado e Jardim Monte Líbano, da região sul; do Jardim do Castelo, Jardim Célia, Jardim Rubilene, da região sudeste; e da Vila Guacuri, da região nordeste; que recebem uma forte influência de Diadema em conseqüência da sua proximidade e da disponibilidade de ônibus em direção a esse Município, que proporciona maiores facilidades de acesso, principalmente para os que 
residem nas proximidades da Av. Alda. Os moradores da região norte se relacionam com Largo 13 de Maio, Shopping Center Interlagos, Av. Yervant Kissajikian e Av. Nossa Senhora do Sabará. Todos eles mantêm muito pouco contato com os centros secundários da Estrada do Alvarenga, Parque Santa Amélia e Jardim Rubilene. Os que moram na região norte, apesar de estarem em uma área de renda alta mantêm o índice de grau relativamente baixo. Os moradores da região sul, sob influência de Diadema, vivem em áreas de renda mediana e baixa.

O objetivo deste capítulo é apresentar a estrutura da rede social desenvolvida por meio da amostra de moradores do Distrito de Pedreira, igualmente, a identificação dos principais nós que podem exercer o papel de centros de influência no processo de satisfação das suas necessidades básicas de abastecimento. Tal fato se deve à distribuição espacial do comércio, e da mobilidade e acessibilidade estabelecidas pelo sistema radioconcêntrico de transporte coletivo urbano.

Realizou-se o levantamento de dados por meio de entrevistas pessoais a uma amostra de 135 moradores, Utilizou-se um roteiro estruturado, com perguntas abertas, conforme o modelo apresentado no apêndice $\mathrm{N}$.

Optou-se por perguntas abertas pela possibilidade da obtenção das respostas em profundidade, perante a diversidade e heterogeneidade local e, desta maneira, contrabalançar algumas das desvantagens da aplicação de perguntas previamente fechadas, a fim de evitar eventuais riscos de induzir determinadas respostas diante de alguns tipos de perguntas fechadas.

A técnica de amostragem por conglomerado foi aplicada, sendo cada conglomerado constituído pelos setores censitários do IBGE adotados no censo demográfico de 2000 . O Distrito de Pedreira está organizado por 135 setores censitários. As entrevistas foram feitas com um morador de cada setor censitário a fim de se obter uma amostra de 135 participantes.

A metodologia empregada para o levantamento de dados foi a entrevista pessoal no local de moradia. Para cada setor censitário, foi providenciado o sorteio de uma quadra e em seguida o sorteio de uma das ruas dessa quadra sorteada. O participante da amostra foi constituído por um morador dessa rua sorteada, porém o seu critério de seleção foi o método de conveniência. 
REDE SOCIAL DO COMÉRCIO - GRUPOS DE MORADORES - EQUIVALÊNCIA AUTOMÓRFICA GRUPO 4 - PARTE A

DISTRITO DE PEDREIRA MAPA NÚMERO 5.19

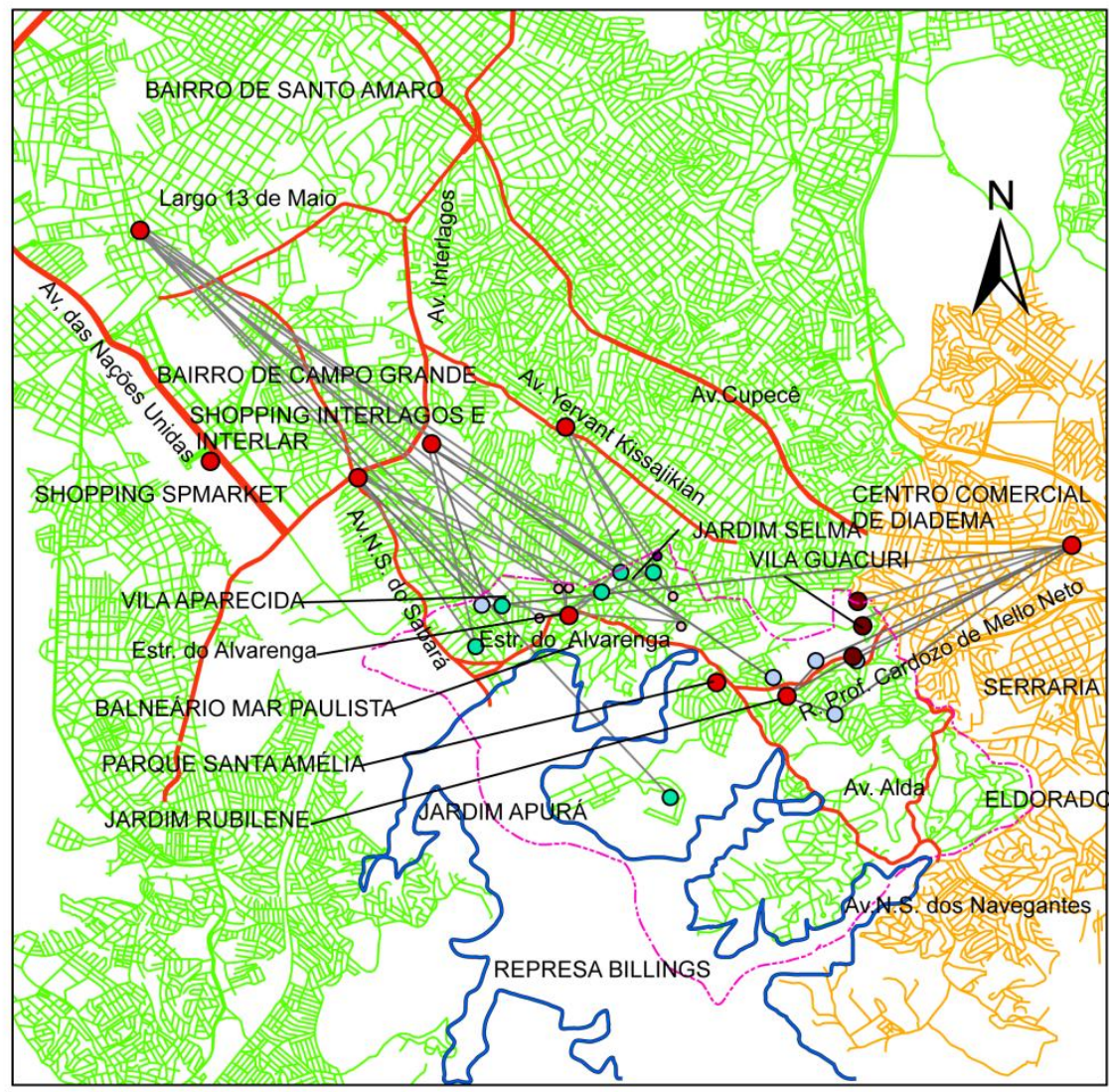

$\begin{array}{lll}0 & 0,5 & 1\end{array}$ 2 Kilometers

Autor: Shinhiti Osanai

Fonte: pesquisa do autor

A medida de grau é representada sem escala
Moradores - Eq. automórfica

O Moradores - grau 12 e 13

- Moradores - grau 11 a 13

O Moradores - grau 14 a 17

- Moradores - grau 15 e 16

- Morador - grau 8

- Centros

- Represa Billings São Paulo - Diadema Divisa Distr. Pedreira 
REDE SOCIAL DO COMÉRCIO - GRUPOS DE MORADORES - EQUIVALÊNCIA AUTOMÓRFICA

GRUPO 4 - PARTE B

DISTRITO DE PEDREIRA MAPA NÚMERO 5.20

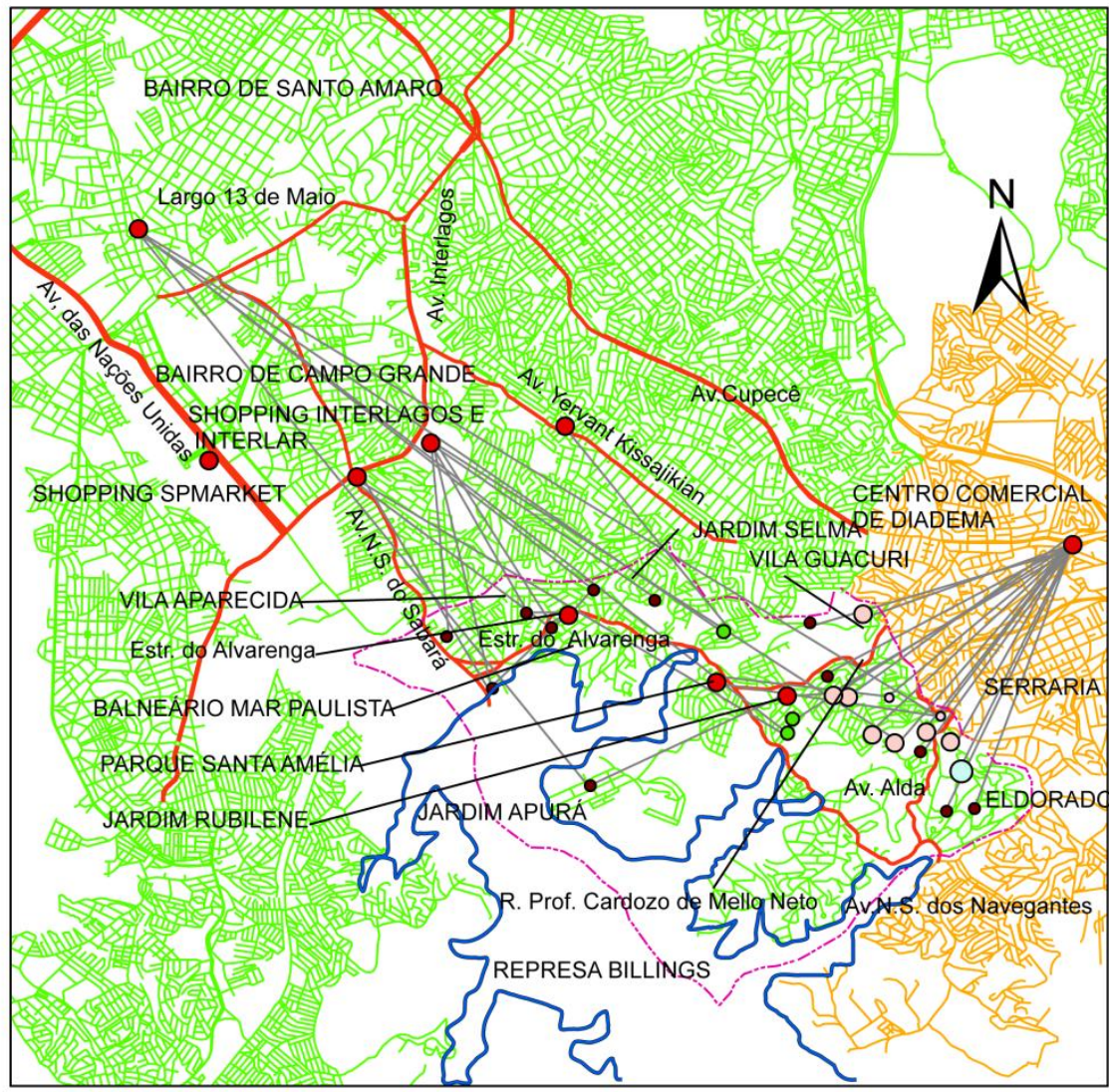

$\begin{array}{lll}0 & 0,5 & 1\end{array}$ 2 Kilometers

Autor: Shinhiti Osanai

Fonte: pesquisa do autor

A medida de grau é representada sem escala
Moradores - Eq. automórfica

- Moradores - grau 5 e 6

Morador - grau 19

- Moradores - grau 10

O Moradores - grau 13 e 14

- Moradores - grau 5 a 14

- Centros

Represa Billings São Paulo - Diadema - Divisa Distr. Pedreira 
Não foi registrada a identificação do entrevistado em garantia da confidencialidade da informação fornecida. (Vide mapa número 5.21)

A rede social foi estruturada por meio de um software, próprio para análise de redes sociais, denominado Ucinet6 para Windows, desenvolvido por Analytic Technologies pelos autores Borgatti, S.P., Everett, M.G. e Freeman, L.C., em 2002.

As respostas dos participantes da amostra foram codificadas e em seguida digitadas no referido software Ucinet6. A primeira etapa constituiu da obtenção de uma matriz adjacente de relações sociais, do mesmo tipo apresentado na página 39, cuja dimensão final é de 499 linhas e colunas. Cada morador e cada ramo de comércio, mencionado pelos entrevistados, receberam um código específico para a constituição da referida matriz.

Na codificação dos ramos de atividades do comércio, o critério adotado está fundamentado no CNAE 2.0 - Classificação Nacional de Atividades Econômicas publicado em 5/9/2006 (vide anexo A. Nessa última edição houve a revisão dos critérios e observam-se significativas mudanças em relação a alguns quesitos adotados pelo CNAE 1.0, em uso nos dados divulgados pelo IBGE tendo a data base até o ano de 2006. Os códigos adotados e as suas respectivas correspondências em relação ao CNAE 2.0 estão no apêndice E.

Nos centros de grande circulação de pessoas, por exemplo, o Largo 13 de Maio, Shopping Center Interlagos ou centro comercial de Diadema existem várias opções de escolha para o mesmo ramo de comércio. Estão presentes várias categorias de lojas de eletrodomésticos, móveis, roupas para cama, mesa e banho, vestuário e calçados. Para o preparo da rede social foi adotado, para cada centro, apenas um código para todas as lojas do mesmo ramo de atividade. Em torno do Largo 13 de Maio estão presentes, na categoria de eletrodomésticos, as lojas Casas Bahia, Ponto Frio, Eletro e muitas outras. Nesse local, o código CE3L13A representa todas as lojas desse ramo de atividade. 


\section{AMOSTRA DE MORADORES}

DISTRITO DE PEDREIRA

MAPA NÚMERO 5.21

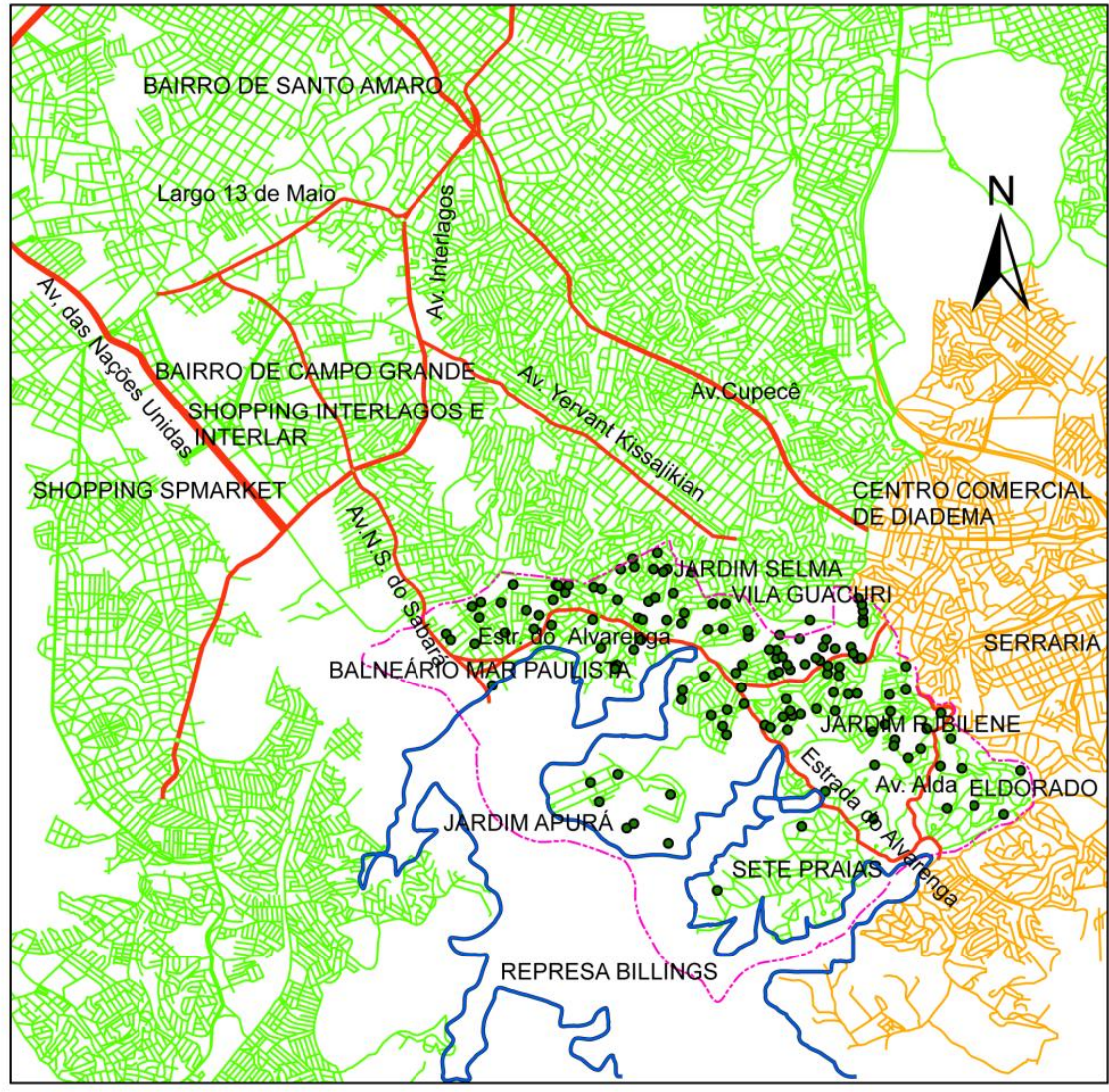

$\begin{array}{lll}0 & 0,5 & 1\end{array}$ 2 Kilometers

Autor: Shinhiti Osanai

Fonte: pesquisa do autor
Legenda

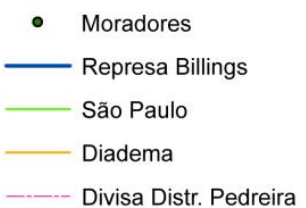


Alguns entrevistados que procuram eletrodomésticos na região do Largo 13 de Maio preferem as Casas Bahia, outros não possuem preferência de loja, mas apenas do local e muitos compram na loja que oferecem a melhor condição de preço, após uma pesquisa de preços, sendo o mais importante o local. Para todas essas respostas a codificação e o registro do relacionamento foram direcionados apenas para o mesmo código, CE3L13A, representando todos os estabelecimentos de eletro-eletrônicos da área do Largo 13 de Maio. Essa mesma metodologia foi aplicada para todos os ramos dos demais centros e locais identificados pelos moradores da amostra.

Às vezes os moradores de setores censitários vizinhos ou bem próximos podem se abastecer, em torno das suas residências, por exemplo, numa única e mesma padaria mais próxima. Foi criado um código CA1064A em relação a essa padaria, representando, caso existam, todas as padarias localizadas no setor censitário 64, mencionadas pelos entrevistados. Foram registrados, neste referido código CA1064A, todos os relacionamentos dos moradores da amostra, em relação essa mesma padaria. $\mathrm{Na}$ periferia, freqüentemente, um determinado código pode representar apenas o único estabelecimento existente num setor censitário específico. Para o comércio local, esta metodologia foi adotada para cada um dos ramos de atividade mencionados pelos entrevistados.

Alguns estabelecimentos, em destaque, do tipo Drogaria São Paulo da Avenida Nossa Senhora do Sabará ou Drogaria Ultra Farma do bairro da Saúde obtiveram seus códigos próprios, e em consequiência da sua intensa procura, receberam um tratamento de exceção no registro do relacionamento. Entre os moradores da amostra, em relação à farmácia, quando se dirigem à Avenida Nossa Senhora do Sabará ou ao bairro da Saúde, utilizam somente esses dois estabelecimentos.

No Parque Santa Amélia, pertencente ao setor censitário 2, existe apenas um supermercado, o Supermercado Pedreira. Todos os relacionamentos registrados para o código CS2002A são referentes a esse estabelecimento.

No Jardim Rubilene, parte do setor censitário 17, existem alguns depósitos de materiais de construção, sendo o mais importante, em termos de preferência, o Depósito 5 Irmãos. O código CM2017A representa todos os estabelecimentos desse mesmo ramo, localizados nesse referido setor censitário, entretanto, dos resultados obtidos, a maioria das respostas se refere apenas ao Depósito 5 Irmãos. 
Ainda, no Jardim Rubilene, existem bem próximos, na mesma rua, dentro do setor censitário 16, dois supermercados médios o Mamb's e o Ki Barato. Os resultados do código CS2016A correspondem ao total dos relacionamentos obtidos por esses dois estabelecimentos.

Todas as vezes que um entrevistado efetua as compras de produtos alimentícios e de materiais de limpeza para o lar no mesmo estabelecimento, adotou-se um critério de exceção, na categoria de produtos de limpeza, com o objetivo de se precaver de eventuais falsas percepções decorrentes de valores de grau muito elevados. Por exemplo, quando um entrevistado compra esses dois produtos no mesmo supermercado foi considerado apenas 1 registro para alimentos, desprezando o registro correspondente ao produto de limpeza.

Após a digitação e a conferência dos códigos utilizaram-se as funções do software Ucinet6 para a obtenção de:

- cálculos das medidas de centralidades grau, proximidade e posicionamento;

- cálculo das equivalências estruturais e automórficas acompanhados dos seus respectivos dendogramas e árvores apresentando a estrutura dos grupos homogêneos.

As análises, comentários e conclusões deste capítulo se baseiam apenas na amostra de 135 moradores do Distrito de Pedreira. Os termos "entrevistados" e "moradores" estão sendo adotados, na maior parte das ocorrências, quando se referem aos participantes da amostra. Portanto, o conceito de "moradores" adotado para este capítulo se atribui aos participantes da amostra e não aos habitantes do Distrito de Pedreira. Toda vez que a conotação a ser apresentada venha a envolver os habitantes do Distrito de Pedreira, a palavra "moradores" não está sendo empregada para esta finalidade específica.

O principal foco deste capítulo é identificar os centros e os seus respectivos níveis hierárquicos e também analisar os padrões da distribuição espacial das influências exercidas pelos centros de hierarquia mais elevada, sobre os moradores do Distrito de Pedreira, fundamentada na rede social estruturada a partir dos dados da amostra.

O critério básico, adotados para a identificação dos centros mais importantes e os seus respectivos níveis hierárquicos, é a medida de grau obtida dos nós que representam os ramos de comércio. As intensidades de atração, exercidas pelos pontos comerciais, são indicadas pelas medidas dos valores de posicionamento desses mesmos nós. Os valores das medidas de 
posicionamento e de proximidade, dos nós do comércio, são úteis para a ratificação e análise de consistência dos níveis de hierarquia.

A morfologia da rede social fornece os subsídios necessários para a análise dos padrões da distribuição espacial das áreas de influência, exercidas pelos centros de hierarquia mais importantes, sobre os moradores do Distrito de Pedreira.

Uma característica importante, da rede social obtida, é a sua constituição somente por laços fracos. Um laço é fraco quando um nó apresenta um relacionamento direto com outros nós sem a constituição de nós intermediários. Nessa rede social os participantes se relacionam diretamente com os seus fornecedores, por exemplo, cada morador se abastece diretamente no supermercado de sua preferência sem a participação de intermediários. Algumas técnicas em redes sociais são funcionais somente quando os laços fortes estiverem presentes. Daí, a análise das semelhanças quanto aos hábitos de compras, que pode ser feita através da aplicação da técnica de equivalência regular, está fora do escopo deste capítulo por exigir a constituição de uma estrutura diferente de rede social, havendo a necessidade da participação de intermediários para a criação de laços fortes. A existência de nós intermediários, algumas vezes, pode ser indesejável para um modelo, cujo objetivo principal é o cálculo dos níveis de hierarquia, tendo em vista a possibilidade de riscos de eventuais distorções nos valores de grau.

A menção do local do Largo 13 de Maio se atribui a toda sua região e não apenas a sua localização pontual e abrange a área compreendida entre a Praça Floriano Peixoto, Avenida Mário Lopes Leão, Rua Barão do Rio Branco, Rua da Matriz, Largo 13 de Maio, Rua Desembargador Bandeira de Mello, Rua Manoel Borba e Rua Voluntário Delmiro Sampaio. Igualmente, em relação a Diadema, se refere aos resultados obtidos na região do centro comercial constituído por Avenida Alda, Praça Castelo Branco, Avenida Antonio Piranga, Praça Lauro Michels, Avenida Fabio Eduardo Ramos Esquivel, Praça Angelina de Melo, Avenida São José e Rua Izautino L. da Silva, ficando excluídos os bairros Eldorado (Navegantes) e Serraria. Quanto ao Shopping Center Interlagos, as informações abrangem todo o Shopping, inclusive o hipermercado Carrefour exceto as lojas localizadas em sua frente na Avenida Interlagos.

Nas regiões de comércio muito precário, localizadas nas proximidades da divisa com Diadema, muitos moradores, diante da falta de opção de transporte coletivo, vão a pé para 
efetuarem as compras no município vizinho, necessitando de um tempo de até 50 minutos em cada percurso. Muitos habitantes são migrantes bem sucedidos e mesmo que tenham uma renda mais privilegiada mantêm, ainda, os hábitos de compras de pessoas de renda mais baixa. Não fazem as compras em locais mais sofisticados, do tipo, Shopping Center Morumbi ou Iguatemi. Apesar de deterem uma renda suficiente, preferem fazer as suas compras em regiões estruturadas para consumidores de renda mais baixa, por exemplo, Diadema ou Largo 13 de Maio em Santo Amaro. Alguns, de melhor nível de renda, moradores da área central do Distrito de Pedreira procuram o Shopping Center Interlagos, na Avenida Interlagos no bairro de Campo Grande, para realizarem, no hipermercado Carrefour, as compras de frequiência mensal, ou então de bens de consumo duráveis ou roupas e calçados no referido Shopping. Para as compras de roupas, alguns preferem a região do Brás ou do Bom Retiro em conseqüência dos preços mais competitivos. No ramo de eletro-eletrônicos, Casas Bahia foi mencionada pela maioria das pessoas, principalmente pela preferência da sua localização, no Largo 13 de Maio ou Diadema e com menor freqüência no Shopping Center Interlagos.

Muitos utilizam os supermercados de vizinhança, de médio ou pequeno porte, para as compras mensais de produtos alimentícios, higiene pessoal e do lar, com destaque para o Supermercado Pedreira, os Supermercados Mamb’s e Ki Barato, todos, na área central do Distrito. Igualmente, a rede Ricoy funciona com vários estabelecimentos na região, inclusive, mantém uma das filiais em Diadema na Avenida Nossa Senhora dos Navegantes, bem próxima à divisa com o bairro de Eldorado.

Geralmente, as compras diárias ou semanais são realizadas em pequenos estabelecimentos em torno das residências. São as padarias, pet shops, quitandas ou sacolões, mercearias e estabelecimentos especializados em produtos de limpeza para o lar. Freqüentemente, nos locais com ausência de padarias, as pequenas mercearias comercializam pão e leite. As farmácias são poucas, há necessidade de as pessoas se deslocarem até Diadema ou até o bairro de Campo Grande. Em alguns bairros os moradores reclamam da falta de comércio nas proximidades de suas residências. Pequenos bazares, pet shops e adegas são encontrados com relativa freqüência, entretanto existe alguma deficiência no comércio local de produtos alimentícios. Nas áreas de favelas ou nas áreas de loteamentos irregulares, existem padarias comunitárias num esforço de compensar a falta de um estabelecimento melhor estruturado. Casas especializadas em produtos provenientes do nordeste, conhecidas como Casas do Norte, 
são relativamente freqüentes, e também são muitas as pequenas lojas de material de construção.

As compras, com a finalidade de atender as mais simples necessidades de manutenção para o lar, por exemplo, a substituição da resistência de um chuveiro ou peças para o reparo de torneiras, é realizada, muitas vezes, nas pequenas mercearias, que às vezes funcionam como bares, ou quando disponível, num pequeno estabelecimento de material de construção localizado na proximidade das residências. Entretanto, as compras de valor mais significativo, por exemplo, uma pia para a cozinha, são realizadas em estabelecimentos maiores, tal como o Depósito 5 Irmãos, ou então, embora mais raro, em hipermercados de construção do tipo Leroy Merlin localizado nas proximidades do Shopping Center Interlagos e do Shopping Center Interlar.

Determinam-se, para cada um dos nós da rede social da amostra de moradores do Distrito de Pedreira, os níveis de hierarquia obtidos a partir da análise das medidas de centralidade grau, proximidade e posicionamento.

Três níveis de participação na opção de escolha de locais de compras estabelecidos como sendo alto, médio e baixo, constam nos mapas (mapas 5.22, 5.23 e 5.24). O critério para a obtenção da classificação está baseado na participação percentual de cada morador em relação à soma de todos os relacionamentos obtidos. Obteve-se o total de 2167 contatos, a saber:

- participação igual ou acima de $0,40 \%$ - classificação alto;

- participação entre $0,10 \%$ e $0,39 \%$ - classificação médio;

- participação abaixo de 0,09\% - classificação baixo.

Os valores de centralidade grau possibilitaram a identificação de três centros importantes, constituídos por Largo 13 de Maio em Santo Amaro, Shopping Center Interlagos e o centro comercial do Município de Diadema, todos fora da área geográfica do Distrito de Pedreira. São os locais de hierarquia mais elevada, em relação ao referido Distrito, correspondem às centralidades mais relevantes, para as compras de produtos de frequiência de demanda baixa. A satisfação das necessidades, relacionadas à freqüência de compras baixa, em parte, é realizada por meio dos produtos dos ramos, que não estão disponíveis neste Distrito de Pedreira, constituídos por eletro-eletrônicos e roupa de cama, mesa e banho. Entretanto, com alguma raridade, encontra-se o comércio de calçados e de roupas. 
A influência de Diadema (mapa 5.23) é mais intensa nas regiões mais próximas com a divisa. Entretanto, o Largo 13 de Maio (mapa 5.22) mantém influência em áreas onde a influência de Diadema é também significativa, pois a sua atuação é, de maneira geral, distribuída por todo o Distrito de Pedreira. A influência do Shopping Center Interlagos (mapa 5.23) é mais forte entre os moradores da região central do distrito. 
Figura 5.1 - REDE SOCIAL DOS MORADORES SOB A INFLUÊNCIA DO LARGO 13 DE MAIO EM SANTO AMARO

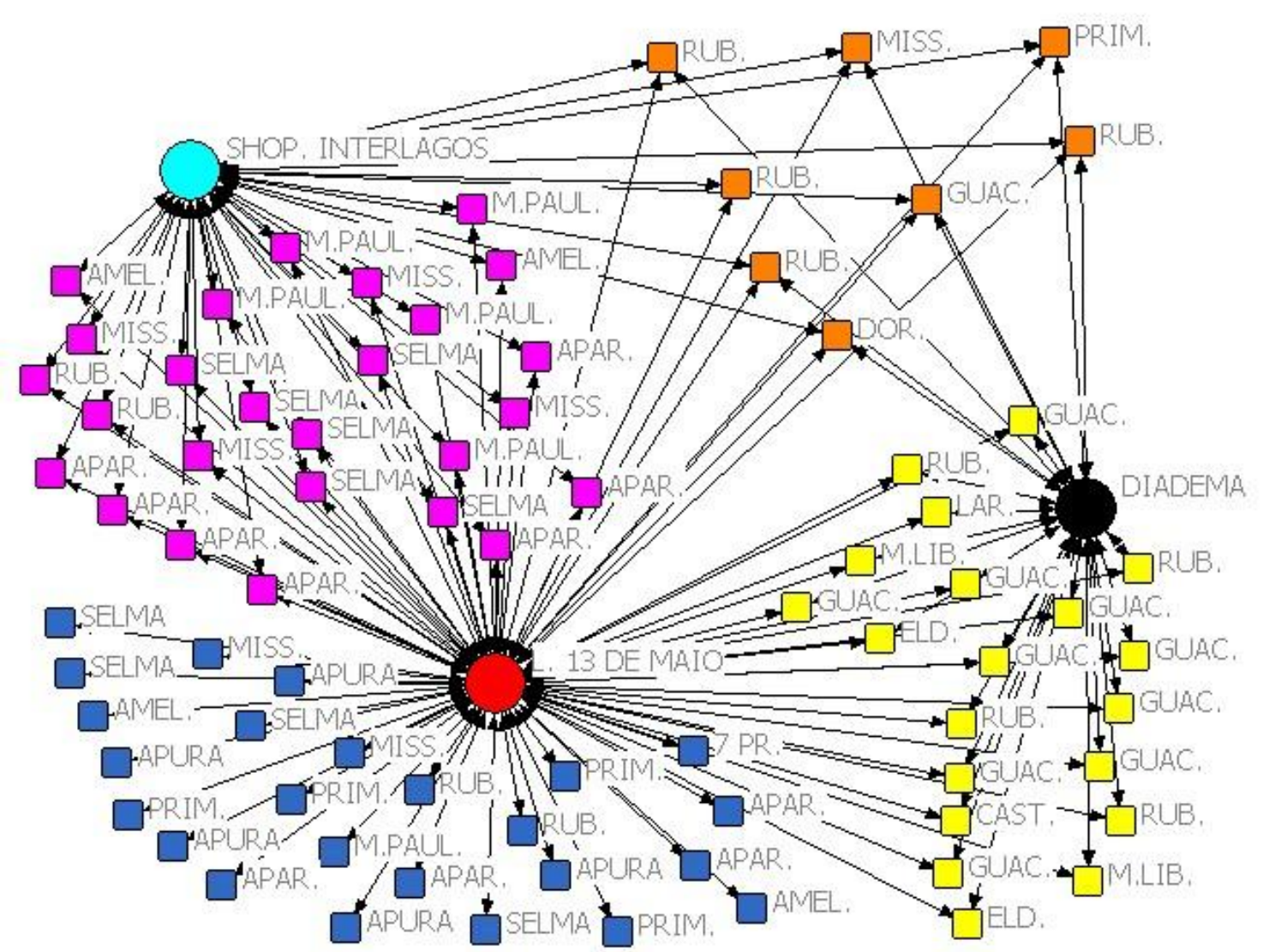

Obs.: alguns moradores também compram em outros centros concomitantemente com o Largo 13 de Maio, podendo ocorrer as compras simultâneas entre o Largo 13 de Maio e Diadema (cor amarela); Largo 13 de Maio e Shopping Center Interlagos (cor lilás); e Largo 13 de Maio, Diadema e Shopping Center Interlagos (cor ocre).

Fonte: pesquisa do autor 


\section{PARTICIPAÇÃO NAS COMPRAS LARGO 13 DE MAIO}

POR SETOR CENSITÁRIO

MAPA NÚMERO 5.22

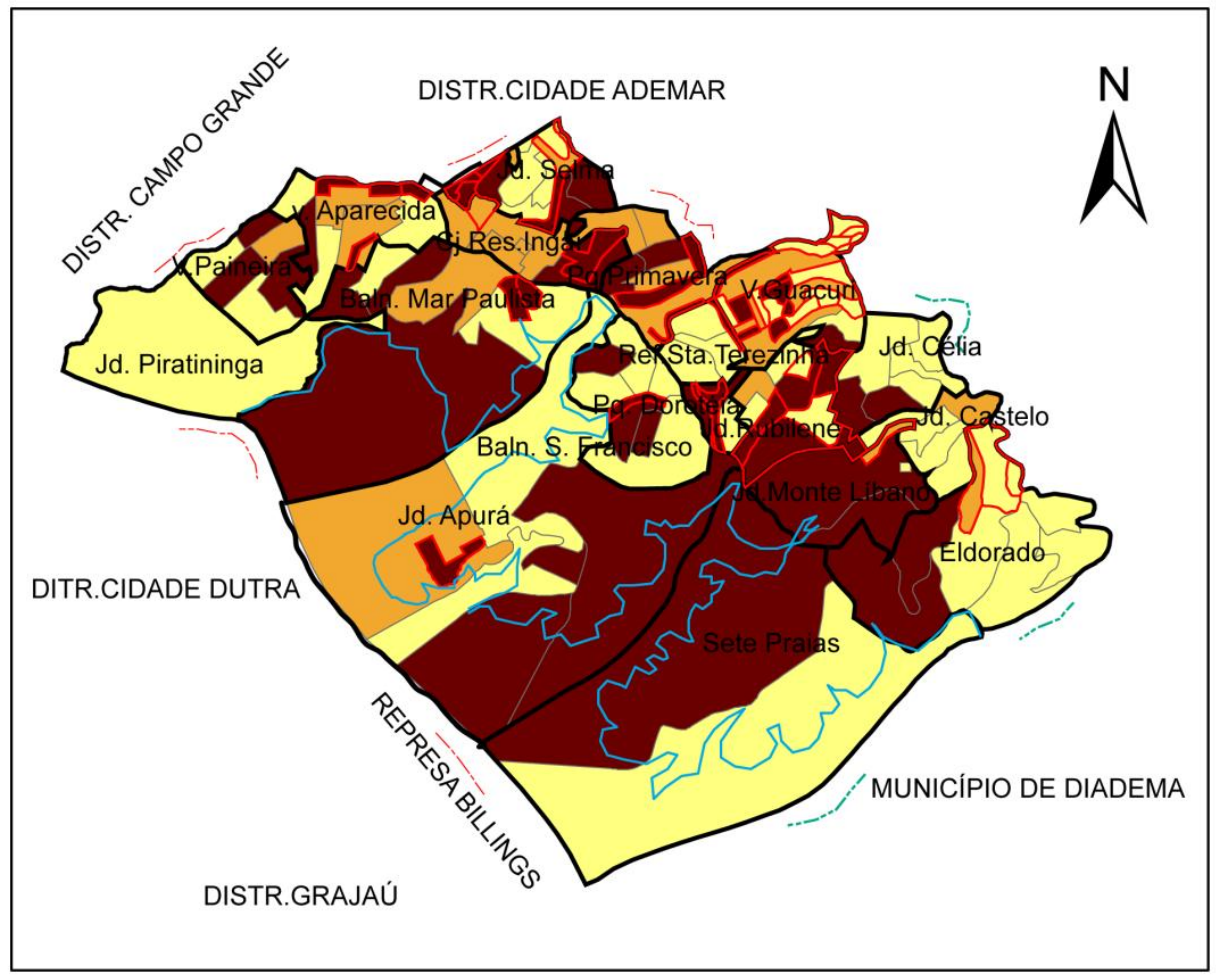

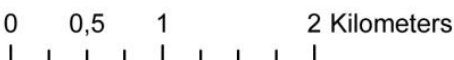

Autor: Shinhiti Osanai

Fonte: pesquisa do autor
Participação nas compras

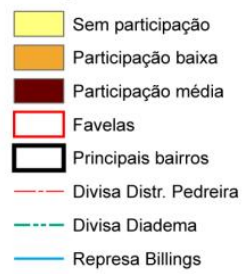


Figura 5.2 - REDE SOCIAL DOS MORADORES SOB A INFLUÊNCIA DE DIADEMA

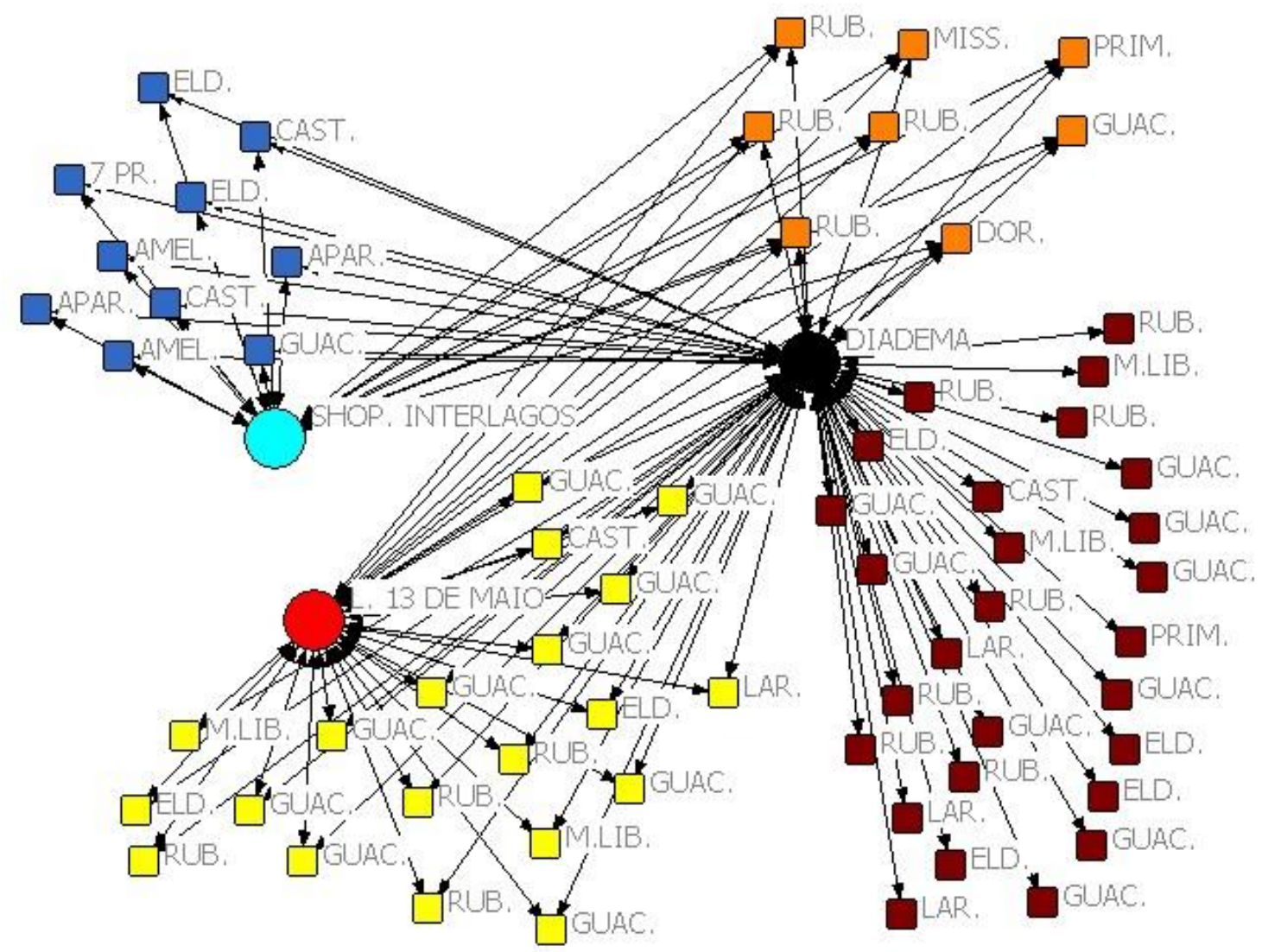

Obs.: alguns moradores também compram em outros centros concomitantemente com Diadema, podendo ocorrer às compras simultâneas entre Diadema e Largo 13 de Maio (cor amarela); Diadema e Shopping Center Interlagos (cor azul); e Largo 13 de Maio, Diadema e Shopping Center Interlagos (cor ocre).

Fonte: pesquisa do autor 


\section{PARTICIPAÇÃO NAS COMPRAS DIADEMA}

POR SETOR CENSITÁRIO

MAPA NÚMERO 5.23

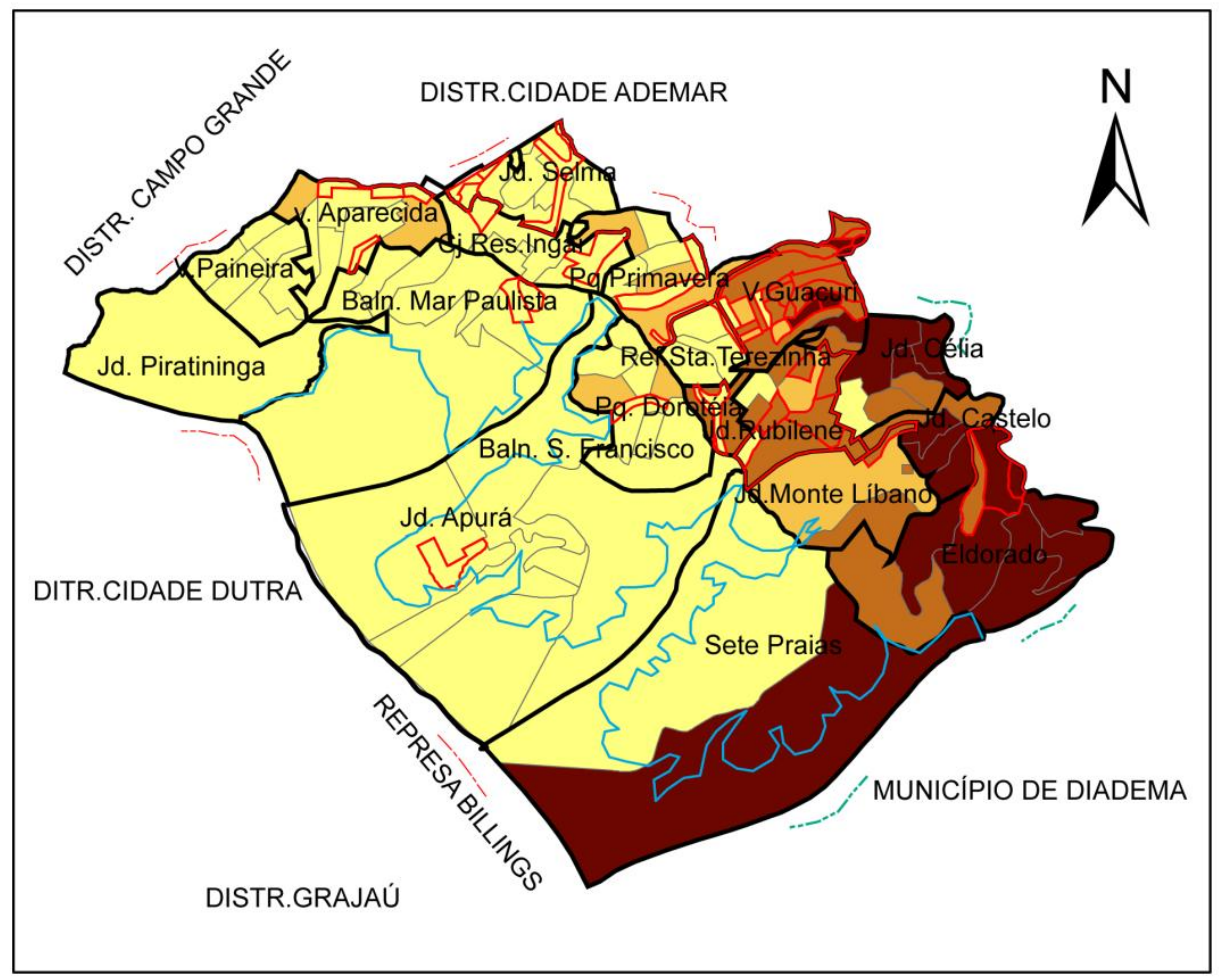

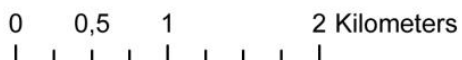

Autor: Shinhiti Osanai

Fonte: pesquisa do autor
Participação nas compras

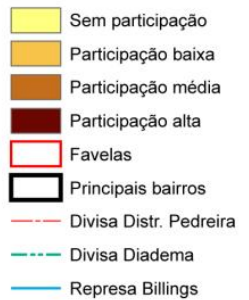


Figura 5.3 - REDE SOCIAL DOS MORADORES SOB INFLUÊNCIA DO SHOPPING CENTER INTERLAGOS

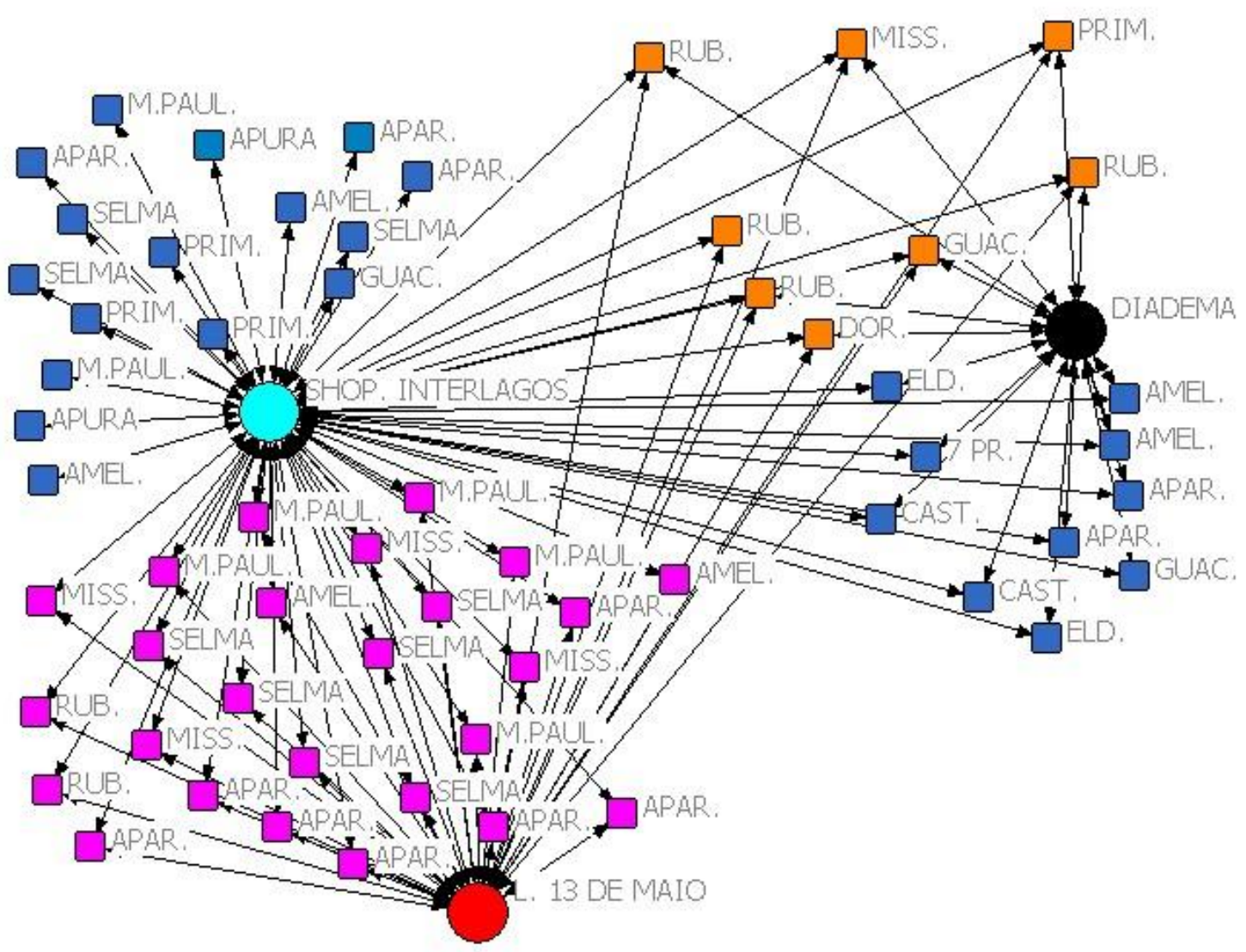

Obs.: alguns moradores também compram em outros centros concomitantemente com Shopping Center Interlagos, podendo ocorrer às compras simultâneas entre Shopping Center Interlagos e Largo 13 de Maio (cor lilás); Shopping Center Interlagos e Diadema (cor azul abaixo de Diadema); e Largo 13 de Maio, Diadema e Shopping Center Interlagos (cor ocre).

Fonte: pesquisa do autor 


\section{PARTICIPAÇÃO NAS COMPRAS}

\section{SHOPPING CENTER INTERLAGOS/INTERLAR}

POR SETOR CENSITÁRIO

MAPA NÚMERO 5.24

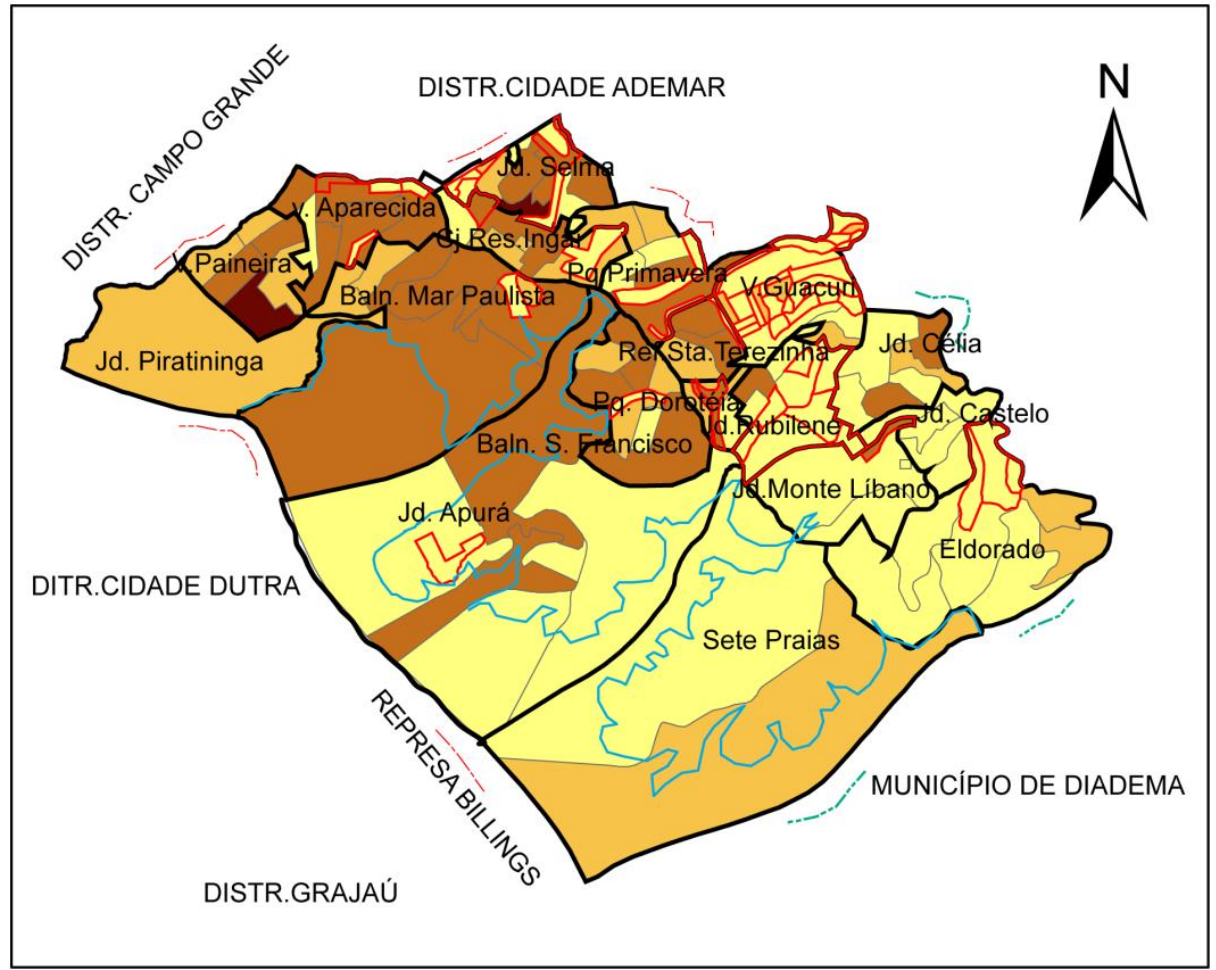

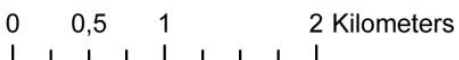

Autor: Shinhiti Osanai

Fonte: pesquisa do autor
Participação nas compras

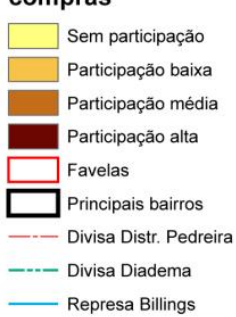




\subsection{Medida de centralidade grau ("degree")}

De acordo com o texto apresentado na página 51, a medida de grau indica a quantidade de relações ou ligações que cada ator ou nó mantêm com os nós de uma determinada rede social. Quanto maior o resultado do grau de um determinado nó, maior é a sua força de atração. Em outras palavras, o tipo de comércio, por exemplo, de roupa para cama, mesa e banho localizado num determinado ponto mais "central", 5.4 apresentar o valor de grau bastante elevado por atrair grande número de consumidores. Os nós hierarquicamente superiores podem apresentar os valores de grau mais elevados. Os níveis de hierarquia de determinados centros podem ser classificados, por meio dos resultados obtidos do cálculo de grau em conseqüência da estrutura de uma rede social.

Em relação ao Distrito de Pedreira, o centro comercial de Diadema, Largo 13 de Maio e Shopping Center Interlagos constituem os centros de hierarquia mais elevados em consequiência da obtenção dos pontos mais altos da medida de grau. Em termos globais, Diadema obteve o total de 336 pontos ficando em primeiro lugar, seguido por Largo 13 de Maio com 302 pontos e o Shopping Center Interlagos em terceiro em decorrência dos 220 pontos (tabela 5.1 e mapas 5.25 e 5.26 ).

Tabela 5.1 - RESULTADO GLOBAL DA MEDIDA DE GRAU

\begin{tabular}{cccc}
\hline TIPOS DE BENS & $\begin{array}{c}\text { LARGO 13 DE } \\
\text { MAIO }\end{array}$ & DIADEMA & $\begin{array}{c}\text { SHOPPING } \\
\text { INTERLAGOS }\end{array}$ \\
\hline Bens duráveis & 267 & 221 & 189 \\
Alimentícios & 28 & 56 & 23 \\
Diversos & 7 & 59 & 8 \\
TOTAL & 302 & 336 & 220
\end{tabular}

Obs.: Resumo das tabelas 5.2; 5.3 e 5.4

Fonte: Apêndice A

Algumas vezes, os valores globais de grau, quando são elevados, podem não ser necessariamente suficientes, para o entendimento das centralidades mais importantes. Ao 
analisar cada centro, por grupo de categoria de produtos, os resultados podem apresentar conclusões mais precisas e específicas.

A análise da medida de centralidade grau encontra-se dividida em três partes: bens de freqüência de demanda baixa; bens de freqüência mediana; bens de freqüência diária ou semanal.

A análise do comércio que colabora para a manutenção de nível hierárquico alto, em conseqüência de freqüência de demanda baixa e necessidade de apresentar maior diversificação possível, foi desenvolvida a partir dos dados obtidos pelo comércio de roupas de cama, mesa e banho, calçados, eletro-eletrônicos, móveis, utensílios para o lar e vestuário.

A classificação do Largo 13 de Maio se reverte para o primeiro lugar em função dos 267 pontos, Diadema cai para o segundo lugar com 221 pontos e o Shopping Center Interlagos, em conseqüência dos 189 pontos, continua em terceiro lugar, o que altera significativamente a posição global dando vantagens a Diadema (Tabela 5.1).

Observa-se alguma preferência pela região do Largo 13 de Maio, bastante freqüente no Distrito de Pedreira, inclusive entre alguns moradores que estão na área de influência significativa do comércio de Diadema. O sistema de transporte urbano favorece o acesso a Santo Amaro, apesar de a sua distância ser bem maior em relação a Diadema.

Tabela 5.2 - MEDIDA DE GRAU - PRODUTOS DE DEMANDA DE FREQÜÊNCIA BAIXA

\begin{tabular}{|c|c|c|c|c|c|c|}
\hline \multirow{2}{*}{$\begin{array}{c}\text { TIPOS DE BENS } \\
\text { Vestuário }\end{array}$} & \multicolumn{2}{|c|}{$\begin{array}{c}\text { LARGO } 13 \text { DE } \\
\text { MAIO }\end{array}$} & \multicolumn{2}{|c|}{ DIADEMA } & \multicolumn{2}{|c|}{$\begin{array}{c}\text { SHOPPING CENTER } \\
\text { INTERLAGOS }\end{array}$} \\
\hline & CR3L13A & 61 & CR3DIAA & 34 & CR3INTA & 36 \\
\hline Cama, mesa e banho & CC3L13A & 57 & CC3DIAA & 33 & CC3INTA & 31 \\
\hline Calçados & CY3L13A & 43 & CY3DIAA & 36 & CY3INTA & 35 \\
\hline Eletro-eletrônicos & CE3L13A & 43 & CE3DIAA & 50 & CE3INTA & 42 \\
\hline Móveis & CX3L13A & 35 & CX3DIAA & 39 & CX3INTA & 25 \\
\hline Utensílios para o lar & CW2L13A & 28 & CW2DIAA & 29 & CW3INTA & 20 \\
\hline TOTAL & & 267 & & 221 & & 189 \\
\hline
\end{tabular}




\section{CENTRALIDADES - NÍVEIS HIERÁRQUICOS} MEDIDA DE GRAU - VALORES GLOBAIS DISTRITO DE PEDREIRA MAPA NÚMERO 5.25

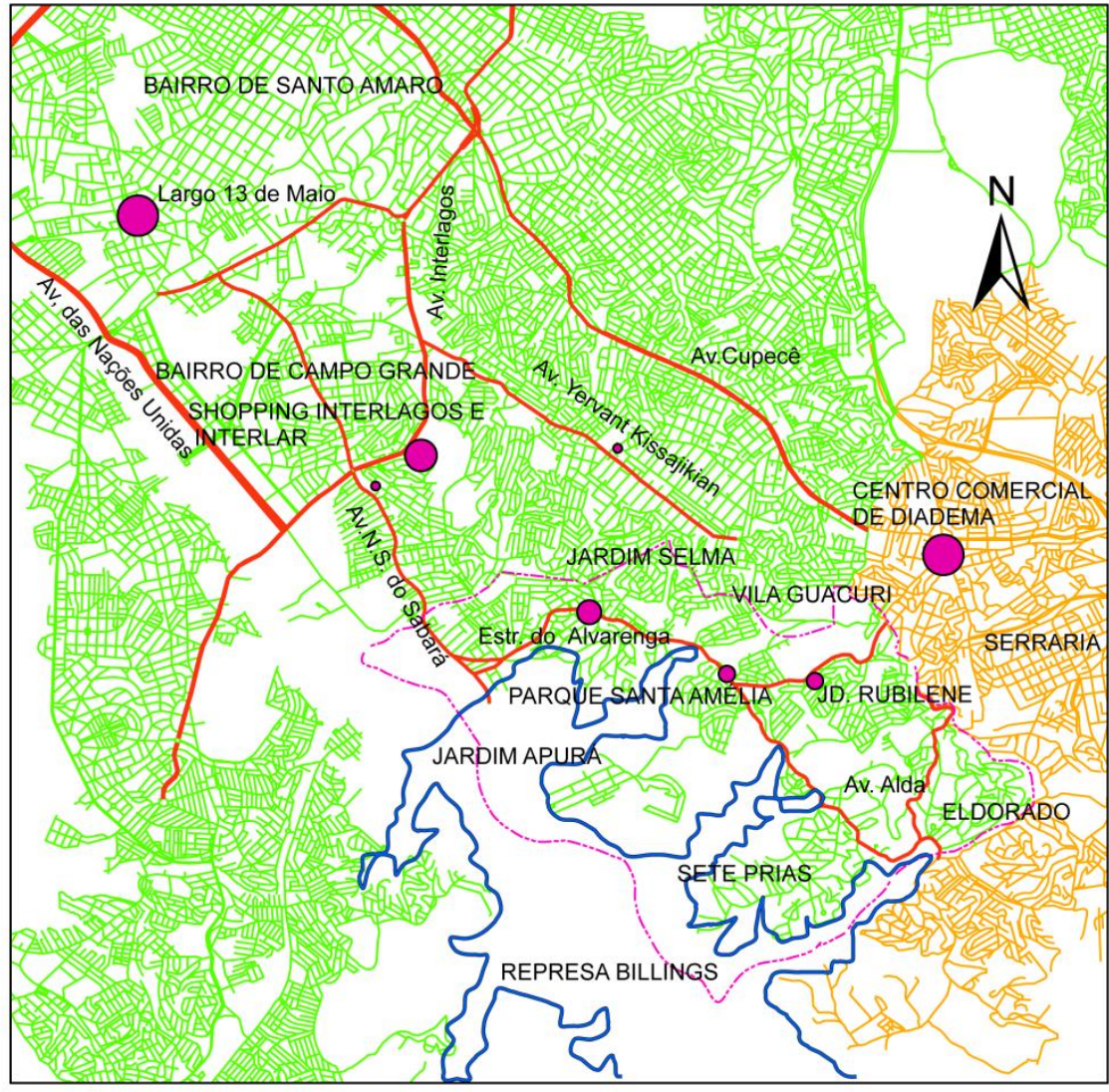

$\begin{array}{lll}0 & 0,5 & 1\end{array}$ 2 Kilometers

Autor: Shinhiti Osanai

Fonte: pesquisa do autor
Medida de grau

- $31-46$

- $47-119$

O $120-160$

$161-220$

221-336

São Paulo Diadema Divisa Distr. Pedreira Represa Billings 
CENTRALIDADES - NÍVEIS HIERÁRQUICOS

MEDIDA DE GRAU - BENS DE FREQÜÊNCIA DE DEMANDA BAIXA

DISTRITO DE PEDREIRA

MAPA NÚMERO 5.26

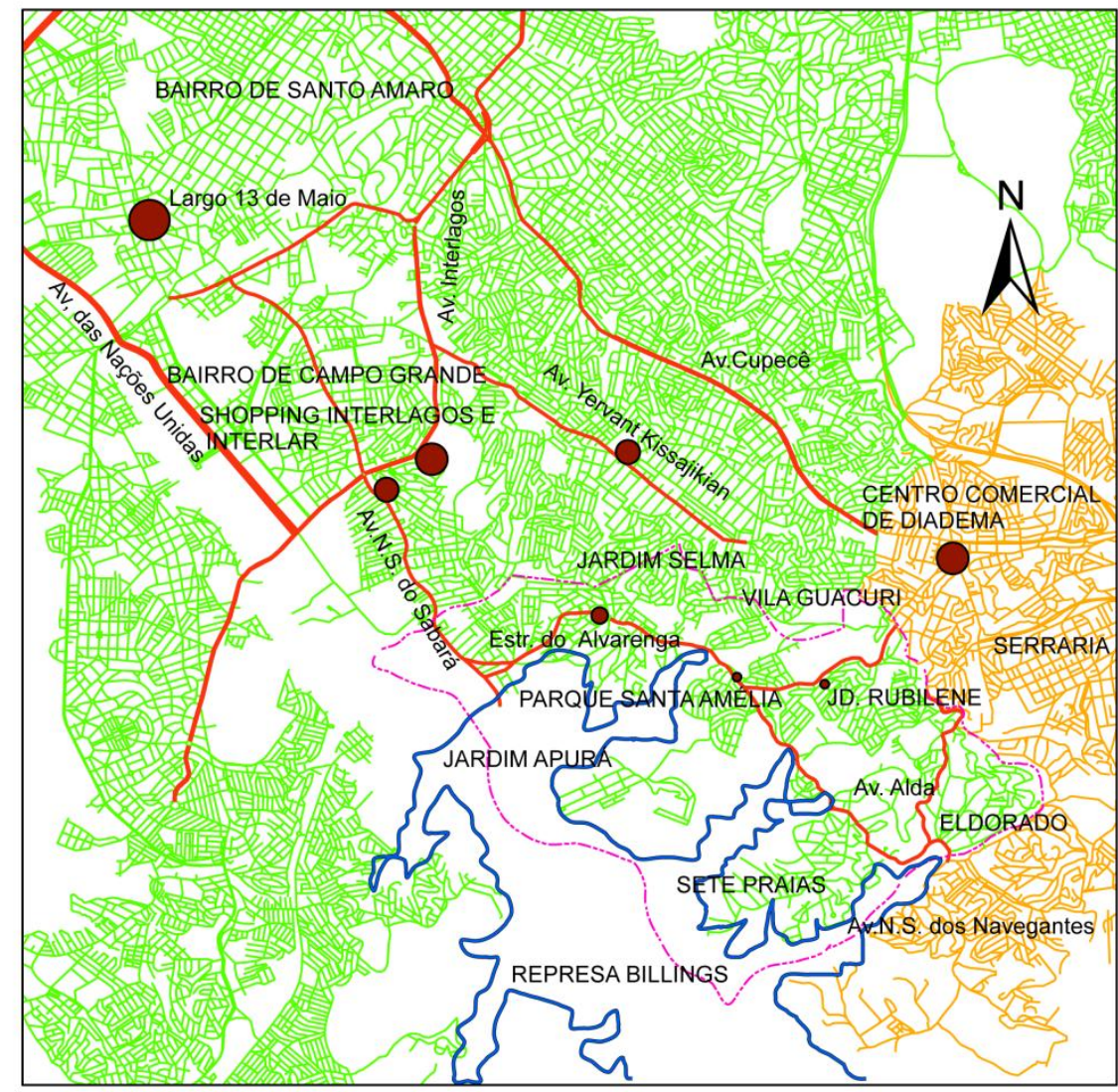

Medida de grau

$\begin{array}{lll}0 & 0,5 & 1\end{array}$ 2 Kilometers

Autor: Shinhiti Osanai

Fonte: pesquisa do autor
-

- 2 - 14

15-20

21-221

$222-267$ São Paulo Diadema Divisa Distr. Pedreira Represa Billings 
Os resultados obtidos para o comércio com característica principal de apoio à moradia, de frequiência mediana de demanda e que colabora para a manutenção de nível hierárquico médio, em conseqüência da diversificação de seus produtos, foram elaborados com base na análise do comércio de artigos para bazar, alimentos, produtos de limpeza, supermercados de grande e médio portes e produtos para animais denominados de pet shop (Tabela 5.3).

Nesses produtos, Diadema obteve 56 pontos e ficou em primeiro lugar, seguido por Largo 13 de Maio e Shopping Center Interlagos com 28 e 23 pontos respectivamente.

Esses ramos de comércio estão presentes no centro comercial de Diadema de maneira significativa e, também são muito freqüentes em todo o Distrito de Pedreira, com exceção de supermercados de grande e médio porte em número bastante reduzido. Não se verificam esses tipos de ramos de atividade no Largo 13 de Maio, exceto poucos bazares e um supermercado de médio porte. Muitos moradores da região de divisa com Diadema, de comércio muito precário, habitualmente são atraídos pelo comércio do município vizinho por causa da sua proximidade. Um dos pontos fortes no ramo de produtos alimentícios, do Largo 13 de Maio e de Diadema, é o comércio especializado em produtos provenientes do nordeste, conhecida por Casa do Norte entre a população. Esse último, não faz parte dos serviços oferecidos pelo Shopping Center Interlagos, exceto o hipermercado Carrefour que também atua em uma unidade bem próxima ao centro de Diadema.

Em relação a outros ramos, tais como farmácia, material de construção e cine, foto e óptica, Diadema permanece em primeiro lugar conseguindo 59 pontos. O Largo 13 de Maio e Shopping Center Interlagos com 7 e 8 pontos, respectivamente, são os menos preferidos. O Shopping Center Interlagos, por causa do seu vizinho Shopping Center Interlar, especializado em decoração e material de construção, não participa nesse tipo de comércio e ambos pertencem à mesma administradora. Em Santo Amaro os estabelecimentos do ramo de material de construção estão em pontos relativamente afastados do Largo 13 de Maio, existe apenas uma ou outra loja especializada em ferragens. Em Diadema muitos estabelecimentos do ramo de material de construção ainda permanecem no centro. Muitos moradores do Distrito de Pedreira preferem comprar remédios na Drogaria São Paulo de Diadema (Tabela 5.4). 
Tabela 5.3 - MEDIDA DE GRAU - PRODUTOS DE DEMANDA DE FREQÜÊNCIA MEDIANA

\begin{tabular}{|c|c|c|c|c|c|c|}
\hline \multirow{2}{*}{$\begin{array}{c}\text { RAMO DE } \\
\text { Bazar }\end{array}$} & \multicolumn{2}{|c|}{ LARGO 13 DE } & \multicolumn{2}{|c|}{ DIADEMA } & \multicolumn{2}{|c|}{ SHOPPING } \\
\hline & CV2L13A & 11 & CV2DIAA & 18 & & \\
\hline Alimentícios & CA2L13N & 15 & CA2DIAN & 14 & & \\
\hline Super & CS2L13A & 2 & CS2DIAA & 3 & CS3INTX & 23 \\
\hline Hiper & & & CS3DIAA & 15 & & \\
\hline Pet shop & & & CP2DIAA & 4 & & \\
\hline Produtos de & & & CZ2DIAA & 2 & & \\
\hline SOMA & & 28 & & 56 & & 23 \\
\hline
\end{tabular}

Fonte: Apêndice A

Tabela 5.4 - MEDIDA DE GRAU - OUTROS PRODUTOS DE FREQÜÊNCIA DE DEMANDA BAIXA

\begin{tabular}{|c|c|c|c|c|c|c|}
\hline RAMO DE & \multirow{2}{*}{\multicolumn{2}{|c|}{$\begin{array}{l}\text { LARGO } 13 \text { DE } \\
\text { MAIO }\end{array}$}} & \multirow{2}{*}{\multicolumn{2}{|c|}{ DIADEMA }} & \multirow{2}{*}{\multicolumn{2}{|c|}{$\begin{array}{c}\text { SHOPPING CENTER } \\
\text { INTERLAGOS }\end{array}$}} \\
\hline ATIVIDADE & & & & & & \\
\hline óptica & CO2L13A & 1 & CO2DIAA & 13 & CO2INTA & 8 \\
\hline Farmácia & CF2L13A & 5 & CF2DIAA & 32 & & \\
\hline $\begin{array}{l}\text { Artigos para } \\
\text { bebê }\end{array}$ & CB2L13A & 1 & & & & \\
\hline $\begin{array}{l}\text { Material de } \\
\text { construção }\end{array}$ & & & CM2DIAA & 14 & & \\
\hline SOMA & & 7 & & 59 & & 8 \\
\hline
\end{tabular}

Fonte: Apêndice A 
Em seguida, são analisados os dados dos centros secundários em relação ao comércio de apoio imediato à moradia, de freqüência diária ou semanal de utilização, e que colabora para a manutenção de nível hierárquico baixo. Os principais centros secundários, localizados no Distrito de Pedreira, são a Estrada do Alvarenga, Parque Santa Amélia, Jardim Rubilene. Fora do Distrito, estão os centos secundários da Av. Yervant Kissajikian e Av. Nossa Senhora do Sabará, localizados, respectivamente, nos Distritos de Cidade Ademar e de Campo Grande.

O comércio da Estrada do Alvarenga (Vide tabela 5.5), com total de 160 pontos, dos quais 48 pontos foram contribuídos pelos supermercados Ricoy, União e Dia e, também pelas casas especializadas em produtos provenientes do nordeste, conta com uma estrutura comercial bastante diversificada através do comércio de vestuário, calçados, utensílios para o lar, óptica, farmácia, bazar, material de construção e principalmente do comércio do tipo Casa do Norte. Os principais usuários são os moradores dos bairros Mar Paulista, Conjunto Residencial Ingaí, Vila Aparecida, Jardim Selma e Vila Missionária. A Estrada do Alvarenga é um dos principais acessos ao Distrito de Pedreira e praticamente a maioria das linhas de ônibus para Santo Amaro passa por ela, também as linhas de ônibus em direção ao metrô Jabaquara, e outras atendendo o Centro Histórico e a região do Itaim Bibi.

O comércio do Parque Santa Amélia (Vide tabela 5.5), obtendo total de 109 pontos, dos quais 66 são provenientes do Supermercado Pedreira, é formado por uma aglomeração de variados ramos de comércio em torno do referido supermercado e, praticamente encontram-se as mesmas atividades do comércio da Estrada do Alvarenga. Os principais usuários são os moradores dos bairros de Parque Santa Amélia, Balneário São Francisco, Parque Primavera, Refúgio Santa Terezinha e Jardim Apurá. O Supermercado Pedreira é uma exceção ao exercer uma força de atração muito forte de preferência dos moradores provenientes de áreas mais distantes, por exemplo, Vila Guacuri, Jardim Rubilene, Eldorado e Mar Paulista. É um local geograficamente privilegiado proporcionado pela disponibilidade de linhas de ônibus que atendem praticamente todos os locais do Distrito de Pedreira. 


\section{PARTICIPAÇÃO NAS COMPRAS ESTRADA DO ALVARENGA}

DISTRITO DE PEDREIRA

POR SETOR CENSITÁRIO

MAPA NÚMERO 5.27

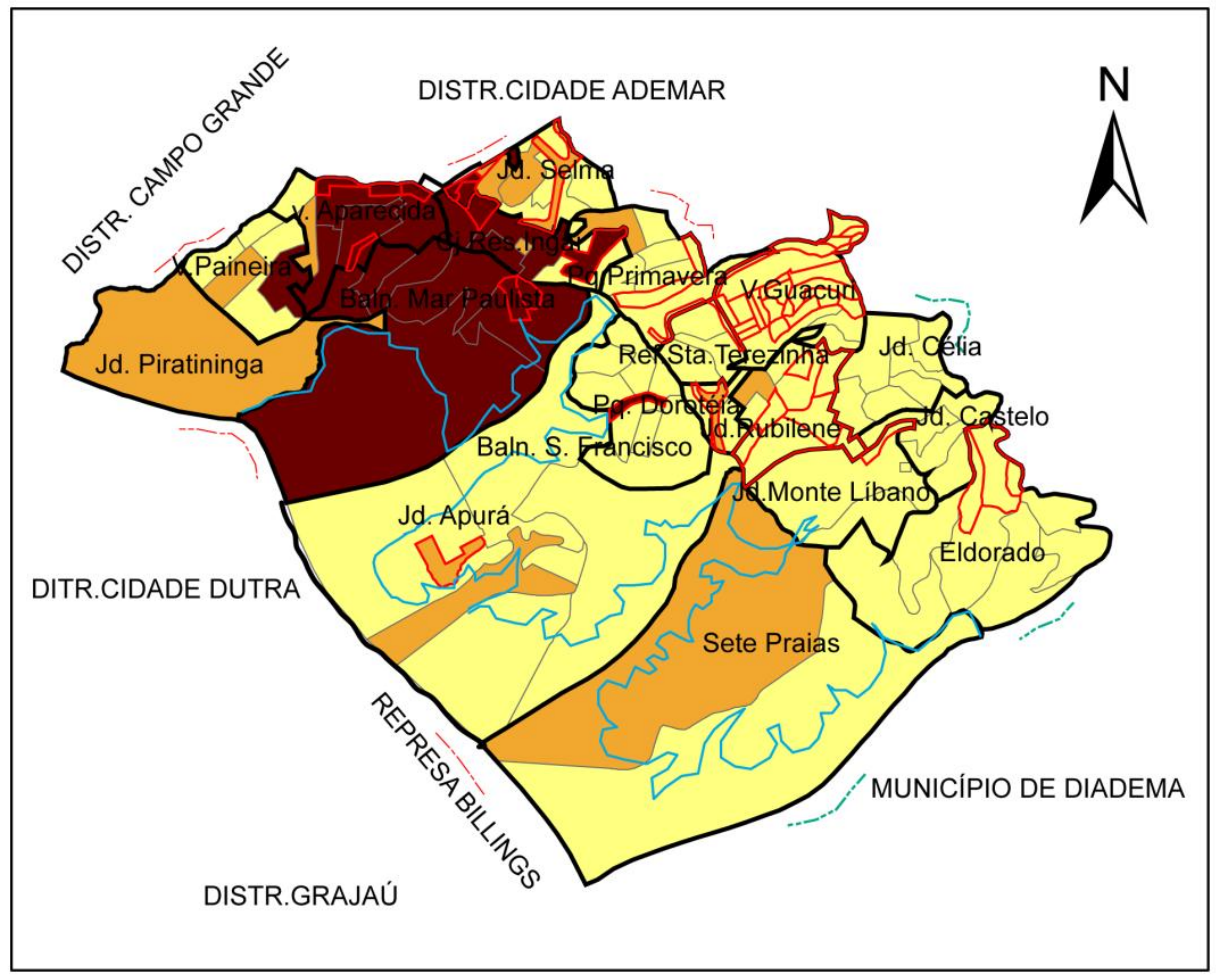

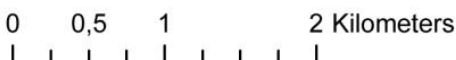

Autor: Shinhiti Osanai

Fonte: pesquisa do autor
Participação nas compras

Sem participação

Participação baixa Participaçăo média Favelas

Principais bairros - Divisa Distr. Pedreira

---- Divisa Diadema

_ Represa Billings 
Figura 5.4 - REDE SOCIAL DOS MORADORES SOB INFLUÊNCIA DA ESTRADA DO ALVARENGA

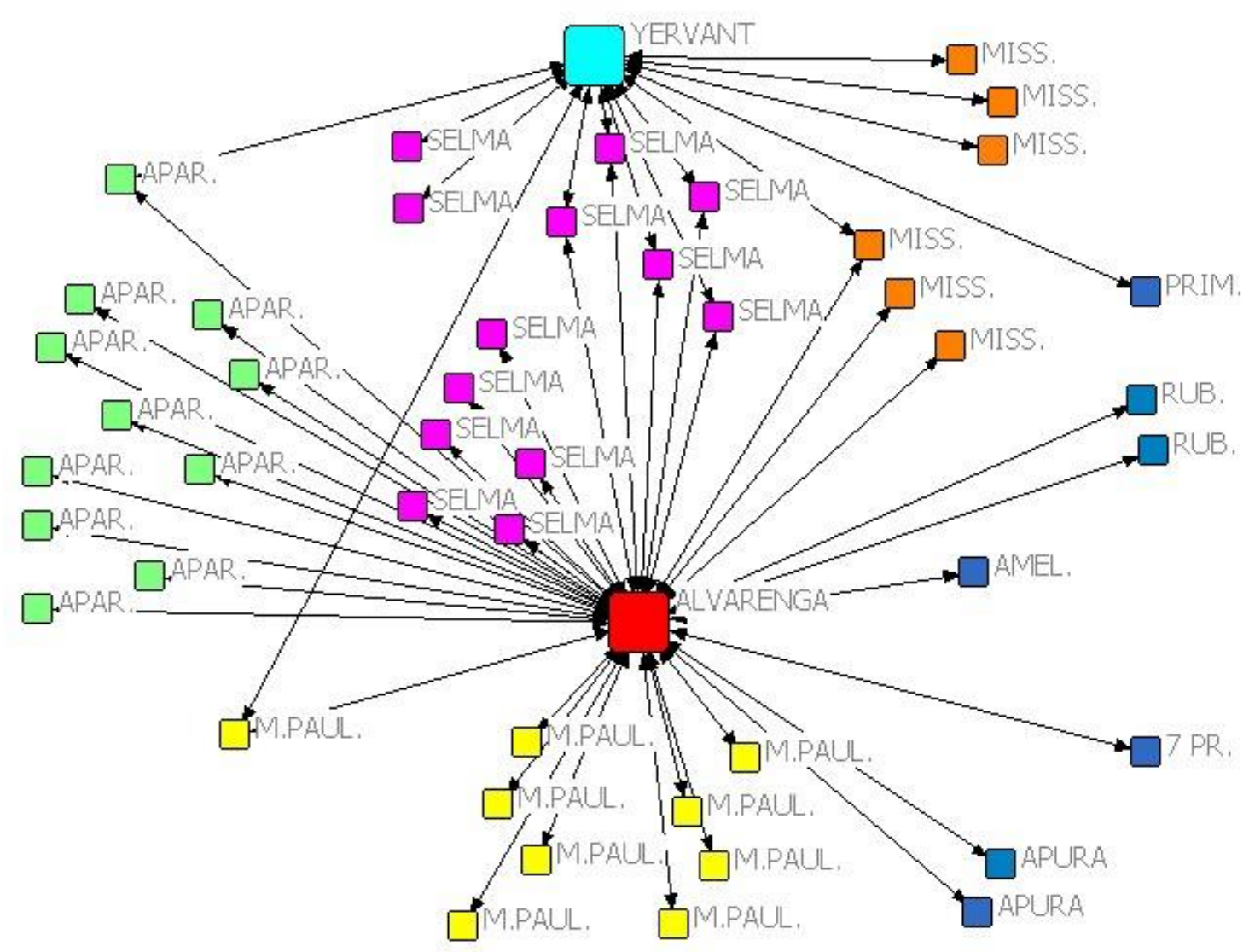

Obs.: alguns moradores compram na Estrada do Alvarenga; e também na Avenida Yervant Kissajikian

Fonte: pesquisa do autor 


\section{PARTICIPAÇÃO NAS COMPRAS PARQUE SANTA AMÉLIA}

DISTRITO DE PEDREIRA

POR SETOR CENSITÁRIO

MAPA NÚMERO 5.28
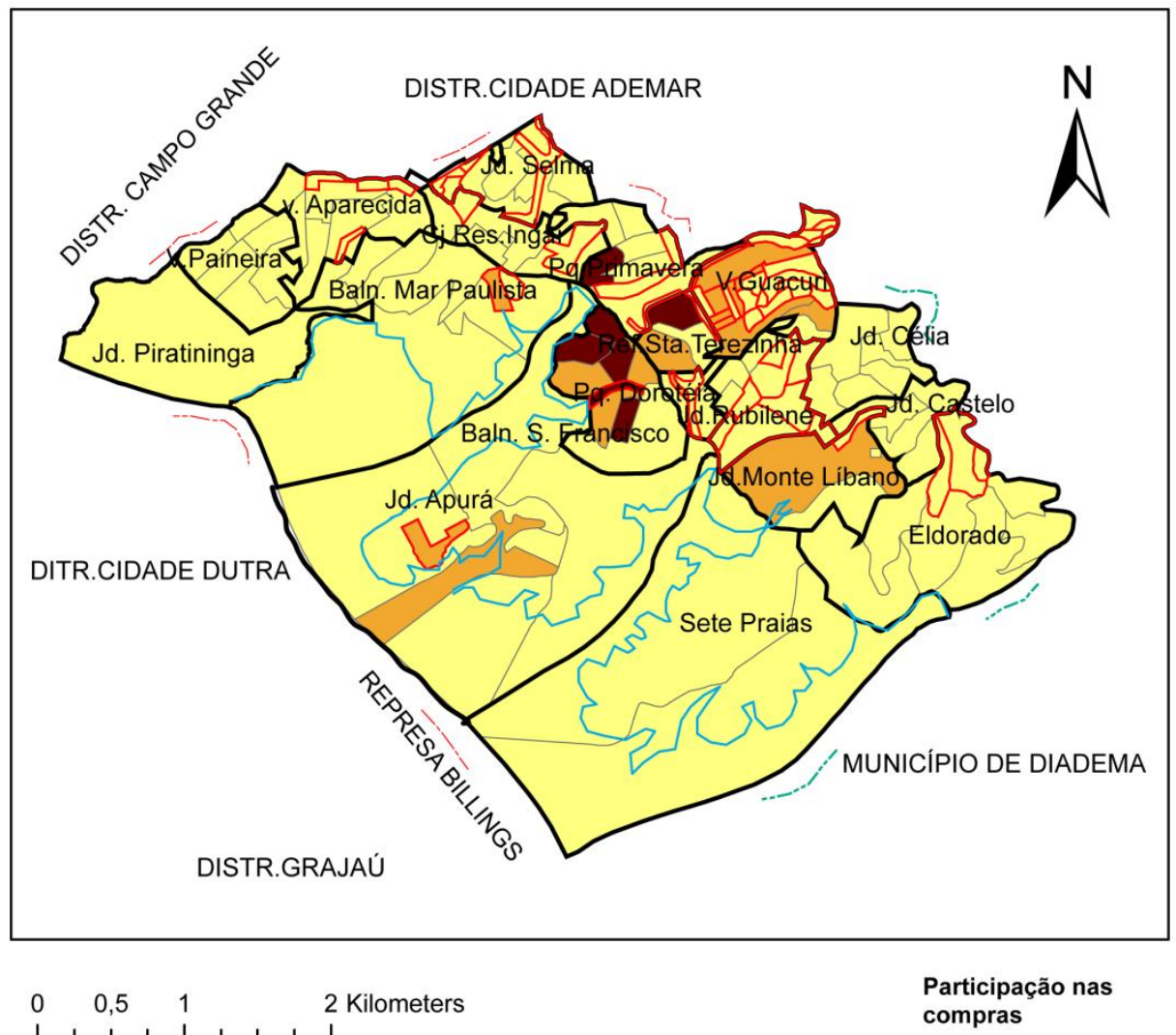

Participação nas

Autor: Shinhiti Osanai

compras

Fonte: pesquisa do autor

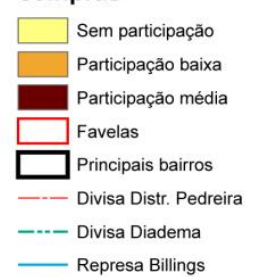




\section{PARTICIPAÇÃO NAS COMPRAS SUPERMERCADO PEDREIRA E DEPÓSITO 5 IRMÃOS}

DISTRITO DE PEDREIRA

POR SETOR CENSITÁRIO

MAPA NÚMERO 5.29

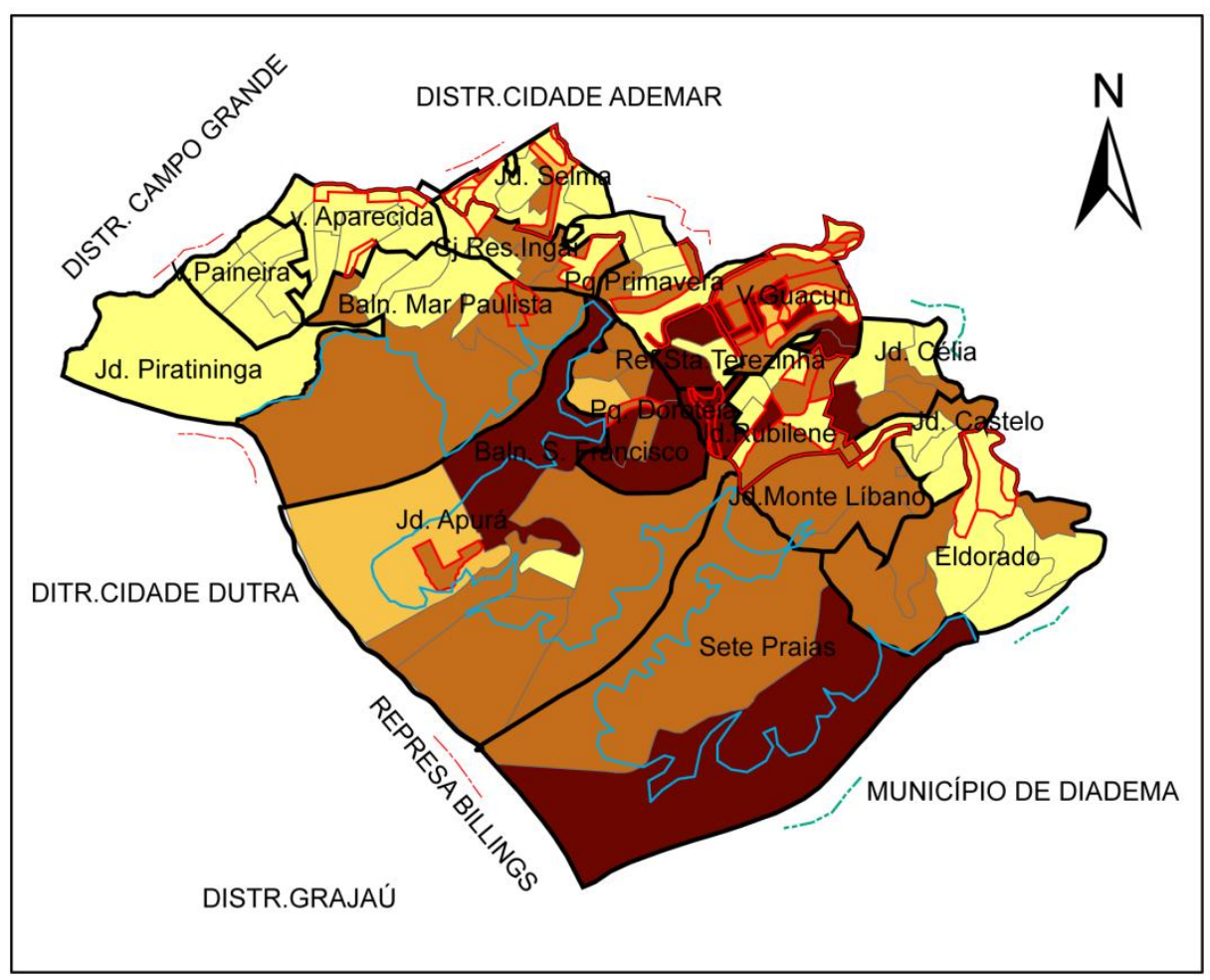

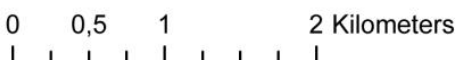

Autor: Shinhiti Osanai

Fonte: pesquisa do autor
Participação nas compras

$\square$ Sem preferência

Somente Dep. 5 Irmãos

Somente Sup. Pedreira

Ambos - Pedreira e 5 Irmãos

$\square$ Favelas

Principais bairros

- Divisa Distr. Pedreira

---- Divisa Diadema

_ Represa Billings 
Figura 5.5 - REDE SOCIAL DOS MORADORES SOB INFLUÊNCIA DA REGIÃO DO PARQUE SANTA AMÉLIA

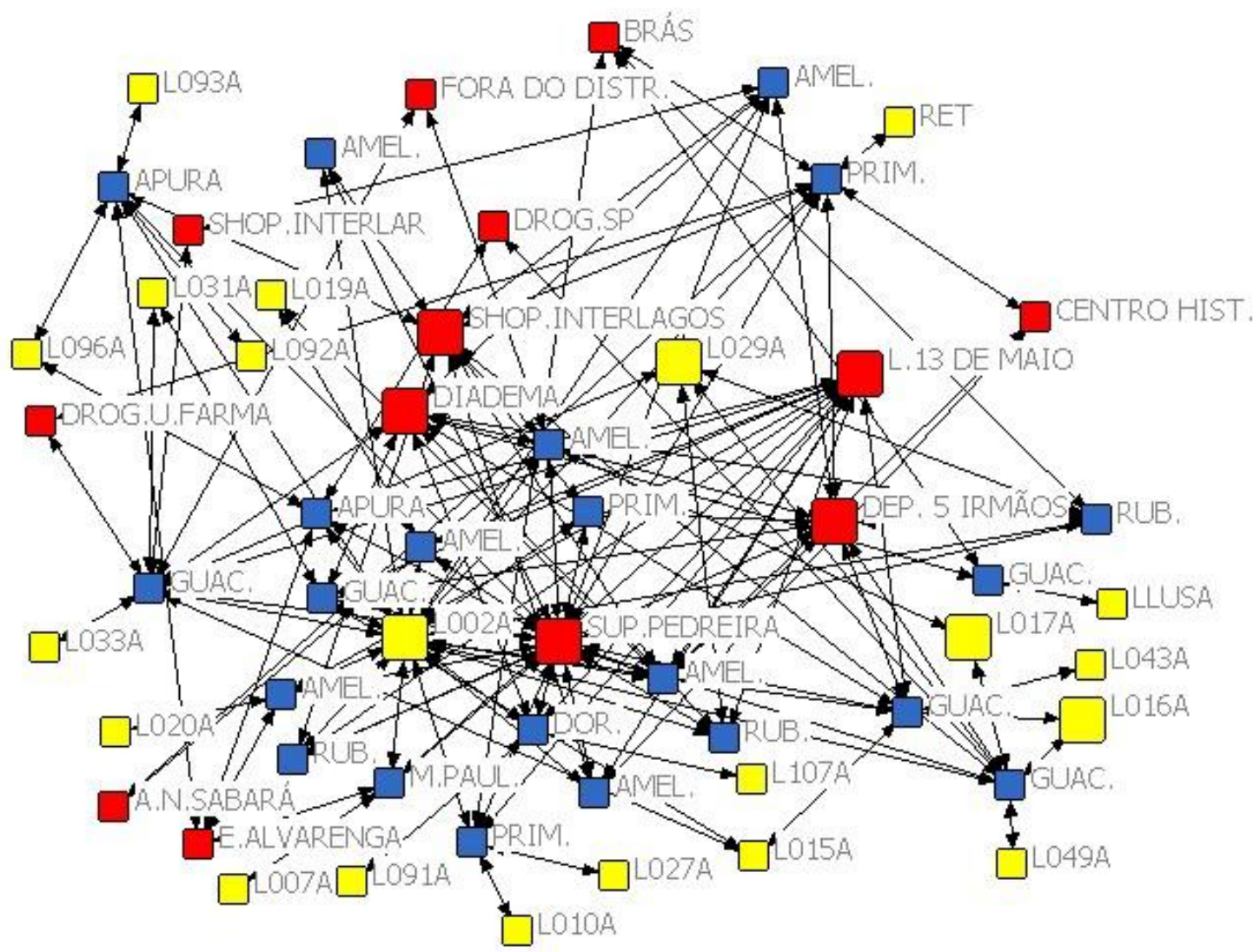

Obs.: grupo de moradores que mantêm uma relação forte com o Supermercado Pedreira e muitos, também, continuam se relacionando fortemente com o Largo 13 de Maio; Shopping Center Interlagos ou Diadema. O Depósito 5 Irmãos aparece com algum destaque.

Fonte: pesquisa do autor 
Figura 5.6 - REDE SOCIAL DOS MORADORES QUE POSSUEM PREFERÊNCIA PELO SUPERMERCADO PEDREIRA E DEPÓSITO 5 IRMÃOS

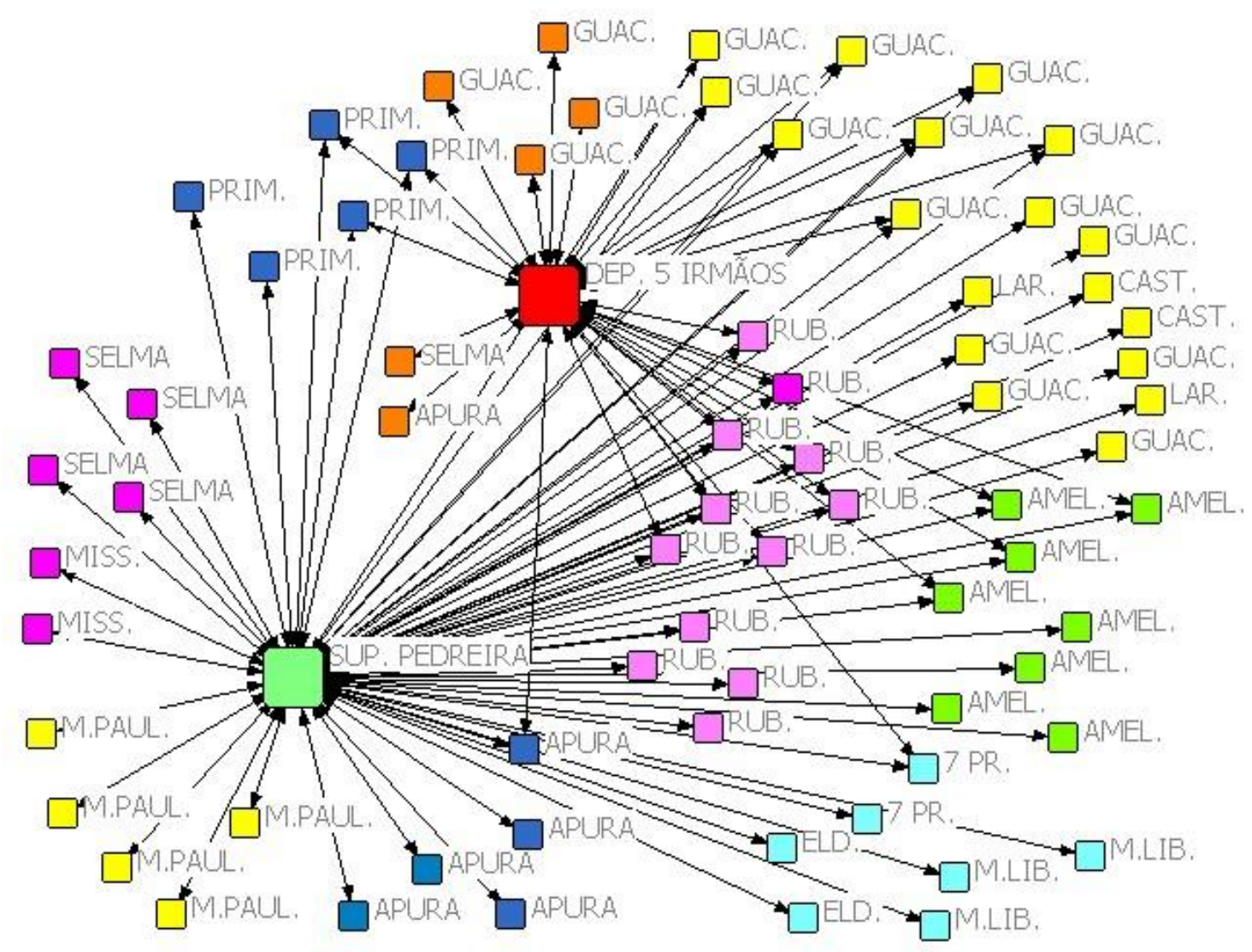

Fonte: pesquisa do autor

O comércio do Jardim Rubilene e de Vila Guacuri (Vide tabela 5.5) obteve 119 pontos, dos quais 58 pontos foram obtidos pelo Depósito 5 Irmãos, Supermercado Mamb’s e Supermercado Ki Barato. Esses dois supermercados atendem principalmente os moradores das proximidades e não atraem compradores de distâncias mais significativas. O Depósito 5 Irmãos atrai compradores praticamente de toda a região sul e central do Distrito de Pedreira. A Rua Professor Cardozo de Mello Neto é a principal via de acesso. Entretanto, conta com um forte concorrente, o comércio de Diadema, principalmente entre os moradores das proximidades da divisa municipal. Atende uma região constituída por grandes favelas, principalmente a do Pantanal que ocupa aproximadamente $75 \%$ da extensão de um dos lados da Rua Professor Cardozo de Mello Neto. Quase todos os estabelecimentos comerciais são de pequeno porte e, proporcionalmente, em número bastante reduzido, nas proximidades da 
divisa com Diadema. Na região de divisa, a legislação de proteção ambiental pode ser uma barreira natural para a instalação de comércio melhor estruturado, verifica-se também a carência de imóveis adequados para a instalação de comércio que demande maior área construída.

O comércio da Avenida Yervant Kissajikian (Vide tabela 5.6), embora tenha uma boa estrutura, inclusive com oferta de agências bancárias, supermercados de médio porte, comércio de eletro-eletrônicos, móveis, vestuário e calçados, é de pouca importância para alguns moradores do Distrito de Pedreira. Obteve apenas 46 pontos e atende principalmente os habitantes da Vila Missionária e Jardim Selma. Deve atrair compradores do Distrito vizinho de Cidade Ademar.

O centro secundário da Avenida Nossa Senhora do Sabará (Vide tabela 5.6) localiza-se no Distrito vizinho de Campo Grande e é de pouca importância para alguns moradores da amostra do Distrito de Pedreira. Obteve apenas 31 pontos, sem incluir a Drogaria São Paulo. No bairro de Campo Grande encontra-se o setor bancário mais próximo do Distrito de Pedreira com a presença de agências dos principais bancos. O principal comércio é de móveis, e conta com a participação de supermercados maiores, tais como o Bom Preço e Dia. A Drogaria São Paulo mantém uma força de atração forte entre os moradores desse Distrito alcançando 20 pontos. Um variado comércio de pequeno porte, por exemplo, bazar, comércio de roupas de cama, mesa e banho, lojas de autopeças, decoração e lojas de cine, foto e óptica está disponível. Efetuam as compras nessa avenida, principalmente alguns moradores de Vila Aparecida e de Mar Paulista. 


\title{
PARTICIPAÇÃO NAS COMPRAS JARDIM RUBILENE
}

\author{
DISTRITO DE PEDREIRA
}

POR SETOR CENSITÁRIO

MAPA NÚMERO 5.30

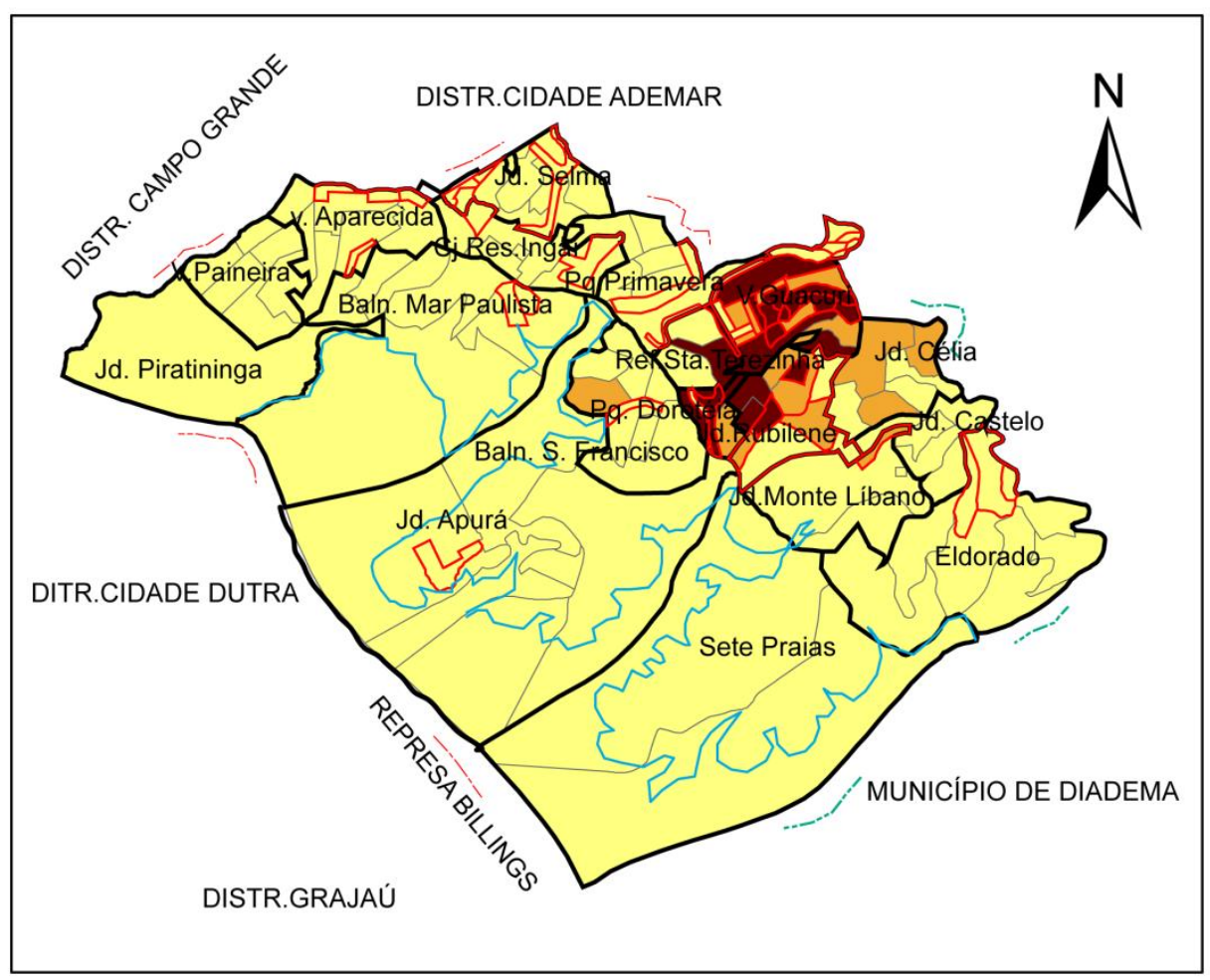

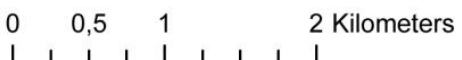

Autor: Shinhiti Osanai

Fonte: pesquisa do autor
Participação nas

compras
$\square$ Sem participação

Participação baixa

Participação média

Favelas

Principais bairros Divisa Distr. Pedreira

---- Divisa Diadema

_ Represa Billings 
Figura 5.7 - REDE SOCIAL DOS MORADORES SOB INFLUÊNCIA DE JARDIM

\section{RUBILENE}

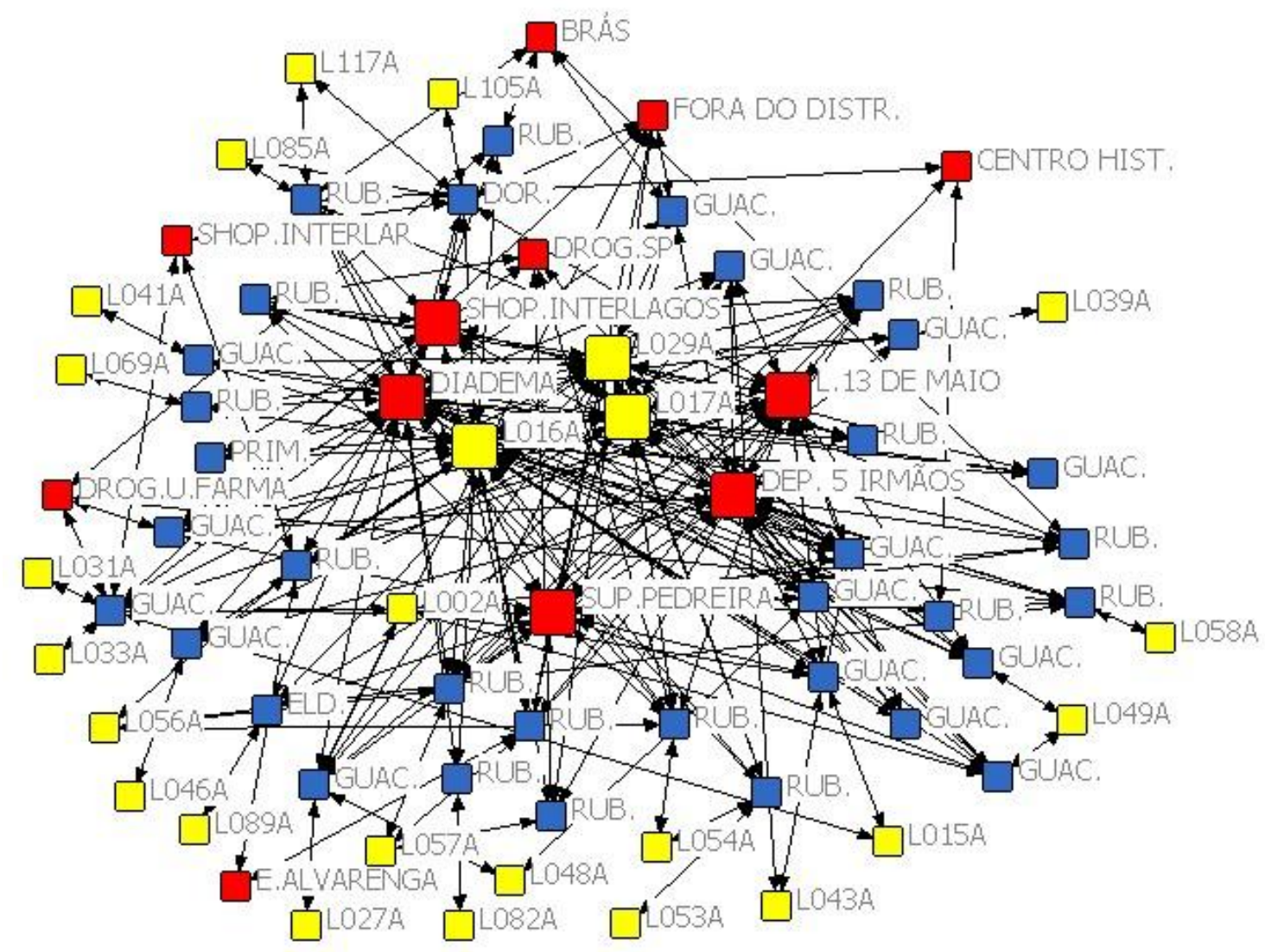

Obs.: os três nós centrais - quadrados amarelos maiores - (L029A; L017A e L016A) representam o comércio local da região do Jardim Rubilene, e existe uma forte relação com o Largo 13 de Maio; Diadema; Shopping Center Interlagos; Depósito 5 Irmãos e Supermercado Pedreira.

Fonte: pesquisa do autor 
Tabela 5.5 - MEDIDA GRAU PARA O COMÉRCIO DA ESTRADA DO ALVARENGA, PARQUE SANTA AMÉLIA E JARDIM RUBILENE

\begin{tabular}{|c|c|c|c|c|c|c|}
\hline \multirow{3}{*}{$\begin{array}{c}\text { RAMO DE } \\
\text { ATIVIDADE } \\
\text { Vestuário }\end{array}$} & \multirow{2}{*}{\multicolumn{2}{|c|}{$\begin{array}{l}\text { ESTRADA DO } \\
\text { ALVARENGA }\end{array}$}} & \multirow{2}{*}{\multicolumn{2}{|c|}{$\begin{array}{c}\text { PARQUE SANTA } \\
\text { AMÉLIA }\end{array}$}} & \multirow{2}{*}{\multicolumn{2}{|c|}{ JARDIM RUBILENE }} \\
\hline & & & & & & \\
\hline & CR3100A & 1 & & & CW2029A & 1 \\
\hline Calçados & CY3064A & 3 & & & & \\
\hline Utensílios & CW2064A & 10 & CW2002A & 1 & & \\
\hline $\begin{array}{l}\text { Cine, foto e } \\
\text { óptica }\end{array}$ & $\mathrm{CO} 2100 \mathrm{~A}$ & 1 & & & & \\
\hline Farmácia & CF2064A & 17 & CF2002A & 11 & CF2016A & 9 \\
\hline $\begin{array}{l}\text { Material de } \\
\text { construção }\end{array}$ & CM2064A & 25 & CM2002A & 6 & CM2017A & 37 \\
\hline Bazar & CV2064A & 24 & CV2002A & 16 & CV2017A & 7 \\
\hline Alimentícios & CA2100A & 25 & & & CA2029A & 19 \\
\hline Super mercados & CS2064A & 27 & CS2002A & 66 & CS2016A & 26 \\
\hline Pet shop & CP2064A & 15 & & & CP2017A & 9 \\
\hline $\begin{array}{l}\text { Produtos de } \\
\text { limpeza }\end{array}$ & & & CZ2002A & 1 & CZ2029A & 1 \\
\hline Padaria & CA1064A & 12 & & & CA1029G & 10 \\
\hline SOMA & & 160 & & 110 & & 119 \\
\hline
\end{tabular}

Fonte: Apêndice A 


\section{PARTICIPAÇÃO NAS COMPRAS AV.YERVANT KISSAJIKIAN}

POR SETOR CENSITÁRIO

MAPA NÚMERO 5.31

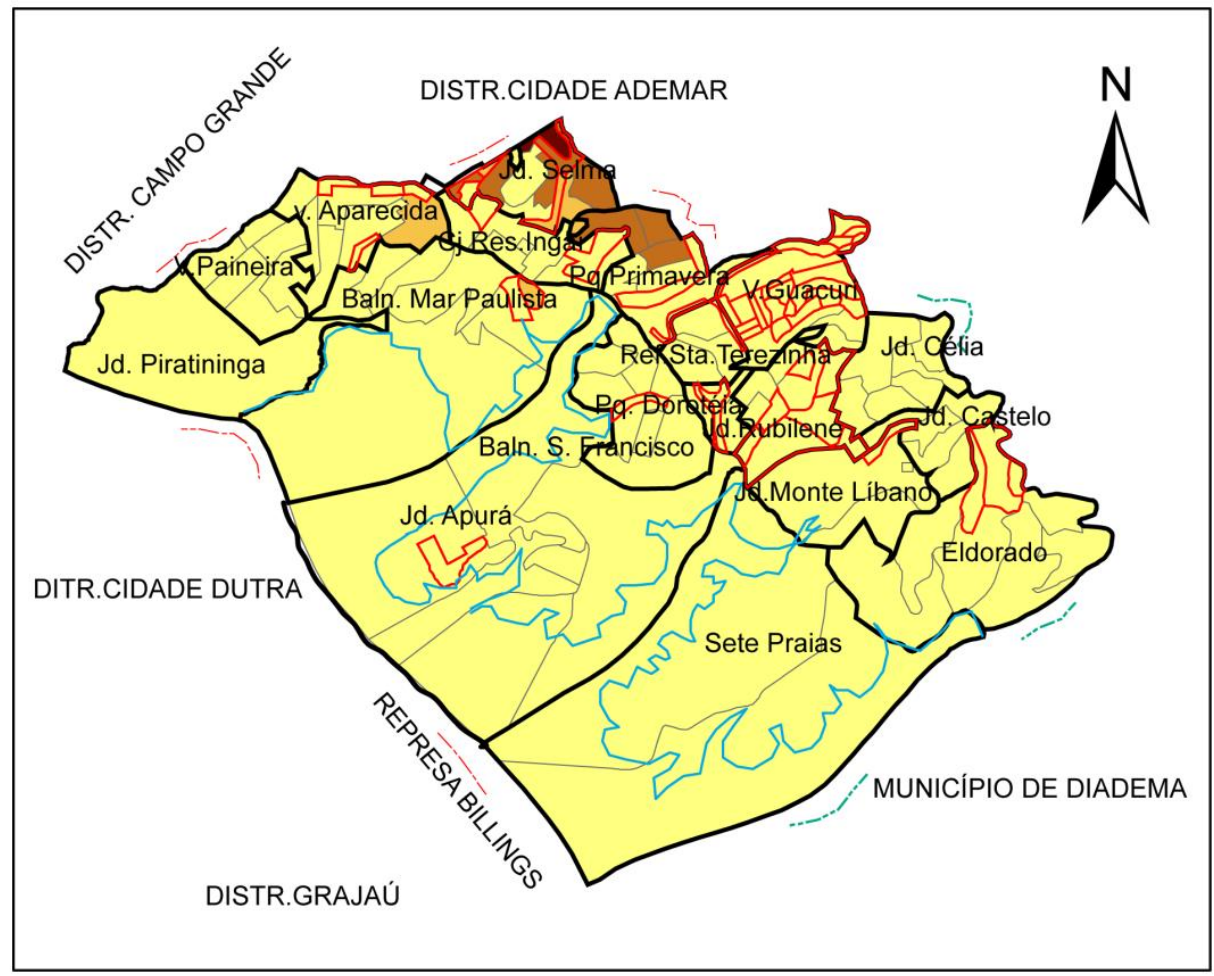

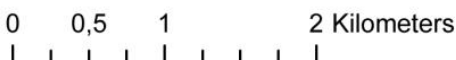

Autor: Shinhiti Osanai

Fonte: pesquisa do autor
Participação nas compras

$\square$ Sem participação

$\square$ Participação baixa

Participação média

Participação alta

$\square$ Favelas

Principais bairros - Divisa Distr. Pedreira

---- Divisa Diadema

_ Represa Billings 
Tabela 5.6 - MEDIDA DE GRAU - COMÉRCIO DA AVENIDA YERVANT KISSAJIKIAN E AVENIDA NOSSA SENHORA DO SABARÁ

\begin{tabular}{|c|c|c|c|c|}
\hline RAMO DE & \multirow{2}{*}{\multicolumn{2}{|c|}{$\begin{array}{l}\text { AV. YERVANT } \\
\text { KISSAJIKIAN }\end{array}$}} & \multirow{2}{*}{\multicolumn{2}{|c|}{$\begin{array}{c}\text { AV. NOSSA SENHORA DO } \\
\text { SABARÁ }\end{array}$}} \\
\hline ATIVIDADE & & & & \\
\hline Vestuário & CR3YERA & 1 & CR3SABA & 2 \\
\hline Cama, mesa e banho & & & $5.31=3 \mathrm{SABA}$ & 1 \\
\hline Calçados & CY3YERA & 2 & CY3SABA & 4 \\
\hline Eletro-eletrônico & CE3YERA & 7 & & \\
\hline Móveis & CX3YERA & 6 & CX3SABA & 6 \\
\hline Utensílios para o lar & CW2YERA & 4 & CW2SABA & 6 \\
\hline Cine, foto e óptica & CO2YERA & 3 & $\mathrm{CO} 2 \mathrm{SABA}$ & 4 \\
\hline Farmácia & CF2YERA & 3 & & \\
\hline $\begin{array}{l}\text { Material de } \\
\text { construção }\end{array}$ & CM2YERA & 7 & CM2SABA & 2 \\
\hline Alimentícios & CA2YERN & 2 & CA2SABN & 1 \\
\hline Super mercado & CS2YERA & 7 & CS2SABA & 3 \\
\hline Pet shop & & & CP2SABA & 1 \\
\hline Bazar & CV2YERA & 4 & CV2SABA & \\
\hline SOMA & & 13 & & 6 \\
\hline
\end{tabular}

Fonte: Apêndice A

Outras localidades (Vide tabela 5.7) foram indicadas pelos moradores, os quais são o Centro Histórico, Brás e Bom Retiro, que atraem principalmente os compradores de vestuário, calçados e roupas para cama mesa e banho, apresentando 55 pontos em seu conjunto. Sua importância é menos significativa para muitos moradores do Distrito de Pedreira. 
Tabela 5.7 - MEDIDA DE GRAU - COMÉRCIO DO CENTRO HISTÓRICO, BRÁS E BOM RETIRO

\begin{tabular}{|c|c|c|c|c|c|c|}
\hline RAMO DE & \multicolumn{2}{|c|}{ CENTRO HISTÓRICO } & \multicolumn{2}{|c|}{ BRÁS } & \multicolumn{2}{|c|}{ BOM RETIRO } \\
\hline Vestuário & CR3CENA & 9 & CR2BRZA & 10 & CR3RETA & 1 \\
\hline $\begin{array}{c}\text { Cama, mesa e } \\
\text { banho }\end{array}$ & CC3CENA & 11 & CC3BRZA & 9 & CC3JPAA & 1 \\
\hline Calçados & CY3CENA & 5 & CY3BRZA & 2 & & \\
\hline $\begin{array}{l}\text { Utensílios } \\
\text { para o lar }\end{array}$ & CW2CENA & 3 & & & & \\
\hline Bazar & CV2CENA & 4 & & & & \\
\hline SOMA & & 32 & & 21 & & 2 \\
\hline
\end{tabular}

Fonte: Apêndice A

Dentre alguns resultados individuais da medida de grau (“degree”), estão em destaque as informações do Largo 13 de Maio, Shopping Center Interlagos/Interlar e Diadema.

Na região do Largo 13 de Maio destaca-se o comércio de vestuário (CR3L13A) que obteve 61 pontos, que se classificou como um dos primeiros colocados. O comércio de roupa de cama, mesa e banho (CC3L13A) alcançou 57 pontos. O comércio de eletro-eletrônicos (CE3L13A) conseguiu 43 pontos junto com o comércio de calçados (CY3L13A). Pode-se considerar que o Largo 13 de Maio é um centro de hierarquia bastante elevada para os moradores de Pedreira, apesar da sua significativa distância. Continua forte o comércio de móveis (CX3L13A), e o comércio de miudezas e utensílios para o lar (CW2L13A) que obtiveram 35 e 28 pontos respectivamente. É um local de muito fácil acesso, pois conta com muitas opções de linhas de ônibus.

O Shopping Center Interlagos perde para o Largo 13 de Maio, apesar de seus resultados significativos. Está em destaque o comércio de eletro-eletrônicos (CE3INTA), que obteve 42 pontos. O ramo de confecção (CR3INTA) alcançou 36 pontos e o comércio de calçados (CY3INTA) conseguiu 35 pontos. Também são importantes os ramos de cama, mesa e banho (CC3INTA) que atingiram 31 pontos e de móveis (CX3INTA) com 25 pontos. 
Conforme o mapa 5.26, uma das causas da hierarquia superior do Largo 13 de Maio, em relação ao Shopping Center Interlagos, pode ser explicada pelo sistema de transporte coletivo diante de muita disponibilidade de linhas para Santo Amaro e atendem os moradores de uma vasta área do Distrito, inclusive de regiões de forte influência do comércio de Diadema. São poucas as linhas de ônibus atendendo esse Shopping apesar da sua proximidade em relação ao Distrito. Os moradores da região central do Distrito, em número inferior, e de renda mais elevada preferem esse Shopping, ao mesmo tempo, existe na área central maiores facilidades de acesso ao Shopping, por ônibus, em comparação a outras áreas do Distrito.

O comércio de miudezas e utensílios para o lar (CW2INTA) chegou aos 20 pontos perdeu significativamente para Santo Amaro ou Diadema.

Em relação ao comércio de Diadema, está em destaque o comércio de eletro-eletrônicos (CE3DIAA), que obteve 50 pontos. O comércio de móveis (CX3DIAA) alcançou 39 pontos. Ambos ganharam do Largo 13 de Maio e do Shopping Center Interlagos. O comércio de calçados (CY3DIAA) chegou aos 36 pontos, é superior ao Shopping Interlagos. O comércio de vestuário (CR3DIAA), apesar dos 34 pontos, perde para Santo Amaro e Shopping Center Interlagos. O comércio de roupas para cama, mesa e banho conseguiu 33 pontos, apesar de perder para Santo Amaro, é superior ao Shopping Interlagos. O comércio de miudezas e utensílios para o lar (CW2DIAA) obteve 29 pontos, é mais significativo em relação a Santo Amaro. O ramo de farmácia (CF2DIAA), muito forte em Diadema, completou 32 pontos, em parte liderada face à preferência pela Drogaria São Paulo, que, em conjunto com outras farmácias, proporciona resultados superiores aos da Drogaria Ultra Farma (CF2SJDA). Localizada no bairro de Saúde, a Drogaria Ultra Farma (CF2SJDA) obteve 16 pontos. A Drogaria São Paulo (CF2DSPA), localizada na Avenida Nossa Senhora do Sabará, conseguiu 20 pontos.

O nó SM3INTA, que representa o Shopping Center Interlar junto com o Supermercado de construções Leroy Merlin, obteve 25 pontos. Apesar da sofisticação dos produtos oferecidos, perde para o concorrente Depósito 5 Irmãos, pouco diferenciado e comercializa produtos menos elaborados, cuja vantagem pode estar na localização de fácil acesso para os moradores de toda a região centro e sul do Distrito. 
Quanto a alguns estabelecimentos com características locais os mais importantes são o Supermercado Pedreira, Supermercado Mamb's, Supermercado Ki Barato, Supermercado Ricoy e o Depósito 5 Irmãos.

O Supermercado Pedreira (CS2002A), localizado no Parque Santa Amélia contíguo ao bairro Balneário São Francisco, recebeu 66 pontos por ser um supermercado, que atende os moradores de uma significativa região do Distrito de Pedreira exceto os pontos mais distantes ao norte, por exemplo, a Vila Aparecida, Jardim Selma e Vila Missionária.

O nó CS2016A, que representa os supermercados Mamb's e Ki Barato, fica em destaque ao obter 24 pontos pela preferência dos moradores da região de Vila Guacuri e Jardim Rubilene.

O Depósito 5 Irmãos (CM2017A), do ramo de material de construção, alcançou 34 pontos, possui uma forte preferência dos moradores de uma extensa área do Distrito de Pedreira. Conforme anteriormente mencionado, leva algumas vantagens em relação ao Shopping Center Interlar que é especializado e oferece produtos mais sofisticados em decoração e materiais de construção.

A unidade do Supermercado Ricoy (CS2064A), localizada na Estrada do Alvarenga, obteve apenas 17 pontos perdendo significativamente para o concorrente Supermercado Pedreira.

\subsection{Medida de proximidade ("closeness")}

De acordo com os conceitos da página 45, numa rede social, quanto mais próximo estiver um determinado ator em relação aos demais atores, é considerado o "mais central". O critério é baseado no cálculo da distância geodésica de uma rede social, ou seja, o ator mais próximo é aquele que apresenta a menor distância geodésica (vide figura 1.2 na página 45) em relação aos outros nós e, conseqüentemente obtêm os valores de proximidade mais baixos. Pode existir certa relação entre as quantidades de relacionamentos e as facilidades de acesso, isto é, as melhores condições de acesso podem permitir o aumento nas quantidades de relacionamentos. Por exemplo, o Supermercado Pedreira, que obteve 66 pontos na medida de grau, é o índice mais baixo de proximidade de todo o Distrito de Pedreira e está em local de fácil acesso a partir de quase todas as localizações do Distrito de Pedreira, por meio dos serviços de ônibus e sem a necessidade de baldeações. Os nós dos pontos de comércio, que oferecem as melhores facilidades de acesso para os consumidores, mesmo mantendo as suas localizações mais distantes de suas residências, podem apresentar valores de proximidade 
mais baixos. Diante das facilidades de acesso, proporcionadas pelas de linhas de ônibus urbano, alguns dos ramos de comércio do Largo 13 de Maio, em Santo Amaro, apresentam os resultados de proximidade relativamente baixos.

A análise global e dos resultados acumulados dos valores de proximidade é realizada através das médias obtidas. De acordo com as médias dos resultados globais (tabela 5.8), o Shopping Center Interlagos obteve o índice mais baixo obtendo 1652 pontos. Em seguida, Diadema alcançou 1681 pontos. O Largo 13 de Maio atingiu 1690 pontos. Aparentemente o Shopping Interlagos deveria ser o local a oferecer mais facilidade de acesso.

\begin{tabular}{cccc} 
Tabela 5.8 - MEDIDA DE CENTRALIDADE DE PROXIMIDADE (“CLOSENESS”) - & \\
& VALORES MÉDIOS \\
\hline TIPOS DE BENS & $\begin{array}{c}\text { LARGO 13 DE } \\
\text { MAIO }\end{array}$ & DIADEMA & SHOPPING \\
INTERLAGOS \\
\hline Bens duráveis & 1399 & 1482 & 1499 \\
Alimentícios & 1721 & 1925 & 1750 \\
Diversos & 1951 & 1635 & 1707 \\
MÉDIA & 1690 & 1681 & 1652
\end{tabular}

Obs.: resumo das tabelas $5.9 ; 5.10$ e 5.11

Fonte: Apêndice B

A seguir, a análise por grupos de atividade de comércio será apresentada, em precaução a eventuais conclusões falaciosas ou precipitadas.

A análise da medida de centralidade proximidade é dividida em três partes: bens de freqüência de demanda baixa; bens de freqüência mediana; bens de freqüência diária ou semanal.

A análise do comércio que colabora para a manutenção de nível hierárquico alto, em conseqüência de freqüência de demanda bastante baixa e necessidade de apresentar maior diversificação possível, foi preparada com fundamento nos resultados do comércio de roupas de cama, mesa e banho, de calçados, eletro-eletrônicos, móveis, utensílios para o lar e vestuário. 
De conformidade com as médias dos valores de proximidade (tabela 5.9), o Largo 13 de Maio obteve o melhor índice obtendo 1399 pontos. Diadema ficou em segundo lugar com 1482 pontos. O Shopping Center Interlagos classificou em terceiro lugar com 1499 pontos. A vantagem do Largo 13 de Maio pode estar no sistema de ônibus urbano, que oferece muitas facilidades de acesso ao local.

Tabela 5.9 - MEDIDA DE PROXIMIDADE - BENS DE COMPRA DE FREQÜÊNCIA

BAIXA - LARGO 13 DE MAIO, DIADEMA E SHOPPING CENTER INTERLAGOS MÉDIA

\begin{tabular}{|c|c|c|c|c|c|c|}
\hline \multirow{2}{*}{$\begin{array}{c}\text { TIPOS DE BENS } \\
\text { Vestuário }\end{array}$} & \multicolumn{2}{|c|}{ LARGO 13 DE MAIO } & \multicolumn{2}{|c|}{ DIADEMA } & \multicolumn{2}{|c|}{$\begin{array}{c}\text { SHOPPING CENTER } \\
\text { INTERLAGOS }\end{array}$} \\
\hline & CR3L13A & 1295 & CR3DIAA & 1509 & CR3INTA & 1431 \\
\hline Cama, mesa, banho & CC3L13A & 1307 & CC3DIAA & 1499 & CC3INTA & 1475 \\
\hline Calçados & CY3L13A & 1401 & CY3DIAA & 1479 & CY3INTA & 1455 \\
\hline Eletro-eletrônicos & CE3L13A & 1397 & CE3DIAA & 1397 & CE3INTA & 1427 \\
\hline Móveis & CX3L13A & 1469 & CX3DIAA & 1459 & CX3INTA & 1617 \\
\hline Utensílios para o lar & CW2L13A & 1525 & CW2DIAA & 1549 & CW3INTA & 1589 \\
\hline MÉDIA & & 1399 & & 1482 & & 1499 \\
\hline
\end{tabular}

Fonte: Apêndice B

A análise do comércio com característica principal de apoio à moradia, de frequiência mediana de demanda e que colabora para a manutenção de nível hierárquico médio em conseqüência da diversificação de seus produtos, foi desenvolvida em função das atividades do comércio de artigos para bazar, alimentos, produtos de limpeza, supermercados de grande e médio portes e produtos para animais (pet shop). 


\section{CENTRALIDADES - NÍVEIS HIERÁRQUICOS}

MEDIDA DE PROXIMIDADE - VALORES GLOBAIS

DISTRITO DE PEDREIRA

MAPA NÚMERO 5.32

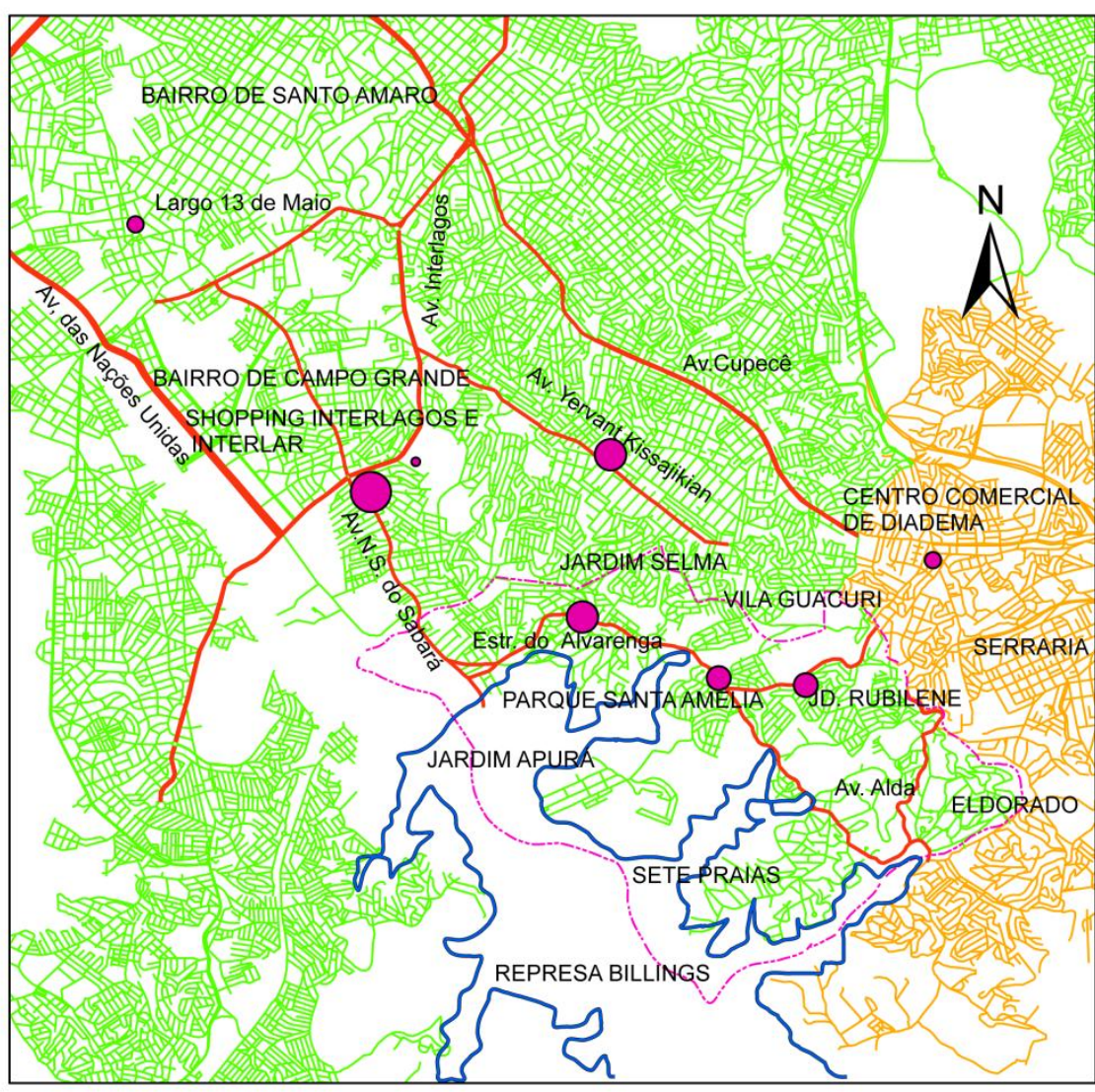

$\begin{array}{lll}0 & 0,5 & 1\end{array}$ 2 Kilometers

\section{\begin{tabular}{|l|l|l|l|l|}
\hline & 1 & 1 & 1 & -1
\end{tabular}}

Autor: Shinhiti Osanai

Fonte: pesquisa do autor

Medida de proximidade
- 1652
○ $1653-1691$
○ $1692-1833$
○ $1834-1909$
? $1910-1977$
- Represa Billings
— São Paulo
— Diadema
____-_ Divisa Distr. Pedreira 


\section{CENTRALIDADES - NÍVEIS HIERÁRQUICOS}

MEDIDA DE PROXIMIDADE - BENS DE FREQÜÊNCIA DE DEMANDA BAIXA DISTRITO DE PEDREIRA

MAPA NÚMERO 5.33

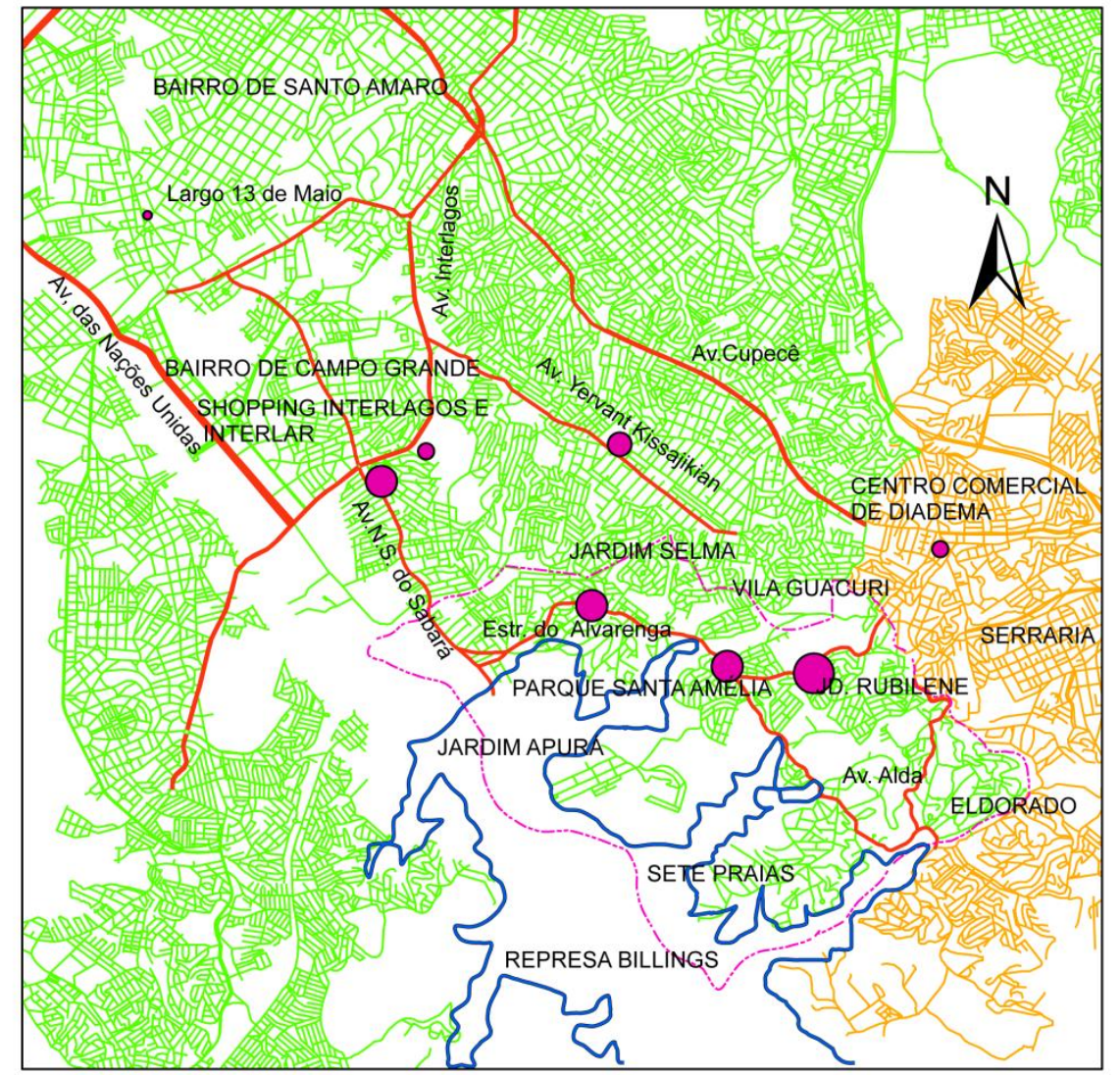

$\begin{array}{lll}0 & 0,5 & 1\end{array}$ 2 Kilometers

Autor: Shinhiti Osanai

Medida de proximidade
- 1399
○ $1340-1499$
○ $1500-1903$
○ $1904-2035$
2 $2036-2139$
— São Paulo
— Diadema
_-_- Divisa Distr. Pedreira
— Represa Billings

Fonte: pesquisa do autor 
As médias de proximidade obtidas (tabela 5.10) apontam novamente para a liderança do Largo 13 de Maio obtendo 1721 pontos. O Shopping Center Interlagos passa para o segundo lugar com 1750 pontos. Diadema fica em terceiro lugar com 1904 pontos. A pontuação mais alta de Diadema, indicando algumas desvantagens, pode ser a consequiência do comércio mais heterogêneo organizado por pequenos estabelecimentos distribuídos por toda a área central, consequientemente podem ajudar a elevar a sua média, o que não acontece com o Shopping Interlagos. A intensa concentração de lojas em único local, como num Shopping Center, deveria oferecer melhor facilidade de acesso, entretanto, o sistema de transporte urbano continua sendo fundamental para facilitar o acesso e, assim, melhorar os índices de proximidade. As vantagens de acessibilidade do Largo 13 de Maio podem eventualmente proporcionar a apresentação dos valores baixos de proximidade. .

\begin{tabular}{|c|c|c|c|c|c|c|}
\hline \multirow{3}{*}{$\begin{array}{c}\text { RAMO DE } \\
\text { ATIVIDADE } \\
\text { Bazar }\end{array}$} & \multicolumn{4}{|c|}{ MÉDIA } & & \\
\hline & \multicolumn{2}{|c|}{ LARGO 13 DE MAIO } & \multicolumn{2}{|c|}{ DIADEMA } & \multicolumn{2}{|c|}{$\begin{array}{c}\text { SHOPPING CENTER } \\
\text { INTERLAGOS }\end{array}$} \\
\hline & CVOI & 1657 & CYתDI & 1070 & & \\
\hline Alimentícios & CA2L13N & 1605 & CA2DIAN & 1827 & & \\
\hline Super mercado & CS2L13A & 1901 & CS2DIAA & 1939 & CS3INTX & 1750 \\
\hline Hiper mercado & & & CS3DIAA & 1863 & & \\
\hline Pet shop & & & CP2DIAA & 1829 & & \\
\hline Produtos de & & & CZ2DIAA & 2123 & & \\
\hline $\begin{array}{l}\text { limpeza } \\
\text { MÉDIA }\end{array}$ & & 1721 & & 1925,5 & & 1750 \\
\hline
\end{tabular}

Fonte: Apêndice B

Em relação a outros ramos, tais como farmácia, material de construção e cine, foto e óptica, de acordo com as médias obtidas (tabela 5.11), Diadema encontra-se em primeiro lugar com 1636 pontos O Shopping Center Interlagos obteve 1707 pontos. O Largo 13 de Maio ficou em terceiro lugar com 1952 pontos. A Drogaria São Paulo de Diadema é de acesso mais fácil para muitos moradores do Distrito de Pedreira, o que ajuda a melhorar as vantagens do valor médio de proximidade. Quanto ao comércio de cine, foto e óptica, os resultados do Shopping 
Center Interlagos apresentam mais vantagens em relação ao valor médio obtido por Largo 13 de Maio.

Tabela 5.11 - MEDIDA DE PROXIMIDADE - BENS DE FREQÜÊNCIA DE COMPRA BAIXA - OUTROS PRODUTOS - LARGO 13 DE MAIO, DIADEMA E SHOPPING CENTER INTERLAGOS - MÉDIA

\begin{tabular}{|c|c|c|c|c|c|c|}
\hline RAMO DE & \multirow{2}{*}{\multicolumn{2}{|c|}{ LARGO 13 DE MAIO }} & \multirow{2}{*}{\multicolumn{2}{|c|}{ DIADEMA }} & \multirow{2}{*}{\multicolumn{2}{|c|}{$\begin{array}{c}\text { SHOPPING CENTER } \\
\text { INTERLAGOS }\end{array}$}} \\
\hline ATIVIDADE & & & & & & \\
\hline óptica & CO2L13A & 1927 & CO2DIAA & 1699 & CO2INTA & 1707 \\
\hline Farmácia & CF2L13A & 1753 & CF2DIAA & 1547 & & \\
\hline $\begin{array}{l}\text { Artigos para } \\
\text { bebê }\end{array}$ & CB2L13A & 2175 & & & & \\
\hline $\begin{array}{l}\text { Material de } \\
\text { construção }\end{array}$ & & & CM2DIAA & 1661 & & \\
\hline MÉDIA & & 1951 & & 1635 & & 1707 \\
\hline
\end{tabular}

Fonte: Apêndice B

Em seguida, serão analisados os dados dos centros secundários, em relação ao comércio de apoio imediato à moradia, de freqüência diária ou semanal de utilização, que colabora para a manutenção de nível hierárquico baixo. Os principais centros secundários, localizados no Distrito de Pedreira, são a Estrada do Alvarenga, Parque Santa Amélia, Jardim Rubilene. Fora do Distrito, estão os centos secundários da Av. Yervant Kissajikian e Av. Nossa Senhora do Sabará, localizados, respectivamente, nos Distritos de Cidade Ademar e de Campo Grande.

De acordo com a tabela 5.12, os valores médios de proximidade mostram poucas diferenças entre o comércio da Estrada do Alvarenga e do Jardim Rubilene, em consequiência do principal público ser constituído por moradores locais das proximidades, permanecendo as facilidades de acesso menos importantes. O Parque Santa Amélia apresenta alguma vantagem em relação a essas três aglomerações de comércio por causa da forte preferência e força de 
atração do Supermercado Pedreira, localizado numa área bastante privilegiada que possibilita o acesso por ônibus a partir de quase toda região do Distrito de Pedreira conforme anteriormente comentado. O comércio do Jardim Rubilene está bem estruturado para o atendimento dos moradores locais, exceto o Depósito 5 Irmãos, do ramo de material de construção, que recebe compradores de regiões relativamente distantes. Todavia, em consequiência ao maior número de estabelecimentos comerciais, o valor médio de proximidade da Estrada do Alvarenga, apesar do público principal estar restrito aos moradores locais com poucos compradores de regiões um pouco mais distantes, continua sendo um pouco mais vantajoso em relação ao Jardim Rubilene.

O comércio da Avenida Yervant Kissajikian (vide tabela 5.13), apesar de atender preferencialmente os moradores de Jardim Selma e Vila Missionária, apresenta os valores médios de proximidade mais vantajosos em comparação ao comércio da região da Estrada do Alvarenga ou Jardim Rubilene. A disponibilidade de lojas que oferecem produtos eletroeletrônicos, móveis e supermercados de médio porte pode ser em consequiência de melhor facilidade de acesso, principalmente para os moradores do Distrito de Cidade Ademar. Tal fato possibilita melhor diversidade de produtos em relação às duas regiões anteriormente mencionadas. No Parque Santa Amélia o Supermercado Pedreira, por causa das melhores facilidades de acesso para os moradores do Distrito de Pedreira, o valor médio de proximidade continua sendo mais vantajoso em comparação ao comércio da Avenida Yervant Kissajikian.

A Avenida Nossa Senhora do Sabará atende poucos moradores do Distrito de Pedreira, exceto alguns da Vila Aparecida que se localiza na divisa com o Distrito de Campo Grande. 
Tabela 5.12 - MEDIDA PROXIMIDADE - COMÉRCIO LOCAL DA ESTRADA DO ALVARENGA, PARQUE SANTA AMÉLIA E JARDIM RUBILENE - MÉDIA

\begin{tabular}{|c|c|c|c|c|c|c|}
\hline \multirow{3}{*}{$\begin{array}{c}\text { RAMO DE } \\
\text { ATIVIDADE } \\
\text { Roupas }\end{array}$} & \multirow{2}{*}{\multicolumn{2}{|c|}{$\begin{array}{l}\text { ESTRADA DO } \\
\text { ALVARENGA }\end{array}$}} & \multirow{2}{*}{\multicolumn{2}{|c|}{$\begin{array}{c}\text { PARQUE SANTA } \\
\text { AMÉLIA }\end{array}$}} & \multirow{2}{*}{\multicolumn{2}{|c|}{ JARDIM RUBILENE }} \\
\hline & & & & & & \\
\hline & CR3100A & 2367 & & & CW2029A & 2139 \\
\hline Calçados & CY3064A & 2041 & & & & \\
\hline Utensílios & CW2064A & 1874 & CW2002A & 2035 & & \\
\hline $\begin{array}{l}\text { Cine, foto e } \\
\text { óptica }\end{array}$ & $\mathrm{CO} 2100 \mathrm{~A}$ & 2057 & & & & \\
\hline Farmácia & CF2064A & 1784 & CF2002A & 1717 & CF2016A & 1867 \\
\hline $\begin{array}{l}\text { Material de } \\
\text { construção }\end{array}$ & CM2064A & 1795 & CM2002A & 1759 & CM2017A & 1809 \\
\hline Bazar & CV2064A & 1736 & CV2002A & 1667 & CV2017A & 1863 \\
\hline Alimentícios & CA2100A & 1986 & & & CA2029A & 1833 \\
\hline Super mercados & CS2064A & 1754 & $\mathrm{CS} 2002 \mathrm{~A}$ & 1253 & CS2016A & 1766 \\
\hline Pet shop & CP2064A & 1867 & & & CP2017A & 1799 \\
\hline $\begin{array}{c}\text { Produtos de } \\
\text { limpeza }\end{array}$ & & & CZ2002A & 2035 & CZ2029A & 2011 \\
\hline Padaria & CA1064A & 1869 & & & CA1029G & 1874 \\
\hline MÉDIA & & 1938 & & 1832 & & 1944 \\
\hline
\end{tabular}

Fonte: Apêndice B 
Tabela 5.13 - MEDIDA DE PROXIMIDADE - COMÉRCIO LOCAL - AV. YERVANT KISSAJIKIAN E AV. NOSSA SENHORA DO SABARÁ - MÉDIA

\begin{tabular}{|c|c|c|c|c|}
\hline RAMO DE & \multirow{2}{*}{\multicolumn{2}{|c|}{$\begin{array}{l}\text { AV. YERVANT } \\
\text { KISSAJIKIAN }\end{array}$}} & \multirow{2}{*}{\multicolumn{2}{|c|}{$\begin{array}{c}\text { AV. NOSSA SENHORA DO } \\
\text { SABARÁ }\end{array}$}} \\
\hline ATIVIDADE & & & & \\
\hline Roupas & CR3 YERA & 2039 & CR3SABA & 2081 \\
\hline Cama, mesa e banho & & & CC3SABA & 2367 \\
\hline Calçados & CY3YERA & 1945 & CY3SABA & 1869 \\
\hline Eletro-eletrônicos & CE3 YERA & 1821 & & \\
\hline Móveis & CX3YERA & 1839 & CX3SABA & 1761 \\
\hline Utensílios para o lar & CW2YERA & 1875 & CW2SABA & 1831 \\
\hline Cine, foto e óptica & CO2YERA & 1915 & $\mathrm{CO} 2 \mathrm{SABA}$ & 1845 \\
\hline Farmácia & CF2YERA & 2033 & & \\
\hline $\begin{array}{l}\text { Material de } \\
\text { construção }\end{array}$ & CM2YERA & 1821 & CM2SABA & 1935 \\
\hline Alimentícios & CA2YERN & 1947 & CA2SABN & 2059 \\
\hline Super mercados & CS2YERA & 1845 & CS2SABA & 1967 \\
\hline Pet shop & & & CP2SABA & 2191 \\
\hline Bazar & CV2YERA & 1889 & CV2SABA & 2025 \\
\hline MÉDIA & & 1906 & & 1977 \\
\hline
\end{tabular}

Fonte: Apêndice B

Outras localidades (Vide tabela 5.14) foram indicadas pelos moradores, os quais são o Centro Histórico, Brás e Bom Retiro.

Um dos pontos mais fortes do Centro Histórico é o comércio de roupas para cama, mesa e banho da região da Rua 25 de Março. No Brás, o comércio de vestuário e o comércio de roupas para cama, mesa e banho constituem os seus pontos fortes. Muitos moradores do 
Distrito de Pedreira, em busca de preços mais competitivos, procuram os centros especializados em vestuário, o que ajuda a melhorar os valores médios de proximidade em conseqüência das facilidades oferecidas pelas empresas especializadas no referido setor.

Tabela 5.14 - MEDIDA DE PROXIMIDADE - OUTROS LOCAIS - CENTRO HISTÓRICO, BRÁS E BOM RETIRO - MÉDIA

\begin{tabular}{|c|c|c|c|c|c|c|}
\hline TIPOS DE & \multicolumn{2}{|c|}{ CENTRO HISTÓRICO } & \multicolumn{2}{|c|}{ BRÁS } & \multicolumn{2}{|c|}{ BOM RETIRO } \\
\hline Vestuário & CR3CENA & 1689 & CR2BRZA & 1657 & CR3RETA & 2073 \\
\hline $\begin{array}{c}\text { Cama, mesa e } \\
\text { banho }\end{array}$ & CC3CENA & 1671 & CC3BRZA & 1669 & CC3JPAA & 2025 \\
\hline Calçados & CY3CENA & 1757 & CY3BRZA & 2091 & & \\
\hline $\begin{array}{l}\text { Utensílios } \\
\text { para o lar }\end{array}$ & CW2CENA & 1775 & & & & \\
\hline Bazar & CV2CENA & 1833 & & & & \\
\hline MÉDIA & & 1795 & & 1805 & & 2083 \\
\hline
\end{tabular}

Fonte: Apêndice B

Dentre alguns resultados individuais da medida de proximidade ("closeness"), estão em destaque as informações do Largo 13 de Maio, Shopping Center Interlagos/ Interlar e Diadema.

Quanto ao Largo 13 de Maio, em Santo Amaro, o comércio de vestuário e de roupa para cama, mesa e banho ocupa os primeiros lugares com 1295 e 1307 pontos, respectivamente. O comércio de calçados e de móveis alcança uma posição em destaque com 1401 e 1469 pontos. Todos esses ramos estão com a classificação melhor em relação aos resultados obtidos por Diadema. O comércio de eletro-eletrônicos recebeu 1397 pontos e empatou com Diadema. O Largo 13 de Maio pode levar algumas vantagens proporcionadas pelas linhas de ônibus urbano, que facilitam o acesso. 
Em Diadema, o comércio de eletro-eletrônicos alcançou 1397 pontos, é o melhor resultado desse Município diante de algumas facilidades de acesso principalmente para os moradores das proximidades da divisa com o Distrito de Pedreira. O ramo de roupas para cama, mesa e banho, obteve 1499 pontos, perde para o Largo 13 de Maio. O ramo de vestuário atingiu 1509 pontos, está em desvantagem em comparação ao Shopping Center Interlagos.

No Shopping Center Interlagos, o comércio de eletro-eletrônicos obtendo 1427 pontos, é a melhor posição obtida nesse local, perdendo para Diadema e para o Largo 13 de Maio. Em geral, o Largo 13 de Maio e Diadema encontram-se com resultados mais vantajosos.

O Shopping Center Interlar especializado em decoração e material de construção, apesar da sofisticação dos serviços e produtos oferecidos, alcançando 1519 pontos, apenas 2 pontos de vantagem em relação ao Depósito 5 Irmãos, que obteve 1521 pontos.

Quanto a alguns estabelecimentos com características locais, os mais importantes são o Supermercado Pedreira, Supermercado Mamb's, Supermercado Ki Barato, Supermercado Ricoy e o Depósito 5 Irmãos.

O Supermercado Pedreira, recebendo 1253 pontos, é o local de melhor facilidade de acesso do Distrito de Pedreira. O bairro Parque Santa Amélia, local do estabelecimento, é bastante próximo dos bairros de densidade populacional mais elevada desse Distrito, por exemplo, Parque Dorotéia, Jardim Rubilene e Vila Guacuri.

\subsection{Medida de posicionamento ("betweeness")}

Conforme as informações apresentadas na página 53 o posicionamento torna-se importante para a análise de atores não adjacentes de uma rede social. O relacionamento entre os nós não adjacentes, desde que haja acessibilidade, pode depender da localização dos nós intermediários. Conceitualmente, em redes sociais, os atores intermediários são aqueles que possuem o poder de controle dos nós não adjacentes, num processo de relacionamento.

Na estrutura da rede social, construída a partir da amostra de moradores do Distrito de Pedreira, não existe a constatação de nós intermediários, em conseqüência dos moradores manterem o relacionamento direto com os seus fornecedores sem a participação de intermediários. Por exemplo, se dirigem diretamente a um grande supermercado localizado a certa distância das suas moradias, ou a uma padaria localizada nas proximidades de sua residência. O posicionamento pode ser um tipo de indicador de dependência, em outras 
palavras, quando os consumidores estiverem diante de maior dependência por um determinado ramo de comércio o valor de seu posicionamento também pode ser mais elevado. Em alguns ramos de comércio do tipo roupa para cama, mesa e banho ou eletro-eletrônicos, por serem muito raros no Distrito de Pedreira, os moradores ficam na dependência dos estabelecimentos localizados em áreas mais centrais, do tipo Largo 13 de Maio ou o centro comercial de Diadema, cujos nós, representando esse tipo de comércio, podem apresentar os índices de posicionamento significativamente elevados em relação aos demais nós da mesma rede social. A medida de grau indica apenas a quantidade de relacionamentos e, às vezes, não pode ser suficiente para a avaliação de níveis hierárquicos sob a ótica de intensidade da força de atração. Por meio da medida de posicionamento podem-se avaliar os níveis hierárquicos, sob o ponto de vista de intensidade da força de atração, em decorrência de maior ou menor dependência dos moradores em relação a determinados produtos.

Na medida de posicionamento, o Largo 13 de Maio obteve o total de 39473 pontos, se classificando em primeiro lugar, ao contrário do observado na pontuação global da medida de grau. Ainda, na medida de posicionamento, permanece em segundo lugar o centro comercial de Diadema obtendo 35775 pontos Em seguida, o Shopping Center Interlagos alcançou 22015 pontos. A medida de posicionamento pode mensurar o poder da força de atração de Santo Amaro, mesmo considerando a ausência de alguns ramos de comércio disponíveis nos demais centros estudados. (vide tabela 5.15)

Tabela 5.15 - RESULTADO DA MEDIDA DE CENTRALIDADE DE POSICIONAMENTO

\begin{tabular}{cccc}
\hline TIPOS DE BENS & $\begin{array}{c}\text { LARGO 13 DE } \\
\text { MAIO }\end{array}$ & DIADEMA & $\begin{array}{c}\text { SHOPPING } \\
\text { INTERLAGOS }\end{array}$ \\
\hline Bens duráveis & 38285 & 28588 & 20825 \\
Alimentícios & 1143 & 2436 & 1035 \\
Diversos & 45 & 4751 & 155 \\
TOTAL & 39473 & 35775 & 22015 \\
\hline
\end{tabular}

Obs.: resumo das tabelas 5.16; 5.17 e 5.18

Fonte: Apêndice C 
Nota-se a intensidade da força de atração do Largo 13 de Maio, quando se analisam individualmente os grupos de comércio.

A análise da medida de centralidade posicionamento está dividida em três partes: bens de freqüência de demanda baixa; bens de freqüência mediana; bens de freqüência diária ou semanal.

A análise do comércio que colabora para a manutenção de nível hierárquico alto, em conseqüência de freqüência de demanda bastante baixa e necessidade de apresentar maior diversificação possível, foi desenvolvida com base nos resultados do comércio de roupas de cama, mesa e banho, de calçados, eletro-eletrônicos, móveis, utensílios para o lar e comércio de roupas e confecções.

Na diferença, entre o resultado do Largo 13 de Maio, que obteve 38285 pontos, e Diadema, que recebeu 28588 pontos, verifica-se a superioridade de 34\% de Santo Amaro. O Shopping Center Interlagos, ao representar uma atração mais fraca, alcançou 20825 pontos, que significa aproximadamente 54\% de Santo Amaro. (vide tabela 5.16).

Tabela 5.16 - MEDIDA DE POSICIONAMENTO - BENS COM FREQÜÊNCIA DE COMPRAS BAIXA - LARGO 13 DE MAIO, DIADEMA E SHOPPING CENTER INTERLAGOS.

\begin{tabular}{|c|c|c|c|c|c|c|}
\hline \multirow{2}{*}{$\begin{array}{c}\text { TIPOS DE BENS } \\
\text { Roupas }\end{array}$} & \multicolumn{2}{|c|}{ LARGO 13 DE MAIO } & \multicolumn{2}{|c|}{ DIADEMA } & \multicolumn{2}{|c|}{$\begin{array}{c}\text { SHOPPING CENTER } \\
\text { INTERLAGOS }\end{array}$} \\
\hline & CR3L13A & 12799 & CR3DIAA & 3266 & CR3INTA & 5026 \\
\hline Cama, mesa, banho & CC3L13A & 10435 & CC3DIAA & 3859 & CC3INTA & 2854 \\
\hline Calçados & CY3L13A & 4777 & CY3DIAA & 4020 & CY3INTA & 4020 \\
\hline Eletro-eletrônicos & CE3L13A & 5139 & CE3DIAA & 9159 & CE3INTA & 6659 \\
\hline Móveis & CX3L13A & 3155 & CX3DIAA & 5535 & CX3INTA & 1203 \\
\hline Utensílios para o lar & CW2L13A & 1980 & CW2DIAA & 2749 & CW3INTA & 1063 \\
\hline TOTAL & & 38285 & & 28588 & & 20825 \\
\hline
\end{tabular}

Fonte: Apêndice C

A análise comércio com característica principal de apoio à moradia, de freqüência mediana de demanda e que colabora para a manutenção de nível hierárquico médio em consequiência da 
diversificação de seus produtos, foi fundamentada nos resultados do comércio de artigos para bazar, alimentos, produtos de limpeza, supermercados de grande e médio portes e produtos para animais denominados de pet shop.

O Largo 13 de Maio, com 1143 pontos, perde para Diadema, que obteve 2436 pontos. O Shopping Center Interlagos recebeu 1035 pontos e ficou abaixo dos dois primeiros. Esse resultado é a consequiência das características próprias do comércio de Diadema, muito mais diversificado para o grupo de produtos considerados na tabela 5.17, em relação a esses dois primeiros centros.

Tabela 5.17 - MEDIDA DE POSICIONAMENTO - BENS COM FREQÜÊNCIA DE COMPRAS MEDIANA - LARGO 13 DE MAIO, DIADEMA E SHOPPING CENTER INTERLAGOS

\begin{tabular}{|c|c|c|c|c|c|c|}
\hline $\begin{array}{l}\text { RAMO DE } \\
\text { ATIVIDADE }\end{array}$ & \multicolumn{2}{|l|}{ MAIO } & \multicolumn{2}{|c|}{ DIADEMA } & \multicolumn{2}{|c|}{$\begin{array}{c}\text { SHOPPING } \\
\text { CENTER } \\
\text { INTERLAGOS }\end{array}$} \\
\hline Bazar & CV2L13A & 344 & CV2DIAA & 659 & & \\
\hline Alimentícios & CA2L13N & 796 & CA2DIAN & 163 & & \\
\hline Super mercados & CS2L13A & 3 & CS2DIAA & 15 & CS3INTX & 1035 \\
\hline Hiper mercados & & & CS3DIAA & 1569 & & \\
\hline Pet shop & & & CP2DIAA & 25 & & \\
\hline Produtos de limpeza & & & CZ2DIAA & 5 & & \\
\hline SOMA & & 1143 & & 2436 & & 1035 \\
\hline
\end{tabular}

Fonte: Apêndice C 


\section{CENTRALIDADES - NÍVEIS HIERÁRQUICOS MEDIDA DE POSICIONAMENTO - VALORES GLOBAIS}

DISTRITO DE PEDREIRA

MAPA NÚMERO 5.34

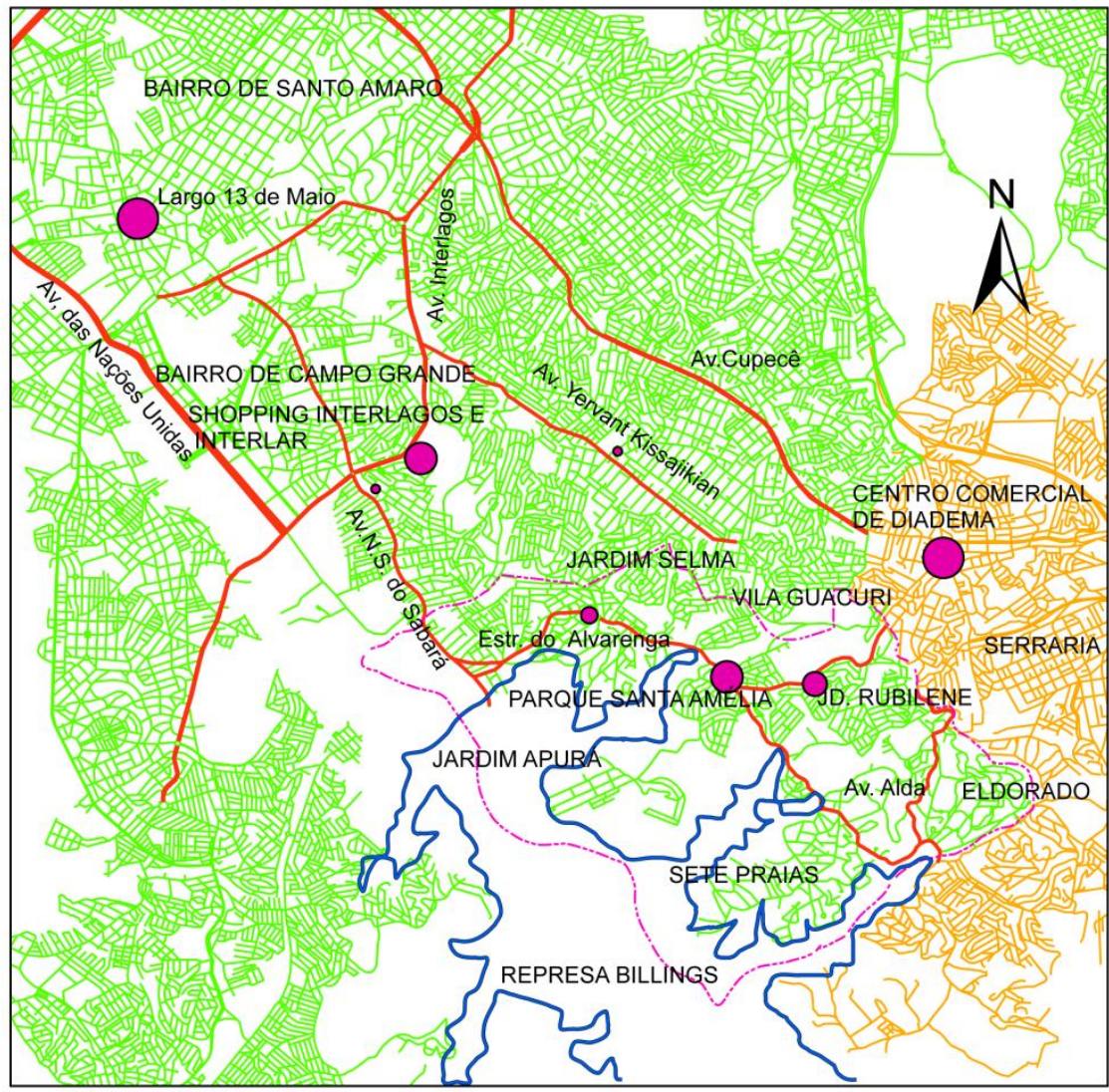

$\begin{array}{lll}0 & 0,5 & 1\end{array}$ 2 Kilometers

Autor: Shinhiti Osanai

Fonte: pesquisa do autor
Medida de posicionamento
- $279-1363$
○ $1364-2978$
○ $2979-6351$
- $6352-22015$
$22016-39473$
— São Paulo
- Diadema
Divisa Distr. Pedreira
- Represa Billings 


\section{CENTRALIDADES - NÍVEIS HIERÁRQUICOS}

MEDIDA DE POSICIONAMENTO - BENS DE DEMANDA DE FREQÜÊNCIA BAIXA DISTRITO DE PEDREIRA MAPA NÚMERO 5.35

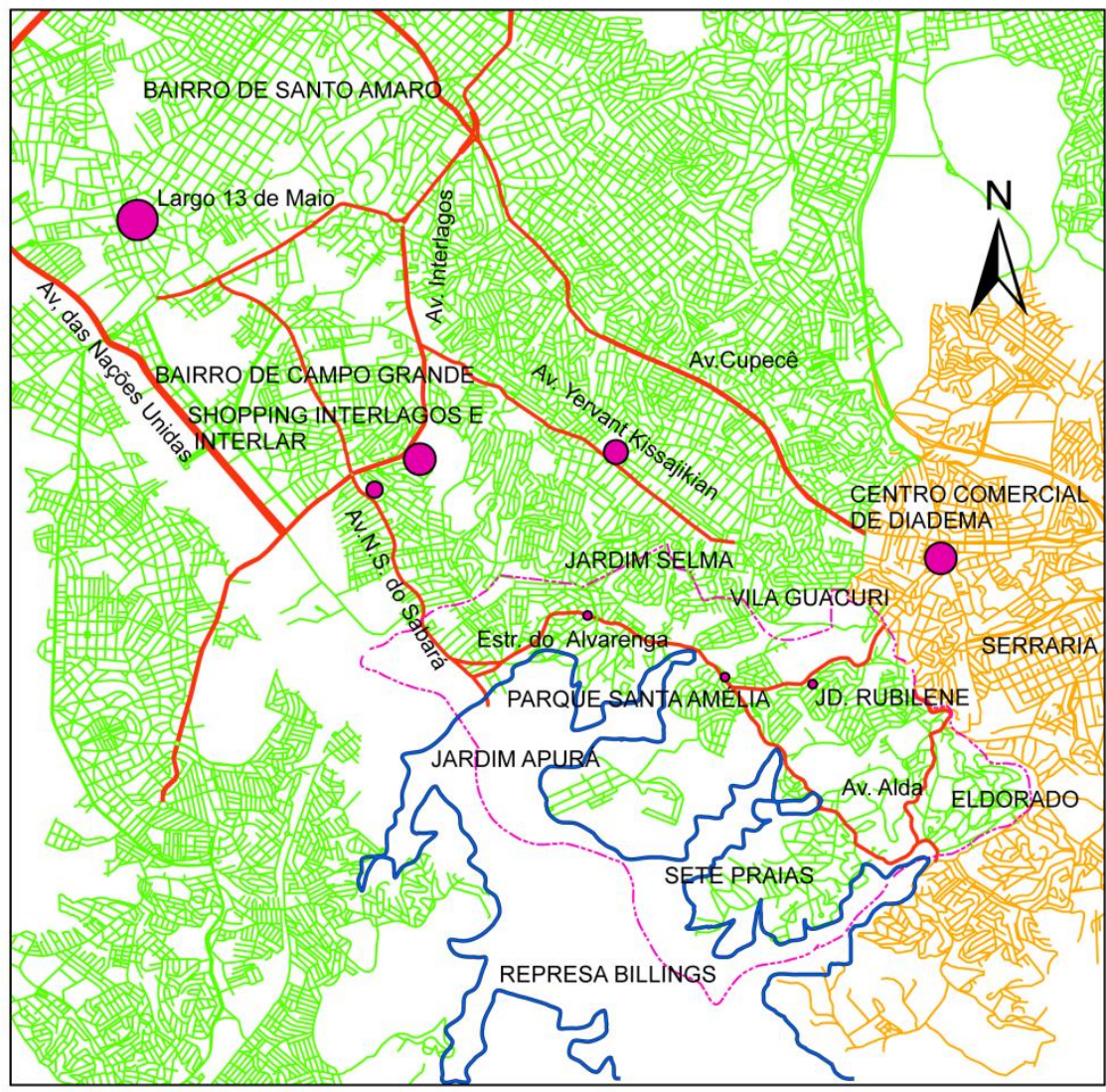

$\begin{array}{lll}0 & 0,5 & 1\end{array}$ 2 Kilometers

Autor: Shinhiti Osanai

Fonte: pesquisa do autor
Medida de posicionamento

- $0-73$

○ $74-231$

( $232-636$

- $637-28588$

2 $28589-38285$

— São Paulo

— Diadema

_-_- Divisa Distr. Pedreira

- Represa Billings 
De acordo com os dados da tabela 5.18, em relação a outros produtos, tais como farmácia, material de construção e cine, foto e óptica, Diadema mantém uma posição significativa com 4751 pontos. Tal fato se deve à força de atração da Drogaria São Paulo e forte preferência dos moradores da amostra pelos serviços de cine, foto e óptica, conseqüentemente, diante da ausência do ramo de material de construção, no Largo 13 de Maio e no Shopping Center Interlagos. Esses dois últimos centros apresentam uma posição praticamente insignificante, com 45 e 155 pontos respectivamente, apesar da disponibilidade no Shopping Center Interlagos dos serviços mais sofisticados de óptica.

\section{Tabela 5.18 -MEDIDA DE POSICIONAMENTO - BENS COM FREQÜÊNCIA DE COMPRAS BAIXA - OUTROS PRODUTOS - LARGO 13 DE MAIO, DIADEMA E SHOPPING CENTER INTERLAGOS}

\begin{tabular}{|c|c|c|c|c|c|c|}
\hline RAMO DE & \multirow{2}{*}{\multicolumn{2}{|c|}{ LARGO 13 DE MAIO }} & \multirow{2}{*}{\multicolumn{2}{|c|}{ DIADEMA }} & \multirow{2}{*}{\multicolumn{2}{|c|}{$\begin{array}{c}\text { SHOPPING CENTEK } \\
\text { INTERLAGOS }\end{array}$}} \\
\hline ATIVIDADE & & & & & & \\
\hline óptica & $\mathrm{CO} 2 \mathrm{~L} 13 \mathrm{~A}$ & 0 & CO2DIAA & 417 & CO2INTA & 155 \\
\hline Farmácia & CF2L13A & 45 & CF2DIAA & 3537 & & \\
\hline $\begin{array}{l}\text { Artigos para } \\
\text { bebê }\end{array}$ & CB2L13A & 0 & & & & \\
\hline $\begin{array}{l}\text { Material de } \\
\text { construção }\end{array}$ & & & CM2DIAA & 797 & & \\
\hline SOMA & & 45 & & 4751 & & 155 \\
\hline
\end{tabular}

Fonte: Apêndice C

Em seguida, serão analisados os dados dos centros secundários em relação ao comércio de apoio imediato à moradia, de freqüência diária ou semanal de utilização, e que colabora para a manutenção de nível hierárquico baixo. Os principais centros secundários, localizados no Distrito de Pedreira, são a Estrada do Alvarenga, Parque Santa Amélia, Jardim Rubilene. Fora do Distrito, encontram-se os centos secundários da Av. Yervant Kissajikian e Av. Nossa Senhora do Sabará, localizados, respectivamente, nos Distritos de Cidade Ademar e de Campo Grande. 
O comércio da Estrada do Alvarenga (tabela 5.19), apesar dos 160 pontos da medida de grau, em decorrência da quantidade significativa de estabelecimentos comerciais, mantém um resultado importante para um comércio local. A sua intensidade de atração de 2978 pontos é baixa, corresponde apenas a 7\% do Largo 13 de Maio devido às restrições do atendimento destinado apenas aos moradores locais e das regiões mais próximas.

O comércio do Parque Santa Amélia (tabela 5.19), obteve 18203 pontos, o que corresponde a 46\% do Largo 13 de Maio, apesar de apresentar apenas 109 pontos na medida de grau. Somente o Supermercado Pedreira obteve 17888 pontos, o que indica a sua forte intensidade de atração e geração de dependência. É 39\% superior em relação ao comércio de vestuário do Largo 13 de Maio, que obteve 12799 pontos. O Supermercado Pedreira possui a melhor localização na região do Distrito de Pedreira, presta serviços muito semelhantes dos hipermercados e oferece uma linha de produtos de muito interesse dos consumidores de renda baixa e média.

Nos comércios do Jardim Rubilene e Vila Guacuri (tabela 5.19), dos 6351 pontos registrados, 3622 pontos são provenientes do Depósito 5 Irmãos e 2053 pontos dos supermercados Mamb’s e Ki Barato. O Depósito 5 Irmãos atrai compradores de uma vasta área do Distrito de Pedreira. Esses dois supermercados atendem apenas os moradores próximos da região e, consequientemente, os resultados obtidos são bem inferiores em relação ao Supermercado Pedreira, cujo raio de atuação é bem mais amplo. Restam 676 pontos para os demais estabelecimentos comerciais, bem inferiores em comparação ao comércio da Estrada do Alvarenga, pois o poder de atração de seu comércio torna-se muito limitado tendo em vista apenas o atendimento dos moradores em torno de suas moradias.

O comércio da Avenida Yervant Kissajikian (tabela 5.20), obtendo 1363 pontos, indica a intensidade de atração muito inferior a da Estrada do Alvarenga. Esse comércio é pouco importante para o Distrito de Pedreira por atender preferencialmente apenas os moradores da Vila Missionária e Jardim Selma.

De acordo com a tabela 5.20, a maioria dos usuários do comércio da Avenida Nossa Senhora do Sabará, que obteve apenas 279 pontos, são os moradores da Vila Aparecida, na divisa com o Distrito de Campo Grande. 
Tabela 5.19 - MEDIDA DE POSICIONAMENTO - COMÉRCIO LOCAL - ESTRADA DO ALVARENGA, PARQUE SANTA AMÉLIA E JARDIM RUBILENE

\begin{tabular}{|c|c|c|c|c|c|c|}
\hline \multirow{3}{*}{$\begin{array}{c}\text { RAMO DE } \\
\text { ATIVIDADE } \\
\text { Roupas }\end{array}$} & \multirow{2}{*}{\multicolumn{2}{|c|}{$\begin{array}{l}\text { ESTRADA DO } \\
\text { ALVARENGA }\end{array}$}} & \multirow{2}{*}{\multicolumn{2}{|c|}{$\begin{array}{c}\text { PARQUE SANTA } \\
\text { AMÉLIA }\end{array}$}} & \multirow{2}{*}{\multicolumn{2}{|c|}{ JARDIM RUBILENE }} \\
\hline & & & & & & \\
\hline & CR3100A & 0 & & & CW2029A & 0 \\
\hline Calçados & CY3064A & 14 & & & & \\
\hline Utensílios & CW2064A & 59 & CW2002A & 0 & & \\
\hline $\begin{array}{l}\text { Cine, foto e } \\
\text { óptica }\end{array}$ & $\mathrm{CO} 2100 \mathrm{~A}$ & 0 & & & & \\
\hline Farmácia & CF2064A & 358 & CF2002A & 259 & CF2016A & 228 \\
\hline $\begin{array}{l}\text { Material de } \\
\text { construção }\end{array}$ & CM2064A & 508 & CM2002A & 55 & CM2017A & 3629 \\
\hline Bazar & CV2064A & 576 & CV2002A & & CV2017A & 71 \\
\hline Alimentícios & CA2100A & 371 & & 1 & CA2029A & 205 \\
\hline $\begin{array}{c}\text { Super } \\
\text { mercados }\end{array}$ & CS2064A & 799 & CS2002A & 17888 & CS2016A & 2053 \\
\hline Pet shop & CP2064A & 212 & & & CP2017A & 61 \\
\hline $\begin{array}{c}\text { Produtos de } \\
\text { limpeza }\end{array}$ & & & CZ2002A & 0 & CZ2029A & 0 \\
\hline Padaria & CA1064A & 81 & & & CA1029G & 77 \\
\hline SOMA & & 2978 & & 18203 & & 6350 \\
\hline
\end{tabular}

Fonte: Apêndice C

Outras localidades (Vide tabela 5.21) foram indicadas pelos moradores, os quais são o Centro Histórico, Brás e Bom Retiro. 
A soma dos valores do Centro Histórico e Brás obtiveram o total 2973 pontos, um resultado muito próximo da Estrada do Alvarenga e a principal atração é exercida pelo comércio de vestuário do Brás, que isoladamente alcançou 1170 pontos. O comércio de roupas para cama, mesa e banho, do Centro Histórico e do Brás, atraem muitos moradores. Na Estrada do Alvarenga, há poucas lojas de roupas não sendo competitivas em relação às concorrentes do Brás. Considerando que os produtos cotidianos para o lar podem ser satisfatoriamente atendidos pelo centro comercial da Estrada do Alvarenga, exceto vestuário, o comércio do Centro Histórico e do Brás, representa pouca importância para o Distrito de Pedreira.

Tabela 5.20 - MEDIDA DE POSICIONAMENTO - COMÉRCIO LOCAL - AV. YERVANT KISSAJIKIAN E AV. NOSSA SENHORA DO SABARÁ

\begin{tabular}{|c|c|c|c|c|}
\hline \multirow{3}{*}{$\begin{array}{c}\text { RAMO DE } \\
\text { ATIVIDADE } \\
\text { Roupas }\end{array}$} & \multirow{2}{*}{\multicolumn{2}{|c|}{ AV. YERVANT }} & \multicolumn{2}{|c|}{ AV. NOSSA SENHORA DO } \\
\hline & & IAN & & \\
\hline & CR3YERA & 0 & CR3SABA & 8 \\
\hline Cama, mesa e banho & & & CC3SABA & 0 \\
\hline Calçados & CY3YERA & 56 & CY3SABA & 29 \\
\hline Eletro-eletrônicos & CE3YERA & 293 & & \\
\hline Móveis & CX3YERA & 256 & CX3SABA & 106 \\
\hline Utensílios para o lar & CW2YERA & 31 & CW2SABA & 88 \\
\hline Cine, foto e óptica & CO2YERA & 12 & CO2SABA & 39 \\
\hline Farmácia & CF2YERA & 48 & & \\
\hline Material de & CM2YERA & 313 & CM2SABA & 2 \\
\hline $\begin{array}{l}\text { construção } \\
\text { Alimentícios }\end{array}$ & CA2YERN & 2 & CA2SABN & 0 \\
\hline Super mercados & CS2YERA & 245 & CS2SABA & 7 \\
\hline Pet shop & & & CP2SABA & 0 \\
\hline Bazar & CV2YERA & 107 & CV2SABA & 0 \\
\hline SOMA & & 1363 & & 279 \\
\hline
\end{tabular}

Fonte: Apêndice C 
Tabela 5.21 - MEDIDA DE POSICIONAMENTO - OUTROS CENTROS - CENTRO HISTÓRICO, BRÁS E BOM RETIRO

\begin{tabular}{|c|c|c|c|c|c|c|}
\hline RAMO DE & \multicolumn{2}{|c|}{ CENTRO HISTÓRICO } & \multicolumn{2}{|c|}{ BRÁS } & \multicolumn{2}{|c|}{ BOM RETIRO } \\
\hline Roupas & CR3CENA & 369 & CR2BRZA & 1170 & CR3RETA & 0 \\
\hline $\begin{array}{c}\text { Cama, mesa e } \\
\text { banho }\end{array}$ & CC3CENA & 514 & CC3BRZA & 769 & CC3JPAA & 0 \\
\hline Calçados & CY3CENA & 92 & CY3BRZA & 4 & & \\
\hline $\begin{array}{l}\text { Utensílios } \\
\text { para o lar }\end{array}$ & CW2CENA & 10 & & & & \\
\hline Bazar & CV2CENA & 45 & & & & \\
\hline SOMA & & 1030 & & 1943 & & 0 \\
\hline
\end{tabular}

Fonte: Apêndice C

Dentre alguns resultados individuais da medida de posicionamento ("betweeness"), estão em destaque as informações do Largo 13 de Maio, Shopping Center Interlagos/ Interlar e Diadema.

Na região do Largo 13 de Maio, torna-se importante o comércio de roupas para cama, mesa e banho (CCL13A), que obteve 10435 pontos, o que corresponde à pontuação mais elevada nessa categoria de comércio, que indica a sua forte atração e dependência em conseqüência desse ramo de negócio ser praticamente inexistente no Distrito de Pedreira. O comércio de vestuário (CR3L13A), que obteve 12799 pontos, apresenta a força de atração muito forte, quase quatro vezes acima de Diadema. O comércio de eletro-eletrônicos (CE3L13A), que recebeu 5139 pontos, perde para Diadema e Shopping Center Interlagos. O comércio de móveis (CX3L13A) alcançou 3155 pontos e perde para Diadema. Os demais ramos, tais como utensílios para o lar (CW3L13A) e alimentos (CA2L13N) exercem baixa força de atração, pois estão disponíveis em grande quantidade em todo o Distrito de Pedreira. 
Em Diadema, destaca-se o comércio de eletro-eletrônicos (CE3DIAA), com 9159 pontos, e de móveis (CX3DIAA), com 5535 pontos. Ambos estão acima do Largo 13 de Maio e do Shopping Center Interlagos. O ramo de calçados (CY3DIAA) atingiu 4020 pontos e fica no mesmo nível do Shopping Center Interlagos, todavia, perde para o Largo 13 de Maio. O comércio de roupas para cama, mesa e banho (CC3DIAA), com 3859 pontos, corresponde a quase um terço da atração exercida pelos seus concorrentes do Largo 13 de Maio.

No Shopping Center Interlagos é intenso o comércio de eletro-eletrônicos (CE3INTA), recebendo 6659 pontos, perde apenas para Diadema. Igualmente é significativo o comércio de vestuário (CR3INTA), que obteve 5026 pontos e se posicionando acima de Diadema. Também é importante o comércio de calçados (CY3INTA) atingindo 4020 pontos. O ramo de roupa para cama, mesa e banho (CC3INTA), com 2854 pontos, equivale apenas à parcela de 27\%, desse mesmo ramo do Largo 13 de Maio. Os demais ramos não apresentam resultados significativos em comparação ao Largo 13 de Maio ou Diadema.

Quanto a alguns estabelecimentos com características locais os mais importantes são o Supermercado Pedreira, Supermercado Mamb's, Supermercado Ki Barato, Supermercado Ricoy e o Depósito 5 Irmãos.

O resultado, com 17888 pontos, obtida pelo Supermercado Pedreira (CS2002A) é o mais elevado do Distrito de Pedreira por atrair compradores de quase todo o Distrito.

Os Supermercados Mamb’s e Ki Barato, que receberam 2053 pontos, é um dos pontos de destaque, apesar de atenderem principalmente os moradores locais. O Supermercado Ricoy da Estrada do Alvarenga obteve apenas 480 pontos, pois sofre a forte concorrência do Supermercado Pedreira e de alguns outros das suas proximidades, por exemplo, os Supermercados Bahia, União, Dia e as filiais localizadas na Avenida Nossa Senhora do Sabará e Avenida Nossa Senhora dos Navegantes, em Diadema, no bairro Navegantes.

Também é destaque local o Depósito 5 Irmãos, que obteve 3622 pontos por atrair compradores de uma extensa área do Distrito de Pedreira. 
TABELAS RESUMO

Tabela 5.22 - MEDIDAS DE CENTRALIDADES - GRAU, PROXIMIDADE E POSICIONAMENTO

\begin{tabular}{|c|c|c|c|}
\hline & \multicolumn{3}{|c|}{$\begin{array}{c}\text { MEDIDAS - BENS DURÁVEIS (roupas de cama, mesa e } \\
\text { banho, calçados, eletro-eletrônicos, móveis, roupas e utensílios } \\
\text { para o lar) }\end{array}$} \\
\hline LOCAIS & $\begin{array}{l}\text { GRAU } \\
\text { (quantidade de } \\
\text { relacionamentos) }\end{array}$ & $\begin{array}{l}\text { PROXIMIDADE } \\
\text { (facilidade de } \\
\text { acesso) }\end{array}$ & $\begin{array}{l}\text { POSICIONAMENTO } \\
\text { (força de atração) }\end{array}$ \\
\hline Largo 13 de Maio & 267 & 1399 & 38285 \\
\hline Diadema & 221 & 1482 & 28588 \\
\hline Shopping Interlagos & 189 & 1499 & 20825 \\
\hline Estrada do Alvarenga & 14 & 2094 & 73 \\
\hline Parque Santa Amélia & 1 & 2035 & 0 \\
\hline Jardim Rubilene & 1 & 2139 & 0 \\
\hline Av. Yervant Kissajikian & 20 & 1903 & 636 \\
\hline Av. N. S. do Sabará & 19 & 1981 & 231 \\
\hline Centro Histórico & 28 & 1758 & 985 \\
\hline Brás & 21 & 1805 & 1943 \\
\hline Bom Retiro & 2 & 2083 & 0 \\
\hline
\end{tabular}

Fontes: Apêndice A, B, C 
O indicador determinante para o estabelecimento da hierarquia são os bens de baixa freqüência de compra (tabela 5.22) por estarem disponíveis, na maioria das vezes, somente em locais de grande fluxo e concentração de pessoas, do tipo Largo 13 de Maio ou centro comercial de Diadema. Os bens de freqüência alta de compra (tabela 5.23), por estarem disponíveis em diversos locais e bem próximos das residências, inclusive nas regiões mais periféricas, deixam de ser importantes para o estabelecimento dos centros de hierarquia mais elevada. Mesmo na categoria de bens de freqüência de compras baixa, alguns ramos, por exemplo, material de construção (tabela 5.24), são pouco importantes, para a determinação de hierarquia mais elevada, por se tratarem de ramos de comércio com número elevado de pequenos estabelecimentos. Esses comércios estão localizados principalmente em áreas da periferia e muitas vezes bem próximos às glebas, que sofreram o processo de invasão.

Quando o valor de grau de um determinado ponto de comércio for elevado pode ser em consequiência de uma forte atração existente naquele local. Entretanto, o uso do valor de grau poder deixar mais complexa a tarefa de avaliar quantitativamente a intensidade de atração, ao mensurar apenas a quantidade de contatos ou a quantidade de pessoas que mantêm relação com um determinado tipo de ramo de comércio. Para bens de baixa freqüência de compras o valor de grau do Largo 13 de Maio é 21\% acima de Diadema. Contudo a diferença da intensidade de atração, do primeiro, é de $34 \%$ superior em conseqüência dos resultados de posicionamento. O melhor indicador para a intensidade de atração, pode ser o valor de posicionamento, diante da sua propriedade de quantificar o poder de intermediação. Uma intensidade de atração mais elevada pode ser em conseqüência de maior dependência do comprador em relação à determinada localização do comércio, às vezes, condicionada pelas vantagens ou desvantagens de acessibilidade. No ramo alimentício, por estar muito pulverizado pelo território, diante da quantidade elevada de pontos de comércio, o poder de atração torna-se pouco intenso em comparação ao ramo de eletrodomésticos, que funciona em poucos locais de vendas. Quando o número de estabelecimentos comerciais for baixo ou escasso, torna-se possível a criação de uma forte dependência, o que obriga os compradores se dirigirem aos centros mais distantes.

Em consequiência da mais vantajosa e melhor facilidade de acesso a determinados locais, muitas vezes, esperam-se que os valores de grau e de posicionamento sejam elevados. A medida de proximidade, conceitualmente, pode dar a conotação de indicar as características de melhor facilidade de acesso. Os valores de grau e de posicionamento mais elevados não 
definem necessariamente a existência de maiores facilidades de acesso, por exemplo, na tabela 5.23, no tocante à categoria de alimentícios. Embora os valores de grau e de posicionamento da Estrada do Alvarenga, em alimentícios, sejam superiores aos do Shopping Center Interlagos, a medida de proximidade do Shopping Center Interlagos, nessa mesma categoria de produtos, é mais vantajosa em comparação à Estrada do Alvarenga. A maior quantidade de estabelecimentos comerciais da Estrada do Alvarenga pode proporcionar valores mais elevados de grau e de posicionamento. Entretanto, a facilidade de acesso do Shopping Interlagos, diante da maior concentração de lojas, pode ser mais vantajosa, por exemplo, por causa do hipermercado Carrefour, onde um morador pode satisfazer todas as suas necessidades num único local, em vez de percorrer vários estabelecimentos distintos, nesse referido logradouro.

\section{Tabela 5.23 - MEDIDAS DE CENTRALIDADES - GRAU, PROXIMIDADE E POSICIONAMENTO}

\begin{tabular}{|c|c|c|c|}
\hline \multirow[b]{2}{*}{ LOCAIS } & \multicolumn{3}{|c|}{$\begin{array}{l}\text { MEDIDAS - ALIMENTÍCIOS (supermercados de } \\
\text { grande e médio pontes, alimentos, produtos de limpeza, } \\
\text { produtos para animais e artigos para bazar) }\end{array}$} \\
\hline & $\begin{array}{l}\text { GRAU (quantidade } \\
\text { de relacionamentos) }\end{array}$ & $\begin{array}{l}\text { PROXIMIDADE } \\
\text { (facilidade de } \\
\text { acesso) }\end{array}$ & $\begin{array}{l}\text { POSICIONAMENTO } \\
\text { (força de atração) }\end{array}$ \\
\hline Largo 13 de Maio & 28 & 1690 & 1143 \\
\hline Diadema & 56 & 1925 & 2436 \\
\hline Shopping Interlagos & 23 & 1750 & 1035 \\
\hline Estrada do Alvarenga & 103 & 1842 & 2039 \\
\hline Parque Santa Amélia & 92 & 1725 & 17889 \\
\hline Jardim Rubilene & 72 & 1857 & 2493,7 \\
\hline Av. Yervant Kissajikian & 13 & 1893 & 354 \\
\hline Av. N. S. do Sabará & 6 & 2060 & 7 \\
\hline Centro Histórico & 4 & 1833 & 45 \\
\hline Brás & 0 & 0 & 0 \\
\hline Bom Retiro & 0 & 0 & 0 \\
\hline
\end{tabular}

Fontes: Apêndice A, B, C 


\section{Tabela 5.24 - MEDIDAS DE CENTRALIDADE - GRAU, PROXIMIDADE E POSICIONAMENTO}

\begin{tabular}{|c|c|c|c|}
\hline & \multicolumn{3}{|c|}{$\begin{array}{c}\text { MEDIDAS - OUTROS PRODUTOS (material para construção, } \\
\text { farmácia e cine, foto e óptica) }\end{array}$} \\
\hline LOCAIS & $\begin{array}{c}\text { GRAU } \\
\text { (quantidade de } \\
\text { relacionamentos) }\end{array}$ & $\begin{array}{l}\text { PROXIMIDADE } \\
\text { (facilidade de acesso) }\end{array}$ & $\begin{array}{l}\text { POSICIONAMENTO } \\
\text { (força de atração) }\end{array}$ \\
\hline Largo 13 de Maio & 7 & 1951 & 45 \\
\hline Diadema & 59 & 1635 & 4751 \\
\hline Shopping Interlagos & 8 & 1707 & 155 \\
\hline Estrada do Alvarenga & 43 & 1878 & 866 \\
\hline Parque Santa Amélia & 17 & 1738 & 314 \\
\hline Jardim Rubilene & 46 & 1838 & 3857 \\
\hline $\begin{array}{l}\text { Av. Yervant } \\
\text { Kissajikian }\end{array}$ & 13 & 1923 & 373 \\
\hline Av. N. S. do Sabará & 6 & 1890 & 41 \\
\hline Centro Histórico & 8 & 0 & 155 \\
\hline Brás & 0 & 0 & 0 \\
\hline Bom Retiro & 0 & 0 & 0 \\
\hline
\end{tabular}

Fontes: Apêndice A, B, C 
Tabela 5.25 - MEDIDAS DE CENTRALIDADE - GRAU, PROXIMIDADE E POSICIONAMENTO

\begin{tabular}{|c|c|c|c|}
\hline \multirow[b]{2}{*}{ LOCAIS } & \multicolumn{3}{|c|}{ MEDIDAS - VALORES GLOBAIS } \\
\hline & GRAU & PROXIMIDADE & POSICIONAMENTO \\
\hline Largo 13 de Maio & 302 & 1690 & 39473 \\
\hline Diadema & 336 & 1681 & 35775 \\
\hline $\begin{array}{l}\text { Shopping } \\
\text { Interlagos }\end{array}$ & 220 & 1652 & 22015 \\
\hline $\begin{array}{l}\text { Estrada do } \\
\text { Alvarenga }\end{array}$ & 160 & 1938 & 2978 \\
\hline $\begin{array}{c}\text { Parque Santa } \\
\text { Amélia }\end{array}$ & 110 & 1832 & 18203 \\
\hline Jardim Rubilene & 119 & 1944 & 6350,7 \\
\hline $\begin{array}{l}\text { Av. Yervant } \\
\text { Kissajikian }\end{array}$ & 46 & 1906 & 1363 \\
\hline Av. N. S. do Sabará & 31 & 1977 & 279 \\
\hline Centro Histórico & 32 & 1795 & 1030 \\
\hline Brás & 21 & 1805 & 1943 \\
\hline Bom Retiro & 2 & 2083 & 0 \\
\hline
\end{tabular}

Fontes: Apêndice A, B, C 


\subsection{Equivalência estrutural e automórfica}

Numa rede social, conforme os conceitos da página 57, observa-se determinada quantidade de atores ou eventualmente um grupo de atores ou nós que mantém relações com esses mesmos atores ou então com esses mesmos grupos de atores. Os atores que satisfazem essas condições são considerados equivalentes. Um dos principais objetivos da aplicação, dos conceitos de equivalência, é identificar grupos de atores que apresentem as mesmas características comuns. Disto, torna-se possível a identificação de grupos de famílias, com os mesmos hábitos ou eventualmente com as mesmas necessidades, no tocante à acessibilidade, em decorrência da localização de determinados centros comerciais, por meio da análise da estrutura morfológica desses relacionamentos comuns, em relação a determinados centros comuns, e organizados em forma de uma rede social.

No método de equivalência, o critério para se estabelecer os grupos ou clusters se baseia em nós relacionados entre si pelos atores desses grupos. Portanto, é possível a identificação dos grupos de nós, os quais correspondem aos grupos de moradores que efetuam as compras nos mesmos centros comerciais comuns a todos desses grupos. Igualmente, é possível, a identificação, de outros grupos de nós, representando os vários ramos de atividades do comércio, em conseqüência das preferências de cada comprador decorrentes, principalmente, das facilidades oferecidas em termos de acessibilidade.

O escopo desta seção enfoca apenas a aplicação de equivalência para o estudo da estruturação de grupos de moradores. O objetivo é analisar os padrões de distribuição espacial de grupos de moradores, em decorrência dos centros de influência, os quais podem estar localizados dentro ou fora do Distrito.

A quantidade elevada de estabelecimentos comerciais, em consequiência de diferentes ramos de atividades, às vezes dentro de um raio não muito distante das aglomerações de moradias para o atendimento das necessidades de freqüência de compras diárias ou semanais, cujo valor da medida de centralidade grau é bastante baixo para cada ramo de comércio, pode formar número bastante elevado de pequenos grupos, de moradores e de pontos de comércio, em função de determinados relacionamentos de cada um dos moradores com os estabelecimentos comerciais. 
Três métodos de equivalência são aplicados:

- equivalência estrutural, fundamentada na técnica de distância euclidiana;

- equivalência estrutural, tendo como base a técnica CONCOR;

- equivalência automórfica.

\subsection{Equivalência estrutural - método de distância euclidiana}

As características dos grupos de moradores, desenvolvidas por meio da aplicação da equivalência estrutural, a partir da estrutura morfológica da rede social, permitiram a avaliação das interferências dos níveis hierárquicos na definição dos padrões de distribuição espacial dos grupos de moradores. Em determinados grupos, identificou-se a influência predominante de apenas um dos centros Em outros grupos observam-se as influências resultantes da participação simultânea de dois, três ou mais centros.

Pelo método da distância euclidiana, obteve-se a identificação de 7 tipos distintos de padrões de formação de grupos. Os centros de influência foram divididos, em duas categorias. A principal, quando estiverem presentes os valores mais elevados da medida de grau, indistintamente com muita ou com pouca intensidade, na estrutura dos grupos: Largo 13 de Maio; Shopping Center Interlagos; Diadema e Supermercado Pedreira. A outra categoria, que corresponde aos demais centros, indiferentemente dos seus valores de grau, recebeu a classificação de centros secundários sendo os mais importantes: a Estrada do Alvarenga; Depósito 5 Irmãos e Avenida Yervant Kissajikian. O Supermercado Pedreira e o Depósito 5 Irmãos, embora sejam pontos isolados, estão recebendo o mesmo tratamento de um centro, em decorrência dos elevados pontos que obtiveram na medida de grau.

Em função da intensidade de atração de cada centro de influência, observou-se a definição de alguns padrões espaciais específicos. Constitui-se um dos padrões quando se verifica a influência quase exclusiva de Diadema, do Largo 13 de Maio ou do Shopping Center Interlagos. Outros padrões foram obtidos pela combinação de alguns centros de influência, tais como Largo 13 de Maio e Diadema, Largo 13 de Maio e Shopping Center Interlagos, Diadema e Shopping Center Interlagos ou Largo 13 de Maio, Diadema e Shopping Center Interlagos. 
O Supermercado Pedreira, embora não participe de maneira mais intensa em todos os grupos, exerce um papel determinante na caracterização de certos grupos. Igualmente, a Estrada do Alvarenga estabelece uma forte influência local em alguns grupos, também pode ser forte a influência do Depósito 5 Irmãos em determinados grupos.

O grupo 1 (mapa 5.4 página 160 e figura 5.8 página 253) localiza-se ao norte e centro do Distrito de Pedreira, abrange os bairros de Vila Aparecida, V. Missionária e Jardim Selma. Os dois últimos fazem divisa com o Distrito de Cidade Ademar.

Nesse grupo, constituído por uma amostra de 3 moradores, o seu resultado indica uma forte influência do comércio da Avenida Yervant Kissajikian, no Distrito de Cidade Ademar, e do Shopping Center Interlagos. A influência de Diadema e da Avenida Nossa Senhora do Sabará, é pouco importante e um dos moradores manifesta uma forte preferência pelo comércio da Estrada do Alvarenga.

Esse grupo ocupa uma área aproximada de $0,2 \mathrm{~km}^{2}$. De acordo com os dados do censo demográfico de 2000, os 20.229 habitantes correspondem à parcela de 15,9\% da população do Distrito, ocupação habitacional média de 3,79 pessoas por domicílio. O ou a chefe de família detém a renda per capita média de $\mathrm{R} \$ 704,95$ e 6,64 anos de tempo médio de estudo.

O grupo 2 (mapa 5.5 página 161 e figura 5.9 página 255) localiza-se na região norte, centro e na primeira península (Jardim Apurá), abrange os bairros de Vila Aparecida, Jardim Apurá, Balneário Mar Paulista, Parque Dorotéia, Vila Guacuri, Vila Missionária, Parque Primavera, Jardim Rubilene, Parque Santa Amélia, Jardim Selma.

Esse grupo é constituído por uma amostra de 23 moradores, seu resultado apresenta uma intensa influência do comércio do Largo 13 de Maio e significativa participação do comércio da Estrada do Alvarenga. É de pouca importância a influência de Diadema e do Shopping Center Interlagos.

Esse grupo ocupa uma área aproximada de $2 \mathrm{~km}^{2}$. De acordo com os dados do censo demográfico de 2000, os 2.348 habitantes correspondem à parcela de 1,8\% da população do Distrito, ocupação habitacional média de 3,74 pessoas por domicílio. O ou a chefe de família detém a renda per capita média de $\mathrm{R} \$ 879,96$ e 6,77 anos de tempo médio de estudo. 


\section{EQUIVALÊNCIA ESTRUTURAL REGIÕES DE INFLUÊNCIA}

DISTRITO DE PEDREIRA

POR SETOR CENSITÁRIO

MAPA NÚMERO 5.36

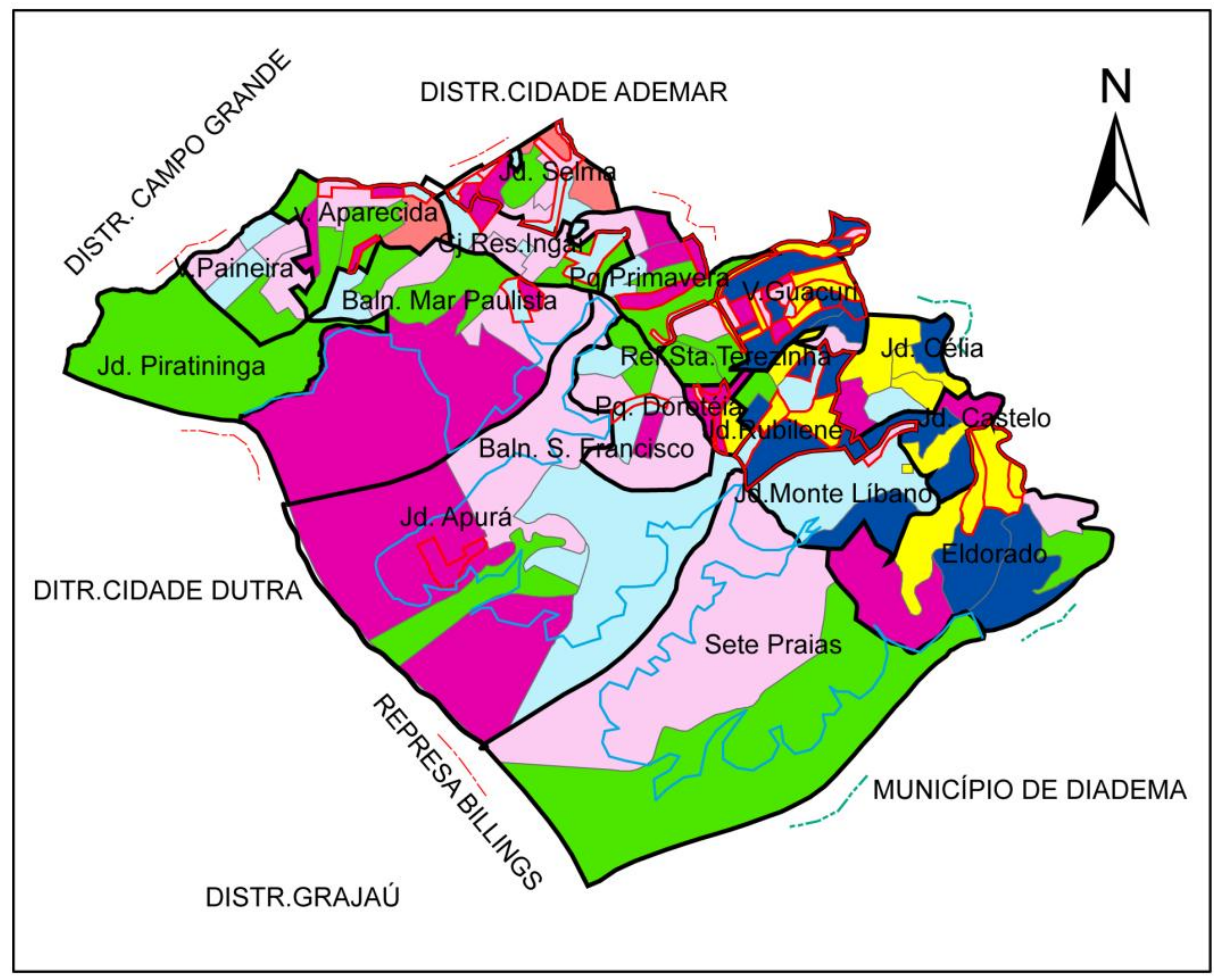

$\begin{array}{llll}0 & 0,5 & 1 & 2 \text { Kilometers }\end{array}$

Autor: Shinhiti Osanai

Fonte: pesquisa do autor
Regiões de influência

$$
\begin{array}{|l}
\hline \text { Yervant } \\
\hline \square \text { L. } 13 \text { de Maio } \\
\text { L. } 13 \text { de Maio } \\
\text { Shop. Interlagos } \\
\hline \square \text { L.13 Maio/S.Interlagos } \\
\hline \text { L.13 Maio/Diadema } \\
\square \text { Diadema } \\
\hline \text { Principais bairros } \\
\hline \text { Favelas } \\
\hline- \text { Divisa Distr. Pedreira } \\
--- \text { Divisa Diadema } \\
\square \text { Represa Billings }
\end{array}
$$


Figura 5.8 - REDE SOCIAL DOS MORADORES SOB PRINCIPAL INFLUÊNCIA DA AVENIDA YERVANT KISSAJIKIAN (GRUPO 1)

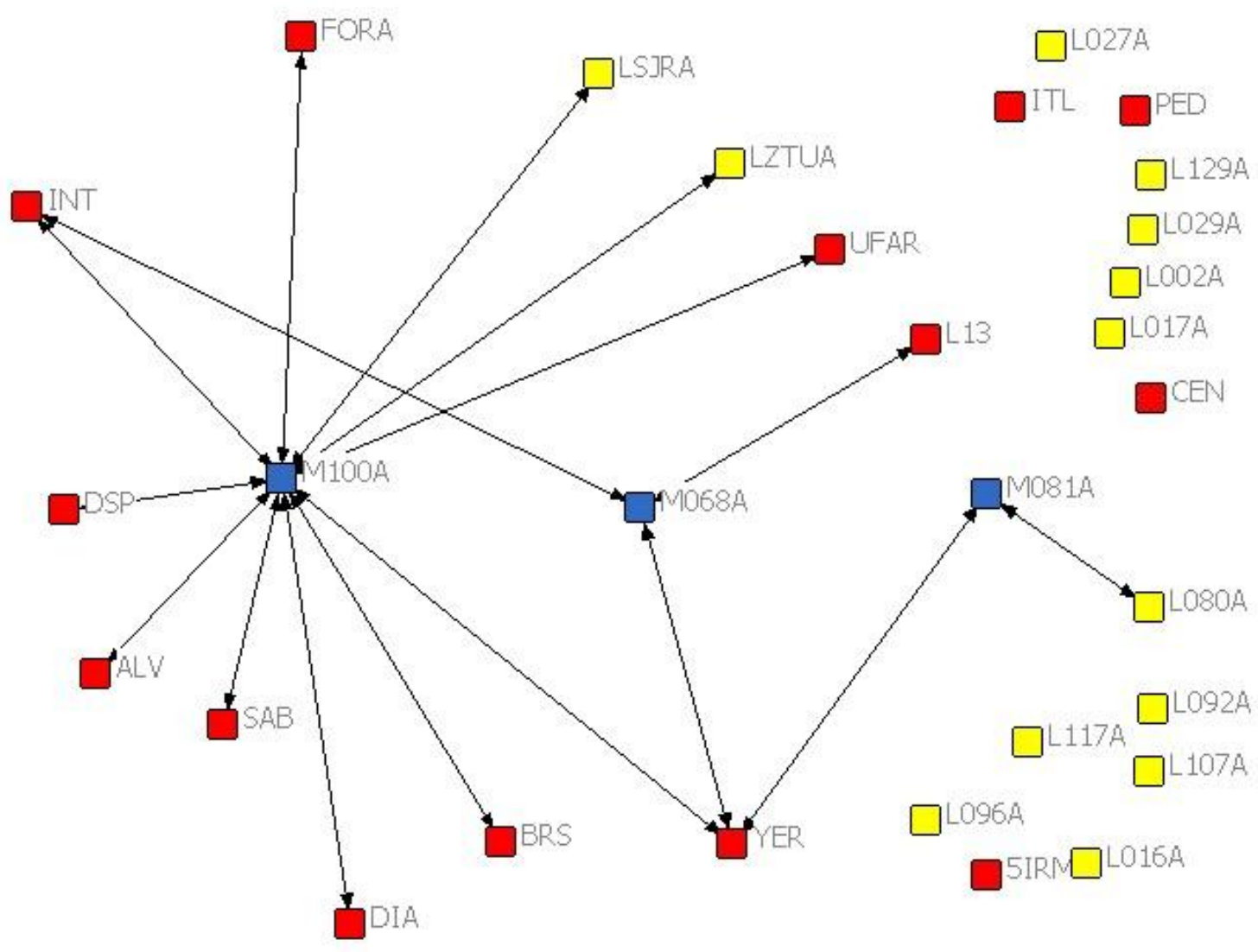

Obs.: Na cor azul os moradores. Relações, na cor vermelha, com os centros Shopping Center Interlagos (INT); Drogaria São Paulo da Avenida Nossa Senhora do Sabará (DSP); Estrada do Alvarenga (ALV); Avenida Nossa Senhora do Sabará (SAB); Diadema (DIA); Brás (BRS); Avenida Yervant Kissajikian (YER); Largo 13 de Maio (L13); Drogaria Ultra Farma (UFAR); vários centros fora do Distrito de Pedreira (FORA). Em amarelo, as relações com o comércio local.

Fonte: pesquisa do autor

O grupo 3 (mapa 5.6 página 162 e figura 5.10 página 256) se localiza ao norte, centro, parte da região sul e nas duas penínsulas (Jardim Apurá e Sete Praias), abrangem os bairros de Vila Aparecida, Jardim Apurá, Balneário Mar Paulista, Parque Dorotéia, Eldorado, Vila Guacuri, Vila Missionária, Parque Primavera, Jardim Rubilene, Parque Santa Amélia e Jardim Selma. 
Esse grupo é constituído por uma amostra de 23 moradores e, seu resultado apresenta uma forte influência do comércio do Largo 13 de Maio e significativa participação do comércio da Estrada do Alvarenga. Existe influência mediana do Shopping Center Interlagos e do comércio da Avenida Yervant Kissajikian. É pouco importante a influência de Diadema.

Esse grupo ocupa uma área aproximada de $4 \mathrm{~km}^{2}$. De acordo com os dados do censo demográfico de 2000, os 23.106 habitantes correspondem à parcela de $18,1 \%$ da população do Distrito, ocupação habitacional média de 3,84 pessoas por domicílio. O ou a chefe de família detém a renda per capita média de $\mathrm{R} \$ 613,12$ e 6,16 anos de tempo médio de estudo.

O grupo 4 (mapa 5.7 página 164 e figura 5.11 página 257) localiza-se ao norte, centro, sul e nas duas penínsulas (Jardim Apurá e Sete Praias), abrange os bairros de Vila Aparecida, Jardim Apurá, Balneário Mar Paulista, Eldorado, Vila Missionária, Parque Primavera, Jardim Rubilene, Parque Santa Amélia, Jardim Selma e Sete Praias.

Esse grupo é constituído por uma amostra de 17 moradores e, o seu resultado encontra sob a influência mediana de Diadema, Largo 13 de Maio e Avenida Nossa Senhora do Sabará. Observa-se forte a influência do Shopping Center Interlagos e participação significativa do comércio da Estrada do Alvarenga. É o grupo que apresenta a maior renda per capita do ou da chefe de família, o que pode ser o motivo da preferência pelo Shopping Center Interlagos.

Esse grupo ocupa uma área aproximada de 4,6 $\mathrm{km}^{2}$. De acordo com os dados do censo demográfico de 2000, os 18.691 habitantes correspondem à parcela de 14,7\% da população do Distrito, ocupação habitacional média de 3,56 pessoas por domicílio. O ou a chefe de família detém a renda per capita média de $\mathrm{R} \$ 906,22$ e 7,19 anos de tempo médio de estudo.

O grupo 5 (mapa 5.8 página 165 e figura 5.12 página 259) localiza-se ao norte, centro, sul e nas duas penínsulas (Jardim Apurá e Sete Praias), abrange os bairros de Vila Aparecida, Jardim Apurá, Balneário Mar Paulista, Parque Dorotéia, Eldorado, Vila Guacuri, Vila Missionária, Parque Primavera, Jardim Rubilene, Parque Santa Amélia, Jardim Selma e Sete Praias.

Esse grupo é constituído por uma amostra de 28 moradores, é bastante intensa a influência do Shopping Center Interlagos e fraca as influências de Diadema e da Avenida Nossa Senhora do Sabará. São medianas as influências do Largo 13 de Maio e da Avenida Yervant Kissajikian. 
Figura 5.9 - REDE SOCIAL DOS MORADORES SOB PRINCIPAL INFLUÊNCIA DO LARGO 13 DE MAIO (GRUPO 2)

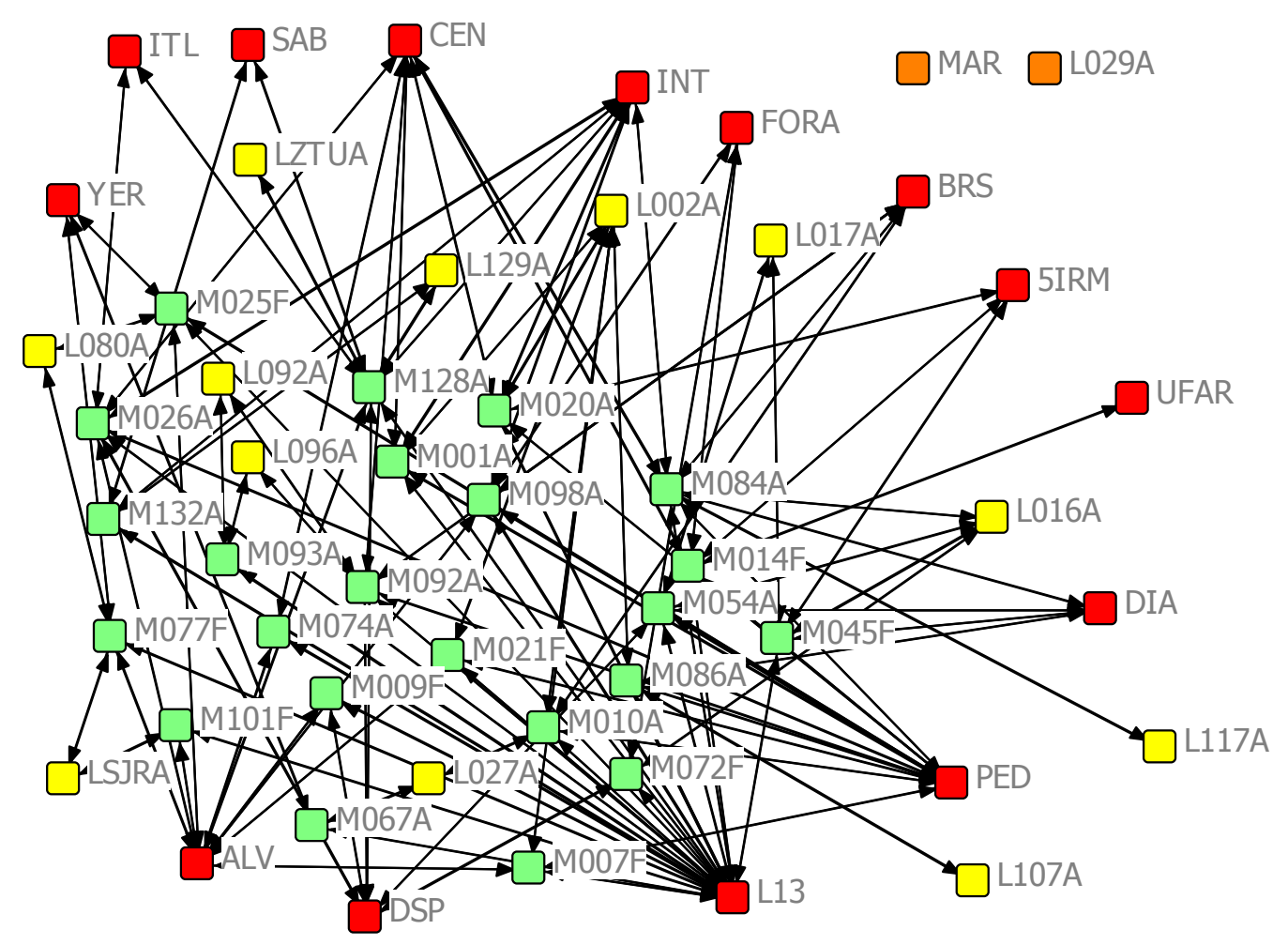

Obs.: Na cor verde os moradores. Relações, na cor vermelha, com os centros Shopping Center Interlagos (INT); Drogaria São Paulo da Avenida Nossa Senhora do Sabará (DSP); Estrada do Alvarenga (ALV); Avenida Nossa Senhora do Sabará (SAB); Diadema (DIA); Brás (BRS); Avenida Yervant Kissajikian (YER); Largo 13 de Maio (L13); Drogaria Ultra Farma (UFAR); vários centros fora do Distrito de Pedreira (FORA); Centro Histórico (CEN); Shopping Center Interlar (ITL); Supermercado Pedreira (PED). Em amarelo, as relações com o comércio local.

Fonte: pesquisa do autor 
Figura 5.10 - REDE SOCIAL SOB PRINCIPAL INFLUÊNCIA DO LARGO 13 DE MAIO (GRUPO 3)

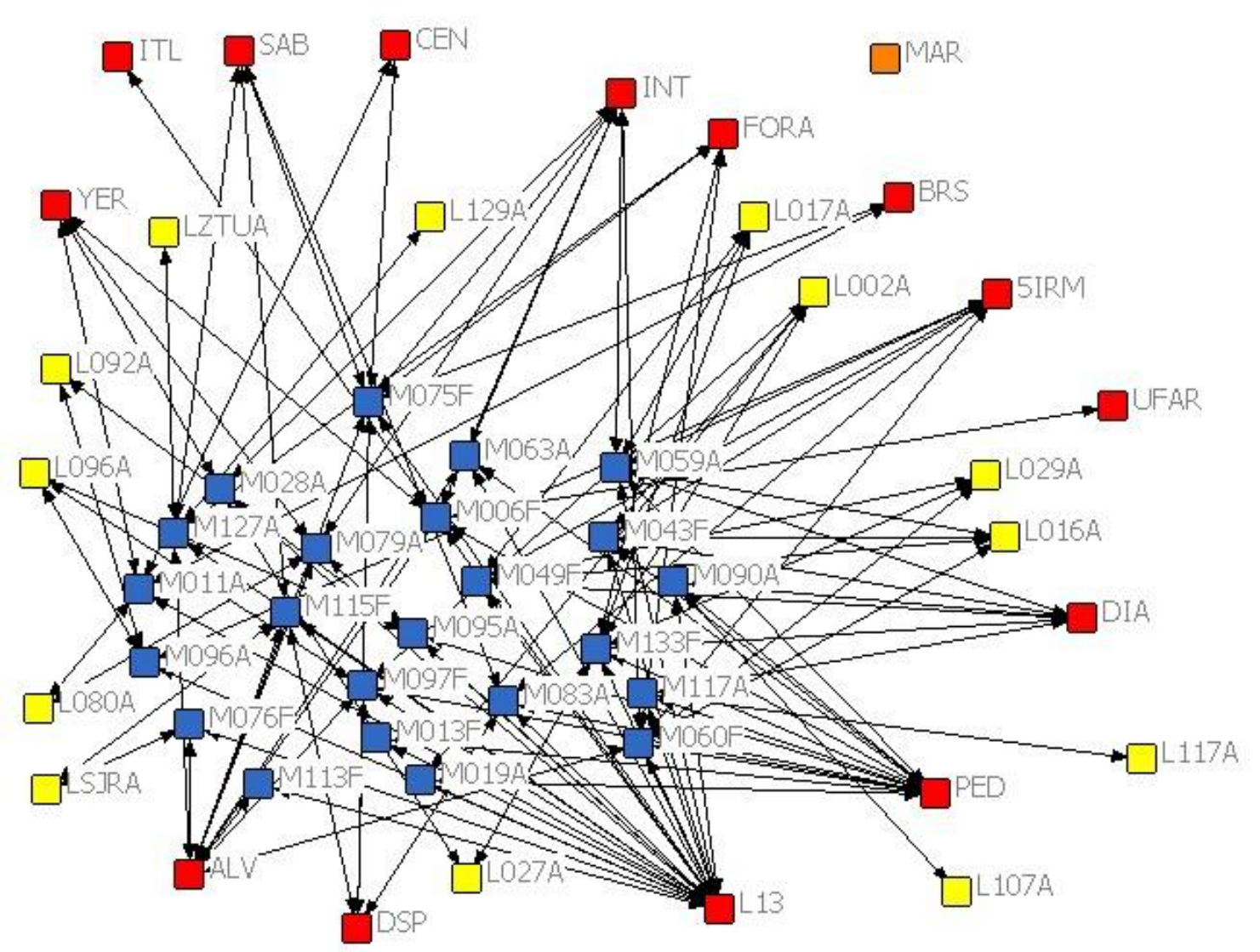

Obs.: Na cor azul os moradores. Relações, na cor vermelha, com os centros Shopping Center Interlagos (INT); Drogaria São Paulo da Avenida Nossa Senhora do Sabará (DSP); Estrada do Alvarenga (ALV); Avenida Nossa Senhora do Sabará (SAB); Diadema (DIA); Brás (BRS); Avenida Yervant Kissajikian (YER); Largo 13 de Maio (L13); Drogaria Ultra Farma (UFAR); vários centros fora do Distrito de Pedreira (FORA); Centro Histórico (CEN); Shopping Center Interlar (ITL); Supermercado Pedreira (PED); Depósito 5 Irmãos (5IRM). Em amarelo, as relações com o comércio local.

Fonte: pesquisa do autor 


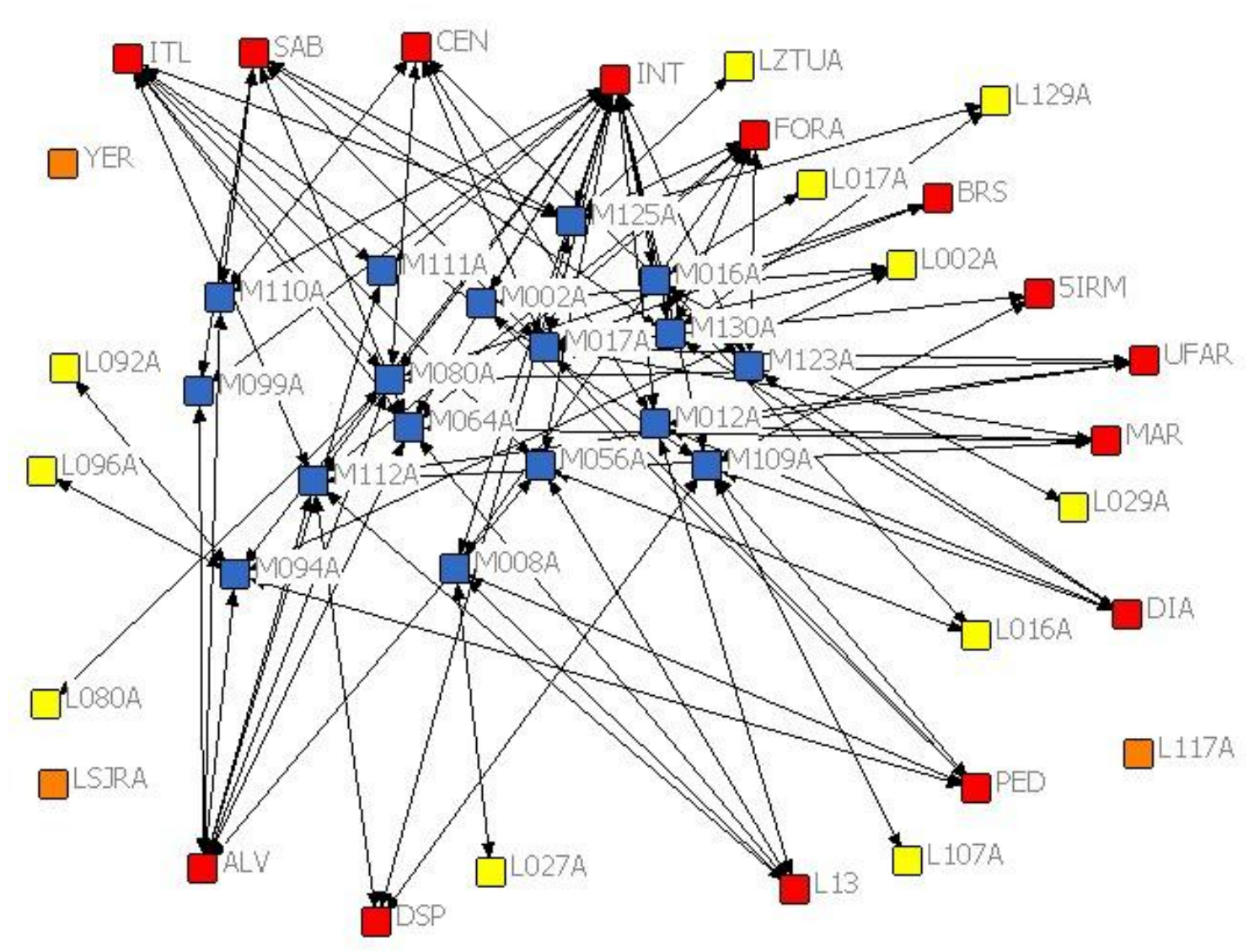

Obs.: Na cor azul os moradores. Relações, na cor vermelha, com os centros Shopping Center Interlagos (INT); Drogaria São Paulo da Avenida Nossa Senhora do Sabará (DSP); Estrada do Alvarenga (ALV); Avenida Nossa Senhora do Sabará (SAB); Diadema (DIA); Brás (BRS); Largo 13 de Maio (L13); Drogaria Ultra Farma (UFAR); vários centros fora do Distrito de Pedreira (FORA); Centro Histórico (CEN); Shopping Center Interlar (ITL); Supermercado Pedreira (PED); Depósito 5 Irmãos (5IRM); Shopping Center SPMarket (MAR). Em amarelo, as relações com o comércio local.

Fonte: pesquisa do autor

Esse grupo ocupa uma área aproximada de 4,2 $\mathrm{km}^{2}$. De acordo com os dados do censo demográfico de 2000, os 25.817 habitantes correspondem à parcela de 20,3\% da população do Distrito, ocupação habitacional média de 3,79 pessoas por domicílio. O ou a chefe de família detém a renda per capita média de $\mathrm{R} \$ 710,87$ e 6,62 anos de tempo médio de estudo.

O grupo 6 (mapa 5.9 página 167 e figura 5.13 página 260) localiza-se ao sul do Distrito inclusive até a divisa com Diadema, abrange os bairros de Parque Dorotéia, Eldorado, Vila Guacuri e Jardim Rubilene. 
Esse grupo é constituído por uma amostra de 23 moradores e, seu resultado apresenta uma intensa influência de Diadema, mediana influência do Largo 13 de Maio e é insignificante a participação do Shopping Center Interlagos. Nenhuma influência dos demais centros mais importantes foi constatada. A influência de Diadema é bastante intensa nas áreas mais próximas à divisa municipal, tendo em vista, no Distrito de Pedreira, o comércio muito deficiente nessa região mais próxima à divisa. É o grupo que apresenta, dentre todos os grupos, a menor renda per capita média do ou da chefe de família.

Esse grupo ocupa uma área aproximada de $1,0 \mathrm{~km}^{2}$. De acordo com os dados do censo demográfico de 2000, os 23.096 habitantes correspondem à parcela de 18,1\% da população do Distrito, ocupação habitacional média de 3,85 pessoas por domicílio. $\mathrm{O}$ ou a chefe de família detém a renda per capita média de $\mathrm{R} \$ 513,86$ e 5,93 anos de tempo médio de estudo.

O grupo 7 (mapa 5.10 página 168 e figura 5.14 página 261) localiza-se ao sul do Distrito inclusive até a divisa com Diadema, abrange os bairros de Parque Dorotéia, Eldorado, Vila Guacuri e Jardim Rubilene.

A influência de Diadema é bastante intensa nas áreas próximas à divisa municipal, tendo em vista, no Distrito de Pedreira, o comércio muito deficiente nas regiões próximas à divisa. A renda per capita média do ou da chefe de família encontra-se em penúltimo lugar.

Esse grupo é constituído por uma amostra de 18 moradores, o resultado dessa amostra apresenta uma intensa influência de Diadema e pouca influência do Largo 13 de Maio. Nenhuma influência, dos demais centros mais importantes, foi constatada.

Esse grupo ocupa uma área aproximada de $1,4 \mathrm{~km}^{2}$, de acordo com os dados do censo demográfico de 2000, os 14.138 habitantes correspondem à parcela de 11,1\% da população do Distrito, ocupação habitacional média de 3,85 pessoas por domicílio. O ou a chefe de família detém a renda per capita média de $\mathrm{R} \$ 594.21$ e 6,19 anos de tempo médio de estudo. 
Figura 5.12 - REDE SOCIAL SOB PRINCIPAL INFLUÊNCIA DO SHOPPING CENTER INTERLAGOS (GRUPO 5)

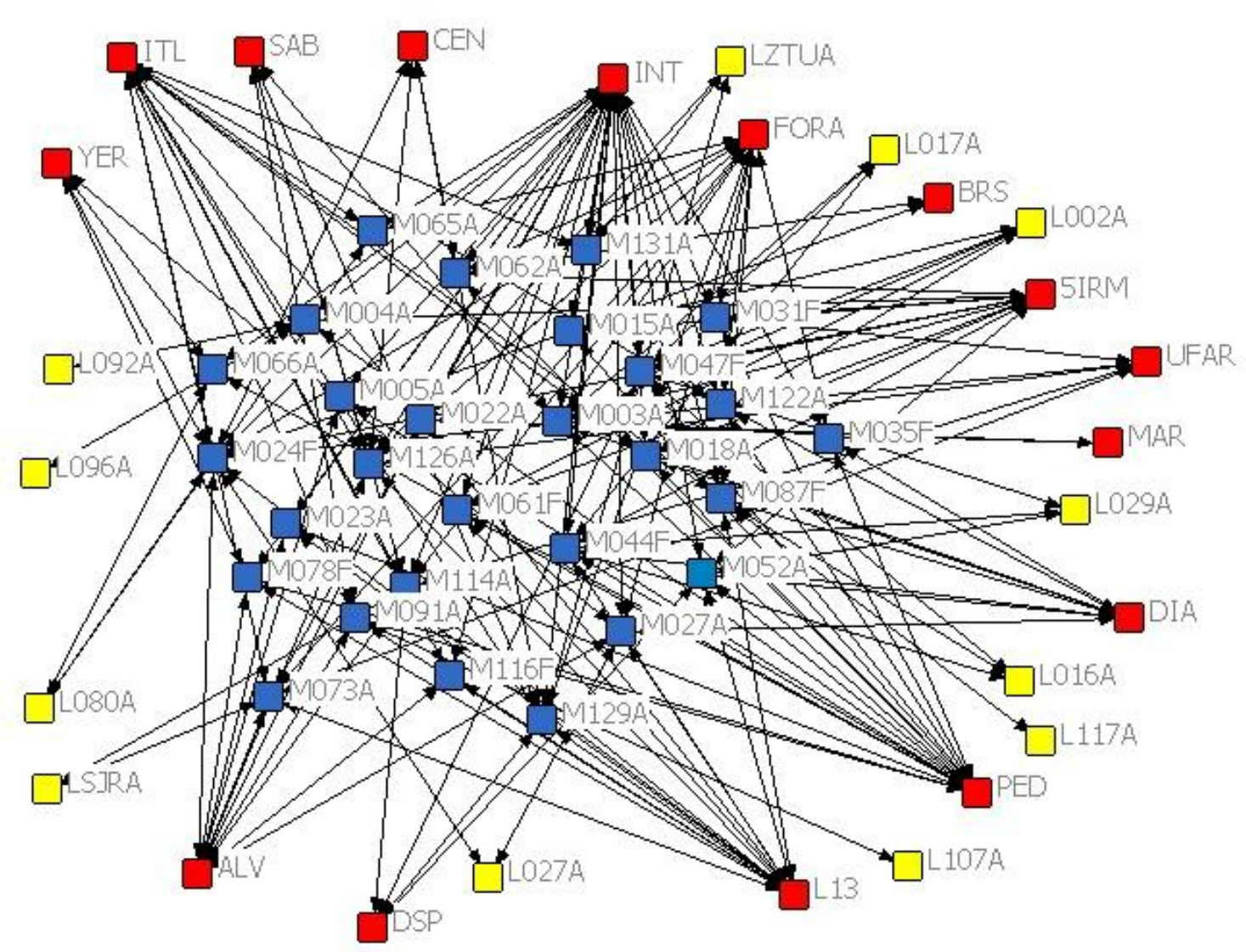

Obs.: Na cor azul os moradores. Relações, na cor vermelha, com os centros Shopping Center Interlagos (INT); Drogaria São Paulo da Avenida Nossa Senhora do Sabará (DSP); Estrada do Alvarenga (ALV); Avenida Nossa Senhora do Sabará (SAB); Diadema (DIA); Brás (BRS); Avenida Yervant Kissajikian (YER); Largo 13 de Maio (L13); Drogaria Ultra Farma (UFAR); vários centros fora do Distrito de Pedreira (FORA); Centro Histórico (CEN); Shopping Center Interlar (ITL); Supermercado Pedreira (PED); Depósito 5 Irmãos (5IRM); Shopping Center SPMarket (MAR). Em amarelo, as relações com o comércio local.

Fonte: pesquisa do autor 
Figura 5.13 - REDE SOCIAL SOB PRINCIPAL INFLUÊNCIA DE DIADEMA (GRUPO 6)

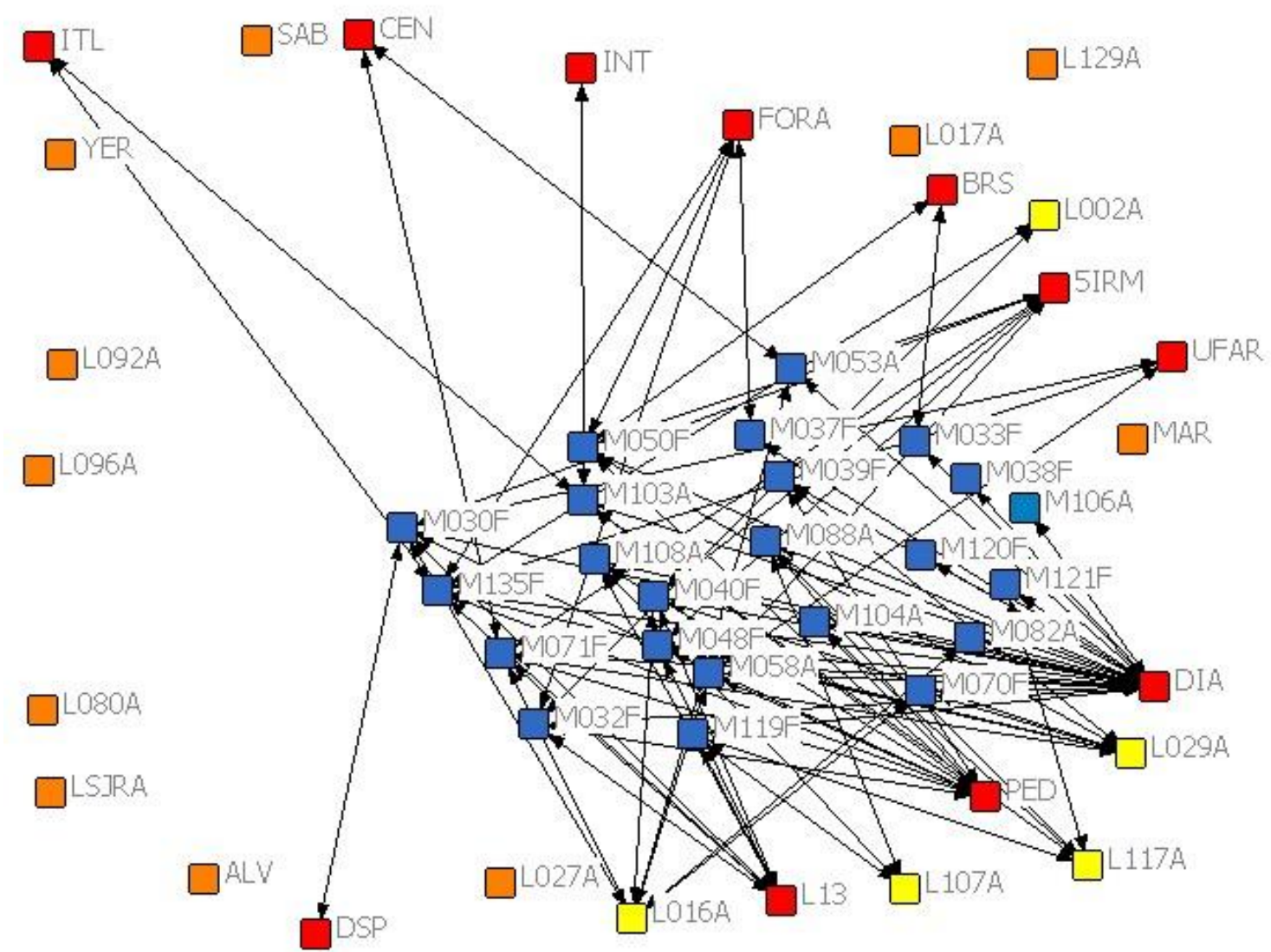

Obs.: Na cor azul os moradores. Relações, na cor vermelha, com os centros Shopping Center Interlagos (INT); Drogaria São Paulo da Avenida Nossa Senhora do Sabará (DSP); Diadema (DIA); Brás (BRS); Largo 13 de Maio (L13); Drogaria Ultra Farma (UFAR); vários centros fora do Distrito de Pedreira (FORA); Centro Histórico (CEN); Shopping Center Interlar (ITL); Supermercado Pedreira (PED); Depósito 5 Irmãos (5IRM). Em amarelo, as relações com o comércio local.

Fonte: pesquisa do autor 
Figura 5.14 - REDE SOCIAL SOB PRINCIPAL INFLUÊNCIA DE DIADEMA (GRUPO 7)

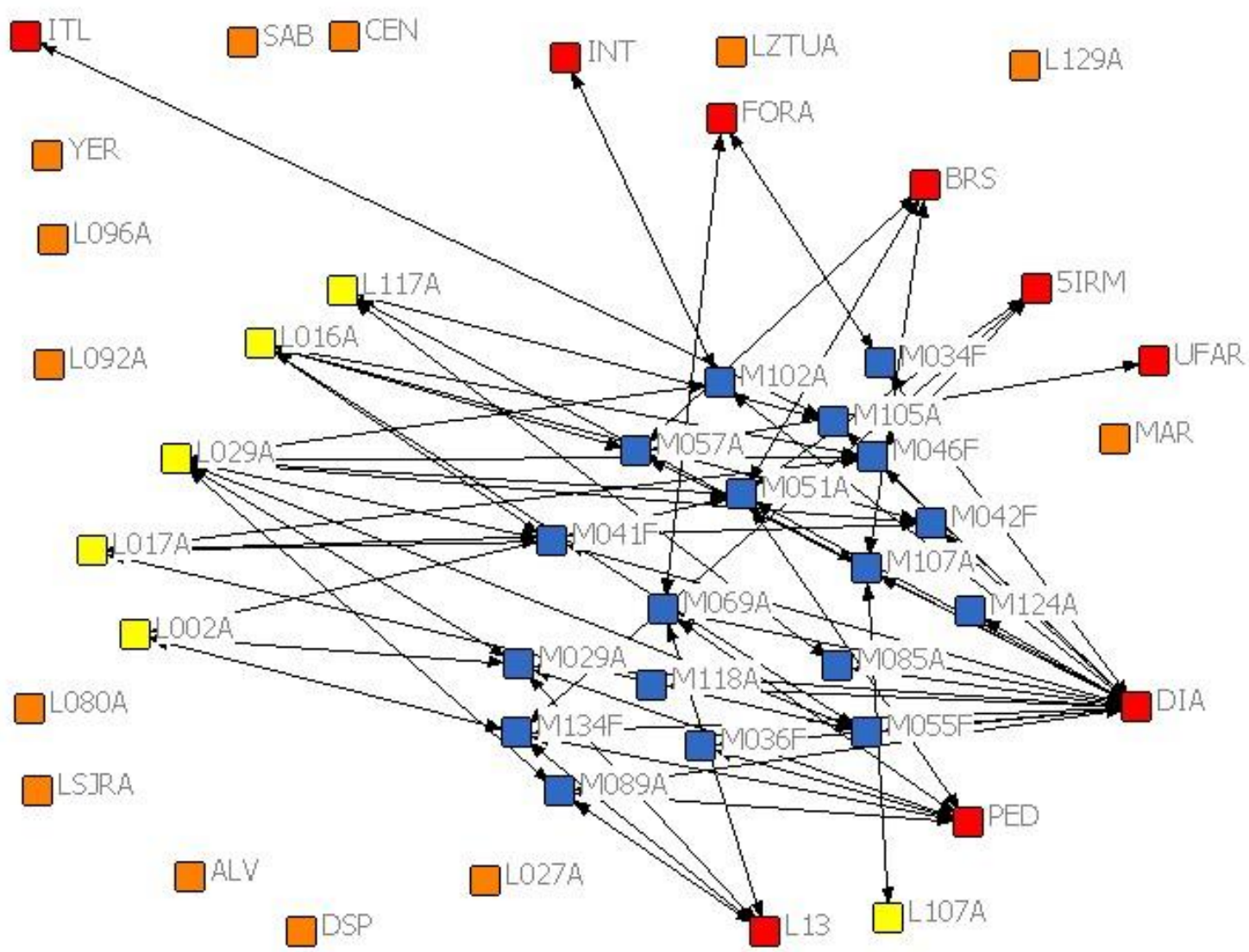

Obs.: Na cor azul os moradores. Relações, na cor vermelha, com os centros Shopping Center Interlagos (INT); Diadema (DIA); Brás (BRS); Largo 13 de Maio (L13); Drogaria Ultra Farma (UFAR); vários centros fora do Distrito de Pedreira (FORA); Shopping Center Interlar (ITL); Supermercado Pedreira (PED); Depósito 5 Irmãos (5IRM). Em amarelo, as relações com o comércio local.

Fonte: pesquisa do autor 
Figura 5.15 - Dendograma de grupo de moradores - equivalência estrutural - distância euclidiana

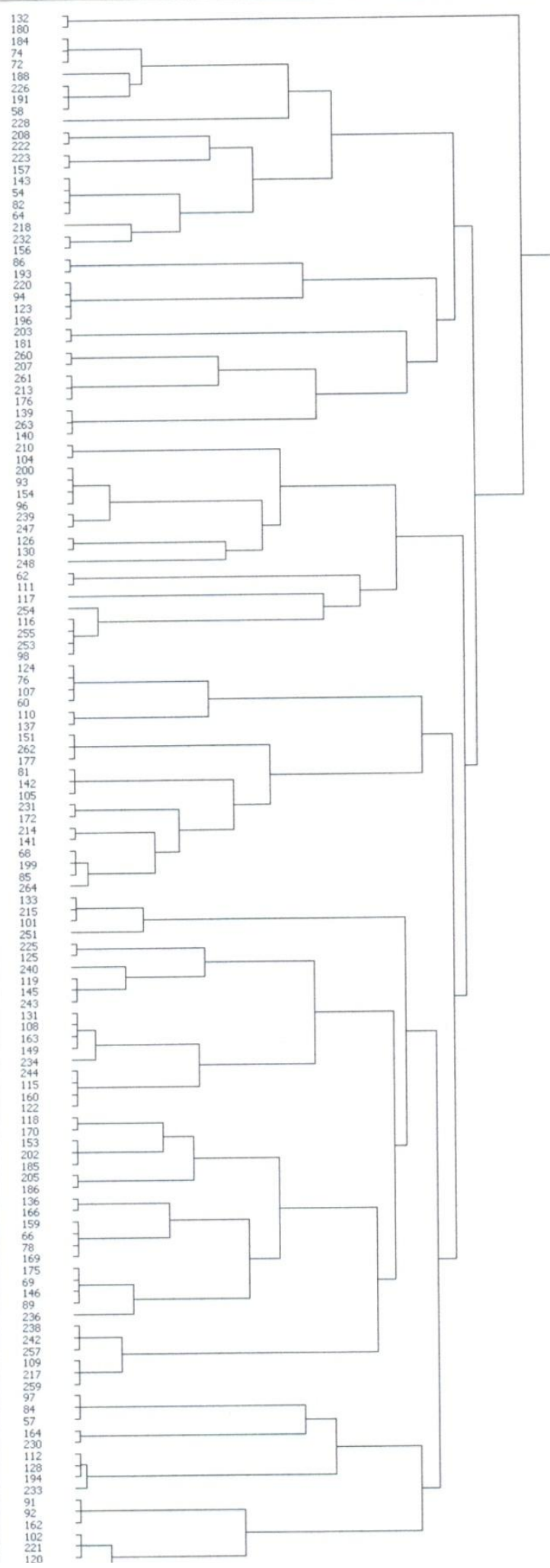

Obs.: Este dendograma corresponde apenas ao recorte da parte que se refere aos 135 moradores Fonte: pesquisa do autor 
5.7 Equivalência estrutural - método CONCOR (CONvergence of interated CORrelations)

A técnica CONCOR, CONvergence of interated CORrelations, baseia-se na organização de subgrupos cujo critério é o coeficiente de correlação entre os nós da rede social. O resultado final, ou seja, a estrutura dos grupos é decorrência do processo de interação, a qual passa por vários estágios. Deste modo, em cada uma das etapas, cria-se uma matriz de correlação e a correspondente produção de subgrupos. O primeiro passo é a criação da matriz de correlação e a geração do primeiro subgrupo. Os passos seguintes são, para cada nova etapa, a criação de novas matrizes de correlação, a partir dos grupos já criados, e a correspondente formação de novos grupos. O procedimento da interação das matrizes de correlação, por meio da criação, em cada etapa, de novas matrizes de correlação e de novos subgrupos, é repetido várias vezes até a obtenção do resultado final.

Após o processamento de 25 interações, houve a possibilidade de organizar todos os elementos da rede social em 8 grupos, sendo 4 deles formados pelos moradores e outros 4 constituídos pelos estabelecimentos comerciais.

No método de distância euclidiana, apresentado no tópico anterior, verifica-se a influência predominante de um dos centros, o mais poderoso, ou da combinação de alguns deles, igualmente fortes na intensidade de atração. É um tipo de padrão permitindo uma visão da participação de vários centros, simultaneamente, num determinado grupo. Por exemplo, na figura 5.12, o resultado mostra a visão de um padrão, com a influência principal do Shopping Center Interlagos, e ao mesmo tempo a participação de outros centros, com a intensidade de atração mais fraca, em conseqüência dos moradores que efetuam as compras em mais de um centro.

No método CONCOR obteve-se outros e diferentes tipos de padrões:

O grupo1 (mapa 5.11 página 170 e figura 5.16 página 266), localiza-se na região norte, centro e na primeira península (Jardim Apurá), abrange os bairros de Vila Aparecida, Parque Santa Amélia, Jardim Apurá, Balneário Mar Paulista, Vila Guacuri, Vila Missionária, Parque Primavera, Jardim Rubilene e Jardim Selma.

Esse grupo é formado por uma amostra de 45 moradores, com destaque as influências dos centros Shopping Center Interlagos, Largo 13 de Maio, Estrada do Alvarenga, Supermercado Pedreira, Avenida Nossa Senhora do Sabará, Shopping Center Interlar, Centro Histórico, 
Shopping Center SPMarket e Depósito 5 Irmãos. Participam todos os principais centros com ênfase nos moradores que compram em mais de um centro.

O grupo 2 (mapa 5.12 página 172 e figura 5.17 página 267) localiza-se na região norte, centro, sul e nas duas penínsulas (Jardim Apurá e Sete Praias), abrange os bairros de Parque Santa Amélia, Vila Aparecida, Jardim Apurá, Balneário Mar Paulista, Vila Missionária, Parque Primavera, Jardim Rubilene, Jardim Selma, Sete Praias.

Esse grupo é constituído por uma amostra de 29 moradores, ficando em destaque as influências do Largo 13 de Maio, Estrada do Alvarenga e Supermercado Pedreira. Estão excluídos os centros Diadema, Shopping Center SPMarket e Bom Retiro.

O grupo 3 (mapa 5.13 página 173 e figura 5.18 página 268) localiza-se na região sul do Distrito até a divisa com Diadema, abrange os bairros de Eldorado, Jardim do Castelo, Vila Guacuri, Jardim Monte Líbano, Jardim Rubilene e Sete Praias.

Esse grupo é formado por uma amostra de 48 moradores, com destaque para as influências de Diadema, Largo 13 de Maio, Supermercado Pedreira e Depósito 5 Irmãos. Estão excluídos os centros Shopping Center SPMarket, Bom Retiro, Avenida Nossa Senhora do Sabará, Avenida Yervant Kissajikian e Estrada do Alvarenga.

O grupo 4 (mapa 5.14 página 175 e figura 5.19, página 269) localiza-se na região sul do Distrito até a divisa com Diadema, abrange os bairros de Eldorado, Vila Guacuri, Jardim das Laranjeiras, Jardim Rubilene.

É formado por uma amostra de 10 moradores, com destaque para a influência de Diadema. Estão excluídos os centros Drogaria Ultra Farma, Shopping Center SPMarket, Bom Retiro, Avenida Nossa Senhora do Sabará, Avenida Yervant Kissajikian, Estrada do Alvarenga, Drogaria São Paulo da Avenida Nossa Senhora do Sabará, Depósito 5 Irmãos e Brás 


\section{EQUIVALÊNCIA ESTRUTURAL - CONCOR REGIÕES HOMOGÊNEAS}

DISTRITO DE PEDREIRA

POR SETOR CENSITÁRIO

MAPA NÚMERO 5.37

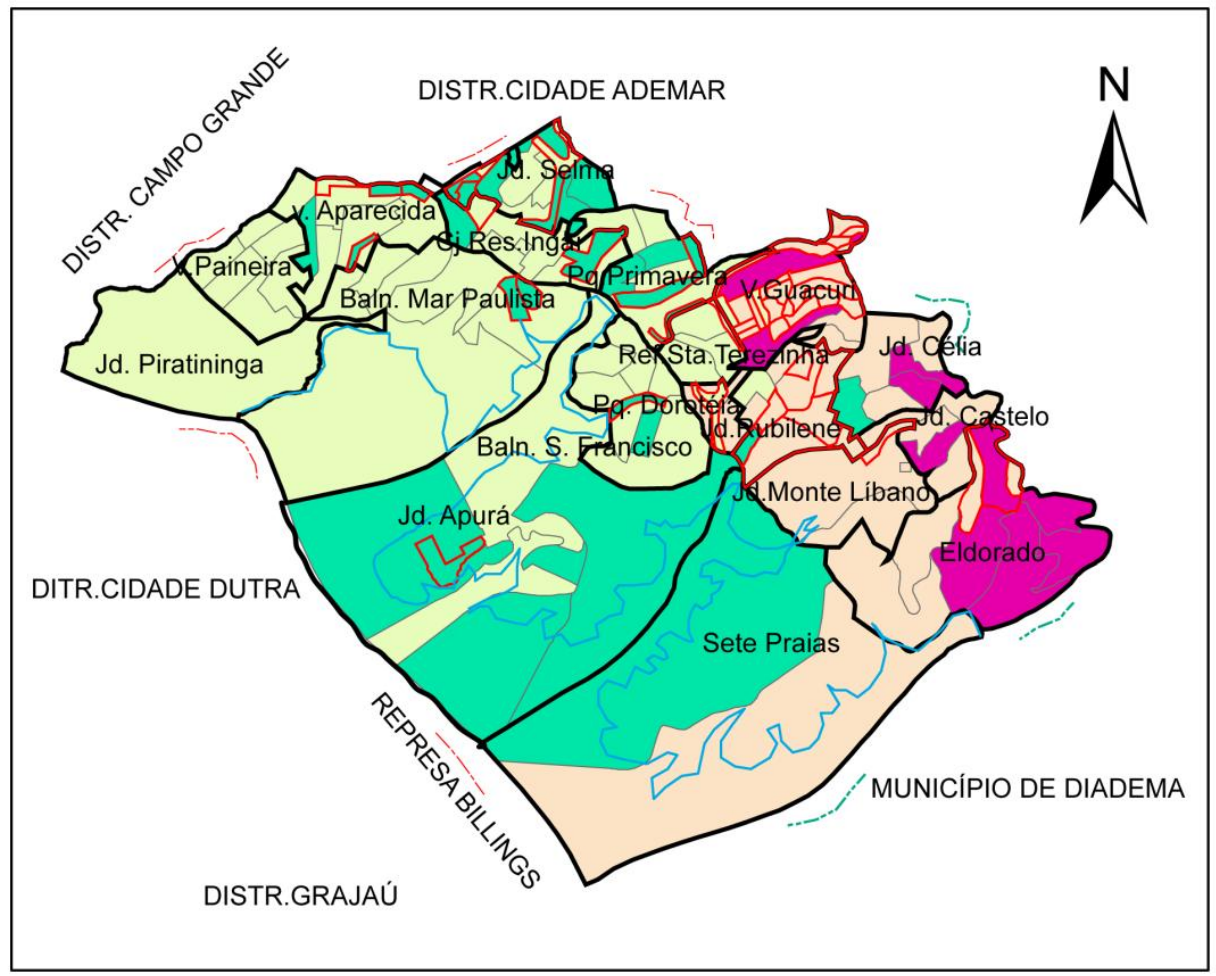

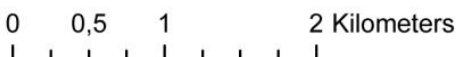

Autor: Shinhiti Osanai

Fonte: pesquisa do autor
Regiões homogêneas

$\square$ Todos (mais de 1 centro) Sem Diadema Sem E. do Alvarenga Diadema Principais bairros Favelas Divisa Distr. Pedreira

---_ Divisa Diadema

_ Represa Billings 
Figura 5.16 - REDE SOCIAL - EQUIVALÊNCIA ESTRUTURAL CONCOR COM A PARTICIPAÇÃO DE TODOS OS PRINCIPAIS CENTROS (GRUPO 1)

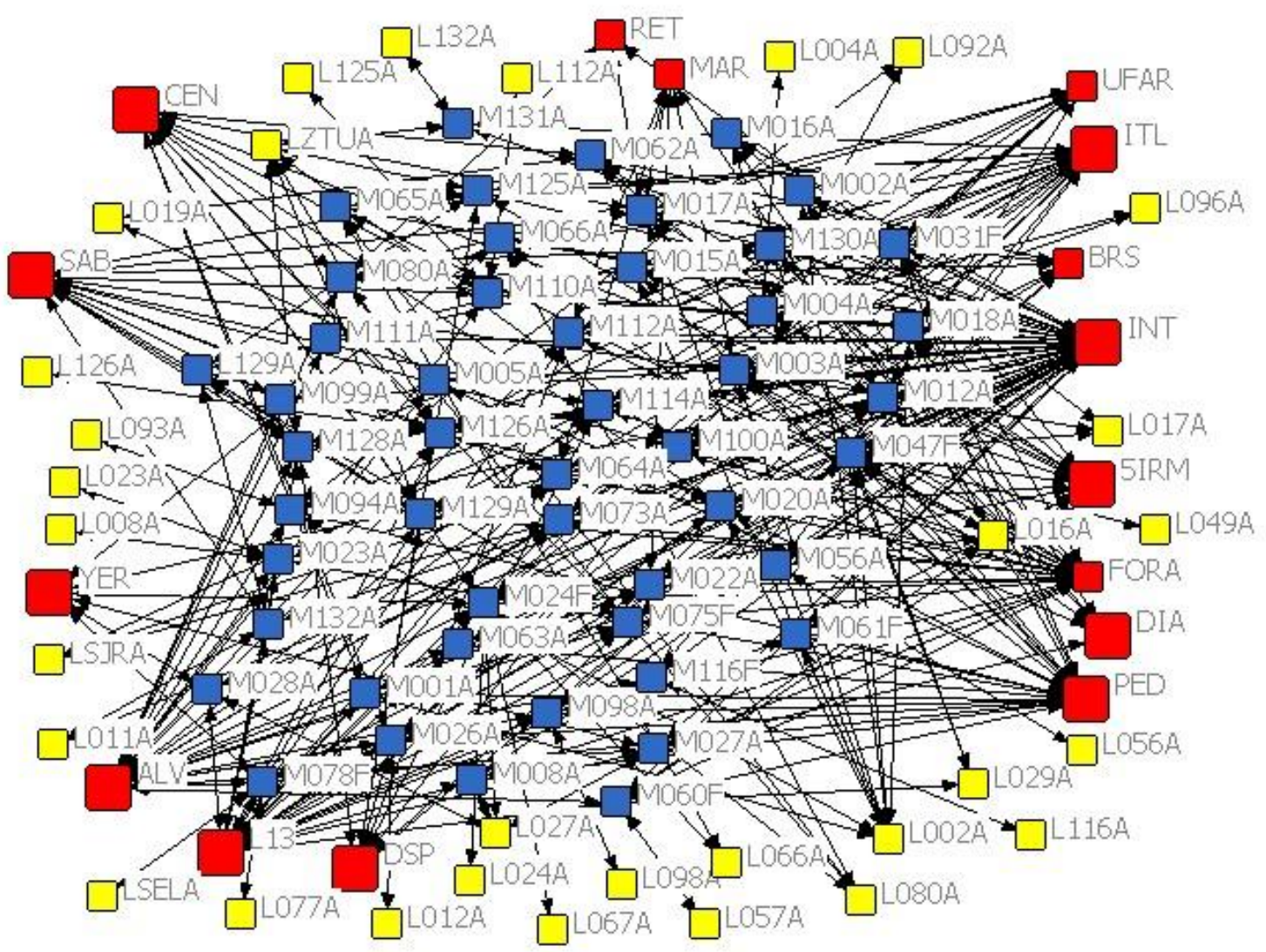

Obs.: Na cor azul os moradores. Relações, na cor vermelha, com os centros Shopping Center Interlagos (INT); Drogaria São Paulo da Avenida Nossa Senhora do Sabará (DSP); Estrada do Alvarenga (ALV); Avenida Nossa Senhora do Sabará (SAB); Diadema (DIA); Brás (BRS); Avenida Yervant Kissajikian (YER); Largo 13 de Maio (L13); Drogaria Ultra Farma (UFAR); vários centros fora do Distrito de Pedreira (FORA); Centro Histórico (CEN); Shopping Center Interlar (ITL); Supermercado Pedreira (PED); Depósito 5 Irmãos (5IRM) e Shopping Center SPMarket (MAR). Em amarelo, as relações com o comércio local. Nota-se em destaque a participação do comércio local do Jardim Rubilene (L016A).

Fonte: pesquisa do autor 
Figura 5.17 - REDE SOCIAL - EQUIVALÊNCIA ESTRUTURAL CONCOR SEM A PARTICIPAÇÃO DE DIADEMA, SHOPPING CENTER SPMARKET E BOM RETIRO (GRUPO 2)

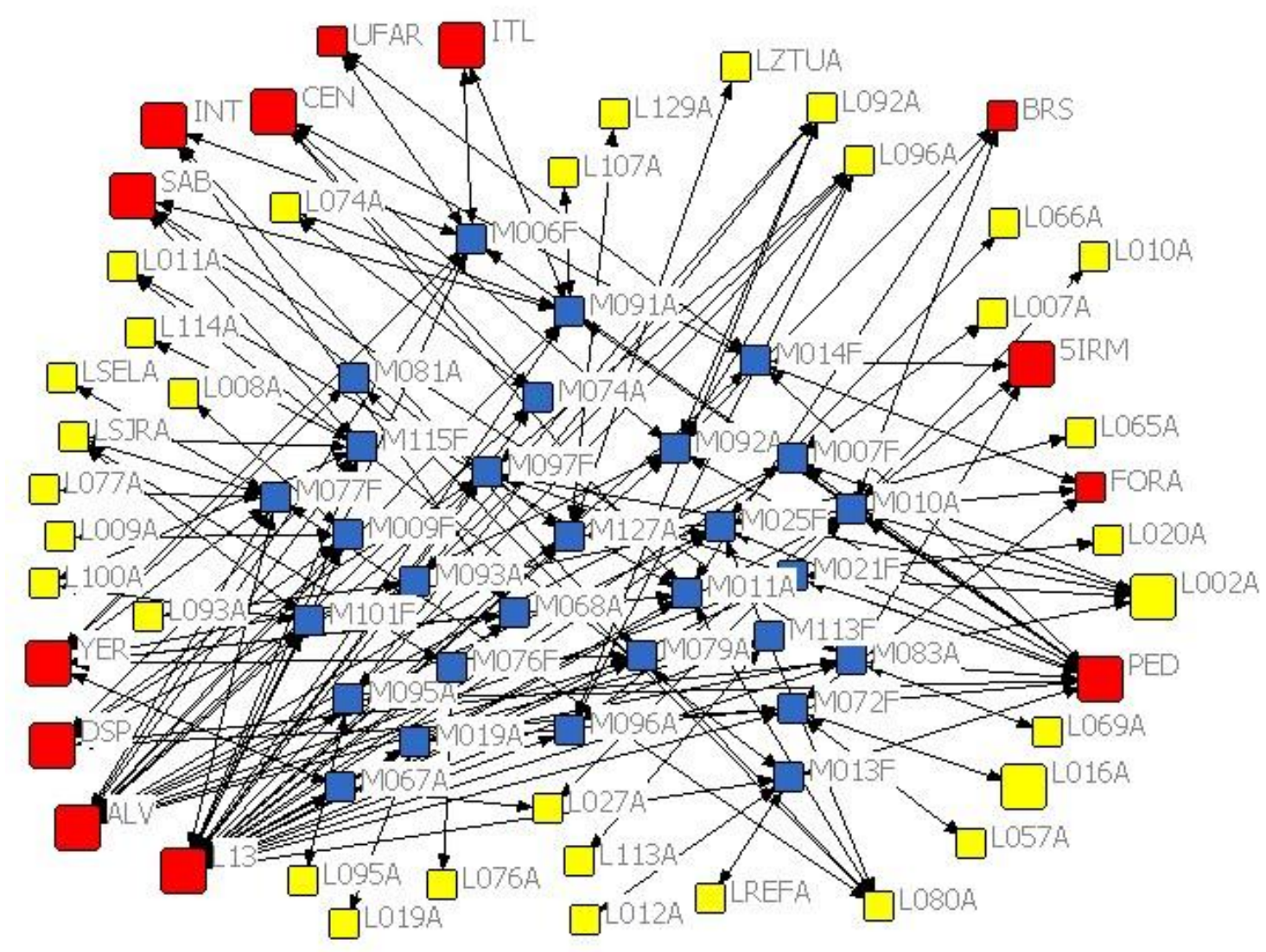

Obs.: Na cor azul os moradores. Relações, na cor vermelha, com os centros Shopping Center Interlagos (INT); Drogaria São Paulo da Avenida Nossa Senhora do Sabará (DSP); Estrada do Alvarenga (ALV); Avenida Nossa Senhora do Sabará (SAB); Brás (BRS); Avenida Yervant Kissajikian (YER); Largo 13 de Maio (L13); Drogaria Ultra Farma (UFAR); vários centros fora do Distrito de Pedreira (FORA); Centro Histórico (CEN); Shopping Center Interlar (ITL); Supermercado Pedreira (PED) e Depósito 5 Irmãos (5IRM). Em amarelo, as relações com o comércio local.

Fonte: pesquisa do autor 
Figura 5.18 - REDE SOCIAL - EQUIVALÊNCIA ESTRUTURAL CONCOR SEM A

PARTICIPAÇÃO DE SHOPPING CENTER SPMARKET, BOM RETIRO, AV. NOSSA

SENHORA DO SABARÁ, AV. YERVANT KISSAJIKIAN E ESTRADA DO

ALVARENGA. (GRUPO 3)

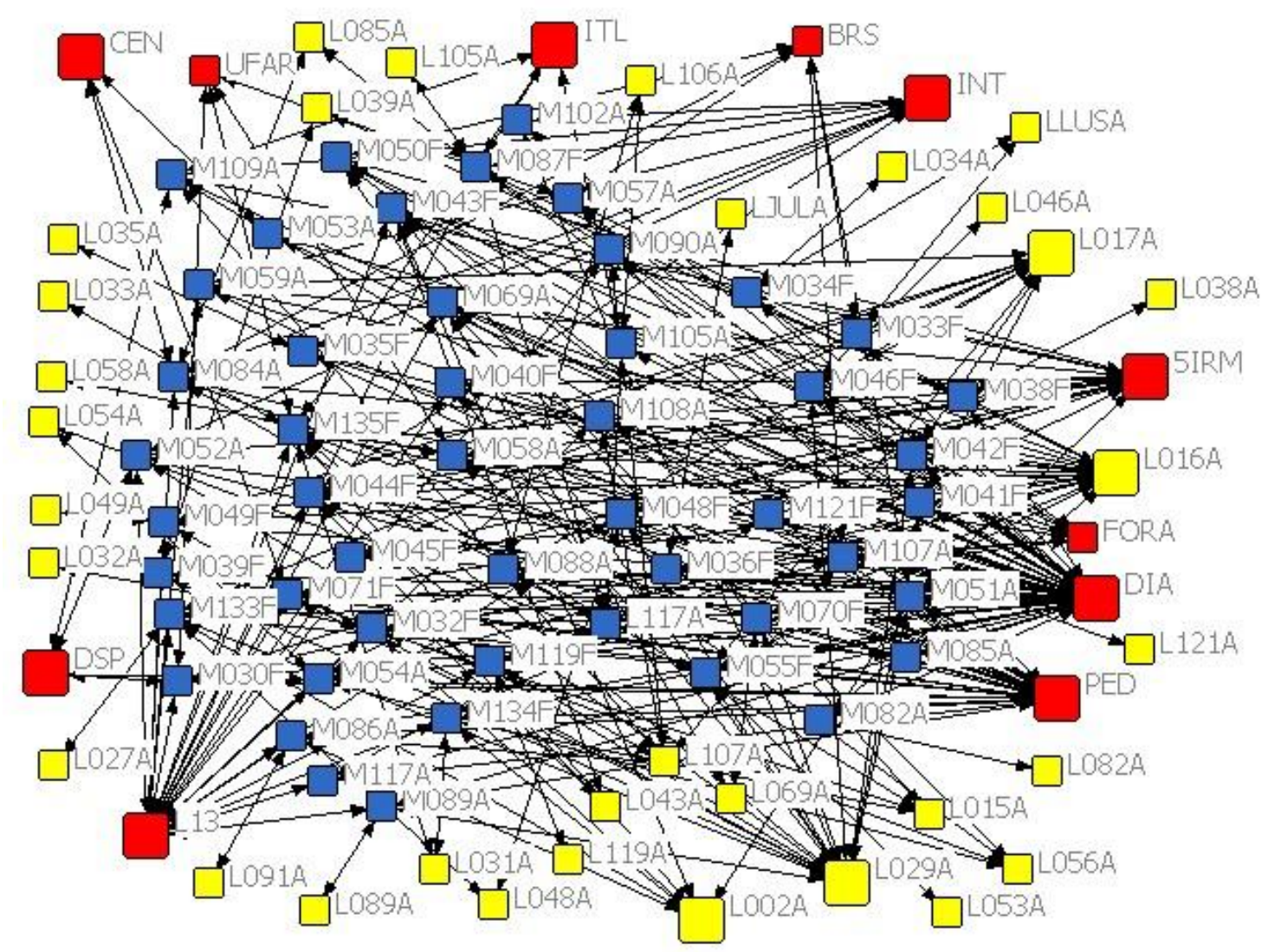

Obs.: Na cor azul os moradores. Relações, na cor vermelha, com os centros Shopping Center Interlagos (INT); Drogaria São Paulo da Avenida Nossa Senhora do Sabará (DSP); Diadema (DIA); Brás (BRS); Largo 13 de Maio (L13); Drogaria Ultra Farma (UFAR); vários centros fora do Distrito de Pedreira (FORA); Centro Histórico (CEN); Shopping Center Interlar (ITL); Supermercado Pedreira (PED); Depósito 5 Irmãos (5IRM). Em amarelo, as relações com o comércio local. Em destaque o comércio local de Jardim Rubilene (L016A, L017A, L029A).

Fonte: pesquisa do autor 
Figura 5.19 - REDE SOCIAL - EQUIVALÊNCIA ESTRUTURAL CONCOR DESTAQUE

\section{DA INFLUÊNCIA DE DIADEMA (GRUPO 4)}

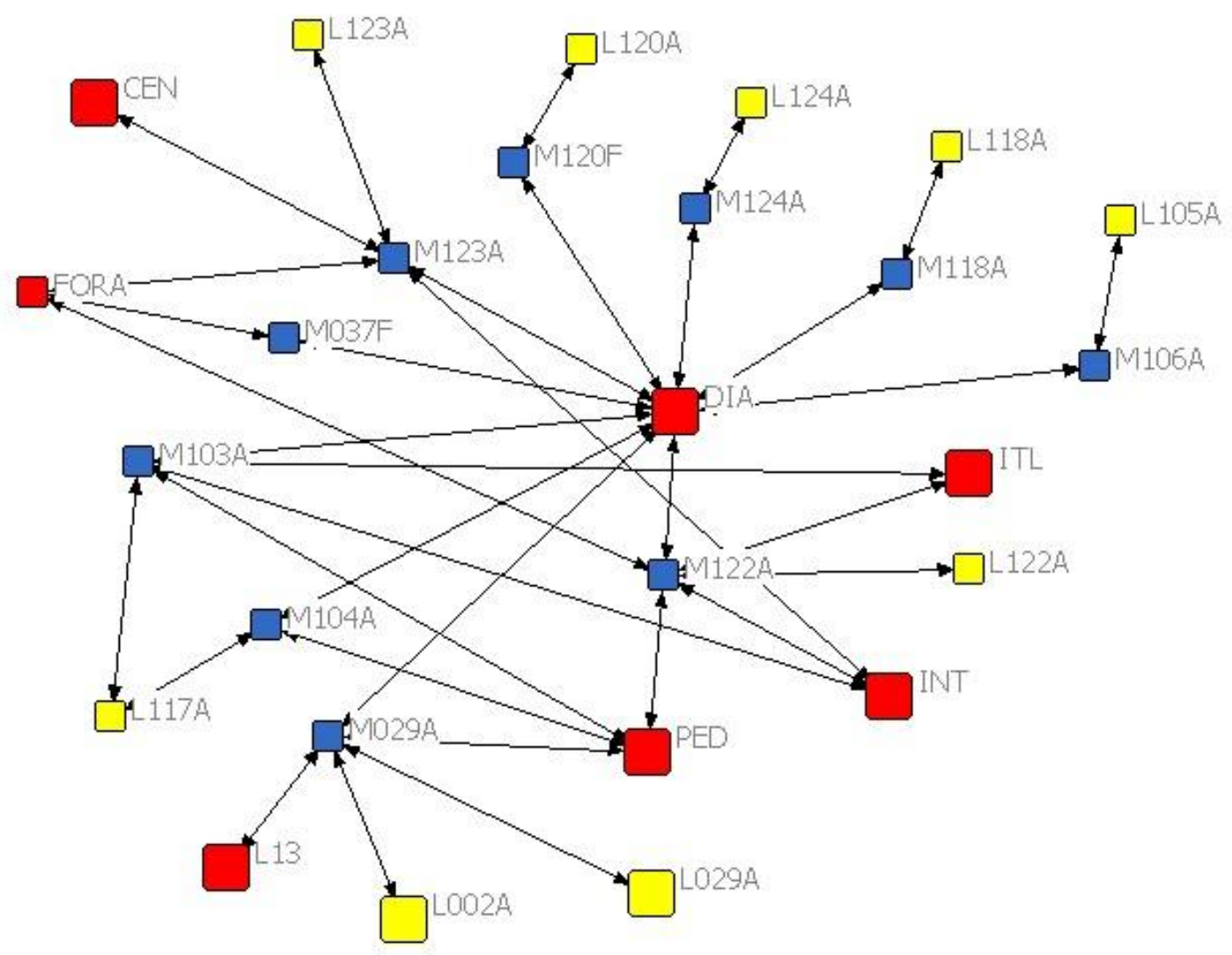

Obs.: Na cor azul os moradores. Relações, na cor vermelha, com os centros Shopping Center Interlagos (INT); Diadema (DIA); Largo 13 de Maio (L13); vários centros fora do Distrito de Pedreira (FORA); Centro Histórico (CEN); Shopping Center Interlar (ITL); Supermercado Pedreira (PED). Em amarelo, as relações com o comércio local.

Fonte: pesquisa do autor

O grupo 5 localiza-se na região norte, central e primeira península (Jardim Apurá), inclusive nos Distritos de Campo Grande e de Cidade Ademar e no Centro Histórico. É formado pelo comércio localizado no Jardim Apurá, Balneário Mar Paulista, Shopping Center Interlagos, Vila Aparecida, Jardim São Jorge, Jardim Selma, Avenida Nossa Senhora do Sabará (Distrito de Campo Grande), Centro Histórico, Largo 13 de Maio, Vila Missionária, Avenida Yervant Kissajikian (Distrito de Cidade Ademar), Parque Primavera, Jardim Rubilene, Parque Dorotéia, Drogaria São Paulo da Avenida Nossa Senhora do Sabará (Distrito de Campo Grande), Vila Guacuri, Parque Santa Amélia e Supermercado Carrefour de Diadema. 
O grupo 6 localiza-se na região norte, central e primeira península (Jardim Apurá), inclusive no Distrito de Campo Grande. É formado pelo comércio localizado no Balneário Mar Paulista, Avenida Yervant Kissajikian (Distrito de Cidade Ademar), Jardim Rubilene, Largo 13 de Maio, Shopping Center SPMarket (Distrito de Campo Grande), Vila Aparecida, Supermercado Pedreira, Supermercado Ricoy da Avenida Nossa Senhora do Sabará (Distrito de Campo Grande), Parque Santa Amélia, Parque Primavera, Vila Missionária, Jardim Selma, Jardim Apurá e Vila Guacuri.

O grupo 7 - localiza-se na região sul até a divisa com Diadema, bem como, no centro comercial de Diadema. É formado pelo comércio localizado no Parque Primavera, Jardim Rubilene, Parque Dorotéia, centro de Diadema, Vila Guacuri e em Eldorado.

O grupo 8 localiza-se na região sul até a divisa com Diadema e no centro comercial de Diadema. É formado pelo comércio localizado em Eldorado, centro de Diadema e Jardim Monte Líbano.

Ao contrário do método de distância euclidiana, pelo método CONCOR foi possível a identificação dos centros de influência em relação à localização geográfica dos moradores. Observa-se a forte influência do Largo 13 de Maio entre os moradores das regiões norte e central do Distrito de Pedreira. A influência de Diadema se verifica com mais intensidade nos moradores da região sul e nordeste. 
Figura 5.20 - Árvore da equivalência estrutural - método CONCOR - grupo de moradores

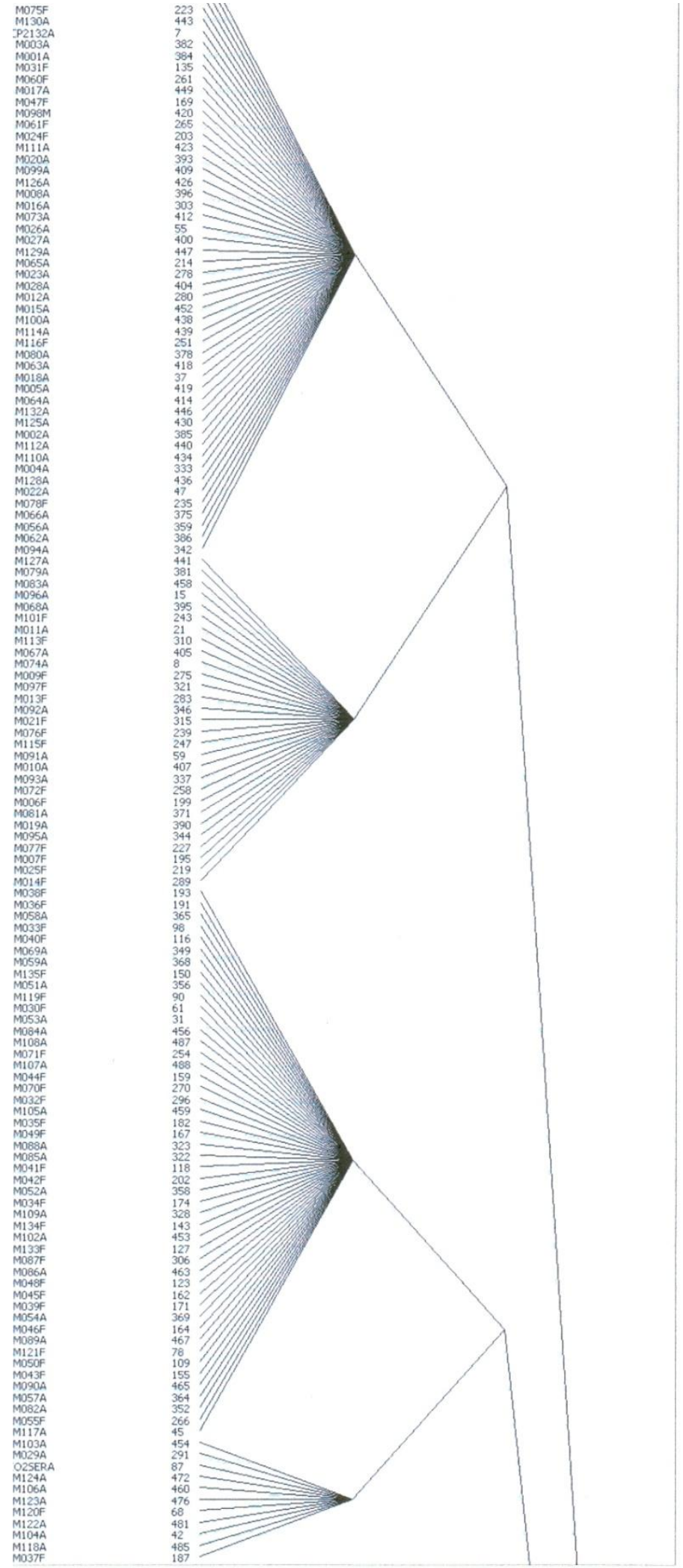

Obs.: Esta árvore corresponde apenas ao recorte da parte que se refere aos 135 moradores Fonte: pesquisa do autor 


\subsection{Equivalência automórfica}

A medida de centralidade grau de cada morador da amostra pode ser a conseqüência de maior ou menor quantidade de opções de locais de compras, muitas vezes, em decorrência da disponibilidade dos estabelecimentos comerciais nas proximidades das residências. Um morador, que obteve o valor de grau igual 10, pode realizar as suas compras em 10 locais distintos, e outro morador pode obter o valor de grau igual a 20 em decorrência da realização de suas compras em 20 locais diferentes. A título de exemplo, na rede social da amostra dos moradores do Distrito de Pedreira, as medidas de grau variam dentro do intervalo de 5 e 23 . Em cada grupo organizado pelo critério de equivalência estrutural, observa-se expressiva variação dos valores da medida de grau, em decorrência das diferentes opções de locais de compras de cada morador.

$\mathrm{Na}$ equivalência estrutural os grupos são organizados de acordo com o critério da estrutura morfológica da rede. Por exemplo, um grupo pode ser formado por moradores que efetuam as compras em Diadema, independentemente do valor de grau de cada um deles. Para a determinação de áreas de influência, o método mais adequado pode ser a equivalência estrutural, pois o local da compra é mais relevante, independentemente do valor de grau de cada morador.

O Distrito de Pedreira apresenta características bastante heterogêneas, alguns setores são bem organizados e apresentam uma boa estrutura urbana, Por exemplo, os bairros de Sete Praias, Balneário Mar Paulista e Balneário São Francisco. Existem muitas regiões de loteamento irregular, de invasão e favelas, principalmente nas áreas de declividade acentuada e nas margens dos córregos e da represa Billings. Ao mesmo tempo, verifica-se o comércio bem organizado nas áreas urbanas com boa estrutura, por exemplo, na Estrada do Alvarenga. Da mesma forma, existem muitas regiões com o comércio bastante precário, principalmente, nas favelas e nas áreas de proteção ambiental próximas à divisa com Diadema. Essas características heterogêneas podem, eventualmente, determinar o padrão de relacionamento de cada morador com o comércio. Existem altas possibilidades de formar uma rede de relacionamento bastante heterogênea, em parte estruturada pelo comércio local mais simples e muitas vezes precário, como conseqüência, os moradores são obrigados a complementarem as suas necessidades de compras junto ao comércio de localização mais distante e melhor estruturado. Diante de tudo isso, naturalmente, se espera uma estrutura da rede de relacionamentos que contemple diversos grupos muito heterogêneos. Habitualmente, nessas 
condições, os grupos estabelecidos pelo critério de equivalência estrutural devem ser heterogêneos, com exceção dos locais de compras, desde que sejam comuns para os indivíduos do mesmo grupo.

Podem-se obter resultados mais homogêneos na formação de grupos, de acordo com as características da organização e distribuição do comércio no Distrito de Pedreira, ao adotar para a identificação dos grupos de moradores, a medida de grau como critério, ou seja, as quantidades de opções de locais de compras de cada morador.

Diante de uma suposição que envolva o hábito de compras bastante semelhante entre a maioria dos moradores, em decorrência de uma estrutura particular do comércio de determinadas áreas, pode-se obter, nessas áreas, a predominância de poucos grupos e muito homogêneos e com elevada quantidade de elementos em cada grupo.

Os valores mais baixos da medida de grau podem ser obtidos, eventualmente, diante de limitações de natureza de acessibilidade, que podem restringir e reduzir o acesso a locais de compras, podendo acontecer, nas regiões de comércio muito precário. Em regiões sem restrições de acessibilidade esperam-se valores mais elevados da medida de grau, em virtude da possibilidade de acesso de maior número de pessoas, embora algumas vezes as preferências individuais possam interferir nas decisões por causa dos critérios pessoais na escolha dos locais mais adequados para as compras.

Na equivalência automórfica os grupos são organizados em função dos valores iguais de grau ou muito próximos, dentro da estrutura de relacionamentos comuns entre os integrantes do grupo. No tocante à rede social da amostra de moradores do Distrito de Pedreira, também se podem analisar os grupos, decorrentes dos hábitos de compras, utilizando-se a medida de grau para a obtenção dos agrupamentos. Quando a maioria dos moradores forem obrigados a satisfazerem as suas necessidades de compras em poucos estabelecimentos existentes, em regiões específicas, espera-se a formação de poucos grupos, com grande quantidade de participantes em cada grupo, e pode representar um padrão de comércio com poucas opções de escolha. O contrário, a constatação de grande quantidade de pequenos grupos, pode ser um indicador da estrutura de comércio, estabelecida pelas muitas opções distintas, oferecendo a oportunidade de vasta gama de alternativas diferentes de escolha.

Obteve-se o total de 23 grupos, cada grupo formado por uma pequena quantidade de moradores, o que indica algumas evidências da disponibilidade de muitas opções distintas em 
relação ao comércio do Distrito. Cada grupo de moradores, em decorrência das particularidades das áreas onde as pessoas habitam, satisfaz as suas necessidades de maneira bastante variada.

Uma das principais causas da estruturação dos grupos, que contribui para a formação de grande quantidade de grupos, são os pequenos estabelecimentos, freqüentemente instalados nas proximidades das moradias. Quanto maior a quantidade de grupos, mais intenso pode ser o padrão de dispersão do comércio localizado nas proximidades das residências, para os bens de freqüência diária ou semanal. Estão presentes, na tabela 5.26, a quantidade de estabelecimentos indicados pelos moradores da amostra, acompanhada das suas localizações nas proximidades das 135 residências pesquisadas. Estão excluídos os estabelecimentos das áreas mais centrais, tais como o Largo 13 de Maio, Diadema ou o Shopping Center Interlagos.

Tabela 5.26 - QUANTIDADE DE ESTABELECIMENTOS EM TORNO DAS RESIDÊNCIAS

\begin{tabular}{cc}
\hline RAMO DE ATIVIDADE & $\begin{array}{r}\text { QUANTIDADE DE ESTABELECIMENTOS } \\
\text { EM TORNO DAS RESIDÊNCIAS }\end{array}$ \\
\hline Padaria & 45 \\
Mercearia & 39 \\
Material de construção & 36 \\
Bazar & 29 \\
Pet shop & 16 \\
Farmácia & 15 \\
Supermercado de médio porte & 9 \\
Casas do norte & 13 \\
Produtos de limpeza & 21 \\
\hline
\end{tabular}

Fonte: pesquisa do autor

Perante a amostra de 135 moradores, existe em média 1 padaria para cada 3 moradores. Em relação às mercearias a média é de 1 estabelecimento para cada 3,46 moradores. Depósitos de material de construção, bazares, casas especializadas em artigos provenientes do nordeste e pet shops são muito freqüentes no Distrito. 
Tabela 5.27 - FORMAÇÃO DOS GRUPOS - EQUIVALÊNCIA AUTOMÓRFICA

\begin{tabular}{|c|c|c|c|c|}
\hline GRUPO & QUANT. & GRAU & PRINCIPAIS INFLUÊNCIAS & MAPA \\
\hline 1 & 10 & 18 a 24 & Largo 13 de Maio e Shopping Center Interlagos & 5.38 \\
\hline 2 & 9 & 8 a 13 & Largo 13 de Maio e Diadema & 5.39 \\
\hline 3 & 6 & 17 e 18 & Largo 13 de Maio e Shopping Center Interlagos & 5.39 \\
\hline 4 & 6 & 14 a 16 & Largo 13 de Maio e Shopping Center Interlagos & 5.39 \\
\hline 5 & 7 & 15 & Largo 13 de Maio & 5.39 \\
\hline 6 & 8 & 13 & Largo 13 de Maio & 5.39 \\
\hline 7 & 6 & 14 & Largo 13 de Maio e Shopping Center Interlagos & 5.39 \\
\hline 8 & 11 & 11 a 13 & Shopping Center Interlagos & 5.39 \\
\hline 9 & 5 & 12 e 13 & Largo 13 de Maio e Diadema & 5.39 \\
\hline 10 & 3 & 18 e 19 & Largo 13 de Maio, Shopping Center Interlagos e & 5.40 \\
\hline 11 & 3 & 14 a 16 & $\begin{array}{c}\text { Diadema } \\
\text { Largo } 13 \text { de Maio, Shopping Center Interlagos e } \\
\text { Diadema }\end{array}$ & 5.40 \\
\hline 12 & 7 & 18 e 19 & Largo 13 de Maio e Shopping Center Interlagos & 5.40 \\
\hline 13 & 9 & 16 e 17 & Largo 13 de Maio e Diadema & 5.40 \\
\hline 14 & 2 & 5 e 6 & Largo 13 de Maio e Diadema & 5.41 \\
\hline 15 & 1 & 19 & Diadema & 5.41 \\
\hline 16 & 3 & 10 & Largo 13 de Maio e Diadema & 5.41 \\
\hline 17 & 5 & 12 e 13 & Largo 13 de Maio e Diadema & 5.41 \\
\hline 18 & 5 & 11 a 13 & Largo 13 de Maio & 5.41 \\
\hline 19 & 6 & 14 a 17 & Largo 13 de Maio & 5.41 \\
\hline 20 & 3 & 15 e 16 & Diadema & 5.41 \\
\hline 21 & 7 & 13 e 14 & Diadema & 5.41 \\
\hline 22 & 12 & 5 a 14 & $\begin{array}{c}\text { Largo } 13 \text { de Maio, Shopping Center Interlagos e } \\
\text { Diadema }\end{array}$ & 5.41 \\
\hline 23 & 1 & 8 & Av. Yervant Kissajikian & 5.41 \\
\hline
\end{tabular}

Fonte: pesquisa do autor 


\section{EQUIVALÊNCIA AUTOMÓRFICA}

GRUPO 1 - INFLUÊNCIA DE LARGO 13 DE MAIO/SHOPPING INTERLAGOS

DISTRITO DE PEDREIRA

POR SETOR CENSITÁRIO

MAPA NÚMERO 5.38

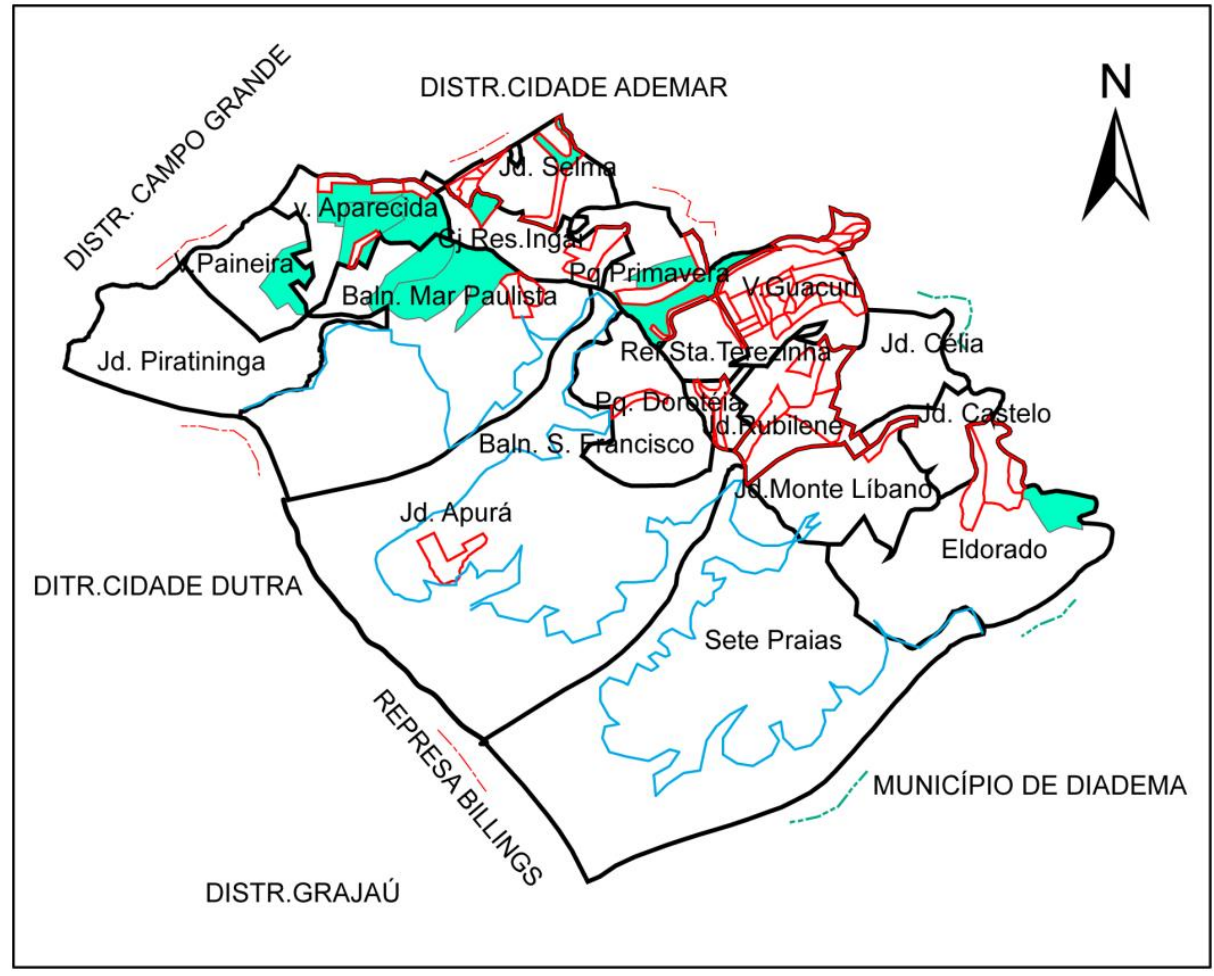

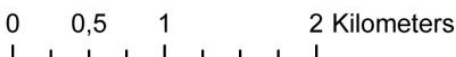

Autor: Shinhiti Osanai

Fonte: pesquisa do autor
Eq.automórfica Grupo 1

Grau 18-24 L13/S.INTERL.

$\square$ Principais bairros

$\square$ Favelas

—-_ Divisa Distr. Pedreira

---- Divisa Diadema

_ Represa Billings 
Figura 5.21 - REDE SOCIAL DA EQUIVALÊNCIA AUTOMÓRFICA DO GRUPO 1 (VIDE MAPA 5.38)

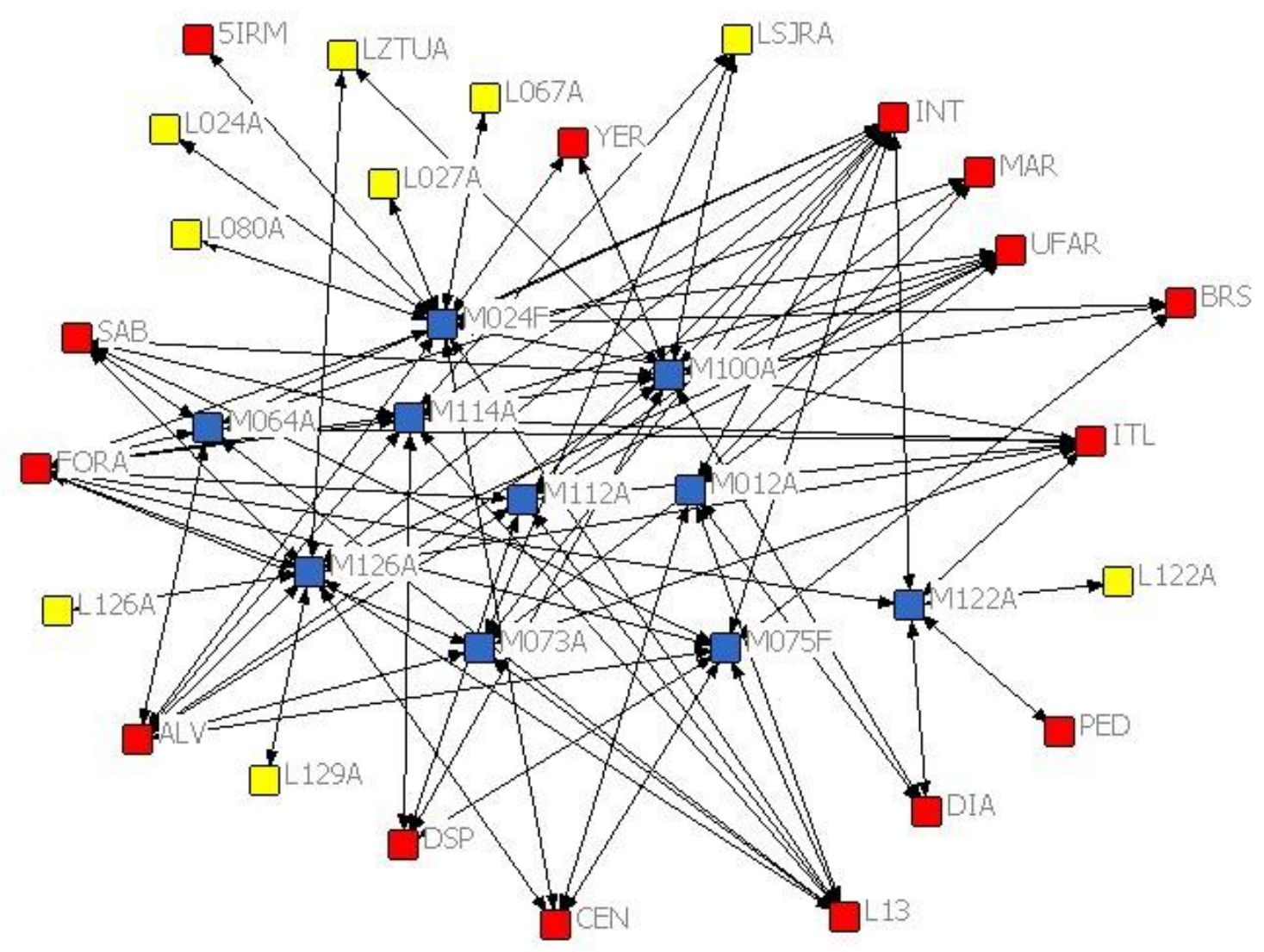

Em destaque as influências dos centros Shopping Center Interlagos (INT), Largo 13 de Maio (L13) e Estrada do Alvarenga (ALV).

Obs.: Na cor azul os moradores. Relações, na cor vermelha, com os centros Shopping Center Interlagos (INT); Drogaria São Paulo da Avenida Nossa Senhora do Sabará (DSP); Estrada do Alvarenga (ALV); Avenida Nossa Senhora do Sabará (SAB); Diadema (DIA); Brás (BRS); Avenida Yervant Kissajikian (YER); Largo 13 de Maio (L13); Drogaria Ultra Farma (UFAR); vários centros fora do Distrito de Pedreira (FORA); Centro Histórico (CEN); Shopping Center Interlar (ITL); Supermercado Pedreira (PED); Depósito 5 Irmãos (5IRM); Shopping Center SPMarket (MAR). Em amarelo, as relações com o comércio local.

Fonte: pesquisa do autor 


\section{EQUIVALÊNCIA AUTOMÓRFICA}

GRUPO 2 - INFLUÊNCIA DE LARGO 13 DE MAIO/SHOPPING INTERLAGOS

DISTRITO DE PEDREIRA

POR SETOR CENSITÁRIO

MAPA NÚMERO 5.39

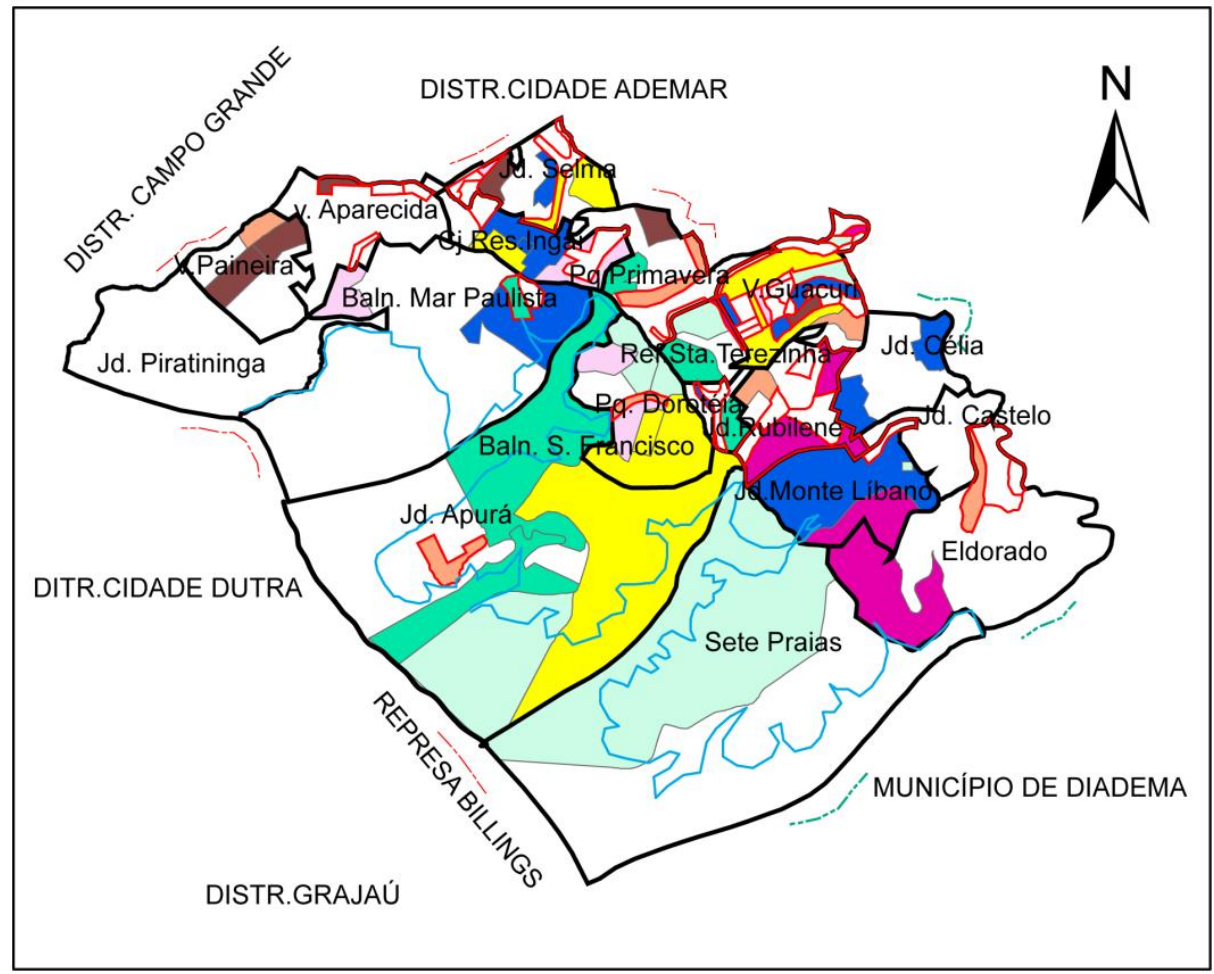

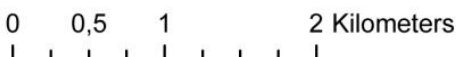

Autor: Shinhiti Osanai

Fonte: pesquisa do autor
Eq.automórfica Grupo 2

Grau 8-13 Dia/L13/nterl

Grau 17-18 L13/Inter Grau 14-16 L13/Interl Grau 15 L 13 Grau 13 L13/Interl Grau 14 L13/Inter Grau 11-13 L/13 Interl Grau 12-13 L13/Diadem Principais bairros Favelas

- - D Divisa Distr. Pedreira

---- Divisa Diadema

_ Represa Billings 
Figura 5.22 - REDE SOCIAL DA EQUIVALÊNCIA AUTOMÓRFICA DO GRUPO 2 (VIDE MAPA 5.39) FORMADO POR UM CONJUNTO DE 9 GRUPOS

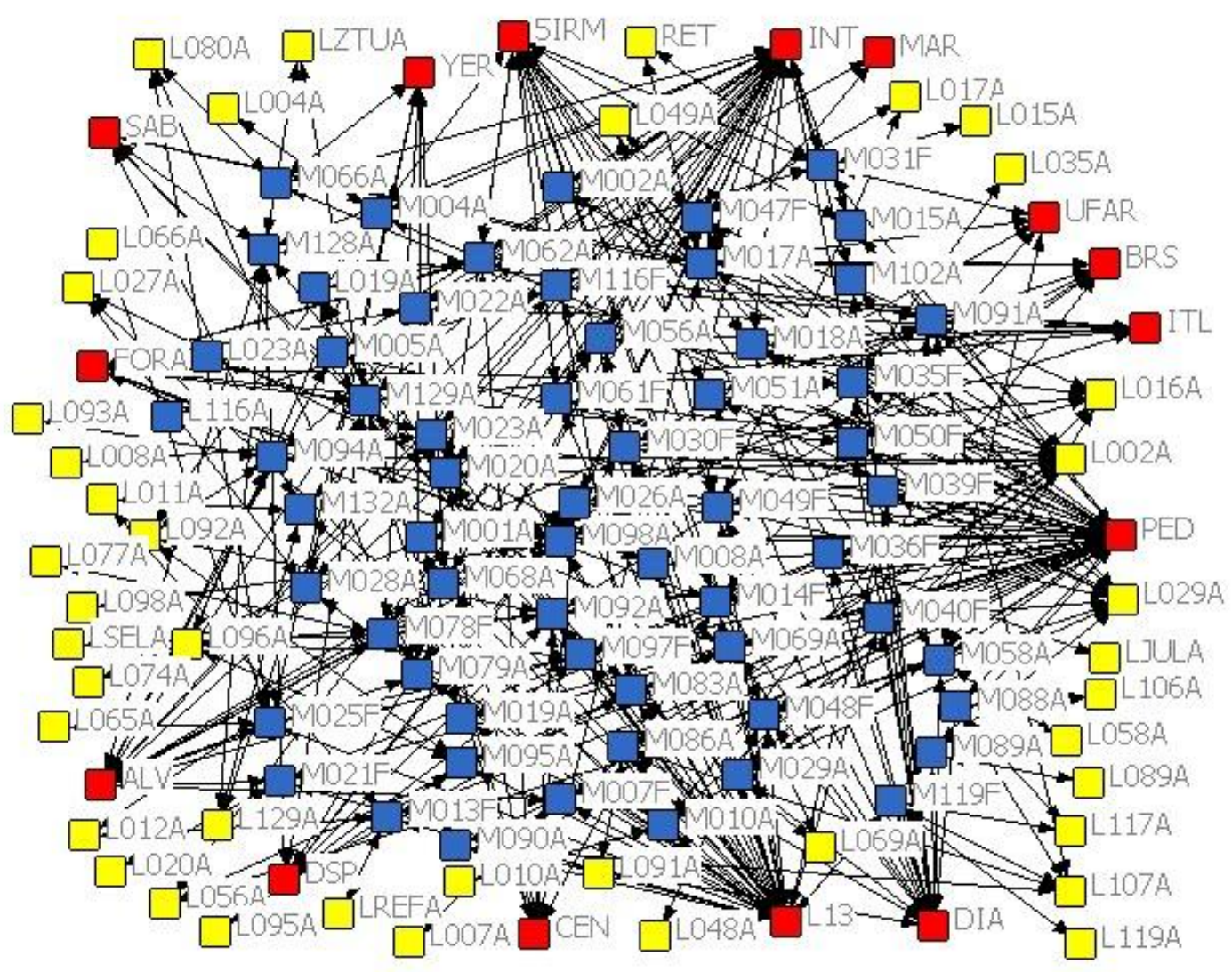

Em destaque as influências dos centros Depósito 5 Irmãos (5IRM), Shopping Center Interlagos (INT), Supermercado Pedreira (PED), Diadema (DIA), Largo 13 de Maio (L13) e Estrada do Alvarenga (ALV).

Obs.: Na cor azul os moradores. Relações, na cor vermelha, com os centros Shopping Center Interlagos (INT); Drogaria São Paulo da Avenida Nossa Senhora do Sabará (DSP); Estrada do Alvarenga (ALV); Avenida Nossa Senhora do Sabará (SAB); Diadema (DIA); Brás (BRS); Avenida Yervant Kissajikian (YER); Largo 13 de Maio (L13); Drogaria Ultra Farma (UFAR); vários centros fora do Distrito de Pedreira (FORA); Centro Histórico (CEN); Shopping Center Interlar (ITL); Supermercado Pedreira (PED); Depósito 5 Irmãos (5IRM); Shopping Center SPMarket (MAR). Em amarelo, as relações com o comércio local.

Fonte: pesquisa do autor 


\section{EQUIVALÊNCIA AUTOMÓRFICA}

GRUPO 3 - INFLUÊNCIA DE LARGO 13 DE MAIO/SHOPPING INTERLAGOS/DIADEMA DISTRITO DE PEDREIRA

POR SETOR CENSITÁRIO

MAPA NÚMERO 5.40

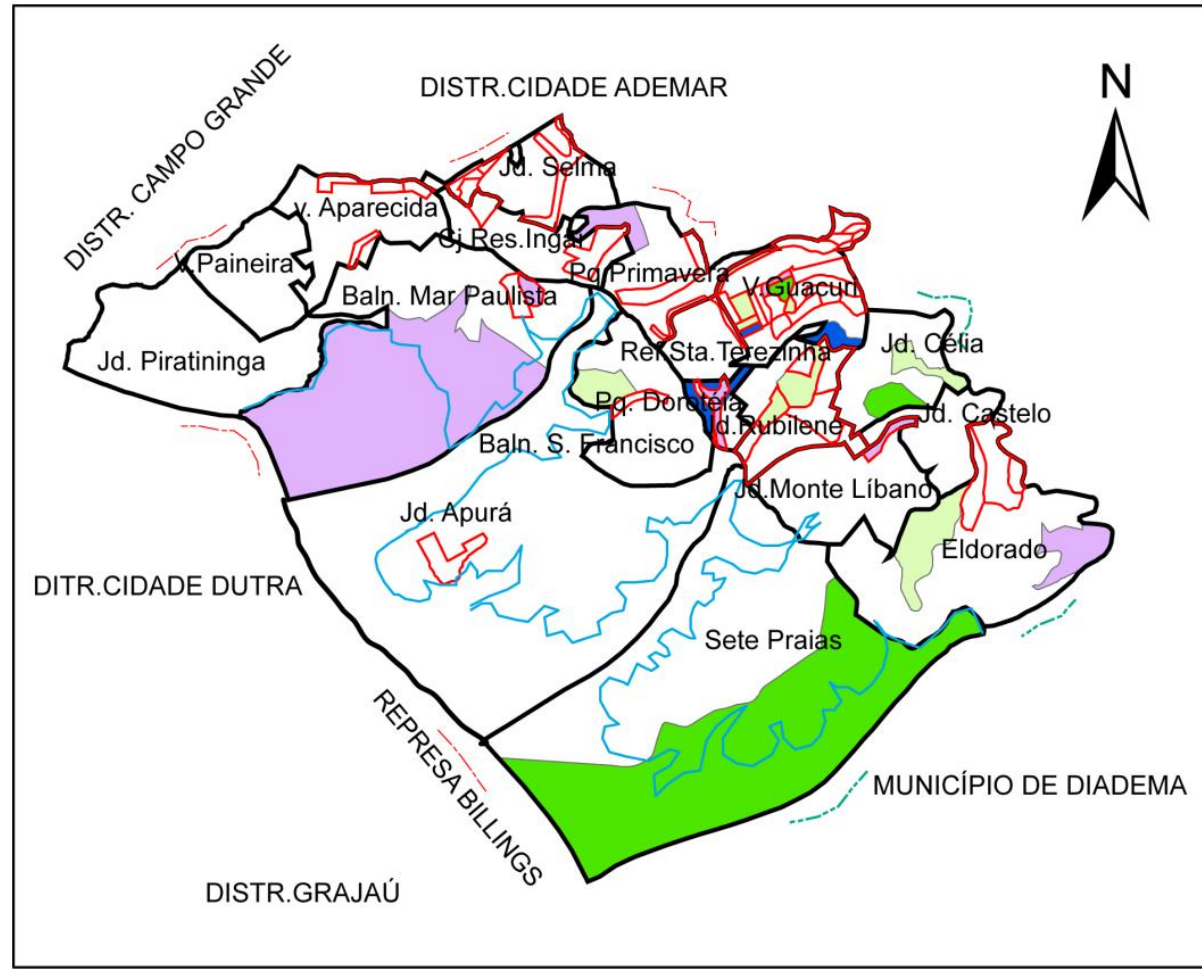

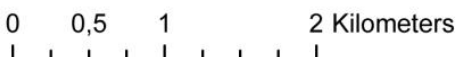

Autor: Shinhiti Osanai

Fonte: pesquisa do autor
Eq.automórfica Grupo 3

Grau 18-19 L13/Inter/Diadema

Grau 14-16 L13/Inter/Diadema Grau 18-19 L13/Interl $\square$ Grau 16-17 L13/Diadema

$\square$ Principais bairros Favelas

-_- Divisa Distr. Pedreira

---- Divisa Diadema 
Figura 5.23 - REDE SOCIAL DE EQUIVALÊNCIA AUTOMÓRFICA DO GRUPO 3 (VIDE MAPA 5.40) FORMADO POR UM CONJUNTO DE 4 GRUPOS

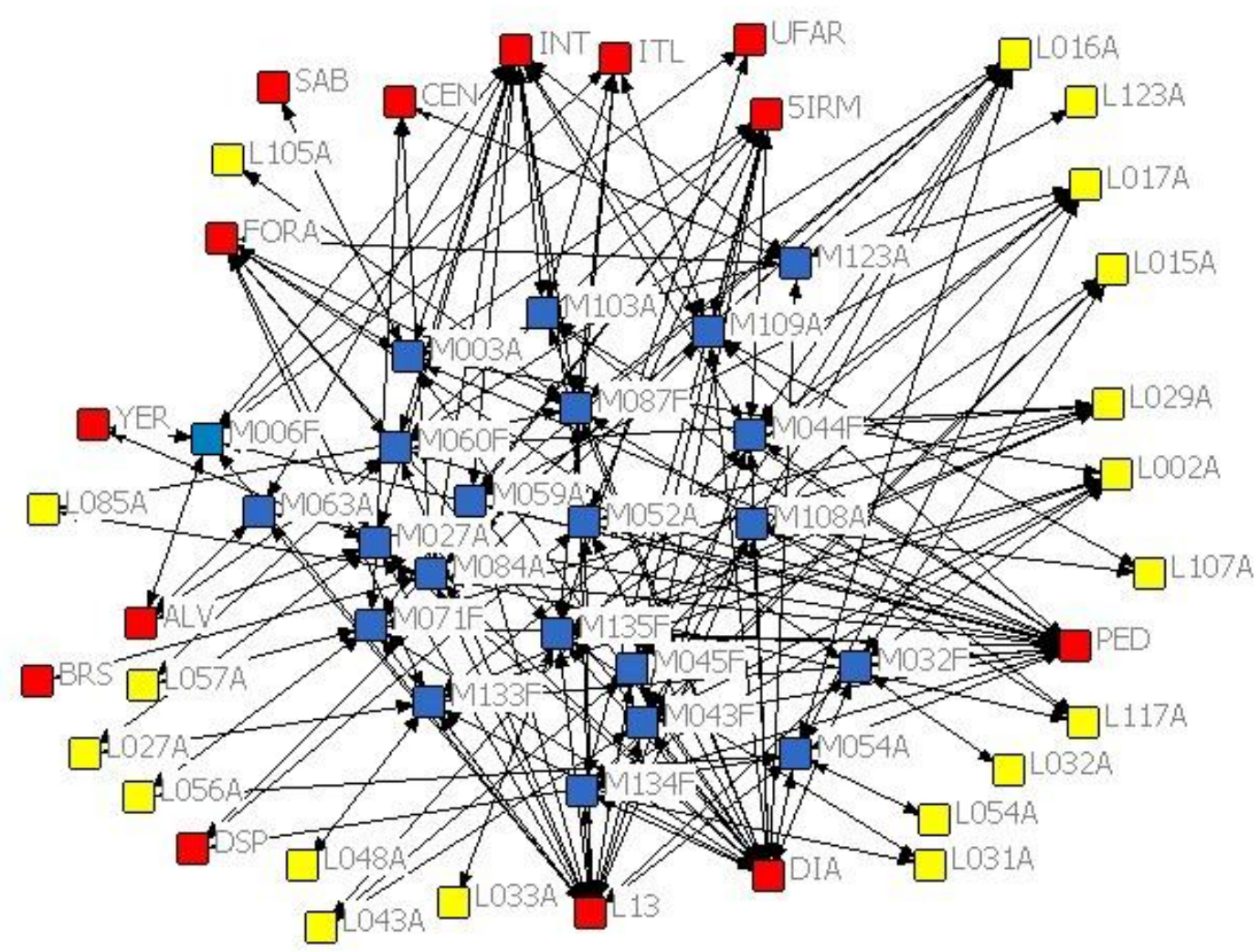

Em destaque as influências dos centros Largo 13 de Maio (L13), Diadema (DIA), Supermercado Pedreira (PED), Depósito 5 Irmãos (5IRM) e Shopping Center Interlagos (INT).

Obs.: Na cor azul os moradores. Relações, na cor vermelha, com os centros Shopping Center Interlagos (INT); Drogaria São Paulo da Avenida Nossa Senhora do Sabará (DSP); Estrada do Alvarenga (ALV); Avenida Nossa Senhora do Sabará (SAB); Diadema (DIA); Brás (BRS); Avenida Yervant Kissajikian (YER); Largo 13 de Maio (L13); Drogaria Ultra Farma (UFAR); vários centros fora do Distrito de Pedreira (FORA); Centro Histórico (CEN); Shopping Center Interlar (ITL); Supermercado Pedreira (PED); Depósito 5 Irmãos (5IRM); Shopping Center SPMarket (MAR). Em amarelo as relações com o comércio local.

Fonte: pesquisa do autor 


\section{EQUIVALÊNCIA AUTOMÓRFICA}

GRUPO 4 - INFLUÊNCIA DE LARGO 13 DE MAIO/SHOPPING INTERLAGOS/DIADEMA DISTRITO DE PEDREIRA

POR SETOR CENSITÁRIO

MAPA NÚMERO 5.41

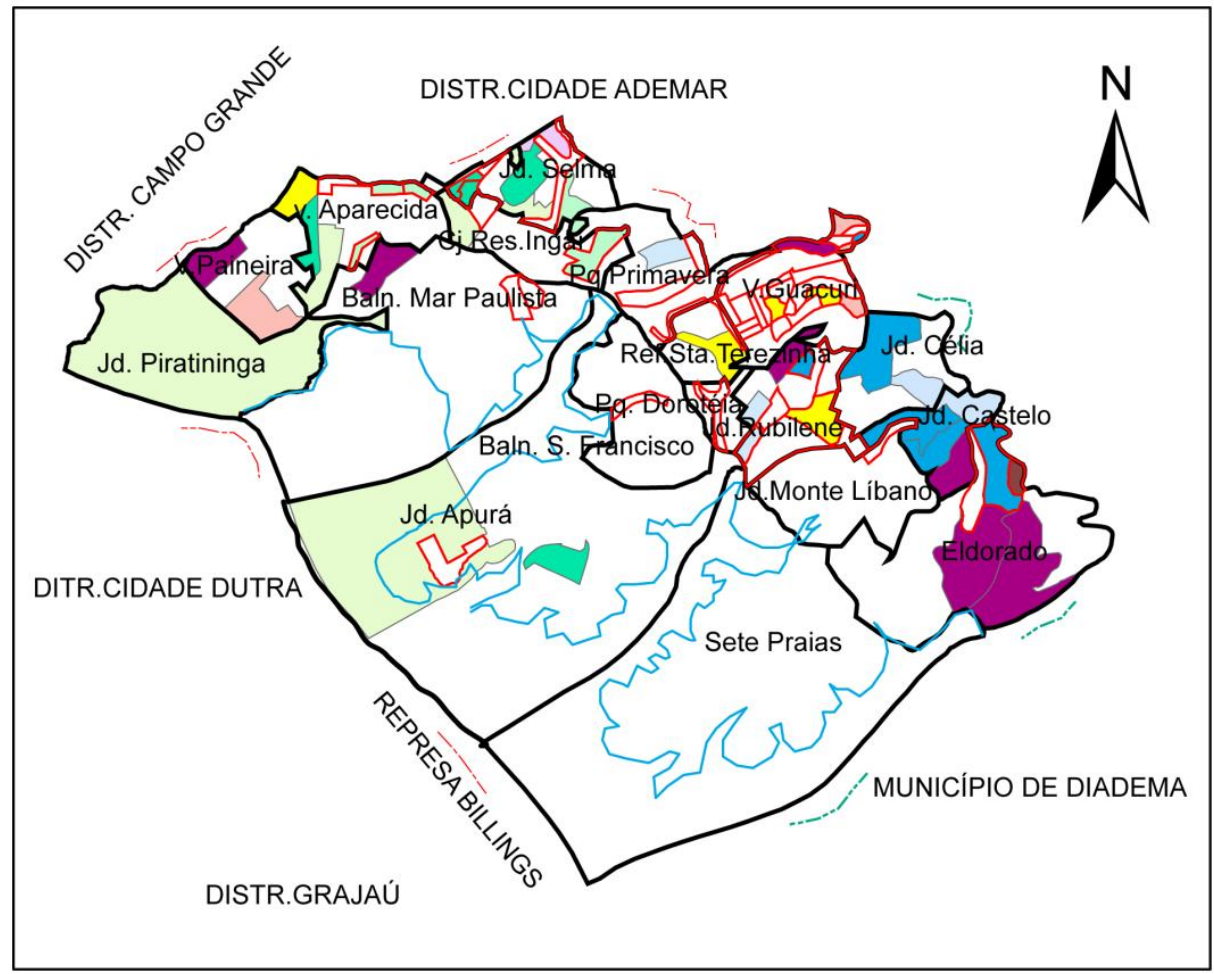

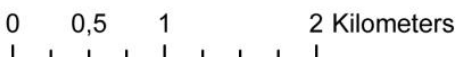

Autor: Shinhiti Osanai

Fonte: pesquisa do autor
Eq.automórfica Grupo 4

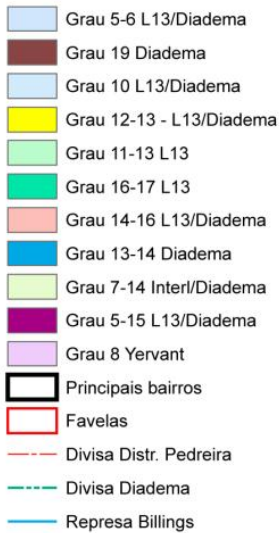


Figura 5.24 - REDE SOCIAL DE EQUIVALÊNCIA AUTOMÓRFICA DO GRUPO 4 (VIDE MAPA 5.41) FORMADO POR UM CONJUNTO DE 11 GRUPOS

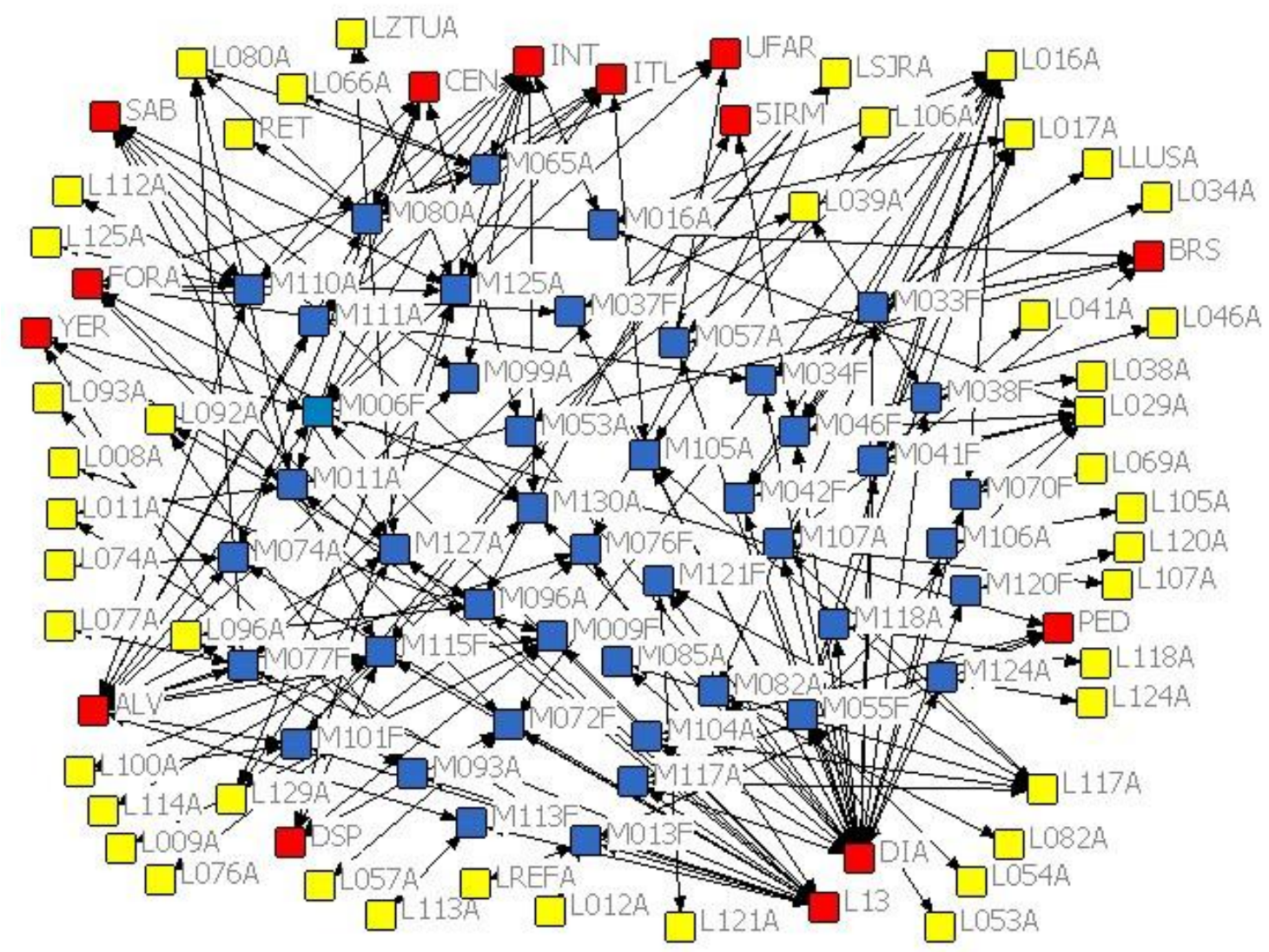

Em destaque as influências dos centros Diadema (DIA), Largo 13 de Maio (L13) e de Shopping Center Interlagos (INT). Influências medianas dos centros Estrada do Alvarenga (ALV), Shopping Center Interlar (ITL) e Avenida Nossa Senhora do Sabará (SAB).

Obs.: Na cor azul os moradores. Relações, na cor vermelha, com os centros Shopping Center Interlagos (INT); Drogaria São Paulo da Avenida Nossa Senhora do Sabará (DSP); Estrada do Alvarenga (ALV); Avenida Nossa Senhora do Sabará (SAB); Diadema (DIA); Brás (BRS); Avenida Yervant Kissajikian (YER); Largo 13 de Maio (L13); Drogaria Ultra Farma (UFAR); vários centros fora do Distrito de Pedreira (FORA); Centro Histórico (CEN); Shopping Center Interlar (ITL); Supermercado Pedreira (PED); Depósito 5 Irmãos (5IRM); Shopping Center SPMarket (MAR). Em amarelo as relações com o comércio local.

Fonte: pesquisa do autor 
Apesar das deficiências da estrutura do comércio das regiões próximas à divisa com Diadema, os resultados obtidos através da equivalência automórfica, apontam alguns indícios de evidências da dispersão espacial de pequenos grupos de comércio instalados nas imediações das residências para o atendimento das necessidades diárias ou semanais.

Na equivalência estrutural, pelo método CONCOR, devido às propriedades da correlação, os grupos são estruturados na ótica da similaridade, isto é, os elementos que compõem cada grupo devem ser similares. Portanto, pode acontecer a constituição de um determinado grupo por meio da participação de todos os principais centros de influência, contemplando também os moradores que compram em mais de um centro, ou então, outros grupos em decorrência da ausência de determinados centros de influência, por exemplo, Diadema ou Estrada do Alvarenga, e finalmente, um grupo distinto com a participação intensa de Diadema. A similaridade está diretamente relacionada com a localização geográfica dos moradores.

O critério básico da equivalência estrutural, pelo método de distância euclidiana, é a dissimilaridade. As características entre os grupos distintos devem ser dissimilares, ou seja, os que compram em Diadema são considerados dissimilares em relação àqueles que satisfazem as suas necessidades de compras no Largo 13 de Maio. Desde que mantenha as dissimilaridades entre os grupos, um determinado centro de influência pode fazer parte de vários grupos distintos. Quando alguns moradores compram em dois ou mais centros, o centro mais forte em intensidade de atração pode determinar a constituição do grupo. Um morador de Diadema, que compre em vários centros, pode ficar, por exemplo, no grupo do Shopping Center Interlagos desde que seja o seu local de maior importância. Outro morador de Diadema, que igualmente compra no Largo 13 de Maio, pode ficar no grupo do Largo 13 de Maio, caso o seu relacionamento com esse último centro seja mais intenso.

Em consequiência dos elementos dicotômicos da matriz de relacionamento (sociomatriz) da rede social do Distrito de Pedreira serem apenas constituídos por valores 1 ou 0 , parte dos resultados, da equivalência estrutural, obtidos pelo método de correlação, ou CONCOR, e no método de dissimilaridade, ou distância euclidiana, podem ser semelhantes.

Caso o objetivo da análise da equivalência estrutural seja a identificação dos grupos homogêneos, na ótica da localização geográfica, em relação aos centros de influência, o método CONCOR pode apresentar alguma vantagem, pois o seu critério se baseia na 
similaridade. Por exemplo, no mapa número 5.37, da página 265, em comparação com o mapa 5.36, da página 252, torna-se mais fácil a visualização da região sem a influência de Diadema.

Sendo o objetivo da análise da equivalência estrutural, a identificação da distribuição espacial dos centros em relação às intensidades de atração, o método da distância euclidiana leva vantagem por agrupar os elementos segundo o critério de dissimilaridades. Por exemplo, no mapa 5.36, da página 252, em comparação com o mapa 5.37, da página 265 , alguns moradores, que compram em Diadema e também em outros dois ou mais centros distintos, podem participar do grupo do Shopping Center Interlagos, desde que a sua intensidade de atração seja mais elevada, e assim deixam de participar do grupo de Diadema. 
Figura 5.25 - Dendograma da equivalência automórfica - grupo de moradores

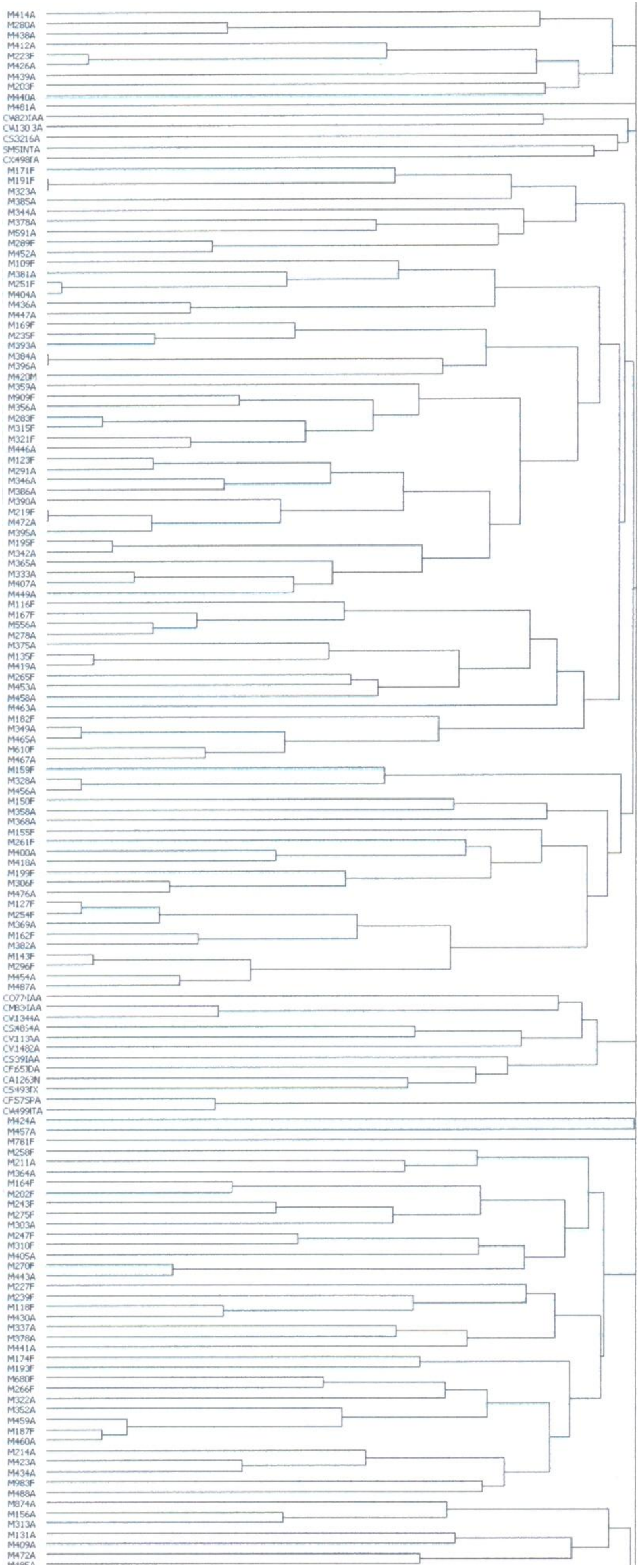

Obs.: Este dendograma corresponde apenas ao recorte da parte que se refere aos 135 moradores Fonte: pesquisa do autor 
6 TÉCNICAS DE ANÁLISE ESPACIAL DOS CENTROS COMERCIAIS 


\subsection{Introdução}

O objetivo deste capítulo é entender algumas características de padrão de agrupamento ou de dispersão de alguns centros utilizando algumas técnicas de análise espacial. A aplicação dos recursos do sistema de informações geográficas e a obtenção dos cálculos de geoestatística foram realizadas em algumas etapas.

A primeira etapa constituiu do levantamento de dados em campo sobre a localização do comércio a partir das indicações feitas pelos entrevistados que participaram na estruturação da rede social do comércio e dos moradores. Os locais dos 1150 estabelecimentos comerciais, apresentados no mapa número 6.3, estão na seção referente às estatísticas de correlação espacial.

A etapa seguinte correspondeu ao georeferenciamento dos locais de moradia dos 135 entrevistados (mapa número 6.1), bem como, de todos os pontos de comércio resultantes do levantamento de campo. Essas tarefas foram realizadas por meio da ajuda de um software de sistema de informações geográficas.

A última etapa envolveu os cálculos de geoestatística utilizando os recursos do software acima mencionado. Os dois tipos de técnicas que foram utilizadas constam no capítulo 2 . $\mathrm{O}$ primeiro, que mede as distribuições geográficas, contempla o centro médio dos moradores, o centro médio do comércio e a elipse padrão direcional. O segundo é utilizado para a análise do padrão da distribuição espacial, compreende a distância média do vizinho mais próximo, as estatísticas globais Moran's I e Getis Ord G, as estatísticas locais Anselin Moran's I e Getis Ord Gi*

Quanto à ocupação do Distrito de Pedreira, as regiões mais antigas ao norte e ao centro estão com a densidade habitacional mais elevada conforme o mapa 4.11 da página 107 e ao sul, apesar das invasões nas áreas de reservas naturais e de declividades acentuadas, ainda permanece com a densidade ocupacional um pouco menos densa. Ao se considerar que as atividades comerciais se organizam nas proximidades de aglomerações populacionais, esperase que o comércio seja mais intenso nas regiões mais densas. Portanto, a localização do centro médio dos moradores (mapa número 6.1 da página 290) pode ser uma das indicações da tendência da instalação do comércio. Por causa das regiões mais densas ao norte, o centro médio dos moradores se aproxima mais da região noroeste e não se encontra no ponto geométrico central do Distrito de Pedreira. Em relação ao centro médio dos moradores, foram 
identificados, através da rede social, dois centros secundários mais próximos: Jardim Rubilene e o Parque Santa Amélia. Um terceiro um pouco mais distante é o centro local da Estrada do Alvarenga. Existe uma coerência entre o espaço de lugar, a localização dos centros comerciais, e o espaço de fluxos, a opção dos moradores pelos locais preferidos das suas compras.

O centro médio dos moradores localiza-se no bairro Refúgio Santa Terezinha, conforme o mapa número 6.1, nas proximidades do Parque Santa Amélia, no início da Rua dos Apiaris e está muito próximo da Estrada do Alvarenga. É uma área muito bem servida por ônibus com destino para quase todas as regiões do Distrito de Pedreira, principalmente para Santo Amaro e outros locais como o Centro Histórico e Jabaquara. (Vide mapa 4.19 da página 138)

Dois importantes estabelecimentos localizam-se bem próximos desse centro médio dos moradores. O Supermercado Pedreira, que foi um dos locais mais citados para as compras mensais, encontra-se na Avenida das Garoupas, no Parque Santa Amélia. O Depósito 5 Irmãos, igualmente muito lembrado pelos entrevistados, localiza-se na Rua Professor Cardozo de Mello Neto, no Jardim Rubilene. Conseqüentemente, a localização desses dois estabelecimentos é bastante privilegiada e vantajosa em relação aos moradores do Distrito de Pedreira.

Alguns centros locais importantes estão dentro do raio de $1 \mathrm{~km}$ a partir desse centro médio, conforme o mapa número 6.2 da página 292, os principais centros locais e secundários estão localizados dentro do raio de $2 \mathrm{~km}$.

Centros localizados, dentro do perímetro de raio aproximado de $2 \mathrm{~km}$, a partir do centro médio dos moradores:

1 - Vila Missionária;

2 - Parque Primavera (dentro do raio de $1 \mathrm{~km}$ );

3 - Jardim Rubilene (dentro do raio de $1 \mathrm{~km}$ );

4 - Parque Santa Amélia (dentro do raio de $1 \mathrm{~km}$ );

5 - Balneário Mar Paulista (Estrada do Alvarenga);

6 - Jardim Selma. 


\section{CENTRO MÉDIO DOS MORADORES}

DISTRITO DE PEDREIRA

MAPA NÚMERO 6.1

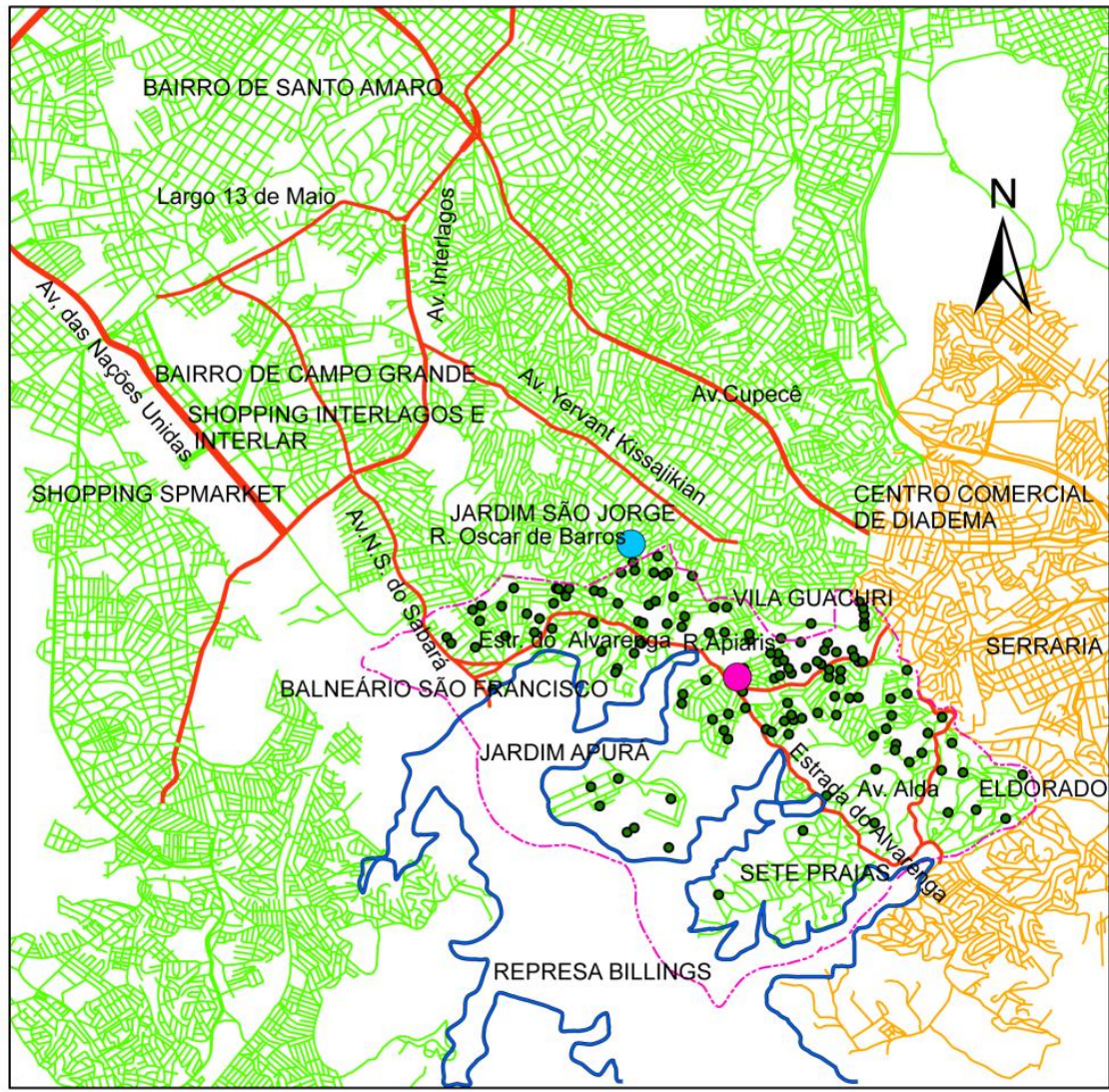

\section{Legenda}

$\begin{array}{lll}0 & 0,5 & 1\end{array}$ 2 Kilometers

Autor: Shinhiti Osanai

Fonte: pesquisa do autor
- Moradores

Centro médio dos moradores

Centro médio do comércio

- Represa Billings

_ São Paulo

— Diadema

Divisa Distr. Pedreira 
Localização dos centros, dentro do perímetro de raio aproximado de $4 \mathrm{~km}$, a partir do centro médio dos moradores:

7 - Jardim Miriam (Avenida Cupecê);

8 - Centro comercial de Diadema;

9 - Bairro de Serraria (Diadema) - Avenida Rotary;

10 - Bairro de Navegantes (Diadema) - Avenida Nossa Senhora dos Navegantes;

11 - Avenida Nossa Senhora do Sabará - bairro de Campo Grande - localiza relativamente próxima do limite de $4 \mathrm{~km}$, sendo a sua distância em linha reta de $4,3 \mathrm{~km}$;

12 - Avenida Yervant Kissajikian - Distrito de Cidade Ademar.

Centros comerciais, mais afastados, cuja localização se encontra além do perímetro de raio de $4 \mathrm{~km}$, a partir do centro médio dos moradores:

13 - Shopping Center Interlagos e Interlar - Distrito de Campo Grande, na Avenida Interlagos - localiza-se bem no limite dos 4 km, sendo a sua distância em linha reta de 3,9 $\mathrm{km}$;

14 - Largo 13 de Maio - bairro de Santo Amaro - a sua distância em linha reta é de 7,4 km; 15 - Shopping Center SPMarket - Distrito de Campo Grande, na Avenida das Nações Unidas - a sua distância em linha reta é de $5,7 \mathrm{~km}$.

O centro médio do comércio (mapa número 6.3 da página 293) se localiza fora do Distrito de Pedreira, na região norte, no bairro Jardim São Jorge, no Distrito de Cidade Ademar, em conseqüência do comércio de Santo Amaro e da localização do Shopping Center Interlagos no bairro de Campo Grande. A rede social concedeu à região do Largo 13 de Maio o nível hierárquico mais elevado, em relação aos moradores de Pedreira. Por conseguinte, o centro médio do comércio está sendo um indicador da localização da tendência espacial das vantagens competitivas de determinados centros principais, tais como o Largo 13 de Maio e o Shopping Center Interlagos. Mais uma vez, o espaço de lugares representado pelo centro médio do comércio é coerente com os centros de preferência dos moradores que foram determinados pelo espaço de fluxos.

Esse centro médio localiza-se no já referido bairro Jardim São Jorge, conforme o mapa número 6.3, na divisa com os Distritos de Pedreira e Cidade Ademar, na Rua Oscar de Barros entre as Ruas Sabrina Kalter e Benedito Gomes. É o mesmo ponto central da elipse padrão direcional cujo eixo principal está na direção de Santo Amaro. (Vide os conceitos no capítulo 2 página 74$)$ 


\section{LOCALIZAÇÃO DE ALGUNS CENTROS}

DISTRITO DE PEDREIRA

MAPA NÚMERO 6.2

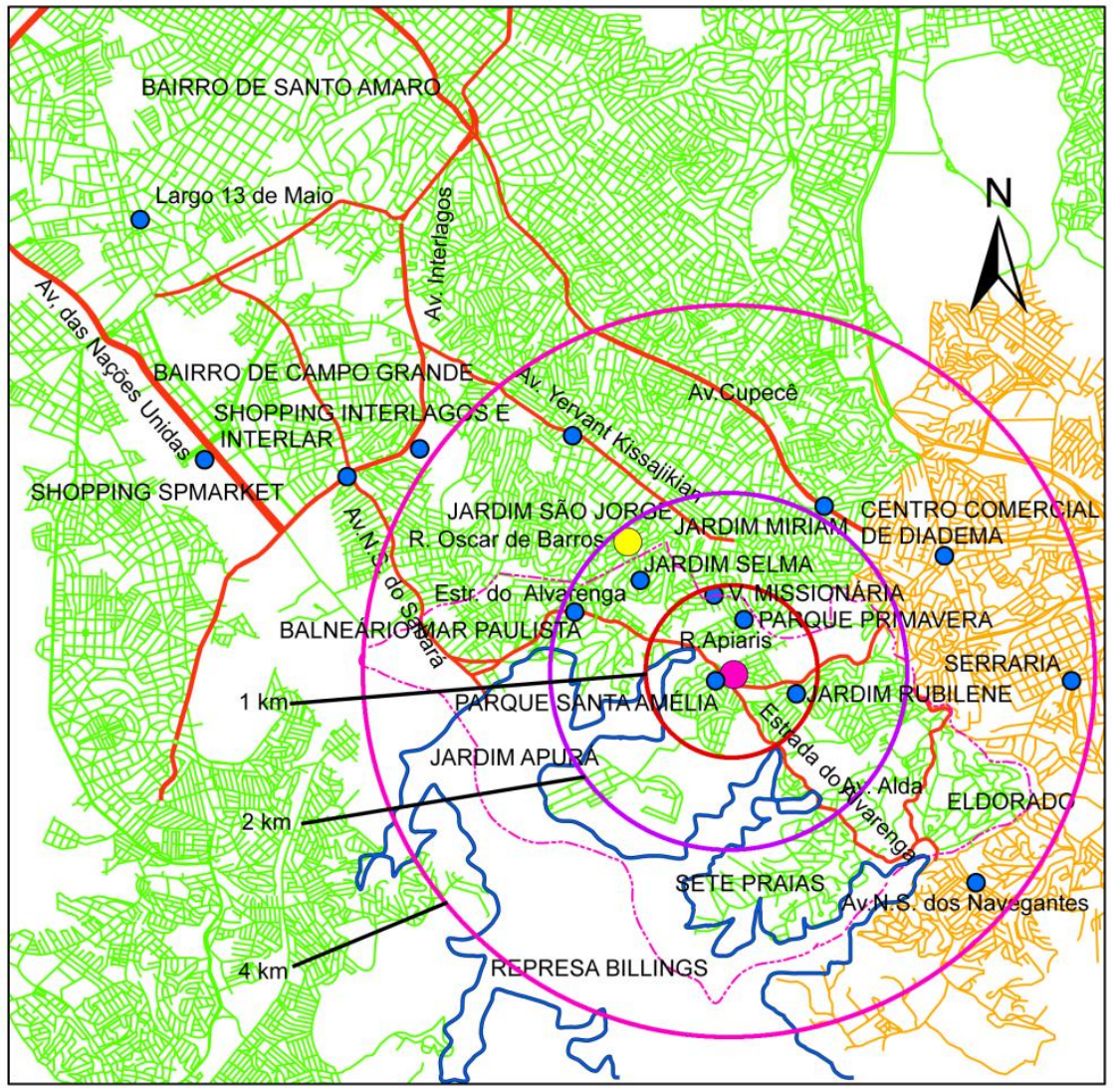

Legenda

$\begin{array}{lll}0 & 0,5 & 1\end{array}$ 2 Kilometers

Autor: Shinhiti Osanai

- Centros principais e secundários

Centro médio dos moradores

Fonte: pesquisa do autor

Centro médio do comércio

- Represa Billings

— São Paulo

— Diadema

-_-_ Divisa Distr. Pedreira 


\section{CENTRO MÉDIO DO COMÉRCIO}

DISTRITO DE PEDREIRA

MAPA NÚMERO 6.3

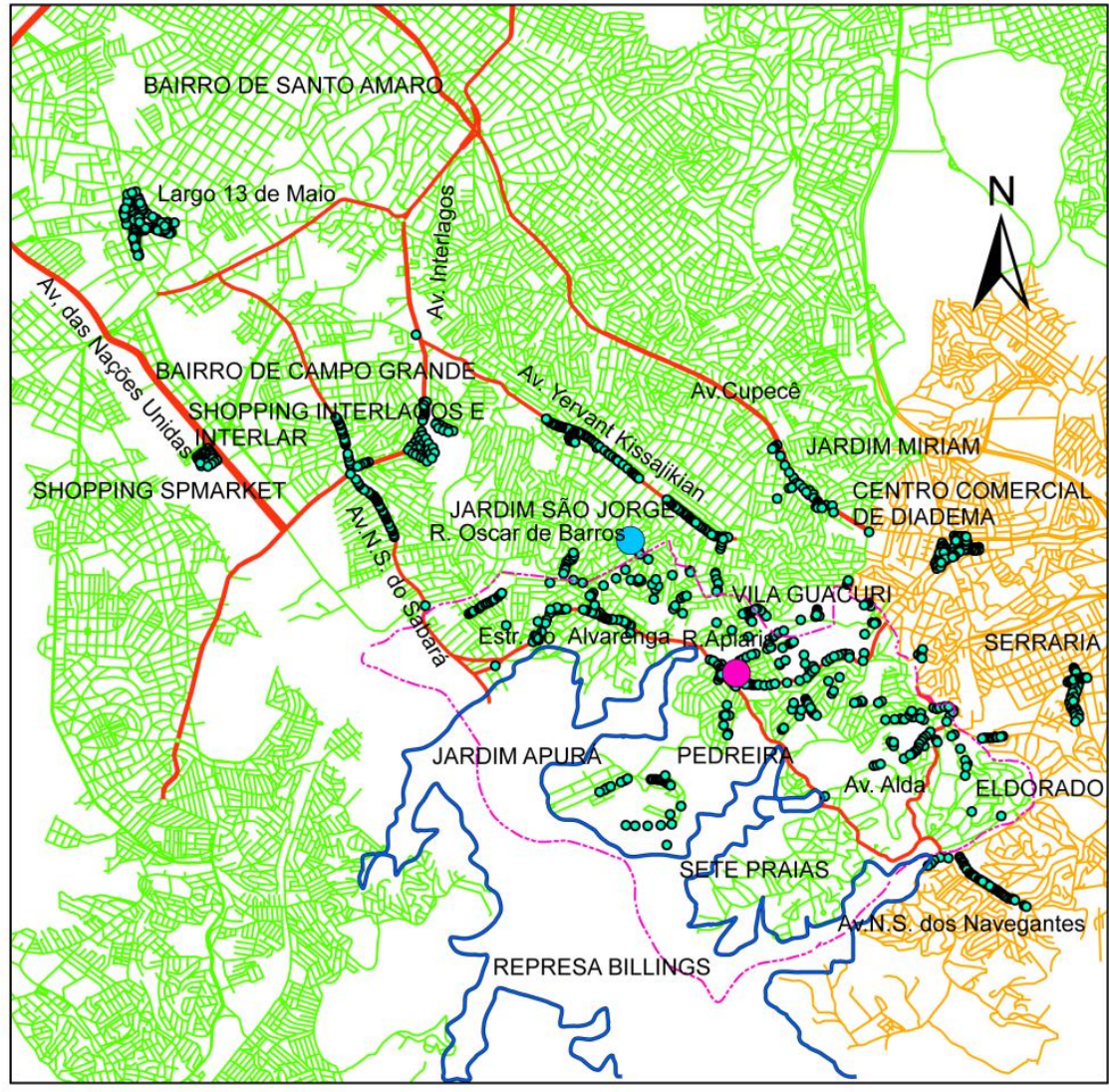

$\begin{array}{lll}0 & 0,5 & 1\end{array}$ 2 Kilometers

Autor: Shinhiti Osanai

Fonte: pesquisa do autor

\section{Legenda}

- Estabelec. Comerciais

Centro médio do comércio

Centro médio dos moradores - Represa Billings - São Paulo - Diadema 
A elipse direcional padrão (mapa número 6.4 da página 295) indica as influências dos três centros principais Largo 13 de Maio, Shopping Center Interlagos e Diadema, sobre os moradores do Distrito de Pedreira. Notamos que a intensidade de Santo Amaro, ao desviar o seu eixo principal em sua direção, é mais forte em comparação a Diadema. Conforme o mapa número 6.4, tem o seu centro localizado na Rua Oscar de Barros no bairro Jardim São Jorge. O seu eixo principal encontra-se na direção de Santo Amaro, passa próximo do Largo 13 de Maio, desviando ligeiramente para o lado oeste, para a Rua Professor Oscar Ramos Arantes. A outra extremidade passa por Diadema, entre os bairros Navegantes e Serraria, cruzando o início da Avenida Antonio Silvio Cunha Bueno no bairro Jardim Inamar. Uma das extremidades do eixo secundário, voltado para o norte, encontra-se na Rua Públio Pimentel no bairro de Americanópolis, Distrito de Cidade Ademar, e o seu lado oposto, voltado para o sul, passa pela Rua do Sossego no bairro de Balneário Mar Paulista (Vide os conceitos no capítulo 2 página 74$)$.

A localização do Shopping Center Interlagos encontra-se relativamente vantajosa, pois está no eixo principal da elipse em conseqüência da força de atração do comércio da região do Largo 13 de Maio.

Pela posição do eixo principal podem-se identificar dois dos pólos principais de atração: a região do Largo 13 de Maio e o comércio do Município de Diadema. Nesse último Município, o comércio dos bairros Navegantes, mais para o sul, e Serraria, mais para o norte, desviam o eixo principal da elipse afastando do centro comercial de Diadema. O comércio instalado nos bairros Jardim Monte Líbano, Jardim Rubilene e Vila Missionária ajuda a afastar o eixo principal do centro comercial de Diadema. O comércio da Avenida Nossa Senhora do Sabará e do Shopping SPMarket na Avenida das Nações Unidas ajudam a desviar o eixo principal para o lado oeste do Largo 13 de Maio. 


\section{ELIPSE DIRECIONAL PADRÃO DO COMÉRCIO}

DISTRITO DE PEDREIRA

MAPA NÚMERO 6.4

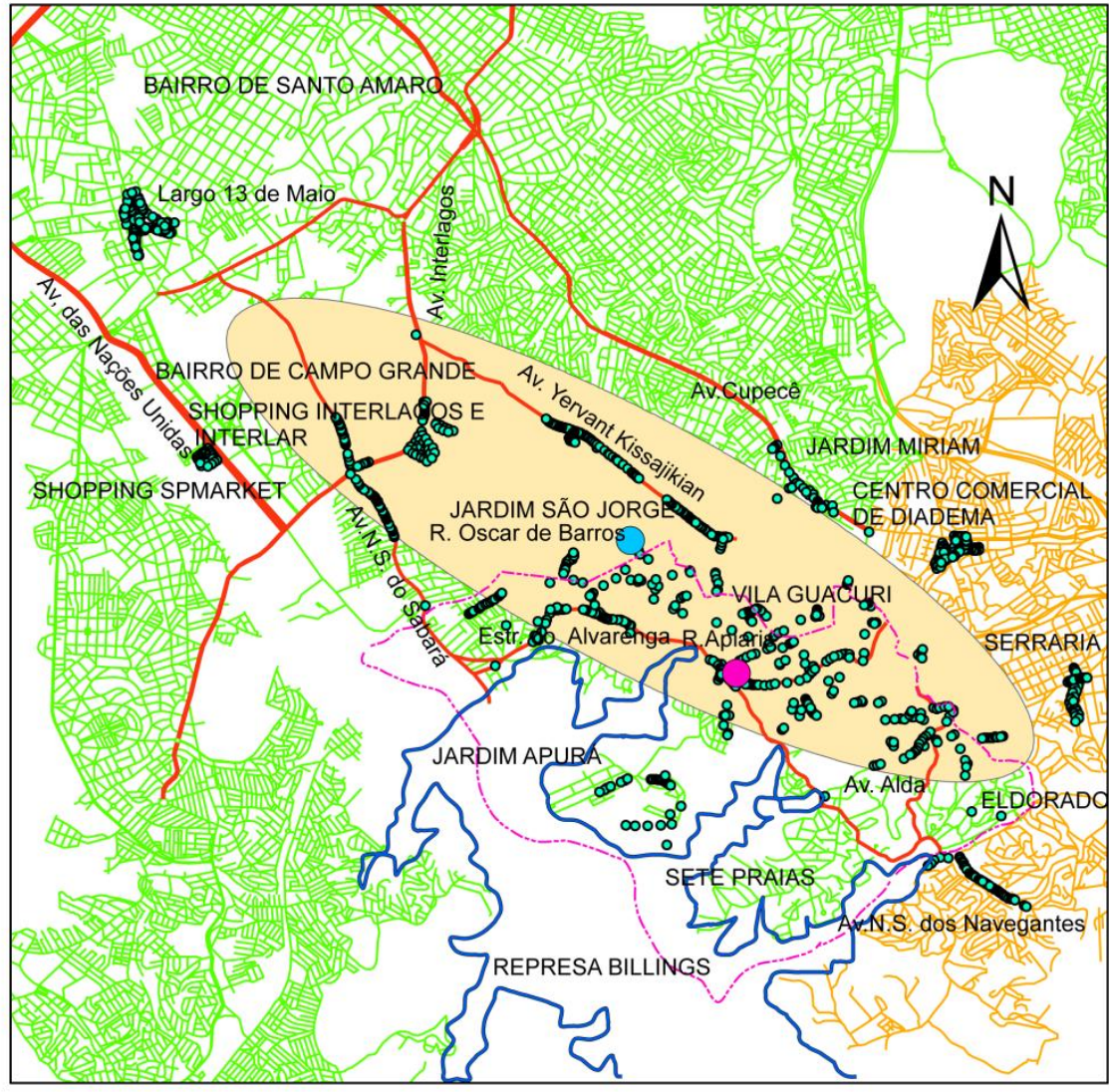

$\begin{array}{lll}0 & 0,5 & 1\end{array}$ 2 Kilometers

\section{Legenda}

Autor: Shinhiti Osanai

Fonte: pesquisa do autor

Elipse direcional padrão

Centro médio do comércio

Centro médio dos moradores Represa Billings São Paulo Diadema 
Os cálculos da distância média do vizinho mais próximo e das estatísticas globais Moran’s I e Getis Ord G confirmam a existência de aglomerações do comércio. A rede social, através dos níveis hierárquicos, indicou os centros principais (mapas 5.25 e 5.26 das páginas 202 e 203) Largo 13 de Maio, Shopping Center Interlagos e Diadema. Igualmente foram obtidos os centros secundários Estrada do Alvarenga, Parque Santa Amélia, Jardim Rubilene, Av. Nossa Senhora do Sabará, Av. Yervant Kissajikian, Serraria e Av. Nossa Senhora dos Navegantes, entre os mais importantes. Aplicaram-se os cálculos das estatísticas locais Moran's I e Getis Ord Gi* e obteve-se a confirmação da qualificação de centros principais para o Largo 13 de Maio e Shopping Center Interlagos. Ainda, essas mesmas estatísticas locais, indicaram o status de centros secundários para os demais referidos centros. As técnicas de análise espacial revelaram os padrões de aglomeração dos centros, o espaço de lugares, e mostrou a sua coerência com o espaço de fluxos diante da representação dos centros em formas de nós na rede social.

Os padrões da distribuição geográfica dos pontos de comércio podem estar agrupados ou dispersos. Sob o ponto de vista econômico, existem algumas vantagens decorrentes da organização das atividades comerciais em locais de grande circulação, em virtude de aglomerados comerciais. Em relação aos custos de transporte, para os compradores, a organização do comércio em determinados pontos centrais pode oferecer algumas vantagens decorrentes da possibilidade de satisfazer as principais necessidades de compras em único local, mais central. Em consequiência os padrões de agrupamento do comércio podem determinar maior ou menor intensidade de atração em relação aos compradores. Segundo Michael Goodchild (2004) há dependência espacial quando se verificam determinados padrões de agrupamento. A situação oposta da dispersão total pode ser caracterizada mediante a não existência da dependência espacial.

Os 1150 pontos de comércio georeferenciados perfazem o total de 2033 estabelecimentos comerciais. A média geral corresponde a 1,76 lojas, e o valor da variância equivale a 12,97. As informações armazenadas no banco de dados, contendo todos esses pontos georeferenciados, são utilizadas para a aplicação de cada uma das técnicas de análise espacial, com o objetivo de avaliar os padrões de agrupamento do comércio do Distrito de Pedreira, e dos seus principais centros comerciais, localizados fora do Distrito. 
Pelas informações obtidas através do cálculo da distância média do vizinho mais próximo, conclui-se que existem grupos de comércio na área em estudo. O resultado do índice é igual a 0,24 , sendo o seu correspondente valor padronizado da estatística $Z$ equivalente a $-48,98$. Ao considerar que o valor do índice é inferior a 1, rejeitou-se a hipótese zero "não existe a constituição de grupos”, perante o nível de significância de $99 \%$ e a correspondente estatística $\mathrm{Z}$ igual a -2,58. Portanto, fica confirmada a formação de grupos de comércio. (Vide os conceitos no capítulo 2 página 67).

Diante da existência de grupos de comércio ou centros, torna-se interessante conhecer quais são os centros de padrões espaciais, que podem ser diferentes, ou semelhantes. A estatística global Moran's I pode ser utilizada para essa finalidade. O seu resultado é igual a 0,03 , sendo o seu correspondente valor da estatística $Z$ igual a 5,34. O seu valor positivo indica a possibilidade da existência de similaridades. Diante da rejeição da hipótese zero "não existe a formação de grupos", de acordo com o nível de significância de 99\% e o seu correspondente valor da estatística $\mathrm{Z}$ igual a 2,58, conclui-se que existem grupos de comércio semelhantes na área em estudo (Vide os conceitos no capítulo 2 página 69).

O resultado obtido, muito próximo de 0 , indica as evidências da constatação de vários agrupamentos de tamanhos pequenos que correspondem aos centros secundários ou locais. Nesses centros menores a quantidade de estabelecimentos por ramo de comércio é, freqüentemente, entre 1 e 2 lojas.

Os detalhes mais específicos, sobre a similaridade ou dissimilaridade de cada grupo ou centro, podem ser obtidos aplicando-se a estatística local Moran's I, a ser apresentado mais adiante. Os seus resultados mostram os valores mais altos e significativos para o comércio do Largo 13 de Maio, Shopping Center Interlagos e Shopping Center Interlar.

A simples constatação das similaridades ou dissimilaridades não é suficiente para o entendimento do padrão de formação dos grupos ou centros. Considerando-se que grupos similares podem variar em seu tamanho, torna-se interessante o conhecimento das características de concentração de cada centro. Nos centros maiores e mais densos pode existir a tendência de significativa concentração em determinados ramos de comércio. Os padrões dessas concentrações podem ser analisados através da estatística global Gets Ord G. O seu resultado é igual a 100,08 sendo o seu correspondente valor da estatística Z igual a 2,56 . Obteve-se o sinal positivo e um resultado maior que o valor esperado igual a 89,31. De 
conformidade com o nível de significância de $95 \%$ e o seu correspondente valor da estatística $\mathrm{Z}$ igual a 1,96 e perante a rejeição da hipótese zero "não existe a constatação de grupos", pode-se concluir que existe um padrão de agrupamento com quantidade elevada de lojas em determinados ramos de comércio, o que apresenta alguma característica de concentração, distribuídos espacialmente no meio de vários ramos que funcionam com pequenas quantidades de lojas (Vide os conceitos no capítulo 2 página 71).

Os detalhes específicos de cada tipo de concentração podem ser obtidos por meio da estatística local Gets Ord Gi*, a ser apresentado nos próximos tópicos. Os valores mais altos e significativos pertencem ao comércio do Largo 13 de Maio, Shopping Center Interlagos e Shopping Center Interlar.

Os resultados provenientes dos cálculos das estatísticas globais Moran's I e Getis Ord G acima referidos, por serem genéricos, não são suficientes para a identificação das características específicas de cada centro ou agrupamento. Por meio dessas duas estatísticas locais identificam-se quais são as regiões onde existem concentração e dispersão das atividades do comércio. Essa identificação possibilita a comparação de cada um deles e a visão da sua diferenciação.

São utilizados para os cálculos das estatísticas locais Anselin Moran's I e Getis Ord Gi*, os 1150 pontos de comércio georeferenciados, correspondendo ao total de 2033 estabelecimentos comerciais, sendo o resultado da média igual a 1,76 lojas e 12,97 o valor da sua variância.

De acordo com o capítulo anterior sobre redes sociais, as regiões externas ao Distrito de Pedreira exercem uma forte influência em relação aos seus moradores. Um dos principais locais são a região do Largo 13 de Maio, em Santo Amaro, o centro comercial de Diadema e o Shopping Center Interlagos. Outras regiões externas, que exercem menor intensidade de atração, também são freqüentadas pelos moradores do Distrito de Pedreira, por exemplo, a Avenida Nossa Senhora do Sabará, Avenida Yervant Kissajikian, o Largo do Jardim Miriam junto à Avenida Cupecê e o Shopping Center SPMarket. Algumas das principais regiões, que mantêm o comércio local, correspondem à Estrada do Alvarenga no Balneário Mar Paulista, Avenida das Garoupas no Jardim Santa Amélia, Rua Professor Cardozo de Mello Neto no Jardim Rubilene, Rua Dr. José Silvio de Camargo e Avenida Alda, estas duas últimas no bairro de Jardim Monte Líbano. Em Diadema, os bairros de Serraria, Vila Conceição, Parque 
Sete de Setembro e Navegantes, esses três últimos localizados na divisa com o Distrito de Pedreira, participam também no abastecimento dos moradores.

O princípio básico para se estabelecer o padrão de agrupamento, está fundamentado na distância que separa cada um dos elementos ou vizinhos, dentro de uma região objeto de estudo. Essa idéia é conhecida como a lei de Tobler": "Everything is related to everything else, but near things are more related than those far apart.” (LONGLEY et al, 2002, p. 61). A aplicação dessa idéia é perfeitamente viável, conforme os resultados obtidos, no estudo dos padrões da distribuição espacial do comércio, satisfatória e eficiente para a descrição das características da organização do comércio.

Segundo Goodchild (2004) a condição básica para a constatação da dependência espacial é uma conseqüência da organização de grupos. Não se verifica a dependência espacial, numa situação de dispersão, na qual não existe a possibilidade de identificar a formação de grupos.

Fundamentada na estatística local Moran's I (mapa 6.5 da página 301), constatou-se a situação de dependência espacial em conseqüência das evidências da existência de grupos de comércio. Os resultados são estatisticamente significativos para a região do Largo 13 de Maio, ratificando a preferência dos moradores verificada na rede social, obtida por meio das medidas de grau e de posicionamento. Apesar dos valores significativos da correlação espacial do Shopping Center Interlagos, a classificação do seu nível hierárquico, fornecida pela rede social, encontra-se em terceiro lugar, sendo uma das possíveis causas algumas restrições de acessibilidade aos usuários de ônibus. Diadema não apresentou resultados significativos, entretanto a sua influencia verificada pela rede social, fica limitada apenas aos moradores mais próximos da divisa, pois não dispõem, nessa região, do comércio melhor estruturado. Existem indícios da sua intensidade de atração estar muito relacionada à precariedade do comércio local, na região da divisa, e também devido a sua proximidade. Por exemplo, a Avenida São José, em Diadema, em decorrência da sua proximidade com a divisa municipal, possibilita a alguns dos moradores de Vila Guacuri o acesso em poucos minutos, a pé, sem a dependência de quaisquer tipos de condução.

A estatística local Getis Ord Gi*, ratifica os resultados da estatística local Moran's I dos centros que apresentam os padrões de aglomeração, ao fornecer os índices de concentração das quantidades de estabelecimentos comerciais de determinados ramos de comércio, os quais

\footnotetext{
${ }^{5}$ Tradução do autor: "no mundo, todas as coisas se parecem; mas as coisas mais próximas são mais parecidas que aquelas mais distantes"
} 
estão presentes nos centros Shopping Centers Interlagos, Interlar e SPMarket e a região do Largo 13 de Maio. Santo Amaro é o local de convergência das vias de comunicação provenientes das principais regiões periféricas da zona sul, e os resultados dessas estatísticas encontram-se de conformidade com as idéias de muitos autores, como Dupuy, que menciona a possibilidade da obtenção de centralidades mais importantes em decorrência da acessibilidade mais vantajosa. Observam-se em muitas das principais vias de comunicação, localizadas na periferia sul do Município de São Paulo, a sua convergência para Santo Amaro. Igualmente, existe a organização de alguns centros secundários instalados nos eixos de grande circulação, em direção a Santo Amaro, por exemplo, a Avenida Nossa Senhora do Sabará, Avenida Yervant Kissajikian e Estrada do Alvarenga.

A comparação de ambas as estatísticas locais Moran’s I e Getis Ord Gi* (mapa 6.6 página 302) mostra que todos os centros comerciais secundários da região em estudo, instalados nos eixos das vias públicas, obtiveram resultados estatísticos pouco significativos e são muito semelhantes entre si. Essas estatísticas estão coerentes com os resultados obtidos nas medidas grau e posicionamento, da rede social, o que pode justificar os seus valores estabelecendo os seus níveis hierárquicos baixos.

O comércio com as características de freqüência de demanda bastante baixa e maior diversificação possível, por exemplo, lojas de roupas para cama, mesa e banho, eletrodomésticos ou de vestuário, que necessitam a localização em pontos de elevada circulação de pessoas, é o principal responsável para a obtenção dos valores mais altos de hierarquia, de acordo com os valores das medidas de grau e de posicionamento da rede social. A estatística local Moran's I, apresenta os valores estatisticamente mais significativos, quando se verificam elevadas concentrações desses ramos de comércio, estabelece a existência da dependência espacial nos níveis hierárquicos, principalmente no comércio de vestuário. Em centros, onde se verificam as maiores concentrações de lojas, os valores da estatística local Getis Ord Gi* apresentam resultados opostos da estatística local Moran's I, todas as vezes que, nas vizinhanças dos ramos com elevada quantidade de lojas, tenham ramos com poucas lojas. Os resultados opostos dessas duas estatísticas mostram a característica do padrão bastante heterogêneo dos centros de elevado nível hierárquico, que funcionam com o comércio bastante diversificado e uma ampla gama de opções de escolha para os compradores. 


\section{PADRÕES DE CONCENTRAÇÃO DO COMÉRCIO ESTATÍSTICA LOCAL MORAN'S I}

DISTRITO DE PEDREIRA

MAPA NÚMERO 6.5

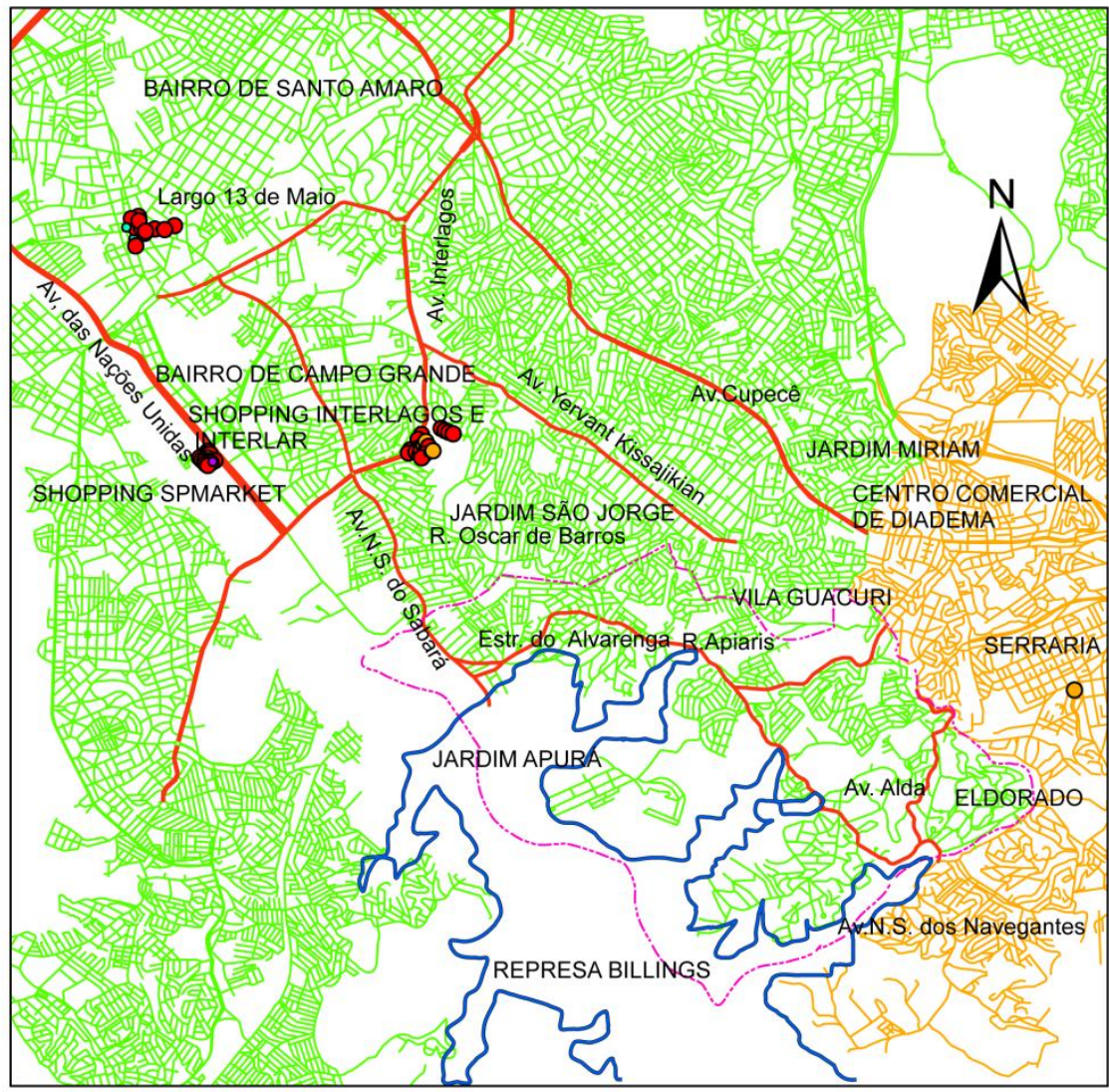

$\begin{array}{lll}0 & 0,5 & 1\end{array}$ 2 Kilometers

Autor: Shinhiti Osanai

Fonte: pesquisa do autor
Padrões de concentração

$$
\begin{array}{ll}
\text { - } & \text { Baixo e dissimilar } \\
\text { - } & \text { Baixo e similar } \\
\text { ○ } & \text { Alto e dissimilar } \\
\text { ○ } & \text { Alto e similar } \\
\hline & \text { Represa Billings } \\
\hline & \text { São Paulo } \\
\hline & \text { Diadema } \\
\hline & \text { Divisa Distr. Pedreira }
\end{array}
$$




\section{PADRÕES DE CONCENTRAÇÃO DO COMÉRCIO ESTATÍSTICA LOCAL MORAN'S I \\ DISTRITO DE PEDREIRA \\ MAPA NÚMERO 6.6}

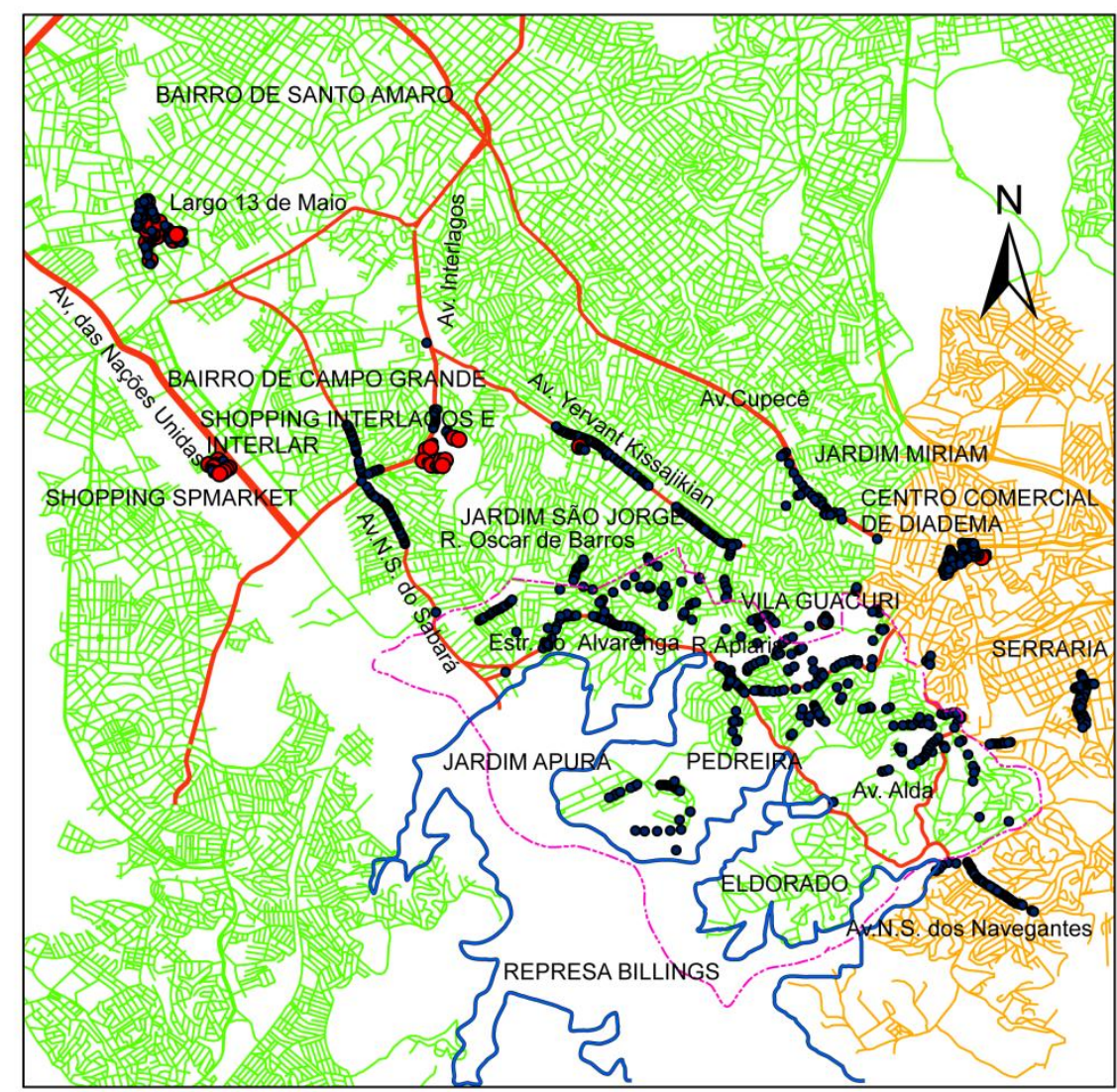

$\begin{array}{lll}0 & 0,5 & 1\end{array}$

2 Kilometers

Autor: Shinhiti Osanai

Fonte: pesquisa do autor
Padrões de concentração

- Baixo não significativo

- Alto não significativo

Represa Billings

— São Paulo

— Diadema

_-_- Divisa Distr. Pedreira 
O comércio de freqüência de demanda alta, sendo diária, semanal ou eventualmente até mensal, por exemplo, a padaria ou a mercearia, por ser local e muito freqüente, e distribuído por diversos locais do Distrito de Pedreira, cuja soma desses pequenos estabelecimentos resulta em grande quantidade, obteve os resultados das estatísticas locais Moran's I e Getis Ord Gi* estatisticamente pouco significativos. Os seus valores estão coerentes com o padrão de comércio localizado nas proximidades das residências, freqüientemente encontrado, exceto nas regiões mais próximas da divisa. Para esses ramos de negócios, os resultados das medidas de grau e de posicionamento são pouco significativos, também coerentes, com os valores das estatísticas locais, Moran's I e Getis Ord Gi*, igualmente, apresentam resultados baixos e de pouca significância. Esses valores indicam alguma homogeneidade quanto ao padrão de organização espacial desses referidos estabelecimentos comerciais.

O comércio de freqüência média, sendo a maioria mensal, quando for diversificado e atendido por estabelecimentos de tamanho significativo, por exemplo, um supermercado médio do porte do Supermercado Pedreira, pode apresentar as estatísticas locais Moran's I e Getis Ord Gi* de pouca significância, diante da existência de apenas um estabelecimento. Embora localizado em ponto estratégico, não caracteriza concentração e nem dispersão sob o ponto de vista estatístico. Entretanto, os resultados da medida de grau e de posicionamento podem ser elevados o que mostra maior dependência desse tipo de comércio para muitos dos moradores.

Torna-se importante a análise de possíveis diferenças entre os vários centros comerciais constatados. As estatísticas locais Morans'I e Getis Ord Gi* quando apresentam resultados opostos, para os mesmos ramos de comércio, ou seja, um deles elevado e outro baixo, podem revelar um padrão de centros bastante diversificados e são três ao todo: Largo 13 de Maio; Shopping Center Interlagos/Interlar e Shopping Center SPMarket. Foi possível a identificação de outro grupo, com características de padrão de distribuição diferente, constituídos por centros secundários, no qual se observa menor concentração de estabelecimentos comerciais, cujos valores das estatísticas locais Moran’s I e Getis Ord Gi* são baixos. Compreendem aos centros comerciais localizados nos eixos dos principais logradouros: Avenida Yervant Kissajikian; Avenida Nossa Senhora do Sabará; Estrada do Alvarenga; Rua Professor Cardozo de Mello Neto; Rua Dr. José Silvio de Camargo; Avenida Alda; Rua Papa Gregório Magno; Avenida Rotary e Avenida Nossa Senhora dos Navegantes, essas duas últimas em Diadema. Finalmente, encontram-se outros tipos diferentes de grupos, distribuídos por toda a área em estudo, constituídos por meio de lojas instaladas em vias 
locais, tais como na favela do Pantanal, Jardim Rubilene, Parque Santa Amélia e Jardim Selma. O centro comercial de Diadema obteve resultados locais das estatísticas Moran's I e Getis Ord Gi* menos significativos, o que caracteriza um padrão de menor concentração de lojas, apesar da diversidade do seu comércio e mesmo classificado em terceiro lugar, em nível hierárquico resultante das medidas de grau e de posicionamento da rede social.

Para a análise dos padrões locais, as atividades do comércio foram divididas em 11 regiões, conforme o mapa índice 6.7:

- $\quad$ Largo 13 de Maio, em Santo Amaro (mapas 6.8.1 e 6.8.2);

- Diadema, o centro comercial (mapas 6.9.1 e 6.9.2);

- Shopping Center Interlagos e Interlar, na Avenida Interlagos (mapas 6.10.1 e 6.10.2);

- Shopping Center SPMarket, na Avenida das Nações Unidas (mapas 6.11.1 e 6.11.2);

- Estrada do Alvarenga abrangendo os bairros de Vila Aparecida, Balneário Mar Paulista, Jardim Selma, Vila Missionária e Parque Primavera (mapas 6.12.1 e 6.12.2);

- Jardim Rubilene abrangendo os bairros de Vila Guacuri, Jardim Rubilene, Jardim Célia, Jardim das Laranjeiras e Jardim do Castelo (mapas 6.13.1 e 6.13.2);

- Parque Santa Amélia abrangendo os bairros Balneário São Francisco, Parque Santa Amélia e Jardim Apurá (mapas 6.14.1 e 6.14.2);

- Eldorado abrangendo os bairros de Monte Líbano, Eldorado e em Diadema os bairros Navegantes, Serraria, Vila Conceição e Parque Sete de Setembro (mapas 6.15.1 e 6.15.2);

- Avenida Yervant Kissajikian no bairro de Vila Joaniza (mapas 6.16.1 e 6.16.2);

- Avenida Cupecê e o Largo do Jardim Miriam, no bairro Jardim Miriam (mapas 6.17.1 e 6.17.2);

- Avenida Nossa Senhora do Sabará, no bairro de Campo Grande (mapas 6.18.1 e 6.18.2). 
MAPA ÍNDICE DAS DIVISÕES DO COMÉRCIO

DISTRITO DE PEDREIRA

MAPA NÚMERO 6.7

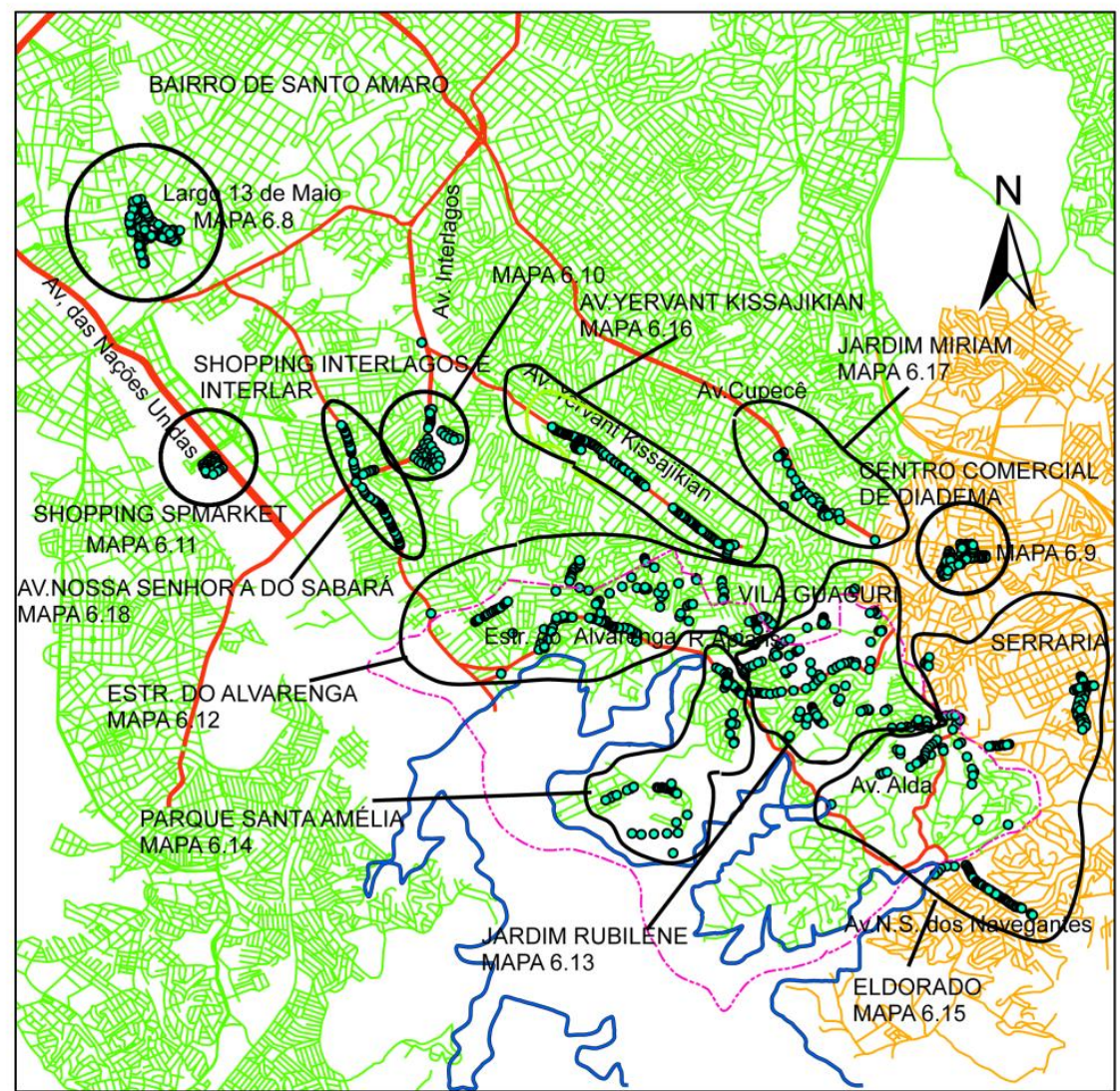

$\begin{array}{lll}0 & 0,5 & 1\end{array}$ 2 Kilometers

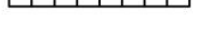

Autor: Shinhiti Osanai

Legenda

Fonte: pesquisa do autor

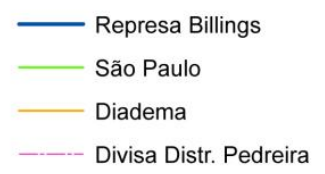


A estatística local Moran's I mostra as intensidades individuais de cada elemento dos grupos e estabelece a sua característica de similaridade quando o seu sinal for positivo ou de dissimilaridade todas as vezes que o seu sinal for negativo. Um elemento do grupo, se apresentar o seu valor abaixo da média, pode ser similar e receber o sinal positivo, quando os seus elementos adjacentes também apresentam os mesmos valores ou as mesmas quantidades de lojas abaixo da média. Por exemplo, na Estrada do Alvarenga, o comércio de cine e foto, com 1 loja e abaixo da média, recebeu o resultado similar igual a 0,33 de sinal positivo, pois tem como vizinhos ramos de atividade com 1 loja, também abaixo da média, tal como uma mercearia.

Quando o elemento alvo e também as lojas vizinhas apresentam valores ou quantidades acima da média, esse elemento é considerado similar e a estatística recebe, igualmente, o sinal positivo. Por exemplo, o ramo de cama, mesa e banho, da Alameda Santo Amaro, com 2 lojas e acima da média, obteve o resultado similar igual a 0,13 de sinal positivo, pois tem nas suas proximidades lojas acima da média, tal como o comércio de confecção com 4 lojas, acima da média.

Sempre que o elemento alvo mantiver o seu valor ou a quantidade acima da média e as lojas adjacentes apresentarem valores ou quantidades abaixo da média, esse elemento é considerado dissimilar e a estatística recebe o sinal negativo. Por exemplo, na Estrada do Alvarenga o comércio de confecções com 2 lojas, acima da média, recebeu o resultado dissimilar igual a -0,05 de sinal negativo pelo fato de manter como seus vizinhos, tal como avícola que funciona com apenas 1 loja, abaixo da média.

O contrário, quando o elemento alvo contiver o seu valor ou quantidade abaixo da média e as lojas adjacentes apresentarem valores ou quantidades acima da média, esse elemento é considerado dissimilar e a estatística recebe o sinal negativo. Por exemplo, a Casas Bahia com 1 loja na Alameda Santo Amaro, obteve o resultado dissimilar igual a -0,52 de sinal negativo, pois faz parte do grupo cuja quantidade de lojas das vizinhanças encontra-se abaixo da média e possui como vizinhos, por exemplo, o comércio de confecção, com 4 lojas, acima da média. (Vide os conceitos no capítulo 2 página 72 ).

O padrão espacial de comércio de característica local, do Distrito de Pedreira, habitualmente é constituído por 1 , ou às vezes, 2 estabelecimentos de cada ramo de atividade. Entretanto, eventualmente, observa-se a participação de 3 ou 4 estabelecimentos. A estatística Moran's I 
nos indica esse tipo de padrão, quando existe agrupamento formado por pouca quantidade de lojas, por meio do resultado muito próximo de 0 e acompanhado de sinal positivo. Constituise a similaridade em situações nas quais o estabelecimento com apenas 1 loja possua como vizinhos outras lojas também com apenas 1 ponto comercial, em cada tipo de ramo de negócio, por exemplo, na Estrada do Alvarenga, o comércio de cine e foto, com 1 loja. Quando ocorre, para um determinado ramo de negócio alvo, 2 ou mais lojas e a sua vizinhança seja constituída por apenas 1 estabelecimento em cada ramo, existe a dissimilaridade que é manifestada através do sinal negativo, por exemplo, na Estrada do Alvarenga o comércio de confecções, com 2 lojas.

Os resultados das estatísticas estão padronizados e são mais significativos quando os seus valores padronizados forem inferiores a $-1,96$ ou superiores a 1,96, de acordo com o nível de significância de $95 \%$. Os resultados que satisfazem essas referidas condições confirmam a formação de agrupamento, reiterando o resultado do índice global Moran’s I.

Todo o comércio instalado nos logradouros dos centros locais ou secundários obteve um resultado pouco significativo em consequiência da disponibilidade de apenas 1 ou 2 estabelecimentos na maioria das vezes. Em geral, obtêm-se resultados mais significativos somente em situações quando se verifica a participação de 10 ou mais lojas. O ramo de vestuário na Avenida Rotary, no bairro de Serraria, em Diadema, obteve o resultado -3,18 por causa das suas 12 lojas. Conseqüentemente, o seu sinal negativo indica a dissimilaridade em decorrência da maioria dos estabelecimentos da sua vizinhança funcionarem com apenas 1 loja.

Obtiveram-se resultados mais significativos nas aglomerações dos Shopping Center Interlagos, Interlar e SPMarket através dos valores abaixo de -1,96 e acima de 1,96. Em algumas ruas da região do Largo 13 de Maio os padrões são semelhantes a um shopping center, apesar de serem comércios instalados em via pública. O comércio de vestuário da Avenida Adolfo Pinheiro, contendo 14 estabelecimentos obteve o resultado 6,43 e o seu sinal positivo indica a participação de muitas lojas, em sua adjacência, cuja quantidade de estabelecimentos ficou acima da média.

A estatística local Moran's I mostra a semelhança do padrão de organização dos ramos de comércio entre os centros locais ou secundários. Indica um padrão diferente de aglomeração 
apenas nos shopping centers e em algumas ruas da região do Largo 13 de Maio em Santo Amaro.

A estatística local Getis Ord Gi* complementa a análise obtida pelo índice local Moran’s I. O critério básico é a comparação direta dos valores de cada elemento em relação aos seus adjacentes. Quando o valor de um elemento alvo for alto, observa-se a existência de grupos que mantêm valores elevados em sua adjacência. $\mathrm{O}$ resultado de um determinado ramo de comércio com um valor alto indica um padrão formado pela participação de outros ramos, concomitantemente, mantendo elevado número de estabelecimentos em seu redor. Por exemplo, as Lojas Americanas no Shopping Center Interlagos, com apenas 1 loja, obteve o resultado elevado igual a 10,24 por ter em suas vizinhanças o comércio de confecções com 87 lojas. O inverso, um ramo de comércio, que apresenta um resultado baixo, pode ser em consequiência da permanência, em sua vizinhança, de outros ramos que operam com poucos estabelecimentos. Por exemplo, o comércio de confecções no Shopping Center Interlagos, com 87 lojas, obteve o resultado baixo igual a 0,56 por ter em suas vizinhanças ramos de comércio com poucas lojas, por exemplo, o comércio de colchões, com apenas 1 loja. (Vide os conceitos no capítulo 2 página 74$)$.

A estatística local Gi* ao mostrar o seu valor próximo de 0 indica a participação de elementos da vizinhança mantendo valores muito próximos da média, igual a 1,76. Por exemplo, na Estrada do Alvarenga, uma loja de calçados, com 1 loja, obteve o valor igual a -0,01 e o ramo de confecção, com 2 lojas, recebeu o resultado igual a -0,52.

A constatação de um agrupamento verificada pela estatística local Moran's I não é suficiente, pois não se sabe as características de cada elemento em relação ao seu tamanho. O seu tamanho é importante, pois um grupo pode estar organizado por muitos elementos de pequena quantidade, por exemplo, um grupo grande formado por 1 loja de cada ramo de atividade em uma determinada via pública do tipo Estrada do Alvarenga. Ou então, por um pequeno grupo composto por grande número de lojas de determinados ramos de atividade. Numa área relativamente pequena do tipo Shopping Center Interlagos o ramo de confecções mantém 87 lojas. A estatística local Getis Ord Gi* permite a avaliação da maior ou menor concentração de cada elemento de um grupo com base na sua quantidade.

A informação sobre o comércio de vestuário na Avenida Adolfo Pinheiro, com 14 lojas, que obteve o resultado da estatística local Moran's I igual a 6,43 e o seu correspondente sinal 
positivo, indica a disponibilidade de muitas lojas trabalhando por meio de quantidades de estabelecimentos acima da média em sua adjacência. Portanto, deve ser complementada por meio do valor da estatística Gi* igual a 0,31 confirmando que os ramos em seu redor, apesar de estarem acima da média, mantêm os seus valores muito próximos à média, com 2 a 3 lojas. Não existem nas suas proximidades outros ramos com valores extremamente elevados, pois a maioria encontra-se bastante próxima da média.

Em conseqüência do padrão do comércio instalado nos centros locais ou secundários, na maioria das vezes, constituído por 1 ou 2 estabelecimentos por ramo de comércio, a estatística local $\mathrm{Gi}^{*}$ apresenta resultados muito próximos de 0 . Os valores mais significativos, acima de 1,96, foram obtidos nos Shopping Centers Interlagos, Interlar e SPMarket, e em alguns locais da região do Largo 13 de Maio.

Os valores da estatística local Gi*, e, igualmente, os resultados da estatística local Moran's I mostram algumas evidências no tocante às semelhanças nos padrões dos vários centros secundários, quanto à organização do comércio que atende os moradores do Distrito de Pedreira. As significativas diferenças estão apenas no comércio da região do Largo 13 de Maio, Shopping Center Interlagos e Shopping Center SPMarket em conseqüência da aglomeração de quantidade elevada de lojas em alguns ramos do comércio.

\subsection{Região do Largo 13 de Maio, em Santo Amaro}

Tabela 6.1.1 - RESULTADOS DA ESTATÍSTICA LOCAL ANSELIN MORAN'S I -

LARGO 13 DE MAIO (mapa número 6.8.1)

\begin{tabular}{cccc}
\hline Moran's I & Média & Lojas & $\%$ \\
\hline$-1,14$ a -0.21 & 1,0 & Quantidade & $19 \%$ \\
$-0,20$ a 0.43 & 1,6 & 75 & $19 \%$ \\
0,44 a 1.65 & 4,3 & 103 & $27 \%$ \\
1,66 a 3.00 & 7,4 & 74 & $19 \%$ \\
3,01 a 8,23 & 15,3 & 61 & $16 \%$ \\
SOMA & & 387 & $100 \%$
\end{tabular}

Os resultados padronizados variam entre $-1,14$ e 8,23

Fonte: apêndice D 


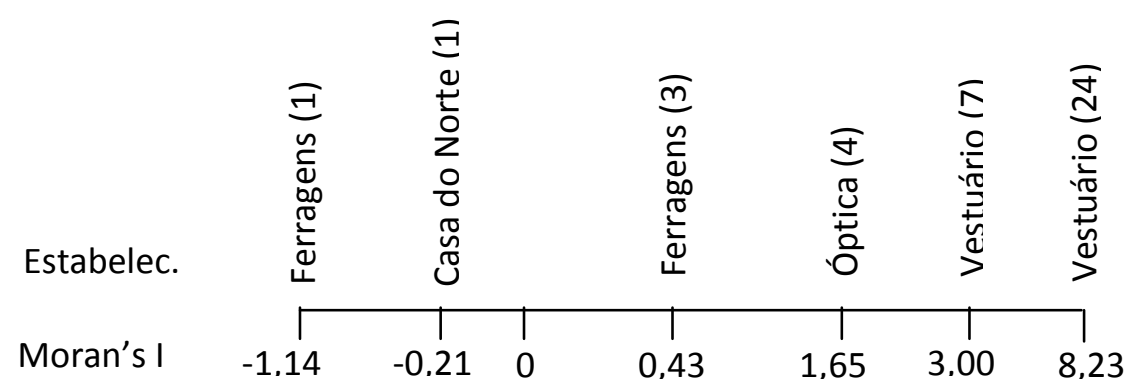

Figura 6.1.1- distribuicão da estatística Moran'I da região do Largo 13 de Maio Fonte: apêndice D

Conforme a tabela 6.1.1, uma quantidade significativa de lojas está dispersa por todo o espaço da região do Largo 13 de Maio objeto deste estudo. Em relação a três primeiras faixas, dentro do intervalo entre $-1,14$ e 1,65, sendo a maioria dos seus valores negativos e dissimilares, observam-se que $65 \%$ das lojas fazem parte de ramos que funcionam com 4 ou menos lojas por tipo de atividade. Aproximadamente a metade desse percentual é constituída por pequenos estabelecimentos com 1 ou 2 pontos de vendas. Alguns são estatisticamente dissimilares quando a quantidade de lojas for igual a 1. Por exemplo, na Alameda Santo Amaro, o ramo de calçados (1 loja) abaixo da média, é dissimilar em relação ao ramo de colchões (4 lojas), que está acima da média. A penúltima faixa, entre 1,66 e 3,00 se refere a alguns ramos com 4 ou mais lojas, por exemplo, o ramo de ótica na R. Desembargador Bandeira de Mello (4 lojas), acima da média, que é similar em relação ao ramo de bijuteria (2 lojas), também acima da média. A significativa concentração de lojas se verifica em poucos ramos, principalmente confecções que ocupa exclusivamente o resultado da última faixa dessa tabela, com valores entre 3,01 e 8,23 .

De acordo com a figura 6.1.1, o intervalo de variação, entre -1,14 e 8,23, é bastante significativo, e reflete os resultados de um centro bastante diversificado em relação ao comércio, onde é possível satisfazer praticamente as principais necessidades de compras de periodicidade mediana ou longa.

É uma região cujo espaço de lugar encontra-se estruturado para o atendimento da população de renda média e baixa. O visual interno das lojas é bastante simples, a fachada de muitas lojas é aproximadamente 5 metros e, devido à falta de um maior espaço para as mercadorias, os produtos ficam expostos nas portas e o tamanho dos corredores internos é o suficiente apenas para os compradores chegarem ao caixa, pois as áreas internas das lojas são necessárias para as mercadorias. Os vendedores fazem a demonstração dos produtos e muitas 
vezes os compradores não têm acesso para examinarem os objetos ao contrário dos grandes magazines. Os estabelecimentos melhor estruturados são as grandes redes, tais como Casas Bahia, Ponto Frio, Marisa, Lojas Americanas, pois seguem um design padrão no arranjo das mercadorias. Exceto algumas das maiores lojas de vestuário ou alguns ramos, por exemplo, relojoaria, óptica ou calçados, é muito rara a exposição dos produtos em vitrines. As lojas de vestuário, principalmente as menores, atraem os compradores pela exposição de peças de roupas, nas portas, em balaios. Algumas lojas de móveis utilizam uma pequena parte das calçadas para deixarem os seus produtos. Alguns trechos das Ruas Capitão Tiago Luz e Senador José Bonifácio são privativos para pedestres entre o Largo 13 de Maio e a Praça Floriano Peixoto.

A obtenção dos resultados da estatística local Moran's I de sinais positivos, quando forem similares, e negativos, quando forem dissimilares, mostra alguns indícios da boa diversificação no padrão de distribuição espacial do comércio dessa região. Os valores muito próximos de 0 indicam a situação de grande quantidade de ramos de comércio com 1 a 4 estabelecimentos, correspondendo a $58 \%$ do total. Os valores mais altos indicam a participação de alguns ramos, por exemplo, 24 lojas de vestuário localizadas na R. Desembargador Bandeira de Mello, os quais contribuem para a determinação dos agrupamentos mais significativos na ótica da estatística espacial. Os sinais negativos indicam as características de dissimilaridades, em decorrência de ramos, com apenas 1 loja. Por exemplo, os 8 ramos distintos da R.Capitão Tiago Luz, cada ramo com apenas 1 loja, funcionam entre as lojas de ramos que atuam com mais estabelecimentos. Os sinais positivos indicam as características de similaridade. Por exemplo, no Largo 13 de Maio, há disponibilidade de alguns ramos similares. O de vestuário (11 lojas) compartilha o mesmo local com o ramo de calçados (4 lojas). A região do Largo 13 de Maio, que é um dos centros de hierarquia mais alta, oferece quase todas as modalidades mais importantes do comércio. Disso, os resultados dissimilares e similares da estatística local Moran's I explicam a diversidade do comércio dessa região. Na permanência do total de 387 lojas, nos seus principais logradouros, destacam os ramos de confecção e calçados com um total de 190 lojas, o que corresponde a $49 \%$ dos estabelecimentos dessa região. 
Tabela 6.1.2 - RESULTADOS DA ESTATÍSTICA LOCAL GETIS ORD GI* - LARGO 13

DE MAIO (mapa número 6.8.2)

\begin{tabular}{cccc}
\hline Getis Ord Gi* & Média & Lojas & $\%$ \\
\hline$-0,29$ a 0,24 & 2,3 & 92 & $23 \%$ \\
0,25 a 0,75 & 2,6 & 103 & $27 \%$ \\
0,76 a 1,33 & 3,2 & 135 & $35 \%$ \\
1,34 a 2,30 & 1,2 & 32 & $8 \%$ \\
2.31 a 4,40 & 2,1 & 25 & $6 \%$ \\
SOMA & & 387 & $100 \%$ \\
\hline
\end{tabular}

Os resultados padronizados variam de $-0,29$ a 4,40

Fonte: apêndice D

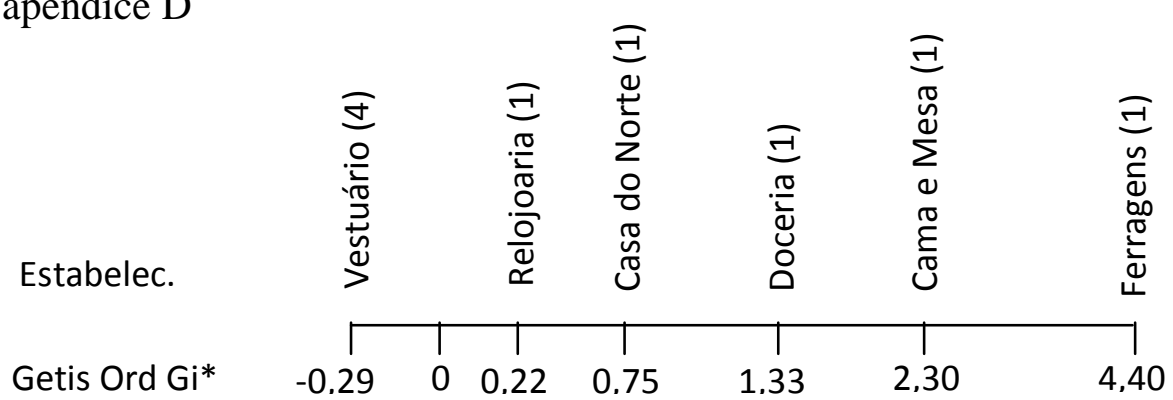

Figura 6.1.2 - distribuição da estatística Getis Ord Gi* da região do Largo 13 de Maio Fonte: apêndice D

Conforme a tabela 6.1.2, uma quantidade significativa de lojas está dispersa por todo o espaço da região do Largo 13 de Maio, objeto deste estudo. Nas três primeiras faixas observa-se que $85 \%$ das lojas fazem parte de ramos que obtiveram índices baixos entre -0,29 e 1,33, em consequiência de estarem localizados em áreas que predominam os ramos que mantêm 4 ou menos lojas. Pertence a esse grupo o ramo de confecções, com elevado número de lojas, e tem como vizinhos os ramos com pequenas quantidades de estabelecimentos, por exemplo, no Largo 13 de Maio, o ramo de vestuário (11 lojas), que tem nas vizinhanças o ramo de móveis (1 ponto de vendas). As duas últimas faixas, com valores entre 1,34 e 4,40, se referem a algumas atividades que se localizam nas vizinhanças de ramos com elevadas quantidades de lojas o que corresponde a $14 \%$ da região. Por exemplo, o ramo de cine e foto (1 loja) da R. Capitão Tiago Luz, possui como vizinho o ramo de cosméticos (4 estabelecimentos). 
Pela figura 6.1.2, o intervalo de variação entre $-0,29$ e 4,40 é bastante significativo, e complementa os resultados da estatística Moran's I. Tal fato indica a existência de dispersão de estabelecimentos menores. No meio dessa dispersão estão os ramos com elevada concentração: confecções; calçados ou móveis. Tal intervalo confirma características de um centro bastante diversificado em relação ao comércio.

Os resultados da estatística local Getis Ord Gi* próximos de 0 indicam a disponibilidade de alguns ramos, que mantêm uma quantidade pequena de estabelecimentos. Por exemplo, 6 modalidades de atividade da Alameda Santo Amaro, com apenas 1 loja, instaladas nas vizinhanças de outros ramos que operam por meio de um número de estabelecimentos acima da média. O ramo de comércio de colchões (4 lojas) nessa mesma via, é um dos exemplos de algumas evidências da diversidade do padrão de agrupamento do comércio.

Os estabelecimentos, que receberam as pontuações mais altas, fazem parte dos ramos que mantêm de 1 a 4 lojas, por exemplo, o ramo de roupa de cama e mesa (1 loja), da R. Voluntário Delmiro Sampaio. Estão instaladas nas adjacências dos ramos que operam com elevada quantidade de pontos comerciais, por exemplo, o ramo de vestuário (11 lojas), da mesma rua. Os ramos que atuam nessa faixa de quantidade de lojas correspondem a $58 \%$ do total das lojas da região.

Por exemplo, o comércio de confecção (14 lojas) da Av. Adolfo Pinheiro, com expressivo número de lojas, obteve resultado baixo e negativo em conseqüência de conviver com vizinhos de diversos ramos com poucas lojas, tal como o comércio de bijuteria (1 loja) dessa mesma avenida. A maioria dos ramos de atividade, com 5 ou mais lojas, exceto $11 \%$ dos estabelecimentos, obtiveram resultados baixos, o que caracteriza o padrão de agrupamento onde se pode observar a dispersão de número elevado de pequenas lojas inseridas no meio de poucos ramos com elevado número de pontos de vendas. Das 387 lojas, apenas 18 receberam pontuação alta e significativa, o que indica na sua vizinhança a disponibilidade dos ramos de atividade com um número elevado de lojas. 


\subsection{Centro comercial de Diadema}

Tabela 6.2.1 - RESULTADOS DA ESTATÍSTICA LOCAL ANSELIN MORAN'S IDIADEMA (mapa número 6.9.1)

\begin{tabular}{cccc}
\hline Moran's I & Média & Lojas & $\%$ \\
\hline$-0,61$ a $-0,28$ & 3,5 & 28 & $16 \%$ \\
$-0,27$ a 0,05 & 1,3 & 58 & $34 \%$ \\
0,06 a 0,24 & 1,6 & 40 & $24 \%$ \\
0,25 a 0,83 & 5,0 & 35 & $21 \%$ \\
0,84 a 1,45 & 9,0 & 9 & $5 \%$ \\
SOMA & & 170 & $100 \%$ \\
\hline
\end{tabular}

Os resultados padronizados variam entre $-0,61$ e 1,45

Fonte: apêndice D

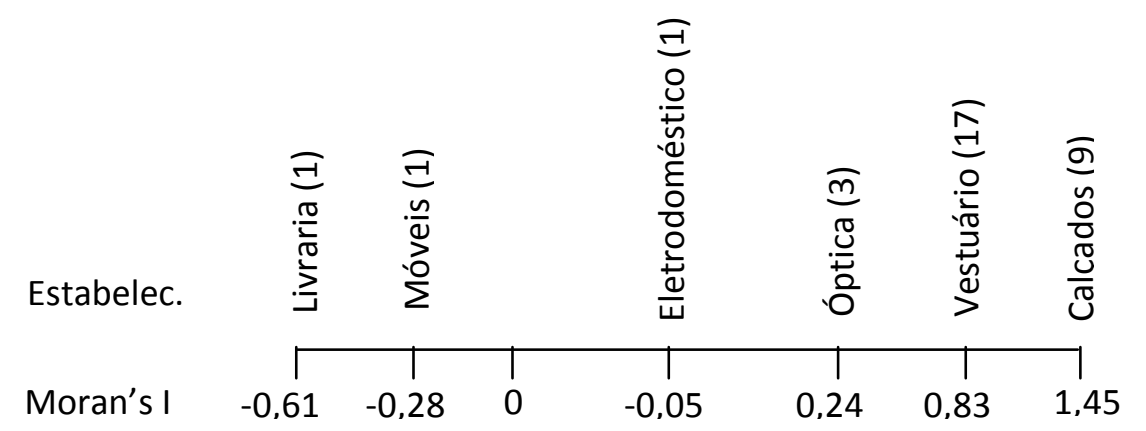

Figura 6.2.1 - distribuição da estatística Moran'I do centro comercial de Diadema Fonte: apêndice D 


\section{COMÉRCIO}

\section{RESULTADO DA ESTATÍSTICA MORAN'S I LOCAL} LARGO 13 DE MAIO - SANTO AMARO

MAPA NÚMERO 6.8.1

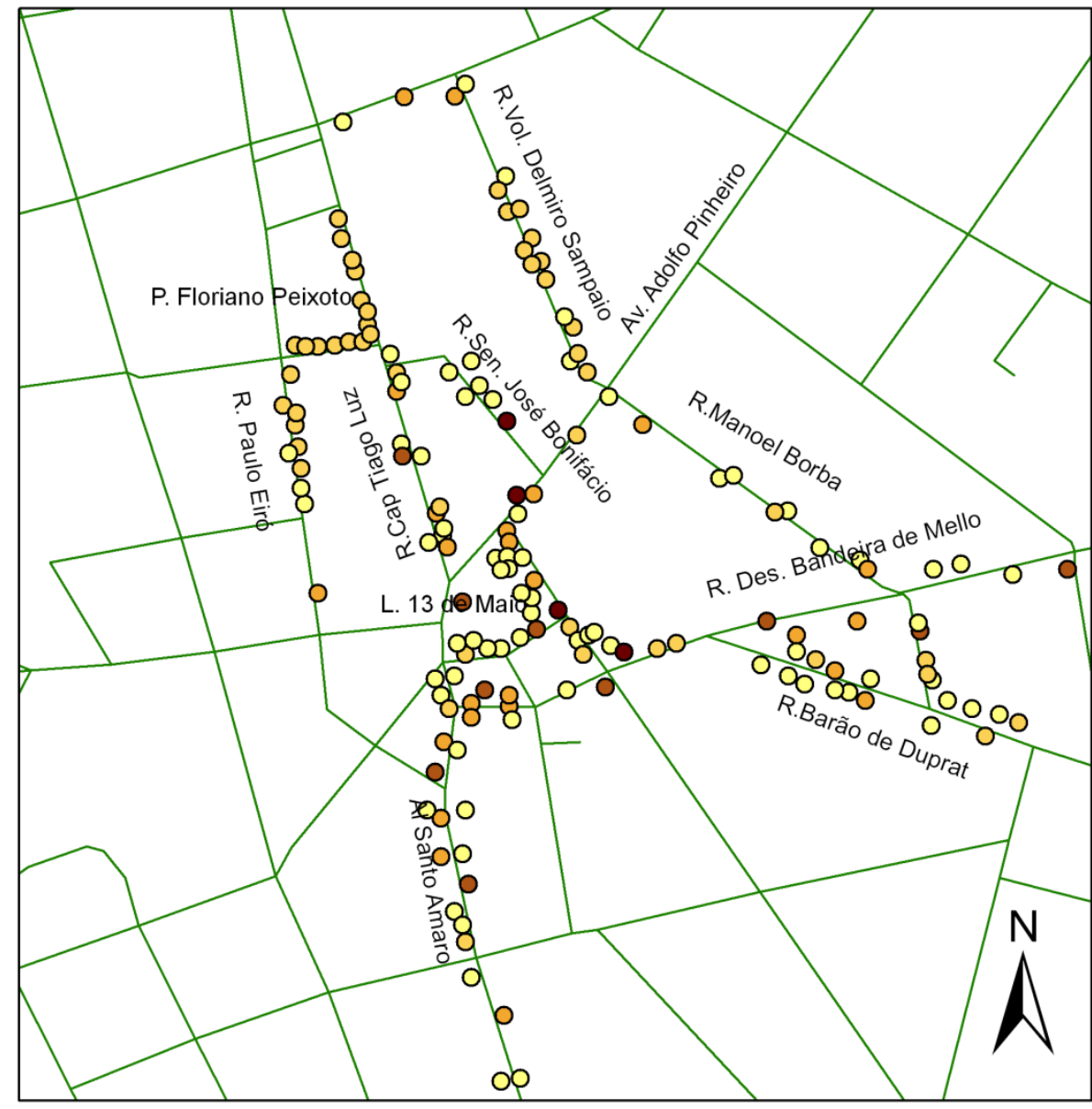

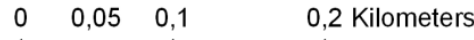$$
0,05 \quad 0,
$$

Autor: Shinhiti Osana

Fonte: pesquisa do autor
Valores padronizados Moran's I local
O $-1,15--0,2$
O $-0,20-0,43$
○ $0,44-1,65$
ㅇ $1,66-3,00$
- $3,01-8,23$ 


\section{COMÉRCIO}

RESULTADO DA ESTATÍSTICA GETIS Gi* LOCAL LARGO 13 DE MAIO - SANTO AMARO

MAPA NÚMERO 6.8.2

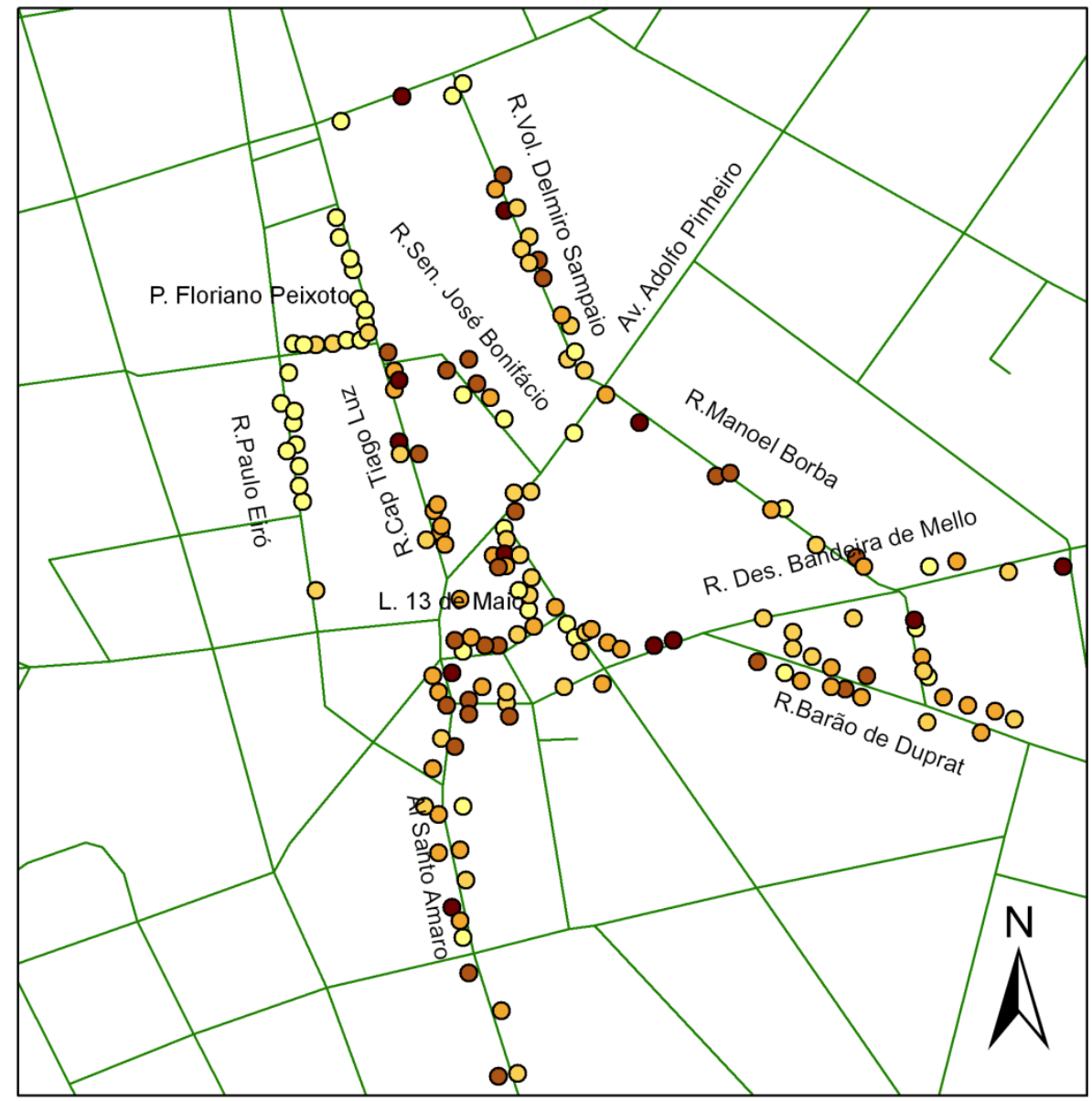

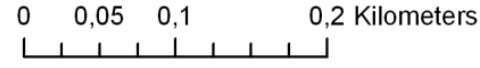

Autor: Shinhiti Osanai

Fonte: pesquisa do autor
Valores padronizados Getis Ord Gi* local
O $-0,29-0,24$
○ $0,25-0,75$
○ $0,76-1,33$
○ $1,34-2,30$
- $2,31-4,40$ 
Conforme a tabela 6.2.1, uma quantidade significativa de lojas encontra-se dispersa por todo o espaço da região do centro comercial de Diadema, objeto deste estudo. Observa-se que 50\% das lojas, pertencentes às duas primeiras faixas, entre $-0,61$ e 0,05 , possuem características dissimilares, pois são ramos que funcionam com número elevado de lojas. Muitas, no ramo de confecções, com 4 a 6 lojas, por exemplo, na Av. Nossa Senhora das Vitórias, com 5 lojas inseridas no meio de outros ramos com apenas 1 loja, do tipo artigos do nordeste (1 loja). A terceira faixa, de 0,06 a 0,24 representa os ramos estatisticamente similares, sendo a quantidade da maioria de lojas composta de valores abaixo da média. Por exemplo, o ramo de relojoaria (1 loja) na Av. São José, tem como vizinhos os ramos com a quantidade de lojas igualmente abaixo da média, tal como o ramo de calçados (1 loja). A penúltima faixa, entre 0,25 e 0,83 , refere-se à maioria dos ramos, estatisticamente similares, com 3 a 4 lojas. Por exemplo, o comércio de cosméticos (3 lojas), na Av. Antonio Piranga, funcionando entre os vizinhos de ramos que mantêm o número de lojas também acima da média, tal como o comércio de bijuteria (3 lojas). A última faixa de 0,84 a 1,45 pertence ao ramo de calçados (9 lojas), da Av. Antonio Piranga, obteve o índice bastante elevado por causa da sua quantidade de estabelecimentos.

Conforme a figura 6.2.1, o intervalo de variação, entre - 0,61 e 1,45, corresponde a um centro comercial menos abrangente que o Largo 13 de Maio, o que reflete os resultados de um centro diversificado em relação ao comércio que permite satisfazer praticamente todas as principais necessidades de compras.

É uma região cujo espaço de lugar encontra-se estruturado para o atendimento da população de renda média e baixa. As características dos estabelecimentos comerciais são muito semelhantes às do Largo 13 de Maio. O visual interno das lojas é bastante simples, a largura da fachada de muitas lojas é relativamente pequena, todavia as mercadorias encontram-se bem arrumadas dentro dos estabelecimentos. Os estabelecimentos das grandes redes, tais como Casas Bahia, Ponto Frio, Marisa, seguem o seu design padrão. Ao contrário do Largo 13 de Maio, estão disponíveis no centro comercial de Diadema, o comércio de material de construção, pequenas mercearias, supermercados e padarias. As maiores lojas se encontram na Av. São José e também na Av. Antonio Piranga. Essa última via apresenta as características de um comércio bastante variado e diversificado, dispõe de um largo calçadão e é utilizada como via privativa para ônibus. Nas demais vias, os imóveis comerciais são menores, abrigando um grande número de estabelecimentos comerciais de menor porte. 
Nota-se pela estatística local Moran's I, que a diversidade do comércio do centro de Diadema é relativamente semelhante ao comércio da região do Largo 13 de Maio em Santo Amaro tendo em vista os resultados de similaridade e de dissimilaridade apontados pelos sinais positivos e negativos. Todavia, os valores das estatísticas são menos significativos, indicam a existência de menor concentração de lojas em relação a Santo Amaro. Do total de 170 estabelecimentos localizados nas principais vias comerciais, estão em destaque os ramos do comércio de vestuário, bazar e calçados, totalizando 82 lojas, o que corresponde a $49 \%$.

Os resultados da estatística, muito próximos de 0 , mostram o indício da disponibilidade de muitos ramos que trabalham com 1 e 2 lojas, por exemplo, o comércio de móveis (1 loja) na Av. Antonio Piranga. Os estabelecimentos dissimilares, que obtiveram sinal negativo, são aqueles com número de lojas acima da média, por exemplo, o comércio de confecções (5 lojas) da Av. Nossa Senhora das Vitórias. Seus vizinhos pertencem aos ramos com quantidade de pontos comerciais abaixo da média, por exemplo, o comércio de cine e foto (1 loja). Existem, também, as características similares, diante de valores acima da média, por exemplo, o comércio de confecções (17 lojas), da Av. Antonio Piranga, que tem nas suas vizinhanças o comércio de calçados (9 lojas). Observa-se, igualmente, a situação de similaridade proveniente de dados abaixo da média, por exemplo, a Casas Bahia (1 loja) da Av. São José, atua ao lado da loja Kolumbus (1 loja). O setor de confecções faz parte de um dos grupos que apresentam característica dissimilar, em conseqüência do seu número elevado de pontos de vendas.

Tabela 6.2.2 - RESULTADOS DA ESTATÍSTICA LOCAL GETIS ORD GI*-DIADEMA (mapa número 6.9.2)

\begin{tabular}{cccc}
\hline Getis Ord Gi* & Média & Lojas & $\%$ \\
\hline$-0,90$ a $-0,59$ & 2,0 & Quantidade & $18 \%$ \\
$-0,58$ a $-0,44$ & 2,6 & 57 & $34 \%$ \\
$-0,43$ a $-0,22$ & 1,5 & 35 & $21 \%$ \\
$-0,21$ a 0,09 & 2,3 & 32 & $19 \%$ \\
0,10 a 0,79 & 1,5 & 16 & $9 \%$ \\
SOMA & & 170 & $100 \%$
\end{tabular}

Os resultados padronizados variam de $-0,90$ a 0,79

Fonte: apêndice D 


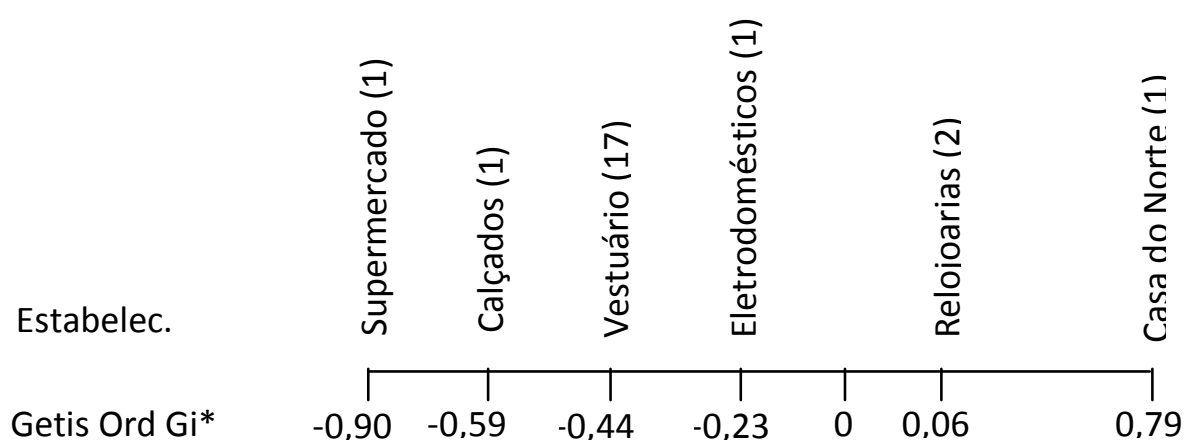

Figura 6.2.2 - distribuição da estatística Getis Ord Gi* do centro comercial de Diadema

Fonte: apêndice D

Conforme a tabela 6.2.2, uma quantidade significativa de lojas está dispersa por todo o espaço da região do centro de Diadema, objeto deste estudo. Observa-se que $91 \%$ das lojas fazem parte de ramos que obtiveram índices baixos, entre $-0,90$ e 0,09 , em consequiência da maioria dos ramos que mantêm pequenas quantidades de lojas, inclusive os que funcionam com 3 ou mais lojas. Em cada um desses quatro grupos, há sempre algum ramo com elevado número de lojas, tais como o ramo de confecções (9 lojas), ou de móveis (4 lojas) da Av. São José. Esse resultado reflete a situação de uma dispersão geral do comércio inclusive de alguns ramos, que apresentam alguma característica de concentração, cuja localização é parte integrante dessa dispersão. A última faixa, entre 0,10 e 0,79, é constituída por ramos atuando com reduzida quantidade de lojas. Por exemplo, o ramo de bazar da R. São Judas Tadeu (1 loja), que tem em sua vizinhança outros ramos também mantendo poucas lojas, tal como o ramo de calçados (1 loja).

Conforme a figura 6.2.2, o intervalo de variação, entre $-0,90$ e 0,79 , é muito estreito, complementa os resultados da estatística Moran's I e indica que existe uma dispersão geral de estabelecimentos menores. Há nessa dispersão a participação conjunta de ramos com número elevado de lojas, e não é possível, estatisticamente, a identificação de focos de concentração.

Em decorrência dos valores da estatística local Getis Ord Gi* próximos de 0, observa-se a distribuição aleatória dos ramos, que operam com maior número de lojas, inseridos entre os ramos, que atuam com menor número de estabelecimentos. Por exemplo, na Av. Antonio Piranga o comércio de confecções (17 lojas) encontra-se aleatoriamente distribuído entre os vários ramos de comércio que mantêm apenas 1 loja. Conseqüentemente, na ótica da estatística espacial, não é possível identificar as áreas específicas que apresentam a 
concentração de maior número de estabelecimentos, ao contrário do que acontece em relação ao comércio da região do Largo 13 de Maio, em decorrência dos resultados de Diadema que são estatisticamente pouco significativos. Verificam-se resultados negativos e positivos, mostrando algumas evidências de diversidade de ramos, tanto de elevado número de lojas, quanto de pequena quantidade de estabelecimentos, conforme o exemplo acima apresentado. O comércio de vestuário, com grande número de lojas, obteve resultado baixo e negativo em virtude dos vizinhos estarem constituídos por diferentes ramos com pequena quantidade de lojas.

\subsection{Shopping Center Interlagos e Shopping Center Interlar}

Tabela 6.3.1 - RESULTADOS DA ESTATÍSTICA LOCAL ANSELIN MORAN'S I-SHOPPING CENTER INTERLAGOS (mapa número 6.10.1)

\begin{tabular}{cccc}
\hline Moran's I & Média & Lojas & $\%$ \\
\hline$-2,37$ a $-0,57$ & 1,0 & Quantidade & $9 \%$ \\
$-0,56$ a 2.64 & 1,9 & 22 & $13 \%$ \\
2,65 a 10,04 & 5,1 & 36 & $15 \%$ \\
10,05 a 21.36 & 14,2 & 71 & $29 \%$ \\
21,36 a 61,92 & 87,0 & 87 & $35 \%$ \\
SOMA & & 247 & $100 \%$
\end{tabular}

Os resultados padronizados variam entre $-2,37$ e 61,92

Fonte: apêndice D

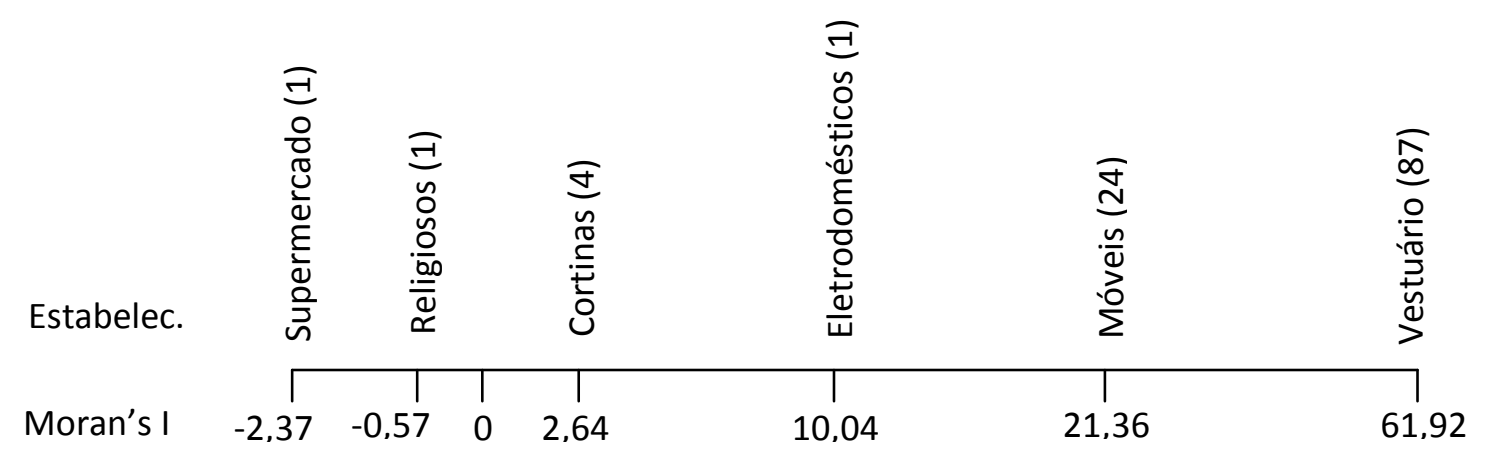

Figura 6.3.1 distribuição da estatística Moran'I do Shopping Center Interlagos Fonte: apêndice D 


\section{COMÉRCIO}

\section{RESULTADO DA ESTATÍSTICA MORAN'S I LOCAL CENTRO COMERCIAL DE DIADEMA}

MAPA NÚMERO 6.9.1
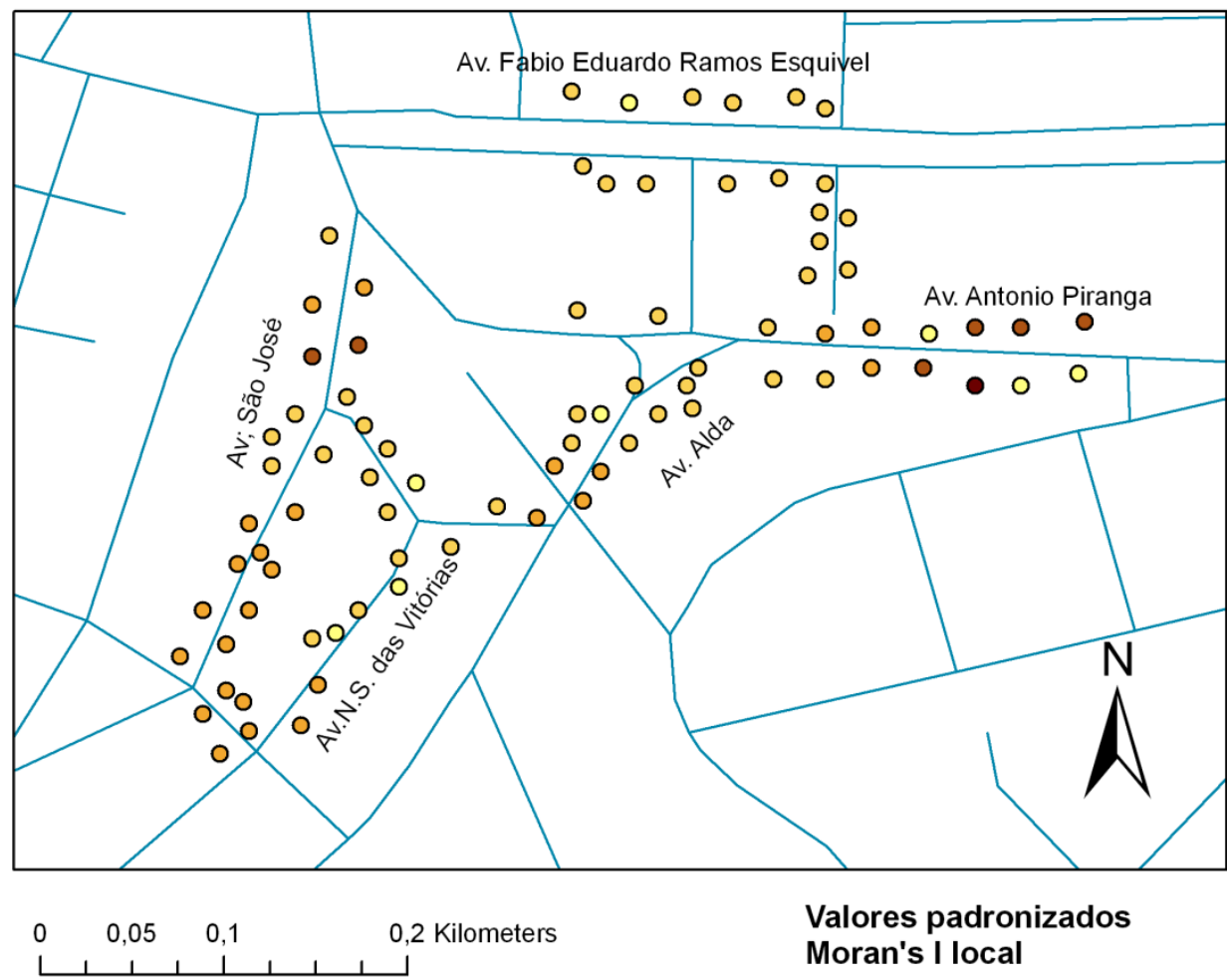

Valores padronizados

Moran's I local

Autor: Shinhiti Osanai
O $-0,61--0,28$
○ $-0,27-0,05$
○ $0,06-0,24$
- $0,25-0,83$
- $0,84-1,45$

Fonte: pesquisa do autor 


\section{COMÉRCIO}

\section{RESULTADO DA ESTATÍSTICA GETIS Gi* LOCAL CENTRO COMERCIAL DE DIADEMA}

MAPA NÚMERO 6.9.2

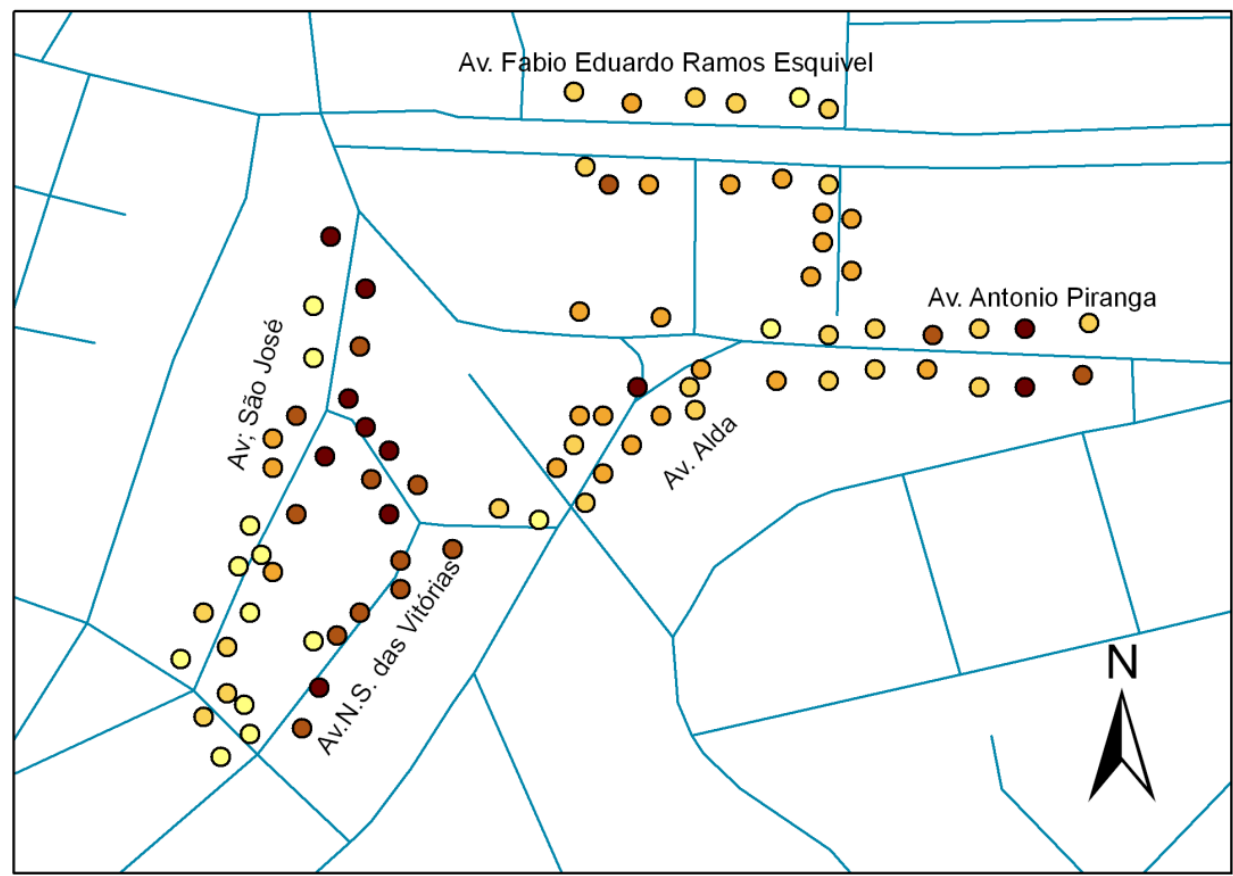

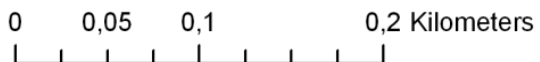

Autor: Shinhiti Osana

Fonte: pesquisa do autor
Valores padronizados Getis Ord Gi* local

$$
\begin{array}{cc}
\text { O } & -0,90--0,59 \\
\text { O } & -0,58--0,44 \\
\text { O } & -0,43--0,22 \\
\text { O } & -0,21-0,09 \\
\hline & 0,10-0,79
\end{array}
$$


Conforme a tabela 6.3.1, as duas primeiras faixas, entre $-2,37$ e 2,64 , correspondem a $22 \%$ das lojas. Representa o grupo de ramo de atividade, a maioria dissimilar, que funciona com 1 ou 2 lojas, por exemplo, o ramo de comércio de brinquedos (1 loja), e tem como seus vizinhos os ramos que atuam por meio da quantidade de lojas acima da média, por exemplo, o comércio de artigos esportivos (3 lojas). O terceiro grupo, na faixa entre 2,65 e 10,04, corresponde aos ramos de atividade que mantém de 4 a 6 lojas, com características similares em relação aos seus vizinhos, que trabalham com elevado número de pontos de vendas, por exemplo, o ramo de cosméticos (5 lojas) nas vizinhanças do ramo de cine e foto (6 lojas). No quarto grupo, no intervalo entre 10,05 e 21,36, existe a variação entre 8 e 24 lojas em cada ramo, continuando similares em relação aos seus vizinhos que operam com quantidades elevadas de estabelecimentos, por exemplo, o ramo de óptica (9 lojas). O último grupo, na faixa de 21,36 a 61,92, representa o ramo de confecções (87 lojas).

Conforme a figura 6.3.1, o intervalo de variação entre -2,37 e 61,92 é bastante significativo, mostra a característica de elevada concentração de lojas, restrito em um único local de área pré determinada, e oferece um comércio bastante diversificado.

O Shopping Interlagos localiza-se no bairro de Campo Grande, na Av. Interlagos. É um local cujo espaço de lugar encontra-se estruturado para o atendimento da população de renda média. Apesar da simplicidade do Shopping Center, o visual interno das lojas é simples e agradável, as lojas mantêm fachadas atraentes com boas vitrines. Grandes redes, tais como Casas Bahia, Ponto Frio, Extra, Marisa, Lojas Americanas, C\&A e outras estão presentes. Encontram-se os principais ramos de comércio, inclusive roupas para cama, mesa e banho, que se encontra ausente nos comércios locais do Distrito de Pedreira. Móveis e decoração são os pontos fortes do Shopping Interlar. O Carrefour mantém um hipermercado, todavia, os produtos para a classe alta são mais raros. Os produtos desse Shopping têm como foco principal o atendimento das necessidades da população de renda média e habitualmente os produtos mais sofisticados não estão disponíveis. Um dos principais atrativos é a praça de alimentação e serviços de lazer.

É a região, cuja pontuação da estatística local Moran's I é a mais elevada, e indica significativa concentração de estabelecimentos comerciais. Observam-se características similares e dissimilares pela ocorrência de sinais positivos e negativos, que indicam a diversidade do comércio desse Shopping Center, diante da permanência de ramos de comércio com elevada quantidade de lojas e distribuídas entre muitos ramos que atuam com quantidade 
pequena de estabelecimentos. Do total de 247 lojas, 30 pontos de vendas, que receberam sinal negativo, pertencem aos ramos de atividade presentes com apenas 1 loja, tais como comércio de colchões, papelaria, tabacaria, entre outros, conseqüentemente abaixo da média. Forma-se um grupo de empresas dissimilares em relação aos seus vizinhos, constituídos por ramos de atividade com quantidade superior a 2 lojas e, portanto, acima da média. Por exemplo, o comércio de artigos esportivos (3 lojas), ou comércio de calçados (17 lojas). Os estabelecimentos, com quantidade igual ou acima de 2 lojas, acima da média, por ramo de atividade, pertencem ao grupo similar, tendo em vista o sinal positivo, em virtude do seu número de pontos acima da média e os seus vizinhos também operarem através do número de lojas acima da média. O comércio de vestuário, de calçados e de eletro-eletrônicos do Shopping Interlagos e de móveis do Shopping Interlar são os ramos que apresentam o total de 141 estabelecimentos, ou seja, constituem $62 \%$ do total desses dois shopping centers. Geralmente os ramos de atividade com maior quantidade de lojas recebem os valores mais elevados nessa estatística local Moran's I. O setor de confecções obteve o valor mais elevado, de resultado igual a 61,92, em conseqüência do total das 87 lojas.

Tabela 6.3.2 - RESULTADOS DA ESTATÍSTICA LOCAL GETIS ORD GI*-SHOPPING CENTER INTERLAGOS (mapa número 6.10.2)

\begin{tabular}{cccc}
\hline Getis Ord Gi* & Média & Lojas & $\%$ \\
\hline$-0,13$ a 0,30 & 2,1 & Quantidade & $7 \%$ \\
0,31 a 1,16 & 10,4 & 114 & $46 \%$ \\
1,17 a 2,62 & 4,4 & 71 & $29 \%$ \\
2,63 a 5,24 & 3,1 & 43 & $17 \%$ \\
5,25 a 10,24 & 1,0 & 2 & $1 \%$ \\
SOMA & & 247 & $100 \%$
\end{tabular}

Os resultados padronizados variam entre $-0,13$ e 10,24

Fonte: apêndice D 


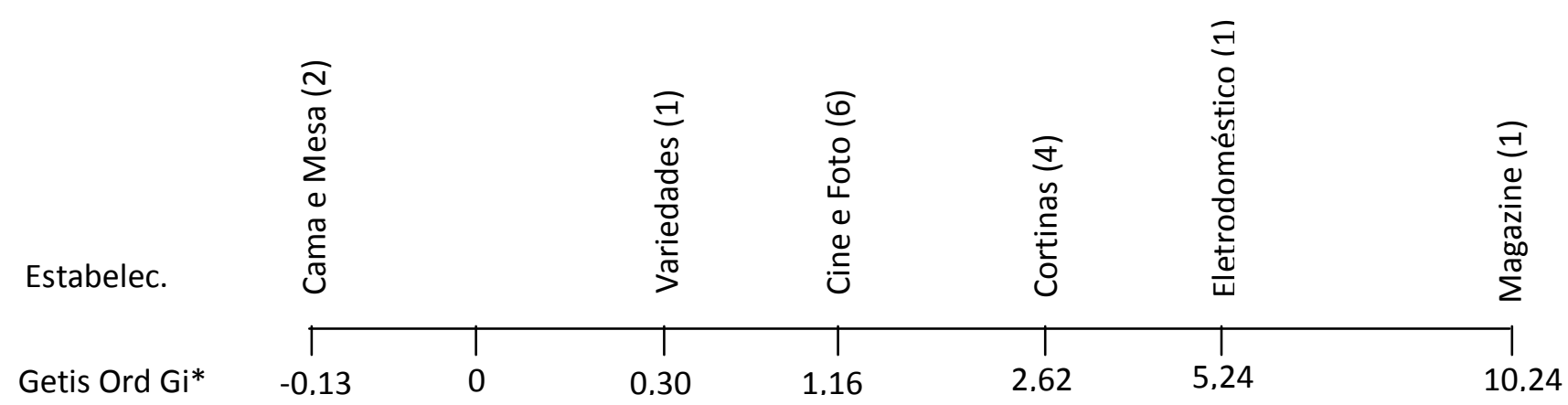

Figura 6.3.2 - distribuição da estatística Getis Ord Gi* do Shopping Center Interlagos Fonte: apêndice D

Conforme a tabela 6.3.2, em cada uma das duas primeiras faixas, entre $-0,13$ e 1,16, correspondendo a 53\% do total das lojas desse Shopping, existe a participação de algum ramo que opera com elevada quantidade de lojas. Por exemplo, o ramo de confecção (87 lojas), tem como vizinhos os ramos com poucas lojas, na maioria das vezes com 1 estabelecimento por ramo de comércio, por exemplo, a tabacaria (1 loja). A outra metade das lojas, representada na terceira e quarta faixa, entre 1,17 e 5,24, está formada por ramos que estão presentes por meio de elevada quantidade de lojas. Por exemplo, o ramo de bijuterias (6 lojas), possui como vizinhos os ramos que funcionam com grandes números de lojas, tal como o ramo de calçados (17 lojas). A última faixa, entre 5,25 e 10,24, representa duas lojas, Casas Bahia e Lojas Americanas, que obtiveram elevados índices. Os seus vizinhos, que são ramos bastante significativos nesse Shopping, trabalham com quantidades elevadas de lojas, por exemplo, o ramo de calçados (17 lojas).

Conforme a figura 6.3.2, o intervalo de variação entre - 0,13 e 10,24 é bastante significativo, complementa os resultados da estatística Moran's I e indica a intensa concentração de estabelecimentos com elevadas quantidades de lojas funcionando entre muitos ramos que mantêm apenas 1 loja.

As estatísticas locais Getis Ord Gi*, de valores mais elevados, podem indicar a concentração habitual de determinados ramos de comércio, nos shopping centers. Os ramos de atividade que atuam com elevada quantidade de lojas, por exemplo, o ramo de comércio de vestuário (87 lojas), calçados (17 lojas) ou móveis (29 lojas), completam, somando aos demais ramos, o total de 229 lojas. As lojas com as pontuações mais altas, por exemplo, o ramo de calçados, são aquelas que contam como vizinhos os ramos com quantidade elevada de 
estabelecimentos, tal como o ramo de vestuário. Inversamente, as lojas que obtiveram as pontuações mais baixas, por exemplo, o ramo de roupas para cama, mesa e banho, possuem como vizinhos outros ramos de atividade com quantidade pequena de lojas, tal como o negócio de colchões. O ramo de confecções (87 lojas) obteve na estatística Gi* uma pontuação baixa igual a 0,56 , devido ao fato de seus vizinhos, de outros ramos, atuarem com menor número de lojas, por exemplo, o ramo de calçados (17 lojas) ou o comércio de brinquedos possuindo apenas 1 única loja. A pontuação mais alta, igual a 7,37, pertence ao comércio de calçados (15 lojas). Seus vizinhos pertencem aos ramos de comércio de pontos de vendas mais elevados, por exemplo, o comércio de móveis (24 lojas). O intervalo de variação, bem considerável, entre -0,13 e 10,24, indica um padrão de distribuição constituído pela participação de elevado número de estabelecimentos comerciais, numa área relativamente pequena, em comparação à região do Largo 13 de Maio.

\subsection{Shopping Center SPMarket}

Tabela 6.4.1 - RESULTADOS DA ESTATÍSTICA LOCAL ANSELIN MORAN'S ISHOPPING CENTER SPMARKET (mapa número 6.11.1)

\begin{tabular}{cccc}
\hline Moran's I & Média & Lojas & $\%$ \\
\hline$-2,22$ a $-0,79$ & 1,0 & 11 & $7 \%$ \\
$-0,78$ a 2,56 & 2,3 & 16 & $10 \%$ \\
2,57 a 6.08 & 4,8 & 29 & $19 \%$ \\
6,09 a 19.94 & 10,0 & 40 & $26 \%$ \\
19,95 a 43.74 & 60,0 & 60 & $38 \%$ \\
SOMA & & 156 & $100 \%$ \\
\hline
\end{tabular}

Os resultados padronizados variam entre $-2,22$ e 43,74

Fonte: apêndice D 


\section{COMÉRCIO}

\section{RESULTADO DA ESTATÍSTICA MORAN'S I LOCAL SHOPPING CENTER INTERLAGOS E INTERLAR}

MAPA NÚMERO 6.10.1

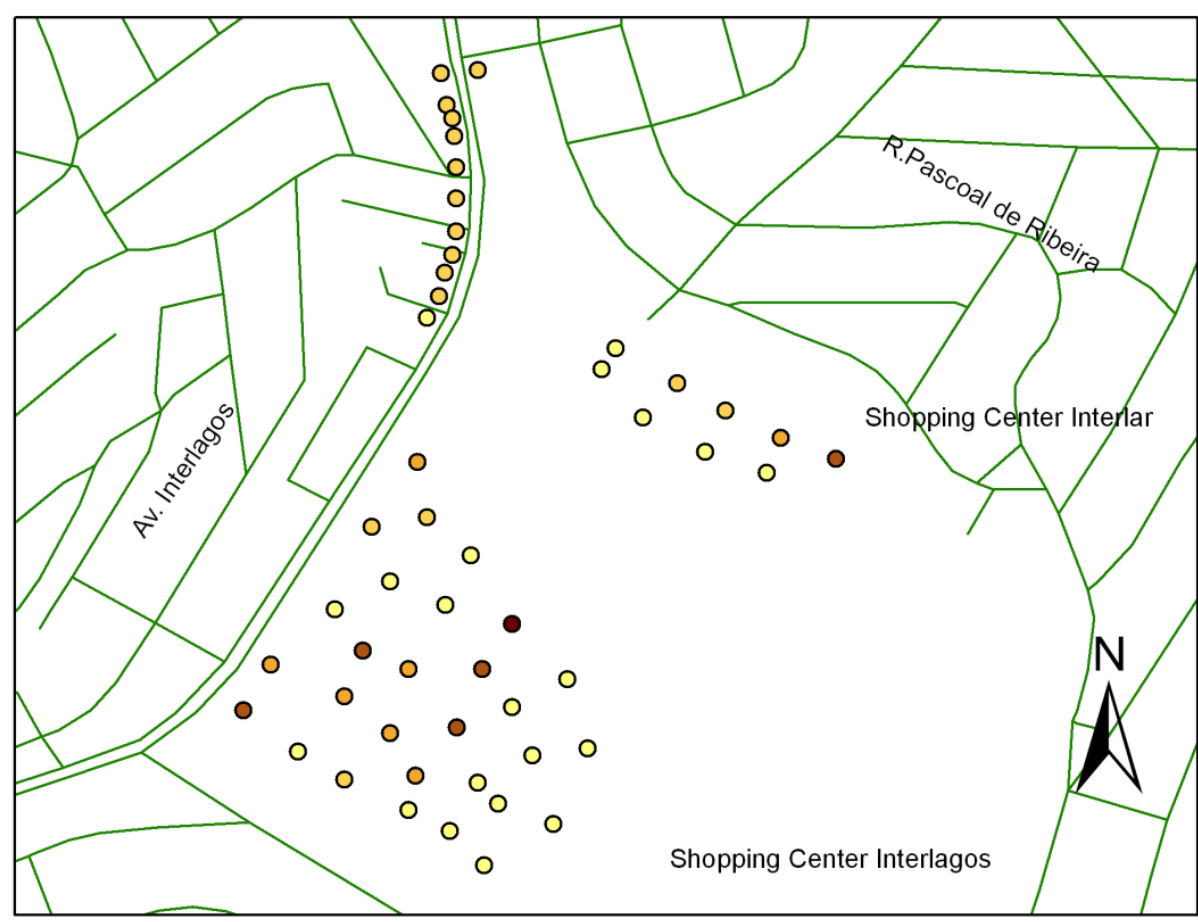

$\begin{array}{lll}0 & 0,05 & 0,1\end{array}$ 0,2 Kilometers

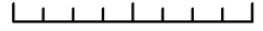

Autor: Shinhiti Osanai

Fonte: pesquisa do autor
Valores padronizados Moran's I local
○ $-2,37--0,57$
○ $-0,56-2,64$
○ $2,65-10,04$
- $10,05-21,36$
- $21,37-61,92$ 


\section{COMÉRCIO}

\section{RESULTADO DA ESTATÍSTICA GETIS Gi* LOCAL SHOPPING CENTER INTERLAGOS E INTERLAR}

MAPA NÚMERO 6.10.2

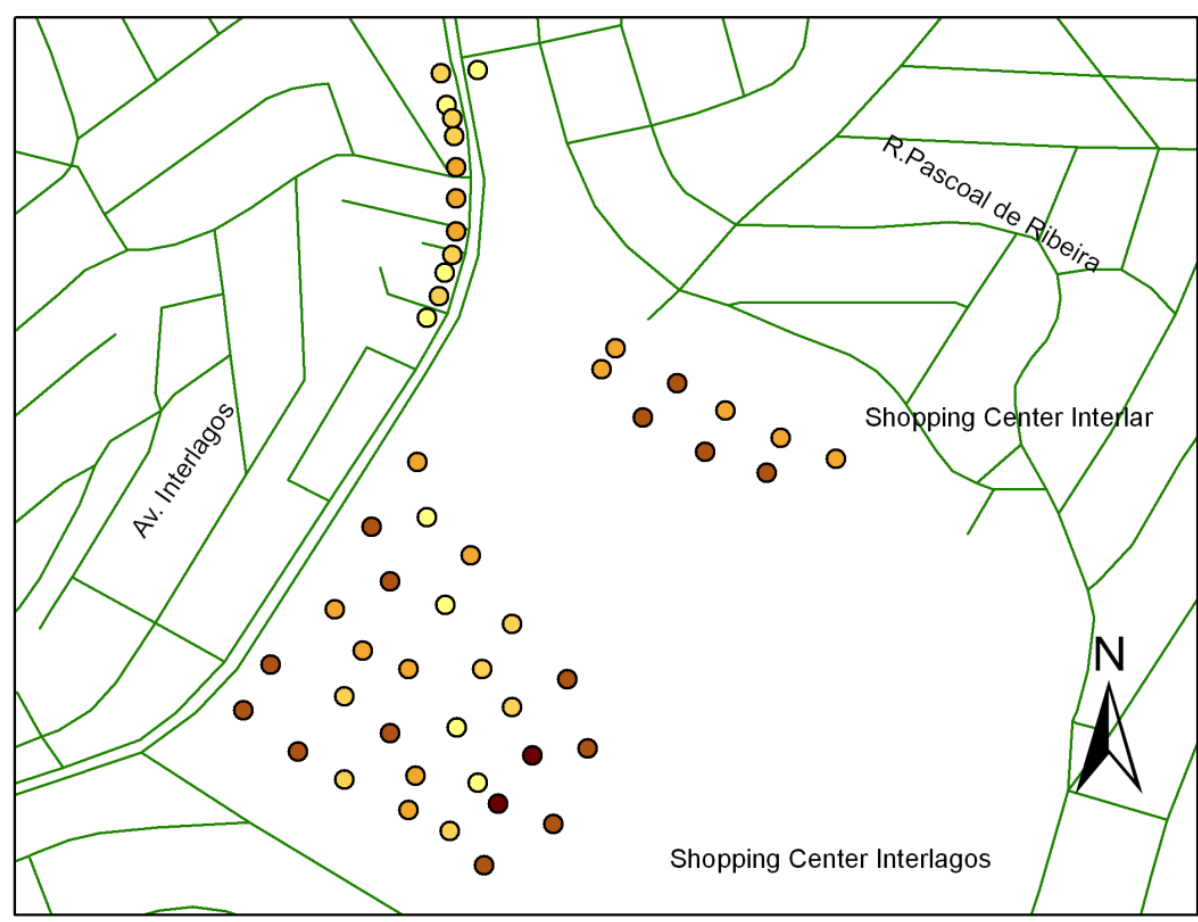

$\begin{array}{lll}0 & 0,05 & 0,1\end{array}$

0,2 Kilometers

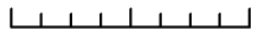

Autor: Shinhiti Osanai

Valores padronizados

Fonte: pesquisa do autor Getis Ord Gi* local
O $-0,13-0,30$
○ $0,31-1,16$
○ $1,17-2,62$
O $2,63-5,24$
- $5,25-10,24$ 


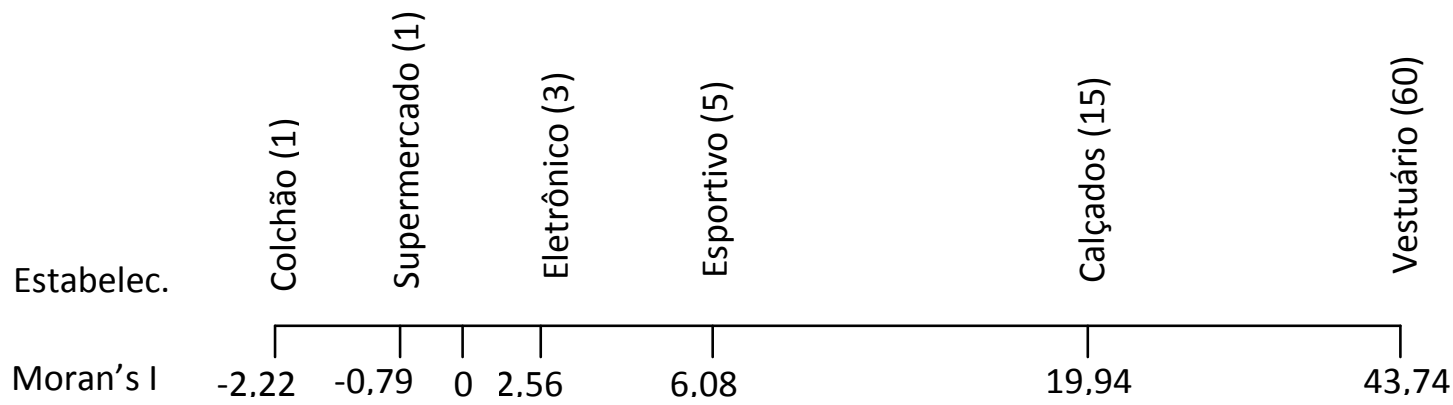

Figura 6.4.1 - distribuição da estatística Moran'I do Shopping SPMarket Fonte: apêndice D

Conforme a tabela 6.4.1, as duas primeiras faixas, entre $-2,22$ e 2,56, que correspondem a $17 \%$ das lojas, representam o grupo de ramo de atividade, a maioria dissimilar, com 1 a 3 lojas. Por exemplo, o comércio de colchões (1 loja), tem como seus vizinhos os ramos com quantidade de lojas acima da média, tal como o comércio de artigos para viagem (5 lojas). O terceiro grupo, na faixa entre 2,57 e 6.08, corresponde aos ramos de atividade mantendo de 3 a 5 lojas, com características similares em relação aos seus vizinhos, que trabalham com elevado número de pontos de vendas. Por exemplo, o ramo do comércio de brinquedos (3 lojas) nas vizinhanças do ramo de aparelhos de telefonia (6 lojas). No quarto grupo, na faixa de 6,09 a 19,94, existe a variação entre 7 e 15 lojas em cada ramo, são similares em relação aos seus vizinhos que operam com quantidades elevadas de estabelecimentos. Por exemplo, o ramo de relojoaria (7 lojas) em meio do ramo de cosméticos (11 lojas). O último grupo, na faixa de 19,95 a 43,74, representa o ramo de confecções (60 lojas).

Conforme a figura 6.4.1, o intervalo de variação entre -2,22 e 43,74 é bastante significativo, mostra a característica de elevada concentração de lojas, restrito em um único local de área pré determinada, e oferece um comércio bastante diversificado, porém a quantidade de lojas é inferior em relação ao Shopping Center Interlagos.

Localiza-se no bairro de Campo Grande, na Av. das Nações Unidas. É um local cujo espaço de lugar está estruturado para o atendimento da população de renda média. Funciona, após as devidas adaptações, em antigas instalações industriais que pertenceram à Catepillar. Apesar da simplicidade do Shopping Center, o visual interno das lojas é simples e agradável, as lojas mantêm fachadas atraentes com boas vitrines. Grandes redes, tais como Casas Bahia, Pernambucanas, C\&A e outras estão presentes. Encontram-se os principais ramos de comércio. Os produtos desse Shopping têm como foco principal o atendimento das necessidades da população de renda média e, habitualmente, produtos mais sofisticados não 
estão disponíveis. A área de estacionamento foi adaptada para uma feira permanente de revenda de automóveis usados. Igualmente, um dos galpões industriais ociosos está sendo utilizado para uma feira permanente de móveis, da qual participa a indústria moveleira de São Bernardo do Campo. A praça de alimentação é um dos atrativos e existe uma área de lazer que é o Parque da Xuxa. Existe uma área especializada em prestação de serviços de manutenção de aparelhos eletrônicos, relógios, roupas, calçados, etc.

Os sinais positivos e negativos da estatística local Moran's I, em relação às similaridades e as dissimilaridades, indicam a diversidade do comércio desse shopping center por meio da oferta de ampla variedade de opções de comércio. No local se observa elevada quantidade de lojas, por ramo de atividade, que compartilham a mesma área com os diversos ramos de quantidade pequena de lojas. Do total de 156 lojas, apenas 11 estabelecimentos, com sinal negativo, são dissimilares por causa da quantidade dos seus pontos de venda abaixo da média, tal como a tabacaria (1 loja), em comparação aos seus vizinhos constituídos por ramos de atividade com quantidade de lojas acima da média, por exemplo, o comércio de calçados (15 lojas). O restante das atividades, com características similares, em consequiência do sinal positivo, indica a disponibilidade de seus vizinhos, que atuam no comércio por meio do número de lojas acima da média, por exemplo, o ramo de papelaria mantendo 2 lojas possui como vizinhos próximos o ramo de relojoaria (7 lojas). O comércio de vestuário, de calçados e de cosméticos constitui a parcela de $54 \%$ do total desse shopping Center com 86 estabelecimentos. Os ramos de atividade, que possuem 3 lojas ou mais, obtiveram os valores mais significativos. O setor de confecções, que obteve o maior valor dessa estatística, apresentou o resultado igual a 43,74 em consequiência do total de 60 lojas.

Tabela 6.4.2 - RESULTADOS DA ESTATÍSTICA LOCAL GETIS ORD GI*-SHOPPING CENTER SPMARKET (mapa número 6.11.2)

\begin{tabular}{cccc}
\hline Getis Ord Gi* & Média & Lojas & $\%$ \\
\hline 1,26 a 1,90 & 2,8 & Quantidade & $9 \%$ \\
1,91 a 2,82 & 11,5 & 92 & $59 \%$ \\
2,83 a 3,49 & 2,1 & 15 & $10 \%$ \\
3,50 a 4,45 & 1,7 & 5 & $3 \%$ \\
4,46 a 7,37 & 5,0 & 30 & $19 \%$ \\
SOMA & & 156 & $100 \%$ \\
\hline
\end{tabular}

Os resultados padronizados variam entre 1,26 e 7,37

Fonte: apêndice D 


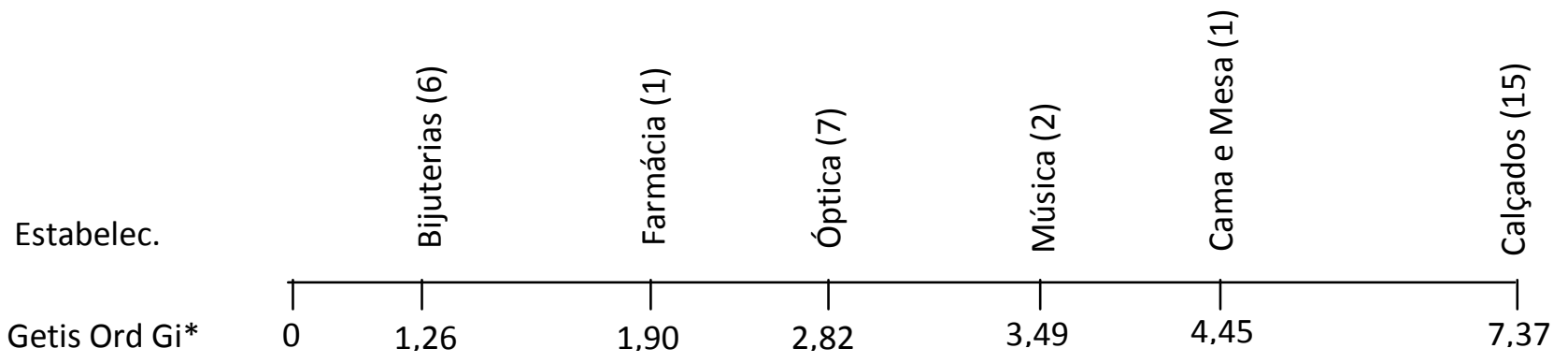

Figura 6.4.2 - distribuição da estatística Getis Ord Gi* do Shopping SPMaket Fonte: apêndice D

Conforme a tabela 6.4.2, em cada uma das duas primeiras faixas, entre 1,26 e 2,82, que corresponde a $68 \%$ do total das lojas desse Shopping, existe a participação de algum ramo que opera com elevada quantidade de lojas. Por exemplo, o ramo de confecção (60 lojas), tem como vizinhos os ramos que funcionam através de poucas lojas, na maioria das vezes com 1 estabelecimento por ramo de comércio, tal como o comércio de colchões (1 loja). A outra metade das lojas, representada na terceira e quarta faixa, entre 2,83 e 4,45, é formada por ramos com baixa quantidade de lojas. Por exemplo, o ramo tabacaria (1 loja), tem como vizinhos os ramos com maior número de lojas, tal como o ramo de artigo para viagens (5 lojas). A última faixa, entre 4,46 e 7,37, é formada por ramos com elevada quantidade de lojas. Por exemplo, o ramo calçados (15 lojas), tem como vizinhos os ramos com elevado número de lojas, tal como o ramo de artigos esportivos (5 lojas).

Conforme a figura 6.4.2, o intervalo de variação entre 0 e 7,37 é bastante significativo, complementa os resultados da estatística Moran's I e indicam que existe uma concentração de estabelecimentos com elevadas quantidades de lojas funcionando entre muitos ramos que mantêm apenas 1 loja.

A maioria dos resultados obtidos pela estatística local Getis Ord Gi* é significativa, está em destaque a contribuição dos ramos de atividade que apresenta elevada quantidade de lojas, por exemplo, o ramo de comércio de confecções (60 lojas), calçados (15 lojas) ou cosméticos (11 lojas). Os estabelecimentos, cujas pontuações obtidas são elevadas, possuem como vizinhos os ramos que mantêm, igualmente, a quantidade alta de pontos de vendas. Inversamente, as lojas que obtiveram as pontuações mais baixas possuem como vizinhos os ramos de atividade com quantidade pequena de lojas. Por exemplo, o ramo de bijuteria (6 lojas), recebeu o resultado mais baixo desse shopping, igual a 1,26, em decorrência de ter como vizinhos 
outros ramos com muito menos lojas, tal como a tabacaria (1 loja). A pontuação mais alta, igual a 7,37, é do comércio de calçados (15 lojas), que possui como vizinhos outros ramos de comércio cuja quantidade de lojas é também elevada, por exemplo, o ramo de vestuário (87 lojas). Apesar da estatística Gi*, ao apresentar resultados elevados, poder indicar alguma concentração em determinados ramos de comércio, os resultados obtidos pelo concorrente Shopping Center Interlagos continuam sendo mais vantajosos.

\subsection{Estrada do Alvarenga e regiões próximas}

Tabela 6.5.1 - RESULTADOS DA ESTATÍSTICA LOCAL ANSELIN MORAN'S I ESTRADA DO ALVARENGA (mapa número 6.12.1)

\begin{tabular}{cccc}
\hline Moran's I & Média & Lojas & $\%$ \\
\hline$-0,70$ a -0.03 & 2,5 & Quantidade & $22 \%$ \\
$-0,02$ a 0.17 & 1,1 & 45 & $20 \%$ \\
0,18 a 0.29 & 1,0 & 67 & $33 \%$ \\
0,30 a 0.43 & 1,0 & 36 & $18 \%$ \\
0,44 a 0.72 & 1,0 & 15 & $7 \%$ \\
SOMA & & 205 & $100 \%$ \\
\hline
\end{tabular}

Os resultados padronizados variam entre $-0,70$ e 0,72

Fonte: apêndice D

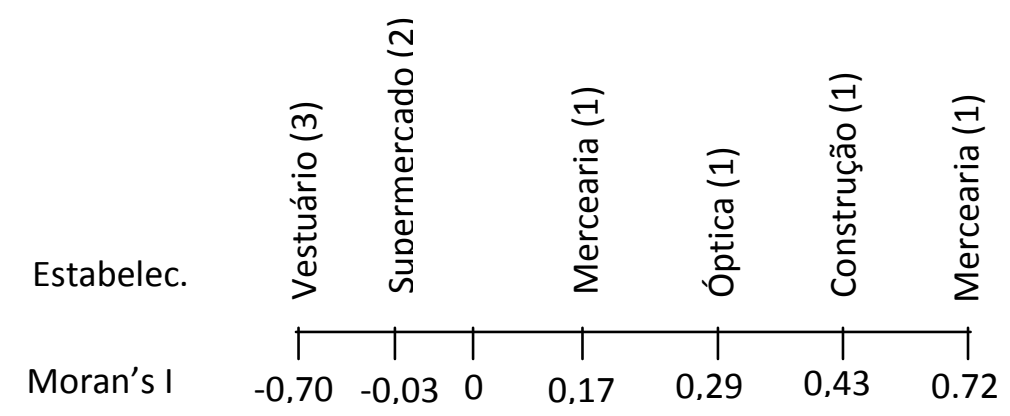

Figura 6.5.1 - distribuição da estatística Moran'I da região da Estrada do Alvarenga Fonte: apêndice D

Conforme a tabela 6.5.1, as lojas estão dispersas por todo o espaço da região da Estrada do Alvarenga. A primeira faixa, entre $-0,70$ e $-0,03$, corresponde a $22 \%$ da região, pertence ao grupo de ramos dissimilares, diante dos sinais negativos, por causa da quantidade acima da média, variando entre 2 e 4 lojas cada ramo. Por exemplo, na Av. Eduardo Pereira Ramos, o 
ramo de mercearia (3 lojas), tem como vizinhos os ramos de comércio com 1 estabelecimento, por exemplo, o ramo de padaria (1 loja). Com exceção do primeiro elemento da segunda faixa, que é dissimilar, todas as demais faixas, entre $-0,02$ e 0,72 , apresentam os ramos estatisticamente similares em decorrência de todos os ramos funcionarem com quantidade de lojas igual a 1 e abaixo da média.

Conforme a figura 6.5.1, o intervalo de variação, entre $-0,70$ e 0,72 , é muito estreita e estatisticamente pouco significativo por não se enquadrar no intervalo de confiança de $95 \%$. Indica a condição do número baixo de lojas, por ramo de comércio, com predominância de 1 e 2 estabelecimentos, caracteriza a região como sendo um centro comercial local e secundário, relativamente diversificado, onde é possível satisfazer praticamente todas as necessidades de frequiência de compras diária ou semanal.

Além do bairro Balneário Mar Paulista, é considerado o comércio da Vila Aparecida, Jardim Selma, Parque São Jorge e Parque Primavera, todos da região norte e parte da região central do Distrito de Pedreira. É uma região cujo espaço de lugar está estruturado para o atendimento da população de renda média e baixa. O visual interno das lojas é bastante simples, a largura da fachada de muitas lojas é relativamente estreita, em geral a variedade do estoque de mercadoria é limitada. Entretanto, encontra-se tudo o que é necessário, para as primeiras necessidades, tais como botijão de gás nas mercearias, venda de roupas nos bazares, saco plástico para lixo nas lojas de doces, frango assado nas padarias aos sábados e domingos, etc. Alguns ramos funcionam aos domingos pela manhã, principalmente os depósitos de material de construção e bazares. Os maiores estabelecimentos são os supermercados de vizinhança, instalados nos maiores imóveis disponíveis, algumas vezes sem a área para estacionamento, porém todas prestam o serviço de entrega domiciliar mediante pagamento de uma pequena tarifa. As padarias e as mercearias estão em imóveis de tamanho médio. As revendedoras de automóveis usados e os depósitos de material de construção, quando ocupam áreas mais significativas, funcionam muitas vezes em terrenos com cobertura. Em geral, os imóveis comerciais são pequenos, com menos de cinqüenta metros quadrados, muitos são prédios residenciais adaptados para o comércio, e alguns são de uso misto com salas ou residências na parte superior. Muitas vezes as lojas de móveis expõem parte dos produtos na calçada por falta de espaço nas suas dependências, e as lojas de confecções expõem os produtos na porta para atrair os compradores. 
Os resultados positivos e negativos, da estatística local Moran's I, mostram a característica de diversidade, todavia são poucas as situações de dissimilaridade diante da quantidade muito pequena de lojas acima da média, por exemplo, o comércio de vestuário (4 lojas) da Rua Bento José de Morais. A maioria dos ramos de atividade estão abaixo da média, com apenas 1 loja. As características dos vizinhos, que estão abaixo da média, são confirmadas através do sinal positivo, o que indica a condição de similaridade. Os resultados próximos de 0 indicam a ausência de concentração em cada ramo de comércio, mostrando alguma evidência da maioria dos ramos funcionarem com apenas 1 loja. Esporadicamente, observam-se algumas exceções diante de uma situação bastante rara, com 2 ou até 4 lojas, por exemplo, há 3 mercearias na Av. Eduardo Pereira Ramos. Da quantidade total de 205 lojas não se observa especial destaque de algum ramo em particular. O resultado dessa estatística revela a característica de comércio de vizinhança, o que limita o interesse para a instalação de maior número de concorrentes diante do poder aquisitivo limitado da população das redondezas.

Tabela 6.5.2 - RESULTADOS DA ESTATÍSTICA LOCAL GETIS ORD GI* - ESTRADA

DO ALVARENGA (mapa número 6.12.2)

\begin{tabular}{cccc}
\hline Getis Ord Gi* & Média & Lojas & $\%$ \\
& 1,1 & 33 & $16 \%$ \\
\hline$-1,35$ a $-0,93$ & 1,1 & 59 & $29 \%$ \\
$-0,92$ a $-0,64$ & 1,3 & 45 & $22 \%$ \\
$-0,63$ a $-0,36$ & 1,1 & 51 & $25 \%$ \\
$-0,35$ a 0,06 & 1,3 & 17 & $8 \%$ \\
0,07 a 1,83 & & 205 & $100 \%$ \\
SOMA & & 205 & \\
\hline
\end{tabular}

Os resultados padronizados variam entre $-1,35$ e 1,83

Fonte: apêndice D

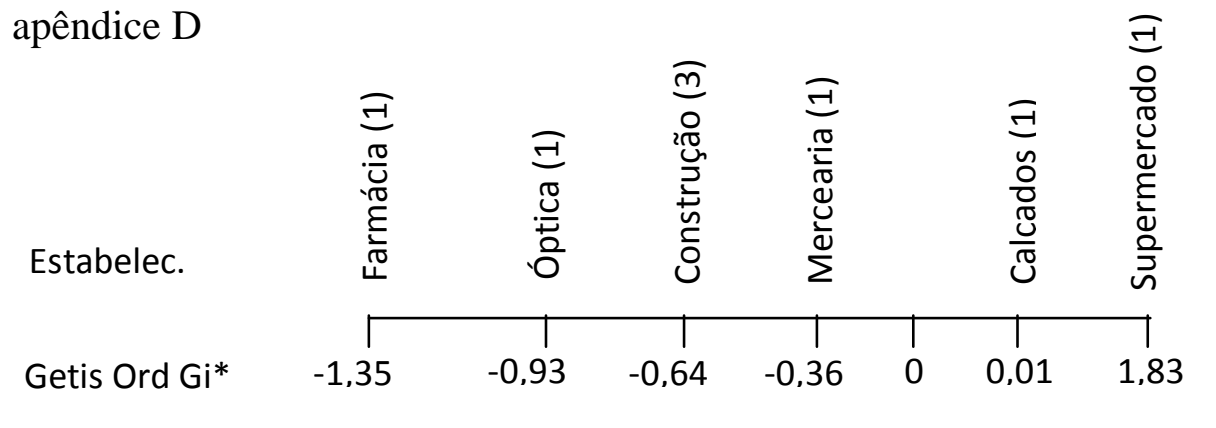

Figura 6.5.2 - distribuição da estatística Getis Ord Gi* da região da Estrada do Alvarenga Fonte: apêndice D 
Conforme a tabela 6.5.2, uma quantidade significativa de lojas está dispersa por todo o espaço da região da Estrada do Alvarenga. Em todas as faixas, entre -1,35 e 1,83, o comércio está localizado em áreas que predominam os ramos que mantêm pequenas quantidades de lojas, sendo a maioria entre 1 e 2 estabelecimentos. Esse resultado reflete a situação de uma dispersão geral do comércio.

Conforme a figura 6.5.2, o intervalo de variação, entre -1,35 e 1,83, é uma faixa muito estreita e estatisticamente pouco significativo por não se enquadrar no intervalo de confiança de $95 \%$. Indica a condição do número baixo de lojas por ramo de comércio com predominância de 1 e 2 estabelecimentos, complementa os resultados da estatística Moran's I e mostra que existe uma dispersão geral de estabelecimentos. Não é possível, estatisticamente, a identificação de focos de concentração.

Os resultados negativos dessa estatística local Getis Ord Gi* indicam um padrão de ausência de concentração, em conseqüência do comércio estabelecido por uma pequena quantidade de lojas em cada ramo de atividade. Mostram a situação de comércio menos estruturado, em comparação aos centros principais, por causa da já referida permanência de poucos estabelecimentos em cada um dos ramos, com 1 ou 2 pontos de vendas, por exemplo, 1 loja do ramo de material de construção na R. Manuel Rodrigues Mexelhão. Portanto, uma determinada loja possui, habitualmente, como vizinho outro ramo de atividade que mantém apenas 1 estabelecimento, por exemplo, o vizinho da loja de material de construção na $R$. Manuel Rodrigues Mexelhão é a casa do norte (1 loja). Tal fato justifica os resultados muito próximos de 0 , diante da situação da maioria dos ramos funcionarem com quantidade de lojas muito próxima da média igual a 1,76 . 


\section{COMÉRCIO}

\section{RESULTADO DA ESTATÍSTICA MORAN'S I LOCAL}

SHOPPING CENTER SPMARKET

MAPA NÚMERO 6.11.1
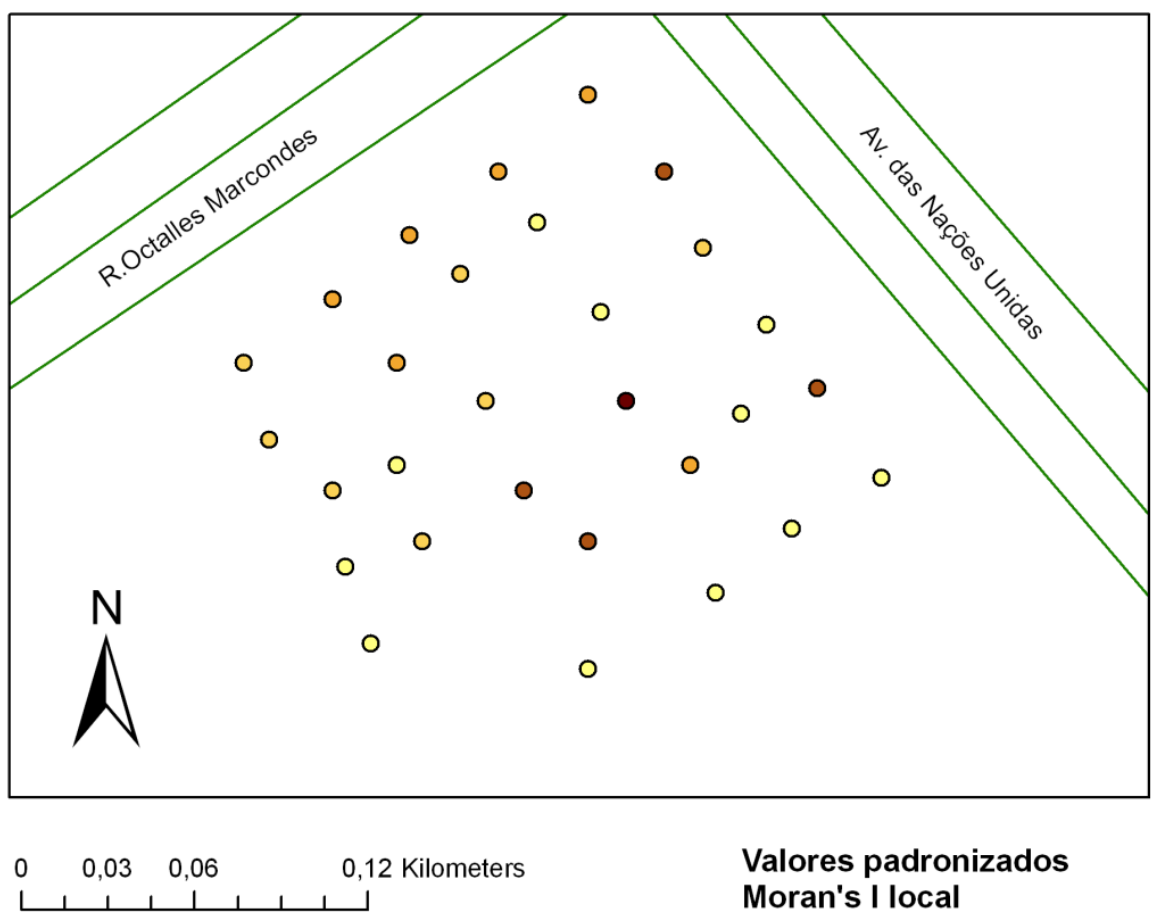

Valores padronizados Moran's I local

Autor: Shinhiti Osanai

$$
\begin{array}{ll}
\text { ○ } & -2,22--0,79 \\
\text { ○ } & -0,78-2,56 \\
\text { ○ } & 2,57-6,08 \\
\text { ○ } & 6,09-19,94 \\
\text { - } & 19,95-43,74
\end{array}
$$




\section{COMÉRCIO}

\section{RESULTADO DA ESTATÍSTICA GETIS Gi* LOCAL} SHOPPING CENTER SPMARKET

MAPA NÚMERO 6.11.2

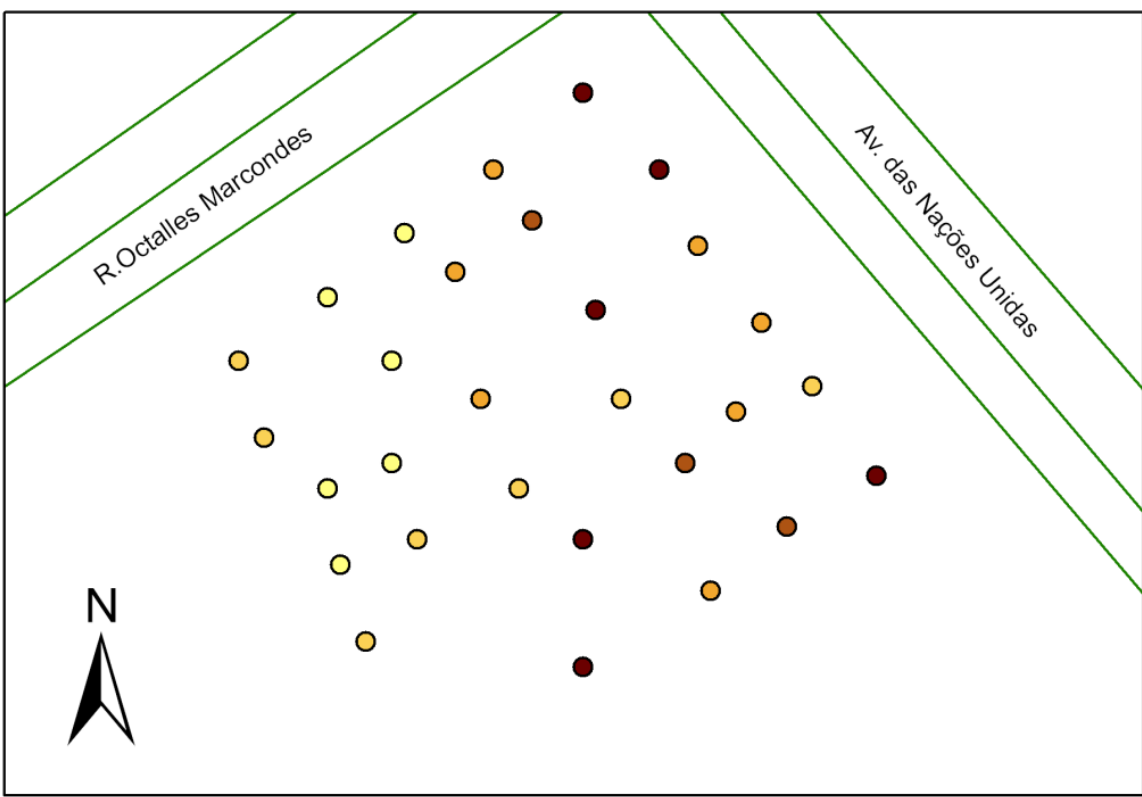

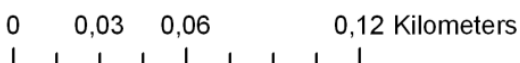

Autor: Shinhiti Osanai

Fonte: pesquisa do autor
Valores padronizados

Getis Ord Gi* local

$$
\begin{array}{cr}
\text { O } & 1,26-1,90 \\
\text { O } & 1,91-2,82 \\
\text { O } & 2,83-3,49 \\
\text { O } & 3,50-4,45 \\
\text { - } & 4,46-7,37
\end{array}
$$




\subsection{Jardim Rubilene}

Tabela 6.6.1 - RESULTADOS DA ESTATÍSTICA LOCAL ANSELIN MORAN'S IJARDIM RUBILENE (mapa número 6.13.1)

\begin{tabular}{cccc}
\hline Moran's I & Média & Lojas & $\%$ \\
\hline$-1,27$ & 8,0 & Quantidade & $5 \%$ \\
$-1,26$ a 0,03 & 1,9 & 8 & $26 \%$ \\
0,04 a 0,30 & 1,0 & 37 & $25 \%$ \\
0,31 a 0,45 & 1,0 & 34 & $23 \%$ \\
0,46 a 0,67 & 1,0 & 29 & $20 \%$ \\
SOMA & & 146 & $100 \%$ \\
\hline
\end{tabular}

Os resultados padronizados variam entre $-1,27$ e 0,67

Fonte: apêndice D

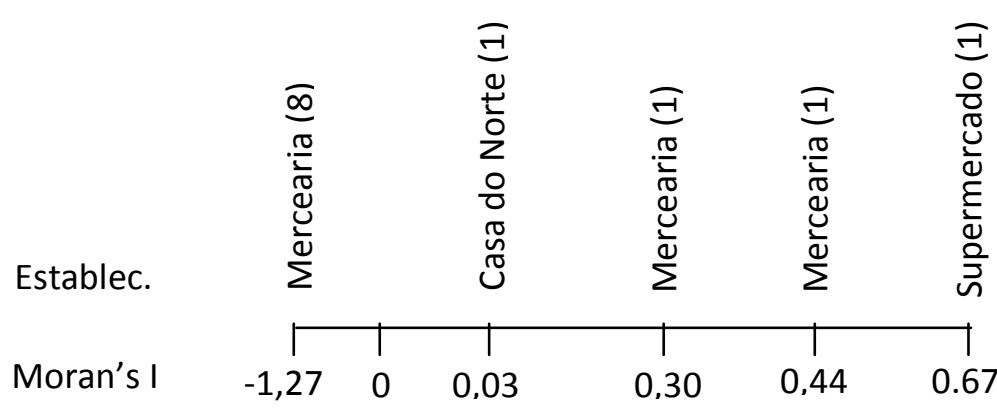

Figura 6.6.1 - distribuição da estatística Moran'I da região do Jardim Rubilene Fonte: apêndice D 


\section{COMÉRCIO}

\section{RESULTADO DA ESTATÍSTICA MORAN'S I LOCAL}

ESTRADA DO ALVARENGA E REGIÕES VIZINHAS

MAPA NÚMERO 6.12.1

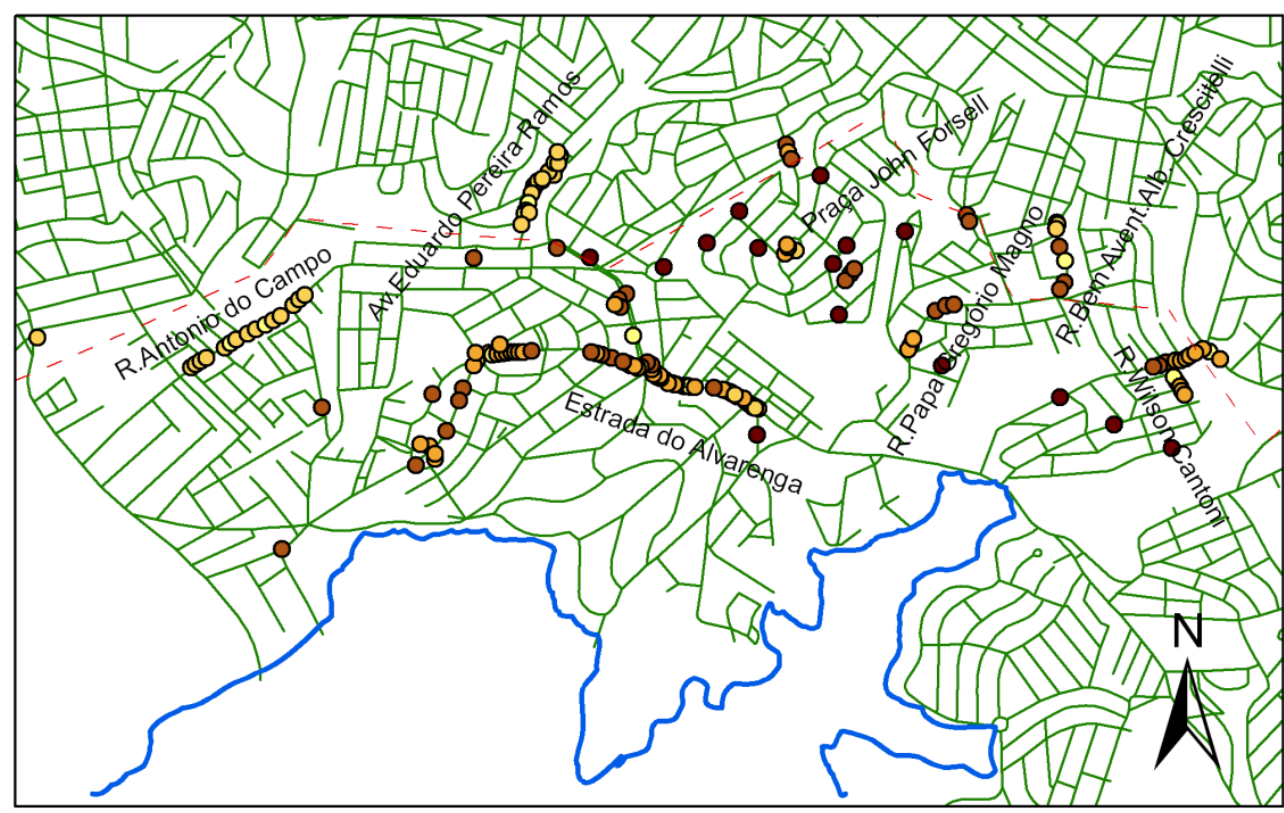

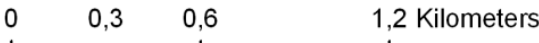

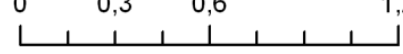

Autor: Shinhiti Osanai

Fonte: pesquisa do autor

\section{Resultados padronizados} Moran's I local

$$
\begin{array}{ll}
\circ & -0,70--0,03 \\
\circ & -0,02-0,17 \\
\circ & 0,18-0,29 \\
\circ & 0,30-0,43 \\
- & 0,44-0,72 \\
\hline & \text { Represa Billings } \\
\hline & \text {--_-- } \text { Distrito de Pedreira }
\end{array}
$$




\section{COMÉRCIO}

\section{RESULTADO DA ESTATISSTICA GETIS Gi* LOCAL ESTRADA DO ALVARENGA E REGIÕES VIZINHAS}

MAPA NÚMERO 6.12 .2
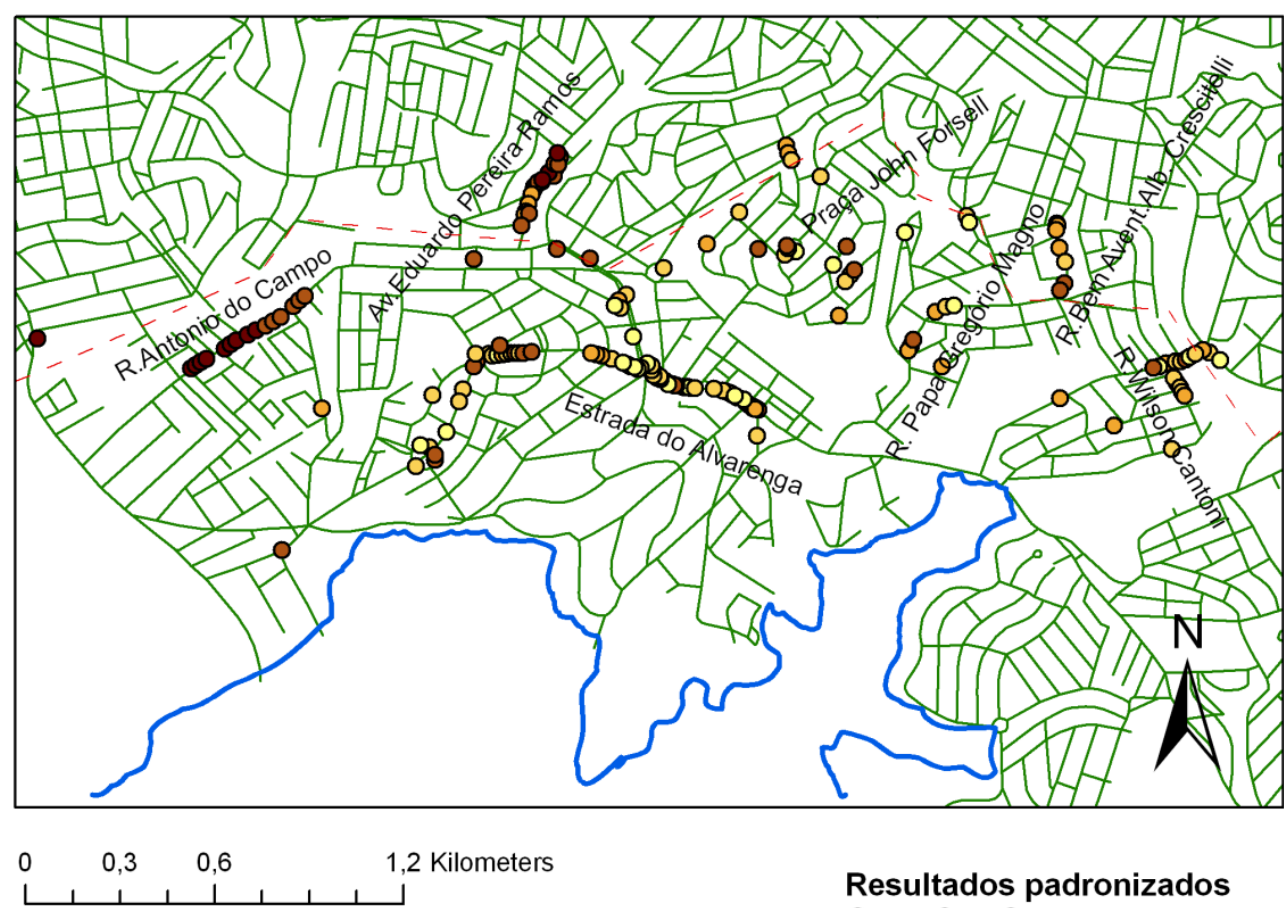

Autor: Shinhiti Osanai

Resultados padronizados Getis Ord Gi local

Fonte: pesquisa do autor

O $-1,35--0,93$

O $-0,92--0,64$

O $-0,63--0,36$

- $-0,35-0,06$

- $0,07-1,83$

Distrito de Pedreira

Represa Billings 
Conforme a tabela 6.6.1, as lojas estão dispersas por todo o espaço da região do Jardim Rubilene. As duas primeiras faixas, entre $-1,27$ e 0,03 , correspondendo a $31 \%$ da região, exceto de dois elementos similares, pertencente ao grupo de ramos dissimilares, diante dos sinais negativos, variando entre 2 e 8 lojas cada ramo, por causa da quantidade acima da média, por exemplo, as 8 pequenas padarias da R. Maria Tereza, na favela do bairro Cidade Júlia, cujos vizinhos são dos ramos de comércio com a quantidade de lojas igual a 1 , tal como o ramo de bebidas (1 loja) nessa mesma via. Todas as demais faixas, entre 0,04 e 0,45, apresentam os ramos estatisticamente similares em decorrência de todos os ramos funcionarem com a quantidade de lojas igual a 1 e abaixo da média.

Conforme a figura 6.6.1, o intervalo de variação, entre -1,27 e 0,67, é muito estreita e estatisticamente pouco significativo por não se enquadrar no intervalo de confiança de $95 \%$. Tal fato indica a condição do número baixo de lojas por ramo de comércio, com 1 e 2 estabelecimentos, e caracteriza a região como sendo um centro comercial local e secundário, relativamente diversificado, onde é possível satisfazer praticamente todas as necessidades de freqüência de compras diária ou semanal.

Corresponde aos bairros Jardim Rubilene, Vila Guacuri, Refúgio Santa Terezinha e Parque Dorotéia, todos da região central do Distrito de Pedreira. É uma região cujo espaço de lugar está estruturado para o atendimento da população de renda média e baixa. As características do comércio são semelhantes da Estrada do Alvarenga, exceto nas áreas de favelas que apresentam estabelecimentos muito precários quanto às instalações.

O ramo de comércio, que apresenta o sinal negativo na estatística local Moran's I, é dissimilar por causa da quantidade de lojas da sua vizinhança, que se encontra acima da média. Esse resultado foi obtido pelas 8 pequenas padarias numa favela da Rua Maria Tereza em comparação aos seus vizinhos de atividades do comércio funcionando com número de lojas abaixo da média, por exemplo, o ramo de pet shop (1 loja). Os demais ramos apresentam as características de similaridade, em decorrência dos resultados de sinal positivo, em consequiência da quantidade de lojas permanecerem abaixo da média e funcionarem com apenas 1 estabelecimento. Por exemplo, na Av. Dr. Carlos de Rezende Enout a farmácia (1 loja), tem como vizinho a padaria (1 estabelecimento). Portanto, essa estatística indica um padrão de agrupamento de comércio de vizinhança e de menor interesse por parte do empresário em investir em maior quantidade de estabelecimentos. 
Fica em destaque, a favela do Pantanal, onde os seus estabelecimentos de pequeno porte mantêm uma estrutura para o atendimento das compras diárias ou semanais, tais como pequenas padarias, mercearias ou lojas de material de limpeza. Na Rua Maria Tereza, onde existe uma grande favela, localizada no bairro de Cidade Júlia, no Distrito de Cidade Ademar, há muitos estabelecimentos de pequeno porte, completando o total de 20 lojas. O comércio dessa região atende prioritariamente as necessidades imediatas dos moradores locais.

O resultado dessa estatística de valor mais elevado, igual a 0,67, pertence ao Supermercado Mamb’s localizado na Rua Dr. Carlos de Rezende Enout. Considerando que os resultados são muito próximos de 0 , essa estatística indica a predominância de pequena quantidade de lojas por ramo de atividade, na maioria dos casos sendo igual a 1. Não se verifica a evidência de concentração de lojas. Com exceção do Depósito 5 Irmãos, dos Supermercados Mamb’s e KiBarato, os estabelecimentos, freqüentemente, são de pequeno porte e de pouco destaque.

Tabela 6.6.2 - RESULTADOS DA ESTATÍSTICA LOCAL GETIS ORD GI*-JARDIM RUBILENE (mapa número 6.13.2)

\begin{tabular}{cccc}
\hline Getis Ord Gi* & Média & Lojas & $\%$ \\
\hline$-1,71$ a $-1,14$ & 1,1 & Quantidade & $16 \%$ \\
$-1,13$ a $-0,82$ & 1,1 & 39 & $27 \%$ \\
$-0,81$ a $-0,52$ & 1,1 & 29 & $20 \%$ \\
$-0,51$ a $-0,001$ & 1,4 & 40 & $27 \%$ \\
$-0,09$ a 1,55 & 1,6 & 14 & $10 \%$ \\
SOMA & & 146 & $100 \%$ \\
\hline
\end{tabular}

Os resultados padronizados variam entre $-1,71$ e 1,55

Fonte: apêndice D 


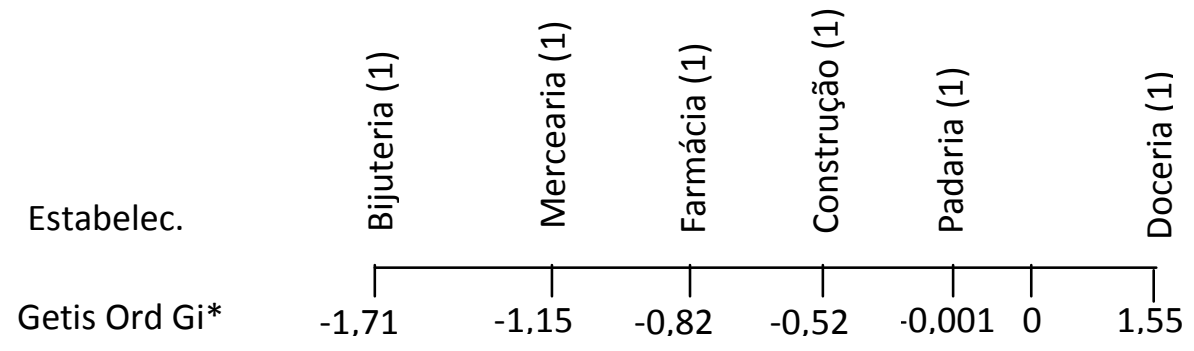

Figura 6.6.2 - distribuição da estatística Getis Ord Gi* da região do Jardim Rubilene Fonte: apêndice D

Conforme a tabela 6.6.2, uma quantidade significativa de lojas encontra-se dispersa por todo o espaço da região do Jardim Rubilene. É um resultado que reflete a situação de uma dispersão geral do comércio. Em todas as faixas, entre -1,71 e 1,55, o comércio está localizado em áreas que predominam os ramos com pequenas quantidades de lojas, a maioria entre 1 e 2 estabelecimentos, exceto na favela da Cidade Júlia onde encontram-se 8 pequenas padarias.

Conforme a figura 6.6.2, o intervalo de variação, entre -1,71 e 1,55, é uma faixa muito estreita e estatisticamente pouco significativo por não se enquadrar no intervalo de confiança de $95 \%$. Tal fato indica a condição do número baixo de lojas por ramo de comércio, com predominância de 1 e 2 estabelecimentos, complementa os resultados da estatística Moran's I e indica que existe uma dispersão geral de estabelecimentos. Não é possível, estatisticamente, a identificação de focos de concentração.

Os resultados negativos, da estatística local Getis Ord Gi*, indicam a característica de comércio, relativamente disperso em toda a área, tendo em vista a disponibilidade de vários ramos com pequena quantidade de lojas, entre 1 e 2 estabelecimentos. Por exemplo, na R. Dr. Cardoso de Mello Neto, há 1 padaria e como vizinho 1 loja de móveis. A vizinhança, em relação a um determinado ramo, é constituída por poucas lojas, na maioria das vezes por apenas 1 estabelecimento, que justifica os resultados de pontuação bastante baixa e próximos de 0 . 


\section{COMÉRCIO}

\section{RESULTADO DA ESTATÍSTICA MORAN'S I LOCAL JARDIM RUBILENE E VILA GUACURI}

MAPA NÚMERO 6.13.1

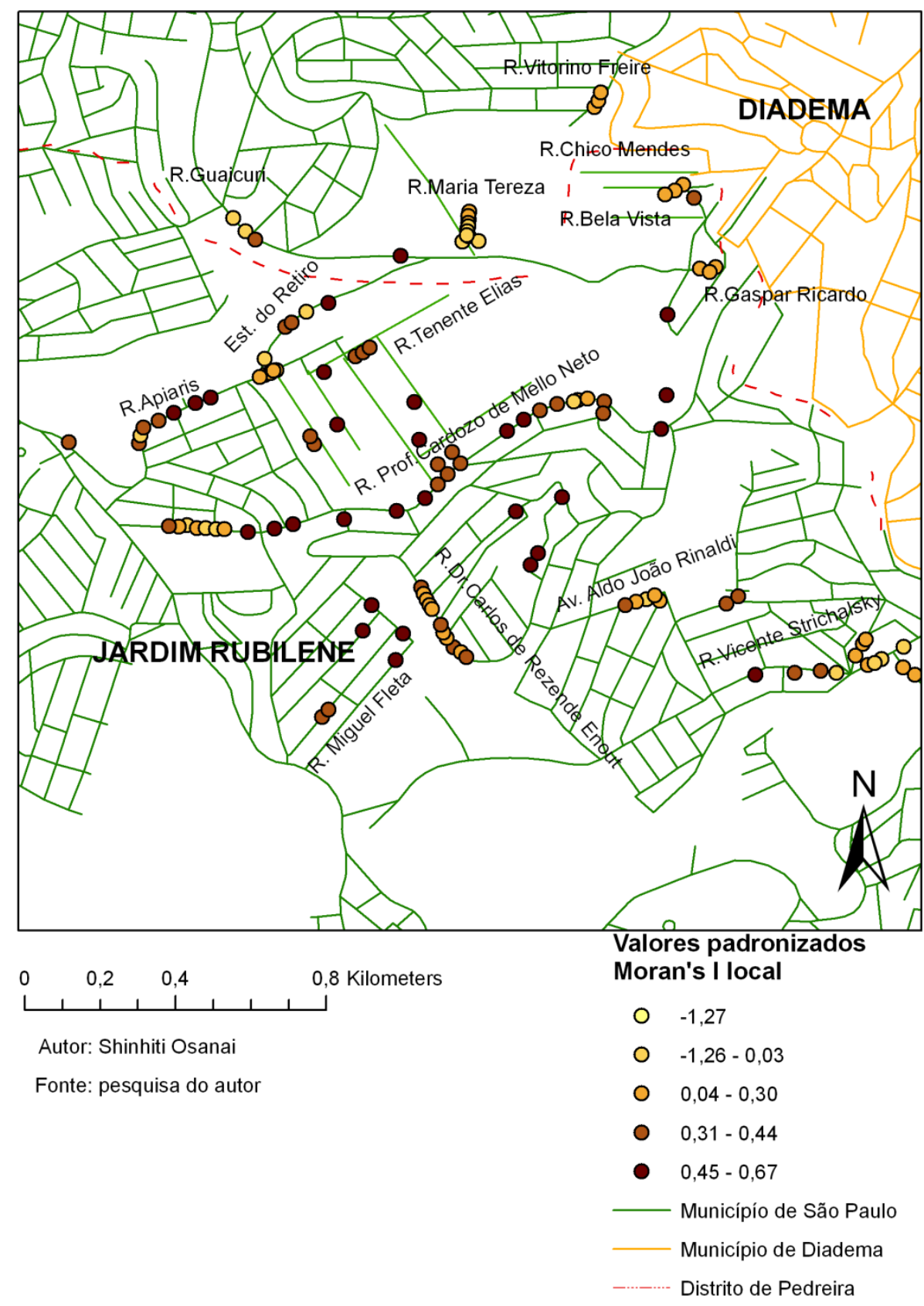


COMÉRCIO

RESULTADO DA ESTATÍSTICA GETIS Gi* I LOCAL JARDIM RUBILENE E VILA GUACURI

MAPA NÚMERO 6.13.2

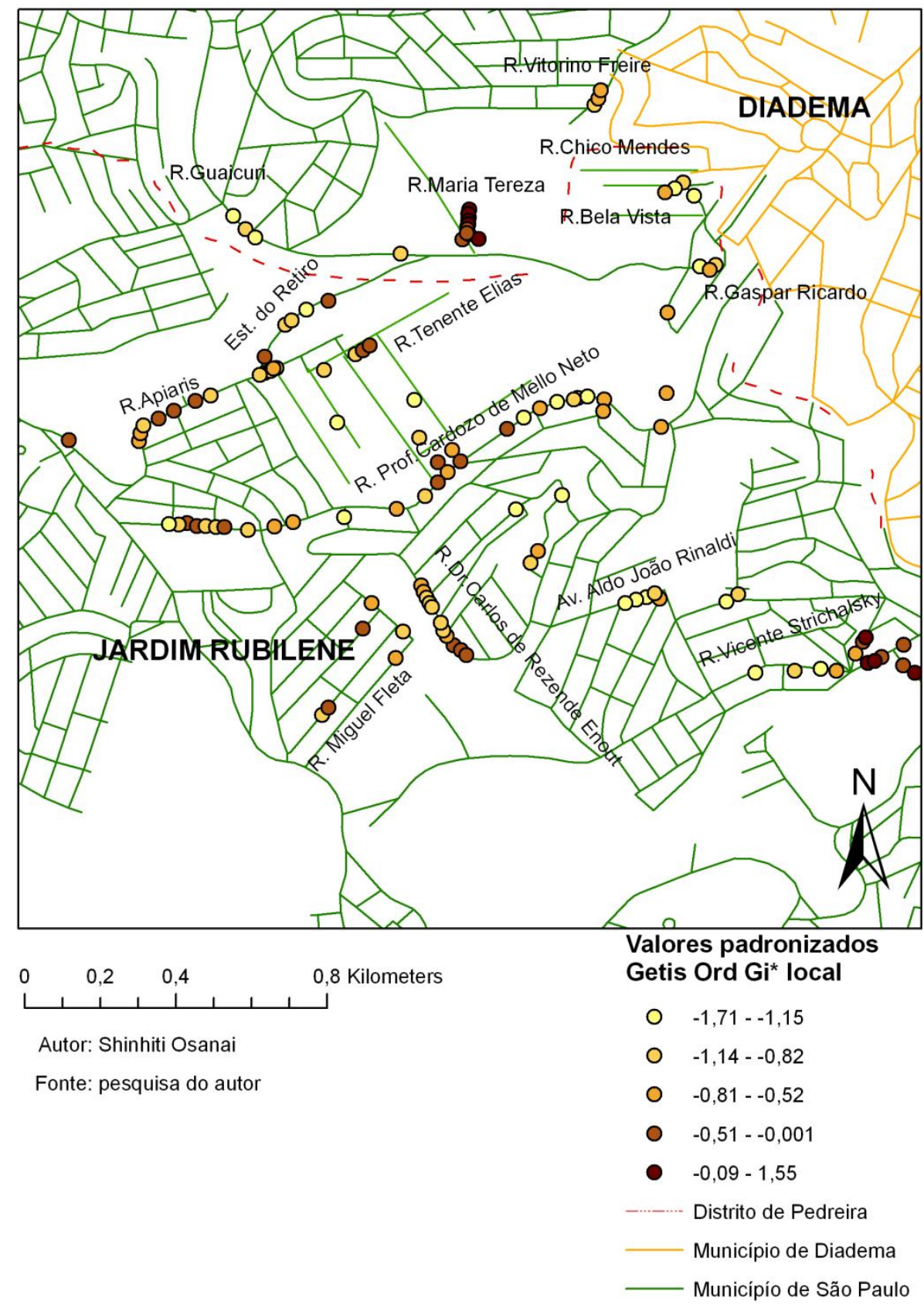


O resultado mais baixo igual a $-1,27$ foi obtido pelo ramo de padaria, localizado na Rua Maria Tereza, com 8 lojas. Esse resultado é o reflexo de uma vizinhança estruturada por diversos ramos constituídos por apenas 1 estabelecimento, por exemplo, o ramo de confecção (1 loja). Os resultados de valores negativos indicam a situação do comércio menos estruturado, e observa-se a participação de poucos estabelecimentos em cada um dos ramos atuantes.

\subsection{Parque Santa Amélia}

Tabela 6.7.1 - RESULTADOS DA ESTATÍSTICA LOCAL ANSELIN MORAN'S IPARQUE SANTA AMÉLIA (mapa número 6.14.1)

\begin{tabular}{cccc}
\hline Moran's I & Média & Lojas & $\%$ \\
\hline$-0,43$ a - $-0,05$ & 2,1 & 15 & $21 \%$ \\
$-0,04$ a 0,22 & 1,0 & 14 & $20 \%$ \\
0,23 a 0,28 & 1,0 & 15 & $21 \%$ \\
0,29 a 0,35 & 1,0 & 15 & $21 \%$ \\
0,36 a 0,60 & 1,0 & 11 & $16 \%$ \\
SOMA & & 70 & $100 \%$
\end{tabular}

Os resultados padronizados variam entre $-0,43$ e 0,60

Fonte: apêndice D

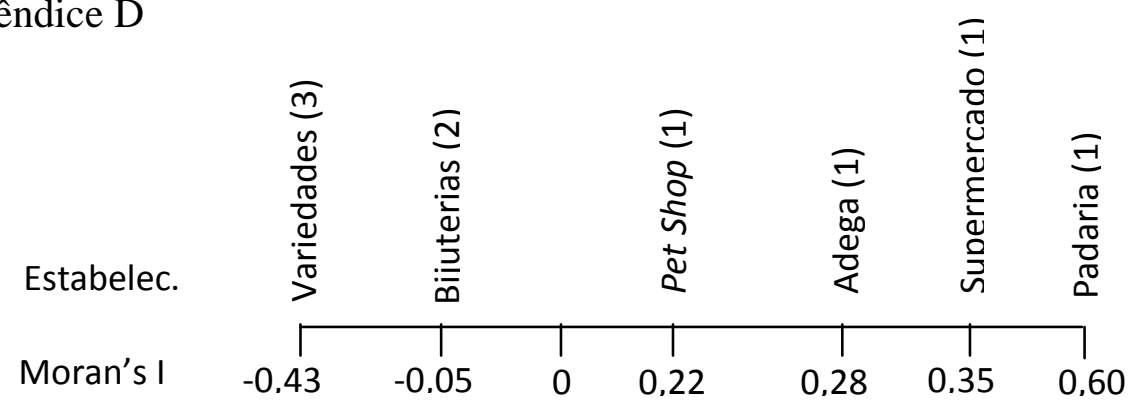

Figura 6.7.1 - distribuição da estatística Moran'I da região do Parque Santa Amélia Fonte: apêndice D

Conforme a tabela 6.7.1, as lojas encontram-se dispersas por todo o espaço da região do Parque Santa Amélia. A primeira faixa, entre -0,43 e - -0,05, que corresponde a $21 \%$ da região, pertence ao grupo de ramos dissimilares, diante dos sinais negativos, por causa da quantidade de lojas acima da média, com 2 e 3 lojas. Por exemplo, o ramo de bijuteria (2 lojas) na Av. 
das Garoupas, tem como vizinhos os ramos de comércio com a quantidade de lojas igual a 1, tal como o ramo de vestuário (1 loja) nessa mesma via. Todas as demais faixas, entre $-0,04 \mathrm{e}$ 0,60, apresentam os ramos estatisticamente similares, em decorrência de todos os ramos funcionarem com quantidade de lojas igual a 1 e abaixo da média.

Conforme a figura 6.7.1, o intervalo de variação entre $-0,43$ e 0,60 , é muito estreito e estatisticamente pouco significativo por não se enquadrar no intervalo de confiança de $95 \%$. Tal fato indica a condição do número baixo de lojas por ramo de comércio, com predominância de 1 e 2 estabelecimentos, e caracteriza a região como sendo um centro comercial local e secundário, relativamente diversificado, onde é possível satisfazer praticamente todas as necessidades de freqüência de compras diária ou semanal.

Corresponde aos bairros Jardim Apurá e Balneário São Francisco, todos na região central do Distrito de Pedreira. É uma região cujo espaço de lugar encontra-se estruturado para o atendimento da população de renda média e baixa. As características do comércio são semelhantes da Estrada do Alvarenga.

Os sinais positivos e negativos, da estatística local Moran's I, mostram algumas características de dissimilaridade. Alguns ramos, diante de 2 ou 3 estabelecimentos, por exemplo, lojas de variedades, pet shop e telefonia, instalados na Avenida das Garoupas nas proximidades do Supermercado Pedreira, obtiveram os pontos negativos em consequiência da constatação de vizinhos com apenas 1 loja. Por exemplo, 2 lojas de telefonia tendo como vizinhos 1 floricultura. Os resultados muito próximos de 0 indicam a participação, na maioria dos casos, de apenas 1 estabelecimento em cada ramo de comércio. Não se verifica evidências de concentração de lojas. Todo o comércio, exceto o Supermercado Pedreira, que funciona com apenas um estabelecimento na região, está estruturado predominantemente para o atendimento das necessidades diárias ou semanais. 
Tabela 6.7.2 - RESULTADOS DA ESTATÍSTICA LOCAL GETIS ORD GI*-PARQUE

SANTA AMÉLIA (mapa número 6.14.2)

\begin{tabular}{cccc}
\hline Getis Ord Gi* & Média & Lojas & Quantidade \\
\hline$-1,53$ a $-1,07$ & 1,0 & 12 & $17 \%$ \\
$-1,06$ a $-0,79$ & 1,3 & 17 & $24 \%$ \\
$-0,78$ a $-0,54$ & 1,2 & 14 & $20 \%$ \\
$-0,53$ a $-0,30$ & 1,1 & 20 & $29 \%$ \\
$-0,29$ a 0,007 & 1,0 & 7 & $10 \%$ \\
SOMA & & 70 & $100 \%$ \\
\hline
\end{tabular}

Os resultados padronizados variam entre $-1,53$ e 0,007

Fonte: apêndice D

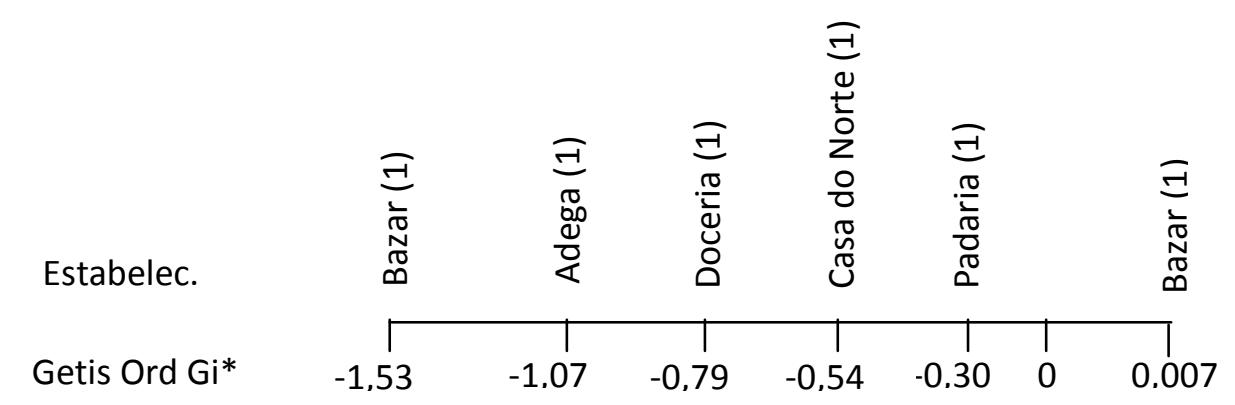

Figura 6.7.2 - distribuição da estatística Getis Ord Gi* da região do Parque Santa Amélia Fonte: apêndice D

Conforme a tabela 6.7.2, uma quantidade significativa de lojas encontra-se dispersa por todo o espaço da região do Parque Santa Amélia. É um resultado que reflete a situação de uma dispersão geral do comércio. Em todas as faixas, entre -1,53 e 0,007, o comércio está localizado em áreas que predominam os ramos que mantêm pequenas quantidades de lojas, sendo a maioria entre 1 e 2 estabelecimentos.

Conforme a figura 6.7.2, o intervalo de variação, entre $-1,53$ e 0,007 , é uma faixa muito estreita e, estatisticamente, pouco significativo por não se enquadrar no intervalo de confiança de $95 \%$. Tal fato indica a condição do número baixo de lojas por ramo de comércio, com predominância da faixa entre 1 e 2 estabelecimentos, complementa os resultados da estatística 
Moran's I, e indica que existe uma dispersão geral de estabelecimentos. Não é possível, estatisticamente, a identificação de focos de concentração.

Os resultados negativos e muito próximos de 0 indicam que a quantidade de estabelecimentos de cada ramo de atividade é próxima da média igual a 1,76, variando cada um dos ramos entre 1 e 2 estabelecimentos, sem maior destaque entre os vários ramos presentes. O resultado mais baixo, igual a $-1,53$, foi obtido por um bazar localizado num pequeno centro comercial local, na Rua Lúcio Dias da Fonseca, no Jardim Apurá, cujo comércio dessa via é organizado por uma vizinhança de poucas lojas, por exemplo, o ramo de farmácia (1 loja). Na Estrada do Alvarenga, no Parque Santa Amélia, igualmente, existe um pequeno centro comercial local, cuja quantidade de cada ramo varia entre 1 e 2 estabelecimentos, por exemplo, o ramo de produtos de limpeza (1 loja). Os resultados negativos mostram a situação de comércio menos estruturado com poucos estabelecimentos em cada um dos ramos. Trata-se de um centro comercial passando por um processo de formação em torno do Supermercado Pedreira.

\subsection{Eldorado e divisa com Diadema}

Tabela 6.8.1 - RESULTADOS DA ESTATÍSTICA LOCAL ANSELIN MORAN'S IELDORADO (mapa número 6.15.1)

\begin{tabular}{cccc}
\hline Moran's I & Média & Lojas & $\%$ \\
& 12,0 & 12 & $5 \%$ \\
$-3,17$ & 3,3 & 40 & $16 \%$ \\
$-3,16$ a $-0,16$ & 1,6 & 88 & $35 \%$ \\
$-0,15$ a 0,09 & 1,0 & 109 & $43 \%$ \\
0,10 a 0,35 & 1,0 & 5 & $2 \%$ \\
0,36 a 0,76 & & 254 & $100 \%$ \\
SOMA & & &
\end{tabular}

Os resultados padronizados variam entre $-3,17$ e 0,76

Fonte: apêndice D

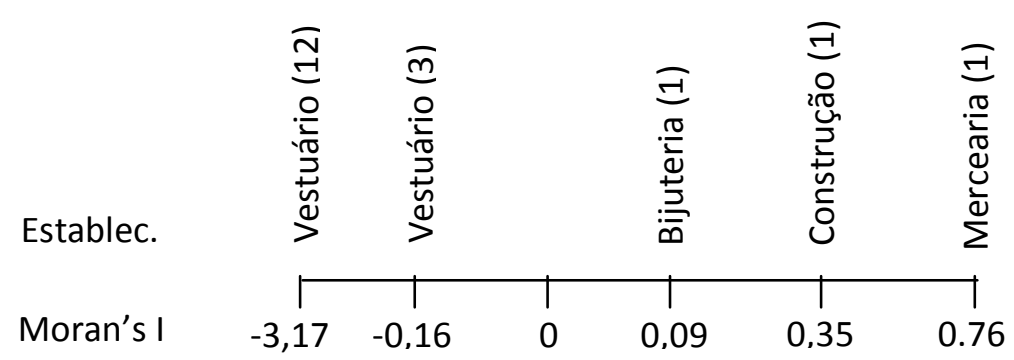

Figura 6.8.1 - distribuição da estatística Moran'I da região de Eldorado Fonte: apêndice D 
Conforme a tabela 6.8.1, as lojas estão dispersas por todo o espaço da região de Eldorado e divisa com Diadema. As três primeiras faixas, entre $-3,17$ e 0,09 , correspondem a $56 \%$ da região, pertencem ao grupo de ramos dissimilares, diante dos sinais negativos, por causa da quantidade de lojas acima da média, e a maioria varia entre 2 e 12 lojas cada ramo. Por exemplo, o ramo de vestuário (4 lojas), em Serraria, na Rua Lico Maia, tem vizinhos dos ramos de comércio com a quantidade de lojas igual a 1 , tal como o ramo de móveis (1 loja) nessa mesma via. Todas as demais faixas, entre 0,10 e 0,76 , apresentam os ramos estatisticamente similares em decorrência de todos os ramos funcionarem com quantidade de lojas igual a 1 e abaixo da média.

Conforme a figura 6.8.1, o intervalo de variação entre $-3,17$ e 0,76 , é muito estreito, exceto o primeiro e único elemento, do ramo de vestuário (12 lojas) em Serraria, o resultado é, estatisticamente, pouco significativo por não se enquadrar no intervalo de confiança de $95 \%$. Tal fato indica a condição do número baixo de lojas por ramo de comércio com predominância da faixa entre 1 e 2 estabelecimentos, e caracteriza a região como um centro comercial local e secundário, relativamente diversificado, onde é possível satisfazer praticamente todas as necessidades de frequiência de compras diária ou semanal.

Corresponde aos bairros de Monte Líbano, Jardim do Castelo e Eldorado na região sul e sudeste do Distrito de Pedreira e os bairros Serraria, Navegantes e Conceição em Diadema. É uma região cujo espaço de lugar está estruturado para o atendimento da população de renda média e baixa. As características do comércio de Serraria são semelhantes ao centro comercial de Diadema. O comércio da Av. Nossa Senhora dos Navegantes (bairro Navegantes), em Diadema, é semelhante à Estrada do Alvarenga. O comércio do bairro de Eldorado, no Distrito de Pedreira, é pouco estruturado e bastante precário, existem alguns estabelecimentos comerciais na R.Dr. José Silvio de Camargo no bairro de Monte Líbano e na Av. Alda no bairro de Jardim do Castelo.

É uma área que recebe forte influência de Diadema, principalmente em conseqüência do comércio bastante precário, no Distrito de Pedreira e a proximidade do município vizinho. Nos locais contíguos à divisa, existe a disponibilidade de ônibus na Avenida Alda em direção a Diadema. Do total de 254 estabelecimentos, 134 se localizam em Diadema. Alguns que vivem na Estrada da Água Santa, mais para o norte, na ausência de um serviço de ônibus, se dirigem a pé em poucos minutos, até a Avenida Afonso Monteiro da Cruz, no Município de Diadema, onde satisfazem as suas necessidades de compras no comércio da Vila Conceição, 
junto à referida Avenida. Outra opção é utilizar o serviço de ônibus urbano de Diadema, com destino ao centro do município vizinho, cujo itinerário contempla a Avenida Rotary, no bairro de Serraria.

Muitos moradores ao sul da Estrada da Água Santa, apesar de contar com uma linha de micro ônibus para Santo Amaro, preferem por causa da proximidade, efetuar as suas compras semanais no bairro de Navegantes, na Avenida Nossa Senhora dos Navegantes. Alguns se locomovem a pé na falta de um serviço de ônibus, a não ser uma linha intermunicipal de tarifa mais elevada e sem a possibilidade de integração. Aqueles que se encontram nas proximidades da Rua dos Marimbas, a nordeste do Distrito de Pedreira, podem dispor de comércio melhor estruturado na Rua Manoel da Nóbrega, e basta atravessar o cruzamento da Avenida Alda, já no trecho sob a jurisdição de Diadema, necessitando apenas alguns minutos a pé.

Existe um pequeno agrupamento de comércio na Avenida Alda bem próxima à divisa com Diadema e também no bairro de Monte Líbano na Rua Dr. José Silvio de Camargo. Nessa última via, a estatística local Moran's I apresenta alguns indicadores de dissimilaridade, manifestados pelos sinais negativos, diante da permanência de alguns ramos de comércio variando entre 2 a 4 lojas. Por exemplo, o ramo de mercearia (4 lojas) localizado numa área estruturada por maioria dos ramos com apenas 1 estabelecimento comercial, por exemplo, o ramo de açougue (1 loja).

A pontuação mais baixa, igual a $-3,17$, indica significativa dissimilaridade, e foi obtida pelo ramo de vestuário, por meio de 12 lojas, localizado no bairro de Serraria, tendo como exemplo o vizinho o ramo de doces (1 ponto de venda). As dissimilaridades mais significativas se localizam na Avenida Rotary, por exemplo, o ramo de óptica (1 loja) atua nas vizinhanças do ramo de variedades (3 pontos de vendas). O mesmo é observado na Avenida Nossa Senhora dos Navegantes, em Diadema.

Nas demais vias, na região do bairro de Eldorado, no Distrito de Pedreira, os poucos estabelecimentos existentes não passam de 1 loja por ramo de atividade o que justifica os resultados dessa estatística muito próxima de 0 . Não se verifica evidências de concentração de lojas. 
COMÉRCIO

RESULTADO DA ESTATÍSTICA MORAN'S I LOCAL PARQUE SANTA AMÉLIA E JARDIM APURÁ

MAPA NÚMERO 6.14.1
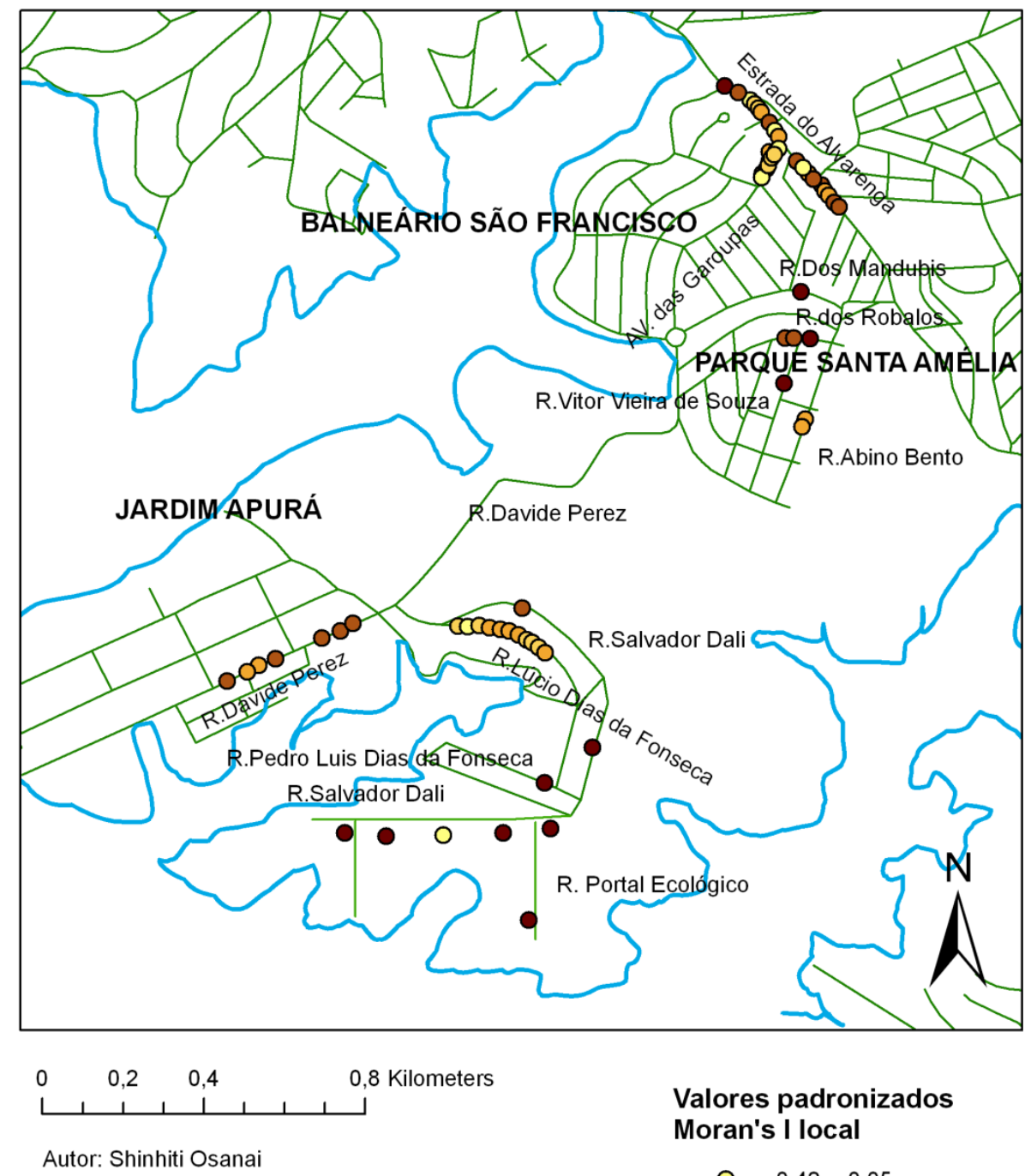

Fonte: pesquisa do autor

Valores padronizados Moran's I local
O $-0,42--0,05$
O $-0,04-0,22$
○ $0,23-0,28$
○ $0,29-0,35$
- $0,36-0,60$
Represa Billings 


\section{COMÉRCIO}

\section{RESULTADO DA ESTATÍSTICA GETIS Gi* LOCAL PARQUE SANTA AMÉLIA E JARDIM APURÁ}

MAPA NÚMERO 6.14.2

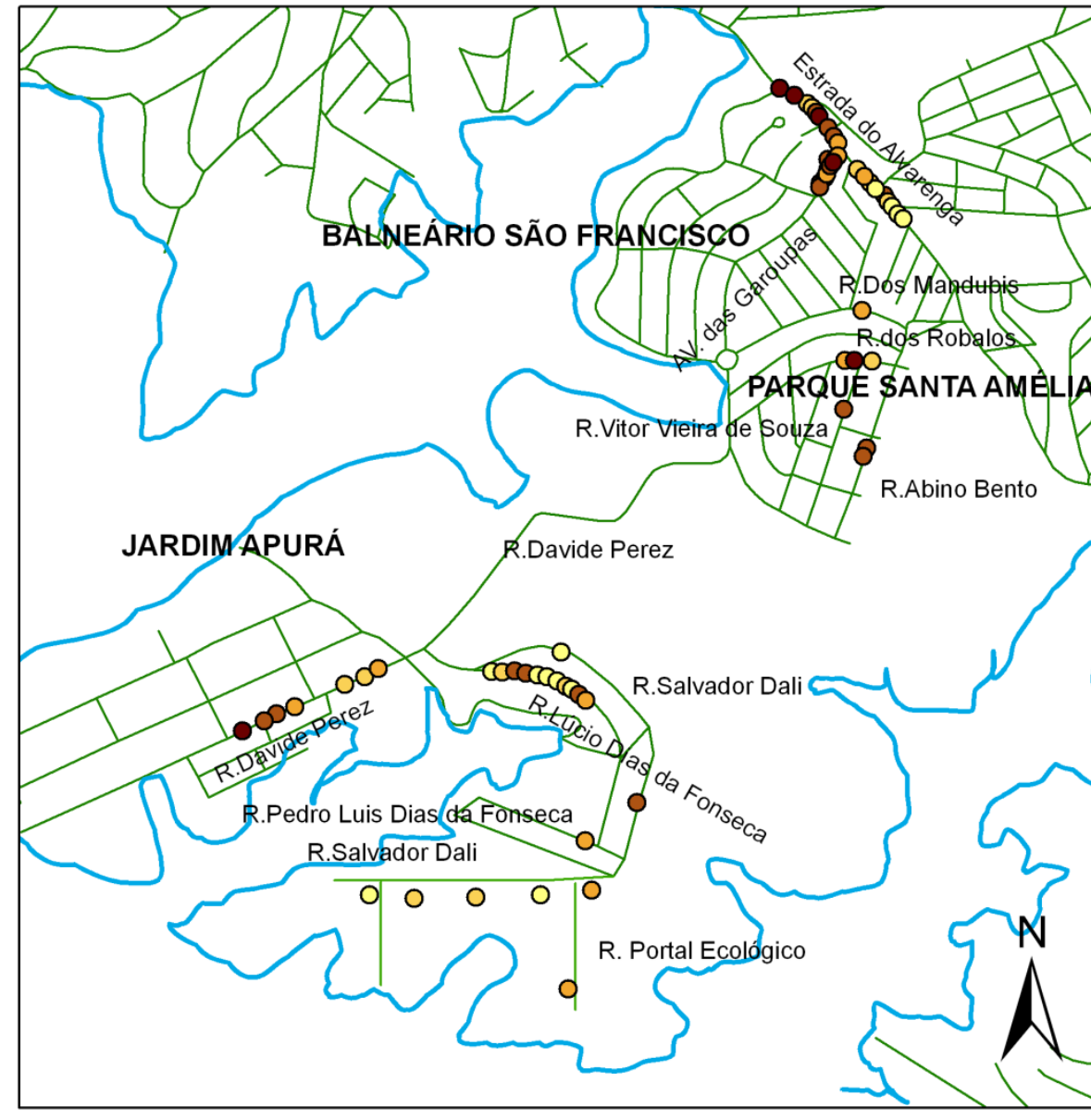

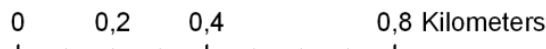

Autor: Shinhiti Osana

Fonte: pesquisa do autor
Valores padronizados Getis Ord Gi* local
O $-1,53--1,07$
O $-1,06--0,79$
O $-0,78--0,54$
O $-0,53--0,30$
- $-0,29-0,007$
Represa Billings 
Tabela 6.8.2 - RESULTADOS DA ESTATÍSTICA LOCAL GETIS ORD GI*-ELDORADO (mapa número 6.15.2)

\begin{tabular}{cccc}
\hline Getis Ord Gi* & Média & Lojas & $\%$ \\
& 1,5 & 29 & $11 \%$ \\
\hline$-1,04$ a $-0,64$ & 1,4 & 90 & $35 \%$ \\
$-0,63$ a $-0,39$ & 1,5 & 103 & $41 \%$ \\
$-0,38$ a $-0,10$ & 1,3 & 28 & $11 \%$ \\
$-0,10$ a 0,53 & 1,0 & 4 & $2 \%$ \\
0,54 a 1,76 & & 254 & $100 \%$ \\
SOMA & & & \\
\hline
\end{tabular}

Os resultados padronizados variam entre $-1,04$ e 1.76

Fonte: apêndice D

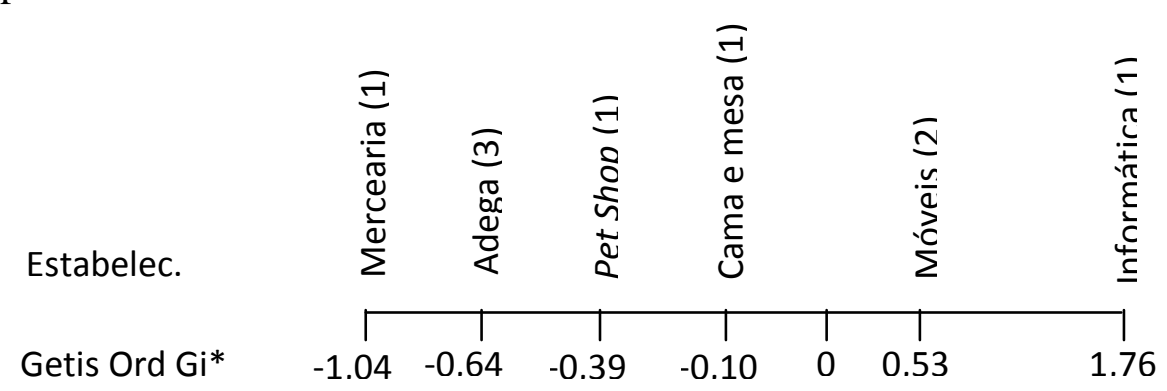

Figura 6.8.2 - distribuição da estatística Getis Ord Gi* da região de Eldorado Fonte: apêndice D

Conforme a tabela 6.8.2, uma quantidade significativa de lojas está dispersa por todo o espaço da região de Eldorado e divisa com Diadema. É um resultado que reflete a situação de uma dispersão geral do comércio. Em todas as faixas, entre -1,04 e 1,76, o comércio está localizado em áreas que predominam os ramos com pequenas quantidades de lojas, a maioria entre 1 e 2 estabelecimentos, por exemplo, o ramo de óptica (1 loja) na Av. Rotary.

Conforme a figura 6.8.2, o intervalo de variação, entre -1,04 e 1,76, é uma faixa muito estreita e estatisticamente pouco significativo por não se enquadrar no intervalo de confiança de $95 \%$. Tal fato indica a condição do número baixo de lojas por ramo de comércio, predominando a faixa entre 1 e 2 estabelecimentos, complementa os resultados da estatística Moran's I, o que indica que existe uma dispersão geral de estabelecimentos. 
Os resultados, da estatística local Getis Ord Gi*, são muito próximos de 0 em consequiência da maioria dos estabelecimentos oferecerem apenas 1 loja por ramo de atividade. Por conseguinte, a quantidade de estabelecimentos, em cada ramo de atividade, apresenta resultados muito próximos da média igual a 1,76. Os resultados acima de 1 , mesmo pouco significativos, foram obtidos pelo comércio dos bairros de Navegantes e de Serraria, ambos em Diadema, em conseqüência de alguns ramos de comércio oferecerem a quantidade variando entre 2 e 4 lojas. Por exemplo, o ramo de vestuário (3 lojas) na R. Lico Maia, em Serraria. Os resultados negativos mostram a situação do comércio menos estruturado, e não se verifica o padrão de concentração mais significativo, diante da existência de poucos estabelecimentos em cada um dos ramos. Na maioria das vezes, há apenas 1 ou 2 lojas, por exemplo, a casa do norte (1 loja) na Estrada da Água Santa.

\subsection{Avenida Yervant Kissajikian}

Tabela 6.9.1 - RESULTADOS DA ESTATÍSTICA LOCAL ANSELIN MORAN'S IAV.YERVANT KISSAJIKIAN (mapa número 6.16.1)

\begin{tabular}{cccc}
\hline Moran's I & Média & Lojas & $\%$ \\
\hline$-1,20$ a $-0,30$ & 4,6 & 37 & $17 \%$ \\
$-0,29$ a $-0,002$ & 3,3 & 63 & $30 \%$ \\
$-0,001$ a 0,10 & 3,5 & 24 & $11 \%$ \\
0,11 a 0,20 & 1,0 & 69 & $32 \%$ \\
0,20 a 0,31 & 1,0 & 21 & $9 \%$ \\
SOMA & & 214 & $100 \%$ \\
\hline
\end{tabular}

Os resultados padronizados variam entre $-1,20$ e 0,31

Fonte: apêndice D

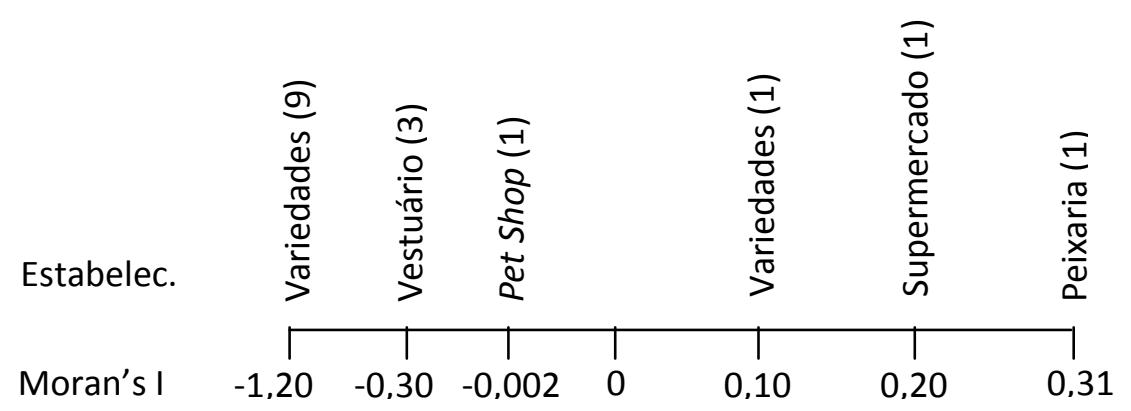

Figura 6.9.1 - distribuição da estatística Moran'I da região da Av.Yervant Kissajikian Fonte: apêndice D 


\section{COMÉRCIO}

\section{RESULTADO DA ESTATÍSTICA MORAN'S I LOCAL REGIÃO DE ELDORADO \\ MAPA NÚMERO 6.15.1}

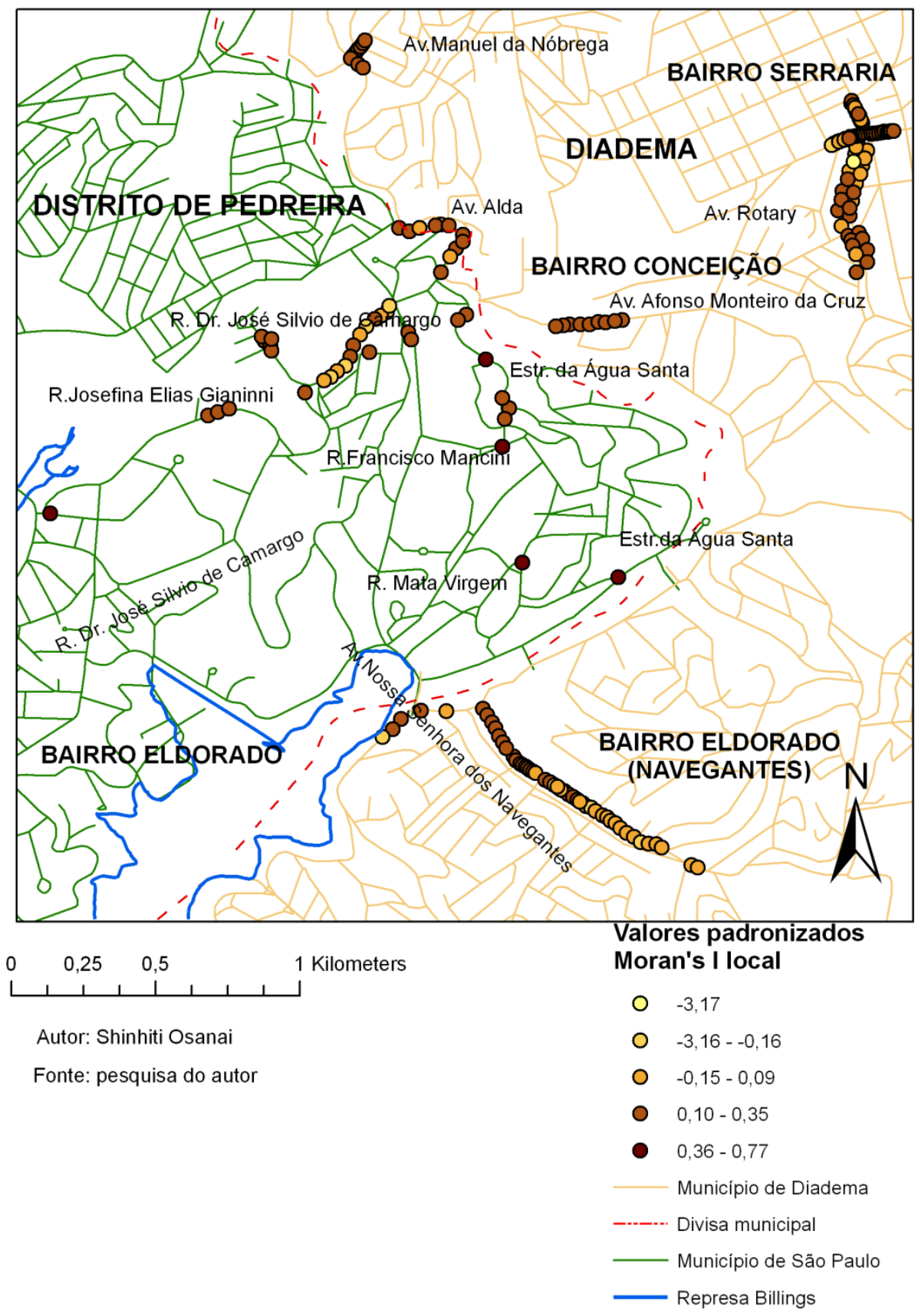




\section{COMÉRCIO}

\section{RESULTADO DA ESTATÍSTICA GETIS Gi* LOCAL REGIÃO DE ELDORADO \\ MAPA NÚMERO 6.15.2}

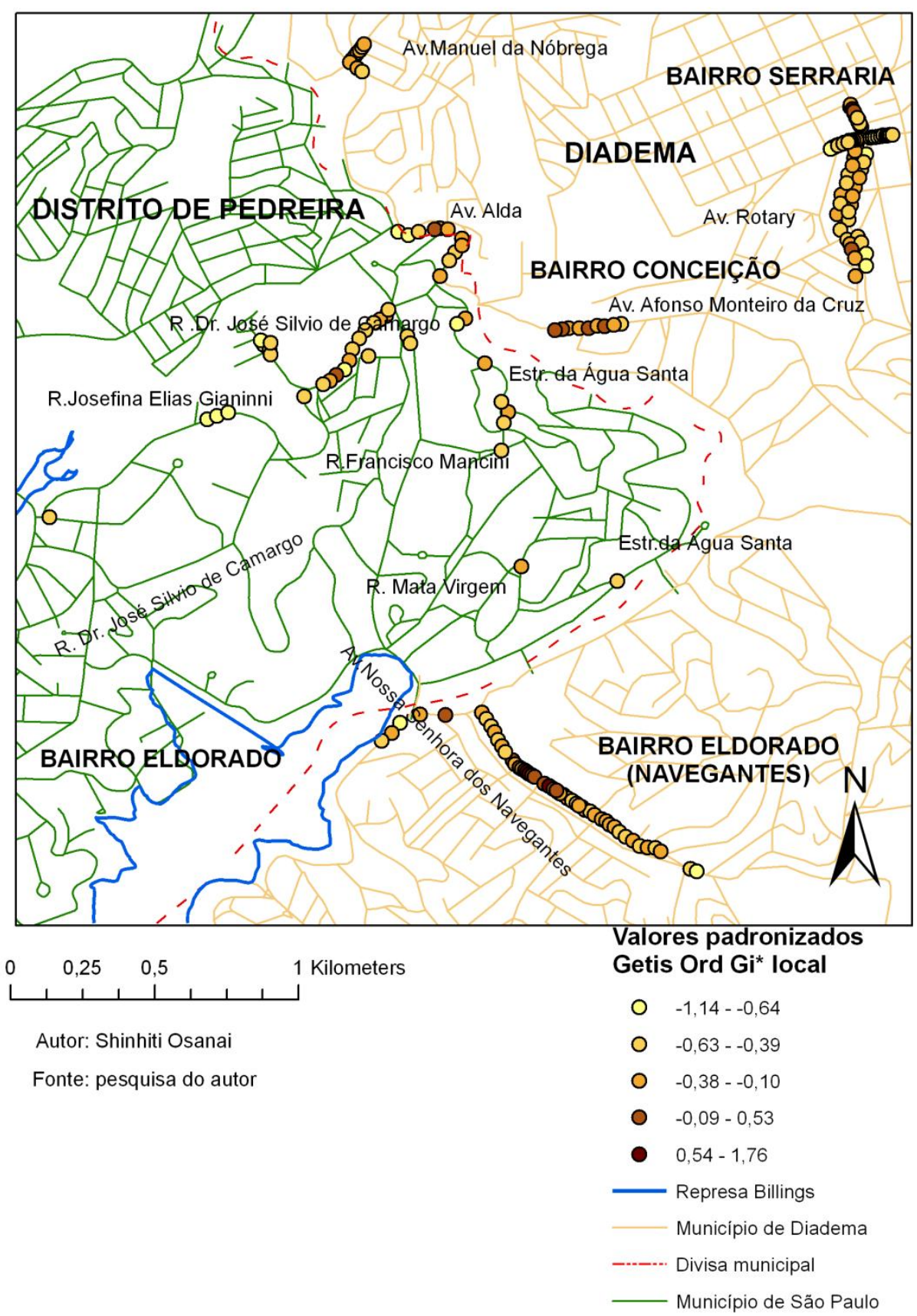


Conforme a tabela 6.9.1, uma quantidade significativa de lojas está dispersa por todo o espaço da região da Av. Yervant Kissajikian, objeto deste estudo. As duas primeiras faixas com o intervalo de $-1,20$ a -0,002, de sinal negativo, correspondem a 47\% das lojas da região, compõem um grupo dissimilar, pelo fato da quantidade de lojas por ramo de atividade estar acima da média, a maioria variando entre 2 e 6 estabelecimentos. Por exemplo, o ramo de vestuário (6 lojas) nas proximidades do Largo da Vila Joaniza, tem vizinhos com ramos de atividade que funcionam com apenas 1 loja, tal como o ramo de óptica (1 loja) nessa mesma via. As três últimas faixas com o intervalo de $-0,001$ a 0,31 , formam um grupo similar, tendo em vista os ramos de atividades funcionarem com 1 loja, por exemplo, o ramo de cosméticos (1 loja) e os seus vizinhos também são ramos de atividades que operam com apenas 1 loja, tal como o ramo de farmácia (1 loja).

Conforme a figura 6.9.1, o intervalo de variação, entre $-1,20$ e 0,31 , é muito estreito, o resultado é estatisticamente pouco significativo por não se enquadrar no intervalo de confiança de $95 \%$. Tal fato indica a condição do número baixo de lojas por ramo de comércio, com predominância da faixa entre 1 e 2 estabelecimentos, e caracteriza a região como um centro comercial local e secundário, relativamente diversificado, onde é possível satisfazer praticamente todas as necessidades de frequiência de compras diária ou semanal.

É uma região cujo espaço de lugar está estruturado para o atendimento da população de renda média e baixa. O visual interno das lojas é bastante simples, a fachada de muitas lojas é relativamente estreita, em geral a variedade do estoque de mercadoria é limitada. Apenas a Casas Bahia faz parte dos estabelecimentos melhor estruturados, por pertencer a grandes redes, e segue um design padrão no arranjo das mercadorias. Algumas lojas de vestuário, principalmente as menores, atraem os compradores expondo as peças de roupas, nas portas. Os imóveis comerciais são pequenos, as padarias e as mercearias ocupam os imóveis de dimensões médias e os alguns supermercados de vizinhança não dispõem de estacionamento. Destacam-se o comércio de confecções e de material de construção.

Localizado no Distrito vizinho de Cidade Ademar, de menor importância para a maioria dos moradores do Distrito de Pedreira, a região apresenta uma razoável estrutura de um centro comercial secundário, tendo em vista a disponibilidade de todos os principais ramos do comércio, por exemplo, eletrodomésticos, magazines e móveis, inclusive agência bancária. Atrai os moradores dos bairros de Jardim Selma, Vila Missionária e Parque Primavera, em consequiência da sua proximidade. Entretanto, o acesso por ônibus está disponível somente 
para os moradores desses três bairros, há a necessidade de transbordo para os moradores provenientes de outras regiões.

Os sinais positivos e negativos, da estatística local Moran's I, indicam a diversidade do comércio local. Constata-se a dissimilaridade, o que apresenta significativa concentração em torno do Largo da Vila Joaniza, em conseqüência de maior participação dos estabelecimentos comerciais. Observa-se a oferta de 4 a 9 lojas em alguns ramos de atividade, por exemplo, o ramo de vestuário (6 lojas), atua na vizinhança do ramo de pet shop (1 ponto de vendas). À medida que se afasta do referido Largo, verifica-se freqüentemente, a redução na disponibilidade de lojas diminuindo para o intervalo entre 1 e 2 lojas por ramo de atividade. Tal fato justifica o resultado dessa estatística bastante próxima de 0 , e não se verifica a ocorrência de evidências de uma forte concentração de lojas.

Tabela 6.9.2 - RESULTADOS DA ESTATÍSTICA LOCAL GETIS ORD GI*-

AV.YERVANT KISSAJIKIAN (mapa número 6.16.2)

\begin{tabular}{cccc}
\hline Getis Ord Gi* & Lojas & $\%$ \\
& Média & Quantidade & \\
\hline$-1,72$ a $-1,14$ & 1,3 & 24 & $11 \%$ \\
$-1,13$ a $-0,76$ & 1,3 & 60 & $28 \%$ \\
$-0,75$ a $-0,47$ & 1,8 & 79 & $37 \%$ \\
$-0,46$ a $-0,12$ & 1,1 & 43 & $20 \%$ \\
$-0,11$ a 0,52 & 1,3 & 8 & $4 \%$ \\
SOMA & & 214 & $100 \%$ \\
\hline
\end{tabular}

Os resultados padronizados variam entre $-1,72$ e 0,52

Fonte: apêndice D

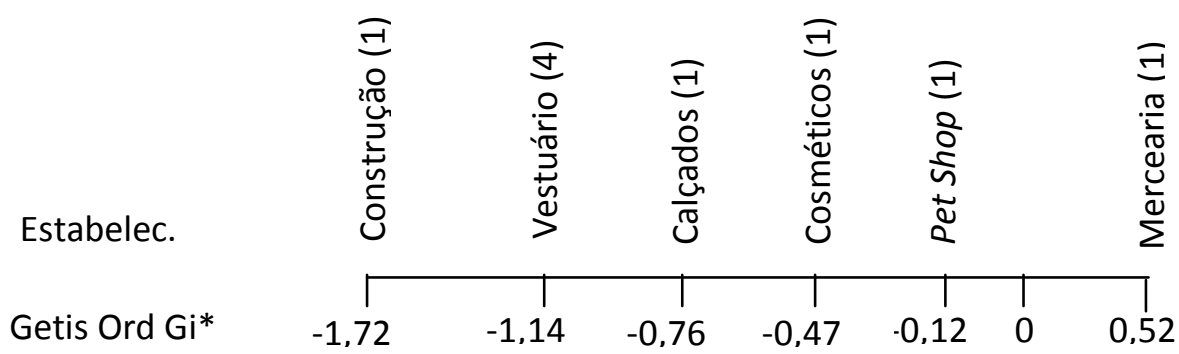

Figura 6.9.2 - distribuição da estatística Getis Ord Gi* da região da Av. Yervant Kissajikian Fonte: apêndice D 
Conforme a tabela 6.9.2, uma quantidade significativa de lojas está dispersa por todo o espaço da região da Av. Yervant Kissajikian. Em todas as faixas, entre -1,72 e 0,52, são encontrados os poucos ramos que mantêm elevado número de lojas, distribuído nas áreas que predominam os ramos com pequenas quantidades de lojas, a maioria entre 1 e 2 estabelecimentos. Esse resultado reflete a situação de uma dispersão geral do comércio.

Conforme a figura 6.5.2, o intervalo de variação, entre $-1,72$ e 0,52 , é uma faixa muito estreita, estatisticamente pouco significativa por não se enquadrar no intervalo de confiança de $95 \%$. Tal fato indica a condição do número baixo de lojas por ramo de comércio, com predominância da faixa entre 1 e 2 estabelecimentos, complementa os resultados da estatística Moran's I o que indica que existe uma dispersão geral de estabelecimentos.

Os resultados das estatísticas locais Getis Ord Gi*, mais próximos de 0, foram obtidos pelos ramos de comércio, que oferecem a quantidade entre 1 e 2 lojas, localizadas um pouco mais afastadas do Largo da Vila Joaniza. Por exemplo, o ramo de pet shop (1 loja) nas proximidades da R. Bauru. Os resultados negativos podem indicar a situação do comércio menos estruturado diante da disponibilidade de menor quantidade de estabelecimentos por ramo de atividade, de maneira geral, e predominância de apenas 1 ou 2 lojas, exceto numa pequena área restrita em torno do Largo da Vila Joaniza. Alguns ramos de comércio, com mais de 4 estabelecimentos, principalmente aqueles mais próximos do Largo da Vila Joaniza, por exemplo, o ramo de vestuário (6 lojas), obteve o resultado negativo em decorrência da disponibilidade de outros ramos que contam com poucas lojas em suas vizinhanças, tal como o ramo de padaria (1 ponto de vendas). 


\section{COMÉRCIO}

RESULTADO DA ESTATÍSTICA MORAN'S I LOCAL AV. YERVANT KISSAJIKIAN

MAPA NÚMERO 6.16.1
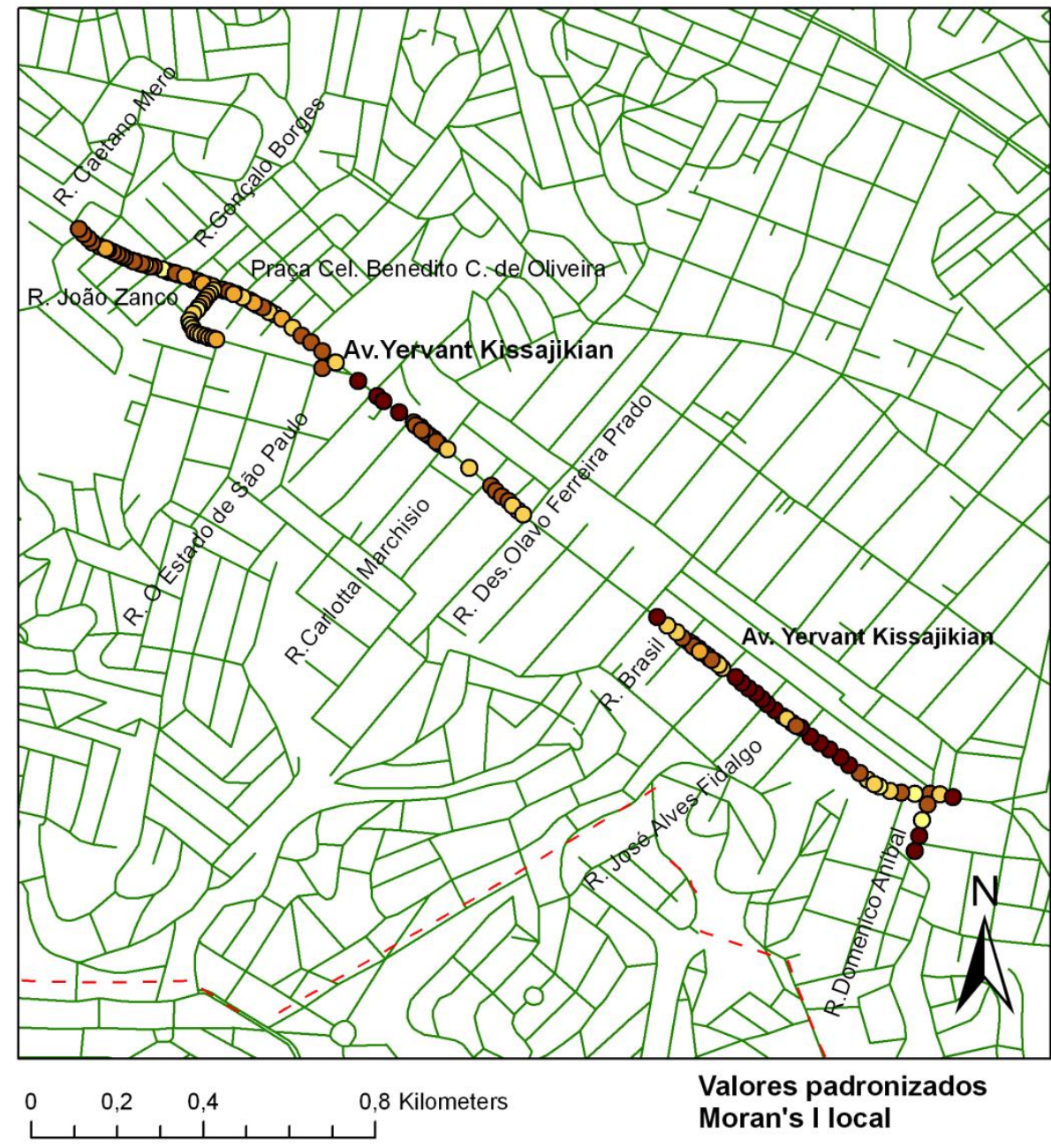

$\begin{array}{cccc}1 & 1 & 1 & 1 \\ \text { Autor: Shinhiti Osanai }\end{array}$

Valores padronizados Moran's I local

Fonte: pesquisa do autor

O $-1,20--0,30$

O $-0,29--0,002$

O $-0,001-0,10$

- $0,11-0,20$

- $0,21-0,31$

Distrito de Pedreira 
COMÉRCIO

RESULTADO DA ESTATÍSTICA GETIS Gi* LOCAL AV. YERVANT KISSAJIKIAN

MAPA NÚMERO 6.16.2
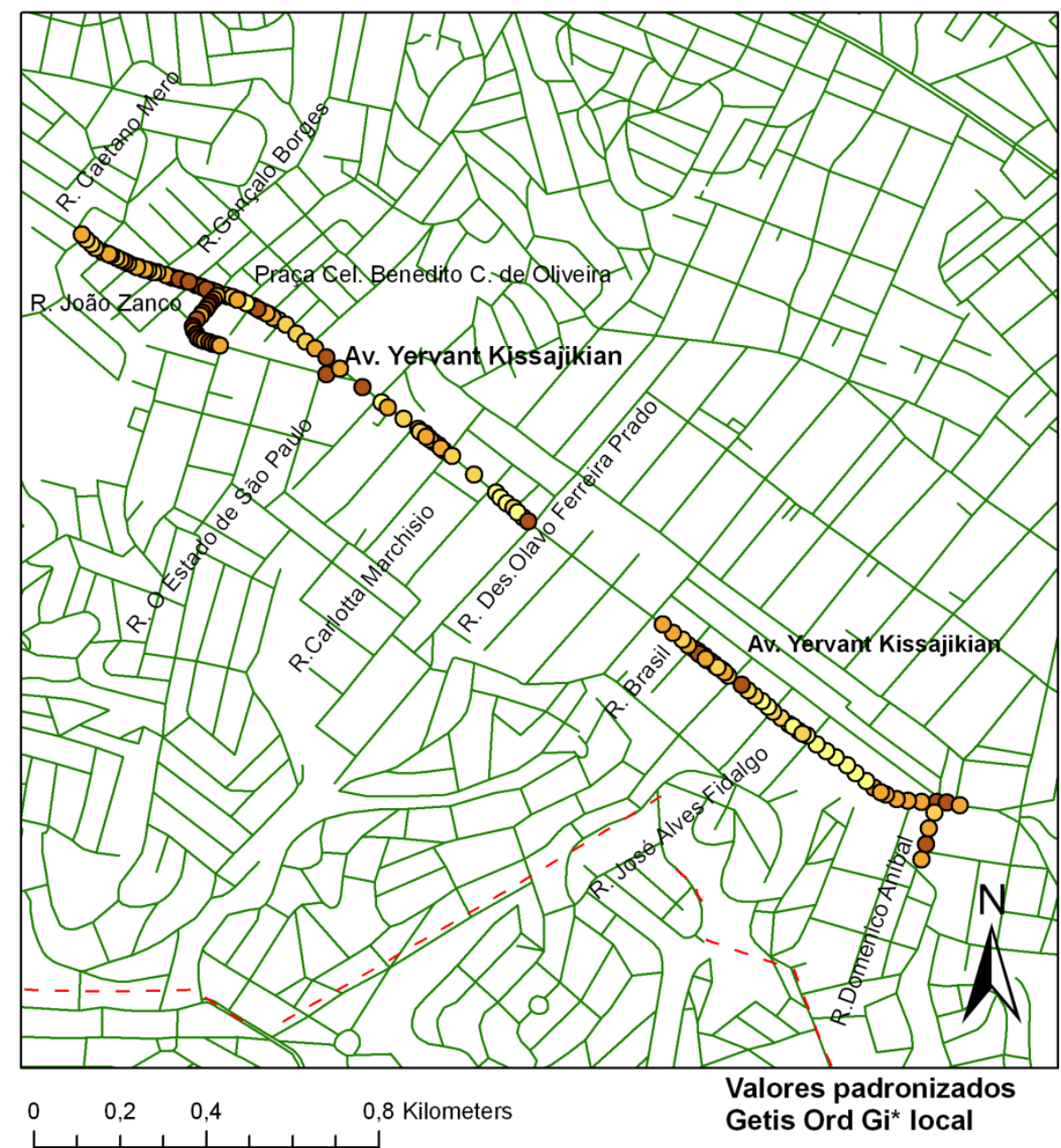

Autor: Shinhiti Osanai

Valores padronizados

Fonte: pesquisa do autor

O $-1,72--1,14$

O $-1,13--0,76$

O $-0,75--0,47$

O $-0,46--0,12$

- $-0,11-0,52$

Distrito de Pedreira 


\subsection{Jardim Miriam}

Tabela 6.10.1 - RESULTADOS DA ESTATÍSTICA LOCAL ANSELIN MORAN'S IJARDIM MIRIAM (mapa número 6.17.1)

\begin{tabular}{cccc}
\hline Moran's I & Média & Lojas & $\%$ \\
\hline$-0,18$ a $-0,01$ & 2,2 & Quantidade & $29 \%$ \\
$-0,009$ a 0,09 & 1,8 & 20 & $31 \%$ \\
0,10 a 0,19 & 1,1 & 16 & $24 \%$ \\
0,20 a 0,28 & 1,0 & 7 & $10 \%$ \\
0,29 a 0,45 & 1,0 & 4 & $6 \%$ \\
SOMA & & 68 & $100 \%$ \\
\hline
\end{tabular}

Os resultados padronizados variam entre $-0,18$ e 0,45

Fonte: apêndice D

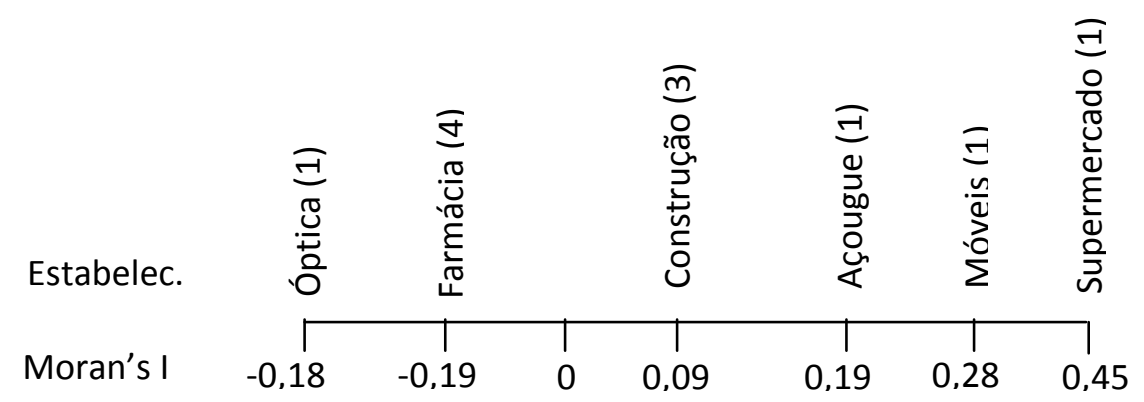

Figura 6.10.1 - distribuição da estatística Moran'I da região do Jardim Miriam Fonte: apêndice D

Conforme a tabela 6.10.1, uma quantidade significativa de lojas está dispersa por todo o espaço da região da Av. Cupecê, no Jardim Miriam, objeto deste estudo. A primeira faixa com o intervalo de $-0,18$ a $-0,01$, de sinal negativo, corresponde a $29 \%$ das lojas da região, compõem um grupo dissimilar, pelo fato da quantidade de lojas por ramo de atividade estar acima da média, a maioria entre 2 e 6 estabelecimentos. Por exemplo, o ramo de vestuário (6 lojas) no Largo do Jardim Miriam tem como seus vizinhos os ramos de atividade que funcionam com apenas 1 loja, tal como o ramo de padaria (1 loja). As quatro últimas faixas com o intervalo de $-0,009$ a 0,45 , formam um grupo similar, tendo em vista a maioria dos ramos de atividades funcionarem com 1 loja. Por exemplo, o ramo de comércio de móveis (1 
loja), tem como vizinhos ramos de atividades que operam com apenas 1 loja, tal como o ramo de material de limpeza (1 loja).

Conforme a figura 6.10.1, o intervalo de variação, entre $-0,18$ e 0,45, é muito estreito, o resultado é estatisticamente pouco significativo por não se enquadrar no intervalo de confiança de $95 \%$. Tal fato indica a condição do número baixo de lojas por ramo de comércio, com predominância da faixa entre 1 e 2 estabelecimentos, e caracteriza a região como um centro comercial local e secundário, relativamente diversificado, onde é possível satisfazer praticamente todas as necessidades de frequiência de compras diária ou semanal.

É uma região cujo espaço de lugar está estruturado para o atendimento da população de renda média e baixa. O visual interno das lojas é bastante simples, a fachada de muitas lojas é relativamente estreita, em geral a variedade do estoque de mercadoria é limitada. Não há lojas que fazem parte de grandes redes. Os imóveis comerciais são pequenos, as padarias e as mercearias ocupam os imóveis de dimensões médias e alguns supermercados de vizinhança funcionam em estabelecimentos de áreas maiores. Destacam-se o comércio de vestuário e de material de construção.

Para alguns moradores da favela da Divisa, contígua à favela do Pantanal, a nordeste do Distrito de Pedreira, na Vila Guacuri, o local mais próximo é o comércio da Avenida São José, no centro de Diadema, que pode ser alcançado a pé em poucos minutos. A região do Largo do Jardim Miriam, cujo acesso é possível através de várias linhas de ônibus passando pela Avenida Senador Vitorino Freire, no bairro do Jardim Luso, pertencente ao Distrito de Cidade Ademar, é uma alternativa relativamente próxima, e oferece o comércio razoavelmente estruturado.

Os valores das estatísticas locais Moran's I mostram que parte do comércio do Largo do Jardim Miriam apresenta características dissimilares em decorrência de alguns ramos oferecerem quantidade de estabelecimentos acima da média. Por exemplo, o ramo de vestuário (6 lojas), nas vizinhanças do ramo de relojoaria (1 loja). Há muitos ramos com apenas 1 ou 2 estabelecimentos. Os resultados muito próximos de 0 indicam a participação maciça de ramos por meio de quantidade de lojas muito próxima à média igual a 1,76, por exemplo, o ramo de produtos para viagem (2 lojas). Não se verifica a ocorrência de evidências de concentração de lojas. 
Tabela 6.10.2 - RESULTADOS DA ESTATÍSTICA LOCAL GETIS ORD GI*-JARDIM

MIRIAM (mapa número 6.17.2)

\begin{tabular}{cccc}
\hline Getis Ord Gi* & Lojas & $\%$ \\
\hline$-1,46$ a $-1,13$ & 1,1 & Quantidade & $12 \%$ \\
$-1,12$ a $-0,91$ & 1,2 & 11 & $16 \%$ \\
$-0,90$ a $-0,50$ & 1,2 & 13 & $19 \%$ \\
$-0,49$ a $-0,22$ & 1,9 & 13 & $19 \%$ \\
$-0,21$ a 0,35 & 1,9 & 23 & $34 \%$ \\
SOMA & & 68 & $100 \%$ \\
\hline
\end{tabular}

Os resultados padronizados variam entre $-1,46$ e 0,35

Fonte: apêndice D

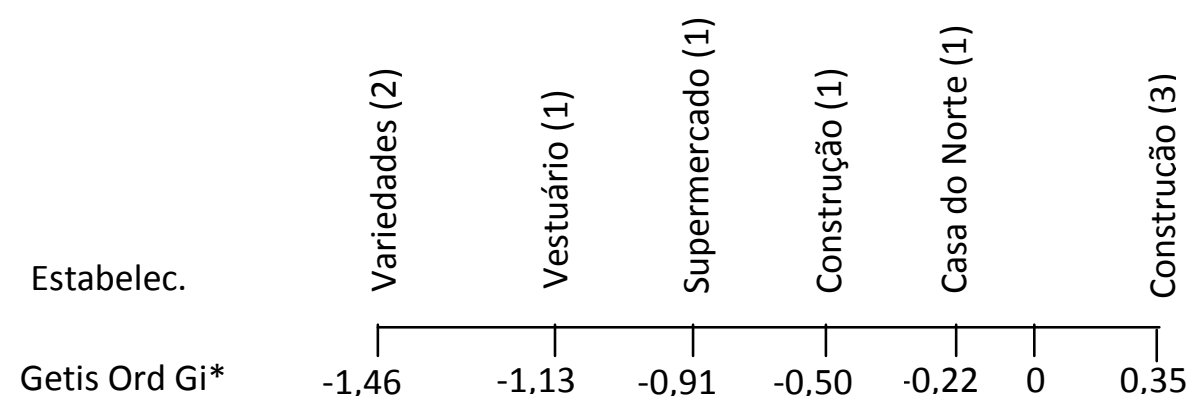

Figura 6.10.2 - distribuição da estatística Getis Ord Gi* da região do Jardim Miriam Fonte: apêndice D

Conforme a tabela 6.10.2, uma quantidade significativa de lojas está dispersa por todo o espaço da região da Av. Cupecê, no Jardim Miriam. Em todas as faixas, entre -1,46 e 0,35, estão os poucos ramos que mantêm elevado número de lojas. Por exemplo, o ramo de confecções (6 lojas), distribuído nas áreas que predominam os ramos que mantêm pequenas quantidades de lojas, a maioria entre 1 e 2 estabelecimentos, por exemplo, o ramo de relojoaria (1 loja). Esse resultado reflete a situação de uma dispersão geral do comércio.

Conforme a figura 6.10.2, o intervalo de variação, entre -1,46 e 0,35, é uma faixa muito estreita, e estatisticamente pouco significativa por não se enquadrar no intervalo de confiança de $95 \%$. Tal fato indica a condição do número baixo de lojas por ramo de comércio, com predominância da faixa entre 1 e 2 estabelecimentos, e complementa os resultados da estatística Moran’s I, o que indica que existe uma dispersão geral de estabelecimentos. 
Os resultados, da estatística local Getis Ord Gi*, muito próximos de 0 indicam a quantidade significativa de lojas muito próxima da média geral igual a 1,76, por exemplo, o ramo de doces (2 lojas). Os valores mais baixos foram obtidos pelos ramos de comércio instalados em regiões que apresentam o funcionamento de apenas 1 loja por ramo de atividade, por exemplo, o ramo de panificação (1 estabelecimento). Os valores negativos, de maneira geral, mostram a situação do comércio trabalhando por meio da participação de poucos estabelecimentos em cada um dos ramos, na maioria das vezes, apenas com 1 ou 2 lojas.

\subsection{Avenida Nossa Senhora do Sabará}

Tabela 6.11.1 - RESULTADOS DA ESTATÍSTICA LOCAL ANSELIN MORAN'S I AVENIDA NOSSA SENHORA DO SABARÁ (mapa número 6.18.1)

\begin{tabular}{cccc}
\hline Moran's I & Média & Lojas & Quantidade \\
\hline$-0,19$ a $-0,06$ & 1,5 & 22 & $19 \%$ \\
$-0,05$ a 0,010 & 1,6 & 31 & $27 \%$ \\
0,011 a 0,05 & 1,1 & 20 & $17 \%$ \\
0,06 a 0,09 & 1,1 & 25 & $22 \%$ \\
0,10 a 0,22 & 1,4 & 18 & $16 \%$ \\
SOMA & & 116 & $100 \%$ \\
\hline
\end{tabular}

Os resultados padronizados variam entre $-0,19$ e 0,22

Fonte: apêndice D

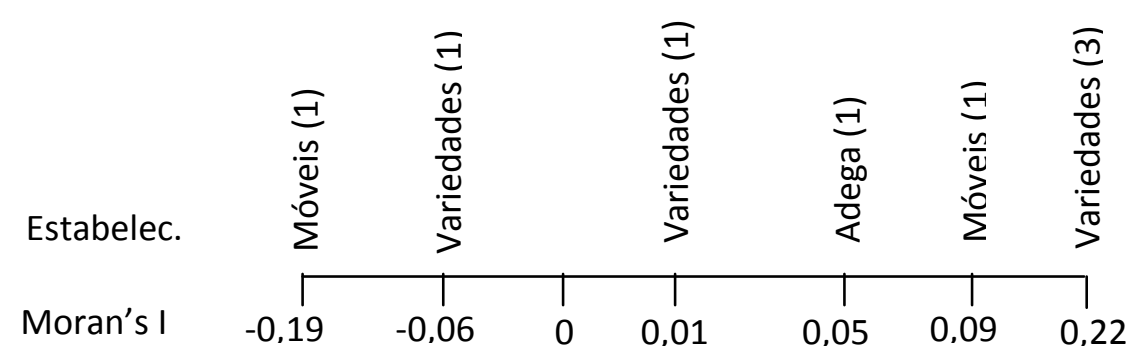

Figura 6.11.1- distribuição da estatística Moran'I da região da Av. N.S. do Sabará Fonte: apêndice D 
COMÉRCIO

\section{RESULTADO DA ESTATÍSTICA MORAN'S I LOCAL AV.CUPECÊ (JARDIM MIRIAM)}

MAPA NÚMERO 6.17.1

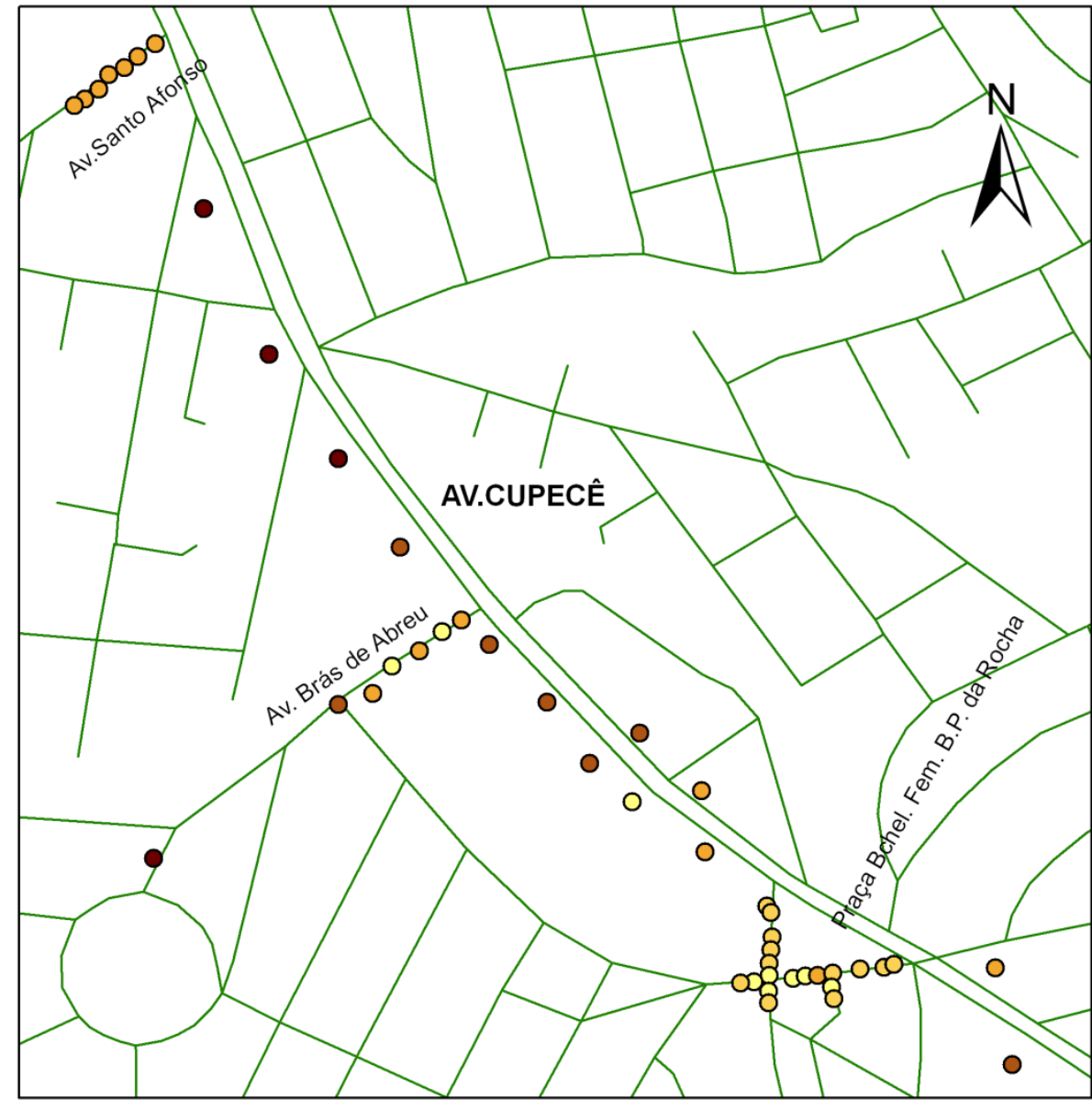

$\begin{array}{llll}0 & 0,05 & 0,1 & 0,2\end{array}$ Kilometers

Valores padronizados

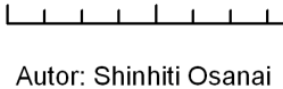
Moran's I local

Fonte: pesquisa do auto
O $-0,18--0,01$
O $-0,009-0,09$
○ $0,10-0,19$
○ $0,20-0,28$
- $0,29-0,45$ 
COMÉRCIO

RESULTADO DA ESTATÍSTICA GETIS Gi* LOCAL AV.CUPECÊ (JARDIM MIRIAM)

MAPA NÚMERO 6.17.2

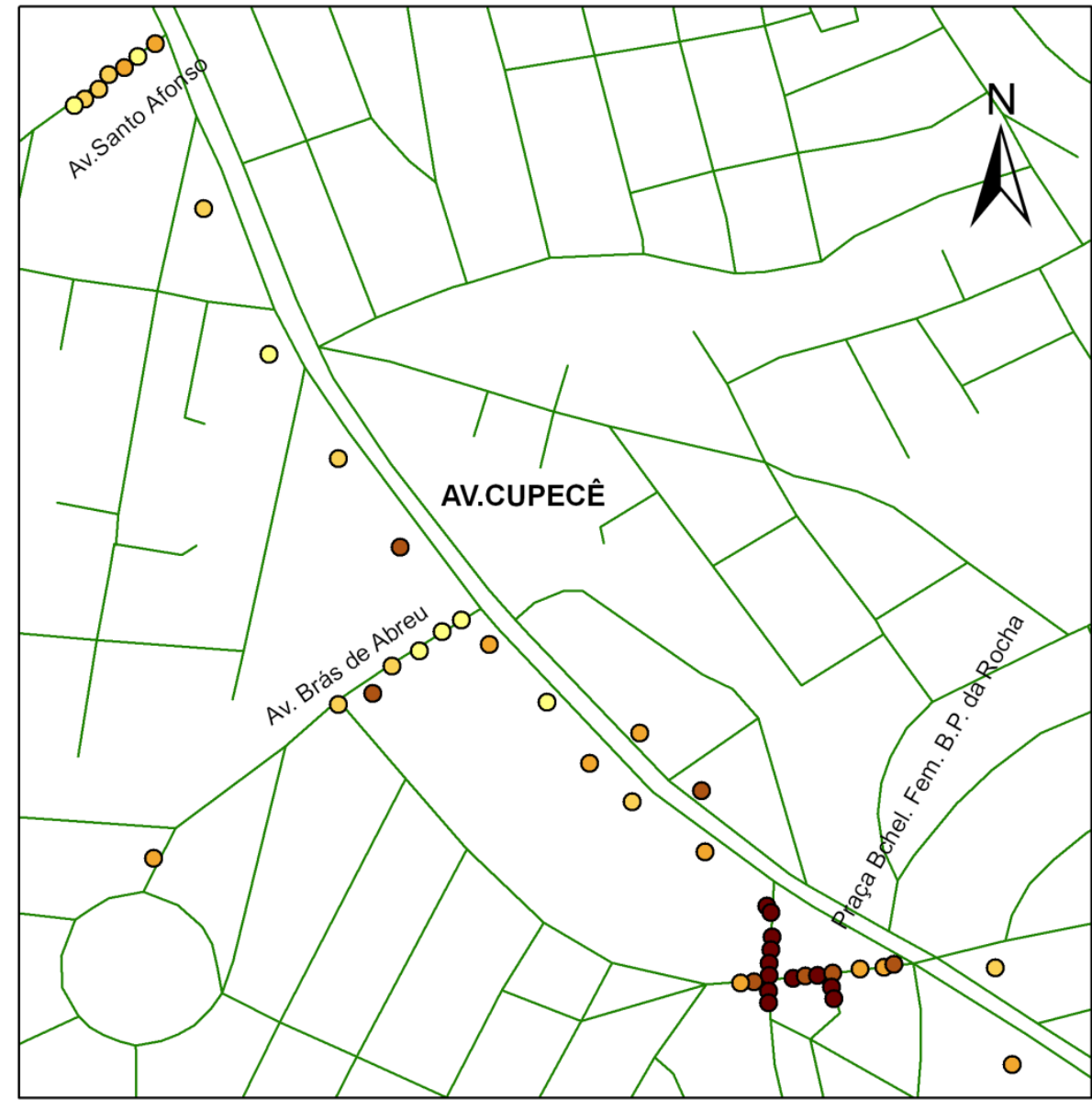

$\begin{array}{llll}0 & 0,05 & 0,1 & 0,2\end{array}$ Kilometers

Autor: Shinhiti Osanai

Valores padronizados Getis Ord Gi* local

Fonte: pesquisa do autor

$$
\begin{array}{ll}
\text { O } & -1,46--1,13 \\
\text { O } & -1,12--0,91 \\
\text { O } & -0,90--0,50 \\
\text { O } & -0,49--0,22 \\
\hline & -0,21-0,35
\end{array}
$$


Conforme a tabela 6.11.1, uma quantidade significativa de lojas está dispersa por todo o espaço da região da Av. Nossa Senhora do Sabará, objeto deste estudo. As duas primeiras faixas com o intervalo de $-0,19$ a 0,010 , maioria de sinal negativo, correspondem a $46 \%$ das lojas da região, compõem um grupo dissimilar, pelo fato da quantidade de lojas por ramo de atividade estar acima da média, a maioria variando entre 2 e 4 estabelecimentos. Por exemplo, o ramo de móveis (3 lojas), tem vizinhos em ramos de atividade que funcionam com apenas 1 loja, tal como o ramo de confecção (1 loja). As três últimas faixas, com o intervalo de 0,011 a 0,22, formam um grupo similar, que apresentam sinais positivos, tendo em vista alguns dos ramos de atividades funcionarem com 1 loja. Por exemplo, o ramo de padaria (1 loja) tem como vizinhos os ramos de atividades que operam com apenas 1 loja, tal como o ramo de colchões (1 loja). Ambas as situações estão abaixo da média, bem como, existem a situação acima da média, com outros ramos de atividades que atuam através de 2 ou mais lojas. Por exemplo, o ramo de comércio de variedades (3 lojas) tem como seus vizinhos, ramos que funcionam por meio de 2 ou mais estabelecimentos, tal como o ramo de farmácia (2 lojas).

Conforme a figura 6.11.1, o intervalo de variação, entre $-0,19$ e 0,22, é muito estreito, o resultado é estatisticamente pouco significativo por não se enquadrar no intervalo de confiança de $95 \%$. Tal fato indica a condição do número baixo de lojas por ramo de comércio, com predominância da faixa entre 1 e 2 estabelecimentos, e caracteriza a região como sendo um centro comercial local e secundário, onde é possível satisfazer praticamente todas as necessidades de frequiência de compras diária ou semanal.

É uma região cujo espaço de lugar encontra-se estruturado para o atendimento da população de renda média e baixa. O visual interno das lojas é bastante simples, a fachada de muitas lojas é relativamente estreita, em geral a variedade do estoque de mercadoria é limitada. A única loja que faz parte de grandes redes é o Supermercado Compre Bem. Os imóveis comerciais são pequenos, as padarias ocupam os imóveis de dimensões médias. Nota-se uma forte presença do ramo de móveis com 13 lojas, ocupando instalações de tamanho médio, e de confecções com 15 lojas. Por causa das lojas de móveis observa-se a participação de lojas de decorações.

Atende preferencialmente, em pequena escala, os moradores da Vila Aparecida e do Balneário Mar Paulista. O comércio de móveis é predominante na região, sendo relevante a oferta do serviço bancário por meio das agências dos principais bancos. É um local de 
transbordo para os ônibus de passagem pela Avenida Interlagos em direção a várias localidades da Cidade de São Paulo.

A quantidade de lojas de alguns ramos de atividade é ligeiramente superior à Avenida Yervant Kissajikian, em termos médios. Os resultados, da estatística local Moran's I, muito próximos de 0 , indicam que a maioria dos ramos atua através da quantidade de lojas muito próxima da média geral igual a 1,76, por exemplo, o ramo de óptica (2 lojas). Não se verifica a ocorrência de evidências de elevada concentração de lojas.

As dissimilaridades, constatadas pelos sinais negativos, são provenientes do ramo de móveis diante de eventuais situações de uma determinada loja, que possui como vizinhos outros ramos de atividade com 1 estabelecimento. Por exemplo, o ramo de móveis (4 lojas) nas vizinhanças do ramo de açougue (1 estabelecimento).

\section{Tabela 6.11.2 - RESULTADOS DA ESTATÍSTICA LOCAL GETIS ORD GI* - AVENIDA NOSSA SENHORA DO SABARÁ (mapa número 6.18.2)}

\begin{tabular}{cccc}
\hline Getis Ord Gi* & Média & Lojas & $\%$ \\
\hline$-0,68$ a $-0,50$ & 1,3 & 21 & $18 \%$ \\
$-0,49$ a $-0,31$ & 1,2 & 30 & $26 \%$ \\
$-0,30$ a $-0,12$ & 1,5 & 35 & $30 \%$ \\
$-0,11$ a 0,12 & 1,4 & 23 & $20 \%$ \\
0,13 a 0,40 & 1,2 & 7 & $6 \%$ \\
SOMA & & 116 & $100 \%$ \\
\hline
\end{tabular}

Os resultados padronizados variam entre $-0,68$ e 0,40

Fonte: apêndice D

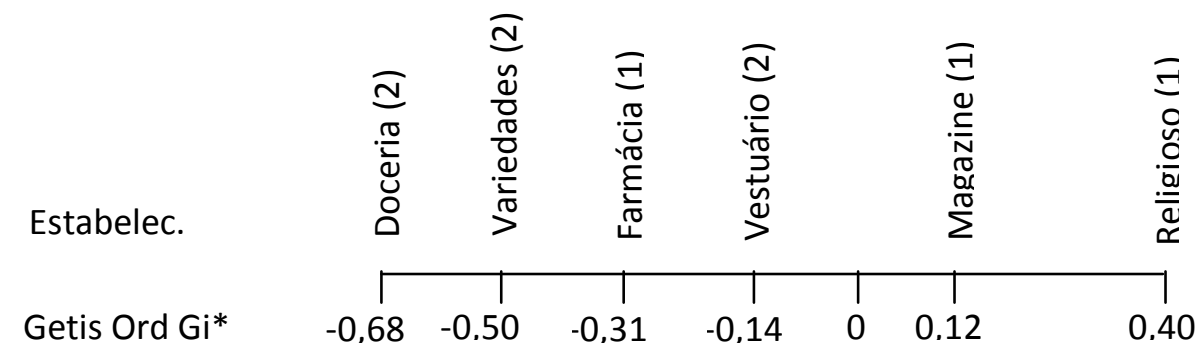

Figura 6.11.2 - distribuição da estatística Getis Ord Gi* da região da Av.N.S. do Sabará

Fonte: apêndice D 
Conforme a tabela 6.11.2, uma quantidade significativa de lojas encontra-se dispersa por todo o espaço da região da Av. Nossa Senhora do Sabará. Em todas as faixas, entre -0,68 e 0,40, são poucos os ramos que mantêm elevado número de lojas, distribuído nas áreas que predominam os ramos que mantêm pequenas quantidades de lojas, sendo a maioria entre 1 e 2 estabelecimentos. Esse resultado reflete a situação de uma dispersão geral do comércio.

Conforme a figura 6.11.2, o intervalo de variação, entre $-0,68$ e 0,40 , é uma faixa muito estreita, e estatisticamente pouco significativa por não se enquadrar no intervalo de confiança de $95 \%$. Tal fato indica a condição do número baixo de lojas por ramo de comércio, com predominância da faixa entre 1 e 2 estabelecimentos, e complementa os resultados da estatística Moran’s I, o que indica que existe uma dispersão geral de estabelecimentos.

Os resultados, da estatística local Getis Ord Gi*, próximos de 0 indicam que a quantidade de lojas dos diversos ramos está muito próxima da média geral igual a 1,76, por exemplo, o ramo de pet shop (2 lojas). Os valores negativos mostram, a situação do comércio menos estruturado pela disponibilidade de poucos estabelecimentos em cada um dos ramos, a maioria com apenas 1 ou 2 lojas, por exemplo, o ramo de calçados (1 ponto de vendas). 
COMÉRCIO

\section{RESULTADO DA ESTATÍSTICA MORAN'S I LOCAL AV.NOSSA SENHORA DO SABARÁ}

MAPA NÚMERO 6.18.1

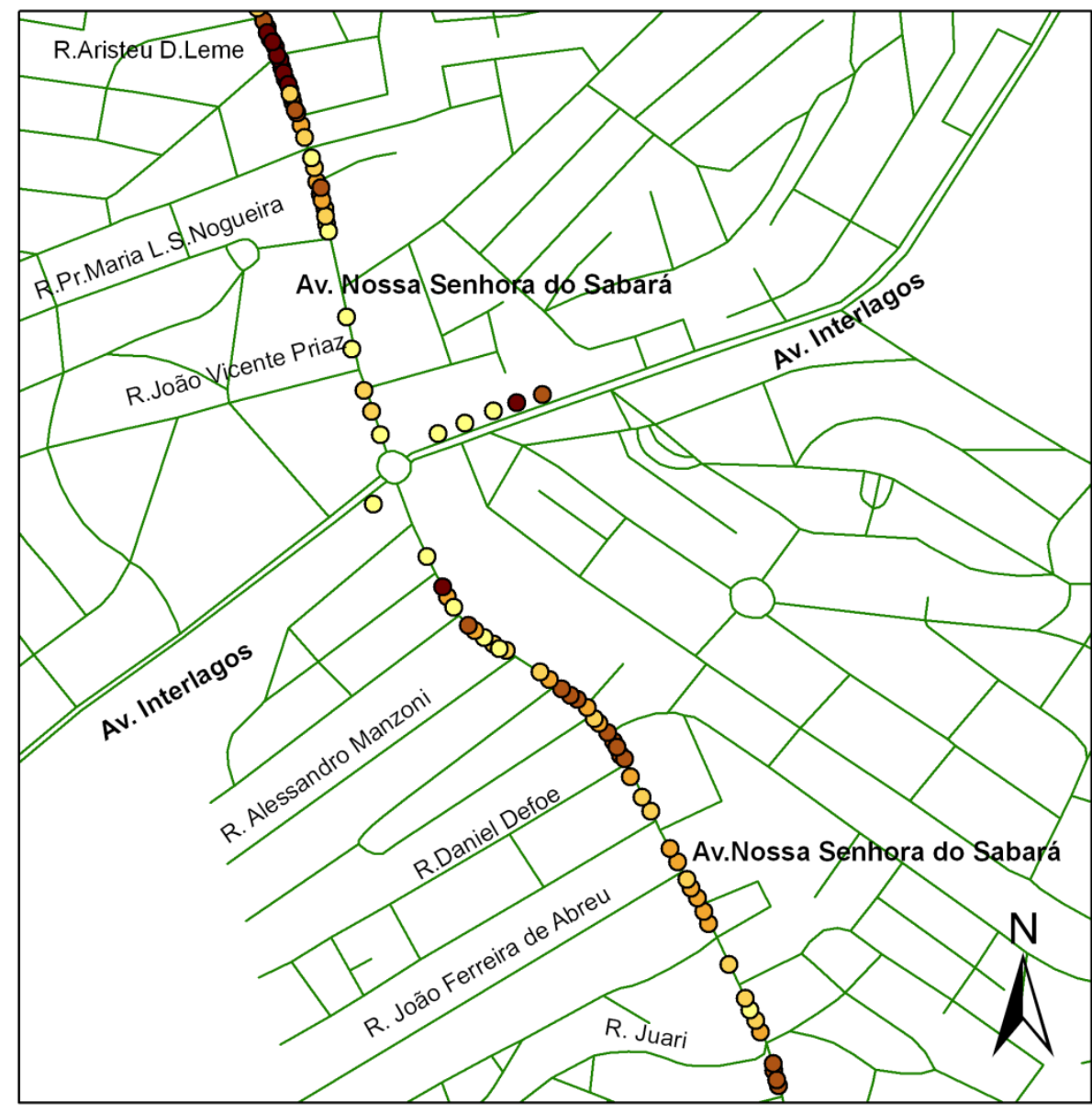

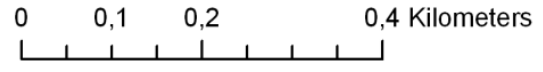

Autor: Shinhiti Osanai

Fonte: pesquisa do autor

\section{Valores padronizados} Moran's I local
O $-0,19--0,06$
O $-0,05-0,01$
○ $0,012-0,05$
○ $0,06-0,09$
- $0,10-0,22$ 


\section{COMÉRCIO}

\section{RESULTADO DA ESTATÍSTICA GETIS Gi* LOCAL AV.NOSSA SENHORA DO SABARÁ}

MAPA NÚMERO 6.18.2

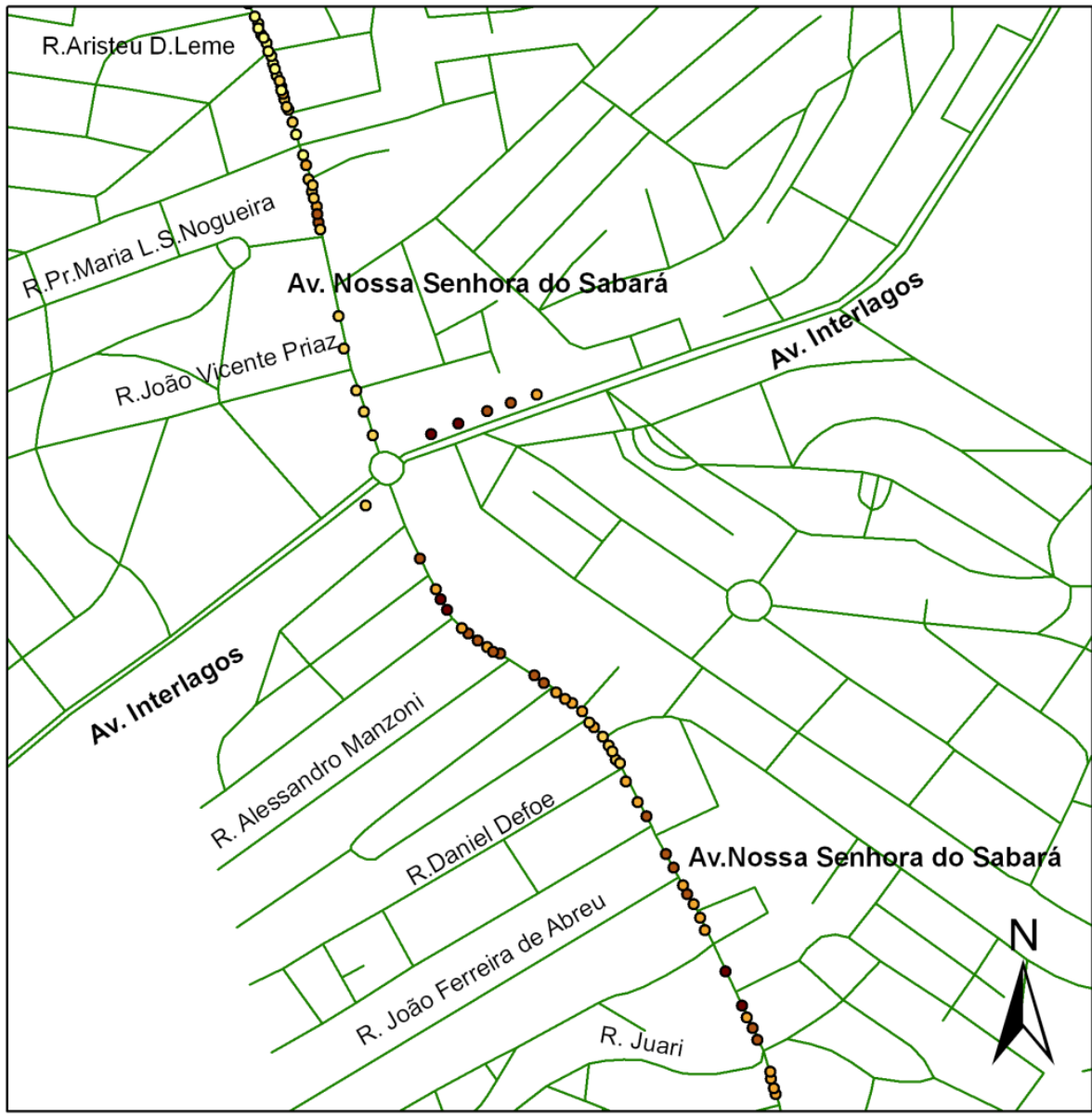

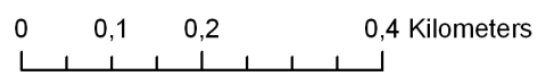

Autor: Shinhiti Osanai

Fonte: pesquisa do autor

\section{Valores padronizados} Getis Ord Gi* local
- $-0,68--0,50$
○ $\quad-0,49--0,31$
- $-0,30--0,12$
- $\quad-0,11-0,12$
- $0,13-0,40$ 
CONSIDERAÇÕES FINAIS 
A proposta deste trabalho é, em relação às pessoas que residem no Distrito de Pedreira, a identificação de uma das causas que torna um local distante, por exemplo, o Largo 13 de Maio, o centro destacado e importante, que compete espacialmente com outros centros mais próximos dos moradores, tais como Diadema ou Shopping Center Interlagos. Para a análise da relação entre a causa e o efeito, obteve-se uma rede de relacionamentos, com os moradores conectados a três pontos de convergência social determinados pelos centros principais, Largo 13 de Maio, Shopping Center Interlagos ou Diadema, bem como, pelos centros secundários, por exemplo, Estrada do Alvarenga, Parque Santa Amélia, entre outros.

Essa rede de relacionamentos é constituída por uma modalidade particular de rede social do comércio, cujo foco principal está delimitado apenas ao abastecimento da população, que apresenta uma morfologia parcial, tendo em vista a ausência das fontes de suprimento dos estabelecimentos comerciais. O objetivo principal dessa referida delimitação é evitar os riscos de alterações nos resultados das medidas de centralidade, que estabelecem os níveis hierárquicos, bem como, na formação dos centros de influência em relação aos grupos de moradores, as quais podem ser causadas pela participação dos fornecedores do comércio, caso todos façam parte da mesma estrutura morfológica da rede. O grande número de atacadistas, que abastecem o comércio dos centros secundários, pode aumentar o valor das medidas de centralidade dos estabelecimentos, que funcionam nesses centros locais menos importantes. Os fabricantes, em menor número, que abastecem as lojas de maior porte localizadas nos centros principais, podem reduzir o valor das medidas de centralidade do comércio instalado nesses centros mais importantes. Portanto, caso haja a participação dos fornecedores, existe o risco de interferência nos resultados proporcionados pelo espaço de fluxos. Por exemplo, as medidas de centralidade do Largo 13 de Maio poderiam apresentar resultados mais baixos e dos centros secundários mais altos, em comparação aos resultados mais consistentes que foram obtidos por meio da aplicação do modelo de uma rede parcial, utilizado neste trabalho.

Entendem-se como lugares os centróides que representam cada setor censitário e também todos os pontos de comércio instalados nos centros principais e secundários, que constituem a estrutura básica dessa rede.

Segundo Castells (2005), o espaço é a expressão da sociedade, na qual inclui as pessoas, que fazem parte de uma rede de relacionamentos. Para ele, a sociedade está construída em torno de fluxos sendo um deles os fluxos de interação organizacional. A idéia e os conceitos de espaço de fluxos, desenvolvidos pelo autor, estão mencionados no capítulo 3 página 81 . Além 
disso, o espaço é também a expressão da natureza o lugar onde se desenvolve todas as atividades da sociedade.

Neste trabalho, o espaço de fluxos para os moradores do Distrito de Pedreira é diretamente dependente de dois itens. O primeiro é o sistema de transporte urbano, que é o suporte para permitir o acesso aos centros principais e secundários por meio dos serviços prestados pelas linhas de ônibus, mencionados no capítulo 4 página 136. O segundo é formado pelos centros principais e secundários cujos conceitos estão apresentados no capítulo 5.

Nessa organização espacial, a conotação básica de espaço não são somente os lugares, mas também de fluxos. Em analogia a uma figura, cada ônibus equivale aos sinais eletrônicos percorrendo uma rede de conexões por internet e a estrutura da rede é composta pelas vias de circulação por onde cada linha de ônibus tem o seu itinerário pré determinado pela administração municipal de São Paulo e de Diadema, para os serviços municipais, e pela Secretaria de Assuntos Metropolitanos, para as linhas intermunicipais. Os centros e os setores censitários, representados por nós de uma rede, são constituídos por lugares. E esses nós fazem parte da estrutura básica necessária para a composição dessa rede e assim permitir a plena circulação dos seus fluxos.

Uma questão básica identificada neste trabalho, em relação aos centros comerciais, é a opção dos moradores para determinados tipos de bens, pelos locais que ficam mais distantes, quando existem alternativas de centros bem mais próximos e que não são utilizadas. Nesse caso considera-se como proximidade apenas a localização geográfica, ou seja, somente a distância, sem levar em consideração o tempo de locomoção nem os custos da tarifa dos serviços de transportes. A estrutura da rede pode fornecer algumas informações sustentáveis ao permitir uma visualização dos fluxos dos relacionamentos, após a análise dos níveis hierárquicos e das suas medidas de centralidade de cada centro, conforme apresentado no capítulo 5.

A interação organizacional através do espaço de fluxos é constituída por meio do suporte oferecido pelo sistema de transporte urbano, que adota uma tarifa única, independentemente da distância percorrida pelo ônibus, além da possibilidade de integração sem o pagamento de uma tarifa adicional durante o período de até três horas. Torna-se possível, dentro desse período de tempo, a locomoção até Santo Amaro, executar rapidamente alguma compra e retornar ao ponto de origem, não havendo a necessidade de pagamento adicional do valor da passagem de volta. Igualmente, fazem parte integrante do espaço de fluxos, as pessoas 
provenientes de setores que podem ser de renda elevada ou baixa, as necessidades de compras de diferentes categorias de bens, a renda da população, etc.

O transporte urbano é um dos fatores indutores dos padrões espaciais. O acesso a Santo Amaro, mais distante, é fácil a partir de qualquer local do Distrito de Pedreira, pois existem serviços de ônibus, com origem em vários bairros, conforme o mapa número 4.19 da página 138. O mesmo não acontece com Diadema, pela carência de serviços intermunicipais, a não ser nas regiões bem próximas à divisa municipal, onde há disponibilidade de serviços urbanos de Diadema. Em geral, as tarifas das linhas intermunicipais são mais elevadas em comparação às municipais e não dão direito a integração fora dos terminais de ônibus.

Por se tratar de espaço de fluxos, a distância física e o tempo de deslocamento estão fora do seu contexto. A tarifa única dos serviços de ônibus é parte integrante desse espaço de fluxos, conseqüentemente a organização espacial por meio dos preços únicos cobrados nos serviços de transporte coletivo é uma das causas principais da determinação dos níveis hierárquicos elevados de alguns centros mais distantes, por exemplo, o Largo 13 de Maio.

Sob a ótica da interação organizacional, dentro do espaço de fluxos a renda também é um dos seus componentes, determinados moradores de setores, que apresentam renda mais elevada, tendem a manter a quantidade mais significativa de contatos com o comércio, realizando compras no Largo 13 de Maio ou no Shopping Center Interlagos, indistintamente, bem como, nos vários centros secundários mais próximos. Outros moradores, também de setores de renda alta, manifestam maior preferência pelo Shopping Center Interlagos e deixam de utilizar os centros secundários mais próximos.

Os moradores de setores de renda mais baixa, preferem o Largo 13 de Maio, utilizam os centros secundários próximos das residências com certa intensidade, mas evitam o Shopping Center Interlagos. Muitos setores de renda mais baixa se localizam na região sul, de relevo acidentado e comércio pouco estruturado. Nesses setores, tanto o relevo desfavorável, quanto a renda baixa dos moradores não incentivam o crescimento do comércio, tendo em vista, que a ocupação do espaço pelo comércio se estabelece diretamente por meio do lucro obtido nos negócios. Por meio do espaço de fluxos, a renda ajuda a fortalecer alguns centros, aumentando os seus níveis hierárquicos, ou podem enfraquecer outros, reduzindo os seus níveis hierárquicos. 
Nas áreas de proteção ambiental principalmente onde se verificam a ocupação por invasão e loteamentos irregulares, muitas vezes formados por favelas, a renda mais baixa e também a estrutura urbana muitas vezes precária, por causa das declividades acentuadas, que podem encarecer significativamente os custos da construção de imóveis comerciais mais adequados, podem criar algumas barreiras para o crescimento comercial, bem como, pode dificultar o acesso dos serviços de ônibus até as proximidades das moradias. Por exemplo, o trecho da Estrada da Água Santa, a partir da Rua Vinte até a Av. Alda, no bairro de Eldorado, torna-se inadequado para a operação de veículos maiores e pesados, do tipo ônibus. O espaço de fluxos, sob a ótica de renda, pode explicar o desenvolvimento espacial desigual, por meio de uma rede de relacionamentos com características nodais heterogêneas de cada um dos seus nós que representam os lugares.

Em relação ao espaço de fluxos, os serviços de transporte coletivo que realizam as conexões entre os nós de uma rede, envolvem os interesses dos empresários que prestam serviços de transporte urbano, apesar de serem administrados pela Prefeitura. Todos os valores arrecadados são recolhidos para uma espécie de "caixa único", a câmara de compensação sob administração da SPTrans, e a Prefeitura remunera as empresas participantes pelo serviço prestado. A maioria dos micros ônibus é operada pelos seus proprietários, associados a determinadas cooperativas, que não possuem interesse em atender itinerários muito longos sob a alegação que a rentabilidade torna-se baixa. Portanto, o espaço de fluxos pode criar populações funcionalmente diferenciadas. O critério da remuneração é a quantidade de passageiros transportados. Todos os empresários procuram operar linhas com elevada demanda de passageiros e por causa disso não chegam a percorrer toda a extensão da Estrada da Água Santa ou da R. Dr. José Silvio de Camargo, pois são considerados trechos de custos elevados e muito pouca demanda.

Enquanto existir demanda elevada de passageiros para Santo Amaro, os empresários estarão motivados a continuarem com a prestação de serviço. O espaço de fluxos é muito vulnerável aos interesses dos empresários de transporte coletivo, sendo assim, o fluxo de pessoas do Distrito de Pedreira para Santo Amaro pode alterar significativamente, na hipótese de mudanças nos atuais itinerários, tornando possível a alteração significativa da atual posição hierárquica vantajosa do Largo 13 de Maio. Novos nós poderão ser formados e estabelecer novos lugares na rede de relacionamentos, sempre que houver alterações no espaço de fluxos na ótica do transporte urbano. 
O espaço de fluxos proporciona vantagens a Santo Amaro e desvantagem a Diadema no processo de competição espacial. O espaço de fluxos pode determinar as forças que entram em ação. Por exemplo, o serviço de transporte coletivo, cuja conseqüência é a produção das formas de organização espacial do comércio, cria diferenciação interna entre os vários centros comerciais. Tornam-se elementos importantes os pontos de conexão e os pontos de embarque e desembarque.

As relações sócio-espaciais podem ser criadas em forma de redes por meio do espaço de fluxos, que determina a morfologia espacial e a divisão funcional do espaço ao estabelecer os níveis hierárquicos. $\mathrm{O}$ espaço de fluxos pode realizar a articulação entre os moradores e o espaço, possibilitar o bem estar espacial no abastecimento ou as vantagens comparativas do espaço de lugares. Entende-se o bem estar espacial como um conjunto de facilidades oferecidas pelo comércio, tais como a variedade dos produtos oferecidos, a localização dos estabelecimentos em relação às moradias, acessibilidade mais vantajosa e a qualidade dos serviços oferecidos. O Shopping Center Interlagos oferece instalações que proporcionam um razoável conforto para as compras ou o Largo 13 de Maio oferece vantagens de preços mais competitivos para os produtos populares.

Quanto aos padrões espaciais, o espaço de fluxos é responsável pelo agrupamento ou a dispersão dos centros comerciais. A dependência espacial, em conseqüência dos agrupamentos decorrentes das formações dos centros, cria necessidades tanto para o comércio quanto para os prestadores de serviços, ou seja, sempre um depende do outro: o empresário do setor de transportes terá interesse pelo itinerário caso haja demanda de passageiros, a qual pode ser a consequiência da atração exercida por um centro comercial, por exemplo, o Largo 13 de Maio. Entretanto, a maior circulação de pessoas pode ser proporcionada pela disponibilidade de um serviço de ônibus, ao conduzir os passageiros até determinados locais. Alterações no espaço de fluxos podem causar a decadência ou o crescimento de certos centros comerciais, a manutenção e a continuidade do espaço de fluxos vigente podem garantir as funcionalidades habituais dos centros já instalados. Os locais dotados de parques industriais, por exemplo, Santo Amaro, apesar das indústrias, aos poucos, estejam se transferindo para outras cidades, continuam a atrair pessoas à procura de trabalho, o que gera o mínimo de fluxo de passageiros e ajuda a fortalecer também o centro comercial existente.

Determinados ramos de comércio podem criar grande fluxo de pessoas, o que ajuda a fortalecer alguns centros. Por exemplo, no Parque Santa Amélia, o Supermercado Pedreira 
incentiva o crescimento de um centro comercial local nas suas proximidades por causa do seu poder de atração dos moradores. Na Estrada do Alvarenga, o comércio estruturado ajuda a atrair as pessoas e possibilita a lucratividade mínima aos empresários locais. No Jardim Rubilene, caso o Supermercado Mamb's encerre as suas atividades, o centro local poderá chegar à decadência. $\mathrm{O}$ espaço de fluxos pode determinar as características principais dos centros secundários do Distrito de Pedreira, que apresenta em cada quadra das vias, onde se encontra instalado, 1 ou 2 lojas por ramo de comércio. No comércio organizado, de forma linear no eixo das vias principais, sempre existe algum local de maior concentração, tais como a Praça Acuri na Estrada do Alvarenga, o Largo do Jardim Miriam na Av. Cupecê, o Largo da Vila Joaniza na Av. Yervant Kissajikian ou no cruzamento da Av. Interlagos com a Av. Nossa Senhora do Sabará.

Um centro comercial pode formar em locais de maior circulação de pessoas, nas proximidades de aglomeração de moradores, por exemplo, a Estrada do Alvarenga. Entretanto, esses agrupamentos de moradores também podem funcionar como uma espécie de geradores de espaço de fluxos podendo acontecer a formação de centros ou lugares como consequiência do espaço de fluxos. Os bairros mais antigos e melhor estruturados do Distrito de Pedreira, tais como Vila Aparecida, Balneário Mar Paulista, Vila Paineira, Jardim Selma, de população elevada, são geradores de espaço de fluxos permitindo a manutenção e a lucratividade necessária para o funcionamento do centro secundário da Estrada do Alvarenga ou continuar a fortalecer o nível hierárquico do Largo 13 de Maio. Todavia, apesar de uma significativa população, os bairros mais periféricos como Eldorado, na ausência de um centro comercial local, funcionam como geradores do espaço de fluxos para os centros de Diadema e estabelecem uma diferenciação funcional do espaço urbano.

O espaço de fluxos, muitas vezes, participa apenas da manutenção do estado vigente do espaço de lugares em função da estrutura existente e nem sempre possui poderes para criar soluções diante do desenvolvimento espacial desigual. Na região sul do Distrito de Pedreira, a lei de proteção dos mananciais pode interferir no espaço de fluxos, ao inviabilizar a instalação de um comércio local adequado e melhor estruturado em áreas bastante populosas e estabelecidas pelo processo de invasão.

Em referência ao conteúdo do capítulo 5, a morfologia da rede social depende de dois importantes componentes: o espaço de lugares e o espaço de fluxos. $\mathrm{O}$ espaço de lugares, que representa os setores censitários, define apenas os nós dos moradores e o determinante dos 
nós do comércio é o espaço de fluxos cujo componente principal é a tarifa dos serviços de transporte coletivo, embora os estabelecimentos comerciais estejam localizados em lugares. A disponibilidade de serviços de ônibus que adota o sistema de tarifa única garante as vantagens de acessibilidade aos centros comerciais localizados relativamente distantes das residências. $\mathrm{O}$ nível hierárquico elevado do Largo 13 de Maio, bastante distante dos moradores, é conseqüência da acessibilidade proporcionada pelo sistema de transporte urbano. O espaço de fluxos organiza uma rede de relacionamentos cujos nós que representam os centros de comércio não estão localizados em lugares em função de variáveis lógicas e racionais do tipo distância, ao contrário do modelo da teoria do lugar central de Christaller. Excepcionalmente, para alguns moradores próximos à divisa, que não dispõem de comércio local estruturado e de serviços de transporte coletivo, o espaço de lugar passa a ser relevante, pois dirigem a pé até o centro comercial secundário instalado em Diadema na Av. Nossa Senhora dos Navegantes. Para outros que vivem na favela Eldorado, embora não haja disponibilidade de ônibus, o espaço de fluxos é determinante, pois caminham até a Av. Afonso Monteiro da Cruz para utilizarem os ônibus de Diadema em direção ao bairro de Serraria. Nesse caso, esses moradores estão conectados ao nó que representa o centro comercial localizado no bairro de Serraria.

Em relação às informações apresentadas no capítulo 6, o centro médio dos moradores (mapa número 6.1 da página 290) representa o espaço de lugares na região central, tendendo para a região sudoeste, se aproxima ligeiramente do norte e da represa Billings, em conseqüência das áreas mais densas ao norte e noroeste e menos densas ao sul. Todavia, o centro médio do comércio (mapa número 6.3 página 293), localizado em lugar fora do Distrito de Pedreira em direção a Santo Amaro, é determinado pelo espaço de fluxos por causa da atração exercida pelo comércio do Largo 13 de Maio e Shopping Center Interlagos. Ainda, a elipse direcional (mapa número 6.4 página 295) representa o resultado global do efeito causado pelo espaço de fluxos por meio dos centros do Largo 13 de Maio, Shopping Center Interlagos, Diadema e os centros secundários.

As estatísticas locais Moran's I e Getis Ord Gi* (capítulo 6 páginas 309 a 373), que confirmam as importâncias do comércio do Largo 13 de Maio e Shopping Center Interlagos, representam o reflexo do espaço de fluxos sobre os espaços de lugares onde esses centros estão instalados. Apesar dos resultados estatísticos concederem mais vantagens de concentração de comércio ao Shopping Center Interlagos, o local preferido pelos moradores 
continua sendo o Largo 13 de Maio, de níveis hierárquicos mais elevados, em conseqüência da disponibilidade de ônibus pertinentes ao espaço de fluxos. Para a localização do comércio, embora as concentrações se verifiquem em locais de maior circulação de pessoas, o espaço de fluxos beneficia os centros com alguma dispersão do comércio em torno das suas vias principais, por exemplo, a região do Largo 13 de Maio.

A preferência e a escolha dos locais de compras indicados pelos moradores estabeleceram os centros de níveis hierárquicos mais elevados, por exemplo, o Largo 13 de Maio, conforme o capítulo 5, todavia, o lugar que oferece muitas vantagens pela significativa concentração de estabelecimentos comerciais, que é o Shopping Center Interlagos, relativamente mais próxima do Distrito, de acordo com o capítulo 6, não se trata de alternativa escolhida em primeiro lugar pelos moradores. Os centros de hierarquia mais elevada são os que dispõem de melhor acessibilidade, permitida pela ampla disponibilidade de linhas de ônibus, que partem praticamente de todos os locais do Distrito de Pedreira, segundo o capítulo 4. Portanto, o serviço de transporte urbano é um dos principais fatores determinantes dos padrões espaciais do comércio pelo fato dos centros de níveis hierárquicos mais elevados se encontrarem em pontos mais distantes dos moradores.

O PRE não estabelece as datas da execução de algumas intervenções que já constam no planejamento conforme apresentado no capítulo 4, página 132. Uma delas se refere à criação de pólos de centralidades e permitirá a regulamentação do comércio e prestação de serviços na área de proteção ambiental. São 5 polares e 2 lineares. Desses, 3 polares (em áreas contíguas) e todos os lineares se localizam na região do Balneário Mar Paulista e futuramente, após a demolição e transformação dos imóveis residenciais em imóveis comerciais de porte significativo, poderá formar um centro comercial local com intensidade suficiente para reduzir o nível hierárquico do Largo 13 de Maio, atualmente mais vantajoso. Conseqüentemente não haverá a necessidade dos moradores se deslocarem até Santo Amaro ou Shopping Center Interlagos e trata-se de uma área de acesso muito fácil, por ônibus, a partir de qualquer bairro do Distrito de Pedreira.

O centro polar de Eldorado é o mais prioritário, apesar de se tratar de uma região de renda baixa e de menor interesse por parte dos empresários, pois, permitirá o desenvolvimento comercial estruturado numa região em que o comércio atualmente é muito pouco expressivo em razão das leis de proteção ambiental. No futuro poderá alterar o nível hierárquico do centro secundário instalado na Av. Nossa Senhora dos Navegantes, em Diadema, bem 
próxima à divisa municipal, que atende, atualmente, os moradores de Eldorado e Mata Virgem. 


\section{Bibliografia}

BEAUJEU-GARNIER, JACQUELINE. Geografia urbana, $2^{\mathrm{a}}$ edição. Tradução Raquel Soeiro de Brito. Lisboa: Fundação Caluste Gulbenkian, 1997. 525 p.

BERRY, BRIAN JOE LOBLEY. Geography of market centers and retail distribution. Englewood Cliffs, N.J.: Prentice-Hall, 1967. 146p.

BERRY, BRIAN J.L., HORTON, FRANK E. [editor] Geographic perspectives on urban systems. Englewwod Cliffs, New Jersey: Prentice-Hall, 1970. 564p.

BIRD, JAMES HAROLD. Centrality and cities. London: Routledge \& Kegan Paul, 1977. 203p.

BIRKIN, MARK, CLARKE GRAHAM, CLARKE MARTIN, WILSON ALAN. Intelligent GIS. New York: John Wiley, 1996. 292p.

BURROUGH, P.A. Principles of geographical information systems for land resources assessment. Oxford: Claredon Press, 1990. 194p.

CAMPOS FILHO, CANDIDO MALTA. Reinvente seu bairro. São Paulo: Editora 34, 2003. 234p.

CARRINGTON, PETER J., SCOTT, JOHN, WASSERMAN, STANLEY [editors]. Models and methods in social network analysis. New York: Cambridge University Press, 2005. $328 \mathrm{p}$.

CASTELlS, MANUEL. A Questão urbana. Tradução Arlene Caetano. Rio de Janeiro: Paz e Terra, 1983. 506p.

A Sociedade em rede. Volume I. $8^{a}$ ed. Tradução Roneide Venancio Majer. São Paulo: Paz e Terra, 2005. 698p.

CHORLEY, RICHARD J. [editor] Modelos sócio-economico em geografia. Rio de Janeiro: EDUSP, 1975. 274p.

CHRISTOFOLETTI, ANTONIO. Perspectivas da geografia. São Paulo: Difel Difusão Editorial, 1982. 318p.

CRESSIE, NOEL A C. Statistics for spatial data. New York: John Wiley, 1993. 900p.

DALTON, ROGER, GARLICK, JOAN, MINSHULL, ROGER, ROBINSON ALAN. Networks in geography. London: George Philip and Son, 1973. 60p. 
DEGENNE, ALAIN, MICHEL FORSÉ. Les réseaux sociaux. 2ed. Paris: Armand Colin, 2004. 294p.

DUPUY, GABRIEL. Systèmes, réseaux et territoires. Paris: Presses Ponts et chaussées, 1985. 168p.

L’urbanisme des réseaux. Paris: Armand Colin, 1991. 198p.

EMPRESA METROPOLITANA DE PLANEJAMENTO DA GRANDE SÃO PAULO, EMPLASA. Sistema cartográfico metropolitano: levantamento aerofotogramétrico, fls. 3334, 3336, 3343, 3345. São Paulo: EMPLASA, 1981. 4 mapas, $91 \mathrm{~cm} \mathrm{X} 65$ cm, escala $1: 10000$.

Carta geológica da região metropolitana da grande São Paulo. São Paulo: EMPLASA, 1980. 4 mapas, $83 \mathrm{~cm} \mathrm{X} 114 \mathrm{~cm}$, escala 1:100000.

EMPRESA METROPOLITANA DE TRANSPORTES URBANOS, EMTU. Linhas de ônibus. Disponível em

$<$ http://www.emtu.sp.gov.br/linha/resultado1.htm?pag=origemdestino.htm\&numlinha=12601 \& tipo $=\&$ rua $=>$. Acesso em 15/09/2007.

FUNDAÇÃO SISTEMA ESTADUAL DE ANÁLISE DE DADOS, SEADE. Informações dos Distritos da Capital. Disponível em

<http://www.seade.gov.br/produtos/imp/distritos/imp.php?page=consulta\&action=new $->$.

Acesso em 30/11/2007.

São Paulo outrora e agora - 2004. Disponível em

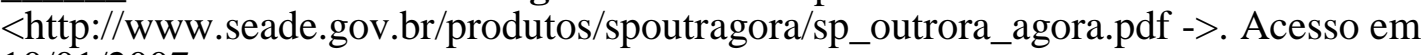
$10 / 01 / 2007$.

Perfil do paulistano. Disponível em

<http://www.seade.gov.br/produtos/pdf/paulistano_2007.pdf ->. Acesso em 10/01/2007.

GEORGE, PIERRE. Geografia do consumo. 2 ed. São Paulo: Difusão Européia Do Livro, 1971. 119p.

. Geografia Urbana. São Paulo: Difel - Difusão Editorial, 1983. 236p.

GEORGE, PIERRE, GUGLIELMO RAYMOND, LACOSTE YVES, KAYSER, BERNARD. A Geografia ativa. Tradução Gil Toledo, Manuel Seabra, Nelson de la Corte, Vincenzo Bochicchio. São Paulo: Difusão Européia do Livro, 1966. 359p.

GOODCHILD, MICHAEL F.; JANELLE, DONALD G. Spatially integrated social science. New York: Oxford, 2004. 455 p. 
GOTTDIENER, MARK. A Produção social do espaço urbano. Tradução G.G. de Souza. São Paulo, EDUSP, 1993. 236p.

HAGGETT, PETER, CHORLEY, RICHARD. Network analysis in geography. London: Edward Arnold, 1969. 348p.

HARARY, FRANK. Graph theory. Secong printing. Reading, Mass: Addison-Wiesley, 1972. 274p.

HARARY, FRANK, NORMAN, ROBERT Z, CARTWRIGHT, DORWIN. Structural models: an introduction of the theory of directed graphs. New York: John Wiley, 1965. 415p.

HARTSHORNE, RICHARD. Perspective on the nature of geography. Chicago: Rand Mcnally, 1960.

HARVEY, DAVID. Explanation in geography. London, Edward Arnold, 1971. 521p.

HEYWOOD, D. IAN; CORNELIUS, SARAH; CARVER, STEVE. An introduction to geographical information systems. 2nd ed. Harlow, England; New York: Prentice Hall, 2002. 295p.

INSTITUTO BRASILEIRO DE GEOGRAFIA E ESTATÍSTICA: Base de informações por setor censitário, censo demográfico 2000, resultados do universo. Rio de Janeiro, 2002. 1 CD-ROOM.

JACOBS, JANE. The economy of cities. New York, Vintage Books, 1970. 268p.

LANGENBUCH, JUERGEN RICHARD. A estruturação da Grande São Paulo. Rio de Janeiro: IBGE, 1971. 354p.

LEE, JAY. Statistical analysis with Arc View GIS. New York: John Wiley, 2001. 192p.

LLOYD, PETER E, DICKEN, PETER. Location in space: a theoretical approach to economic geography. New York: Harper \& Row, 1972. 292p.

LONGLEY, PAUL A, GOODCHILD, MICHAEL F, MAGUIRE, DAVID J, RHING, DAVID W. Geographic Information System and Science. West Sussex: John Wiley, 2001,454p.

MAGUIRE, DAVID J, GOODCHILD, MICHAEL F., RHIND, DAVID W. [editores]. Geographical information systems: principles and applications. New York: Longman Scientific \& Techinical Wiley, 1991. v1. 
MAPOGRAF EDITORA. O guia mapograf São Paulo e municípios. São Paulo: Mapograf, 2004. 1054p.

MEYER, REGINA MARIA PROSPERI; GROSTEIN, MARTA DORA; BIDERMAN, CIRO. São Paulo metrópole. São Paulo: EDUSP, 2004. 290p.

MITCHELL, ANDY. Spatial measurements' \& statistics. 1 ed. Redlands: ESRI Press, 2005. 238p.

MITCHELL, J.CLYDE. Social networks. Annual Review of Anthropology. Vol. 3 - 279299, 1974.

NOOY, WOUTER DE, MRVAR, ANDREJ, BATAGELJ, VLADIMIR. Exploratory social network analysis with Pajek. New York: Cambridge University Press, 2005. 333p.

OPENSHAW, S. Developing appropriate spatial analysis methods for gis. In: MAGUIRE, DAVID J, GOODCHILD, MICHAEL F., RHIND, DAVID W. Geographical information systems: principles and applications. New York: Longman Scientific \& Techinical Wiley, 1991. 389p.

PENTEADO, ANTONIO ROCHA. Os subúrbios de São Paulo. In AZEVEDO, AROLDO DE [org]. A cidade de São Paulo. São Paulo: Cia Editora Nacional, [1958], v4.

PETRONE, PASQUALE [org]. Pinheiros: aspectos geográficos de um bairro paulistano. São Paulo: EDUSP, 1963. 196p.

PREFEITURA DE DIADEMA. Itinerário de ônibus municipais. Disponível em $<$ http://www.diadema.sp.gov.br/apache2-

default/index.php?option=com_content $\&$ view $=$ article $\& i d=20 \&$ Itemid=10>. Acesso em $10 / 10 / 2007$.

RADESCA, MARIA DE LOURDES P. SOUZA. O problema da energia elétrica. In AZEVEDO, AROLDO DE [org]. A cidade de São Paulo. São Paulo: Cia Editora Nacional, [1958], v3.

RAIA JUNIOR, ARCHIMEDES AZEVEDO. Acessibilidade e mobilidade na estimativa de um índice de potencial de viagens utilizando redes neurais artificiais e sistemas de coesrmações geográficas. 2000. 196p. Tese (Doutorado em Engenharia Civil - Transportes) - Escola de Engenharia de São Carlos, Universidade de São Paulo, São Carlos, 2000.

ROCHEFORT, MICHEL. Redes e sistemas. Tradução Antonio de Padua Danesi. São Paulo: Hucitec, 1998. 174p. 
Économie géographique et aménagement du territoire. Paris: Centre de Documentation Universitaire, 1975. 159p.

SANTOS, MILTON. A natureza do espaço: técnica e tempo, razão e emoção. 4. ed. São Paulo: Editora da Universidade de São Paulo, 2004. 384p.

Economia espacial: críticas e alternativas. 2. ed. São Paulo: EDUSP, 2003. 204p.

Por uma geografia nova: da crítica da geografia a uma geografia crítica. São Paulo: Editora da Universidade de São Paulo, 2002. 285p.

SÃO PAULO TRANSPORTE S.A, SPTrans. Itinerários. Disponível em <http://200.99.150.170/PlanOperWeb/ >. Acesso em: 30/09/2007.

SCHENSUL, JEAN J, LE COMPTE, MARGARET D, TROTTER II, ROBERT $T$, CROMLEY, ELLEN K, SINGER, MERRILL. Mapping social networks, spatial data, \& hidden populations. Walnut Creek: AltaMira, 1999. 205p.

SCOTT, JOHN. Social network analysis. 2 ed. London: SAGE, 2006. 208p.

SECRETARIA MUNICIPAL DE PLANEJAMENTO DE SÃO PAULO. Anexo XVI Livro XVI Plano Regional Estratégico da Subprefeitura da Cidade Ademar. Disponível em <http://sempla.prefeitura.sp.gov.br/urb_zon_parte2_anexos_cidade_ademar.php>. Acesso em: $15 / 04 / 2008$.

Histórico demográfico do município de São Paulo. Mapa de expansão da área urbanizada da região metropolitana de São Paulo 2002/2003.

Disponível em < http://sempla.prefeitura.sp.gov.br/historico/>. Acesso em 15.04.2008.

Município em mapas. Maciços de solo e rocha. Carta geotécnica do município de São Paulo 1992. Disponível em <http://sempla.prefeitura.sp.gov.br/mm/panorama/>. Acesso em 10.03.2008.

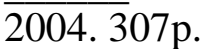

Plano diretor estratégico 2002 - 2012. São Paulo: SENAC/Prefeitura de São Paulo,

SECRETARIA MUNICIPAL DO TRABALHO DE SÃO PAULO. Atlas do trabalho e desenvolvimento da cidade de São Paulo, 2007. Disponível em

<http://atlasmunicipal.prefeitura.sp.gov.br/Download/frmDownload.aspx>. Acesso em:

2/01/2008.

SOJA, EDWARD W. Geografias pós-modernas. Rio de Janeiro: Zahar, 1993. 324p. 
TARIFA, JOSÉ ROBERTO; ARMANI, GUSTAVO. Unidades climáticas urbanas da cidade de São Paulo: $1^{a}$ aproximação, 2000. Disponível em

<http://atlasambiental.prefeitura.sp.gov.br/mapas/107.pdf>. Acesso em 20.09.2009.

TOURINHO, ANDRÉA DE OLIVEIRA. Do centro aos centros: bases teórico-conceituais para o estudo da centralidade em São Paulo. 2004. 438p. Tese (Doutorado). Faculdade de Arquitetura e Urbanismo, Universidade de São Paulo, São Paulo, 2004.

VILLAÇA, FLAVIO. A estrutura territorial da metrópole sul brasileira: áreas residenciais e comerciais. 1978. 2v. Tese (Doutorado). Faculdade de Filosofia, Letras e Ciências Humanas, Universidade de São Paulo, São Paulo, 1978.

WASSERMAN, STANLEY, FAUST, KATHERINE. Social network analysis. New York: Cambridge University Press, 1997. 825p.

WASSERMAN, STANLEY, JOSEPH GALASKIEWICZ [editores]. Advances in social network analysis. Thousand Oaks: SAGE, 1994. 299p.

WELLMAN, BARRY, BERKOWTZ S.D. [editores]. Social structures. New York: Cambridge University Press, 1988. 513p.

ZEILER, MICHAEL. Modeling our world. Redlands. ESRI Press, 1999. 199p. 
Apêndice A 


\section{Apêndice A - RESULTADOS DOS CÁLCULOS DA MEDIDA DE GRAU}

FREEMAN'S DEGREE CENTRALITY MEASURES:

Diagonal valid?

Model:

Input dataset:

Pedreira \RPREDREIRA C21
NO

SYMMETRIC

C: \Doutorado \Tese $\backslash$ Rede

2

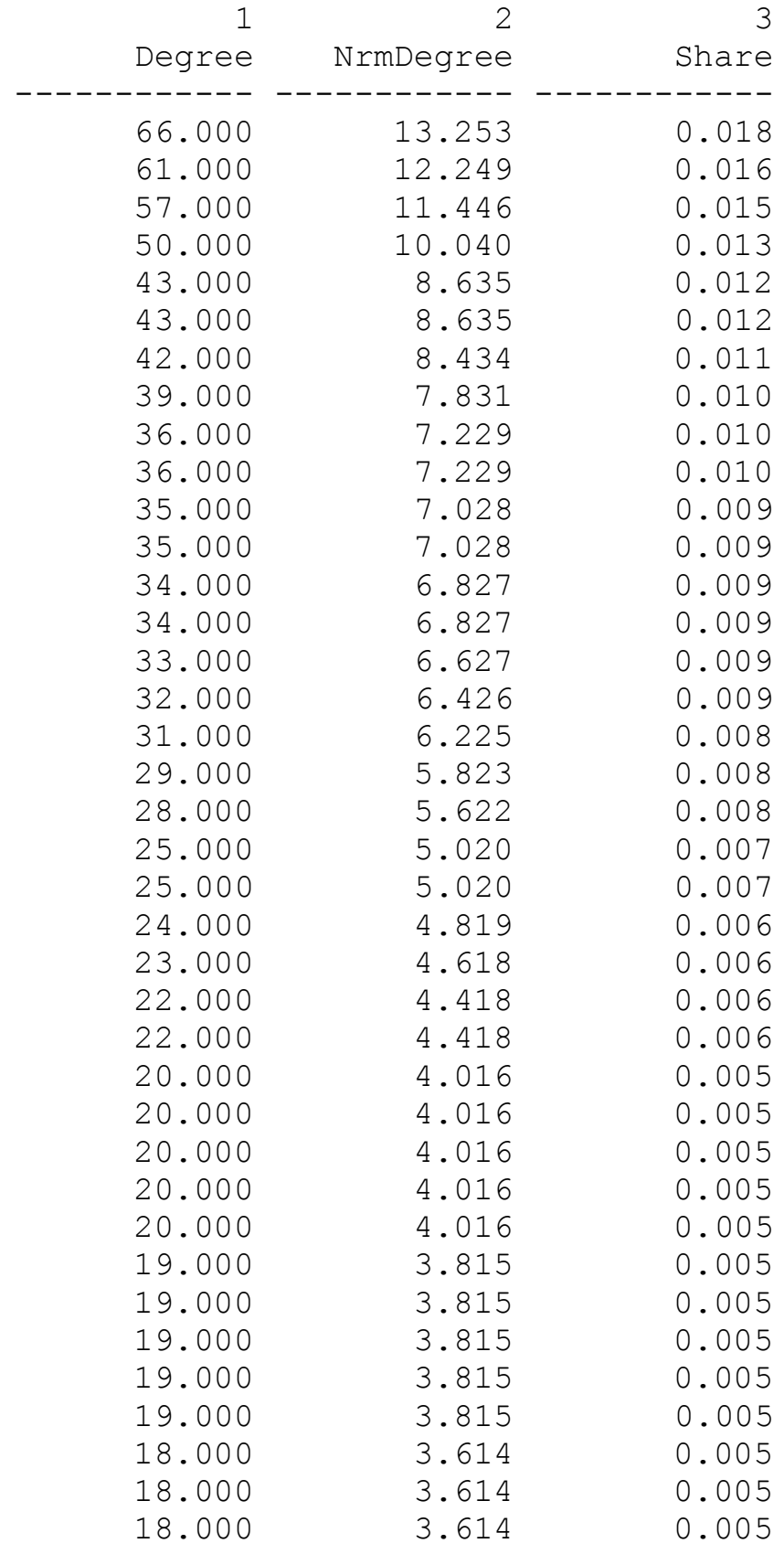

38 CS2002A

25 CR3L13A

19 CC3L13A

33 CE3DIAA

67 CY3L13A

14 CE3L13A

497 CE3INTA

81 CX3DIAA

495 CR3INTA

72 CY3DIAA

496 CY3INTA

129 CX3L13A

40 CM2017A

34 CR3DIAA

35 CC3DIAA

36 CF 2DIAA

494 CC3INTA

82 CW2DIAA

130 CW2L13A

5 SM3INTA

498 CX3INTA

32 CS2016A

481 M122A

$203 \mathrm{M} 024 \mathrm{~F}$

440 M112A

CF2DSPA

426 M126A

223 M075F

499 CW3INTA

$439 \mathrm{M} 114 \mathrm{~A}$

$155 \mathrm{M} 043 \mathrm{~F}$

280 M012A

$438 \mathrm{M100A}$

412 M073A

78 M121F

306 M087F

328 M109A

199 M006F 


\begin{tabular}{|c|c|c|c|c|}
\hline 476 & M123A & 18.000 & 3.614 & 0.005 \\
\hline 456 & M0 $84 \mathrm{~A}$ & 18.000 & 3.614 & 0.005 \\
\hline 487 & M1 08A & 17.000 & 3.414 & 0.005 \\
\hline 261 & M0 60F & 17.000 & 3.414 & 0.005 \\
\hline 414 & M0 64A & 17.000 & 3.414 & 0.005 \\
\hline 113 & CV2DIAA & 17.000 & 3.414 & 0.005 \\
\hline 418 & M0 63A & 17.000 & 3.414 & 0.005 \\
\hline 143 & M1 34F & 17.000 & 3.414 & 0.005 \\
\hline 447 & M129A & 17.000 & 3.414 & 0.005 \\
\hline 227 & M077F & 17.000 & 3.414 & 0.005 \\
\hline 48 & CS2064A & 17.000 & 3.414 & 0.005 \\
\hline 109 & M050F & 17.000 & 3.414 & 0.005 \\
\hline 400 & M027A & 17.000 & 3.414 & 0.005 \\
\hline 159 & M0 4 4F & 17.000 & 3.414 & 0.005 \\
\hline 436 & M128A & 17.000 & 3.414 & 0.005 \\
\hline 296 & M032F & 17.000 & 3.414 & 0.005 \\
\hline 381 & M079A & 16.000 & 3.213 & 0.004 \\
\hline 148 & CV2002A & 16.000 & 3.213 & 0.004 \\
\hline 254 & M071F & 16.000 & 3.213 & 0.004 \\
\hline 369 & M0 54A & 16.000 & 3.213 & 0.004 \\
\hline 193 & M038F & 16.000 & 3.213 & 0.004 \\
\hline 239 & M0 76F & 16.000 & 3.213 & 0.004 \\
\hline 454 & M1 03A & 16.000 & 3.213 & 0.004 \\
\hline 162 & M0 4 5F & 16.000 & 3.213 & 0.004 \\
\hline 118 & M0 41F & 16.000 & 3.213 & 0.004 \\
\hline 150 & M135F & 16.000 & 3.213 & 0.004 \\
\hline 127 & M133F & 16.000 & 3.213 & 0.004 \\
\hline 404 & M028A & 16.000 & 3.213 & 0.004 \\
\hline 65 & CF2SJDA & 16.000 & 3.213 & 0.004 \\
\hline 251 & M116F & 16.000 & 3.213 & 0.004 \\
\hline 169 & M0 4 7F & 15.000 & 3.012 & 0.004 \\
\hline 98 & M033F & 15.000 & 3.012 & 0.004 \\
\hline 441 & M127A & 15.000 & 3.012 & 0.004 \\
\hline 321 & M0 97F & 15.000 & 3.012 & 0.004 \\
\hline 90 & M119F & 15.000 & 3.012 & 0.004 \\
\hline 493 & CS3INTX & 15.000 & 3.012 & 0.004 \\
\hline 382 & M0 03A & 15.000 & 3.012 & 0.004 \\
\hline 488 & M107A & 15.000 & 3.012 & 0.004 \\
\hline 283 & M013F & 15.000 & 3.012 & 0.004 \\
\hline 174 & M034F & 15.000 & 3.012 & 0.004 \\
\hline 126 & CA2L13N & 15.000 & 3.012 & 0.004 \\
\hline 430 & M1 25A & 15.000 & 3.012 & 0.004 \\
\hline 315 & $\mathrm{M} 021 \mathrm{~F}$ & 15.000 & 3.012 & 0.004 \\
\hline 356 & M051A & 15.000 & 3.012 & 0.004 \\
\hline 393 & M020A & 15.000 & 3.012 & 0.004 \\
\hline 235 & M078F & 15.000 & 3.012 & 0.004 \\
\hline 337 & M093A & 14.000 & 2.811 & 0.004 \\
\hline 195 & M0 07F & 14.000 & 2.811 & 0.004 \\
\hline 420 & M0 98M & 14.000 & 2.811 & 0.004 \\
\hline 446 & M132A & 14.000 & 2.811 & 0.004 \\
\hline 368 & M059A & 14.000 & 2.811 & 0.004 \\
\hline 266 & M055F & 14.000 & 2.811 & 0.004 \\
\hline 39 & CS3DIAA & 14.000 & 2.811 & 0.004 \\
\hline 68 & M120F & 14.000 & 2.811 & 0.004 \\
\hline 378 & M0 80A & 14.000 & 2.811 & 0.004 \\
\hline 83 & CM2DIAA & 14.000 & 2.811 & 0.004 \\
\hline 359 & M056A & 14.000 & 2.811 & 0.004 \\
\hline 134 & CV2064A & 14.000 & 2.811 & 0.004 \\
\hline
\end{tabular}




\begin{tabular}{|c|c|c|c|c|}
\hline 407 & $\mathrm{M} 010 \mathrm{~A}$ & 14.000 & 2.811 & 0.004 \\
\hline 358 & M052A & 14.000 & 2.811 & 0.004 \\
\hline 365 & M0 58A & 14.000 & 2.811 & 0.004 \\
\hline 460 & M1 06A & 13.000 & 2.610 & 0.003 \\
\hline 77 & CO2DIAA & 13.000 & 2.610 & 0.003 \\
\hline 164 & M0 4 6F & 13.000 & 2.610 & 0.003 \\
\hline 465 & M0 90A & 13.000 & 2.610 & 0.003 \\
\hline 459 & M1 05A & 13.000 & 2.610 & 0.003 \\
\hline 384 & M001A & 13.000 & 2.610 & 0.003 \\
\hline 167 & M0 4 9F & 13.000 & 2.610 & 0.003 \\
\hline 214 & M0 65A & 13.000 & 2.610 & 0.003 \\
\hline 434 & M110A & 13.000 & 2.610 & 0.003 \\
\hline 342 & M0 94A & 13.000 & 2.610 & 0.003 \\
\hline 219 & M025F & 13.000 & 2.610 & 0.003 \\
\hline 291 & M029A & 13.000 & 2.610 & 0.003 \\
\hline 323 & M0 88A & 13.000 & 2.610 & 0.003 \\
\hline 61 & M030F & 13.000 & 2.610 & 0.003 \\
\hline 116 & M0 $40 F$ & 13.000 & 2.610 & 0.003 \\
\hline 396 & M0 08A & 13.000 & 2.610 & 0.003 \\
\hline 349 & M0 69A & 13.000 & 2.610 & 0.003 \\
\hline 191 & M036F & 13.000 & 2.610 & 0.003 \\
\hline 202 & $\mathrm{M} 042 \mathrm{~F}$ & 13.000 & 2.610 & 0.003 \\
\hline 352 & M0 82A & 13.000 & 2.610 & 0.003 \\
\hline 275 & M009F & 13.000 & 2.610 & 0.003 \\
\hline 449 & M017A & 13.000 & 2.610 & 0.003 \\
\hline 322 & M0 85A & 13.000 & 2.610 & 0.003 \\
\hline 243 & M101F & 13.000 & 2.610 & 0.003 \\
\hline 123 & M0 48F & 13.000 & 2.610 & 0.003 \\
\hline 333 & M0 $04 \mathrm{~A}$ & 13.000 & 2.610 & 0.003 \\
\hline 187 & M037F & 13.000 & 2.610 & 0.003 \\
\hline 11 & CM2100A & 13.000 & 2.610 & 0.003 \\
\hline 467 & M089A & 13.000 & 2.610 & 0.003 \\
\hline 346 & M0 92A & 13.000 & 2.610 & 0.003 \\
\hline 390 & M019A & 13.000 & 2.610 & 0.003 \\
\hline 423 & M111A & 13.000 & 2.610 & 0.003 \\
\hline 55 & M026A & 12.000 & 2.410 & 0.003 \\
\hline 171 & M039F & 12.000 & 2.410 & 0.003 \\
\hline 395 & M0 68A & 12.000 & 2.410 & 0.003 \\
\hline 278 & M023A & 12.000 & 2.410 & 0.003 \\
\hline 310 & M113F & 12.000 & 2.410 & 0.003 \\
\hline 458 & M0 83A & 12.000 & 2.410 & 0.003 \\
\hline 50 & $\mathrm{CM} 2064 \mathrm{~A}$ & 12.000 & 2.410 & 0.003 \\
\hline 47 & M022A & 12.000 & 2.410 & 0.003 \\
\hline 303 & M016A & 12.000 & 2.410 & 0.003 \\
\hline 386 & M0 62A & 12.000 & 2.410 & 0.003 \\
\hline 247 & M115F & 12.000 & 2.410 & 0.003 \\
\hline 270 & M070F & 12.000 & 2.410 & 0.003 \\
\hline 198 & CA2064N & 11.000 & 2.209 & 0.003 \\
\hline 443 & M130A & 11.000 & 2.209 & 0.003 \\
\hline 132 & CV2L13A & 11.000 & 2.209 & 0.003 \\
\hline 147 & CF 2002A & 11.000 & 2.209 & 0.003 \\
\hline 419 & M0 05A & 11.000 & 2.209 & 0.003 \\
\hline 463 & M0 86A & 11.000 & 2.209 & 0.003 \\
\hline 12 & CC 3 CENA & 11.000 & 2.209 & 0.003 \\
\hline 405 & M0 67A & 11.000 & 2.209 & 0.003 \\
\hline 182 & M035F & 11.000 & 2.209 & 0.003 \\
\hline 453 & M1 02A & 11.000 & 2.209 & 0.003 \\
\hline 135 & $\mathrm{M} 031 \mathrm{~F}$ & 11.000 & 2.209 & 0.003 \\
\hline
\end{tabular}




\begin{tabular}{|c|c|c|c|c|}
\hline 375 & M0 66A & 11.000 & 2.209 & 0.003 \\
\hline 265 & $\mathrm{M} 061 \mathrm{~F}$ & 11.000 & 2.209 & 0.003 \\
\hline 246 & CA2100N & 10.000 & 2.008 & 0.003 \\
\hline 485 & M118A & 10.000 & 2.008 & 0.003 \\
\hline 258 & M072F & 10.000 & 2.008 & 0.003 \\
\hline 21 & M011A & 10.000 & 2.008 & 0.003 \\
\hline 364 & M057A & 10.000 & 2.008 & 0.003 \\
\hline 289 & $\mathrm{M} 014 \mathrm{~F}$ & 10.000 & 2.008 & 0.003 \\
\hline 385 & $\mathrm{M} 002 \mathrm{~A}$ & 10.000 & 2.008 & 0.003 \\
\hline 104 & CR2BRZA & 10.000 & 2.008 & 0.003 \\
\hline 244 & CV2100A & 10.000 & 2.008 & 0.003 \\
\hline 229 & CS2100A & 10.000 & 2.008 & 0.003 \\
\hline 452 & M015A & 9.000 & 1.807 & 0.002 \\
\hline 114 & CA2DIAN & 9.000 & 1.807 & 0.002 \\
\hline 344 & M095A & 9.000 & 1.807 & 0.002 \\
\hline 103 & CC 3BRZA & 9.000 & 1.807 & 0.002 \\
\hline 472 & M124A & 9.000 & 1.807 & 0.002 \\
\hline 59 & M091A & 9.000 & 1.807 & 0.002 \\
\hline 41 & CP2002A & 9.000 & 1.807 & 0.002 \\
\hline 245 & CF $2100 A$ & 9.000 & 1.807 & 0.002 \\
\hline 54 & CP2064A & 8.000 & 1.606 & 0.002 \\
\hline 161 & CA2017N & 8.000 & 1.606 & 0.002 \\
\hline 409 & M099A & 8.000 & 1.606 & 0.002 \\
\hline 53 & CF2064A & 8.000 & 1.606 & 0.002 \\
\hline 371 & M0 81A & 8.000 & 1.606 & 0.002 \\
\hline 29 & CR 3CENA & 8.000 & 1.606 & 0.002 \\
\hline 120 & CF 2029A & 8.000 & 1.606 & 0.002 \\
\hline 6 & CO2INTA & 8.000 & 1.606 & 0.002 \\
\hline 91 & CS 2NAVA & 8.000 & 1.606 & 0.002 \\
\hline 44 & CP2117A & 8.000 & 1.606 & 0.002 \\
\hline 46 & CA2117A & 7.000 & 1.406 & 0.002 \\
\hline 201 & CM2YERA & 7.000 & 1.406 & 0.002 \\
\hline 45 & M117A & 7.000 & 1.406 & 0.002 \\
\hline 13 & CP2100A & 7.000 & 1.406 & 0.002 \\
\hline 37 & M018A & 7.000 & 1.406 & 0.002 \\
\hline 207 & CS3INTA & 7.000 & 1.406 & 0.002 \\
\hline 1 & M131A & 7.000 & 1.406 & 0.002 \\
\hline 27 & CE 3YERA & 7.000 & 1.406 & 0.002 \\
\hline 60 & CM2107A & 7.000 & 1.406 & 0.002 \\
\hline 51 & SM3MARA & 7.000 & 1.406 & 0.002 \\
\hline 3 & CS2ZTUA & 7.000 & 1.406 & 0.002 \\
\hline 205 & CS 2 YERA & 7.000 & 1.406 & 0.002 \\
\hline 110 & CA1029A & 7.000 & 1.406 & 0.002 \\
\hline 319 & CM2002A & 6.000 & 1.205 & 0.002 \\
\hline 131 & CM2027A & 6.000 & 1.205 & 0.002 \\
\hline 331 & CV2NAVA & 6.000 & 1.205 & 0.002 \\
\hline 373 & CX3YERA & 6.000 & 1.205 & 0.002 \\
\hline 8 & M074A & 6.000 & 1.205 & 0.002 \\
\hline 231 & CW2100A & 6.000 & 1.205 & 0.002 \\
\hline 49 & CA1064A & 6.000 & 1.205 & 0.002 \\
\hline 383 & CX3SABA & 6.000 & 1.205 & 0.002 \\
\hline 52 & SC 3SPMA & 6.000 & 1.205 & 0.002 \\
\hline 230 & CS 2S JRA & 6.000 & 1.205 & 0.002 \\
\hline 250 & CW2SABA & 6.000 & 1.205 & 0.002 \\
\hline 43 & CM2117A & 6.000 & 1.205 & 0.002 \\
\hline 20 & CF 2092A & 6.000 & 1.205 & 0.002 \\
\hline 9 & CA1100A & 6.000 & 1.205 & 0.002 \\
\hline 15 & M096A & 5.000 & 1.004 & 0.001 \\
\hline
\end{tabular}




\begin{tabular}{|c|c|c|c|c|}
\hline 122 & $\mathrm{CP} 2017 \mathrm{~A}$ & 5.000 & 1.004 & 0.001 \\
\hline 160 & CV2029A & 5.000 & 1.004 & 0.001 \\
\hline 17 & CS2096A & 5.000 & 1.004 & 0.001 \\
\hline 432 & CA2129A & 5.000 & 1.004 & 0.001 \\
\hline 197 & CF2L13A & 5.000 & 1.004 & 0.001 \\
\hline 42 & M1 $04 \mathrm{~A}$ & 5.000 & 1.004 & 0.001 \\
\hline 290 & CY 3CENA & 5.000 & 1.004 & 0.001 \\
\hline 31 & M053A & 5.000 & 1.004 & 0.001 \\
\hline 429 & CV2129A & 4.000 & 0.803 & 0.001 \\
\hline 329 & CA1107A & 4.000 & 0.803 & 0.001 \\
\hline 210 & CV2CENA & 4.000 & 0.803 & 0.001 \\
\hline 125 & CA2029A & 4.000 & 0.803 & 0.001 \\
\hline 427 & CA1129A & 4.000 & 0.803 & 0.001 \\
\hline 397 & CV2027A & 4.000 & 0.803 & 0.001 \\
\hline 226 & $\mathrm{CO} 2 \mathrm{SABA}$ & 4.000 & 0.803 & 0.001 \\
\hline 225 & CY $3 S A B A$ & 4.000 & 0.803 & 0.001 \\
\hline 206 & CA2027A & 4.000 & 0.803 & 0.001 \\
\hline 398 & CF 2027A & 4.000 & 0.803 & 0.001 \\
\hline 374 & CV2YERA & 4.000 & 0.803 & 0.001 \\
\hline 208 & CW2YERA & 4.000 & 0.803 & 0.001 \\
\hline 200 & CW2064A & 4.000 & 0.803 & 0.001 \\
\hline 330 & CW2NAVA & 4.000 & 0.803 & 0.001 \\
\hline 121 & CA2029N & 4.000 & 0.803 & 0.001 \\
\hline 139 & CE3SAUA & 4.000 & 0.803 & 0.001 \\
\hline 115 & CP2DIAA & 4.000 & 0.803 & 0.001 \\
\hline 213 & CP2080A & 3.000 & 0.602 & 0.001 \\
\hline 64 & CV2016A & 3.000 & 0.602 & 0.001 \\
\hline 18 & CM2096A & 3.000 & 0.602 & 0.001 \\
\hline 474 & CM2NAVA & 3.000 & 0.602 & 0.001 \\
\hline 376 & CA2080A & 3.000 & 0.602 & 0.001 \\
\hline 24 & CM2080A & 3.000 & 0.602 & 0.001 \\
\hline 222 & CV2080A & 3.000 & 0.602 & 0.001 \\
\hline 360 & CV2056A & 3.000 & 0.602 & 0.001 \\
\hline 149 & CA2015N & 3.000 & 0.602 & 0.001 \\
\hline 140 & CW2015A & 3.000 & 0.602 & 0.001 \\
\hline 217 & CF2080A & 3.000 & 0.602 & 0.001 \\
\hline 242 & CM2S JRA & 3.000 & 0.602 & 0.001 \\
\hline 173 & CV2039A & 3.000 & 0.602 & 0.001 \\
\hline 10 & CL1074A & 3.000 & 0.602 & 0.001 \\
\hline 26 & CF2YERA & 3.000 & 0.602 & 0.001 \\
\hline 76 & CF2SERA & 3.000 & 0.602 & 0.001 \\
\hline 431 & CS2SABA & 3.000 & 0.602 & 0.001 \\
\hline 101 & CS2DIAA & 3.000 & 0.602 & 0.001 \\
\hline 84 & CM2SERA & 3.000 & 0.602 & 0.001 \\
\hline 70 & CS 2SERA & 3.000 & 0.602 & 0.001 \\
\hline 156 & CA1043A & 3.000 & 0.602 & 0.001 \\
\hline 163 & CV2017A & 3.000 & 0.602 & 0.001 \\
\hline 188 & CA2DIAA & 3.000 & 0.602 & 0.001 \\
\hline 413 & CW2CENA & 3.000 & 0.602 & 0.001 \\
\hline 22 & CA1011A & 3.000 & 0.602 & 0.001 \\
\hline 340 & CM2096C & 3.000 & 0.602 & 0.001 \\
\hline 238 & CO2YERA & 3.000 & 0.602 & 0.001 \\
\hline 475 & CF 2NAVA & 3.000 & 0.602 & 0.001 \\
\hline 23 & CA2011A & 3.000 & 0.602 & 0.001 \\
\hline 262 & CS2L13A & 2.000 & 0.402 & 0.001 \\
\hline 256 & CA2057A & 2.000 & 0.402 & 0.001 \\
\hline 192 & CA2DIAG & 2.000 & 0.402 & 0.001 \\
\hline 144 & CA1031A & 2.000 & 0.402 & 0.001 \\
\hline
\end{tabular}




\begin{tabular}{|c|c|c|c|c|}
\hline 388 & CP 2AERA & 2.000 & 0.402 & 0.001 \\
\hline 314 & CM2112A & 2.000 & 0.402 & 0.001 \\
\hline 96 & CV2107A & 2.000 & 0.402 & 0.001 \\
\hline 425 & CA $2100 A$ & 2.000 & 0.402 & 0.001 \\
\hline 66 & CA $2016 \mathrm{~N}$ & 2.000 & 0.402 & 0.001 \\
\hline 387 & CA1019A & 2.000 & 0.402 & 0.001 \\
\hline 215 & CA1066A & 2.000 & 0.402 & 0.001 \\
\hline 233 & CV2077A & 2.000 & 0.402 & 0.001 \\
\hline 403 & CP2027A & 2.000 & 0.402 & 0.001 \\
\hline 232 & CM2SELA & 2.000 & 0.402 & 0.001 \\
\hline 16 & CA1096A & 2.000 & 0.402 & 0.001 \\
\hline 282 & CM2011A & 2.000 & 0.402 & 0.001 \\
\hline 437 & CM2SABA & 2.000 & 0.402 & 0.001 \\
\hline 237 & CY3YERA & 2.000 & 0.402 & 0.001 \\
\hline 255 & CV2056A & 2.000 & 0.402 & 0.001 \\
\hline 117 & CS 2029A & 2.000 & 0.402 & 0.001 \\
\hline 271 & CA2069A & 2.000 & 0.402 & 0.001 \\
\hline 305 & CM2016A & 2.000 & 0.402 & 0.001 \\
\hline 212 & CA2YERN & 2.000 & 0.402 & 0.001 \\
\hline 417 & CR3SABA & 2.000 & 0.402 & 0.001 \\
\hline 402 & SC2SAUA & 2.000 & 0.402 & 0.001 \\
\hline 401 & CA1027A & 2.000 & 0.402 & 0.001 \\
\hline 308 & CV2117A & 2.000 & 0.402 & 0.001 \\
\hline 325 & CA2106A & 2.000 & 0.402 & 0.001 \\
\hline 154 & CV2JMIA & 2.000 & 0.402 & 0.001 \\
\hline 326 & $\mathrm{CF} 2107 \mathrm{~A}$ & 2.000 & 0.402 & 0.001 \\
\hline 389 & CA $2002 \mathrm{~N}$ & 2.000 & 0.402 & 0.001 \\
\hline 142 & CY3SAUA & 2.000 & 0.402 & 0.001 \\
\hline 172 & CA1039A & 2.000 & 0.402 & 0.001 \\
\hline 300 & CM2 JMIA & 2.000 & 0.402 & 0.001 \\
\hline 362 & CP $2016 \mathrm{~A}$ & 2.000 & 0.402 & 0.001 \\
\hline 99 & CA1JULA & 2.000 & 0.402 & 0.001 \\
\hline 85 & CV2SERA & 2.000 & 0.402 & 0.001 \\
\hline 336 & CP2096A & 2.000 & 0.402 & 0.001 \\
\hline 89 & CP2SERA & 2.000 & 0.402 & 0.001 \\
\hline 74 & CW2SERA & 2.000 & 0.402 & 0.001 \\
\hline 105 & CY3BRZA & 2.000 & 0.402 & 0.001 \\
\hline 276 & CA 2008A & 2.000 & 0.402 & 0.001 \\
\hline 30 & CM2RFUA & 2.000 & 0.402 & 0.001 \\
\hline 339 & CZ20 96A & 2.000 & 0.402 & 0.001 \\
\hline 309 & CV2085A & 2.000 & 0.402 & 0.001 \\
\hline 257 & CP2029A & 2.000 & 0.402 & 0.001 \\
\hline 249 & CY3100A & 2.000 & 0.402 & 0.001 \\
\hline 88 & CA2SERN & 2.000 & 0.402 & 0.001 \\
\hline 392 & CV2019A & 2.000 & 0.402 & 0.001 \\
\hline 73 & CE 3SERA & 2.000 & 0.402 & 0.001 \\
\hline 102 & CZ2DIAA & 2.000 & 0.402 & 0.001 \\
\hline 363 & CM2056A & 2.000 & 0.402 & 0.001 \\
\hline 399 & CA $2027 \mathrm{~N}$ & 2.000 & 0.402 & 0.001 \\
\hline 444 & CM2129A & 2.000 & 0.402 & 0.001 \\
\hline 234 & CF2SELA & 2.000 & 0.402 & 0.001 \\
\hline 338 & CA1093A & 2.000 & 0.402 & 0.001 \\
\hline 445 & CF 2129A & 2.000 & 0.402 & 0.001 \\
\hline 86 & CV2DIAA & 1.000 & 0.201 & 0.000 \\
\hline 4 & CM2132A & 1.000 & 0.201 & 0.000 \\
\hline 63 & CS 3MARA & 1.000 & 0.201 & 0.000 \\
\hline 267 & CA1053A & 1.000 & 0.201 & 0.000 \\
\hline 284 & CZ2012A & 1.000 & 0.201 & 0.000 \\
\hline
\end{tabular}




\begin{tabular}{|c|c|c|c|c|}
\hline 112 & CS 3BNAA & 1.000 & 0.201 & 0.000 \\
\hline 7 & CP2132A & 1.000 & 0.201 & 0.000 \\
\hline 286 & CV2011A & 1.000 & 0.201 & 0.000 \\
\hline 62 & CA1016A & 1.000 & 0.201 & 0.000 \\
\hline 179 & $\mathrm{CM} 2034 \mathrm{~A}$ & 1.000 & 0.201 & 0.000 \\
\hline 334 & CA1004A & 1.000 & 0.201 & 0.000 \\
\hline 56 & CZ2012A & 1.000 & 0.201 & 0.000 \\
\hline 128 & CA1048A & 1.000 & 0.201 & 0.000 \\
\hline 253 & $\mathrm{CO} 2100 \mathrm{~A}$ & 1.000 & 0.201 & 0.000 \\
\hline 293 & CA2029C & 1.000 & 0.201 & 0.000 \\
\hline 287 & CP2RFUA & 1.000 & 0.201 & 0.000 \\
\hline 108 & CA2JULN & 1.000 & 0.201 & 0.000 \\
\hline 311 & CA1113A & 1.000 & 0.201 & 0.000 \\
\hline 94 & CA1119A & 1.000 & 0.201 & 0.000 \\
\hline 221 & CV2065A & 1.000 & 0.201 & 0.000 \\
\hline 80 & CZ2121A & 1.000 & 0.201 & 0.000 \\
\hline 345 & CZ2095A & 1.000 & 0.201 & 0.000 \\
\hline 97 & CA2117C & 1.000 & 0.201 & 0.000 \\
\hline 69 & CA1120A & 1.000 & 0.201 & 0.000 \\
\hline 318 & CW2002A & 1.000 & 0.201 & 0.000 \\
\hline 100 & CS2JULA & 1.000 & 0.201 & 0.000 \\
\hline 304 & CW2029A & 1.000 & 0.201 & 0.000 \\
\hline 87 & CX3SERA & 1.000 & 0.201 & 0.000 \\
\hline 106 & CM2JULA & 1.000 & 0.201 & 0.000 \\
\hline 292 & CA1029C & 1.000 & 0.201 & 0.000 \\
\hline 324 & CA1106A & 1.000 & 0.201 & 0.000 \\
\hline 355 & CP2082A & 1.000 & 0.201 & 0.000 \\
\hline 341 & CA $2096 \mathrm{~N}$ & 1.000 & 0.201 & 0.000 \\
\hline 295 & CV2029C & 1.000 & 0.201 & 0.000 \\
\hline 298 & CA2015A & 1.000 & 0.201 & 0.000 \\
\hline 220 & CM2065A & 1.000 & 0.201 & 0.000 \\
\hline 111 & CA1029G & 1.000 & 0.201 & 0.000 \\
\hline 175 & $\mathrm{CA} 1034 \mathrm{~A}$ & 1.000 & 0.201 & 0.000 \\
\hline 145 & CZ2031A & 1.000 & 0.201 & 0.000 \\
\hline 224 & CY3064A & 1.000 & 0.201 & 0.000 \\
\hline 302 & CV2015A & 1.000 & 0.201 & 0.000 \\
\hline 241 & CA2S JRN & 1.000 & 0.201 & 0.000 \\
\hline 366 & CA2058A & 1.000 & 0.201 & 0.000 \\
\hline 166 & CZ2046A & 1.000 & 0.201 & 0.000 \\
\hline 58 & CR3CENB & 1.000 & 0.201 & 0.000 \\
\hline 354 & CM2082A & 1.000 & 0.201 & 0.000 \\
\hline 184 & CS3ITAA & 1.000 & 0.201 & 0.000 \\
\hline 107 & CV2JULA & 1.000 & 0.201 & 0.000 \\
\hline 186 & CF 2PARA & 1.000 & 0.201 & 0.000 \\
\hline 124 & CA1048A & 1.000 & 0.201 & 0.000 \\
\hline 297 & CA1032A & 1.000 & 0.201 & 0.000 \\
\hline 95 & CA2119A & 1.000 & 0.201 & 0.000 \\
\hline 252 & CA1116A & 1.000 & 0.201 & 0.000 \\
\hline 377 & CR3YERA & 1.000 & 0.201 & 0.000 \\
\hline 347 & CA1092A & 1.000 & 0.201 & 0.000 \\
\hline 379 & SC3INTC & 1.000 & 0.201 & 0.000 \\
\hline 380 & CR3JPAA & 1.000 & 0.201 & 0.000 \\
\hline 71 & CZ2CONA & 1.000 & 0.201 & 0.000 \\
\hline 367 & CV2058A & 1.000 & 0.201 & 0.000 \\
\hline 259 & CS $3 A E R A$ & 1.000 & 0.201 & 0.000 \\
\hline 353 & CA1082A & 1.000 & 0.201 & 0.000 \\
\hline 136 & CC 3 SAUA & 1.000 & 0.201 & 0.000 \\
\hline 137 & CR3SAUA & 1.000 & 0.201 & 0.000 \\
\hline
\end{tabular}




\begin{tabular}{|c|c|c|c|c|}
\hline 263 & CV2057A & 1.000 & 0.201 & 0.000 \\
\hline 264 & CO2L13A & 1.000 & 0.201 & 0.000 \\
\hline 157 & CA2043A & 1.000 & 0.201 & 0.000 \\
\hline 141 & CV2SAUA & 1.000 & 0.201 & 0.000 \\
\hline 391 & CZ2019A & 1.000 & 0.201 & 0.000 \\
\hline 361 & CF 2016A & 1.000 & 0.201 & 0.000 \\
\hline 269 & CM2053A & 1.000 & 0.201 & 0.000 \\
\hline 394 & CA 2019N & 1.000 & 0.201 & 0.000 \\
\hline 146 & CM2015A & 1.000 & 0.201 & 0.000 \\
\hline 272 & CM2069A & 1.000 & 0.201 & 0.000 \\
\hline 273 & CZ2069A & 1.000 & 0.201 & 0.000 \\
\hline 274 & CP20 69A & 1.000 & 0.201 & 0.000 \\
\hline 119 & CZ2041A & 1.000 & 0.201 & 0.000 \\
\hline 28 & CB2L13A & 1.000 & 0.201 & 0.000 \\
\hline 277 & CA2009A & 1.000 & 0.201 & 0.000 \\
\hline 92 & CZ2119A & 1.000 & 0.201 & 0.000 \\
\hline 279 & CV2023A & 1.000 & 0.201 & 0.000 \\
\hline 93 & CW2107A & 1.000 & 0.201 & 0.000 \\
\hline 343 & CA2064G & 1.000 & 0.201 & 0.000 \\
\hline 406 & CZ2027A & 1.000 & 0.201 & 0.000 \\
\hline 158 & CM2043A & 1.000 & 0.201 & 0.000 \\
\hline 408 & CA2010A & 1.000 & 0.201 & 0.000 \\
\hline 285 & CF 2RFUA & 1.000 & 0.201 & 0.000 \\
\hline 410 & CC 3 SABA & 1.000 & 0.201 & 0.000 \\
\hline 411 & CR3100A & 1.000 & 0.201 & 0.000 \\
\hline 288 & CP2011A & 1.000 & 0.201 & 0.000 \\
\hline 133 & CF 2 JMIA & 1.000 & 0.201 & 0.000 \\
\hline 165 & CA1046A & 1.000 & 0.201 & 0.000 \\
\hline 415 & CS 3GUAA & 1.000 & 0.201 & 0.000 \\
\hline 416 & CO2SAUA & 1.000 & 0.201 & 0.000 \\
\hline 168 & CA2049A & 1.000 & 0.201 & 0.000 \\
\hline 294 & CM2029C & 1.000 & 0.201 & 0.000 \\
\hline 170 & CA2049A & 1.000 & 0.201 & 0.000 \\
\hline 327 & CV2106A & 1.000 & 0.201 & 0.000 \\
\hline 421 & CA1098A & 1.000 & 0.201 & 0.000 \\
\hline 422 & CM2CIDA & 1.000 & 0.201 & 0.000 \\
\hline 299 & CZ2015A & 1.000 & 0.201 & 0.000 \\
\hline 424 & CA2100G & 1.000 & 0.201 & 0.000 \\
\hline 301 & CM2032A & 1.000 & 0.201 & 0.000 \\
\hline 177 & CS2JMIA & 1.000 & 0.201 & 0.000 \\
\hline 178 & CZ2034A & 1.000 & 0.201 & 0.000 \\
\hline 428 & CA2126B & 1.000 & 0.201 & 0.000 \\
\hline 180 & CV2LUSA & 1.000 & 0.201 & 0.000 \\
\hline 181 & CF2LUSA & 1.000 & 0.201 & 0.000 \\
\hline 151 & CY3JMIA & 1.000 & 0.201 & 0.000 \\
\hline 183 & CA2035A & 1.000 & 0.201 & 0.000 \\
\hline 153 & CV2015A & 1.000 & 0.201 & 0.000 \\
\hline 185 & CX3SAUA & 1.000 & 0.201 & 0.000 \\
\hline 435 & CA1125A & 1.000 & 0.201 & 0.000 \\
\hline 281 & CS3DIAC & 1.000 & 0.201 & 0.000 \\
\hline 313 & CW2112A & 1.000 & 0.201 & 0.000 \\
\hline 189 & SC 3 STOA & 1.000 & 0.201 & 0.000 \\
\hline 190 & SC $3 \mathrm{SBCA}$ & 1.000 & 0.201 & 0.000 \\
\hline 316 & CA1020B & 1.000 & 0.201 & 0.000 \\
\hline 317 & CZ2002A & 1.000 & 0.201 & 0.000 \\
\hline 442 & CM2ZTUA & 1.000 & 0.201 & 0.000 \\
\hline 194 & CA2038A & 1.000 & 0.201 & 0.000 \\
\hline 320 & CA2020N & 1.000 & 0.201 & 0.000 \\
\hline
\end{tabular}




\begin{tabular}{|c|c|c|c|c|}
\hline 196 & CA2007A & 1.000 & 0.201 & 0.000 \\
\hline 260 & CM2057A & 1.000 & 0.201 & 0.000 \\
\hline 75 & CV2CONA & 1.000 & 0.201 & 0.000 \\
\hline 448 & CA 2SABN & 1.000 & 0.201 & 0.000 \\
\hline 138 & CR3RETA & 1.000 & 0.201 & 0.000 \\
\hline 450 & CC3JPAA & 1.000 & 0.201 & 0.000 \\
\hline 451 & CV2SABA & 1.000 & 0.201 & 0.000 \\
\hline 79 & CA1121A & 1.000 & 0.201 & 0.000 \\
\hline 204 & CA2067A & 1.000 & 0.201 & 0.000 \\
\hline 268 & CA 2054A & 1.000 & 0.201 & 0.000 \\
\hline 455 & CA $2117 \mathrm{~N}$ & 1.000 & 0.201 & 0.000 \\
\hline 332 & CP 2NAVA & 1.000 & 0.201 & 0.000 \\
\hline 457 & CZ2085A & 1.000 & 0.201 & 0.000 \\
\hline 209 & CM20 66A & 1.000 & 0.201 & 0.000 \\
\hline 335 & CV0 96A & 1.000 & 0.201 & 0.000 \\
\hline 211 & CA $2024 \mathrm{~N}$ & 1.000 & 0.201 & 0.000 \\
\hline 461 & CA1105A & 1.000 & 0.201 & 0.000 \\
\hline 462 & CM2105A & 1.000 & 0.201 & 0.000 \\
\hline 152 & CM2033A & 1.000 & 0.201 & 0.000 \\
\hline 464 & CA2091A & 1.000 & 0.201 & 0.000 \\
\hline 216 & CA2066A & 1.000 & 0.201 & 0.000 \\
\hline 466 & CP2NAVA & 1.000 & 0.201 & 0.000 \\
\hline 218 & CA2 $2066 \mathrm{~N}$ & 1.000 & 0.201 & 0.000 \\
\hline 468 & CA1089A & 1.000 & 0.201 & 0.000 \\
\hline 469 & CA 2089A & 1.000 & 0.201 & 0.000 \\
\hline 470 & CC3NAVA & 1.000 & 0.201 & 0.000 \\
\hline 471 & CM2089A & 1.000 & 0.201 & 0.000 \\
\hline 348 & CA 2096A & 1.000 & 0.201 & 0.000 \\
\hline 473 & CA1124A & 1.000 & 0.201 & 0.000 \\
\hline 350 & CA2069A & 1.000 & 0.201 & 0.000 \\
\hline 351 & CA2 JMIN & 1.000 & 0.201 & 0.000 \\
\hline 228 & CA1077B & 1.000 & 0.201 & 0.000 \\
\hline 477 & CM2123A & 1.000 & 0.201 & 0.000 \\
\hline 478 & CA2NAVN & 1.000 & 0.201 & 0.000 \\
\hline 479 & CA1NAVA & 1.000 & 0.201 & 0.000 \\
\hline 480 & CW2SAUA & 1.000 & 0.201 & 0.000 \\
\hline 357 & CZ2029A & 1.000 & 0.201 & 0.000 \\
\hline 482 & CA1122A & 1.000 & 0.201 & 0.000 \\
\hline 483 & CA $2122 \mathrm{~N}$ & 1.000 & 0.201 & 0.000 \\
\hline 484 & CZ2122A & 1.000 & 0.201 & 0.000 \\
\hline 236 & CA1SELA & 1.000 & 0.201 & 0.000 \\
\hline 486 & $\mathrm{CA} 2118 \mathrm{~A}$ & 1.000 & 0.201 & 0.000 \\
\hline 176 & CA2LUSA & 1.000 & 0.201 & 0.000 \\
\hline 240 & CA1076B & 1.000 & 0.201 & 0.000 \\
\hline 489 & CA $2107 A$ & 1.000 & 0.201 & 0.000 \\
\hline 490 & CY3NAVA & 1.000 & 0.201 & 0.000 \\
\hline 491 & CA2NAVG & 1.000 & 0.201 & 0.000 \\
\hline 492 & CP2107A & 1.000 & 0.201 & 0.000 \\
\hline 307 & CZ2105A & 1.000 & 0.201 & 0.000 \\
\hline 370 & CZ2054A & 1.000 & 0.201 & 0.000 \\
\hline 433 & CP 2SABA & 1.000 & 0.201 & 0.000 \\
\hline 372 & CZ2080A & 1.000 & 0.201 & 0.000 \\
\hline 248 & CA1114A & 1.000 & 0.201 & 0.000 \\
\hline 37 & CS2112A & 1.000 & 0.201 & 0.000 \\
\hline & CA1132A & 1.000 & 0.201 & 0.00 \\
\hline
\end{tabular}


DESCRIPTIVE STATISTICS

$\begin{array}{rrrrr} & & 1 & 2 & 3 \\ & & \text { Degree } & \text { NrmDegree } & \text { Share } \\ 1 & \text { Mean } & 7.459 & 1.498 & 0.002 \\ 2 & \text { Std Dev } & 9.100 & 1.827 & 0.002 \\ 3 & \text { Sum } & 3722.000 & 747.390 & 1.000 \\ 4 & \text { Variance } & 82.801 & 3.339 & 0.000 \\ 5 & \text { SSQ } & 69080.000 & 2785.439 & 0.005 \\ 6 & \text { MCSSQ } & 41317.906 & 1666.018 & 0.003 \\ 7 & \text { Euc Norm } & 262.831 & 52.777 & 0.071 \\ 8 & \text { Minimum } & 1.000 & 0.201 & 0.000 \\ 9 & \text { Maximum } & 66.000 & 13.253 & 0.018\end{array}$

Network Centralization $=11.80 \%$

Heterogeneity $=0.50 \%$ Normalized $=0.30 \%$

Actor-by-centrality matrix saved as dataset FreemanDegree

Running time: 00:00:01

Output generated: 07 jan 09 20:36:25

Copyright (c) 1999-2005 Analytic Technologies 
Apêndice B 


\section{Apêndice B - RESULTADOS DOS CÁLCULOS DA MEDIDA DE PROXIMIDADE}

Input dataset:

Pedreira $\backslash$ RPREDREIRA_C21

Method:

Output dataset:
C: \Doutorado \Tese $\backslash$ Rede

Geodesic paths only (Freeman Closeness)

C: \Doutorado\Tese $\backslash$ Rede Pedreira \Closeness

Closeness Centrality Measures

$\begin{array}{rrrr} & & 1 & 2 \\ & & \text { Farness } & \text { nCloseness } \\ 38 & \text { CS2002A } & 1253.000 & 39.745 \\ 25 & \text { CR3L13A } & 1295.000 & 38.456 \\ 19 & \text { CC3L13A } & 1307.000 & 38.103 \\ 456 & \text { M084A } & 1330.000 & 37.444 \\ 328 & \text { M109A } & 1338.000 & 37.220 \\ 358 & \text { M052A } & 1338.000 & 37.220 \\ 159 & \text { M044F } & 1346.000 & 36.999 \\ 150 & \text { M135F } & 1348.000 & 36.944 \\ 368 & \text { M059A } & 1364.000 & 36.510 \\ 127 & \text { M133F } & 1376.000 & 36.192 \\ 254 & \text { M071F } & 1378.000 & 36.139 \\ 155 & \text { M043F } & 1388.000 & 35.879 \\ 369 & \text { M054A } & 1388.000 & 35.879 \\ 162 & \text { M045F } & 1396.000 & 35.673 \\ 14 & \text { CE3L13A } & 1397.000 & 35.648 \\ 33 & \text { CE3DIAA } & 1397.000 & 35.648 \\ 61 & \text { M030F } & 1398.000 & 35.622 \\ 467 & \text { M089A } & 1400.000 & 35.571 \\ 481 & \text { M122A } & 1400.000 & 35.571 \\ 487 & \text { M108A } & 1400.000 & 35.571 \\ 67 & \text { CY3L13A } & 1401.000 & 35.546 \\ 143 & \text { M134F } & 1408.000 & 35.369 \\ 349 & \text { M069A } & 1410.000 & 35.319 \\ 296 & \text { M032F } & 1410.000 & 35.319 \\ 465 & \text { M090A } & 1412.000 & 35.269 \\ 382 & \text { M003A } & 1412.000 & 35.269 \\ 454 & \text { M103A } & 1422.000 & 35.021 \\ 497 & \text { CE3INTA } & 1427.000 & 34.898 \\ 116 & \text { M040F } & 1430.000 & 34.825 \\ 261 & \text { M060F } & 1430.000 & 34.825 \\ 495 & \text { CR3INTA } & 1431.000 & 34.801 \\ 185 & \text { M117A } & 1438.000 & 34.631 \\ 496 & \text { CY3INTA } & 1455.000 & 34.250 \\ 81 & \text { CX3DIAA } & 1459.000 & 34.133\end{array}$




\begin{tabular}{|c|c|c|c|}
\hline 265 & M0 61F & 1462.000 & 34.063 \\
\hline 167 & M0 4 9F & 1462.000 & 34.063 \\
\hline 235 & M078F & 1464.000 & 34.016 \\
\hline 418 & M0 63A & 1464.000 & 34.016 \\
\hline 129 & CX3L13A & 1469.000 & 33.901 \\
\hline 393 & M020A & 1470.000 & 33.878 \\
\hline 199 & M0 0 6F & 1472.000 & 33.832 \\
\hline 55 & $\mathrm{M} 026 \mathrm{~A}$ & 1472.000 & 33.832 \\
\hline 306 & M087F & 1472.000 & 33.832 \\
\hline 169 & M0 4 7F & 1474.000 & 33.786 \\
\hline 278 & M023A & 1474.000 & 33.786 \\
\hline 494 & CC3INTA & 1475.000 & 33.763 \\
\hline 384 & M001A & 1476.000 & 33.740 \\
\hline 109 & M050F & 1476.000 & 33.740 \\
\hline 365 & M058A & 1478.000 & 33.694 \\
\hline 203 & $\mathrm{M} 024 \mathrm{~F}$ & 1478.000 & 33.694 \\
\hline 72 & CY3DIAA & 1479.000 & 33.671 \\
\hline 346 & M0 92A & 1482.000 & 33.603 \\
\hline 420 & M0 98M & 1486.000 & 33.513 \\
\hline 476 & M123A & 1488.000 & 33.468 \\
\hline 291 & M029A & 1492.000 & $33.37 \varepsilon$ \\
\hline 396 & M0 08A & 1492.000 & 33.378 \\
\hline 90 & M119F & 1494.000 & 33.333 \\
\hline 359 & M056A & 1496.000 & 33.289 \\
\hline 123 & M0 4 8F & 1496.000 & 33.289 \\
\hline 35 & CC3DIAA & 1499.000 & 33.222 \\
\hline 386 & M0 62A & 1500.000 & 33.200 \\
\hline 458 & M0 83A & 1500.000 & 33.200 \\
\hline 412 & M073A & 1500.000 & 33.200 \\
\hline 453 & M1 02A & 1504.000 & 33.112 \\
\hline 59 & M091A & 1504.000 & 33.112 \\
\hline 34 & CR3DIAA & 1509.000 & 33.002 \\
\hline 356 & M051A & 1514.000 & 32.893 \\
\hline 37 & M018A & 1514.000 & 32.893 \\
\hline 407 & M010A & 1514.000 & 32.893 \\
\hline 426 & M126A & 1514.000 & 32.893 \\
\hline 333 & M0 $04 \mathrm{~A}$ & 1516.000 & 32.850 \\
\hline 289 & $\mathrm{M} 014 \mathrm{~F}$ & 1518.000 & 32.806 \\
\hline 5 & SM3INTA & 1519.000 & 32.785 \\
\hline 223 & M075F & 1520.000 & 32.763 \\
\hline 419 & M0 05A & 1520.000 & 32.763 \\
\hline 400 & M027A & 1520.000 & 32.763 \\
\hline 40 & CM2017A & 1521.000 & 32.742 \\
\hline 130 & CW2L13A & 1525.000 & 32.656 \\
\hline 219 & M025F & 1526.000 & 32.634 \\
\hline 321 & M0 97F & 1526.000 & 32.634 \\
\hline 449 & M017A & 1528.000 & 32.592 \\
\hline 452 & M015A & 1530.000 & 32.549 \\
\hline 283 & $\mathrm{M} 013 \mathrm{~F}$ & 1534.000 & 32.464 \\
\hline 315 & $\mathrm{M} 021 \mathrm{~F}$ & 1538.000 & 32.380 \\
\hline 195 & M0 07F & 1540.000 & 32.338 \\
\hline 381 & M079A & 1540.000 & 32.338 \\
\hline 342 & M0 94A & 1540.000 & 32.33 \\
\hline 390 & M019A & 1542.000 & 32.29 \\
\hline 375 & M0 66A & 1542.000 & 32.29 \\
\hline 436 & M128A & 1542.000 & 32.29 \\
\hline 395 & M0 68A & 1544.000 & 32.254 \\
\hline 440 & M112A & 1546.000 & 32.21 \\
\hline
\end{tabular}




\begin{tabular}{|c|c|c|c|}
\hline 36 & CF2DIAA & 1547.000 & 32.191 \\
\hline 47 & $\mathrm{M} 022 \mathrm{~A}$ & 1548.000 & 32.171 \\
\hline 82 & CW2DIAA & 1549.000 & 32.150 \\
\hline 191 & $\mathrm{M} 036 \mathrm{~F}$ & 1550.000 & 32.129 \\
\hline 323 & M088A & 1550.000 & 32.129 \\
\hline 385 & $\mathrm{M} 002 \mathrm{~A}$ & 1550.000 & 32.129 \\
\hline 171 & M039F & 1552.000 & 32.088 \\
\hline 446 & M132A & 1560.000 & 31.923 \\
\hline 251 & M116F & 1560.000 & 31.923 \\
\hline 344 & M095A & 1560.000 & 31.923 \\
\hline 42 & M1 0 4A & 1560.000 & 31.923 \\
\hline 447 & M129A & 1562.000 & 31.882 \\
\hline 439 & M114A & 1562.000 & 31.882 \\
\hline 404 & M028A & 1574.000 & 31.639 \\
\hline 135 & M031F & 1576.000 & 31.599 \\
\hline 499 & CW3INTA & 1589.000 & 31.340 \\
\hline 57 & CF2DSPA & 1595.000 & 31.223 \\
\hline 438 & M100A & 1600.000 & 31.125 \\
\hline 280 & $\mathrm{M} 012 \mathrm{~A}$ & 1602.000 & 31.086 \\
\hline 126 & CA2L13N & 1605.000 & 31.028 \\
\hline 65 & CF2SJDA & 1609.000 & 30.951 \\
\hline 498 & CX3INTA & 1617.000 & 30.798 \\
\hline 32 & CS2016A & 1617.000 & 30.798 \\
\hline 414 & M0 64A & 1618.000 & 30.779 \\
\hline 258 & $\mathrm{M} 072 \mathrm{~F}$ & 1620.000 & 30.741 \\
\hline 493 & CS3INTX & 1625.000 & 30.646 \\
\hline 39 & CS 3DIAA & 1627.000 & 30.608 \\
\hline 364 & M057A & 1628.000 & 30.590 \\
\hline 441 & M127A & 1628.000 & 30.590 \\
\hline 303 & M016A & 1642.000 & 30.329 \\
\hline 247 & M115F & 1650.000 & 30.182 \\
\hline 378 & M080A & 1654.000 & 30.109 \\
\hline 227 & M077F & 1656.000 & 30.072 \\
\hline 104 & CR2BRZA & 1657.000 & 30.054 \\
\hline 132 & CV2L13A & 1657.000 & 30.054 \\
\hline 275 & M0 O9F & 1658.000 & 30.036 \\
\hline 113 & CV2DIAA & 1659.000 & 30.018 \\
\hline 337 & M093A & 1660.000 & 30.000 \\
\hline 83 & CM2DIAA & 1661.000 & 29.982 \\
\hline 239 & M076F & 1662.000 & 29.964 \\
\hline 134 & CV2064A & 1663.000 & 29.946 \\
\hline 148 & CV2002A & 1667.000 & 29.874 \\
\hline 310 & M113F & 1668.000 & 29.856 \\
\hline 103 & CC 3BRZA & 1669.000 & 29.838 \\
\hline 207 & CS3INTA & 1669.000 & 29.838 \\
\hline 12 & CC 3 CENA & 1671.000 & 29.803 \\
\hline 243 & M101F & 1672.000 & 29.785 \\
\hline 405 & M0 67A & 1676.000 & 29.714 \\
\hline 98 & M033F & 1678.000 & 29.678 \\
\hline 21 & M011A & 1678.000 & 29.678 \\
\hline 118 & M0 41F & 1680.000 & 29.643 \\
\hline 202 & $\mathrm{M} 042 \mathrm{~F}$ & 1684.000 & 29.572 \\
\hline 29 & CR 3CENA & 1689.000 & 29.485 \\
\hline 430 & M125A & 1694.000 & 29.398 \\
\hline 164 & M0 4 6F & 1698.000 & 29.329 \\
\hline 77 & CO2DIAA & 1699.000 & 29.311 \\
\hline 270 & M070F & 1704.000 & 29.225 \\
\hline 91 & CS 2NAVA & 1705.000 & 29.208 \\
\hline
\end{tabular}




\begin{tabular}{|c|c|c|c|}
\hline 6 & CO2INTA & 1707.000 & 29.174 \\
\hline 443 & M130A & 1710.000 & 29.123 \\
\hline 51 & SM3MARA & 1715.000 & 29.038 \\
\hline 147 & $\mathrm{CF} 2002 \mathrm{~A}$ & 1717.000 & 29.004 \\
\hline 41 & CP $2002 A$ & 1719.000 & 28.970 \\
\hline 459 & M1 05A & 1724.000 & 28.886 \\
\hline 423 & $\mathrm{M} 111 \mathrm{~A}$ & 1726.000 & 28.853 \\
\hline 48 & CS2064A & 1727.000 & 28.836 \\
\hline 53 & $\mathrm{CF} 2064 \mathrm{~A}$ & 1727.000 & 28.836 \\
\hline 460 & M106A & 1728.000 & 28.819 \\
\hline 187 & M037F & 1732.000 & 28.753 \\
\hline 44 & CP2117A & 1739.000 & 28.637 \\
\hline 488 & M107A & 1740.000 & 28.621 \\
\hline 214 & M0 65A & 1740.000 & 28.621 \\
\hline 120 & CF2029A & 1741.000 & 28.604 \\
\hline 331 & CV2NAVA & 1749.000 & 28.473 \\
\hline 161 & CA2017N & 1749.000 & 28.473 \\
\hline 434 & M110A & 1752.000 & 28.425 \\
\hline 197 & CF2L13A & 1753.000 & 28.408 \\
\hline 52 & SC $3 \mathrm{SPMA}$ & 1755.000 & 28.376 \\
\hline 110 & CA1029A & 1755.000 & 28.376 \\
\hline 290 & CY 3CENA & 1757.000 & 28.344 \\
\hline 319 & CM2002A & 1759.000 & 28.312 \\
\hline 383 & CX3SABA & 1761.000 & 28.279 \\
\hline 46 & CA2117A & 1763.000 & 28.247 \\
\hline 114 & CA2DIAN & 1763.000 & 28.247 \\
\hline 131 & CM2027A & 1769.000 & 28.151 \\
\hline 122 & CP2017A & 1769.000 & 28.151 \\
\hline 60 & CM2107A & 1769.000 & 28.151 \\
\hline 352 & M082A & 1770.000 & 28.136 \\
\hline 121 & CA2029N & 1771.000 & 28.120 \\
\hline 160 & CV2029A & 1775.000 & 28.056 \\
\hline 413 & CW2CENA & 1775.000 & 28.056 \\
\hline 43 & $\mathrm{CM} 2117 \mathrm{~A}$ & 1777.000 & 28.025 \\
\hline 1 & M131A & 1778.000 & 28.009 \\
\hline 229 & CS2100A & 1781.000 & 27.962 \\
\hline 266 & M055F & 1782.000 & 27.946 \\
\hline 11 & CM2100A & 1783.000 & 27.930 \\
\hline 360 & CV2056A & 1785.000 & 27.899 \\
\hline 15 & M096A & 1786.000 & 27.884 \\
\hline 78 & $\mathrm{M} 121 \mathrm{~F}$ & 1788.000 & 27.852 \\
\hline 329 & CA1107A & 1789.000 & 27.837 \\
\hline 193 & M038F & 1794.000 & 27.759 \\
\hline 330 & CW2NAVA & 1797.000 & 27.713 \\
\hline 8 & M074A & 1798.000 & 27.697 \\
\hline 402 & SC2SAUA & 1799.000 & 27.682 \\
\hline 174 & M034F & 1800.000 & 27.667 \\
\hline 31 & M053A & 1800.000 & 27.667 \\
\hline 322 & M0 85A & 1800.000 & 27.667 \\
\hline 300 & CM2 JMIA & 1801.000 & 27.651 \\
\hline 140 & CW2015A & 1801.000 & 27.651 \\
\hline 68 & M120F & 1802.000 & 27.636 \\
\hline 125 & CA2029A & 1803.000 & 27.621 \\
\hline 246 & CA2100N & 1803.000 & 27.621 \\
\hline 198 & CA20 $64 \mathrm{~N}$ & 1805.000 & 27.590 \\
\hline 50 & $\mathrm{CM} 2064 \mathrm{~A}$ & 1807.000 & 27.559 \\
\hline 309 & CV2085A & 1807.000 & 27.559 \\
\hline 154 & CV2 JMIA & 1809.000 & 27.529 \\
\hline
\end{tabular}




\begin{tabular}{|c|c|c|c|}
\hline 244 & CV2100A & 1809.000 & 27.529 \\
\hline 156 & CA1043A & 1811.000 & 27.499 \\
\hline 362 & CP2016A & 1811.000 & 27.499 \\
\hline 144 & CA1031A & 1817.000 & 27.408 \\
\hline 363 & CM2056A & 1817.000 & 27.408 \\
\hline 257 & CP2029A & 1817.000 & 27.408 \\
\hline 485 & M118A & 1818.000 & 27.393 \\
\hline 27 & CE 3YERA & 1821.000 & 27.348 \\
\hline 201 & CM2YERA & 1821.000 & 27.348 \\
\hline 54 & CP2064A & 1821.000 & 27.348 \\
\hline 472 & M124A & 1824.000 & 27.303 \\
\hline 457 & CZ2085A & 1827.000 & 27.258 \\
\hline 115 & CP 2DIAA & 1829.000 & 27.228 \\
\hline 250 & CW2SABA & 1831.000 & 27.198 \\
\hline 3 & CS2ZTUA & 1831.000 & 27.198 \\
\hline 64 & CV2016A & 1833.000 & 27.169 \\
\hline 210 & CV2CENA & 1833.000 & 27.169 \\
\hline 163 & CV2017A & 1833.000 & 27.169 \\
\hline 332 & CP2NAVA & 1835.000 & 27.139 \\
\hline 84 & CM2SERA & 1835.000 & 27.139 \\
\hline 149 & $\mathrm{CA} 2015 \mathrm{~N}$ & 1837.000 & 27.109 \\
\hline 373 & CX3YERA & 1839.000 & 27.080 \\
\hline 70 & CS2SERA & 1841.000 & 27.051 \\
\hline 76 & CF2SERA & 1841.000 & 27.051 \\
\hline 245 & CF2100A & 1841.000 & 27.051 \\
\hline 271 & CA2069A & 1843.000 & 27.021 \\
\hline 226 & CO2SABA & 1845.000 & 26.992 \\
\hline 152 & CM2033A & 1845.000 & 26.992 \\
\hline 153 & CV2015A & 1845.000 & 26.992 \\
\hline 205 & CS2YERA & 1845.000 & 26.992 \\
\hline 151 & CY3JMIA & 1845.000 & 26.992 \\
\hline 89 & CP 2SERA & 1851.000 & 26.904 \\
\hline 85 & CV2SERA & 1851.000 & 26.904 \\
\hline 66 & $\mathrm{CA} 2016 \mathrm{~N}$ & 1855.000 & 26.846 \\
\hline 256 & CA2057A & 1855.000 & 26.846 \\
\hline 188 & CA2DIAA & 1855.000 & 26.846 \\
\hline 255 & CV2056A & 1857.000 & 26.817 \\
\hline 73 & CE 3SERA & 1859.000 & 26.789 \\
\hline 192 & CA2DIAG & 1863.000 & 26.731 \\
\hline 49 & $\mathrm{CA} 1064 \mathrm{~A}$ & 1867.000 & 26.674 \\
\hline 206 & CA2027A & 1867.000 & 26.674 \\
\hline 231 & CW2100A & 1869.000 & 26.645 \\
\hline 225 & CY 3SABA & 1869.000 & 26.645 \\
\hline 409 & M099A & 1870.000 & 26.631 \\
\hline 142 & CY3SAUA & 1871.000 & 26.617 \\
\hline 9 & CA1100A & 1871.000 & 26.617 \\
\hline 20 & CF2092A & 1871.000 & 26.617 \\
\hline 128 & CA1048A & 1873.000 & 26.588 \\
\hline 133 & CF2 JMIA & 1873.000 & 26.588 \\
\hline 208 & CW2YERA & 1875.000 & 26.560 \\
\hline 200 & CW2064A & 1879.000 & 26.503 \\
\hline 22 & CA1011A & 1881.000 & 26.475 \\
\hline 23 & CA2011A & 1881.000 & 26.475 \\
\hline 96 & CV2107A & 1883.000 & 26.447 \\
\hline 157 & CA2043A & 1885.000 & 26.419 \\
\hline 370 & CZ2054A & 1885.000 & 26.419 \\
\hline 222 & CV2080A & 1885.000 & 26.419 \\
\hline 158 & CM2043A & 1885.000 & 26.419 \\
\hline
\end{tabular}




\begin{tabular}{|c|c|c|c|}
\hline 376 & CA2080A & 1889.000 & 26.363 \\
\hline 242 & CM2S JRA & 1889.000 & 26.363 \\
\hline 374 & CV2YERA & 1889.000 & 26.363 \\
\hline 139 & CE3SAUA & 1889.000 & 26.363 \\
\hline 213 & CP2080A & 1893.000 & 26.307 \\
\hline 62 & CA1016A & 1895.000 & 26.280 \\
\hline 63 & CS 3MARA & 1895.000 & 26.280 \\
\hline 469 & CA2089A & 1897.000 & 26.252 \\
\hline 87 & CX3SERA & 1897.000 & 26.252 \\
\hline 482 & CA1122A & 1897.000 & 26.252 \\
\hline 468 & CA1089A & 1897.000 & 26.252 \\
\hline 483 & $\mathrm{CA} 2122 \mathrm{~N}$ & 1897.000 & 26.252 \\
\hline 470 & CC 3NAVA & 1897.000 & 26.252 \\
\hline 484 & CZ2122A & 1897.000 & 26.252 \\
\hline 471 & CM2089A & 1897.000 & 26.252 \\
\hline 432 & CA2129A & 1901.000 & 26.197 \\
\hline 262 & CS2L13A & 1901.000 & 26.197 \\
\hline 340 & CM2096C & 1903.000 & 26.169 \\
\hline 145 & CZ2031A & 1905.000 & 26.142 \\
\hline 398 & CF2027A & 1905.000 & 26.142 \\
\hline 146 & CM2015A & 1905.000 & 26.142 \\
\hline 397 & CV2027A & 1905.000 & 26.142 \\
\hline 299 & CZ2015A & 1907.000 & 26.114 \\
\hline 302 & CV2015A & 1907.000 & 26.114 \\
\hline 298 & CA2015A & 1907.000 & 26.114 \\
\hline 301 & $\mathrm{CM} 2032 \mathrm{~A}$ & 1907.000 & 26.114 \\
\hline 297 & CA1032A & 1907.000 & 26.114 \\
\hline 351 & CA2 JMIN & 1907.000 & 26.114 \\
\hline 17 & CS2096A & 1907.000 & 26.114 \\
\hline 350 & CA2069A & 1907.000 & 26.114 \\
\hline 466 & CP2NAVA & 1909.000 & 26.087 \\
\hline 13 & CP2100A & 1913.000 & 26.032 \\
\hline 387 & CA1019A & 1915.000 & 26.005 \\
\hline 238 & CO2YERA & 1915.000 & 26.005 \\
\hline 117 & CS2029A & 1915.000 & 26.005 \\
\hline 455 & CA2117N & 1919.000 & 25.951 \\
\hline 305 & CM2016A & 1919.000 & 25.951 \\
\hline 230 & CS2S JRA & 1921.000 & 25.924 \\
\hline 217 & CF2080A & 1921.000 & 25.924 \\
\hline 24 & CM2080A & 1923.000 & 25.897 \\
\hline 264 & Co2L13A & 1927.000 & 25.843 \\
\hline 263 & CV2057A & 1927.000 & 25.843 \\
\hline 336 & CP2096A & 1929.000 & 25.816 \\
\hline 427 & CA1129A & 1931.000 & 25.790 \\
\hline 282 & CM2011A & 1933.000 & 25.763 \\
\hline 429 & CV2129A & 1933.000 & 25.763 \\
\hline 437 & CM2SABA & 1935.000 & 25.736 \\
\hline 215 & CA1066A & 1935.000 & 25.736 \\
\hline 234 & CF2SELA & 1935.000 & 25.736 \\
\hline 232 & CM2SELA & 1935.000 & 25.736 \\
\hline 233 & CV2077A & 1935.000 & 25.736 \\
\hline 10 & CL1074A & 1939.000 & 25.683 \\
\hline 101 & CS2DIAA & 1939.000 & 25.683 \\
\hline 464 & CA2091A & 1939.000 & 25.683 \\
\hline 392 & CV2019A & 1941.000 & 25.657 \\
\hline 338 & CA1093A & 1943.000 & 25.630 \\
\hline 308 & CV2117A & 1943.000 & 25.630 \\
\hline 339 & CZ2096A & 1943.000 & 25.630 \\
\hline
\end{tabular}




\begin{tabular}{|c|c|c|c|}
\hline 237 & CY3YERA & 1945.000 & 25.604 \\
\hline 475 & CF2NAVA & 1947.000 & 25.578 \\
\hline 276 & CA2008A & 1947.000 & 25.578 \\
\hline 212 & CA2YERN & 1947.000 & 25.578 \\
\hline 186 & CF 2 PARA & 1951.000 & 25.525 \\
\hline 389 & $\mathrm{CA} 2002 \mathrm{~N}$ & 1951.000 & 25.525 \\
\hline 183 & CA2035A & 1951.000 & 25.525 \\
\hline 184 & CS 3ITAA & 1951.000 & 25.525 \\
\hline 185 & CX3SAUA & 1951.000 & 25.525 \\
\hline 388 & CP 2AERA & 1957.000 & 25.447 \\
\hline 399 & $\mathrm{CA} 2027 \mathrm{~N}$ & 1959.000 & 25.421 \\
\hline 168 & CA2049A & 1959.000 & 25.421 \\
\hline 445 & CF2129A & 1961.000 & 25.395 \\
\hline 236 & CA1SELA & 1961.000 & 25.395 \\
\hline 394 & $\mathrm{CA} 2019 \mathrm{~N}$ & 1967.000 & 25.318 \\
\hline 431 & CS2SABA & 1967.000 & 25.318 \\
\hline 56 & CZ2012A & 1969.000 & 25.292 \\
\hline 58 & CR3CENB & 1969.000 & 25.292 \\
\hline 307 & CZ2105A & 1969.000 & 25.292 \\
\hline 279 & CV2023A & 1971.000 & 25.266 \\
\hline 170 & CA2049A & 1971.000 & 25.266 \\
\hline 112 & CS 3BNAA & 1973.000 & 25.241 \\
\hline 111 & CA1029G & 1973.000 & 25.241 \\
\hline 209 & $\mathrm{CM} 2066 \mathrm{~A}$ & 1975.000 & 25.215 \\
\hline 444 & CM2129A & 1975.000 & 25.215 \\
\hline 366 & CA2058A & 1975.000 & 25.215 \\
\hline 211 & $\mathrm{CA} 2024 \mathrm{~N}$ & 1975.000 & 25.215 \\
\hline 204 & $\mathrm{CA} 2067 \mathrm{~A}$ & 1975.000 & 25.215 \\
\hline 367 & CV2058A & 1975.000 & 25.215 \\
\hline 347 & CA1092A & 1979.000 & 25.164 \\
\hline 348 & CA2096A & 1979.000 & 25.164 \\
\hline 422 & CM2CIDA & 1983.000 & 25.113 \\
\hline 99 & CA1 JULA & 1983.000 & 25.113 \\
\hline 421 & CA1098A & 1983.000 & 25.113 \\
\hline 173 & CV2039A & 1983.000 & 25.113 \\
\hline 478 & CA2NAVN & 1985.000 & 25.088 \\
\hline 480 & CW2SAUA & 1985.000 & 25.088 \\
\hline 479 & CA1NAVA & 1985.000 & 25.088 \\
\hline 477 & CM2123A & 1985.000 & 25.088 \\
\hline 292 & CA1029C & 1989.000 & 25.038 \\
\hline 295 & CV2029C & 1989.000 & 25.038 \\
\hline 294 & CM2029C & 1989.000 & 25.038 \\
\hline 293 & CA2029C & 1989.000 & 25.038 \\
\hline 95 & CA2119A & 1991.000 & 25.013 \\
\hline 92 & CZ2119A & 1991.000 & 25.013 \\
\hline 97 & CA2117C & 1991.000 & 25.013 \\
\hline 94 & CA1119A & 1991.000 & 25.013 \\
\hline 93 & CW2107A & 1991.000 & 25.013 \\
\hline 124 & CA1048A & 1993.000 & 24.987 \\
\hline 361 & CF2016A & 1993.000 & 24.987 \\
\hline 325 & CA2106A & 1995.000 & 24.962 \\
\hline 30 & CM2RFUA & 1999.000 & 24.912 \\
\hline 403 & CP2027A & 2005.000 & 24.838 \\
\hline 401 & CA1027A & 2005.000 & 24.838 \\
\hline 326 & CF2107A & 2005.000 & 24.838 \\
\hline 428 & CA2126B & 2011.000 & 24.764 \\
\hline 357 & CZ2029A & 2011.000 & 24.764 \\
\hline 408 & CA2010A & 2011.000 & .4 .76 \\
\hline
\end{tabular}




\begin{tabular}{|c|c|c|c|}
\hline 334 & CA1004A & 2013.000 & 24.739 \\
\hline 335 & CV0 96A & 2013.000 & 24.739 \\
\hline 18 & CM2096A & 2015.000 & 24.715 \\
\hline 224 & CY3064A & 2017.000 & 24.690 \\
\hline 16 & CA1096A & 2019.000 & 24.666 \\
\hline 314 & CM2112A & 2021.000 & 24.641 \\
\hline 220 & CM2065A & 2023.000 & 24.617 \\
\hline 221 & CV2065A & 2023.000 & 24.617 \\
\hline 450 & CC 3 JPAA & 2025.000 & 24.593 \\
\hline 451 & CV2SABA & 2025.000 & 24.593 \\
\hline 286 & CV2011A & 2031.000 & 24.520 \\
\hline 288 & CP2011A & 2031.000 & 24.52 \\
\hline 285 & CF 2RFUA & 2031.000 & 24.520 \\
\hline 284 & CZ2012A & 2031.000 & 24.520 \\
\hline 287 & CP2RFUA & 2031.000 & 24.520 \\
\hline 26 & CF 2YERA & 2033.000 & 24.496 \\
\hline 320 & CA2020N & 2035.000 & 24.472 \\
\hline 172 & CA1039A & 2035.000 & 24.472 \\
\hline 318 & CW2002A & 2035.000 & 24.472 \\
\hline 317 & CZ2002A & 2035.000 & 24.472 \\
\hline 316 & CA1020B & 2035.000 & 24.472 \\
\hline 343 & CA2064G & 2037.000 & 24.448 \\
\hline 196 & CA2007A & 2037.000 & 24.448 \\
\hline 377 & CR3YERA & 2039.000 & 24.424 \\
\hline 391 & CZ2019A & 2039.000 & 24.424 \\
\hline 324 & CA1106A & 2047.000 & 24.328 \\
\hline 327 & CV2106A & 2047.000 & 24.328 \\
\hline 252 & CA1116A & 2057.000 & 24.210 \\
\hline 253 & $\mathrm{CO} 2100 \mathrm{~A}$ & 2057.000 & 24.210 \\
\hline 345 & CZ2095A & 2057.000 & 24.210 \\
\hline 448 & CA $2 \mathrm{SABN}$ & 2059.000 & 24.186 \\
\hline 425 & $\mathrm{CA} 2100 \mathrm{~A}$ & 2063.000 & 24.140 \\
\hline 249 & CY3100A & 2065.000 & 24.116 \\
\hline 137 & CR3SAUA & 2073.000 & 24.023 \\
\hline 138 & CR3RETA & 2073.000 & 24.023 \\
\hline 136 & CC 3 SAUA & 2073.000 & 24.023 \\
\hline 141 & CV2SAUA & 2073.000 & 24.023 \\
\hline 417 & CR3SABA & 2081.000 & 23.931 \\
\hline 105 & CY3BRZA & 2091.000 & 23.816 \\
\hline 281 & CS 3DIAC & 2099.000 & 23.726 \\
\hline 416 & CO2SAUA & 2115.000 & 23.546 \\
\hline 415 & CS 3GUAA & 2115.000 & 23.54 \\
\hline 260 & CM2057A & 2117.000 & 23.524 \\
\hline 259 & CS $3 A E R A$ & 2117.000 & 23.524 \\
\hline 102 & CZ2DIAA & 2123.000 & 23.457 \\
\hline 442 & CM2ZTUA & 2125.000 & 23.435 \\
\hline 304 & CW2029A & 2139.000 & 23.282 \\
\hline 248 & CA1114A & 2147.000 & 23.19 \\
\hline 380 & CR3JPAA & 2151.000 & 23.152 \\
\hline 379 & SC3INTC & 2151.000 & 23.152 \\
\hline 228 & CA1077B & 2153.000 & 23.131 \\
\hline 277 & CA2009A & 2155.000 & 23.109 \\
\hline 341 & CA $2096 \mathrm{~N}$ & 2157.000 & 23.08 \\
\hline 241 & CA2S JRN & 2159.000 & 23.066 \\
\hline 240 & CA1076B & 2159.000 & 23.06 \\
\hline 311 & CA1113A & 2165.000 & 23.002 \\
\hline 312 & CS2112A & 2165.000 & 23.00 \\
\hline 313 & CW2112A & 2165.000 & 23.00 \\
\hline
\end{tabular}




\begin{tabular}{|c|c|c|c|}
\hline 406 & CZ2027A & 2173.000 & 22.918 \\
\hline 100 & CS2 JULA & 2175.000 & 22.897 \\
\hline 106 & CM2 JULA & 2175.000 & 22.897 \\
\hline 28 & CB2L13A & 2175.000 & 22.897 \\
\hline 108 & CA 2 JULN & 2175.000 & 22.897 \\
\hline 107 & CV2JULA & 2175.000 & 22.897 \\
\hline 119 & CZ2041A & 2177.000 & 22.876 \\
\hline 433 & CP $2 \mathrm{SABA}$ & 2191.000 & 22.729 \\
\hline 165 & CA1046A & 2195.000 & 22.688 \\
\hline 166 & CZ2046A & 2195.000 & 22.688 \\
\hline 272 & CM2069A & 2201.000 & 22.626 \\
\hline 274 & CP2069A & 2201.000 & 22.626 \\
\hline 273 & CZ2069A & 2201.000 & 22.626 \\
\hline 474 & CM2NAVA & 2205.000 & 22.585 \\
\hline 371 & M081A & 2212.000 & 22.514 \\
\hline 424 & CA2100G & 2223.000 & 22.402 \\
\hline 462 & CM2105A & 2225.000 & 22.382 \\
\hline 461 & CA1105A & 2225.000 & 22.382 \\
\hline 189 & SC 3 STOA & 2229.000 & 22.342 \\
\hline 190 & SC $3 \mathrm{SBCA}$ & 2229.000 & 22.342 \\
\hline 490 & CY3NAVA & 2237.000 & 22.262 \\
\hline 218 & CA $2066 \mathrm{~N}$ & 2237.000 & 22.262 \\
\hline 492 & CP2107A & 2237.000 & 22.262 \\
\hline 491 & CA2NAVG & 2237.000 & 22.262 \\
\hline 489 & CA $2107 A$ & 2237.000 & 22.262 \\
\hline 216 & CA $2066 \mathrm{~A}$ & 2237.000 & 22.262 \\
\hline 435 & CA1125A & 2249.000 & 22.143 \\
\hline 355 & CP 2082A & 2267.000 & 21.967 \\
\hline 353 & CA1082A & 2267.000 & 21.967 \\
\hline 354 & CM2082A & 2267.000 & 21.967 \\
\hline 74 & CW2SERA & 2273.000 & 21.909 \\
\hline 88 & CA2SERN & 2273.000 & 21.909 \\
\hline 2 & CA1132A & 2275.000 & 21.890 \\
\hline 4 & CM2132A & 2275.000 & 21.890 \\
\hline 7 & CP2132A & 2275.000 & 21.890 \\
\hline 268 & CA 2054A & 2279.000 & 21.852 \\
\hline 269 & CM2053A & 2279.000 & 21.852 \\
\hline 267 & CA1053A & 2279.000 & 21.852 \\
\hline 86 & CV2DIAA & 2285.000 & 21.794 \\
\hline 80 & CZ2121A & 2285.000 & 21.794 \\
\hline 79 & CA1121A & 2285.000 & 21.794 \\
\hline 194 & CA 2038A & 2291.000 & 21.737 \\
\hline 177 & CS2JMIA & 2297.000 & 21.680 \\
\hline 178 & CZ2034A & 2297.000 & 21.680 \\
\hline 176 & CA2LUSA & 2297.000 & 21.680 \\
\hline 179 & $\mathrm{CM} 2034 \mathrm{~A}$ & 2297.000 & 21.680 \\
\hline 181 & CE2LUSA & 2297.000 & 21.680 \\
\hline 175 & CA1034A & 2297.000 & 21.680 \\
\hline 180 & CV2LUSA & 2297.000 & 21.680 \\
\hline 75 & CV2CONA & 2299.000 & 21.662 \\
\hline 69 & CA1120A & 2299.000 & 21.662 \\
\hline 71 & CZ2CONA & 2299.000 & 21.662 \\
\hline 486 & CA2118A & 2315.000 & 21.512 \\
\hline 473 & CA1124A & 2321.000 & 21.456 \\
\hline 410 & CC 3 SABA & 2367.000 & 21.039 \\
\hline 411 & CR3100A & 2367.000 & 21.039 \\
\hline 372 & CZ2080A & 2709.000 & 18.383 \\
\hline
\end{tabular}


Statistics

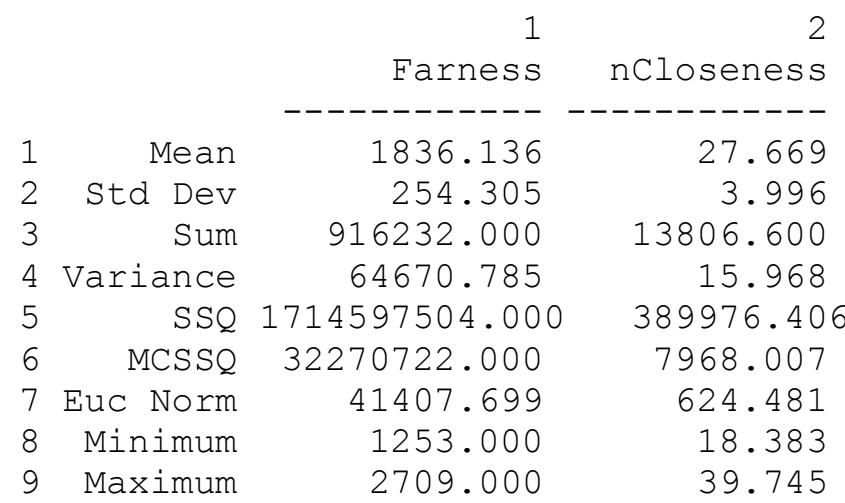

Network Centralization $=24.22 \%$

Output actor-by-centrality measure matrix saved as dataset C: \Doutorado\Tese \Rede Pedreira \Closeness

Running time: 00:00:01

Output generated: 07 jan 09 20:07:58

Copyright (c) 1999-2005 Analytic Technologies 
Apêndice $\mathbf{C}$ 


\title{
Apêndice C - RESULTADOS DOS CÁLCULOS DA MEDIDA DE POSICIONAMENTO
}

\author{
FREEMAN BETWEENNESS CENTRALITY
}

Input dataset:

C: \Doutorado \Tese \Rede

Pedreira $\backslash$ RPREDREIRA_C21

Important note: this routine binarizes but does NOT symmetrize.

Un-normalized centralization: 8592517.943

1

Betweenness nBetweenness

38 CS2002A

17888.543

14.455

5 CR3L13A

12799.063

10.342

19 CC3L13A

10435.100

9159.286

8.432

6659.927

7.401

5535.062

5.382

497 CE 3INTA

81 CX3DIAA

14 CE3L13A

5139.529

4.473

5026.419

4840.517

4.153

495 CR3INTA

481 M122A

67 CY3L13A

496 CY3INTA

72 CY3DIAA

35 CC3DIAA

40 CM2017A

476 M123A

36 CF 2DIAA

296 M032F

$174 \quad \mathrm{M} 034 \mathrm{~F}$

203 M024F

283 M013F

34 CR3DIAA

129 CX3L13A

$90 \quad$ M119F

$150 \quad$ M135F

494 CC3INTA

4777.015

4.062

3.911

4169.761

4020.844

3.369

3859.104

3.249

3622.910

3.118

3549.750

2.928

2.868

3537.548

2.859

3494.448

2.824

3494.244

3373.816

3313.570

2.824

2.726

2.678

3266.140

2.639

3155.579

2.550

2992.454

2.418

2962.629

2.394

2854.651

2.307

2782.904

2.249

2774.137

2.242

2766.768

2.236

5 SM3INTA

82 CW2DIAA

467 M089A

2749.585

2.222

2710.568

2.190

2631.537

2.126

2615.157

2.113

2607.986

2.107

M0 43F

M107A

2479.133

2.003

2476.109

2.001

2449.131

1.979

456 M084A

2355.486

1.903 


\begin{tabular}{|c|c|c|c|}
\hline 291 & M029A & 2313.796 & 1.870 \\
\hline 143 & M1 34F & 2275.701 & 1.839 \\
\hline 182 & M035F & 2253.040 & 1.821 \\
\hline 315 & $\mathrm{M} 021 \mathrm{~F}$ & 2217.370 & 1.792 \\
\hline 68 & $\mathrm{M} 120 \mathrm{~F}$ & 2065.194 & 1.669 \\
\hline 32 & CS2016A & 2053.225 & 1.659 \\
\hline 487 & M108A & 2035.659 & 1.645 \\
\hline 261 & $\mathrm{M} 060 \mathrm{~F}$ & 2034.398 & 1.644 \\
\hline 127 & M133F & 2020.191 & 1.632 \\
\hline 109 & M0 50F & 1980.338 & 1.600 \\
\hline 130 & CW2L13A & 1980.083 & 1.600 \\
\hline 310 & M113F & 1966.514 & 1.589 \\
\hline 349 & M0 69A & 1952.085 & 1.577 \\
\hline 365 & M058A & 1933.248 & 1.562 \\
\hline 254 & $\mathrm{M} 071 \mathrm{~F}$ & 1907.239 & 1.541 \\
\hline 369 & M0 54A & 1900.122 & 1.535 \\
\hline 323 & M0 88A & 1885.067 & 1.523 \\
\hline 400 & M027A & 1866.909 & 1.509 \\
\hline 219 & M025F & 1859.292 & 1.502 \\
\hline 61 & M030F & 1817.071 & 1.468 \\
\hline 270 & M070F & 1774.767 & 1.434 \\
\hline 159 & M0 $44 \mathrm{~F}$ & 1760.131 & 1.422 \\
\hline 414 & M0 64A & 1743.630 & 1.409 \\
\hline 266 & M055F & 1707.149 & 1.379 \\
\hline 280 & $\mathrm{M} 012 \mathrm{~A}$ & 1700.199 & 1.374 \\
\hline 426 & $\mathrm{M} 126 \mathrm{~A}$ & 1696.929 & 1.371 \\
\hline 333 & M0 $04 \mathrm{~A}$ & 1687.823 & 1.364 \\
\hline 420 & M0 98M & 1656.397 & 1.338 \\
\hline 352 & M0 82A & 1633.327 & 1.320 \\
\hline 227 & M0 77F & 1622.322 & 1.311 \\
\hline 438 & $\mathrm{M} 100 \mathrm{~A}$ & 1621.451 & 1.310 \\
\hline 404 & M028A & 1600.921 & 1.294 \\
\hline 465 & M0 90A & 1598.262 & 1.291 \\
\hline 378 & M0 80A & 1580.739 & 1.277 \\
\hline 346 & M0 92A & 1578.733 & 1.276 \\
\hline 39 & CS 3DIAA & 1569.974 & 1.269 \\
\hline 454 & M1 03A & 1566.311 & 1.266 \\
\hline 337 & M0 93A & 1540.935 & 1.245 \\
\hline 1 & M131A & 1517.361 & 1.226 \\
\hline 55 & M026A & 1504.621 & 1.21 \\
\hline 251 & M116F & 1488.573 & 1.203 \\
\hline 342 & M0 94A & 1476.548 & 1.193 \\
\hline 223 & M075F & 1474.610 & 1.192 \\
\hline 381 & M079A & 1462.401 & 1.182 \\
\hline 239 & M076F & 1454.688 & 1.175 \\
\hline 393 & M020A & 1453.365 & 1.17 \\
\hline 447 & M129A & 1422.054 & 1.14 \\
\hline 460 & M1 06A & 1413.840 & 1.142 \\
\hline 449 & M017A & 1412.409 & 1.141 \\
\hline 358 & M052A & 1411.563 & 1.14 \\
\hline 446 & M132A & 1380.131 & 1.11 \\
\hline 214 & M0 65A & 1372.715 & 1.10 \\
\hline 359 & M0 56A & 1347.927 & 1.08 \\
\hline 162 & M0 4 5F & 1318.521 & 1.06 \\
\hline 375 & M0 66A & 1311.184 & 1.06 \\
\hline 187 & M037F & 1308.166 & 1.05 \\
\hline 164 & M0 4 6F & 1278.495 & 1.03 \\
\hline 258 & $\mathrm{M} 072 \mathrm{~F}$ & 1243.091 & 1.00 \\
\hline
\end{tabular}




\begin{tabular}{|c|c|c|c|}
\hline 65 & CF 2S JDA & 1234.940 & 0.998 \\
\hline 498 & CX3INTA & 1203.208 & 0.972 \\
\hline 321 & M0 97F & 1202.467 & 0.972 \\
\hline 436 & M128A & 1201.376 & 0.971 \\
\hline 368 & M0 59A & 1192.819 & 0.964 \\
\hline 390 & M019A & 1192.170 & 0.963 \\
\hline 247 & M115F & 1178.782 & 0.953 \\
\hline 21 & M011A & 1176.890 & 0.951 \\
\hline 104 & CR2BRZA & 1170.248 & 0.946 \\
\hline 409 & M0 99A & 1145.688 & 0.926 \\
\hline 441 & M127A & 1140.273 & 0.921 \\
\hline 382 & M0 03A & 1140.209 & 0.921 \\
\hline 169 & M0 47F & 1128.796 & 0.912 \\
\hline 193 & M038F & 1120.706 & 0.906 \\
\hline 412 & M073A & 1119.532 & 0.905 \\
\hline 57 & CF 2DSPA & 1118.760 & 0.904 \\
\hline 303 & M016A & 1099.179 & 0.888 \\
\hline 430 & M125A & 1093.741 & 0.884 \\
\hline 407 & M010A & 1081.140 & 0.874 \\
\hline 434 & M110A & 1074.835 & 0.869 \\
\hline 278 & M023A & 1064.503 & 0.860 \\
\hline 499 & CW3INTA & 1063.896 & 0.860 \\
\hline 356 & M051A & 1061.890 & 0.858 \\
\hline 396 & M0 08A & 1055.867 & 0.853 \\
\hline 167 & M0 4 9F & 1054.204 & 0.852 \\
\hline 440 & $\mathrm{M} 112 \mathrm{~A}$ & 1052.495 & 0.850 \\
\hline 118 & M0 41F & 1044.976 & 0.844 \\
\hline 485 & M118A & 1027.237 & 0.830 \\
\hline 191 & $\mathrm{M036F}$ & 995.497 & 0.804 \\
\hline 199 & M0 0 6F & 981.872 & 0.793 \\
\hline 123 & M0 48F & 972.480 & 0.786 \\
\hline 386 & M0 62A & 940.708 & 0.760 \\
\hline 395 & M0 68A & 916.164 & 0.740 \\
\hline 344 & M0 95A & 909.049 & 0.735 \\
\hline 463 & M0 86A & 903.564 & 0.730 \\
\hline 405 & M0 67A & 900.530 & 0.728 \\
\hline 423 & $\mathrm{M} 11 \mathrm{~A}$ & 889.949 & 0.719 \\
\hline 458 & M0 83A & 881.715 & 0.712 \\
\hline 171 & M039F & 874.207 & 0.706 \\
\hline 439 & $\mathrm{M1} 14 \mathrm{~A}$ & 860.503 & 0.695 \\
\hline 275 & M009F & 845.968 & 0.684 \\
\hline 195 & M0 07F & 830.720 & 0.671 \\
\hline 116 & M0 $40 \mathrm{~F}$ & 817.483 & 0.661 \\
\hline 472 & M124A & 803.806 & 0.650 \\
\hline 83 & CM2DIAA & 797.253 & 0.644 \\
\hline 126 & CA $2 \mathrm{~L} 13 \mathrm{~N}$ & 796.149 & 0.643 \\
\hline 103 & CC3BRZA & 769.305 & 0.622 \\
\hline 364 & M057A & 762.493 & 0.616 \\
\hline 443 & M130A & 754.456 & 0.610 \\
\hline 418 & M0 63A & 730.609 & 0.590 \\
\hline 453 & $\mathrm{M} 102 \mathrm{~A}$ & 719.533 & 0.581 \\
\hline 493 & CS3INTX & 701.845 & 0.567 \\
\hline 113 & CV2DIAA & 659.025 & 0.533 \\
\hline 384 & $\mathrm{M} 001 \mathrm{~A}$ & 619.225 & 0.500 \\
\hline 148 & CV2002A & 584.692 & 0.472 \\
\hline 371 & M0 81A & 554.176 & 0.448 \\
\hline 243 & M101F & 528.677 & 0.427 \\
\hline 12 & CC 3 CENA & 514.361 & 0.416 \\
\hline
\end{tabular}




\begin{tabular}{|c|c|c|c|}
\hline 91 & CS 2NAVA & 509.399 & 0.412 \\
\hline 59 & M0 91A & 485.836 & 0.393 \\
\hline 48 & CS2064A & 480.495 & 0.388 \\
\hline 385 & M0 02A & 443.708 & 0.359 \\
\hline 134 & CV2064A & 438.330 & 0.354 \\
\hline 47 & M022A & 418.392 & 0.338 \\
\hline 77 & CO2DIAA & 417.333 & 0.337 \\
\hline 45 & M117A & 388.052 & 0.314 \\
\hline 459 & M1 05A & 378.497 & 0.306 \\
\hline 289 & M014F & 378.401 & 0.306 \\
\hline 29 & CR3CENA & 369.051 & 0.298 \\
\hline 322 & M0 85A & 347.779 & 0.281 \\
\hline 265 & M0 61F & 347.712 & 0.281 \\
\hline 132 & CV2L13A & 344.242 & 0.278 \\
\hline 207 & CS3INTA & 334.676 & 0.270 \\
\hline 229 & CS2100A & 319.243 & 0.258 \\
\hline 201 & CM2YERA & 313.450 & 0.253 \\
\hline 419 & M005A & 305.942 & 0.247 \\
\hline 11 & CM2100A & 302.922 & 0.245 \\
\hline 27 & CE 3YERA & 293.554 & 0.237 \\
\hline 147 & $\mathrm{CF} 2002 \mathrm{~A}$ & 259.897 & 0.210 \\
\hline 373 & CX3YERA & 256.551 & 0.207 \\
\hline 205 & CS2YERA & 245.175 & 0.198 \\
\hline 202 & M0 42F & 241.574 & 0.195 \\
\hline 44 & CP2117A & 236.716 & 0.191 \\
\hline 245 & CF $2100 \mathrm{~A}$ & 226.413 & 0.183 \\
\hline 120 & CF 2029A & 218.781 & 0.177 \\
\hline 60 & CM2107A & 210.752 & 0.170 \\
\hline 50 & $\mathrm{CM} 2064 \mathrm{~A}$ & 206.956 & 0.167 \\
\hline 331 & CV2NAVA & 204.954 & 0.166 \\
\hline 452 & M015A & 204.930 & 0.166 \\
\hline 246 & CA2100N & 191.794 & 0.155 \\
\hline 37 & M018A & 173.977 & 0.141 \\
\hline 41 & CP $2002 \mathrm{~A}$ & 164.522 & 0.133 \\
\hline 6 & CO2INTA & 155.839 & 0.126 \\
\hline 161 & CA2017N & 155.831 & 0.126 \\
\hline 198 & CA $2064 \mathrm{~N}$ & 147.005 & 0.119 \\
\hline 244 & CV2100A & 138.478 & 0.112 \\
\hline 114 & CA2DIAN & 137.179 & 0.111 \\
\hline 51 & SM3MARA & 137.106 & 0.111 \\
\hline 53 & $\mathrm{CF} 2064 \mathrm{~A}$ & 132.602 & 0.107 \\
\hline 3 & CS2ZTUA & 132.394 & 0.107 \\
\hline 15 & M0 96A & 132.077 & 0.107 \\
\hline 13 & $\mathrm{CP} 2100 \mathrm{~A}$ & 117.144 & 0.095 \\
\hline 8 & M074A & 114.883 & 0.093 \\
\hline 42 & M1 $04 \mathrm{~A}$ & 108.028 & 0.087 \\
\hline 374 & CV2YERA & 107.339 & 0.087 \\
\hline 383 & CX3SABA & 106.946 & 0.086 \\
\hline 54 & CP2064A & 95.959 & 0.078 \\
\hline 290 & CY 3CENA & 92.955 & 0.075 \\
\hline 250 & CW2SABA & 88.065 & 0.071 \\
\hline 9 & CA1100A & 81.805 & 0.066 \\
\hline 110 & CA1029A & 77.948 & 0.063 \\
\hline 46 & CA2117A & 72.598 & 0.059 \\
\hline 20 & CF2092A & 72.506 & 0.059 \\
\hline 329 & CA1107A & 72.011 & 0.058 \\
\hline 160 & CV2029A & 71.835 & 0.058 \\
\hline 52 & SC 3 S PMA & 67.245 & 0.05 \\
\hline
\end{tabular}




\begin{tabular}{|c|c|c|c|}
\hline 139 & CE 3SAUA & 65.667 & 0.053 \\
\hline 122 & CP2017A & 61.335 & 0.050 \\
\hline 131 & CM2027A & 60.226 & 0.049 \\
\hline 237 & CY3YERA & 56.067 & 0.045 \\
\hline 330 & CW2NAVA & 55.442 & 0.045 \\
\hline 319 & $\mathrm{CM} 2002 \mathrm{~A}$ & 55.380 & 0.045 \\
\hline 76 & CF 2SERA & 49.609 & 0.040 \\
\hline 70 & CS $2 S E R A$ & 49.609 & 0.040 \\
\hline 26 & CF2YERA & 48.508 & 0.039 \\
\hline 210 & CV2CENA & 45.976 & 0.037 \\
\hline 197 & CF2L13A & 45.608 & 0.037 \\
\hline 84 & CM2SERA & 43.580 & 0.035 \\
\hline 402 & SC2SAUA & 42.764 & 0.035 \\
\hline 231 & CW2100A & 41.678 & 0.034 \\
\hline 230 & CS2S JRA & 40.774 & 0.033 \\
\hline 226 & $\mathrm{CO} 2 \mathrm{SABA}$ & 39.157 & 0.032 \\
\hline 432 & CA2129A & 38.950 & 0.031 \\
\hline 17 & CS2096A & 38.559 & 0.031 \\
\hline 22 & CA1011A & 37.779 & 0.031 \\
\hline 23 & CA2011A & 37.779 & 0.031 \\
\hline 140 & CW2015A & 37.451 & 0.030 \\
\hline 43 & $\mathrm{CM} 2117 \mathrm{~A}$ & 36.977 & 0.030 \\
\hline 49 & CA1064A & 31.297 & 0.025 \\
\hline 475 & CF 2NAVA & 31.237 & 0.025 \\
\hline 208 & CW2YERA & 31.079 & 0.025 \\
\hline 121 & CA2029N & 30.581 & 0.025 \\
\hline 225 & CY $3 S A B A$ & 29.991 & 0.024 \\
\hline 222 & CV2080A & 29.115 & 0.024 \\
\hline 206 & CA2027A & 26.599 & 0.021 \\
\hline 115 & CP2DIAA & 25.863 & 0.021 \\
\hline 73 & CE 3SERA & 24.796 & 0.020 \\
\hline 188 & CA2DIAA & 23.711 & 0.019 \\
\hline 271 & CA2069A & 22.992 & 0.019 \\
\hline 142 & CY3SAUA & 22.401 & 0.018 \\
\hline 85 & CV2SERA & 21.309 & 0.017 \\
\hline 89 & CP2SERA & 21.309 & 0.017 \\
\hline 24 & CM2080A & 21.017 & 0.017 \\
\hline 31 & M053A & 20.949 & 0.017 \\
\hline 360 & CV2056A & 20.610 & 0.017 \\
\hline 213 & CP2080A & 20.319 & 0.016 \\
\hline 242 & CM2S JRA & 19.371 & 0.016 \\
\hline 427 & CA1129A & 18.876 & 0.015 \\
\hline 200 & CW2064A & 18.723 & 0.015 \\
\hline 376 & CA2080A & 17.981 & 0.015 \\
\hline 154 & CV2JMIA & 17.023 & 0.014 \\
\hline 215 & CA1066A & 16.663 & 0.013 \\
\hline 217 & CF $2080 A$ & 16.658 & 0.013 \\
\hline 163 & CV2017A & 16.157 & 0.013 \\
\hline 125 & CA2029A & 16.137 & 0.013 \\
\hline 101 & CS2DIAA & 15.457 & 0.012 \\
\hline 429 & CV2129A & 14.611 & 0.012 \\
\hline 249 & CY3100A & 14.533 & 0.012 \\
\hline 314 & CM2112A & 13.131 & 0.011 \\
\hline 397 & CV2027A & 13.077 & 0.011 \\
\hline 398 & CF 2027A & 13.077 & 0.011 \\
\hline 238 & CO2YERA & 12.917 & 0.010 \\
\hline 340 & CM2096C & 12.472 & 0.010 \\
\hline 474 & CM2NAVA & 12.109 & 0.01 \\
\hline
\end{tabular}




\begin{tabular}{|c|c|c|c|}
\hline 362 & $\mathrm{CP} 2016 \mathrm{~A}$ & 10.799 & 0.009 \\
\hline 413 & CW2CENA & 10.548 & 0.009 \\
\hline 10 & CL1074A & 10.380 & 0.008 \\
\hline 64 & CV2016A & 9.730 & 0.008 \\
\hline 149 & CA2015N & 9.518 & 0.008 \\
\hline 300 & CM2 JMIA & 8.939 & 0.007 \\
\hline 417 & CR3SABA & 8.599 & 0.007 \\
\hline 326 & $\mathrm{CF} 2107 \mathrm{~A}$ & 7.895 & 0.006 \\
\hline 305 & CM2016A & 7.369 & 0.006 \\
\hline 431 & CS $2 \mathrm{SABA}$ & 7.232 & 0.006 \\
\hline 336 & CP2096A & 5.890 & 0.005 \\
\hline 30 & CM2RFUA & 5.794 & 0.005 \\
\hline 102 & CZ2DIAA & 5.643 & 0.005 \\
\hline 99 & CA1JULA & 5.391 & 0.004 \\
\hline 173 & CV2039A & 5.251 & 0.004 \\
\hline 18 & CM2096A & 5.131 & 0.004 \\
\hline 88 & CA2SERN & 5.073 & 0.004 \\
\hline 144 & $\mathrm{CA} 1031 \mathrm{~A}$ & 4.675 & 0.004 \\
\hline 256 & CA2057A & 4.637 & 0.004 \\
\hline 66 & $\mathrm{CA} 2016 \mathrm{~N}$ & 4.296 & 0.003 \\
\hline 105 & CY3BRZA & 4.296 & 0.003 \\
\hline 282 & CM2011A & 4.243 & 0.003 \\
\hline 338 & CA1093A & 4.070 & 0.003 \\
\hline 339 & CZ2096A & 4.070 & 0.003 \\
\hline 444 & CM2129A & 4.040 & 0.003 \\
\hline 445 & $\mathrm{CF} 2129 \mathrm{~A}$ & 3.834 & 0.003 \\
\hline 192 & CA2DIAG & 3.830 & 0.003 \\
\hline 363 & $\mathrm{CM} 2056 \mathrm{~A}$ & 3.814 & 0.003 \\
\hline 262 & CS2L13A & 3.585 & 0.003 \\
\hline 309 & CV2085A & 3.533 & 0.003 \\
\hline 234 & CF 2SELA & 3.524 & 0.003 \\
\hline 233 & CV2077A & 3.524 & 0.003 \\
\hline 232 & CM2SELA & 3.524 & 0.003 \\
\hline 74 & CW2SERA & 3.504 & 0.003 \\
\hline 96 & CV2107A & 2.857 & 0.002 \\
\hline 308 & CV2117A & 2.796 & 0.002 \\
\hline 387 & CA1019A & 2.614 & 0.002 \\
\hline 437 & CM2SABA & 2.599 & 0.002 \\
\hline 388 & CP $2 A E R A$ & 2.574 & 0.002 \\
\hline 276 & CA $2008 \mathrm{~A}$ & 2.489 & 0.002 \\
\hline 156 & CA1043A & 2.432 & 0.002 \\
\hline 425 & $\mathrm{CA} 2100 \mathrm{~A}$ & 2.399 & 0.002 \\
\hline 16 & CA1096A & 2.393 & 0.002 \\
\hline 255 & CV2056A & 2.354 & 0.002 \\
\hline 212 & CA2YERN & 2.024 & 0.002 \\
\hline 392 & CV2019A & 1.855 & 0.001 \\
\hline 389 & $\mathrm{CA} 2002 \mathrm{~N}$ & 1.799 & 0.001 \\
\hline 325 & CA2106A & 1.210 & 0.001 \\
\hline 399 & $\mathrm{CA} 2027 \mathrm{~N}$ & 1.139 & 0.001 \\
\hline 172 & CA1039A & 1.116 & 0.001 \\
\hline 117 & CS2029A & 0.934 & 0.001 \\
\hline 257 & CP 2029A & 0.835 & 0.001 \\
\hline 403 & $\mathrm{CP} 2027 \mathrm{~A}$ & 0.766 & 0.001 \\
\hline 401 & $\mathrm{CA} 1027 \mathrm{~A}$ & 0.766 & 0.001 \\
\hline 86 & CV2DIAA & 0.000 & 0.000 \\
\hline 4 & CM2132A & 0.000 & 0.000 \\
\hline 63 & CS 3MARA & 0.000 & 0.000 \\
\hline 267 & CA1053A & 0.000 & 0.000 \\
\hline
\end{tabular}




\begin{tabular}{|c|c|c|c|}
\hline 284 & CZ2012A & 0.000 & 0.000 \\
\hline 112 & CS 3BNAA & 0.000 & 0.000 \\
\hline 7 & CP2132A & 0.000 & 0.000 \\
\hline 286 & CV2011A & 0.000 & 0.000 \\
\hline 62 & CA1016A & 0.000 & 0.000 \\
\hline 179 & $\mathrm{CM} 2034 \mathrm{~A}$ & 0.000 & 0.000 \\
\hline 334 & $\mathrm{CA} 1004 \mathrm{~A}$ & 0.000 & 0.000 \\
\hline 56 & CZ2012A & 0.000 & 0.000 \\
\hline 128 & CA1048A & 0.000 & 0.000 \\
\hline 253 & $\mathrm{CO} 2100 \mathrm{~A}$ & 0.000 & 0.000 \\
\hline 293 & CA2029C & 0.000 & 0.000 \\
\hline 287 & CP2RFUA & 0.000 & 0.000 \\
\hline 108 & CA2JULN & 0.000 & 0.000 \\
\hline 311 & CA1113A & 0.000 & 0.000 \\
\hline 94 & CA1119A & 0.000 & 0.000 \\
\hline 221 & CV2065A & 0.000 & 0.000 \\
\hline 80 & CZ2121A & 0.000 & 0.000 \\
\hline 345 & CZ2095A & 0.000 & 0.000 \\
\hline 97 & CA2117C & 0.000 & 0.000 \\
\hline 69 & CA1120A & 0.000 & 0.000 \\
\hline 318 & CW2002A & 0.000 & 0.000 \\
\hline 100 & CS 2JULA & 0.000 & 0.000 \\
\hline 304 & CW2029A & 0.000 & 0.000 \\
\hline 87 & CX3SERA & 0.000 & 0.000 \\
\hline 106 & CM2JULA & 0.000 & 0.000 \\
\hline 292 & CA1029C & 0.000 & 0.000 \\
\hline 324 & CA1106A & 0.000 & 0.000 \\
\hline 355 & CP2082A & 0.000 & 0.000 \\
\hline 341 & CA $2096 \mathrm{~N}$ & 0.000 & 0.000 \\
\hline 295 & CV2029C & 0.000 & 0.000 \\
\hline 298 & CA $2015 A$ & 0.000 & 0.000 \\
\hline 220 & CM2065A & 0.000 & 0.000 \\
\hline 111 & CA1029G & 0.000 & 0.000 \\
\hline 175 & CA1034A & 0.000 & 0.000 \\
\hline 145 & CZ2031A & 0.000 & 0.000 \\
\hline 224 & CY3064A & 0.000 & 0.000 \\
\hline 302 & CV2015A & 0.000 & 0.000 \\
\hline 241 & CA2S JRN & 0.000 & 0.000 \\
\hline 366 & CA2058A & 0.000 & 0.000 \\
\hline 166 & CZ2046A & 0.000 & 0.000 \\
\hline 58 & CR3CENB & 0.000 & 0.000 \\
\hline 354 & CM2082A & 0.000 & 0.000 \\
\hline 184 & CS3ITAA & 0.000 & 0.000 \\
\hline 107 & CV2JULA & 0.000 & 0.000 \\
\hline 186 & CF 2PARA & 0.000 & 0.000 \\
\hline 124 & CA1048A & 0.000 & 0.000 \\
\hline 297 & CA1032A & 0.000 & 0.000 \\
\hline 95 & CA2119A & 0.000 & 0.000 \\
\hline 252 & CA1116A & 0.000 & 0.000 \\
\hline 377 & CR3YERA & 0.000 & 0.000 \\
\hline 347 & CA1092A & 0.000 & 0.000 \\
\hline 379 & SC3INTC & 0.000 & 0.000 \\
\hline 380 & CR3JPAA & 0.000 & 0.000 \\
\hline 71 & CZ2CONA & 0.000 & 0.000 \\
\hline 367 & CV2058A & 0.000 & 0.000 \\
\hline 259 & CS $3 A E R A$ & 0.000 & 0.000 \\
\hline 353 & CA1082A & 0.000 & 0.000 \\
\hline 136 & CC 3 SAUA & 0.000 & 0.000 \\
\hline
\end{tabular}




\begin{tabular}{|c|c|c|c|}
\hline 137 & CR3SAUA & 0.000 & 0.000 \\
\hline 263 & CV2057A & 0.000 & 0.000 \\
\hline 264 & Co2L13A & 0.000 & 0.000 \\
\hline 157 & CA2043A & 0.000 & 0.000 \\
\hline 141 & CV2SAUA & 0.000 & 0.000 \\
\hline 391 & CZ2019A & 0.000 & 0.000 \\
\hline 361 & $\mathrm{CF} 2016 \mathrm{~A}$ & 0.000 & 0.000 \\
\hline 269 & CM2053A & 0.000 & 0.000 \\
\hline 394 & CA2019N & 0.000 & 0.000 \\
\hline 146 & CM2015A & 0.000 & 0.000 \\
\hline 272 & CM2069A & 0.000 & 0.000 \\
\hline 273 & CZ2069A & 0.000 & 0.000 \\
\hline 274 & CP2069A & 0.000 & 0.000 \\
\hline 119 & CZ2041A & 0.000 & 0.000 \\
\hline 28 & CB2L13A & 0.000 & 0.000 \\
\hline 277 & CA2009A & 0.000 & 0.000 \\
\hline 92 & CZ2119A & 0.000 & 0.000 \\
\hline 279 & CV2023A & 0.000 & 0.000 \\
\hline 93 & CW2107A & 0.000 & 0.000 \\
\hline 343 & CA2064G & 0.000 & 0.000 \\
\hline 406 & CZ2027A & 0.000 & 0.000 \\
\hline 158 & CM2043A & 0.000 & 0.000 \\
\hline 408 & CA2010A & 0.000 & 0.000 \\
\hline 285 & CF 2RFUA & 0.000 & 0.000 \\
\hline 410 & CC $3 \mathrm{SABA}$ & 0.000 & 0.000 \\
\hline 411 & CR3100A & 0.000 & 0.000 \\
\hline 288 & CP2011A & 0.000 & 0.000 \\
\hline 133 & CF 2 JMIA & 0.000 & 0.000 \\
\hline 165 & CA1046A & 0.000 & 0.000 \\
\hline 415 & CS 3GUAA & 0.000 & 0.000 \\
\hline 416 & CO2SAUA & 0.000 & 0.000 \\
\hline 168 & CA2049A & 0.000 & 0.000 \\
\hline 294 & CM2029C & 0.000 & 0.000 \\
\hline 170 & CA2049A & 0.000 & 0.000 \\
\hline 327 & CV2106A & 0.000 & 0.000 \\
\hline 421 & CA1098A & 0.000 & 0.000 \\
\hline 422 & CM2CIDA & 0.000 & 0.000 \\
\hline 299 & CZ2015A & 0.000 & 0.000 \\
\hline 424 & CA2100G & 0.000 & 0.000 \\
\hline 301 & CM2032A & 0.000 & 0.000 \\
\hline 177 & CS2JMIA & 0.000 & 0.000 \\
\hline 178 & CZ2034A & 0.000 & 0.000 \\
\hline 428 & CA $2126 B$ & 0.000 & 0.000 \\
\hline 180 & CV2LUSA & 0.000 & 0.000 \\
\hline 181 & CF2LUSA & 0.000 & 0.000 \\
\hline 151 & CY3JMIA & 0.000 & 0.000 \\
\hline 183 & CA2035A & 0.000 & 0.000 \\
\hline 153 & CV2015A & 0.000 & 0.000 \\
\hline 185 & CX3SAUA & 0.000 & 0.000 \\
\hline 435 & CA1125A & 0.000 & 0.000 \\
\hline 281 & CS 3DIAC & 0.000 & 0.000 \\
\hline 313 & CW2112A & 0.000 & 0.000 \\
\hline 189 & SC 3STOA & 0.000 & 0.000 \\
\hline 190 & SC 3 SBCA & 0.000 & 0.000 \\
\hline 316 & CA1020B & 0.000 & 0.000 \\
\hline 317 & CZ2002A & 0.000 & 0.000 \\
\hline 442 & CM2ZTUA & 0.000 & 0.000 \\
\hline 194 & CA2038A & 0.000 & 0.000 \\
\hline
\end{tabular}




\begin{tabular}{|c|c|c|c|}
\hline 320 & CA $2020 \mathrm{~N}$ & 0.000 & 0.000 \\
\hline 196 & CA2007A & 0.000 & 0.000 \\
\hline 260 & CM2057A & 0.000 & 0.000 \\
\hline 75 & CV2CONA & 0.000 & 0.000 \\
\hline 448 & CA 2 SABN & 0.000 & 0.000 \\
\hline 138 & CR3RETA & 0.000 & 0.000 \\
\hline 450 & CCЗJPAA & 0.000 & 0.000 \\
\hline 451 & CV2SABA & 0.000 & 0.000 \\
\hline 79 & CA1121A & 0.000 & 0.000 \\
\hline 204 & CA2067A & 0.000 & 0.000 \\
\hline 268 & CA2054A & 0.000 & 0.000 \\
\hline 455 & CA2117N & 0.000 & 0.000 \\
\hline 332 & CP2NAVA & 0.000 & 0.000 \\
\hline 457 & CZ2085A & 0.000 & 0.000 \\
\hline 209 & CM20 66A & 0.000 & 0.000 \\
\hline 335 & CV0 96A & 0.000 & 0.000 \\
\hline 211 & CA $2024 \mathrm{~N}$ & 0.000 & 0.000 \\
\hline 461 & CA1105A & 0.000 & 0.000 \\
\hline 462 & CM2105A & 0.000 & 0.000 \\
\hline 152 & CM2033A & 0.000 & 0.000 \\
\hline 464 & CA2091A & 0.000 & 0.000 \\
\hline 216 & CA2066A & 0.000 & 0.000 \\
\hline 466 & CP2NAVA & 0.000 & 0.000 \\
\hline 218 & CA2 2066N & 0.000 & 0.000 \\
\hline 468 & CA1089A & 0.000 & 0.000 \\
\hline 469 & CA2089A & 0.000 & 0.000 \\
\hline 470 & CC 3NAVA & 0.000 & 0.000 \\
\hline 471 & CM2089A & 0.000 & 0.000 \\
\hline 348 & CA2096A & 0.000 & 0.000 \\
\hline 473 & CA1124A & 0.000 & 0.000 \\
\hline 350 & CA2069A & 0.000 & 0.000 \\
\hline 351 & CA2 JMIN & 0.000 & 0.000 \\
\hline 228 & CA1077B & 0.000 & 0.000 \\
\hline 477 & CM2123A & 0.000 & 0.000 \\
\hline 478 & CA2NAVN & 0.000 & 0.000 \\
\hline 479 & CA1NAVA & 0.000 & 0.000 \\
\hline 480 & CW2SAUA & 0.000 & 0.000 \\
\hline 357 & CZ2029A & 0.000 & 0.000 \\
\hline 482 & CA1122A & 0.000 & 0.000 \\
\hline 483 & CA $2122 \mathrm{~N}$ & 0.000 & 0.000 \\
\hline 484 & CZ2122A & 0.000 & 0.000 \\
\hline 236 & CA1SELA & 0.000 & 0.000 \\
\hline 486 & CA2118A & 0.000 & 0.000 \\
\hline 176 & CA2LUSA & 0.000 & 0.000 \\
\hline 240 & CA1076B & 0.000 & 0.000 \\
\hline 489 & CA2107A & 0.000 & 0.000 \\
\hline 490 & CY3NAVA & 0.000 & 0.000 \\
\hline 491 & CA2NAVG & 0.000 & 0.000 \\
\hline 492 & CP2107A & 0.000 & 0.000 \\
\hline 307 & CZ2105A & 0.000 & 0.000 \\
\hline 370 & CZ2054A & 0.000 & 0.000 \\
\hline 433 & CP2SABA & 0.000 & 0.000 \\
\hline 372 & CZ2080A & 0.000 & 0.000 \\
\hline 248 & CA1114A & 0.000 & 0.000 \\
\hline 312 & CS2112A & 0.000 & 0.000 \\
\hline & CA1132A & 0.000 & 0.00 \\
\hline
\end{tabular}


DESCRIPTIVE STATISTICS FOR EACH MEASURE

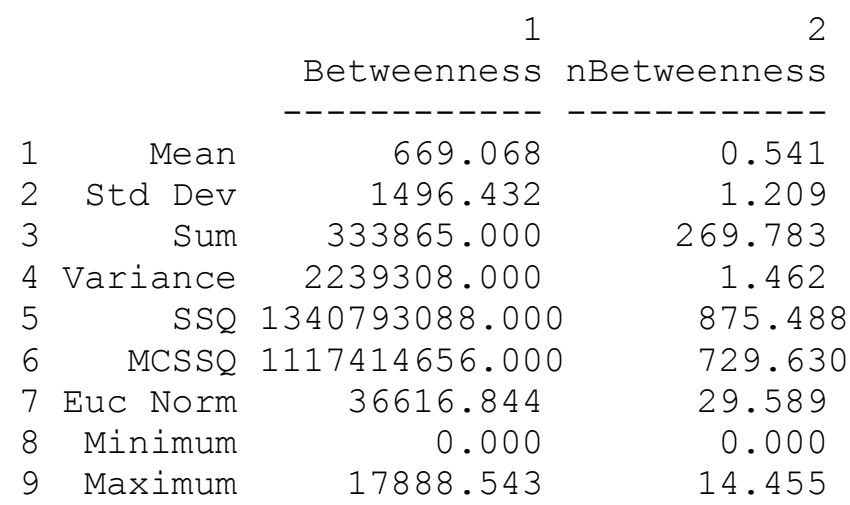

Network Centralization Index $=13.94 \%$

Output actor-by-centrality measure matrix saved as dataset FreemanBetweenness

Running time: 00:00:01

Output generated: 07 jan 09 20:13:21

Copyright (c) 1999-2005 Analytic Technologies 
Apêndice D 
ApRndice D - RESULTADO DAS ESTATISTICAS LOCAIS MORAN'S I E GETIS ORD GI"

RAMO DE ATMIDADE

PADARLA JÓLA DO ALVARENGA

FARMÁCIA FENICIA

BAZAR

PRODUTO DE LIMPEZA

AÇOUGUE

CASA DO NORTE

AVICOLA

PET SHOP IRMXOS RAMALHO

VESTUARR

OPTICA

TINTA

MATERIAL DE CONSTRUČ̃O

COMERCIO DE BONECAS DE PELÚCIA

FLORICULTURA

MEACEARIA

COSMÉTKCOS

DOCES E BOMBONS

FARMÁCIA ILMA

AÇOUGUE

PADARIA

SUPERMERCADO RICOY

MATERIAL DE CONSTRUCYAO

AVICOLA

MATERIAL DE CONSTRUÇÃO

MÓVEIS

ARTIGOS RELIGIOSOS

AVICOLA

PET SHOP

FLORICULTURA

ÓPICA

COSMETICOS

VIDRAÇARLA

BAZAR

VESTUÁRIO

FERRAGENS

MERCEARIA

OPTICA

CASA DO NORTE

EMBALAGEM

BAZAR

MOVEIS

HORTI FRUTI GRANUEIROS

VESTUÁAIO

MATERIAL DE CONSTRUÇÃO

PADARIA

ACCOUGUE

BAZAR

CALCADOS

MATERIAL ELÉTRICO

PADARIA

VESTUÁRIO

VARIEDADES

MATERIAL DE CONSTRUÇAO

AVICOLA

FARMÁCIA

OPTICA

SUPERMERCADO UNIÃO

CALCADOS

CINE E FOTO

PET SHOP

SUPERMERCADO DIA

MATERIAL DE CONSTRUÇAO

TINTAS

FARMÁCIA

COMERCIO DE GESSO

MATERIAL DE CONSTRUÇÃOO

PET SHOP

PRODUTOS DE LIMPEZA

PADARIA

MERCEARIA

AÇOUGUE

BUOUTERLA

BOLSAS

CALCYADOS

CAMA, MESA E BANHO

CASA DO NORTE

COSMÉTICOS

ELETRÓNICA
LOGRADOURO

ESTR. DO ALVARENGA - ESQ CÓRREGOAZUL

ESTR DO ALVARENGA - ESQ CORREGOAZUL

ESTR. DO ALVARENGA - ESQ CORREGOAZUI

ESTR. DO ALVAREMGA - ESQ CORREGOAZUL

ESTR. DO ALVARENGA - ESQ CORREGOAZUL

ESTR. DO ALVARENGA - ESQ CORREGOAZUL

ESTR. DO ALVARENGA - ESQ CÓRREGOAZUL

ESTR. DO ALVAREMGA - ESQ EUCUIDES C CARVALHO

ESTR. DO ALVARENGA - ESQ EUCUIDES C CARVALHO

ESTR. DO ALVARENGA - ESQ EUCUIDES C CARVALHO

ESTR. DO ALVARENGA - ESQ EUCUDES C CARVALHO

ESTR. DO ALVARENGA - ESQ EUCUDES C CARVALHO

ESTR. DO ALVARENGA - ESQ EUCUIDES C CARVALHO

ESTR. DO ALVARENGA - ESQ, EUCLIDES C CARVALHO

ESTR DO ALVARENGA - ESQ CÓRREGOAZUL

ESTR. DO ALVARENGA - ESQ CORREGOAZUL

ESTR. DO ALVARENDA - ESQ.PROF.SALATIEL DE TOLEDO

ESTR. DO ALVARENGA - ESQ.R.DR. SÁ PIRES

ESTR. DO ALVARENGA - ESQ.R.DR. SÁ PIRES

ESTR. DO ALVARENGA - ESQR.DR. SÁ PIRES

ESTR. DO ALVARENGA - ESOR.DR. SA PIRES

ESTR. DO ALVARENGA - ESQR.DR. SÁ PIRES

ESTR. DO ALVARENGA - ESQ.R.DR. SÁ PIRES

ESTR. DO ALVARENGA - ESQR.JOSE VIEIRA MARTINS ESTR. DO ALVARENGA - ESQR.JOSE VIEIRA MARTINS ESTR. DO ALVARENGA - ESQ,R.JOSE VIEIRA MARTINS ESTR. DO ALVARENGA - ESQ, R.JOSE VIEIRA MARTINS ESTR. DO ALVARENGA - ESQ R.JOSE VIEIRA MARTINS ESTR. DO ALVARENGA - ESQ R.JOSE VIEIRA MARTINS ESTR. DO ALVARENGA - ESQ R. VICENTE PAULO SILVA ESTR. DO ALVARENGA - ESQ R. VICENTE PAULO SILVA ESTR. DO ALVARENGA - ESQ R. VICENTE PAULO SILVA ESTR. DO ALVARENGA - ESQ R. VICENTE PAULO SILVA ESTR. DO ALVARENGA - ESQ R. VICENTE PAULO SILVA ESTR. DO ALVARENGA - ESQ R. VICENTE PAULO SILVA ESTR. DO ALVARENGA - ESQ R. VICENTE PAULO SILVA PRAÇA ACURI

PRAÇA ACURI

PRACAAACURI

PRACAA ACUR

ESTR. DO ALVARENGA - ESQ AUGUSTO DE CASTRO

ESTR DO ALVARENGA - ESQ AUGUSTO DE CASTRO ESTR. DO ALVARENGA - ESQ AUGUSTO DE CASTRO ESTR. DO ALVARENGA - ESQ AUGUSTO DE CASTRO ESTR. DO ALVARENGA - ESQ AUGUSTO DE CASTRO ESTR. DO ALVARENGA - ESQ ALGUSTO DE CASTRO ESTR. DO ALVARENGA - ESQ R. PROF. DANTAS JUNIIOR ESTR. DO ALVARENGA - ESQ R. PROF. DANTAS JUNIIOR ESTR. DO ALVARENGA - ESQ R. PROF, DANTAS JUNIIOR ESTR. DO ALVARENGA - ESQ, R. PROE. DANTAS JUNIIOR ESTR. DO ALVARENGA - ESQ, PR D.LUIS DE MASCARENHAS ESTR. DO ALVARENGA - ESQ, PR D.LUIS DE MASCARENHAS ESTR. DO ALVARENGA - ESO PR D.LUIS DE MASCARENHAS ESTR. DO ALVARENGA - ESQ, PR D.LUIS DE MASCARENHAS ESTR. DO ALVARENGA - ESQ PR D.LUIS DE MASCARENHAS ESTR. DO ALVARENGA - ESQ PR D.LUIS DE MASCARENHAS ESTR. DO ALVARENGA - ESQ PR D.LUIS DE MASCARENHAS ESTR. DO ALVARENGA - ESQ PR D.LUIS DE MASCARENHAS ESTR. DO ALVARENGA - ESO PR D.LUIS DE MASCARENHAS ESTR DO ALVARENGA - ESQ R PROF CORREIA BRITO ESTR. DO ALVARENGA - ESQ R.PROF.CORREIA BAITO ESTR. DO ALVARENGA - ESQ R.DR POMPEU ROSS ESTR. DO ALVARENGA - ESQ R.DR. POMPEU ROSSI ESTR. DO ALVARENGA - ESQ R.DR. POMPEU ROSSI PRAÇA ALEXANDRE FRANCISCO REBOUÇAS PRACA ALEXANDRE FRANCISCO REBOUCAS PRACA ALEXANDRE FRANCISCO REBOUCAS PRACSA ALEXANDRE FRANCISCO REBOUÇAS PRACCA ALEXXNDRE FRANCISCO REBOUÇAS

ESTR. DO ALVARENGA - ESQ PR D.LUIS DE MASCARENHAS R.DESEMBARGADOR BANDEIRA DE MELLO R.OESEMBARGADOR BANDEIRA DE MELLO R.DESEMBARGADOR BANDEIRA DE MELLO R.DESEMBARGADOR BANDEIRA DE MELLO R.DESEMEARGADOR BANDEIRA DE MELLO R.DESEMBARGADOR BANDEIRA DE MELLO R.DESEMBARGADOR BANDEIRA DE MELLO R.DESEMBARGADOR BANDEIRA DE MELLO
LOJAS MORAN'SI GETIS ORDGI*

\begin{tabular}{|c|c|}
\hline 0,237 & $-0,925$ \\
\hline 0,229 & $-0,924$ \\
\hline$-0,060$ & $-0,909$ \\
\hline 0,209 & $-1,091$ \\
\hline 0,229 & $-0,253$ \\
\hline 0,196 & $-0, \mathbf{B 1 0}$ \\
\hline 0,248 & $-0,707$ \\
\hline 0,176 & $-0,732$ \\
\hline$-0,054$ & $-0,526$ \\
\hline 0,221 & $-0,936$ \\
\hline 0,157 & $-0,506$ \\
\hline 0,204 & $-0,318$ \\
\hline 0,148 & $-0,268$ \\
\hline 0,169 & $-0,512$ \\
\hline 0,241 & $-1,023$ \\
\hline 0,172 & $-0,978$ \\
\hline 0,393 & $-0,888$ \\
\hline 0,244 & $-1,136$ \\
\hline 0,187 & $-0,761$ \\
\hline 0,142 & $-0,849$ \\
\hline 0,213 & $-0,555$ \\
\hline$-0,053$ & $-0,985$ \\
\hline 0,281 & $-0,857$ \\
\hline 0,238 & $-1,151$ \\
\hline 0,249 & $-1,197$ \\
\hline 0,255 & $-0,760$ \\
\hline 0,283 & $-0,697$ \\
\hline 0,222 & $-0,317$ \\
\hline 0,260 & $-1,146$ \\
\hline 0,266 & $-0,781$ \\
\hline 0,257 & $-1,201$ \\
\hline 0,218 & $-0,553$ \\
\hline 0,224 & $-0,867$ \\
\hline 0,246 & $-0,549$ \\
\hline 0,260 & $-0,780$ \\
\hline 0.205 & $-0,898$ \\
\hline 0,297 & $-0,849$ \\
\hline 0,317 & $-0,849$ \\
\hline 0,337 & $-1,197$ \\
\hline 0,293 & 0,723 \\
\hline 0,277 & $-0,747$ \\
\hline 0,397 & $-0,816$ \\
\hline 0,280 & $-0,987$ \\
\hline 0,268 & $-1,081$ \\
\hline 0,272 & $-0,942$ \\
\hline 0,317 & $-0,997$ \\
\hline 0,313 & $-0,442$ \\
\hline 0,281 & $-0,558$ \\
\hline 0,313 & $-0,540$ \\
\hline 0,190 & $-0,731$ \\
\hline$-0,062$ & $-0,662$ \\
\hline 0,217 & $-0,994$ \\
\hline 0,232 & $-0,585$ \\
\hline 0,295 & $-0,689$ \\
\hline 0,224 & $-0,670$ \\
\hline 0,215 & $-0,342$ \\
\hline 0,223 & $-0,813$ \\
\hline 0,254 & $-0,010$ \\
\hline 0,334 & $-0,191$ \\
\hline 0,255 & $-0,324$ \\
\hline 0,268 & $-0,320$ \\
\hline 0,368 & $-0,768$ \\
\hline 0,371 & $-0,882$ \\
\hline 0,390 & $-1,352$ \\
\hline 0,255 & $-0,858$ \\
\hline 0,273 & $-0,944$ \\
\hline 0,339 & $-0,924$ \\
\hline 0,224 & $-0,328$ \\
\hline 0,222 & $-0,324$ \\
\hline 0,284 & $-0,343$ \\
\hline 1,201 & 1,417 \\
\hline 0,281 & 3,146 \\
\hline$-0,699$ & 0,739 \\
\hline 2,672 & 0,506 \\
\hline 0,237 & 2,896 \\
\hline 0,689 & 0,554 \\
\hline 0,641 & 0,595 \\
\hline$-0,598$ & 0,747 \\
\hline
\end{tabular}


Aplndica D - RESULTADO DAS ESTATISTHCAS LOCAIS MORAN'S I E GETIS ORD Gi*

RAMO DE ATIVIDADE

COMÉRCIO DE MÚSICA

OPTICA

VARIEDADES

DOCES E BOMBONS

PEIXARIA

ELETRODOMESTICO - CASAS BAHIA

MÓVEIS - MARABRAS

FERRAGENS

PRODUTOS PARA BEBES

COMERCIO DE EMBALAGENS

BAZAR

BOISAS

CALÇADOS

CAMA, MESA E BANHO

COLCHOES

VESTUÁRIO

COSMETTCOS

ELETRONICA

FARMÁCIA

GALERIA

MOVEIS

ÓPTICA

RELOJOARIA

DOCES E BOMBONS

ELETRODOMÉSTICO - CASAS BAHIA

ELETRODOMESTICO - PONTO FRIO

COLCHÖES

FERRAGENS

ELETRODOMESTICO

ARMARINHOS

CALCADOS

FARMACIA

OPTKCA

VARIEDADES

DOCES E BOMBONS

AÇOUGUE

BAZAR

CALCADOS

CAMA, MESA E BANHO

CASA DO NORTE

VESTUÁRIO

FARMÁCIA

COMÉRCIO DE MÚSICA

ÓPTICA

VARIEDADES

FERRAGENS

DOCES E BOMBONS

COMERCIO DE ERVAS MEDICINAIS

ARMARINHOS

DECORAÇZ̃O

MOVEIS

BOLSAS

CALÇADOS

COSMETICOS

RELOIOAAIA

ARMARINHOS

VESTUÁRIO

AÇOUGUE

BOLSAS

CALÇADOS

CASA DONORTE

VESTUARIO

ARTGOS ESPORTIVOS

FERRAGENS

ELETRODOMÉSTICO CASAS BAHIA

CALCADOS

VESTUARIO

FARMACIA

BUUTERIA

CALCADOS

VESTUÁRIO

COSMÉTICOS

ELETRONICA

MOVEIS

OPTICA

VARIEDADES - AMERICANAS

BOLSAS

CALCCADOS
LOGRADOURO

R.DESEMBARGADOR BANDEIRA DE MELLO

RESEMBaRgador baNDEIRA DE MELLO

R. OESEMBARGADOR BANDEIRA DE MEULO

R.DESEMBARGADOR BANDEIRA DE MELIO

R.DESEMBARGADOR BANDEIRA DE MELLO

ROESEMBARGADOR BANDEIRA DE MELLO

R.OESEMBARGADOR BANDEIRA DE MELLO

R.DESEMBARGADOR BANDEIRA DE MELLO

R.DESEMBARGADOR BANDEIRA DE MELLO

R.DESEMBARGADOR BANDEIRA DE MELLO

ALAMEDA SANTO AMARO

ALAMEDA SANTO AMARO

ALAMEDA SANTO AMARO

ALAMEDA SANTO AMARO

ALAMEDA SANTO AMARO

ALAMEDA SANTO AMARO

ALAMEDA SANTO AMARO

ALAMEDA SANTO AMARO

ALAMEDA SANTO AMARO

ALAMEDA SANTO AMARO

ALAMEDA SANTO AMARO

ALAMEDA SANTO AMARO

ALAMEDA SANTO AMARO

ALAMEDA SANTO AMARO

ALAMEDA SANTO AMARO

ALAMEDA SANTO AMARO

ALAMEDA SANTO AMARO

ALAMEDA SANTO AMARO

ALAMEOA SANTO AMARO

ALAMEDA SANTO AMARO

R.SEMADOR FLAQUER

R.SENADOR FLAQUER

RSENADOR FLAQUER

R.SEMADOR FLAQUER

R.SENADOR FLAQUER

R. AARÃO DE DUPRAT

R.BARXXO DE DUPRAT

R.BARAOO OE DUPRAT

R.BARAO DE DUPRAT

R. BARAO OE DUPRAT

R.BARAO DE DUPRAT

R.BARAOO DE DUPRAT

R.BARAO DE DUPRAT

R.BARAO DE DUPRAT

R. BARAO DE DUPRAT

R. BARÄO DE DUPRAT

R. BARĀO DE DUPRAT

R.BARAัO DE DUPRAT

R. BARAO DE DUPRAT

R.BARÃO DE DUPRAT

R.BARAO DE DUPRAT

R. SENADOR IOSÉ BONIFÁCIO

R.SENADOR JOSÉ BONIFÁCIO

R.SENADOR JOSE BONIFACIO

R SENADOR JOSÉ BONIFACI

R.SENADOR JOSÉ BONIFÁCIO

R.SENADOR JOSÉ BONIFÁCIO

LARGO 13 DE MAIO

LARGO 13 DE MAIO

LARGO 13 DE MAIO

LARGO 13 DE MANO

LARGO 13 DE MAIO

LARGO 13 DE MAIO

LARGO 13 DE MAIO

LARGO 13 DE MAIO

LARGO 13 DE MAIO

LARGO 13 DE MAIO

LARGO 13 DE MANO

LARGO 13 DE MAIO

LARGO 13 DE MAIO

LARGO 13 OE MAIO

LARGO 13 DE MAIO

LARGO 13 DE MAIO

LARGO 13 DE MAIO

LARGO 13 DE MAIO

LARGO 13 DE MAIO

R.CAPITZO TLAGO LUZ

R.CAPITAO TLAGO LUZ
LOJAS MORAN'SI GETISORDGI*

$1,258 \quad 0,55$

$1,658 \quad 0,58$

$2,712 \quad 2,523$

$1,839 \quad 0,684$

$0,735 \quad 1,417$

$-0,517 \quad 2,030$

$-1,111 \quad 1,00$

$2,370 \quad 1,12$

$-0,499 \quad 1,106$

$-0,547 \quad 0,243$

$-0,357 \quad 1,10$

$-0,360 \quad 0,806$

$-0,384 \quad 2,672$

$0,130 \quad 1,767$

$1,147 \quad 0,29$

$0,940 \quad 0,806$

$-0,473 \quad 1,417$

$1,871 \quad 1,105$

$-0,519 \quad 0,856$

$0,696 \quad 0,806$

$2.179 \quad 0,660$

$0,373 \quad 2,672$

$-0,522 \quad 1,963$

$-0,318 \quad 0,856$

$-0,527 \quad 0,025$

$-0,486 \quad 0,619$

$1,206 \quad 1,303$

$0,431 \quad 0,025$

$0,271 \quad 0,352$

$0,268 \quad 1,787$

$0,193 \quad 0,109$

$-0,468 \quad-0,059$

$-0,339 \quad 0,555$

$0,176 \quad 0,68$

$-0,374 \quad 1,339$

$-0,390 \quad 0,595$

$-0,519 \quad 1,716$

$-0,349 \quad 0,035$

$0,121 \quad 0,466$

$-0,485 \quad 1,438$

$0,890 \quad 1,24$

$\begin{array}{lll}-0,358 & 1,479\end{array}$

$-0,312$

$-0,294 \quad 1,073$

$-0,280 \quad 1,11$

$0,094 \quad 0,546$

$1,202 \quad 0,829$

$-0,382 \quad 0,339$

$0,094 \quad 0,965$

$-0,338 \quad 1,248$

$-0,346 \quad 0,840$

$-0,325 \quad 1,417$

$-0,346 \quad 1,767$

$-0,330$

$-0,382 \quad 0,025$

$-0,531 \quad 1,161$

$5,216 \quad 0,201$

$-0,397$

$-0,519 \quad 0,352$

$-0,345 \quad 1,623$

$0,099 \quad 0,025$

$1,930 \quad 0,845$

$-0,343 \quad 1,188$

$-0,526 \quad 0,096$

$-0,355 \quad 1,963$

$1,317 \quad 0,201$

$3,007 \quad 0,856$

$-0,325 \quad 0,996$

$0,642 \quad 0,554$

$1,194 \quad 0,510$

$5,059 \quad 0,856$

$-0,443 \quad 0,605$

$-0,409 \quad 0,166$

$-0,301 \quad 2,474$

$-0,253 \quad 1,232$

$-0,256 \quad 1,787$

$0,094 \quad 1,213$

$1,438 \quad 1,213$ 
Aplmellea D - RESULTADO DAS ESTATISTICAS LOCALS MOAN'S I E GETIS ORD G|*

RAMO DE ATIVIDADE

CINE E FOTO

VESTUARIO

COSMÉTICOS

FARMACIA

MOVEIS

OPTICA

RELOJOARLA

VARIEDADES

ELETRODOMESTICOS - PONTO FRIO

DOCES E BOMBONS

VARIEDADES - PERNAMBUCANAS

BUUTERLA

BOLSAS

CALÇADOS

VESTUARRO

VARIEDADES

AÇOUGUE

BUUTERKA

CALCADOS

CAMA, MESA E BANHO

CASA DO NORTE

VESTUARRO

COSMETTCOS

ARTKGOS ESPORTNOS

GALERIA

Móvels

OPTICA

VARIEDADES

FERRAGENS

BAUTERIA

BAZAR

CALÇADOS

CAMA, MESA E BANHO

CASA DO NORTE

CINE E FOTO

VESTUÁRIO

COSMEticos

FARMACIA

GALERA

COMERCIO DE MÚSICA

OPTKCA

VARIEDADES

FERRAGENS

DOCES E BOMBONS

ELETRODOMÉSTKCO

BUUTERIA

BOLSAS

VESTUÁRIO

LIVRARIA

MERCEARIA

OPTKCA

VARIEDADES

DOCES E BOMBONS

VESTUARIO - PERNAMBUCANAS

EMBALAGEM

BOtSAS

CALCADOS

VESTUARHO

COSHEETICOS

FARMACIA

GALERIA

OPTICA

MOVEIS

RELOJOARLA

DOCES E BOMBONS

ELETROOOMMESTICOS - CASAS BAHIA

ELETRODOMESTICOS - EXTRA

ELETRODOMÉSTICO

CAMA, MESA E BANHO

BAZAR

CAMA MESA E BANHO

MATERLAL DE CONSTRUÇAO

FEIRA

SUPERMERCADO PEDREIRA

GAZAR

BIUTTERIA

MERCEARIA

SUPERMERCADO
LOGRADOURO

R.CAPTIXO TLAGO LU

R.CAPTIAO TLAGO LUZ

R.CAPITAO TIAGO LUZ

R.CAPTTAO TIAGO LUZ

R.CAPTAO TAGO LUZ

R.CAPTAO TIAGO LUZ

R.CAPTAO TLAGO LUZ

R.CAPTXO TUGOLUZ

R.CAPITAO TIAGOLUZ

R. CAPTIXO THAGOLUZ

R.CAPITAO TUAGO LUR

AV.ADOLFO PINHEIRO

AV ADOUFO PINHEIRO

AV.ADOLFO PINHEIRO

AV ADOLFO PINHEIRO

AV ADOLFO PINHEIRO

R.MANOEL BORBA

R.MANOEL BORBA

R.MANOEL BORBA

R.MANOEL BORBA

R.MANOEL BORBA

R.MANOEL BOABA

R.MANOEL BORBA

R.MANOEL BORBA

R.MANOEL BORBA

R.MANOEL BORBA

R.MANOEL BORBA

R.MANOEL BORBA

R.MANOEL BORBA

R. VOLUNTARIO DELMIRO SAMPAIO

R.VOLUNTARIO DELMIRO SAMPAO

R.VOLUNTARIO DELMIRO SAMPAIO

R.VOLUNTARЮO DELMIRO SAMPAIO

R. VOLUNTARIO DELMIRO SAMPAЮO

R VOLUMTAROO DELIMIRO SAMPAIO

R.VOLUNTARIO DELMIRO SAMPAIO

RVOLUNTARKO DELMIRO SAMPAL

R VOLUNTARIO DELMIRO SAMPAIO

R. VOLUNTARIO DELMIRO SAMPAIO

R VOLUNTARIO DELMIRO SAMPAIO

R.VOLUNTARIO DELMIRO SAMPAIO

R. VOLUNTARIO DELMIRO SAMPAIO

R.VOLUNTARIO DELMIRO SAMPAIO

R.VOLUNTARIO DELMIRO SAMPAIO

RVOLUNTARIO DELMIRO SAMPAIO

R.PAULO EIRO

R.PAULOEERO

R.PAULOETRO

R.PAULO EIŔ

R.PAULO ETRÓ

R.PAULOEIRÓ

R.PAULO EIŔ́

R.PAULOE EIŔ́

R.PAULOE EIŔ

R.PAULO EIRÓ

PRACA FLORLANO PEIXOTO

PRACCA FLORLNO PEDOTO

PRACA FLORLANO PEOXOTO

PRACA FLORLANO PEXXOTO

PRACA FLORLANO PEIXOTO

PRACA FIORLANO PEXXOTO

PRACA FLORLANO PEIXOTO

PRACA FLORLANO PEIXOTO

PRACA FLORLANO PEDXOTO

PRACA FLORLANO PEDXOTO

PRACA FLORLANO PEIXOTO

PRACA FLORIANO PEIXOTO

PRACA FLORLANO PEIXOTO

PRACA FLORLANO PEIXOTO

AV.MARIO LOPES LEAOO

AV.MARIO LOPES LEXO

R. DR. OOSÉ SILVIO DE CAMARGO

AV.AUGUSTO DE CASTRO

AV.DAS GAROUPAS

R. VICENTE STRICHALSKY

R.VICENTE STRICHALSKY

R. VICENTE STRICHALSKY

RVICENTE STRICHALSKY
LOJAS MORAN'SI GETLSORDGI*

$\begin{array}{ccc}1 & -0,726 & 3,023\end{array}$

0,703

$\begin{array}{ll}0,793 & 0,900 \\ -0,285 & 1,076\end{array}$

$\begin{array}{ll}-0,285 & 1,076 \\ -0,444 & 0,668\end{array}$

$1,337 \quad 0,800$

$0,130 \quad 1,026$

$-0,701 \quad 1,667$

$-0,252 \quad 2,141$

$0,286 \quad 1,072$

$0,454 \quad 3,023$

$\begin{array}{ll}-0,804 & 1,932\end{array}$

$0,210 \quad 0,118$

$1,417 \quad 0,567$

$\begin{array}{rl}-0,481 & 0,319 \\ -0,257 & 0,962\end{array}$

$-0,257 \quad 0,162$

$0,154 \quad 1,009$

$0,448 \quad 1,389$

$-0,334 \quad 1,970$

$-0,537 \quad 0,750$

$1,959 \quad-0,073$

$1,535 \quad 3,768$

$0,324 \quad 0,037$

$0,093 \quad 1,299$

$-0,319 \quad 1,816$

$0,885 \quad 0,927$

$0,074 \quad 0,720$

$-1,147 \quad 4,405$

$0,065 \quad 0,497$

$0,101 \quad 0,605$

$0,041 \quad 2,474$

$-0,217 \quad 2,309$

$-0,210 \quad 0,370$

$-0,059 \quad 1,509$

$1,533 \quad-0,181$

$0,054 \quad 0,813$

$0,147 \quad 1,674$

$0,080 \quad 0,673$

$0,093 \quad 0,303$

$0,193 \quad-0,063$

$0,226 \quad 1,146$

$-0,150 \quad 0,371$

$-0,057 \quad 0,605$

$-0,717 \quad 0,110$

$-0,172 \quad-0,127$

$-0,158 \quad 0,169$

$0,356 \quad-0,295$

$-0,174 \quad 0,074$

$-0,294 \quad-0,032$

$0,083 \quad 0,155$

$1,643 \quad 0,329$

$-0,138 \quad 0,109$

$-0,255 \quad 0,155$

$-0,265 \quad-0,116$

$-0,090 \quad 0,074$

$0,019 \quad 0,230$

$0,027 \quad 0,329$

$-0,103 \quad 0,285$

$-0,088 \quad 0,001$

$-0,084 \quad 0,054$

$-0,081 \quad 0,012$

$0,062 \quad-0,062$

$-0,083 \quad 0,230$

$0,082 \quad 0,356$

$-0,082 \quad 0,076$

$-0,082 \quad 0,011$

$-0,158 \quad-0,015$

$-0,080 \quad-0,016$

$-0,437 \quad-0,032$

$0,824 \quad 2,381$

$-0,208 \quad-0,372$

$-0,129 \quad-0,992$

$0,248 \quad-0,378$

$-0,038 \quad-0,262$

$0,526 \quad-1,716$

$0,320 \quad-1,303$

$0,131 \quad 0,414$ 
Apindice D - RESULTADO DAS ESTATISTICAS LOCANS MOANN'S I E GETIS ORD GI*

RAMO DE ATIVIDADE PRODUTOS DE LIMPEZA

PET SHOP

AVICOLA

MATERIAL DE CONSTRUCSAO

PADARIA

MERCEARIA

PADARIA

MATEAIAL DE CONSTRUÇAO

MATERLAL DE CONSTRUCAO

PRODUTOS DE UMPEZA

MERCEARLA

ACCOUGUE

FARMÁC

MERCEARLA

MOVEIS

PET SHOP

MATERIAL DE CONSTRUÇAOO

PADARIA

HORTI FRUTI GRANJEIROS

HORTI FRUTI GRANUEIROS

SUPERMERCADO KL-BARATO

SUPERMERCADO MAMB'S

PET SHOP

MATERIAL DE CONSTRUGCXO - 5 IRMTOS

MERCEARIA

PRODUTOS DE LIMPEZA

ACCOUGUE

BAZAR

VESTUARIO

FARMÁCIA

MERCEARIA

ÓPTICA

VARIEDADES

PADARIA

PET SHOP

SUPERMERCADO

DOCES E BOMBONS

AVICOLA

MATERLAL DE CONSTRUÇÃo

BAZAR

VESTUARIO

FARMACIA

MERCEARIA

COMÉACOO DE MÚSICA

MATERIAL DE CONSTRUÇAO

GALERIA

BOLSAS

ARTIGOS ESPORTIVOS

COMERCIO DE PRODUTOS IMPORTADOS

BUUTERIAS

CALCADOS

CAMA, MESA E BANHO

COMÉRCIO DE MÚSICA

ELETRONNICA

CINE E FOTO

COICHÖ́S

COMEACLO DE PRODUTOS DE DECORACAO

FARMACIA

ELETRODOMÉSTICO

SUPERMERCADO

JOALHERIA

COMERCIO DE BRINQUEDOS

VESTUARRO

OPTKA

cosménicos

PET SHOP

PRODUTOS ORTOPÉDICOS

TABACARIA

INFORMATICA

CASAS BAHIA

LOJAS AMERICANAS

CASAS PERNAMBUCANAS

PONTO FRIO

EXTRA

FASTSHOP

PAOOUTOS PARA BANHEIRO

COLCHOES
LOGRADOURO

R. VICENTE STPHCHALSKY

R.VICENTE STRICHALSKY

R.VICENTE STRICHALSKY

R.VICENTE STRICHALSKY

AV.GERALDO C.FREIRE

R.DOS MARATIS

AV.ALDO JORO RINALDI

AV.GERALDO C.FAEIRE

AV.ALDO JOAO RINALD

R.DOS PARGOS

R.DOS PAAGOS

AV.ALOA

AV.ALDA

AV.ALDA

AV.ALDA

AY.ALDA

AV.ALDA

AV.ALDA

AV.ALDA

AV.ALDA

R.DOS ABIQUARAS

R.DR.CARLOS DE REZENDE ENOUT

R.DR.CARLOS DE REZENDE ENOUT

AV.DAS GAROUPAS

AV.CARDOSO OE MELLO NETO

ESTR. DO ALVARENGA(JARDIM SANTA AMELLA)

R.DOS ANFQUIS

AV.EDUARDO PEREIRA RAMOS

AV.EDUARDO PEREIRA RAMOS

AV.EDUARDO PEREIRA RAMOS

AV.EDUARDO PEREIRA RAMOS

AV.EDUARDO PEREIRA RAMOS

AV.EDUARDO PEREIRA RAMOS

AV.EDUARDO PEREIRA RAMOS

AV.EDUARDO PEREIRA RAMOS

AV.EDUARDO PEREIRA RAMOS

AV.EDUARDO PEREIRA RAMOS

AV.EDUAROO PERETRA RAMOS

AV.EDUAARDO PEREIRA RAMOS

AV.EDUARDO PEREIRA RAMOS

R.BENTO JOSE DE MORAES

R. BENTO JOSÉ DE MORAES

R.BENTO JOSE DE MORAES

R.BENTO JOSE DE MORAES

R.BENTO JOSE DE MORAES

R.BENTO JOSE DE MORAES

LARGO 13 DE MANO

SHOPPING INTERLAGOS

SHOPPING INTERLAGOS

SHOPPING INTERLAGOS

SHOPPING INTERLAGOS

SHOPPING INTERLAGOS

SHOPPING INTERLAGOS

SHOPPING INTERIAGOS

SHOPPING INTERLAGOS

SHOPPING INTERLAGOS

SHOPPING INTERLAGOS

SHOPPING INTERLAGOS

SHOPPHG INTERLAGOS

SHOPPING INTERLAGOS

SHOPPING INTERLAGOS

SHOPPING INTERLAGOS

SHOPPING INTERLAGOS

SHOPPING INTERLAGOS

SHOPPING INTERLAGOS

SHOPPING INTERLAGOS

SHOPPING INTERLAGOS

SHOPPING INTERLAGOS

SHOPPING INTERLAGOS

SHOPPING INTERLAGOS

SHOPPING INTERLAGOS

SHOPPING INTERLAGOS

SHOPPING INTERLAGOS

SHOPPING INTERLAGOS

SHOPPING INTERLAGOS

SHOPPING INTERLAGOS

SHOPPING INTERLAR

SHOPPING INTERLAR
IOSA

\begin{tabular}{|c|c|c|}
\hline & & \\
\hline 2 & $-0,083$ & $-0,676$ \\
\hline 2 & $-0,075$ & $-0,416$ \\
\hline 1 & 0,427 & $-0,861$ \\
\hline 3 & $-0,299$ & 0,077 \\
\hline 1 & 0,278 & 0,166 \\
\hline 1 & 0,406 & $-0,970$ \\
\hline 1 & 0,254 & 0,639 \\
\hline 1 & 0,247 & $-0,325$ \\
\hline 2 & $-0,074$ & $-1,436$ \\
\hline 1 & 0,245 & $-0,566$ \\
\hline 1 & 0,189 & $-0,326$ \\
\hline 1 & 0,308 & $-0,719$ \\
\hline 1 & 0,262 & $-0,734$ \\
\hline 2 & $-0,076$ & $-0,440$ \\
\hline 2 & $-0,058$ & $-0,125$ \\
\hline 1 & 0,248 & $-0,292$ \\
\hline 1 & 0,243 & $-0,604$ \\
\hline 2 & $-0,077$ & $-0,410$ \\
\hline 1 & 0,239 & $-0,292$ \\
\hline 1 & 0,350 & $-0,125$ \\
\hline 1 & 0,407 & $-1,216$ \\
\hline 1 & 0,322 & $-0,807$ \\
\hline 1 & 0,672 & $-1,58$ \\
\hline 1 & 0,228 & $-0,38$ \\
\hline 2 & 0,083 & $-0,446$ \\
\hline 1 & 0,304 & $-0,468$ \\
\hline 1 & 0,360 & $-0,419$ \\
\hline 1 & 0,040 & $-0,190$ \\
\hline 3 & $-0,213$ & $-0,144$ \\
\hline 2 & $-0,038$ & $-0,193$ \\
\hline 1 & 0,140 & $-0,358$ \\
\hline 3 & $-0,171$ & $-0,537$ \\
\hline 1 & 0,079 & $-0,380$ \\
\hline 1 & 0,139 & 0,24 \\
\hline 1 & 0,071 & $-0,0$ \\
\hline 1 & 0,036 & 0,295 \\
\hline 2 & $-0,037$ & $-0,36$ \\
\hline 1 & 0,156 & $-0,30$ \\
\hline 1 & 0,107 & $-0,20$ \\
\hline 1 & 0,164 & 0,36 \\
\hline 2 & $-0,007$ & $-0,41$ \\
\hline 4 & $-0,431$ & $-0,43$ \\
\hline 1 & 0,016 & $-0,148$ \\
\hline 3 & $-0,195$ & $-0,571$ \\
\hline 1 & 0,045 & 0,061 \\
\hline 1 & 0,173 & $-0,281$ \\
\hline 1 & $-0,413$ & 0,433 \\
\hline 4 & 3,687 & 1,729 \\
\hline 3 & 2,131 & 3,947 \\
\hline 1 & $-1,607$ & 1,703 \\
\hline 6 & 8,625 & 4,35 \\
\hline 17 & 21,272 & 2,95 \\
\hline 2 & 0,447 & $-0,1$ \\
\hline 1 & $-1,594$ & 3,397 \\
\hline 13 & 19,389 & $2, \infty$ \\
\hline 6 & 8,273 & 1,16 \\
\hline 1 & $-1,433$ & 4,13 \\
\hline 4 & 4,146 & 3,397 \\
\hline 2 & 0,384 & 1,16 \\
\hline 6 & 10,042 & 2,421 \\
\hline 1 & $-2,375$ & 0,066 \\
\hline 8 & 21,250 & 1,151 \\
\hline 1 & $-2,180$ & 1,882 \\
\hline 87 & 61,922 & 0,57 \\
\hline 9 & 13,486 & $-0,10$ \\
\hline 5 & 4,350 & 1,539 \\
\hline 1 & $-1,005$ & 2,421 \\
\hline 1 & $-0,985$ & 0,079 \\
\hline 1 & $-1,933$ & 0,570 \\
\hline 1 & $-0,867$ & 0,640 \\
\hline 1 & $-0,840$ & 9,90 \\
\hline 1 & $-1,246$ & 10,2 \\
\hline 1 & $-2,302$ & 4,0 \\
\hline 1 & $-1,366$ & 3,01 \\
\hline 1 & $-0,878$ & 3,11 \\
\hline 1 & $-1,016$ & $5,24 \mathrm{C}$ \\
\hline 1 & $-0,601$ & 2,5 \\
\hline 4 & 2,330 & 2,9 \\
\hline
\end{tabular}


Aplndice D - RESULTADO DAS ESTATISTICAS LOCAS MORAN'S I EETS ORD GP

RAMO DE ATIVIDADE

CORTINAS

COZNHAS

NOVEIS

MATERIAL DE CONSTRUICAAO

PAPEL PARA PARED

PAPELARIA

PRESENTES

VESTUARIO

LIVRARIA

BUOUTERIA

CASAS PERNAMBUCANAS

BAZAR

CALCADOS

LOJAS MARABRAS

COSMETICOS

COMÉRCIO DE MÚSICA

OPTICA

FARMACIA

SUPERMERCADO COMPRE BEM

VARIEDADES

AÇOUGUE

GAIERIA

MÓVEIS

LOJAS MARISA

COLCHÓES

VESTUÁRIO

MÓVEIS

FARMACIA

LOJAS MARABRAS

LOJAS PONTO FRIO

AÇOUGUE

CASAS BAHIA

LOJAS KOLUMBUS

MERCEARLA

CAlSADOS

BOLSAS

BAZAR

RELOJOARIA

OPTICA

CAMA, MESA E BANHO

CASA DO NORTE

ELETRONICA

CASAS BAHIA

VESTUÁRIO

CASA DO NORTE

VESTUÁRIO

CALCADOS

BAZAR

RELONOARIA

OPTICA

VESTUÁRIO

BQZAR

CASA DO NORFE

VESTUARIO

COSMÉticos

BAZAR

OPTICA

VARIEDADES

VESTUÁRIO

ARTIGOS RELIGLOSOSS

COSMETICOS

OPTICA

GAZAR

VESTUÁRIO

OPTKCA

CALÇADOS

AÇOUGUE

FARMACIA

ELETRONICA

VESTUARIO

ARTIGOS RELIGIOSOS

AÇOUGUE

ARTRGOS ESPORTIVOS

CNNE E FOTO

ARTIGOS RELGG

COSMÉTICOS

FARMACIA

ELETRONICA
LOGRADOURO

SHOPPING INTERLAR

SHOPPING INTERLAR

SHOPPING INTERLAR

SHOPPING INTERLAR

SHOPPING INTERLAR

SHOPPING INTERLA

SHOPPING INTERLAR

AV.ANTONO PIRANGA - DUDEMA

AV.ANTONIO PIRANGA - DLADEMA

AVANTONO PIRANGA - DUDEMA

AV.ANTONO PIRANGA - DLADEMA

AV.ANTONHO PIRANGA - DIADEMA

AV.ANTOMIO PIRANGA - DIADEMA

AV.ANTONIO PIRANGGA - DIADEMM

AV.ANTONIO PIRANGA - DLADEMA

AV.ANTONIO PIRANGA - OLADEMA

AV.ANTONO PIRANGA - DIADEMA

AV.ANTONHO PIRANGA - OLADEMA

AV.ANTONIO PIRANGA - DIADEMA

AV ANTONIO PIRANGA - DIADEMA

AV.ANTONIO PIRANGA - DLADEMA

AV.ANTOWO PIRANGA - DIADEMA

AV.ANTONOO PIRANGA - DIADEMA

AV.SAOO IOSÉ(DIADEMA)

AV.SXOO IOSÉ(DIADEMA)

AV SAOO JOSE (OIADEMA)

AV.SXO JOSE(DLADEMA)

AV.SAO JOSÉ(DHDEMA)

AV.SAOO JOSE (OLADEMA)

AV.SAOO IOSÉ(OLADEMA)

AV.SZO JOSE(OUDEMA)

AV.SAO JOSÉ(DLADEMA)

AV.SAO IOSE(DIADEMA)

AV.SRO JOSÉ(DINDEMA)

AV.SATO JOSE(DUDEMA)

AV SAO IOSE (DIADEMA)

AV.SAO JOSÉ(DLADEMA)

AV.SAO JOSE (DTADEMA)

AV.SAOO IOSE (DLADEMA)

AV,SÃo JOSÉ(DIADEMA)

AV.SAO JOSÉ(DLADEMA)

AV.SAO JOSÉ(DLADEMA)

AV.ANTONYO PIRANGA - DLADEMA

AV.SANTA MARLA - DLADEMA

AV.SANTA MARIA - DIADEMA

R.SAO JUDAS TADEU - DAADEMA

R STO JUDAS TADEU-DIADEMA

R.SAO JUDAS TADEU - DIADEMA

R.SAO JUDAS TADEU - DIADEM

RSAO IUDAS TADEU - DIADEMA

AV.N.S.DAS VITORIAS - DIADEMA

AV N.S DAS VTTÓRLAS - DIADEMA

AV.N.S.DAS VTTORLAS - DLADEMA

PR.JOVINIANO DE CARVALHO-DLADEMA

PRLJOVINANO DE CARVALHO-DLADEMA

PRJoviniano de CarvalHo-dLADEMa

PRJOVINLANO DE CARVALHO-OLADEMA

PRLOVINLANO DE CARVALHO-OIADEMA

R.SILVIO DONINI - DLADEMA

R.SILVIO DONINI - DIADEMA

R.SILVTO DONINI - DAADEMA

R.SHLVO DONINI - DIADEMA

R.SILMO DOMINH - DLADEMA

AV.ALDA - DLADEMA

AV.ALDA - DIADEMA

AV.ALDA - DLADEMA

AV.ALOA - DLADEMA

AV AIDA-DADEMA

AV MIOA - DIADEMA

R.RAURINO LOPES DA SILVA-DIADEMA

R.ZAURINO LOPES DA SILVA-DAADEMA

R. RAUAINO LOPES DA SILVA-OLADEMA

R.IZAURINO LOPES DA SIVA-DIADEMA

RIZAURINO LOPES DA SILVA-DUDEMA

AV.N.S. DAS VITORIAS - DIADEMA

AV.N.S.DAS VITORIAS - DIADEMA

AV.MSS.DAS VITORLAS - DIADEMA

AV.N.S.DAS VITORLAS - DIADEMA
LOJAS MORANSI GETIS ORDG

$2,643 \quad 2,625$

$4,701 \quad 2,382$

$21,362 \quad 2,585$

$-0,631 \quad 2,384$

$-0,970 \quad 3,42$

$-1,063 \quad 3,15$

$-1,247 \quad 3,14$

$0,837 \quad-0,442$

$-0,613 \quad-0,074$

$0,751 \quad 0,205$

$-0,481 \quad 0,205$

$0,535 \quad-0,458$

$1,452 \quad-0,458$

$-0,287 \quad 0,152$

$0,405 \quad 0,391$

$0,227 \quad-0,521$

$\begin{array}{ll}0,246 & -0,521 \\ 0,125 & -0,560\end{array}$

0,560

$-0,560$

$0,021 \quad-0,616$

$\begin{array}{ll}-0,051 & -0,290 \\ 0,017 & -0,378\end{array}$

$0,012 \quad-0,250$

$-0,166 \quad 0,374$

$0,072 \quad 0,163$

$0,085 \quad-0,608$

$0,352 \quad 0,009$

$0,378 \quad-0,608$

$-0,081 \quad 0,319$

$-0,022 \quad-0,048$

$0,021 \quad 0,321$

$0,055 \quad-0,376$

$0,091 \quad-0,048$

$0,130 \quad-0,600$

$\begin{array}{ll}0,128 & -0,376 \\ 0,143 & -0,731\end{array}$

$0,155 \quad 0,602$

$0,167 \quad 0,568$

$0,171 \quad-0,456$

$0,178 \quad-0,849$

$-0,008 \quad-0,376$

$0,011 \quad-0,235$

$0,012 \quad 0,024$

$0,027 \quad-0,518$

$-0,429 \quad-0,125$

$-0,048 \quad 0,213$

$-0,057 \quad 0,213$

$0,010 \quad 0,061$

$0,010 \quad 0,163$

$-0,388 \quad-0,082$

$-0,372 \quad-0,143$

$0,111 \quad 0,791$

$-0,291 \quad-0,387$

$0,053 \quad-0,578$

$0,071 \quad-0,359$

$-0,001 \quad 0,217$

$-0,011 \quad-0,250$

$0,022 \quad-0,239$

$0,004 \quad-0,239$

$0,011 \quad-0,399$

$-0,040 \quad-0,365$

$0,035 \quad-0,399$

$0,033 \quad-0,378$

$0,036 \quad-0,383$

$-0,011 \quad-0,469$

$0,070 \quad-0,387$

$0,026 \quad-0,447$

$0,078 \quad-0,489$

$0,164 \quad-0,456$

$0,174 \quad-0,568$

$0,166 \quad-0,602$

$0,166-0,602$

$\begin{array}{ll}0,172 & -0,666 \\ 0,160 & -0,664\end{array}$

$0,150 \quad 0,097$

$\begin{array}{ll}-0,020 & 0,009\end{array}$

$-0,068 \quad-0,082$

$0,032 \quad-0,608$ 
ApRndKCo D - RESULTADO DAS ESTATISTICAS LOCANS MORAN'S I E GETIS ORD GI*

RAMO DE ATIVIDADE
CINE E FOTO
BOLSAS
VESTUARIO
FERRAGENS
QAZAR
TINTAS
BUUTERIAS
COMÉRCIO DE MÚSICA
MÓVEIS
FARMACIA
OPTICA
ELETRONICA
MERCEARIA
ARTRGOS ESPORTIVOS
BOLSAS
COMERCIO DE PRODUTOS DE DECORAÇÃO
BUUTERIAS

LOGRADOURO

AV.N.S.DAS VITÓRLAS - DLADEMA

AV. FABIO E.R.EZEQUIEL - DIADEMA

AV.FABN E.R.EZEQUHEL - DAADEMA

AV.FABIO E.R.EZEQUIEL - OLADEMA

AV.FABIO E.R.EZEQUIEL - DUADEMA

AV.FABIO E.R. EZEQUIEL - DLADEMA

AV.FABЮ E.R.EZEQUIEL - DLADEMA

AV.FABIO E.R. EZEQUIEL - DIADEMA

AV.FABiO E.R.EZEQUIEL - DLADEMA

AV.FABIO E.R.EZEQUIEL - DLADEMA

AV.FABW E.R.EZEQUIEL - DIADEMA

AV.FABIO E.R.EZEQUIEL - DIADEMA

AV.FABYO E.R EZFQUIEL - DLADEMA

SHOPPING SPMARKET - NAÇOES UNIDAS

SHOPPING SPMARKET - NAÇÖES UNIDAS

SHOPPING SPMARKET - NAÇOES UNIDAS

SHOPPING SPMARKET - NAÇOES UNIDAS

SHOPPING SPMARKET - MAÇOZES UNIDAS

SHOPPING SPMARKET - MACOES UNIDAS

SHOPPING SPMARKET - NAÇOES UNIDAS

SHOPPING SPMARKET - NAÇŌES UNIDAS

SHOPPING SPMARKET - NAÇOES UNIDAS

SHOPPING SPMARKET - NACOOES UNIDAS

SHOPPING SPMARKET - NACOES UNIDAS

SHOPPING SPMARKET - NAÇOES UNIDAS

SHOPPING SPMARKET - NAÇOES UNIDAS

SHOPPING SPMARKET - NAČOES UNIDAS

SHOPPING SPMARKET - MACOOES UNIDAS

SHOPPING SPMARKET - NAČOES UNIDAS

SHOPPING SPMARKET - NAÇOEES UNIDAS

SHOPPING SPMARKET - NAÇOES UNIDAS

SHOPPING SPMARKET - NACOOES UNIDAS

SHOPPING SPMARKET - MAÇOES UNIDAS

SHOPPING SPMARKET - NACÖES UNIDAS

SHOPPING SPMARKET - NACCOES UNIDAS

SHOPPING SPMARKET - NAÇOES UNIDAS

SHOPPING SPMARKET - NAÇÖES UNIDAS

SHOPPING SPMARKET - NACCOES UNIDAS

SHOPPING SPMARKET - NACOES UNEDAS

SHOPPING SPMARKET - NACOES UNIDAS

SHOPPIAG SPMARKET - NAÇOES UNIDAS

SHOPPING SPMURKET - NAÇOES UNIDAS

R.DESEMBARGADOR BANOEIRA DE MELLO

R. DR.JOSÉ SILVIO DE CAMARGO

R. DRJOSE SILVIO DE CAMARGO

R.DRJOSE SILVIO DE CAMARGO

R.TTALO CAMPANINI

R.DRJOSÉ SHLVIO DE CAMARGO

RTATU

E AGUA SANTA

E.AGUA SANTA

R.DEZ (ESTR.DA AGUA SANTA)

E.AGUA SANTA

AV.DOS GUATAMBUS (R.MATA VIRGEM)

R.JOSEPHINA GLANFNNI EUAS

R.JOSEPHINA GLANINNI ELLAS

R.JOSEPHINA GIANINNI ELLAS

EST.PACOVA (JOSEPHINA)

R.AFONSO RENDANO (RUST)

R.DENIS FRUTEL (RUST)

ESTR. DO ALVARENGA(JARDIM PIRATININGA)

AV.BATISTA MACIEL

R.CONEGO ANTONO PINTO

R.SETE DE ABRIL/AV.PROF.ARAUJO LIMA

R.DOS ROBALOS

R.OS Rogalos

R.DOS ROBALOS

R. VITOR VIEHA DE SOUZA

RALBINO BENTO

AV.DAS GAROUPAS

AV.CARDOSO DE MELO NETO

AV.CARDOSO DE MELO NETO

R.AUCE OOS SANTOS PERXE

R.MARLA CLOTILE MARTINS

R.DRCARLOS DE REZENDE ENOUT

R.DR.CARLOS DE REZENDE ENOUT

R.JUVENTINO TAVARES

R.JUVENTINO TAVARES

\begin{tabular}{|c|c|c|}
\hline LOJAS & MORAN'SI & GETIS ORD GI \\
\hline 1 & 0,065 & $-0,701$ \\
\hline 1 & $-0,093$ & $-0,578$ \\
\hline 6 & $-0,299$ & 0,383 \\
\hline 2 & 0,032 & $-0,447$ \\
\hline 2 & 0,022 & $-0,575$ \\
\hline 3 & $-0,027$ & 0,718 \\
\hline 1 & $-0,037$ & $-0,489$ \\
\hline 1 & $-0,030$ & 0,229 \\
\hline 1 & $-0,003$ & $-0,377$ \\
\hline 1 & 0,015 & $-0,405$ \\
\hline 1 & 0,023 & $-0,560$ \\
\hline 2 & 0,005 & $-0,021$ \\
\hline 1 & $-0,059$ & $-0,560$ \\
\hline 5 & 6,086 & 5,699 \\
\hline 5 & 4,689 & 2,903 \\
\hline 4 & 3,175 & 1,650 \\
\hline 6 & 5,722 & 1,267 \\
\hline 3 & 1,568 & 2,301 \\
\hline 15 & 19,949 & 7,379 \\
\hline 1 & $-1,376$ & 4,459 \\
\hline 2 & 0,386 & 3,499 \\
\hline 6 & 6.019 & 1,906 \\
\hline 2 & 0,278 & 2,541 \\
\hline 2 & 0,534 & $\mathbf{3 , 1 3 1}$ \\
\hline 1 & $-2,223$ & 6,327 \\
\hline 3 & 2,569 & 3,070 \\
\hline 1 & $-1,025$ & 1,906 \\
\hline 2 & 0,248 & 1,267 \\
\hline 1 & $-1,654$ & 3,271 \\
\hline 60 & 43,743 & 2,731 \\
\hline 7 & 10,423 & 2,821 \\
\hline 2 & 0,305 & 2,361 \\
\hline 11 & 13,119 & 2,387 \\
\hline 3 & 3,254 & 4,447 \\
\hline 7 & 10,413 & 5,699 \\
\hline 1 & $-0,915$ & 2,362 \\
\hline 1 & $-0,798$ & 1,890 \\
\hline 1 & $-1,769$ & 3,483 \\
\hline 1 & $-1,343$ & 5,387 \\
\hline 1 & $-1,304$ & 3,834 \\
\hline 1 & $-1,370$ & 3,174 \\
\hline 1 & $-1,346$ & 5,699 \\
\hline 24 & 8,233 & 1,263 \\
\hline 1 & 0,090 & $-0,113$ \\
\hline 3 & $-0,225$ & 0,474 \\
\hline 1 & 0,332 & $-0,423$ \\
\hline 1 & 0,222 & $-0,418$ \\
\hline 1 & 0,115 & $-0,636$ \\
\hline 1 & 0,467 & $-0,416$ \\
\hline 1 & 0,476 & $-0,234$ \\
\hline 1 & 0,304 & $-0,123$ \\
\hline 1 & 0,347 & $-0,416$ \\
\hline 1 & 0.551 & $-0,462$ \\
\hline 1 & 0,567 & $-0,209$ \\
\hline 1 & 0,334 & $-0,799$ \\
\hline 1 & 0,303 & $-1,049$ \\
\hline 1 & 0,358 & $-0,968$ \\
\hline 1 & 0,765 & $-0,600$ \\
\hline 1 & 0.222 & $-0,887$ \\
\hline 1 & 0,211 & $-0,508$ \\
\hline 1 & 0,413 & $-0,234$ \\
\hline 1 & 0,384 & $-0,419$ \\
\hline 1 & 0,416 & $-0,672$ \\
\hline 1 & 0,721 & $-0,364$ \\
\hline 1 & 0,308 & $-0,721$ \\
\hline 1 & 0,440 & $-0,925$ \\
\hline 1 & 0,302 & 0,007 \\
\hline 1 & 0,560 & $-0,352$ \\
\hline 1 & 0,280 & $-0,521$ \\
\hline 1 & 0,186 & $-0,399$ \\
\hline 1 & 0,258 & $-0,246$ \\
\hline 2 & $-0,076$ & $-1,101$ \\
\hline 1 & 0,313 & $-0,477$ \\
\hline 1 & 0,578 & $-0,723$ \\
\hline 1 & 0,324 & $-0,432$ \\
\hline 1 & 0,291 & $-0,234$ \\
\hline 1 & 0,352 & $-1,068$ \\
\hline 1 & 0,356 & $-0,280$ \\
\hline
\end{tabular}


Aplindice D - RESULTADO DAS ESTATISTCAS LOCAS MORANS I E GETS OAD GI*

RAMO DE ATIMDADE

BAZAR

MERCEARIA

BAZAR

PET SHOP

MERCEARIA

PADARIA

PRODUTOS DE LIMPEZA

PADARIA

MERCEARIA

MATERLAL DE CONSTRUCAOO

MATERIAL DE CONSTRUCAOO

PADARIA

PADARIA

PADARIA

PADARIA

BAZAR

FARMACIA

BAR

PET SHOP

PADARIA

BAZAR

PADARIA

CASA DO MORTE

MATERLAL DE CONSTRUÇÁO

MERCEARIA

PADARIA

BAR

PAPELARIA

PADARUA

MERCEARIA

PADARIA

MERCEARIA

PROOUTO DE LIMPEZA

MATERLAL DE CONSTRUGAOO

BAZAR

FARMACK

BAZAR

PRODUTOS DE LIMPEZA

MERCEARIA

MATERIAL DE CONSTRUCXO

BAZAR

CASA DO NORTE

MERCEARIA

PRODUTOS DE LIMPEZA

PADARIA

PROOUTOS DE UMPEZA

PRODUTOS DE UMMPEZA

MERCEARIA

MERCEARIA

MADARIA

MERCEARIA

CASA DO NORTE

PADARIA

MIUDEZAS

BAZAR

MATERIAL DE LIMPESA

PADARIA

PADARIA

PRODUTOS DE LIMPEZA

BAZAR

PADARLA

CASA DO NORTE

BAZAR

PADARLA

MERCEARM

MATERIAL DE CONSTRUÇAO

PADARIA

MERCEARIA

MATERLAL OE CONSTRUÇZ̃O

BAZAR

PADARIA

PADARLA

MATERLAL de CONSTRUÇAO

MERCEARIA

PADARIA

MERCEARLA

PRODUTOS DE LIMPEZA
LOGRADOURO

R.MANUEL TABACOW HIDAL

R.MIGUEL FLETA

R.MIGUEL FLETA

AVMIDO JOAO RINALDI

R.PAULINA ALVES ESCUDEIRO

R.SALVADOR DAL

R.PEORO LUIS DIAS DA FONSECA(SALVADOR DAU)

AV.ALDO JOAO RINALDI

R.DR.AUGUSTO GONRAGA

R.PASQUALE ANFOSSI

R.DR.AUGUSTO GONZAGA

R.MHGUEL FLETA

R.PONTES DE MORAES

AV.AUGUSTO DE CASTRO

PC.JUUO BENEDICT

R.ALICE DOS SANTOS PEDEE

R.2O(PEDRO FERMANDES ARAGAO)

R.ALICE DOS SANTTOS PEIXE

R.PEDRO FERNANDES ARAGAOO

RALKCE DOS SANTOS PEIXE

R.MANUEL RODRIGUES MEXELHAO

R.MARIA DOLORES FERREIRA DE OUIVEIRA

R. FREI FRANCISCO FERREIRA

RMMNUEL RODRIGUES MEXEUHAO

R.MANUEL RODRIGUES MEXELHAO

R.JAMIL JORGE DAMIEL

RGASPAR RICARDO

R.DA ASSEMBLELA

R.GASPAR RKCARDO

R.MARIA TEREZA

R.BELA CINTRA

R.CHICO MENDES

R.VITORINO FREIRE

R.BELA VISTA

R.CHICO MENDES

R.VTTORINO FREIRE

R. VTTORINO FREIRE

R.ANTONOPOT

R.PRIMAVERA

R.MARLA TEREZA

R.GUAKCURI

R.MARIA TEREZA

RMARLA TEREZA

R.DA SAUDE

R.DA SAUDE

E.AGUA SANTA

E.AGUA SANTA

E.AGUA SANTA

R.SETE DE SETEMBRO

R.SETE DE SETEMBRO

R.ANDRE

R.SEVERINO

R.APIARIS

REDUARDO MAGALHXES

R.APURIS

R.APIARIS

R.EDUARDO MASAL RIBEIRO

RRUST

RRUST

R.DENIS FRUTEL(RUST)

R.MANDUBIS

R.ALBANO BENTO

R.DOS PARGOS

E.DO RETIRO

R.APIARS

RDORETRO

R.DOS DOURADOS

R.DOS DOURADOS

R.DOS DOURADOS

R.DOS DOURADOS

R.TENENTE ELIAS

R.TENENTE ELLAS

R.TENENTE ELAS

R.TENENTE ELIAS

R.WILSON CANTON

R.WILSON CANTON

AV.ANTONIO VIEIRA MARCONDES
LOAAS MORAN'SI GETISORDGI"

$0,576 \quad 0,315$

$0,555 \quad-0,563$

$0,512-1,046$

$0,225 \quad-1,062$

$0,639 \quad-1,151$

$0,555 \quad-0,415$

$0,484 \quad-0,604$

$0,273 \quad-1,450$

$0,632-1,178$

$0,478 \quad 0,995$

$0,475 \quad-0,523$

$0,577 \quad-0,731$

$0,412 \quad-0,321$

$0,375 \quad-0,865$

$0,581 \quad-0,692$

$0,279 \quad-0,435$

$0,601 \quad-0,482$

$0,325 \quad-0,822$

$0,581 \quad 0,896$

$0,500-0,316$

$0,309 \quad-1,185$

$0,621 \quad-0,623$

$0,650 \quad-0,965$

$0,369-0,723$

$0,334 \quad-0,313$

$0,484 \quad-0,724$

$0,259 \quad-1,038$

$0,304 \quad-1,202$

$0,247 \quad-0,795$

$0,006 \quad-0,467$

$0,362 \quad-1,229$

$0,286 \quad-0,913$

$0,226 \quad-0,988$

$0,263 \quad-1,241$

$0,301 \quad-0,627$

$0,208 \quad-0,800$

$0,250 \quad-0,749$

$0,594 \quad 0,618$

$0,57 \quad 0,574$

$-1,273 \quad 0,306$

$0,529 \quad-1,013$

$\begin{array}{rl}-0,107 & 0,194\end{array}$

$0,033 \quad 0,263$

$0,239 \quad-0,592$

$0,250 \quad-0,488$

$0,326 \quad-0,328$

$0,322 \quad 0,663$

$0,326 \quad-0,436$

$0,428 \quad-0,243$

$0,440 \quad 0,641$

$0,628 \quad-1,242$

$0,572 \quad 0,986$

$0,322 \quad-0,535$

$0,398 \quad-1,015$

$-0,087 \quad 0,781$

$0,323 \quad-0,969$

$0,398 \quad-1,142$

$0,595 \quad-1,280$

$0,217 \quad-0,499$

$0,235 \quad-0,901$

$0,244 \quad-0,499$

$0,604 \quad-0,656$

$0,277 \quad-0,50$

$0,191 \quad 0,096$

$0,338 \quad-0,935$

$0,447 \quad 0,343$

$0,326 \quad-0,876$

$0,251 \quad-0,002$

$0,221-1,081$

$0,201-0,982$

$0,277-1,137$

$0,568 \quad-1,049$

$0,365 \quad-0,904$

$0,314 \quad-0,380$

$\begin{array}{ll}0,351 & 0,373 \\ 0,255 & -0,176\end{array}$

$-0,084$

$0,639 \quad-0,772$ 
Apendke D - RESULTADO DAS ESTATISTICAS LOCAIS MORAN'S I EETIS ORD GI

RAMO DE ATIVIDADE

MATERIAL OE CONSTRUÇAO

BAZAR

PET SHOP

PET SHOP

MATERIAL DE CONSTRUÇAOO

MERCEARIA

BAZAR

PROOUTOS DE LIMPEZA

DOCES E BOMBONS

SUPERMERCADO DIA

VARIEDADES

ACOUGUE

PRODUTOS DE UMPEZA

HORTI FRUTI GRANIEIROS

VIDRAÇARIA

MOVEIS

VESTUÁRIO

MOVELS

VARIEDADES

ADEGA

INFORMÁTICA

COSMÉTICOS

VESTUARトO

PADARIA

CAMA, MESA E BANHO

MOVEIS

VESTUARIO

VARIEDADES

PADARIA

TINTAS

MATERIAL DE CONSTRUÇZO

FARMACIA

CINE, FOTO E OPTCA

ROUPAS

VARIEDADES

AÇOUGUE

TECIDO

VESTUARIO

SUPERMERCADO COMPRE BEM

VARIEDADES

VARIEDADES

FARMÁCIA

COSMÉTICOS

CINE, FOTO E OPTICA

VESTUÁRLO

CALCADOS

FARMACIA

COLCHÖES

VESTUARIO

MÓVEIS

VARIEDADES

FERRAGENS

CALCADOS

VARIEDADES

VESTUÁRIO

MAGAZINES

VARIEDADES

PADARLA

AÇOUGUE

MATERIAL OE CONSTRUCXO

MÓvelS

FARMÁCK

CINE, FOTO E OPTICA

VESTUÁRIO

CALCADOS

DOCES E BOMBONS

VARTEDADES

ACOUGUE

MATERIAL ELETRICO

FERRAGENS

MATERLAL DE CONSTRUCAO

MÓVELS

ARTSGOS ESPORTIVOS

COSMÉtICOS

VESTUARRO

CALCADOS

PLANTAS E FLORES

PET SHOP
LOGRADOURO

RGUAICURI

R.WILSON CANTONI

R. WILSON CANTONI

R.GUAICURI

R.WILSON CANTONI

AV.PAPA GREGORIO MAGNO

AV.PAPA GREGORIO MAGNO

R.DORIVAL F. DA SILVA

AV.NOSSA SENHORA DO SABARA(DANIEL)

AV.NOSSA SENHORA DO SABARA(CURIA)

AV NOSSA SENHORA DO SABARA(CURIA)

AV.NOSSA SENHORA DO SABARA(CURLA)

AV.NOSSA SENHORA DO SABARÁ(CURIA)

AV.NOSSA SENHORA DO SABARA(JUARI)

AV.NOSSA SENHORA DO SABARA,JUARI)

AV.NOSSA SENHORA DO SARARAUUARI)

AV.NOSSA SENHORA DO SABARA(JUARH)

AV.NOSSA SENHORA DO SABARA (JAIME)

AV.NOSSA SENHORA DO SABARA (JOǍO FEREREIRA)

AV. NOSSA SENHORA DO SABARA(JOAO FEREREIRA)

AV.NOSSA SENHORA DO SABARÁ(JOẌO FEREREIRA]

AV.NOSSA SENHORA DO SABARA(JOAO FEREREIRA)

AV.NOSSA SENHORA DO SABARA (JOAO FEREREIRA)

AV.NOSSA SENHORA DO SABARA(AFONSO)

AV.NOSSA SENHORA DO SABARA(AFONSO)

AV.NOSSA SENHORA DO SABARA(DANIEL)

AV.NOSSA SENHORA DO SABARA(DANIEL)

AV.NOSSA SENHORA DO SABARÁ(HERMINDA)

AV.NOSSA SENHORA DO SABARÁ(HERMINDA)

AV.NOSSA SENHORA DO SABARA(HERMINDA]

AV.NOSSA SENHORA DO SABARA(HERMINOA)

AV.NOSSA SENHORA DO SABARÁ(HERMINDA)

AV.NOSSA SENHORA DO SABARÁ(HERMINDA)

AV.NOSSA SENHORA DO SABARÁ(HERMIMDA)

AV. NOSSA SENHORA DO SABARÁ(ELYOЮ)

AV.NOSSA SENHORA DO SABARA(ELYOHO)

AV.NOSSA SENHORA DO SABARÁ(ELYDIO)

AV.NOSSA SENHORA DO SABARA|ELYDIO)

AV. NOSSA SENHORA DO SABARA(ALESSANDRO)

AV.MOSSA SENHORA DO SABARL(ALESSANDRO)

AV.MOSSA SENHORA DO SABARA (TTAPUI)

AV.NOSSA SENHORA DO SABARA(ITAPUI)

AV.MOSSA SENHORA DO SABARA(ITAPUI)

AV.NOSSA SENHORA DO SABARA(ITAPU!)

AV.NOSSA SENHORA DO SABARAIITAPUI)

AV.NOSSA SENHORA DO SABARA(ITAPUI]

AV.NOSSA SENHORA DO SABARA(AFONSO)

AV.NOSSA SENHORA DO SABARQ(AFONSO)

AV.NOSSA SENHORA DO SABARA(AFONSO)

AV.MOSSA SENHORA DO SABARAMOVES

AV. NOSSA SENHORA DO SABARA(INTERLAGOS)

AV.NOSSA SENHORA DO SABARÁ(INTERLAGOS)

AV.NOSSA SENHORA DO SABARAYINTERLAGOS

AV.NOSSA SENHORA DO SABARA(JOÄO VICENTE)

AV. NOSSA SENHORA DO SABARAUOAO VICENTE)

AV. NOSSA SENHORA DO SABARA(NORMA)

AV. NOSSA SENHORA DO SABARA (NORMA)

AV.NOSSA SENHORA DO SABARA (NORMA)

AV. NOSSA SENHORA DO SABARA'(NORMA)

AV.NOSSA SENHORA DO SABARA(NORMA)

AV NOSGA SENHORA DO SABARA (NORMA)

AV.NOSSA SENHORA DO SABARÁNORMA)

AV.NOSSA SENHORA DO SABARA (NORMA)

AV.NOSSA SENHORA DO SABARA(NORMA)

AV.NOSSA SENHORA DO SABARÁNORMA

AV.NOSSA SENHORA DO SABARAPPROF.MARLA)

AV.NOSSA SENHORA DO SABARALPROF.MARIA)

AV. NOSSA SENHORA DO SABARAPROF.MARIA

AV.NOSSA SENHORA DO SABARA(PROF.MARLA)

AV.NOSSA SENHORA DO SABARA(PROF.MARLA)

AV. NOSSA SENHORA DO SABARA PROF MARIA

AV MOSSA SENHORA DO SARARAPROFMARV

AV. MOSSA SENHORA DO SABARÁ(PROF.MARIA)

AV.NOSSA SENHORA DO SABARA(PROF.MARIA)

AV.MOSSA SENHORA DO SABARA(PROF.MARLA)

AV.MOSSA SENHORA DO SABARA(PROF.MARLA)

AV.MOSSA SENHORA DO SABARÁ(PROF MARIA)

AV.NOSSA SENHORA DO SABARALPROF.MARIA)

\begin{tabular}{|c|c|c|}
\hline LOJAS & MORAN'SI & GETIS ORD GI" \\
\hline 3 & $-0,426$ & $-0,648$ \\
\hline 1 & 0,251 & $-0,738$ \\
\hline 1 & 0,245 & $-0,731$ \\
\hline 1 & 0,187 & $-1,215$ \\
\hline 1 & 0,282 & $-0,382$ \\
\hline 2 & $-0,070$ & $-0,254$ \\
\hline 1 & 0,236 & $-0,439$ \\
\hline 1 & 0,623 & $-0,441$ \\
\hline 1 & 0,034 & $-0,238$ \\
\hline 1 & 0,065 & $-0,191$ \\
\hline 1 & 0,076 & $-0,236$ \\
\hline 1 & 0,074 & $-0,295$ \\
\hline 1 & 0,068 & $-0,222$ \\
\hline 1 & 0,032 & 0,025 \\
\hline 1 & $-0,002$ & 0,123 \\
\hline 3 & $-0,119$ & $-0,196$ \\
\hline 1 & $-0,030$ & 0,291 \\
\hline 1 & 0,004 & 0,203 \\
\hline 1 & 0,046 & $-0,123$ \\
\hline 1 & 0,056 & $-0,172$ \\
\hline 1 & 0,053 & $-0,157$ \\
\hline 1 & 0,028 & $-0,052$ \\
\hline 2 & $-0,014$ & $-0,259$ \\
\hline 1 & 0,025 & $-0,075$ \\
\hline 1 & 0,018 & $-0,058$ \\
\hline 2 & 0,011 & $-0,072$ \\
\hline 2 & 0,006 & $-0,147$ \\
\hline 1 & 0,080 & $-0,357$ \\
\hline 1 & 0,084 & $-0,360$ \\
\hline 1 & 0,073 & $-0,329$ \\
\hline 1 & 0,086 & $-0,365$ \\
\hline 1 & 0,076 & $-0,9355$ \\
\hline 1 & 0,038 & $-0,182$ \\
\hline 2 & $-0,019$ & $-0,377$ \\
\hline 1 & 0.053 & $-0,211$ \\
\hline 1 & 0,067 & $-0,267$ \\
\hline 1 & 0,068 & $-0,261$ \\
\hline 1 & 0,058 & $-0,215$ \\
\hline 1 & 0,039 & $-0,086$ \\
\hline 1 & 0,011 & 0,045 \\
\hline 3 & $-0,011$ & $-0,026$ \\
\hline 2 & 0,010 & $-0,214$ \\
\hline 1 & $-0,079$ & 0,094 \\
\hline 2 & 0,030 & 0,068 \\
\hline 3 & 0,078 & $-0,168$ \\
\hline 1 & $-0,081$ & 0,119 \\
\hline 2 & 0,045 & 0,241 \\
\hline 1 & $-0,136$ & 0,222 \\
\hline 4 & 0,160 & $-0,176$ \\
\hline 1 & $-0,191$ & 0,092 \\
\hline 1 & $-0,066$ & 0,361 \\
\hline 1 & $-0,039$ & $-0,321$ \\
\hline 1 & $-0,052$ & $-0,430$ \\
\hline 1 & $-0,085$ & $-0,399$ \\
\hline 1 & $-0,105$ & $-0,375$ \\
\hline 1 & $-0,070$ & 0,129 \\
\hline 2 & $-0,010$ & $-0,282$ \\
\hline 1 & 0,060 & $-0,320$ \\
\hline 1 & 0,052 & $-0,384$ \\
\hline 1 & $-0,007$ & $-0,275$ \\
\hline 4 & $-0,135$ & 0,424 \\
\hline 3 & $-0,091$ & $-0,559$ \\
\hline 1 & $-0,009$ & $-0,012$ \\
\hline 1 & 0,040 & $-0,344$ \\
\hline 1 & 0,062 & $-0,330$ \\
\hline 1 & 0,046 & $-0,414$ \\
\hline 2 & 0,005 & $-0,503$ \\
\hline 1 & 0,072 & $-0,457$ \\
\hline 2 & $-0,025$ & $-0,476$ \\
\hline 1 & 0,067 & $-0,515$ \\
\hline 1 & 0,118 & $-0,580$ \\
\hline 1 & 0,126 & $-0,588$ \\
\hline 1 & 0,126 & $-0,618$ \\
\hline 1 & 0,122 & $-0,580$ \\
\hline 1 & 0,105 & $-0,447$ \\
\hline 1 & 0,049 & $-0,246$ \\
\hline 1 & 0,071 & $-0,439$ \\
\hline 2 & $-0,028$ & $-0,515$ \\
\hline
\end{tabular}


ApAndico D - RESULTADO DAS ESTA If́STICAS LOCAIS MORAN'S I E GETIS ORD Gi*

RAMO DE ATIVIDADE

VARIEDADES

VIORACARIA

MADEERAS E ARTEFATOS

MÓVEIS

FARMÁCIA

CINE, FOTOE ÓPTICA

BUOUTERIA

DOCES E BOMBONS

FERRAGENS

ARTIGO DE ARMARINHO

FARMACIA

SUPERMERCADO DIA

MERCEARIA

MERCEARIA

VARIEOADES

PADARIA

MATERIAL DE CONSTRUÇÃO

TELEFONIA

MÓVEIS

COSMÉTICOS

VESTUÁRIO

RELOSOARIA

PET SHOP

CASA DO NORTE

MERCEARIA

VARIEDADES

AÇOUGUE

MATERIAL DE CONSTRUÇÃO

FARMÁCIA

VESTUÁRIO

PET SHOP

VARIEDADES

HORTI FRUTI GRANUEIROS

COSMÉTICOS

PADARIA

DOCES E BOMBONS

AÇOUGUE

MORTI FRUTI GRANIEIROS

TINTAS

VIDRAÇARIA

FARMACIA

VESTUÁRIO

PET SHOP

CASA DO NORTE

MAGAZINE

PRODUTOS DE LIMPEZA

HORTI FRUTI GRANUEIROS

MATERIAL DE CONSTRUCAOO

TELEFONIA

MÓVEIS

VESTUÁRIO

PET SHOP

SUPERMERCADO RICOY

AÇOUGUE

MÓVEIS

PADARIA

FARMÁCIA

VESTUARIO

CALCADOS

CINE E FOTO

CAMA, MESA E BANHO

VESTUÁRIO

CASA DO NORTE

COSMÉTICOS

OPTICA

AÇOUGUE

ARMARINHO

EMBALAGEM

DISCOS

OPTICA

VESTUÁRIO

CALÇADOS

FOTO

MERCEARIA

MAGAZINE CASAS BAHIA

VARIEDADES

TINTAS

MATERIAL de CONSTRUÇĀo
LOGRADOURO

AV.NOSSA SENHORA DO SABARÁ(MAGNICARO)

AV.NOSSA SENHORA DO SABARA(MAGNICARO)

AV.NOSSA SENHORA DO SABARÁ(MAGNICARO)

AV.NOSSA SENHORA DO SABARA(MAGNICARO)

AV.NOSSA SENHORA DO SABARA(MAGNICARO)

AV.NOSSA SENHORA DO SABARÁ(MAGNICARO)

AV.NOSSA SENHORA DO SABARA(MAGNICARO)

AV.NOSSA SENHORA DO SABARA(ARISTEU)

AV.NOSSA SENHORA DO SABARA(ARISTEU)

AV.NOSSA SENHORA DO SABARA(ARISTEU)

AV.NOSSA SENHORA DO SABARA(ARISTEU)

AV.YERVANT KISSAIIKIAN(PRACCA)

AV.YERVANT KISSAUIKLAN(LARGO DA JOANIZA]

AV.YERVANT KISSAIIKIAN(DES. OLAVO)

AV.YERVANT KISSAIIKIAN(LARGO DA JOANIZA)

AV.YERVANT XISSA IKIAN(LARGO DA JOANIZA)

AV.YERVANT KISSAIIKIAN(LARGO DA JOANIZA)

AV.YERVANT KISSAIIXIAN/LARGO DA JOANIZA]

AV.YERVANT KISSAIKIAN(LARGO DA JOANIZA)

AV.YERVANT KISSAUIKIAN(LARGO DA JOANIRA)

AV.YERVANT KISSAIKIIAN(LARGO DA JOANIZA)

AV.YERVANT KISSAIIKIAN(LARGO DA JOANIZA)

AV.YERVANT KISSAIIKIAN(LARGO DA JOANIZA)

AV.YERVANT KISSAIKLAN(LARGO DA JOANIZA)

AV.YERVANT KISSAIKIAN(PRACCA)

AV.YERVANT KISSAIIKIAN(PRACA)

AV.YERVANT KISSAIIKIAN(PRACA)

AV.YERVANT KISSAIKIAN(PRACA)

AV.YERVANT KISSAIKIAN(PRACA)

AV.YERVANT KISSANIKIAN(PRACA)

AV.YERVANT KISSAIIKIAN(PRAÇA)

AV.YERVANT KISSAUIKLAN(NICOUNO)

AV.YERVANT KISSAJKLAN(NICOUNO)

AV.YERVANT KISSAIKIAN(NICOLINO)

AV.YERVANT KISSAUIKLAN(CARLOTTA)

AV.YERVANT KISSAUIKLANYCARLOTTA

AV. YERVANT KISSAIIKIANYCARLOTTA)

AV.YERVANT KISSAIIXIANICARLOTTA)

AV.YERVANT KISSAIKIAN(CARLOTTA)

AV.YERVANT KISSAIKKIANICARLOTTA)

AV.YERVANT KISSAIIKIAN(CARLOTTA)

AV.YERVANT KISSAIKILIAN(CARLOTTA)

AV.YERVANT KISSAIKIANICARLOTTA)

AV.YERVANT KISSAIKIANYCARLOTTA)

AV YERVANT KISSAIKLANUGALUANO

AV.YERVANT KISSAJIKIAN(GALLIANO)

AV.YERVANT KISSAIKIAN(DES. OLAVO)

AV.YERVANT KISSAIKLIANHDES, OLAVO)

AV.YERVANT KISSAIIKIANYDES. OLAVO)

AV.YERVANT KISSAIKLANIDES. OLAVO)

AV.YERVANT KISSAIIXIAN(OES. OLAVO)

AV.YERVANT KISSAIIKIAN(DES. OLAVO)

AV.YERVANT KISSAIKIANILARGO DA JOANIZA)

AV.YERVANT KISSAIKIAN(LARGO DA JOANIZA)

AV.YERVANT KISSAJIKIAN(LARGO DA JOANIZA)

AV.YERVANT KISSAIIKIANILARGO DA JOANIZA]

AV.YERVANT KISSAIKIAN(LARGO DA JOANIZA)

AV.YERVANT KISSAIIKLAN(LARGO DA JOANIZA)

AV.YERVANT KISSAIIKLAN(LARGO DA JOANIZA)

AV.YERVANT KISSAIIKIANYLARGO DA JOANIZA]

AV.YERVANT KISSAIIKLANYPEDRO)

AV.YERVANT KISSA IIKLANYPEDRO)

AV.YERVANT KISSAJIKIAN(PEDRO)

AV.YERVANT KISSAIIKLAN/PEDRO)

AV.YERVANT KISSAIIKIAN(PEDRO)

AV.YERVANT KISSAVIKIAN (GONCCALO)

AV.YERVANT KISSAIIKIAN(GONCALO)

AV.YERVANT KISSA IKIANYGONCALO)

AV.YERVANT KISSASIKIAN(GONÇALO)

AV.YERVANT KISSAUIKIAN(GONCCALO)

AV.YERVANT KISSAIIKIAN(GONCALO)

AV.YERVANT KISSAIIKIAN(GONCALO)

AV.YERVANT KISSA IKIAN(GONCALO)

AV.YERVANT KISSAUIKIAN(GASPAR)

AV.YERVANT KISSAIIKIAN(GASPAR)

AV.YERVANT KISSAIKIAN(GASPAR)

AV.YERVANT KISSA IIKIAN(GASPAR)

AV.YERVANT KISSAIIKIAN(GASPAR)
10

MORAN'SI GETISORDGi*

$0,129-0,603$

$0,117 \quad-0,608$

$0,108 \quad-0,559$

$0,097 \quad-0,564$

$0,115 \quad-0,559$

$0,127-0,608$

$0,118 \quad 0,643$

$-0,024 \quad-0,682$

$0,061 \quad-0,466$

$0,065 \quad-0,465$

$0,047 \quad-0,458$

$0,205 \quad-0,286$

$0,101 \quad-0,836$

$-0,024 \quad-0,906$

$-0,035 \quad-0,843$

$0,133 \quad-0,537$

$0,134 \quad-0,904$

$0,118 \quad-0,709$

$0,059 \quad-0,352$

$0,025 \quad-0,480$

$-0,432 \quad-1,145$

$-0,026 \quad-0,575$

$0,123 \quad-0,564$

$0,088 \quad-0,350$

$0,092 \quad-0,793$

$-0,041 \quad-0,774$

$0,168 \quad-0,876$

$0,193 \quad-0,687$

$0,201 \quad 0,285$

$-0,057 \quad 0,488$

$0,273 \quad 0,306$

$0,220 \quad-1,320$

$0,224 \quad-0,556$

$0,277 \quad-0,857$

$0,179 \quad-0,489$

$0,181 \quad-0,706$

$0,157 \quad-0,799$

$0,189-1,306$

$0,181 \quad 0,995$

$0,164 \quad-0,253$

$0,179 \quad-0,930$

$0,158 \quad-0,840$

$0,164 \quad-0,686$

$0,174 \quad-0,706$

$-0,061 \quad-0,858$

$-0,071 \quad-0,866$

$0,188 \quad-1,385$

$0,175 \quad-1,416$

$0,167 \quad-1,269$

$0,122 \quad-0,974$

$-0,033 \quad-1,215$

$-0,027 \quad-0,289$

$0,099 \quad-0,809$

$0,122 \quad-0,825$

$-0,033 \quad-0,953$

$0,127 \quad-0,881$

$-0,035 \quad-1,181$

$0,115 \quad-0,831$

$0,130 \quad-0,88$

$0,094 \quad-0,733$

$0,139 \quad 0,075$

$-0,021 \quad 0,035$

$0,046 \quad-0,403$

$0,125 \quad 0,187$

$0,092 \quad-0,403$

$-0,039 \quad-0,365$

$0,130 \quad-0,256$

$0,136 \quad-0,312$

$0,142 \quad 0,348$

$0,117 \quad-0,148$

$-0,308 \quad-0,514$

$0,132-0,27$

$0,104 \quad-0,154$

$0,142 \quad-0,341$

$0,139 \quad-0,710$

$0,107-0,699$

$0,162-0,738$

$0,165 \quad-0,870$ 
Apindlce D - RESULTADO DAS ESTATISTICAS LOCAIS MORAN'S I E GETSS ORD GF

RAMO DE ATIVIDADE

MÓVE

COLCHOES

FARMÁCIA

VESTUÁRIO

BOLSAS

PET SHOP

SUPERMERCADO

VARIEDADES

DOCES E BOMBONS

HORTI FRUTI GRANUEIROS

VIDRACARIA

MATERLAL DE CONSTRUÇĀo

VESTUÁRIO

PRODUTOS DE LIMPEZA

VARIEDADES

TELEFONIA

FLORICUITURA

PET SHOP

MECEARIA

VARIEDADES

HORTI FRUTI GRANUEIROS

MATERLAL DE CONSTRUCÁ

FIOS

OPTICA

VESTUÁRIO

PET SHOP

MERCEARIA

VARIEDADES

DOCES E BOMBONS

MATERIAL DE CONSTRUÇAOO

TELEFONIA

FARMÁCIA

VESTUÁRIO

FLORICULTURA

PET SHOP

CASA DO NORTE

ACOUGUE

BAZAR

CALCCADOS

CINE E FOTO

VESTUÁRIO

FARMACIA

MERCEARIA

MÓVEIS

OPTICA

ARTIGOS RELUGIOSOSS

SUPERMERCADO RICO

MATERIAL DE CONSTRUÇĀO

AVKCOLA

PADARIA

PET SHOP

AÇOUGUE

ELETRO̊NICA

FLORICULTURA

VARIEDADE

MATERLAL DE CONSTRUÇAO

HORTI FRUTI GRANJEIROS

SUPERMERCADO DIA

AÇOUGUE

BAZAR

VESTUÁRIO

FARMÁCIA

DOCERIA

BAZAR

CALCCADOS

CASA DONORTE

VESTUÁRIO

BOLSA

COSMÉTICOS

FARMÁCIA

MERCEARIA

MÓVEIS

MATERIAL DE CONSTRUCÃO

HORTI FRUTI GRANUEIROS

DOCERIA

AVICOLA

VIDRACCARIA

SUPERMERCADO
LOGRADOURO

AV.YERVANT KISSAIIKLAN(GASPAR)

AV.YERVANT KISSAIIKLAN(GASPAR)

AV.YERVANT KISSAIIKLAN(GASPAR)

AV.YERVANT KISSAIKLAN(GASPAR)

AV.YERVANT KISSAIKIAN(GASPAR)

AV.YERVANT KISSAUIXIAN(GASPAR)

AV.YERVANT KISSAUIKIAN(CELSO)

AV.YERVANT KISSAUIKIAN(CELSO)

AV.YERVANT KISSA IKIAN(CELSO)

AV.YERVANT KISSAUIKIANCCELSO)

AV.YERVANT KISSAJKLLAN(CELSO)

AV.YERVANT XISSAUIKIAN(CELSO)

AV.YERVANT KISSAIKIANMCELSO)

AV.YERVANT KISSAIIKLAN(CELSO)

AV.YERVANT KISSAIIKIAN(CAETANO)

AV.YERVANT KISSAIIKLAN(CAETANO)

AV.YERVANT KISSAIIKIAN(CAETANO)

AV.YERVANT KISSAIIKIAN(CAETANO)

R.JOAO ZANCO(JOANIZA)

R.JOÃOZANCO(JOANIZA

RJOAO ZANCOUOANIZA

R.JOAOZANCO(JOANIZA)

R.JOAOZZANCO(JOANIZA)

R.JOÃO ZANCO(JOANIZA)

R.JOÃOZANCD(JOANIZA)

R.JOAO ZANCO (JOANIZA)

R.ESTANISLAU MONIUSKO(IOANZA)

R.ESTANISLAU MONIUSKO(JOANZA)

R.ESTANISLAU MONIUSKO(JOANIZA)

R.FSTANISLAU MONIUSKO|JOANIZA)

RESTAMISLAU MONUUSKOUIOANRA)

RESTANISLAU MONIUSKO(JOANIZA)

R.ESTANISLAU MONIUSKOUJOANIZA)

R.ESTANISLAU MONIUSKO(JOANIZA

RESTANISLAU MONIUSKOLJOANIZA

R.ESTANISLAU MONIUSKO(JOANIZA)

AV.YERVANT KISSAIKIAN/BAURU)

AV.YERVANT KISSAIIKIAN(BAURU)

AV.YERVANT KISSAIIKLAN(BAURU)

AV.YERVANT KISSAIKLLAN(BAURU)

AV.YERVANT KISSAIKIAN(BAURU)

AV.YERVANT KISSAIKIAN/BAURU)

AV.YERVANT KISSAIKLAN(BAURU)

AV.YERVANT KISSAIKLAN(BAURU)

AV.YERVANT KISSAIIKLAN(BAURU)

AV.YERVANT KISSAIIKLAN(BAURU)

AV.YERVANT KISSAIKKAN(BAURU)

AV.YERVANT KISSAIIKIAN(BAURU)

AV. YERVANT KISSAIIKIAN(BAURU)

AV.YERVANT KISSAUIKIAN(BAURU)

AV.YERVANT KISSAIKIAN(BAURU)

AV.YERVANT KISSAUIKLAN(JOSE ALVES)

AV. YERVANT KISSAUIKIAN(JOSÉ ALVES)

AV.YERVANT KISSAUIKIAN(JOSÉ ALVES)

AV.YERVANT KISSAUIKIAN(JOSÉ ALVES)

AV.YERVANT KISSAUIKIAN(JOSÉ ALVES)

AV.YERVANT KISSAUIKIAN(JOSÉ ALVES)

AV.YERVANT KLSSAUIKIAN(JOSÉ ALVES)

AV.YERVANT KISSAIIKLAN(BEM-AVENTURADO)

AV.YERVANT KISSAUIKIAN(BEM-AVENTURADO)

AV.YERVANT KISSAUIKIANMIEEM-AVENTURADO

AV.YERVANT KISSAJIKIANMBEM-AVENTURADO

AV.YERVANT K'SSAIIKIAN(BEM-AVENTURADO)

AV.YERVANT KISSAIIKIANDOMENICO)

AV.YERVANT KISSAUIKIANYDOMENICO)

AV.YERVANT KISSAIIKIANYDOMENICO)

AV.YERVANT KISSAYIKIAN(DOMENICO

AV.YERVANT KISSAIIKIANIDOMENICO)

AV.YERVANT KISSAIIKIAN(DOMENICO)

AV.YERVANT KISSAIIKIAN(DOMENICO)

AV.YERVANT KISSAIIKIAN(DOMENICO)

AV.YERVANT KISSAIIKIAN(DOMENICO)

AV.YERVANT KISSAIIKIAN(DOMENICO)

AV.YERVANT KISSAIIKIAN(DOMENICO)

AV.YERVANT KISSAIIKLAN(DOMENICO)

AV.YERVANT KISSANIKIAN(DOMENICO)

AV.YERVANT KISSAIIKLAN(DOMENICO)

AV.YERVANT KISSAIIKIAN(DOMENICO)

\section{Lotas}

MORAN'S I GETIS ORD Gi"

$0,141 \quad-0,812$

$-0,042 \quad-0,865$

$0,141 \quad-0,738$

$0,157 \quad-0,586$

$0,191 \quad 0,959$

$0,181 \quad-0,410$

$0,181 \quad-0,712$

$0,176 \quad 0,986$

$0,138 \quad-0,900$

$-0,034 \quad-0,823$

$0,142 \quad-0,327$

$0,074 \quad-0,591$

$0,164 \quad-0,947$

$0,158 \quad-1,026$

$0,154 \quad-0,906$

$0,151 \quad-0,757$

$\begin{array}{ll}-0,006 & -0,497\end{array}$

$-0,437 \quad-0,533$

$0,012 \quad 0,035$

$0,027 \quad-0,398$

$0,027 \quad-0,334$

$-0,075 \quad-0,235$

$-0,603 \quad-0,502$

$-0,114 \quad-0,123$

$-0,216 \quad 0,523$

$-1,210 \quad-0,574$

$-0,202 \quad 0,075$

$0,009 \quad-0,155$

$-0,004 \quad-0,174$

$-0,015 \quad-0,487$

$0,066 \quad-0,273$

$0,096 \quad-0,178$

$0,104 \quad-0,371$

$0,107 \quad-0,647$

$0,148 \quad-0,350$

$-0,341 \quad-0,732$

$0,128 \quad-0,591$

$-0,026 \quad-0,646$

$-0,458 \quad-0,749$

$-0,271 \quad-0,611$

$\begin{array}{ll}-0,052 & \mathbf{0}, 270\end{array}$

$0,230 \quad-0,528$

$0,166-1,159$

$0,244 \quad-1,524$

$0,272-1,632$

$0,286-1,721$

$0,286 \quad-1,689$

$0,291-1,648$

$-0,002 \quad-0,724$

$0,211-1,252$

$0,193 \quad-1,101$

$0,183 \quad-1,118$

$0,263-1,070$

$0,257 \quad-0,866$

$-0,059 \quad-1,251$

$0,193 \quad-1,113$

$0,251 \quad-1,306$

$0,256 \quad-1,245$

$0,254-1,115$

$0,244 \quad-0,939$

$0,233 \quad-0,445$

$-0,225 \quad-0,881$

$0,149-0,766$

$0,156 \quad-0,944$

$0,148 \quad-0,676$

$0,041 \quad-0,299$

$-0,044 \quad-0,273$

$0,134 \quad-0,786$

$0,159 \quad-0,808$

$-0,040 \quad-0,794$

$-0,197 \quad-0,700$

$0,151 \quad-0,273$

$0,161 \quad-0,442$

$0,119 \quad-0,314$

$\begin{array}{ll}0,143 & -0,790 \\ 0,094 & -0,550\end{array}$ 
ApJindice D - RESULTADO DAS ESTATISIICAS LOCAIS MOAAN'S I E GETIS ORD GI*

BAZAR

MOVEIS

MATERIAL DE CONSTRUÇAO

AOEGA

MERCEARIA

VARIEDADES

DOCES E BOMBONS

AÇOUGUE

ADEGAS

HORTI FRUTI GRANJEIROS

VESTUÁRIO

CASA DO NORTE

VARIEDADES

SUPERMERCADO

PADARIA

HORTI FRUTI GRANUEIROS

MATERIAL DE CONSTRUCAOO

COSMÉTTCOS

PET SHOP

DOCES E BOMBONS

AÇOUGUE

MATERIAL DE CONSTRUÇAOO

PETSHOP

MERCEARIA

VARIEDADES

PADARIA

HORTI FRUTI GRANUEIROS

MATERIAL DE CONSTRUCAOO

VESTUÁRHO

BUUTERIA

PRODUTOS DE LIMPEZA

MERCEARIA

MATERLAL DE CONSTRUCĀO

FARMÁCIA

MATERLAL DE CONSTRUÇÃo

HORTI FRUTI GRANUEIROS

PADARIA

PEIXARIA

BAZAR

VESTUÁRIO

BUOUTERIA

MERCEARIA

HORTI FRUTI GRANUEIROS

VESTUÁRIO

VARIEDADES

MATERIAL DE CONSTRUÇĀO

COSMÉTICOS

DOCES E BOMBONS

AÇOUGUE

ADEGA

HORTI FRUTI GRANUEIROS

MATERIAL DE CONTRUÇÃO

VESTUÁRIO

PET SHOP

MERCEARIA

VARIEDADES

ADEGA

HORTI FRUTI GRANUEIROS

FARMÁCIA

ROUPAS

PRODUTOS DE LMPEZA

MERCEARIA

VARIEDADES

DOCES E BOMBONS

HORTI FRUTI GRANUEIROS

MATERIAL DE CONSTRUCCÃO

BAZAR

FARMÁCIA

VESTUÁRIO

BUUTERIAS

PET SHOP

CASA DO NORTE

VARIEDADES

PADARIA

MATERIAL DE CONSTRUÇÁ

VESTUÁRL

MÓVEIS

VARIEDADES
LOGRADOURO

AV.YERVANT KISSAIKLAN(BRASIL)

AV.YERVANT KISSAJIKLAN(BRASIL)

AV.YERVANT KLSSAIIKIAN(BRASIL)

AV.YERVANT KISSAIIKLAN(BRASIL)

R.DR.JOSESSIIVIO DE CAMARGO

R.DR.JOSÉSILVIO DE CAMARGO

R.DR.JOSESILVO DE CAMARGO

R.DR.JOSÉSILVIO DE CAMARGO

R.DR.JOSESIIVIO DE CAMARGO

R.DR.JOSÉSIVIIO DE CAMARGO

R.DR.JOSESSIVIO DE CAMARGO

R.DRJOSESSHVIO DE CAMARGO

PRJOHN FORSELL

PRJOHN FORSELL

PR.JOHN FORSELL

PRIOHN FORSEL

PR.JOHN FORSEL

PR.JOHN FORSEIL

PR.JOHN FORSELI

R.ANTONIO DO CAMPO(ALZIRA)

R.ANTONIO DO CAMPO(ALZIRA)

R.ANTONIO DO CAMPO(ALZIRA)

R.ANTONFO DO CAMPO(ALZIRA)

R.ANTONIO DO CAMPO(ANDRADE)

R.ANTONIO DO CAMPO(ANDRADE)

R.ANTONIO DO CAMPO(ANDRADE)

R ANTONIODO CAMPOANDRADE)

RANTONIO DO CAMPOIANDRADE)

R.ANTONIO DO CAMPO(ANDRADE)

R.ANTONIO DO CAMPOAANDRADE

R.ANTONIO DO CAMPO(ANDRADE)

R.ANTONIO DO CAMPO(BATISTA MACIEL)

R.ANTONIO DO CAMPO(BATISTA MACIEL)

R.ANTONO DO CAMPO(BATISTA MACIEL)

AV.PAPA GREGORIO MAGNO

AV.PAPA GREGORIO MAGNO

AV.PAPA GREGORIO MAGNO

R.DOMENICO ANIBAL

R.DOMENICO ANIBAL

R.DOMENICO ANIBAL

R.DOMENICO ANIBAL

RGUAICURI

R.GUARCURI

R.ARAUUO LIMA

R.ARAUSO UMMA

R.ARAUJO UMA

R.MARIA TEREZA

R.MARIA TEREZA

R. MAFIA TEREZA

R.MARLA TEREZA

R.MARIA TEREZA

R.MARIA TEREZA

R.MARIA TEREZA

AV.ANGELO CRISTLANIMI

AVANGELO CRISTAANINI

AV.ANGELO CRISTIANINI

AV.ANGELO CRISTIANINI

AV.ANGELO CRISTIANINI

AV.ANGELO CRISTIANIMI

R.AMAD MASSUD (SAIVADOR DAU)

RIUCIO DIAS OA FONSECA

R. LUCHO DIAS DA FONSECA

RLUUCIO DIAS DA FONSECA

R.LUCLO DIAS DA FONSECA

R. LUCIO DUAS DA FONSECA

RLUCIO DIAS DA FONSECA

R.LUCIO DIAS DA FONSECA

R.LUCIO DIAS DA FONSECA

R. LUCIO DIAS DA FONSECA

R.LUCIO DIAS DA FONSECA

R.LUCIO DUS DA FONSECA

R. DAVIDE PEREZ

R.DAVIDE PEREZ

R.DAVIOE PEREZ

R.DAVIDE PERE

R.SALVADOR DAL

R.SALVADOR DAL!

\begin{tabular}{|c|c|c|}
\hline LOJAS & MORAN'SI & GETIS ORD G \\
\hline 1 & 0,179 & $-0,750$ \\
\hline 2 & $-0,054$ & $-0,881$ \\
\hline 2 & $-0,059$ & $-0,755$ \\
\hline 1 & 0,248 & $-0,624$ \\
\hline 4 & $-0,637$ & $-0,573$ \\
\hline 2 & $-0,034$ & $-0,530$ \\
\hline 1 & 0,176 & $-0,412$ \\
\hline 1 & 0,144 & $-0,239$ \\
\hline 3 & $-0,232$ & $-0,648$ \\
\hline 3 & $-0,132$ & 0,077 \\
\hline 4 & $-0,452$ & $-0,387$ \\
\hline 1 & 0,065 & $-0,516$ \\
\hline 2 & $-0,057$ & $-1,011$ \\
\hline 1 & 0,186 & $-0,011$ \\
\hline 1 & 0,176 & $-0,390$ \\
\hline 1 & 0,161 & $-1,033$ \\
\hline 1 & 0,200 & $-0,676$ \\
\hline 1 & 0,175 & $-0,390$ \\
\hline 1 & 0,198 & $-0,322$ \\
\hline 1 & 0,116 & 0,541 \\
\hline 1 & 0,117 & 0,351 \\
\hline 1 & 0,119 & 0,367 \\
\hline 1 & 0,115 & 0,517 \\
\hline 2 & 0,006 & 0,785 \\
\hline 4 & $-0,339$ & 0,177 \\
\hline 1 & 0,007 & 0,725 \\
\hline 1 & 0,119 & 0,288 \\
\hline 1 & 0,126 & 0,162 \\
\hline 2 & $-0,039$ & $-0,140$ \\
\hline 1 & 0,136 & $-0,097$ \\
\hline 1 & 0,169 & $-0,233$ \\
\hline 1 & 0,178 & $-0,308$ \\
\hline 1 & 0,163 & $-0,327$ \\
\hline 1 & 0,172 & $-0,330$ \\
\hline 1 & 0,432 & $-0,431$ \\
\hline 1 & 0,360 & $-0,915$ \\
\hline 1 & 0,390 & $-1,072$ \\
\hline 1 & 0,313 & $-0,732$ \\
\hline 1 & 0,230 & $-0,243$ \\
\hline 3 & $-0,405$ & 0,516 \\
\hline 1 & 0,158 & $-0,843$ \\
\hline 2 & $-0,084$ & $-1,093$ \\
\hline 1 & 0,362 & $-1,282$ \\
\hline 2 & $-0,054$ & $-1,225$ \\
\hline 1 & 0,321 & $-0,455$ \\
\hline 1 & 0,300 & $-1,248$ \\
\hline 1 & 0,321 & $-0,343$ \\
\hline 1 & 0,115 & 1,551 \\
\hline 1 & 0,152 & 0,405 \\
\hline 1 & 0,129 & 0,568 \\
\hline 1 & 0,089 & 0,148 \\
\hline 2 & $-0,024$ & 0,148 \\
\hline 1 & $-0,004$ & $-0,287$ \\
\hline 1 & $-0,189$ & $-0,305$ \\
\hline 1 & 0,290 & $-0,688$ \\
\hline 1 & 0,263 & $-0,677$ \\
\hline 1 & 0,252 & $-0,246$ \\
\hline 1 & 0,256 & $-1,072$ \\
\hline 1 & 0,225 & 0,604 \\
\hline 1 & 0,271 & $-0,783$ \\
\hline 1 & 0,460 & $-1,122$ \\
\hline 1 & 0,218 & $-1,254$ \\
\hline 2 & $-0,066$ & $-0,865$ \\
\hline 1 & 0,222 & 0,333 \\
\hline 1 & 0,245 & $-0,312$ \\
\hline 1 & 0,242 & $-1,086$ \\
\hline 1 & 0,241 & $-1,535$ \\
\hline 1 & 0,247 & $-1,342$ \\
\hline 1 & 0,217 & $-0,812$ \\
\hline 1 & 0,211 & $-1,075$ \\
\hline 1 & 0,224 & $-0,500$ \\
\hline 1 & 0,250 & $-0,549$ \\
\hline 1 & 0,248 & $-0,317$ \\
\hline 1 & 0,250 & $-0,304$ \\
\hline 1 & 0,313 & $-0,712$ \\
\hline 1 & 0,332 & $-0,231$ \\
\hline 1 & 0,433 & $-1,023$ \\
\hline 2 & $-0,120$ & 0,980 \\
\hline
\end{tabular}


Apindice D - RESULTADO DAS ESTATISTICAS LOCAIS MORAN'S I E GETIS ORD GI*

RAMO DE ATIVIDADE

ADEGA

VESTUARIO

SUPERMERCADO

VESTUÁRIO

PADARIA

MERCEARIA

MATERIAL DE CONSTRUÇÃo

PET SHOP

MADEIRAS, ARTEFATOS

FARMACIA

PET SHOP

VARIEDADES

PADARIA

CALCCADOS

MÓVEIS

FLORICULTURA

MATERIAL DE CONSTRUÇĀO

VARIEDADES

AÇOUGUE

HORTI FRUTI GRANIEIROS

MADEIRA E ARTEFATOS

FARMACIA

OPTICA

PET SHOP

FOTOE CINE

SUPERMERCADO

ADEGA

MATERLAL DE CONSTRUÇAO

VARIEDADES

FARMÁCIA

VESTUÁRIO

PET SHOP

PRODUTOS DE UIMPEZA

VARIEDADES

ADEGA

EQUIP. TELEFONIA

OPTICA

VESTUÁRIO

BUOUTERIAS

FLORICULTURA

MAGAZINE

MATERIAL DE CONSTRUÇÃO

VARIEDADES

AÇOUGUE

FERRAGENS

TELEFONIA

COLCHŌES

LIVROS

FARMÁCIA

COSMÉTICOS

VESTUARIO

ARTIGOS RELIGIOSOS

MERCEARIA

VARIEDADES

MÓVEIS

VESTUÁRIO

ARTIGOS RELIGIOSOS

FARMACIA

VIDRAÇARIA

MERCEARIA

FARMACIA

ELETRONICA

VESTUARIO

SUPERMERCADO

VARIEDADE

PADARIA

AÇOUGUE

HORTI FRUTI GRANUEIROS

FARMACIA

PET SHOP

HORTI FRUTI GRANUEIROS

MÓVEIS

MADEIRA

MATERIAL DE CONSTRUÇAO

VARIEDADES

SUPERMERCADO

DOCES E BOMBONS

MATERIAL DE CONSTRUÇÁO
LOGRADOURO

R.SALVADOR DALI

R.SALVADOR DALI

R.SALVADOR DALI

AV.CARDOSO OE MELO NETO(JOAQUIM)

AV.CARDOSO DE MELOO NETO(BAHIA)

AV.CARDOSO DE MELO NETO(BAHIA)

AV.CARDOSO DE MELO NETO(BAHIA)

AV.CARDOSO DE MELO NETO(BAHIA)

AV.CARDOSO DE MELO NETO(CLUBE)

AV.CARDOSO DE MELO NETOACLUBE)

AV.CARDOSO DE MELO NETO(CLUBE)

AV.CARDOSO DE MELO NETOXENOUT)

AV.CARDOSO DE MELO NETO(ENOUT)

AV.CARDOSO DE MELO NETO(ENOUT]

AV.CARDOSO DE MELO NETO(ENOUT)

AV.CARDOSO DE MELO NETO(ENOUT)

ESTR.DO ALVARENGA(BALNEÁRIO SĀO FRANCISCO)

ESTR DO ALVARENGA(BALNEARIO SÅO FRANCISCO)

ESTR DO ALVARENGA(BALNEÁRIO SÃO FRANCISCO)

ESTR.DO ALVARENGA(BALNEARIO SÄO FRANCISCO)

ESTR.DO ALVARENGAJBALNEÁRJO SÃO FRANCISCO)

ESTR.DO ALVARENGA(BALNEÁRIO SĂO FRANCISCO)

ESTR.DO ALVARENGA(BALNEÁRIO SÃO FRANCISCO)

ESTR.DO ALVARENGA(BALNEÁRIO SAO FRANCISCO)

ESTR DO ALVARENGAL(BALNEÁRIO SZ̃O FRANCISCO)

ESTR. DO ALVARENGAIJAROIM SANTA AMELLIA)

ESTR.DO ALVARENGA(IARDIM SANTA AMELLIA)

ESTR.DO ALVARENGA(JARDIM SANTA AMÉLIA)

ESTR.DO ALVARENGAUIARDIM SANTA AMELLA)

ESTR. DO ALVARENGA(JARDIM SANTA AMELLA)

ESTR.DO ALVARENGA(JARDIM SANTA AMÉLIA)

ESTR.DO ALVARENGAIJARDIM SANTA AMÉLIA)

ESTR.DO ALVARENGA(JARDIM SANTA AMÉLIA)

AV.DAS GAROUPAS

AV.DAS GAROUPAS

AV.DAS GAROUPAS

AV.DAS GAROUPAS

AV.DAS GAROUPAS

AV.DAS GAROUPAS

AV.DAS GAROUPAS

AV.INTERLAGOS(SHOPPING)

AV.JNTERLAGOS(SHOPPING)

AV.INTERLAGOS(SHOPPING)

AV.INTERLAGOS(SHOPPING)

AV.INTERLAGOS(SHOPPING)

AV.INTERLAGOS(SHOPPING)

AVINTERLAGOS(SHOPPING)

AV.INTERLAGOS(SHOPPING)

AV.INTERLAGOS(SHOPPING)

AV.INTERLAGOS(SHOPPING)

AV.INTERLAGOS SSHOPPING

AV.INTERLAGOS(SHOPPING)

AV.INIERLAGOS(TREVO)

AV.INTERLAGOS(TREVO)

AV.INTERLAGOS (TREVO)

AV.INTERLAGOS(TREVO)

AV.INTERLAGOS(TREVO)

AV.INTERLAGOS(TREVO)

AV AUGUSTO DE CASTRO

AV.AUGUSTO DE CASTRO

AV.AUGUSTO DE CASTRO

AV.AUGUSTO DE CASTRO

AV.AUGUSTO DE CASTRO

AV.SANTO AFONSO

AV.SANTO AFONSO

AV.SANTO AFONSO

AV.SANTO AFONSO

AV.SANTO AFONSO

AV.SANTO AFONSO

AV.SANTO AFONSO

AV.CUPEC\&(SANTO AFONSO)

AV.CUPECE(SANTO AFONSO)

AV.CUPECE(SANTO AFONSO)

AV.CUPECE(SANTO AFONSO)

R.BRÁS DE ABREU

R.BRAS DE ABREU

R.BRÁS DE ABREU

R.BRÁS DE ABREU
LOJAS MORAN'SI GETISORDGi*

$0,453 \quad-1,075$

$0,466 \quad-0,738$

$0,357-1,207$

$0,585 \quad-0,649$

$0,155 \quad-0,872$

$0,300 \quad-1,275$

$-0,057 \quad-1,105$

$0,385 \quad-1,182$

$0,437 \quad-0,243$

$0,519 \quad-0,825$

$0,404 \quad-0,772$

$-0,077 \quad-0,866$

$0,297-0,126$

$0,507 \quad-0,886$

$0,288 \quad-0,940$

$0,375-1,200$

$0,419 \quad-0,083$

$-0,438 \quad-0,792$

$0,175 \quad-0,802$

$0,215 \quad-0,319$

$0,334 \quad-0,009$

$0,242 \quad-0,18$

$0,300 \quad-0,411$

$-0,081 \quad-0,524$

$0,265 \quad-0,610$

$0,321 \quad-0,926$

$0,284 \quad-0,886$

$0,309-1,233$

$-0,087 \quad-0,755$

$0,274 \quad-1,007$

$0,281 \quad-1,27$

$0,293 \quad-1,355$

$0,312 \quad-1,457$

$0,169 \quad-0,048$

$0,224 \quad-0,843$

$-0,064 \quad-0,451$

$0,223 \quad-0,621$

$0,225 \quad 0,512$

$-0,060 \quad-0,610$

$0,219 \quad-0,243$

$-0,223 \quad 1,047$

$-0,300 \quad 2,035$

$-0,150 \quad 0,306$

$-0,189 \quad 0,780$

$0,080 \quad 2,035$

$-0,278 \quad 2,035$

$-0,272 \quad 0,087$

$-0,257 \quad 0,721$

$0,033 \quad 0,721$

$-0,321 \quad 0,104$

$0,846 \quad 0,540$

$-0,572 \quad 0,144$

$0,096 \quad-0,238$

$0,229 \quad 0,074$

$-0,176 \quad 0,064$

$-0,117 \quad 0,312$

$-0,107 \quad 0,400$

$-0,168 \quad-0,318$

$0,409 \quad-0,154$

$0,490 \quad-0,356$

$0,299 \quad-0,539$

$0,309 \quad-0,892$

$0,294 \quad-1,070$

$\mathbf{0 , 1 7 0}-0,778$

$0,154-0,979$

$0,172 \quad-1,188$

$0,192 \quad-0,509$

$0,172 \quad-0,917$

$0,170 \quad-1,004$

$0,154 \quad-1,157$

$0,367-1,042$

$0,288-0,380$

$0,391 \quad-1,236$

$0,353 \quad-1,002$

$-0,049 \quad-1,460$

$0,459 \quad-0,516$

$-0,053 \quad-0,912$

$0,229-1,002$ 
Apindle D - RESULTADO DAS ESTATISTICAS LOCASS MORAN'S I E GETIS ORD GI*

RAMO DE ATIVIDADE

VESTUÁRIO

PET SHOP

PRODUTOS DE LIMPEZA

SUPERMERCADO

VARIEDADES

TINTAS

MATERIAL DE CONSTRUÇAO

INSTRUMENTOS MUSICAIS

PET SHOP

ARTIGOS RELIGIOSOS

MERCEARIA

PADARIA

AÇOUGUE

MATERIAL DE CONSTRUČ̉O

TELECOMUNICAÇÃO

FARMACHA

OPTICA

VESTUARIO

CALÇADOS

BOLSAS

BUOUTERIA

PRODUTOS DE LIMPEZA

CINE E FOTO

SUPERMERCADO

MATERIAL DE CONTRUČCAOO

PET SHOP

MERCEARIA

HORTI FRUTI GRANUEIROS

VESTUÁRIO

VESTUÁRIO

COSMETTICOS

MERCEARIA

MAGAZINE

PADARIA

HORTI FRUTI GRANUEIROS

MATERIAL DE CONSTRUÇĀO

FARMACIA

VESTUARIO

PET SHOP

SUPERMERCADO

MERCEARIA

VARIEDADE

PADARIA

MATERIAL OE CONSTRUÇÃo

OPTICA

PET SHOP

LATICINIOS

AÇOUGUE

SUPERMERCADO

VARIEDADES

PADARIA

MATERIAL DE CONSTRUÇÃo

PET SHOP

DOCES E BOMBONS

ACYOUGUE

HORTI FRUTI GRANUEIROS

CASA DO NORTE

MERCEARIA

VARIEDADES

DOCES E BOMBONS

ACCOUGUES

FERRAGENS

MATERIAL DE CONSTRUÇAO

MÓVEIS

ARMARINHO

CAMA, MESA E BANHO

UNROS

FARMACIA

COSMÉticos

OPTICA

VESTUÁRIO

BOLSAS

BUOUTERIA

PETSHOP

PRODUTOS DE LIMPEZA

CASA DO NORTE

MERCEARIA

VARIEDADES
IOGRADOURO

R. BRÁS DE ABREU

R. BRÁS DE ABREU

R. BRÁS DE ABREU

AV.CUPECE'(BRASS DE ABREU)

AV. CUPECE(BRÁS DE ABREU)

AV.CUPECE(BRÁS DE ABREU)

AV.CUPECE(BRASS DE ABREU)

AV.CUPECE'(BRÁS DE ABREU\})

AV. CUPECE(BRAS DE ABREU)

AV. CUPECE (BRAS DE ABREU]

AV.CUPECE(LARGO DO JARDIM MIRIAM)

AV.CUPECE(LARGO DO JARDIM MIRLAM)

AV.CUPECE(LARGO DO JARDIM MIRIAM

AV.CUPECE(LARGO DO JARDIM MIRLAM)

AV.CUPECEE(LARGO DO JARDIM MIRLAM)

AV.CUPECE(LARGO DO IARDIM MIRIAM)

AV.CUPECE(LARGO DO IARDIM MIRIAM)

AV.CUPECE\{LARGO DO IARDIM MIRIAM

AV.CUPECE(LARGO DO JAROIM MIRIAM)

AV.CUPECE[LARGO DO JARDIM MIRIAM]

AV.CUPECEE(LARGO DO JARDIM MIRIAM)

AV.CUPECEE(LARGO DO JARDIM MIRIAM)

AV.CUPECE'(LARGO DO JARDIM MIRIAM

AV.CUPECE(IRACEMA ARRUDA)

AV.CUPECE(IRACEMA ARRUOA)

R.APIARIS

E.DORETIRO

E.DO RETIRO

EDO RETIRO

R.DOS DOURADOS

AV.ALDO JOAO RINALDI

R.DR.CARLOS DE REZENDE ENOUT

R.DR.CARLOS DE REZENDE ENOUT

R.DRCARLOS DE REZENDE ENOUT

R.DR.CARLOS DE REZENDE ENOUT

R.DR.CARLOS DE REZENOE ENOUT

R.DR.CARLOS DE REZENDE ENOU

R.DR.CARLOS DE REZENDE ENOU

R. DR.CARLOS DE REZENDE ENOUT

AV.MANUUEL OA NÓBREGA(DTADEMA/DIVISA)

AV.MANUEL DA NÓBREGA(DIADEMAVDIVISA)

AV.MANUEL DA NÓBREGA(DIADEMA/DIVISA)

AV.MANUEL DA NÓBREGA(DLADEMAYOIVISA)

AV.MANUEL DA NOBREGA(DIADEMA/DNISA]

AV.MANUEL DA NÓBREGA(DIADEMA/DIVISA)

AV.MANUEL DA NÓBREGA(DIADEMA/DIVISA)

AV.ALDA_DIADEMAVIVISA

AV.ALOA(DLADEMAVIVISA)

AV.AFONSO MONTEIRO DA CRUZ(CONCEICAOO)

AV.AFONSO MONTEIRO DA CRUZ(CONCEICXO)

AV.AFONSO MONTEIRO DA CRUZ(CONCEICZ̄O)

AV.AFONSO MONTEIRO DA CRUZ(CONCEIÇĀO)

AV.AFONSO MONTEIRO DA CRUZ(CONCEIÇAO)

AV.AFONSO MONTEIRO DA CRUZZCONCEICYAOO

AV.AFONSO MONTEIRO DA CRUZ(CONCEIČ̃̃)

AV.AFONSO MONTEIRO DA CRUZZCONCEICĀO)

AV.AFONSO MONTEIRO DA CRUZZ(CONCEIÇĀO

AV.ROTARY(MARGARIDANDIADEMA/SERRARIA)

AV.ROTARY(MARGARIOADIADEMAVSERRARIA)

AV.ROTARY(MARGARIDA/DLADEMA/SERRARIA)

AV.ROTARY(MARGARIDA/DIADEMA/SERRARIA)

AV.ROTARY(MARGARIDA/DUAOEMAYSERRARIA)

AV.ROTARY(MARGARIDAVDIADEMA/SERRARIA)

AV.ROTARY(MARGARIDA/DLADEMAVSERRARIA)

AV.ROTARY(MABGARIDAOLADEMAISERRARIA

AV.ROTARY(MARGARIDA/DIADEMAVSERRARIA)

AV.ROTARY(MARGARIDA/DIADEMA/SERPARIA)

AV.ROTARY(MARGARIDA/DIADEMA/SERRARIA)

AV.ROTARY(MARGARIDA/DIADEMA/SERRARIA)

AY.ROTARY(MARGARIDA/DIADEMA/SERPARIA)

AV.ROTARY(MARGARIDA/DIADEMA/SERRARIA)

AV.ROTARY(MARGARIDAVDIADEMA/SERRARIA)

AV.ROTARY[MARGARIDAVOIADEMAVSERRARIA

AV.ROTARY(MARGARIDAJOIADEMA/SERRARIA)

AV.ROTARY(MARGARIDAVDLADEMAVSERRARIA)

AV.ROTARY(MARGARIDA/DLADEMA/SERRARIA)

AV.ROTARY(ANTONLO/DIADEMA/SERRARIA)

AV.ROTARY(ANTONIO/DIADEMA/SERRARIA)
LOJAS MORAN'SI GETIS ORDGi*

$0,153 \quad-1,13$

$0,151 \quad-1,335$

$0,184 \quad-0,303$

$0,209 \quad-0,585$

$0,261-1,304$

$0,222 \quad-0,724$

$-0,052 \quad-0,967$

$0,187 \quad-0,432$

$0,146-0,58$

$0,216 \quad-0,746$

$0,043 \quad 0,252$

$0,029 \quad 0,360$

$0,048 \quad 0,137$

$0,092 \quad 0,360$

$0,039 \quad-0,034$

$-0,019 \quad-0,034$

$0,181 \quad 0,194$

$-0,091 \quad-0,274$

$0,169 \quad-0,029$

$0,016 \quad-0,313$

$-0,007 \quad-0,756$

$0,065 \quad-0,625$

$0,074 \quad-0,42$

$0,191 \quad-0,911$

$0,226 \quad-0,509$

$0,493 \quad-0,454$

$-0,124 \quad-1,218$

$-0,104 \quad-0,279$

$0,519 \quad-0,280$

$0,191-0,654$

$0,353 \quad-1,651$

$0,294 \quad-0,774$

$0,281 \quad-0,77$

$0,273-0,881$

$0,249 \quad-0,999$

$0,313 \quad-0,294$

$0,266-0,845$

$0,287 \quad-0,992$

$0,343 \quad-0,980$

$0,197 \quad-0,410$

$0,207 \quad-0,639$

$0,200-0,172$

$0,207 \quad-0,239$

$0,195 \quad-0,315$

$0,192 \quad 0,475$

$0,201-0,312$

$0,248 \quad-0,172$

$0,257 \quad-0,475$

$0,247 \quad-0,32$

$0,277 \quad-0,313$

$0,269 \quad 0,040$

$0,239-0,052$

$0,257 \quad 0,392$

$0,251 \quad 0,179$

$0,247 \quad 0,136$

$0,243 \quad-0,325$

$0,269 \quad 0,090$

$0,129 \quad-0,314$

$-0,027 \quad-0,690$

$-0,047 \quad-0,201$

$0,008 \quad-0,467$

$-0,008 \quad-0,484$

$-0,033 \quad-0,30$

$0,172 \quad-0,274$

$-0,050 \quad-0,312$

$0,212 \quad-0,102$

$0,203 \quad-0,433$

$-0,062 \quad-0,475$

$-0,028 \quad-0,307$

$0,028 \quad-0,604$

$-3,180 \quad-0,323$

$0,045 \quad-0,238$

$0,104 \quad-0,450$

$0,151 \quad-0,323$

$0,187 \quad-0,475$

$0,177 \quad-0,433$

$0,196-0,611$

$0,215 \quad-0,45$ 
Apindice D - RESULTADO DAS ESTATISTICAS LOCAIS MORAN'S I E GETSS ORD GF*

RAMO DE ATIVIDADE AÇOUGUE

PEIXARIA

VIDRAÇARIA

MATERIAL DE CONSTRUÇAO

VESTUÁRIO

BUOUTERIA

AÇOUGUE

SUPERMERCADO

VARIEDADES

DOCES E BOMBONS

ADEGA

FERRAGENS

MATERLAL HIORÁULICO

INFORMÁTICA

TELEFONIA

ELETRODOMÉSTICOS CASAS BAHIA

FARMÁCIA

VESTUARIO

CALCCADOS

PET SHOP

SUPERMERCADO

MERCEARIA

VARIEDADES

DOCES E BOMBONS

AÇOUGUE

ADEGA

HORTI FRUTI GRANUEIROS

MATERIAL DE CONSTRUÇ̧̧O

MÓVEIS

FARMÁCIA

COSMETKCOS

OPTICA

VESTUÁRIO

CALÇADOS

BUOUTERLA

PET SHOP

MERCEARIA

VARIEDADES

ADEGA

HORTI FRUTI GRANUEIROS

MATERIAL DE CONSTRUÇZO

INFORMÁTICA

TELEFONIA

VESTUÁRIO

PET SHOP

PRODUTO DE LIMPEZA

VARIEDADES

ADEGA

HORTI FRUTI GRANUEIROS

CAL, AREIA

MATERIAL DE CONSTRUÇĀO

ARMARINHO

FARMACIA

VESTUÁRIO

PET SHOP

MERCEARIA

PADARIA

MATERIAL ELÉTRTCO

MATERLAL DE CONSTRUÇĀO

TELEFONIA

MÓVEIS

VESTUÁRIO

SUPERMERCADO

MERCEARIA

VARIEDADES

PADARIA

AÇOUGUE

MATERIAL DE CONSTRUÇÃO

TELEFONIA

INSTRUMENTOS MUSICAIS

FARMÁCIA

COSMÉticos

VESTUÁRIO

CALCCADOS

FLORICULTURA

PET SHOP

CASA DO NORTE

SUPERMEACADO
LOGRADOURO

AV.ROTARY(ANTONIO/DIADEMA/SERRARIA)

AV.ROTARY(ANTONIO/DIADEMA/SERRARIA)

AV.ROTARY(ANTONIO/DIADEMA/SERRARIA)

AV.ROTARY(ANTONIO/DIADEMA/SERRARIA)

AV.ROTARY(ANTONIO/DLADEMA/SERRARIA)

AV.ROTARYIANTONIO/DIADEMA/SERRARIA)

AV.ROTARY(LEON/OLAOEMA/SERRARIA)

R.JOSÉBONIFACIO(DIADEMA/SERRARIA)

R.JOSÉBONIFÁCIO(DIADEMAVSERRARIA)

R.JOSÉBONIFACIO(DIADEMA/SERRARIA)

R.JOSÉBONIFACIO(DIADEMA/SERRARIA)

R.JOSÉBONIFÁCIO(DLADEMA/SERRARLA)

R.JOSÉBONIFÁCIO(DIADEMA/SERRARIA)

R.JOSÉBONIFACIO(DIADEMA/SERRARIA)

R.JOSÉBONIFACIO(DIADEMN/SERRARIA)

R.JOSÉBONIFACIO(DLADEMA/SERRARIA)

R.JOSÉBONIFÁCIO\{DIADEMA/SERRARIA)

R.JOSÉBONIFACIO(DIADEMA/SERRARIA)

R.JOSÉBONIFACIOODIADEMA/SERRARIA]

R.JOSÉBONIFÁCIO(DLADEMA/SERRARIA)

R.UCO MAIA(DLADEMAVSERRARIA)

R.LICO MAIA(DIADEMAVSERRARIA)

R.LICO MALA(DIADEMA/SERRARIA)

R.LICO MAIA(DIADEMA/SERRARIA)

R.LICO MAIA(DIADEMA/SERRARIA)

R.LICO MAIA(DLADEMA/SERRARIA)

R.LICO MAIA(DIADEMA/SERRARIA)

R. LICO MALA(DIADEMA/SERRARLA)

R.LICO MAIA(DIADEMA/SERRARIA)

R.LICO MAIA(DIADEMA/SERRARIA)

R.LICO MAIA(DIADEMA/SERRARIA)

R.LICO MAIA(DIADEMA/SERRARLA)

R. LICO MAIA(DLADEMA/SERRARLA)

R.LICO MAIA(DIADEMA/SERRARIA)

R.LICO MALA(DIADEMA/SERRARIA)

R. LICO MAIA(DLADEMA/SERRARIA)

R. LICO MAIAIALVARES/DIADEMA/SERRARIA)

R.LICO MAIA(ALVARES/DIADEMA/SERRARIA)

R.LICO MALA(ALVARES/DIADEMA/SERRARIA)

R.LICO MAIAIALVARES/DIADEMA/SERRARIA

R.LICO MAIA(ALVARES/DIADEMA/SERRARIA)

R.LICO MAIA(ALVARES/DIADEMA/SERRARIA)

R.LICO MALA(ALVARES/DIADEMA/SERRARIA)

R. LICO MAIA(ALVARES/DIADEMA/SERRARIA)

R.LICO MAIA(ALVARES/DIADEMA/SERRARIA)

R.LICO MAIA/ALLARES/DIADEMA/SERRAREA)

AV.NOSSA SENHORA DOS NAVEGANTES(ANDRE/OLADEMA/ELD)

AV.NOSSA SENHORA DOS NAVEGANTES(ANDRE/DIADEMAVELD)

AV.NOSSA SENHORA DOS NAVEGANTES(ANDRE/DIADEMAVELD)

AV.NOSSA SENHORA DOS NAVEGANTESYANDRE/DIADEMA/ELD)

AV.NOSSA SENHORA DOS NAVEGANTES(ANDRE/DIADEMAVELD)

AV.NOSSA SENHORA DOS NAVEGANTES(ANDRE/DIADEMAVELD)

AV.NOSSA SENHORA DOS NAVEGANTES(ANDRE/DLADEMAVELD)

AV.NOSSA SENHORA DOS NAVEGANTES(ANDRE/DLADEMAVELD)

AV.NOSSA SENHORA DOS NAVEGANTES(ANDRE/DIAOEMA/ELD)

AV.NOSSA SENHORA DOS NAVEGANTES(MANUEL/DIAD/ELD)

AV.NOSSA SENHORA DOS NAVEGANTES(MANUEL/DIAD/ELD)

AV.NOSSA SENHORA DOS NAVEGANTES(MANUEUDIAD/ELD)

AV.NOSSA SENHORA DOS NAVEGANTES(MANUEL/DIAD/ELD)

AV.NOSSA SENHORA DOS NAVEGANTES(MANUELUDIAD/ELD)

AV.NOSSA SENHORA DOS NAVEGANTES(MANUEL/DIAD/ELD)

AV.NOSSA SENHORA DOS MAVEGANTES(MANUEUDLAD/ELD)

AV.NOSSA SENHORA DOS NAVEGANTES(JOAO/DIAD/ELD)

AV.NOSSA SENHORA DOS NAVEGANTES(JOAO/DIAD/ELD)

AV.NOSSA SENHORA DOS NAVEGANTES(JOZO/DIAD/ELD)

AV.NOSSA SENHORA DOS NAVEGANTES(JOAO/DIAD/ELD)

AV.NOSSA SENHORA DOS NAVEGANTES(JOAO/DIAD/ELD)

AV.NOSSA SENHORA DOS NAVEGANTES(JOAO/DIAD/EL)

AV.NOSSA SENHORA DOS NAVEGANTESUOAZO/DIAD/ELD)

AV.NOSSA SENHORA DOS NAVEGANTES(JOAO/DIAD/ELD)

AV.NOSSA SENHORA DOS NAVEGANTES(JOAO/DIAD/ELD)

AV.NOSSA SENHORA DOS NAVEGANTES(JOAO/DIAD/ELD)

AV.NOSSA SENHORA DOS NAVEGANTES(JOAO/DIAD/ELD)

AV.NOSSA SENHORA DOS NAVEGANTES(JOAO/DIAD/ELD)

AV.NOSSA SENHORA DOS NAVEGANTES(JOÃO/DIAD/ELD)

AV.NOSSA SENHORA DOS NAVEGANTES(JOÄO/DIAD/ELD)

AV.NOSSA SENHORA DOS NAVEGANTES/IOXO/DIAD/ELD)

AV.NOSSA SENHORA DOS NAVEGANTES(FREI/DIAD/ELD)

\begin{tabular}{|c|c|c|}
\hline COJAS & MORAN'SI & GETIS ORD GI* \\
\hline 1 & 0,189 & $-0,311$ \\
\hline 1 & 0,215 & $-0,467$ \\
\hline 1 & 0,191 & 0,334 \\
\hline 1 & 0,223 & $-0,690$ \\
\hline 2 & $-0,062$ & $-0,307$ \\
\hline 1 & 0,231 & $-0,690$ \\
\hline 1 & 0,260 & $-0,288$ \\
\hline 1 & 0,152 & $-0,311$ \\
\hline 3 & $-0,273$ & $-0,201$ \\
\hline 1 & 0,145 & $-0,454$ \\
\hline 1 & 0,136 & $-0,345$ \\
\hline 1 & 0,149 & $-0,318$ \\
\hline 1 & 0,159 & $-0,336$ \\
\hline 1 & 0,142 & 1,765 \\
\hline 1 & 0,111 & $-0,288$ \\
\hline 1 & 0,151 & $-0,355$ \\
\hline 1 & 0,120 & $-0,334$ \\
\hline 1 & 0,083 & 0,099 \\
\hline 2 & $-0,044$ & $-0,519$ \\
\hline 1 & 0,146 & $-0,448$ \\
\hline 2 & $-0,041$ & $-0,501$ \\
\hline 1 & 0,109 & $-0,310$ \\
\hline 2 & $-0,042$ & 0,083 \\
\hline 1 & 0,133 & $-0,024$ \\
\hline 1 & 0,138 & $-0,453$ \\
\hline 1 & 0,138 & $-0,467$ \\
\hline 1 & 0,121 & $-0,621$ \\
\hline 2 & $-0,033$ & $-0,521$ \\
\hline 1 & 0,057 & $-0,382$ \\
\hline 2 & $-0,017$ & $-0,363$ \\
\hline 1 & 0,051 & $-0,372$ \\
\hline 1 & 0,004 & $-0,155$ \\
\hline 4 & $-0,377$ & $-0,664$ \\
\hline 2 & $-0,019$ & $-0,497$ \\
\hline 1 & 0,095 & $-0,553$ \\
\hline 1 & 0,135 & $-0,492$ \\
\hline 1 & 0,115 & $-0,593$ \\
\hline 2 & $-0,042$ & $-0,753$ \\
\hline 1 & 0,133 & $-0,632$ \\
\hline 1 & 0,153 & $-0,685$ \\
\hline 1 & 0,152 & $-0,664$ \\
\hline 1 & 0,137 & $-0,603$ \\
\hline 1 & 0,086 & $-0,382$ \\
\hline 3 & $-0,247$ & $-0,678$ \\
\hline 1 & 0,064 & $-0,292$ \\
\hline 1 & 0,107 & $-0,471$ \\
\hline 1 & 0,222 & 0,180 \\
\hline 1 & 0,250 & $-0,278$ \\
\hline 1 & 0,237 & $-0,572$ \\
\hline 1 & 0,232 & $-0,428$ \\
\hline 1 & 0,233 & $-0,246$ \\
\hline 1 & 0,243 & $-0,411$ \\
\hline 1 & 0,237 & $-0,358$ \\
\hline 1 & 0,246 & $-0,395$ \\
\hline 1 & 0,209 & $-0,188$ \\
\hline 1 & 0,188 & 0,094 \\
\hline 1 & 0,178 & $-0,178$ \\
\hline 1 & 0,169 & 0,257 \\
\hline 1 & 0,166 & 1,081 \\
\hline 1 & 0,163 & 1,178 \\
\hline 1 & 0,135 & 0,535 \\
\hline 2 & $-0,049$ & 0,185 \\
\hline 1 & 0,169 & $-0,079$ \\
\hline 1 & 0,120 & 2,414 \\
\hline 3 & $-0,252$ & $-0,034$ \\
\hline 1 & 0,069 & $-0,073$ \\
\hline 2 & $-0,030$ & $-0,319$ \\
\hline 1 & 0,126 & $-0,307$ \\
\hline 1 & 0,141 & $-0,463$ \\
\hline 1 & 0,120 & $-0,458$ \\
\hline 2 & $-0,031$ & $-0,513$ \\
\hline 1 & 0,048 & $-0,305$ \\
\hline 3 & $-0,168$ & $-0,420$ \\
\hline 2 & $-0,006$ & $-0,357$ \\
\hline 2 & $-0,028$ & $-0,272$ \\
\hline 1 & 0,092 & $-0,330$ \\
\hline 1 & 0,066 & $-0,065$ \\
\hline 2 & 0,002 & $-0,335$ \\
\hline
\end{tabular}


Aplindlce D - RESULTADO DAS ESTATISTICAS LOCAIS MORAN'S I E GETSS ORD GF*

RAMO DE ATIVIDADE

VARIEDADES

DOCES E BOMBONS

MATERIAL DE CONSTRUÇÃO

MÓvEIS

FARMÁCIA

COSMÉTICOS

VESTUÁRIO

BUOUTERIA

PET SHOP

CASAS DO NORTE

PADARIA

MATERIAL DE CONSTRUČ̃o

MATERIAL DE CONSTRUÇĀO

PET SHOP

FLORICULTURA

VARIEDADES

MERCEARIA

CASA DO NORTE

PET SHOP

RELOJOARIA

VARIEDADES

DOCES E BOMBONS

COSMÉTICOS

BAZAR

PRODUTOS DE LIMPEZA

HORTI FRUTI GRANUEIROS

VESTUÁRIO

DOCES, BOMBNS

MATERIAL DE CONSTRUÇÃO

CAL. E AREIA

COSMETICOS

DOCES E BOMBONS

PRODUTOS DE LIMPEZA

MERCEARIA

PADARIA

PADARIA

MERCEARIA

AÇOUGUE

FARMACIA

PET SHOP

VARIEDADES

VESTUÁRIO

HORTI FRUTI GRANUEIROS

ADEGA

PADARIA

MERCEARIA

MERCEARIA

PET SHOP

PRODUTOS DE LIMPEZA

PADARIA

BAZAR

PRODUTOS DE LIMPEZA

SUPERMERCADO RICOY SABARA

SUPERMERCADO EXTRA INTERLAGOS

SUPERMERCADO CARREFOUR DIADEMA

MERCEARIA

DOCES E BOMBONS

PRODUTOS DE LIMPEZA
LOGRADOURO

AV.NOSSA SENHORA DOS NAVEGANTES(FREI/DIAD/ELD)

AV NOSSA SENHORA DOS NAVEGANTES/FREY/DIAD/EID)

AV.NOSSA SENHORA DOS NAVEGANTES(FREI/DIAD/ELD)

AV.NOSSA SENHORA DOS NAVEGANTES(FREI/DIAD/ELD)

AV.NOSSA SENHORA DOS NAVEGANTES(FREI/DIAD/ELD)

AV NOSSA SENHORA DOS NAVEGANTES(FREI/DIAD/ELD)

AV.NOSSA SENHORA DOS NAVEGANTES(FREI/DLAD/ELD)

AV.NOSSA SENHORA DOS NAVEGANTES(FFEI/DIAD/ELD)

AV.NOSSA SENHORA DOS NAVEGANTES(FREI/DLAD/ELD)

AV.NOSSA SENHORA DOS NAVEGANTES(FREI/DIAD/ELD)

AV.NOSSA SENHORA DOS NAVEGANTES(INDIANWDDIAD/ELD)

AV.NOSSA SENHORA DOS MAVEGANTES(INDIANAVDIAD/ELD)

AV.DAS PEROBAS(DIADEMA/ELDORADO)

AV.DAS PEROBAS(DLADEMAVELDORADO)

AV.DAS PEROBAS(DIADEMA/ELDORADO)

AV.DAS PEROBAS(DIADEMAVELDORADO)

AV.DAS PEROBAS(DIADEMAVELDORADO)

AV.CUPECE(LARGO DO IARDIM MIRIAM)

AV CUPECE (LARGO DO IARDIM MIRIAM)

AV.CUPECE(LARGO DO IARDIM MIRIAM)

AV.CUPECE(LARGO DO IARDIM MIRLAM)

AV.CUPECEILARGO DO JARDIM MIRIAM)

AV.CUPECE(LARGO DO IARDMM MIRIAM)

AV.CARDOSO DE MELO NETO(BAHIA)

AV.CARDOSO DE MELO NETO(BAHL)

AV.CARDOSO DE MELO NETO(BAHIA)

AV.CARDOSO DE MELO NETO(BAHLA)

AV.CARDOSO DE MELO NETO(CLUBE)

AV.CARDOSO DE MELO NETO(CLUBE)

AV.CARDOSO DE MELO NETO(ENOUT)

AV.CARDOSO DE MELO NETO(ENOUT)

R.APLARIS

R.APLARIS

R.GANDARA DE OLIVAIS

R.EDUARDO CINEUU

AV.PAPA GREGORIO MAGNO

R.BEM AVENTURADO ALBERICO CRESCITELL

R. BEM AVENTURADO ALBERICO CRESCITELL

R. BEM AVENTURADO ALBERICO CRESCITELU

R. BEM AVENTURADO ALBERICO CRESCITELL

R. BEM AVENTURADO ALBERICO CRESCITELL

R. BEM AVENTURADO ALBERICO CRESCTELU

R. BEM AVENTURADO ALBERHCO CRESCITELU

R.BEM AVENTURADO ALBERICO CRESCITELI

R.PADRE NATAL PIGATO

R.PADRE MATAL PIGATO

R.ALICE DOS SANTOS PEIXE

R.ALICE DOS SANTOS PEIX

R.JOSE MAURO DE MENDONÇA

R,FARIAS BHLLINGS

AV.ALDA

AV.ALDA

AV.NOSSA SENHORA DO SABARA

AV.INTERLAGOS

AV.SENADOR VITORINO FREIRE

R. DAVIDE PEREZ

R.DAVDE PEREZ

R.DAVIDE PEREZ

\begin{tabular}{|c|c|c|}
\hline LOJAS & MORAN'SI & GE IIS ORD Gi* \\
\hline 3 & $-0,089$ & $-0,359$ \\
\hline 2 & $-0,005$ & $-0,342$ \\
\hline 1 & 0,053 & $-0,341$ \\
\hline 1 & 0,068 & $-0,427$ \\
\hline 2 & $-0,016$ & $-0,500$ \\
\hline 2 & $-0,001$ & $-0,276$ \\
\hline 4 & $-0,345$ & $-0,608$ \\
\hline 1 & 0,014 & $-0,221$ \\
\hline 2 & $-0,024$ & $-0,553$ \\
\hline 1 & 0,071 & $-0,384$ \\
\hline 1 & 0,086 & $-0,498$ \\
\hline 2 & $-0,035$ & $-0,749$ \\
\hline 2 & $-0,093$ & 0,029 \\
\hline 1 & 0,319 & $-0,274$ \\
\hline 1 & 0,257 & $-0,752$ \\
\hline 1 & 0,187 & $-0,387$ \\
\hline 3 & $-0,456$ & $-0,497$ \\
\hline 1 & $-0,058$ & $-0,229$ \\
\hline 1 & $-0,063$ & 0,330 \\
\hline 1 & $-0,031$ & $-0,058$ \\
\hline 2 & 0,003 & $-0,537$ \\
\hline 2 & 0,005 & 0,273 \\
\hline 1 & 0,000 & $-0,049$ \\
\hline 1 & 0,529 & $-0,418$ \\
\hline 1 & 0,467 & $-1,207$ \\
\hline 1 & 0,437 & $-0,589$ \\
\hline 1 & 0,361 & $-0,585$ \\
\hline 1 & 0,621 & $-0,651$ \\
\hline 1 & 0,432 & $-0,234$ \\
\hline 1 & 0,528 & $-0,657$ \\
\hline 1 & 0,561 & $-0,768$ \\
\hline 1 & 0,527 & $-0,829$ \\
\hline 1 & 0,506 & $-0,379$ \\
\hline 1 & 0,286 & $-0,728$ \\
\hline 1 & 0,673 & $-0,472$ \\
\hline 1 & 0,285 & $-0,272$ \\
\hline 1 & 0,153 & $-0,401$ \\
\hline 1 & 0,139 & $-0,375$ \\
\hline 1 & 0,153 & $-0,376$ \\
\hline 1 & 0,138 & 0,400 \\
\hline 1 & 0,357 & 0,467 \\
\hline 3 & $-0,703$ & 0,787 \\
\hline 1 & 0,337 & $-0,331$ \\
\hline 1 & 0,353 & $-0,359$ \\
\hline 1 & 0,308 & $-0,839$ \\
\hline 1 & 0,309 & $-0,968$ \\
\hline 1 & 0,473 & $-1,140$ \\
\hline 1 & 0,519 & $-0,335$ \\
\hline 1 & 0,375 & $-0,591$ \\
\hline 1 & 0,556 & 0,634 \\
\hline 1 & 0,185 & 0,003 \\
\hline 1 & 0,227 & $-0,104$ \\
\hline 1 & 0,032 & 1,836 \\
\hline 1 & $-0,695$ & 1,574 \\
\hline 1 & 0,456 & $-0,909$ \\
\hline 1 & 0,289 & $-0,835$ \\
\hline 1 & 0,346 & $-0,791$ \\
\hline 1 & 0,313 & $-0,638$ \\
\hline
\end{tabular}


Apêndice E 
Apendice E - Códiges das atividades do comb́rcio

Rede social CNAE-2.0 Descrição

CA1004A C2-4721101 Padaria e confeitarla com predominância de produçăo própria

CA1011A C2-4721 101 Padaria e confeltarla com predominancta de produça propria

CA1016A C2-4721101 Padaria e confeltaria com predominăncia de produçăo própria

CA1019A C2-4721101 Padarla e confeitaria com predominância de produçấo própria

CA1020B C2-4721101 Padaria e confettaria com predorninância de produçấo propria

CA1027A C2-4721101 Padaria e confeitaria com predominância de produçăo própria

CA1029A C2-4721101 Padaria e conteltaria com predominâncla de produç̧ăo própria

CA1029C C2-4721101 Padaria e confettaria com predominância de produçaso própria

CA1029G C2-4721 101 Padaria e confeitaria com predorninâncta de produçăo própria

CA1031A C2-4721101 Padaria e confeitaria com predominância de produçáo próprta

CA1032A C2-4721101 Padaria e confeitaria com predominância de produçăo própria

CA1034A C2-4721101 Padaria e confeitaria com predominância de produçáo própria

CA1039A C2-4721101 Padaria e confeitaria com predominància de produçáo própria

CA1043A C2-4721101 Padaria e confeitaria com predorninância de produç̧̌̉o própria

CA1046A C2-4721101 Padaria e confeitaria com predominância de produçăo própria

CA1048A C2-4721101 Padaria e confeitaria com predominåncia de produçało própria

CA1048A C2-4721101 Padaria e confeitaria com predominåncia de produçá própria

CA1053A C2-4721101 Padaria e confeitaria com predominancia de produçato própria

CA1064A C2-4721101 Padaria e confeitaria com predominăncia de produçáo própria

CA1066A C2-4721101 Padaria e confeitaría com predorninância de produçăto própria

CA1076B C2-4721101 Padaria e confeitaria com predominância de produçąo própria

CA10778 C2-4721101 Padaria e confeitaria com predorninância de produçắo propria

CA1082A C2-4721101 Padaria e confeitaria com predominancia de produçăo própria

CA1089A C2-4721101 Padarie e confétaria com predominância de produçáo própria

CA1092A C2-4721101 Padaria e confeitaria com predorninância de produçăo própria

CA1093A C2-4721101 Padaria e confeltaria com predorninância de produçá própria

CA1096A C2-4721101 Padaria e confeitaria com predominância de produçáo própria

CA1098A C2-4721101 Padaria e confétaria com predominåncia de produçáo própria

CA1100A C2-4721101 Padaria e confeitaria com predominância de produçăo própria

CA1105A C2-4721101 Padaria e confeitaria com predominåncia de produçáo próprta

CA1106A C2-4721101 Padaria e confeitaria com predominância de produçăo própria

CA1107A C2-4721101 Padaria e confeitaria com predominância de produçăo própria

CA1113A C2-4721101 Padaria e confeitaria com predornináncia de produçáo propria

CA1114A C2-4721101 Padaria e confeltaria com predominancla de produçato própria

CA1116A C2-4721101 Padaria e conteltaria com predominancia de produçáco própria

CA1119A C2-4721101 Padaria e confeltaria com predominåncia de produçá própria

CA1120A C2-4721101 Pactaria e conteitaria com predominåncla de produçáo própria

CA1121A C2-4721101 Padaria e confeitaria com predominância de produçato própria

CA1122A C2-4721101 Pactaria e confeitaria com predominância de producto própria

CA1124A C2-4721101 Padaria e confeitaria com predominância de produçao própria

CA1125A C2-4721101 Padaria e confeitaria com predominância de producto propria

CA1129A C2-4721101 Padaria e confeitaria com predominancia de producto própria

CA1132A C2-4721101 Padarla e confeitaria com predominancia de producto própria

CALULA C2-4721101 Padaria e confeittaria com predominalincia de produçato propria

CAINAVA C2-4721101 Padaria e confeitaria com predominância de produçáo própria

CA1SELA C2-4721101 Padarta e confeitaria com predominåncia de produçáo própria

CA2002N C2-4712100 Comércio varejista de mercadorias ern geral, com predominância de produtos allimenticlos - minłmercados, mercearlas e armazénes

CA2007A C2 -4712100 Combrcio varejista de mercadorias em geral, com predominância de produtos allmenticios - minimercados, mercearias e armazéns

CA2008A C2-4712100 Comércio varejista de mercadorias em geral, com predominăncia de produtos alimenticios - minimercados, mercearias e ammazéne

CA2009A C2-4712100 Comércio varejista de mercadorias em geral, com predominåncta de produtos alimenticios - minimercados, mercearlas e armazéns

CA2010A C2-4712100 Comércio vareiista de mercadorias em gerzi, com predominância de produtos allmenticios - minimercados, merceartas e armaźn

CA2011A C2-4712100 Comércio varejista de mencadorias em geral, com predominåncia de produtos alimenticios - minimercados, mercearias e armezéns

CA2015A C2-4712100 Comnércio varejista de mercadorias em gera, com predominalncia de produtos alimenticios - minimercados, mercearias e ammazéns

CA2015N C2-4712100 Comércio varejista de mercadorias em gera, com predominância de produtos alimenticios - minimercados, mercearias e armazéns

CA2016N C2-4712100 Comércio varejista de mercadorias em geral, com predominância de produtos alimenticios - minimercados, merceerias e armazéns

CA2017N C2-4712100 Comércio varelista de mercadorias em geral, com predominancia de produtos alimenticios - minimercados, mercearias $\theta$ armazenn

CA2019N C2-4712100 Comércio varejista de mercadorias em geral, com predominấncia de produtos alimentícios - minimercados, mercearias e armazéns

CA2020N C2-4712100 Comercio varejista de mercadorias em geral, com predomináncla de produtos alimenticios - minimercados, mercearias e armazéns

CA2024N C2-4712100 Comércio varejista de mercadorlas em geral, com predominancia de produtos alimenticios - minimercados, mercearias e armazéns

CA2027A C2-4712100 Comércio varejista de mercadorias em geral, com predominâncla de produtos atimenticios - minimercados, mercearias e armazéns

CA2027 N C2-4712100 Comércio varejista de mercadorlas em geral, com predominatncia de produtos alimenticios - minimercados, merceerias e armazénes

CA2029A C2-4712100 Comércio varejista de mercadorias em geral, com predominâncla de produtos alimenticios - minimercados, mercearias e armazéne

CA2029C C2-4712100 Comércio varejista de mercadorias em geral, com predominância de produtos alimenticios - minimercados, mercearies e armezéns

CA2029N C2-4712100 Comérclo varejista de mercadorias em geral, com predominância de produtos alimenticios - minimercados, mercearias e armazéns

CA2035A C2-4712100 Comercio varejista de mercadorlas em geral, com predominância de produtos alimenticios - minimercados, merceartas e armazéns

CA2038A C2-4712100 Comércio varejista de mercadorias em geral, com precominancia de produtos alimenticios - minimercados, mercoarias e armazéns

CA2043A C2-4712400 Comércio varejista de mercadorias en geral, com predominância de produtos alimenticios - minimercados, mercearias e armazźns

CA2049A C2-4712100 Comercio varejista de mercadorias em gera, com predominância de produtos alimenticios - minimercados, mercearias e armezens

CA2049A C2-4712100 Comércio varejista de mercadorias em geral, com predominância de produtos alimenticios - minimercados, mercearias e armazéns

CA2054A C2-4712100 Comércio varejista de mercadorias em geral, com predominăncia de produtos alimenticios - minimercados, mercearias e armazéns

CA2057A C2-4712100 Comércio varejista de mercadorias em geral, com predominăncia de produtos alimenticios - minimercados, mercearias e armazéns

CA2058A C2-4712100 Connércio varejista de mercadorias em gerad, com predominåncia de produtos alirnentícios - minimercados, mercearias e armazéns

CA2064G C2-4712100 Cọnércio varejista de mercadorias em geral, com predominância de produtos alimentícios - minimercados, mercearias e armaźñns

CA2064N C2-4712100 Comérclo varejista de mercadorlas em geral, com predominância de produtos alimenticios - minimercados, mercearias e armaźńs

CA2066A C2-4712100 Comercio varejista de mercadorias em geral, com predominancia de produtos alimenticios - minimercados, mercearias e armazéns 
Apindkse E - Códiges das attuldades do comircio

CA2066N C2-4712100 Comércio varejista de mercadories em geral, com predominância de produtos alimenticios - minimercados, mercearies e armazéns CA2067A C2-4712100 Combrcio varejista de mercadortas em geral, com predominancta de produtos afimenticios - minimercados, mercearias e armezéns CA2069A C2-4712100 Comércio varejista de mercadoxtas em geral, com predominância che produtos alimenticios - minimercados, mercearias a amazéns CA2069A C2-4712100 Connércio varejista de mercadorias em geral, com predorninâncla de produtos alimenticios - minimercedos, mercearies e ammezéns CA2080A C2-4712100 Comércio varejesta de mercadortas em geral, com predominancia de produtos alimenticios - minimercados, mercearias e armaźrna CA2089A C2-4712100 Comércio varejista de mercadorias en geral, com predominância de produtos atimenticios - minimercados, mercearias e armazéns CA2091A C2-4712100 Comércio varejista de mercadorias em geral, com predominância de produtos alimentictos - minitmercados, mercearlas e armazéns CA2096A C2-4712100 Comércio varejista de mercadorias em geral, com predominância de produtos alimenticios - minimercados, merceartas e ournezíns CA2096N C2-4712:00 Comnércio varejista de mercadorias em geral, com predominåncia de produtos alimenticios - minirnercacos, mercearias e ammazéns CA2100A C2-4712100 Comércio varejista de mercadorias en geral, com predominancla de produtos alimenticios - minimercados, merceerias e armezéns CA2100G C2-4712100 Comércio varejista de mercadorias em geral, com predomináncia de produtos alisnenticios - minimercados, mercearias e armazzéns CA2100N C2-4712100 Comércio varejista de mercadorias em geral, com predominancia de produtos alimenticios - minimercados, mercearias e armazéns CA2106A C2-4712100 Combrcio varejlata de mercedorlas em geral, com predominância de produtos alimentícios - minimercados, mercearias e armazéns CA2107A C2-4712100 Comércio varejista de mercadorias em geral, com predomináncia de produtos alimenticios - minimercados, mercesias a arnazins CA2117A C2-4712100 Comercio varejista de mercadorias em geral, com predominância de produtos alimentícios - minimercados, mercearias e armazéns CA2117C C2-4712100 Comércio varejista de mercadorias em gerat, com predominăncia de produtos alimentícios - minimercados, mercearlas e armezzéns CA2117N C2-4712100 Comsrcio varejista de mercadorlas em geral, com predominâncla de produtos atimenticios - minimercados, mercearias e armazéns CA2118A C2-4712100 Comercio varejista de mercadorias em geral, com predominância de produtos alimenticios - minimercados, mercearias e armazins CA2119A C2-4712100 Comércio varejista de mercadorias em geral, com predorninancia de produtos alimentícios - minimercados, mercearias e armaźńs CA2122N C2-4712100 Comércio varejista de mercadorias en geral, com predominância de produtos alimenticios - minimercados, mercearias e armazéns CA2126B C2-4712100 Comércio varejista de mercadorias em geral, com predominância de produtos altmenticios - minimercados, mercearias e armazéns CA2129A C2-4712100 Comércio varejista de mercadories em geral, com predominância de produtos alimenticios - minimercados, mercearies e ammazéns CA2D1AA C2-4712100 Comérclo varejista de mercadorias em geral, com predominancia de produtos alimenticios - minimercados, mercearias e armaźrns CA2DIAG C2-4712100 Comércio varejista de mercadories em geral, com predorninatncia de produtos alimenticios - minimercados, mercearias a amaźn CA2DIAN C2-4712100 Comércio varejista de mercadorias em geral, com predominância de produtos alimentícios - minimercados, mercencias a armazáns CA2JMIN C2-4712100 Comercio varejista de mercadorias em gera, com predominåncia de produtos alimenticios - minlmercados, mercearias e armazins CA2JULN C2-4712100 Comércio varejista de mercadorias em geral, com predominância de produtos alimenticios - minimercados, mercearias e armazbnes CA2L13N C2-4712100 Cornércio varejista de mercadorias em geral, com predominância de produtos alimentícios - minimercacos, mercearias e armezéns CA2LUSA C2-4712100 Comércio varejista de mercadorias en geral, com predominancla de produtos allmenticios - minimercados, mercearias e armezíns

CA2NAVG C2-4712900 Comércio varejista de mercadorias em geral, com predominância de produtos alimenticios - minimercados, mercearies $\theta$ armazéns

CA2NAVN C2-4712100 Comércio varejista de mercadorias en geral, com predominância de produtos alimenticios - minimercados, mercearias e armazéns CA2SABN C2-4712100 Comércio varejista de mercadorias en geral, com prodomináncia de produtos alimenticios - minimercados, mercearias e armazéns CA2SERN C2-4712100 Comércio varejista de mencadorias em geral, com predominåncia de produtos alimenticios - minimercados, mercearias a amrazéns CA2SIRN C2-4712100 Comércio varejista de mercadorias em geral, com predoninância de produtos alimenticios - minimercados, mercearias e armazéns CA2YERN C2-4712100 Comercio varejista de mercadorias en geral, com predominăncia de produtos alimenticios - minlmercados, mercearias e armazérn CB2L13A

CC3BRZA

CCBCENA

CCBDIAA

CCBINTA

CCBIPAA

CC3L13A

CCBNAVA

CC3SABA

CCISAUA

CE3DIAA

CESINTA C2-4781400 Comércio varejista de artigos do vestuário e acessórios

C2-4755503 Comercio varejista de artigos de cama, mesa e banho

C2-4755503 Comercio varejista de artigos de cama, mesa e banhe

C2-4755503 Comercio varejista de artigos de cama, mesa e banho C2-4755503 Comercio varefista de artigos de cama, mese e banho C2-4755503 Comercio varejista de artigos de cama, mesa e banho C2-4755503 Comercio varejista de artigos de cama, mesa e banho C2-4755503 Comercio varejista de artigos de cama, mesa e banho C2-4755503 Comercio varejista de artipos de cama, mesa e banho C2-4755503 Comercio varejista de artigos de cama, mesa o banho C2-4753900 Comérclo varejista especializado de eletrodomesticos e equipamentos de áudio e vídeo C2-4753900 Comércio varejista especializado de eletrodomésticoss e equipamentos de áudio video C2-4753900 Comércio varejista especializado de eletrodomésticos e equipamentos de áudio e vídeo C2-4753900 Combrcio varejista espectalizado de eletrodomesticos a equipamentos de áudio e video C2-4753900 Comércio varejksta especializado de eletrodomestlcos e equipamentos de áucio e vídeo C2-4753900 Comércio varejista especializado de eletrodomésticos e equipamentos de áudio e vídeo C2-4771701 Coméncio varejista de produtos farmactuticos, sem manipulaça de fómulas C2-4771701 Comércio varejtsta de produtos farmaceuticos, som manipulacho de fórmulas C2-4771701 Comércio varejista de produtos farmactuticos, sem manipulaçào de fórmulas C2-4771701 Comércio varejista de produtos farmacêuticos, sem manipulaça de fómulas C2-4771701 Comércio varejista de produtos farmacésticos, sem manipulaça de formulas C2-4771701 Comércio varejista de produtos tarmacêuticos, sem manipulaçbo de fórmulas C2-4771701 Comércio varejista de produtos farmacéuticos, sem manipulaça de fómmilas C2-4771701 Comércio varejista de produtos farmacetuticos, sern manipulaçáto de formulas C2-4771701 Comnércio varejista de produtos farmaciuticos, sem maniptlaçto de fórmulas C2 4771701 Comércto varejista de produtos farmaceuticos, sem manipulaçato de fómulas C2-4771701 Comercio varejista de produtos farmactuticos, sem manipulaçao de fórmulas C2-4771701 Comércio varejista de produtos farmactuticos, sern manipulaçato de fórmulas C2-4771701 Comércio varejigta de produtos farmaçuticos, sem manipulaçà de fórmulas C2-4771701 Comércio varejiata de produtos farmactuticos, sem manipulaço de formulas C2-477170i Cornércio varejista de produlos farmacêuticos, sem manlpulaçầo de fórmulas C2-4771701 Combrcio varejista de produtos farmectuticos, sem manipulaçăo de fómulas C2-4771701 Comércio varejista de produtos farmactuticos, sem manipulaçá de fórmulas C2-477170 Combrcio varejista de produtos farmacéticos, sem manipulaçáo de fórmulas C2-4771701 Comércio varejista de produtos farmaceuticos, sem manipulaçato de fórmulas C2-4771701 Comércto varejista de produtos farmacêtuticos, sem manipulaçấ de fórmulas C2-4771701 Comércio varejista de produtos farmactuticos, sem manipulaçáo de fómulas C2-4771701 Comẹrclo varejista de produtos farmactuticos, sem manipulaça de fórmulas C2-4789099 Comércio varejista de outros produtos nAo especificados anteriormente C2-4744099 Comércio varejista de materiais de construcha em geral 


\begin{abstract}
Apindicen E - Codizos des attridades do comirclo
Rede social CNAE-2.0 Deserição

CM2011A C2-4744099 Comércio varejista de materiais de construço em geral

CM2015A C2-4744099 Combrcto varejista de materiais de construça om geral

CM2016A C2\$474099 Combrcio varejista de makeriais de construpto en geral

CM2017A C2-4744099 Comércio varejlsta de materlais de construça em geral

CM2027A C2-4744099 Comercto varejista de materiais de construç6 em geral

CM2029C C2-4744099 Comérclo varejista de matoriais de construçAo em genal

CM2032A C2-4744099 Comércio varejeta de materials de construça em geral

CM2033A C2-4744099 Confircio varejlota de materiais de constructo em geral

CM2034A C2-4744099 Combrcio varejista de materiais de construça em geral

CM2043A C2-4744099 Comercio varejista de materials de construgato em geral

CM2053A C2-4744099 Comerclo varejieta de materiais de conetrugato em geral

CM2056A C2-4744099 Comerclo varejista de materieis de construçio em geral

CM2057A C2-4744009 Comercio varejista de materials de constructio em geral

CM2064A C2-4744099 Comércio varefista de matertais de construçato en geral

CM2065A C2-4744098 Comercio varejista de materiais de constructio em geral

CM2066A C2-4744099 Comerclo varejista de materiais de construçăo em gerat

CM2069A C2-4744099 Combrcio varefista de materials de constructo em geral

CM2080A C2-4744099 Comércio varejista de materiais de construçato em geral

CM2082A C2-4744099 Comercio varejista de materials de construçato em geras

CM2089A C2-4744099 Combrcio varejista de materlais do construçato em geral

CM2096A C2-4744099 Comércio varejista de materlais de construpto en gergel

CM2096C C2-4744099 Comérclo varejista de materiala de construçaso em geral

CM2100A C2-4744099 Coméncio varejista de materiais de constructio em geral

CM2105A C2-4744099 Combrcio varejista de materiais de construça em geral

CM2107A C2-4744099 Comercio varejista de materiais de construçato em geral CM2112A C2-4744099 Comercio varejista de materlais de conetruça em gera| CM2117A C2-4744099 Comercio varejista de matertais de constructáo em geral

CM2123A C2-4744099 Comércio varejista de materiais de construçalo en geral

CM2129A C2-4744099 Combrcio varejista de materiais de constructo em geral

CM2132A C2-4744099 Comércio varejista de materiais de construçáo em geral

CM2CIDA C2-4744099 Comercio varejista de materiais de constructo en geral

CM2DIAA C2-4744089 Comércio varejista de materiais de constructo en geral

CM2IMIA C2-4744099 Combrcio varejista de materiais de construçáo em geral

CM2JULA C2-4744099 Comércio varejista de matertais de construçáo en geral

CM2NAVA C2-4744009 Comércio varejista de materiais de constructo em geral

CM2RFUA C2-4744099 Comércio varejista de materiais de conetrugato em geral

CM2SABA C2-4744090 Comérclo varejista de materiais de construçăo em gerai

CM2SELA C2-4744090 Comércio varejista de materiais de construçato em geral

CM2SERA C2-4744099 Conercio varejesta de materiais de constructo em geral

CM2SJRA C2-4744099 Comércio varejata de materiais de construça en geral

CM2YERA C2-4744099 Combicio varejista de makeriais de construça em geral

CM2ZTUA C2-4744099 Comercio varejista de materiais de construçato em geral

CO2100A C2-4774100 Combrcio varejista de artigos de optica
\end{abstract}

CO2DIAA C2-4774100 Combrcio varejista de artigos de optica

CO2INTA C2-4774100 Comércio varejista de artigos de optica

CO2L13A C2-4774100 Comércio varejista de artigos de óptica

CO2SABA C2-4774100 Comérclo varejtsta de artigos de dptica

CO2SAUA C2-4774100 Comercio varejista de artigos de óptica

CO2YERA C2-4774100 Comercio varefista de artigos de óptica

CP2002A C2-4788004 Comércio varefista de animais vivos e de artigos e alimentos para anirnais de estimacato

CP2011A C2-4789004 Comércio varejista de animais vivos e de artigos e alimentos para animais de estimaçat

CP2016A C2-4789004 Comérclo varejista de animais vivos e de artigos e alimentos pern animaiz de estimach

CP2017A C2-4789004 Confricio varejista de animals vivos e de artigos e alimentos para antmais de estimacko

CP2027A C2-4789004 Comércio varejista de animais vivos a de artigos e alimentos para animais de estimaça

CP2029A C2-4789004 Comércio varejista de enimais vivos e de artigos e alimentos pera animais de estimacato

CP2064A C2-4789004 Comercio varejleta de animals vivos e de artigos e atimentos para animais de estmaça

CP2069A C2-4789004 Comércio varejista de animeis vivos e de artioos o alimentos para animais de estimacto

CP2080A C2-4789004 Combrcio verejista de animals vivos e de artigos e alimentos para animals de estimacto

CP2082A C2-4789004 Comb́rcio varejista de animais vivos e de artigos e alimentos para animais do estimaça

CP2096A C2-4789004 Comércio varejata de anirnais vivos e de artigos e alimentos para animais de estimaçáto

CP2100A C2-4789004 Combrcio varejista de animals vios a de artigos e allmentos para animais de estumacto

CP2107A C2-4789004 Comércio varejista de animais vivos o de artipos e alimentos para animais de wetimacho

CP2117A C2-4789004 Condrcio varejista de animais vivos e de artigos e alimentos para animais de estimactio

CP2132A C2-4789004 Comercio varejtata de animais vivos e de artigos e alimentos para animals de eatimaça

CP2AERA C2-4789004 Condercio varejtsta de animais vivos e de artigos e alimentos para animais de extimaça

CP2DiAA C2-4789004 Combrcio varejista de animais vivos e de artigos e allmentos para animaia de estimaça

CP2NAVA C2-4780004 Combrcio varejista de animais vivos e de artigos e allimentos para animais de estimeça

CP2NAVA C2-4789004 Conércio varejista de animais vivos e de artigos e alimentos para animais de estimacio

CP2RFUA C2-4789004 Comercio varejlsta de animais vivos e de artigos a elimentos para animais de estimaça

CP2SABA C2-4709004 Comércio varej|sta de animals vivos e de artigos e elimentos para animals de estimaça

CP2SERA C2-4789004 Comercio varejiste de animais vivos e de artigos a alimentos para animals de estimaçato

CR2BRZA

CR3100A

CR3CENA

C2-4781 400 Combrcio varejista de artigos do vestuario e acessórios

C2-4781400 Comercio varejista de artigos do veotudrio e acessórios

C2-4781400 Combrcio varejista de artigos do vestuário e acessórios 
Apindice E - Coeligon das attidades do comórcio

Rede social CNAE-2.0 Descriçăo

CR3DIAA C2-4781400 Comércio varejlsta de artigos do vestuário e acessórios

CRBINTA

C2-4781400 Comércio varejista de artigos do vesturio e acossórios

CR3L13A

CRBRETA

CRBSABA

CR3SAUA

CR3YERA

CS2002A

CS2016A

CS2029A

CS2064A

CS2096A

CS2100A

CS2112A

CS2DIAA

CSIJMIA

CSIULAA

CS2L13A

CS2NAVA

CS2SABA

CS2SERA

CS2SJRA

CS2YERA

CSZZTUA

CS3AERA

CSBBNAA

CS3DIAA

CSBDIAC

CSBGUAA

CSBINTA

CSIINTX C2-4781400 Comercio varejista de artigos do vestudio e acesssórios C2-4781400 Combrcio varejista de artigos do vestúrio e aceseórios C2-4781 400 Comercio varejista de artigos do vestuário $\theta$ acessórios C2-4781400 Comércio varejista de artigos do vestuário e acesabrios C2-4781400 Comércio varejilata de artigos do vestuário e aceasórtios C2-4781400 Comércio varejista de artigos do vestuario e acessórios

C2-4711302 Comércio varejista de mercadorias em geral, com predominância de produtos alimentícios - supermercados C2-4711302 Comércio varejista de mercadorias em geral, com predorninância de produtos alimenticios - supermercados C2-4711302 Comércio varejista de mercadorlas em geral, com predominåncta de produtos alimenticlos - supermercados C2-4711302 Comb́rcio varejista de mercadorias em geral, com predominância de produtos alimenticios - supermercados C2-4711302 Comércio varejilsta de mercadorias em geral, com predominancia de produtos alimenticios - supermercados C2-471 1302 Comércio varejista de mercadorias em geral, com predominancia de produtos alimentícios - supermercados C2-4711302 Comercio varejista de mercadorias em geral, com predominância de produtos alimentícios - supermercados C2-4711302 Comercio varejista de mercadorias em geral, com predominância de produtos alimenticios - supermercados C2-4711302 Comercio varejista de mercadorias em geral, com predominancia de produtos allimenticios - supermercadios C2-4711302 Comércio varejista de mercadorias em geral, com predominância de produtos alimentícios - supermercados C2-4711302 Comércio varejista de mercadorias em geral, com predorninância de produtos allmentícios - supermercados C2-4711302 Combrcio varefista de mercadorias em geral, com predominancia de produtos alimentícios - supermercados C2-4711302 Comércio varejista de mercadorias em geral, com predominancia de produtos alimenticios - supermercadios C2-4711302 Comércio varejista de mercadorias em geral, com predorninancia de produtos alimenticlos - supermercados C2-4711302 Conerclo varejista de mercadorias en geral, com predominancia de produtos alimentícios - supermercados C2-4711302 Comércio varejista de mercadories em geral, com predominancia de produtos alimenticios - supermercados C2-4711302 Comérclo varejista de mercedorias em geral, com predominância de produtos alimenticlos - supermercados C2-4711301 Comerclo varejista de mercadorias em geral, com predominancia de produtos alimenticios - hipermercados C2-4711301 Comércio varejista de mercadorias en geral, com predorninAncia de produtos alimenticios - hipermercados C2-4711301 Comércio varejista de mercadonias em geral, com predominâncta de produtos alimenticios - hipermercados C2-4711301 Comércio varejista de mercadorias em geral, com predominancia de produtos alimenticios - hipermercados C2-4711301 Comb́rcio varejista de mercadortas em geral, com predominancia de produtos alimenticios - hipermercados C2-4711301 Comercio varejista de mercadorias em geral, corn predominăncla de produtos alimenticios - hipermercados C2-4711301 Comércio varejista de mercadorlas em geral, com predorninância de produtos alimenticlos - hipermercados C2-4711301 Connárcio varejista de mercadorias em geral, com predominância de produtos alimenticios - hipermercados

CS3MARA C2-4711301 Comércio varejtsta de mercadorias en geral, com predominância de produtos alimenticios - hipermercedos

CVOPGA

$0 \mathrm{rog} 24$ C2-4761003 Comercio varejista de artigos de papelaria C2-4761003 Comércio varejista de artigos de papelaria C2-4781003 Comércio varejsta de artigos de papelaria C2-4761003 Comércio varejista de artigos de papelarta C2-4761003 Comércio varejista de artigos de papelaria C2-4761003 Comércio varejista de artigos de papelarta C2-4761003 Comercio varejista de artigos de papelaria C2-4761003 Comercio varejista de artigos de papelaria C2-4761003 Comércio varej|sta de arthos de papelaria C2-4761003 Comercio varejista de artigos de papelaria C2-4781003 Comércio varejista de artigos de papelaria C2-4761003 Comércio varejelsta de artigos de papelaria C2-4761003 Comércio varefista de artigos de papelaria C2-4761003 Comórcio varejista de artigos de papelaria C2-4781003 Comércio varejista de artigos de papelarie C2-4761003 Comercio varejista de artigos de papelaria C2-4761003 Comercio varejista de artigos de papelaría C2-4761003 Comérclo verejista de artigos de papelaria C2-4761003 comercio varejista de artigos de papelaria C2-4761003 Comercio verejista de artigos de papelaria C2-4761000 Comércio varejlsta de artigos de papelaria C2-4781003 Comercio varejista de artigos de papelarta C2-4761003 Comércio varejista de artigos de papelaria C2-4761003 Comércio varejista de artigos de papelaria C2-4781003 Condrcio varejista de artigos de pepelarta C2-4761003 Combrcio varejista de artigos de papelaria C2-4761003 Comercio varejista de artigos de papetaria C2-4761003 Comércio varejista de artigos de papelaria C2-4761003 Comércio vareflsta de artigos de papelaria C2-4761003 Comércio varejista de artigos de papelarie C2-4761003 Comercio varejista de artigos de papelaria C2-4781003 Comércio varejista de artigos de papelaria C2-4761003 Comercio varejista de artigos de papetaria C2-4761003 Comercio varejista de artigos de papelaria C2-4761003 Combrcio varejista de artigos de pepelaria C2-4761003 Comércio varejista de artigos de papelaria C2-4761003 Comércio varejista de artigos de papelaria C2-4761003 Combrcio varejista de artigos de papetaria C2-47B1003 Combircio varejista de artigos de papelaria C2-4761003 Combrcio varejista de artigos de papelaria 
Apind lea E - Codigos des atvidades do combicto

Rede soclal CNAE-2.0 Descriçăo

CW2015A C2-4713002 Lojas de variedades, exceto lojas de departarnentos ou magazines

CW2029A C2-4713002 Lojes de variedades, exceto lojas de departamentos ou magazines

CW2064A C2-4713002 Lojas de variedades, exceto lojas de departarnentos ou magazines

CW2100A C2-4713002 Lojas de variectactes, exceto lojas de departamentos ou magazines

CW2107A C2-4713002 Lojas de variectades, exceto lojas de departamentos ou magazines

CW2112A C2-4713002 Lojas de variedades, exceto lojas de departamentos ou magazines

CW2CENA C2-4713002 Lojes de variedades, exceto lojas de departamentos ou magazines

CW2DIAA C2-4713002 Lojas de variedades, exceto lojas de departamentos ou magazines

CW2L13A C2-4713002 Lojas de variedades, exceto lojas de departamentos ou magazines

CW2NAVA C2-4713002 Lojas de variedades, exceto lojas de departantentos ou magazines

CW2SABA C2-4713002 Loias de varledades, exceto lojas de departamentos ou magazines

CW2SAUA C2-4713002 Lojas de variedades, excelo lojas de departamentos ou magaxines

CW2SERA C2-4713002 Lojas de variedades, exceto lojas de departamentos ou magazines

CW2YERA C2-4713002 Lojas de variedades, exceto lojes de depertamentos ou magarines

CW3INTA C2-4713002 Lojas de variedades, exceto lojas de departamentos ou magazines

CX3DIAA C2-4754701 Coméclo varej|sta de móveis

CX3INTA C2-4754701 Comércio varejista de móveis

CX3L13A C2-4754701 Comercio varejista de móveis

CX35ABA C2-4754701 Comércio varejista de móveis

CX3SAUA C2-4754701 Comercio varejista de móveis

CX3SERA C2-4754701 Comfricio varejejta de móveis

CX3YERA C2-4754701 Comercio varejlste de moveis

CY3064A C2-4782201 Comercio varejista de calcados

CY3100A C2-4782201 Comercio varefista de calçados

CY3BRZA C2-4782201 Comércio varejlsta de calcados

CY3CENA C2-4782201 Comércio varejieta de calçados

CY3DIAA C2-4782201 Comércio varejista de cakados

CYIINTA C2-4782201 Comércio varejista de calçados

CY3MMIA C2-4782201 Comercio varejista de calçados

CY3L13A C2-4782201 Comercio varejista de calçados

CY3NAVA C2-4782201 Comérclo varejista de calcados

CY3SABA C2-4782201 Comórcio varej|sta de calcados

CY3SAUA C2-4782201 Comereio varejista de calcados

CY3YERA C2-4782201 Comércio varejista de calcados

CZ2002A C2-4789005 Combrcio varejista de produtos saneentes domissanitarios

CZ2012A C2-4789005 Comércio varejista de produtos saneantes domissanitarios

CZ2012A C2-4789005 Comerclo varej|sta de produtos saneantes domissanititios

CZ2015A C2-4789005 Comérclo varejista de produtos saneantes domiseanitatios

CZ2019A C2-4789005 Comércio varejista de produtos saneantes domtasanitarios

CZ2027A C2-4789005 Comércio varejlsta de produtos saneantes domisanitarios

CZ2029A C2-4785005 Comércio verejlsta de produtos saneantes domizeanitérios

CZ2031A C2-4789005 Comércio varejista de produtos saneartes domiseanitários

CZ2034A C2-478S005 Comerclo varejista de produtos saneantes domissanitários

CZ2041A C2-4785005 Comércio varejista de produtos saneantes domissanthírios

C2046A C2-4789005 Comércio varejista de produtos seneantes domissanitúrios

CZ2054A C2-4789005 Comércio varejista de produtos seneantes domiasanitários

CZ2069A C2-4789005 Comerclo varejista de produtos saneantes domissantithrios

C22080A C2-4789005 Comércio varejista de produtos saneantes domissanitarios

C2085A C2-4789005 Comercio varejista de produtos saneantes domissanitarios

CZ2095A C2-4789005 Combrolo varejista de produtos saneantes domissanitários

CZ2096A C2-4789005 Combrcio varejista de produtos saneantes domissenitárice

C22105A C2-4789005 Comercio varejista de produtos seneantes domissantíninoes

C22119A C2-4789005 Comércho varejista de produtos saneantes domissantúrios

C22121A C2-4789005 Comércio varejista de produtos saneantes domissaniltarios

CZ2122A C2-4789005 Comérclo varejista de produtos saneantes domissantínicio

CZ2CONA C2-4789005 Comércio varejista de produtos saneantes domissanit́rios

C22DIAA C2-4789005 Comérclo varejista de produtos saneantes domissanitários

SC2SAUA C2-4711302 Comércio varejista de mercadorias em geral, com predominancia de produtos alimenticios - supermercadioe

SM3INTA C2-4744099 Combrcio varejista de materiais de construstio em geral

SM3MARA C2-4744099 Comércio varejista de materiais de construçato ern gera 
Apêndice F 
Apêndice F - RESULTADO DO MODELO DE REGRESSÃO ENTRE LINHA DE ÔNIBUS E QUANTIDADE DE ESTABELECIMENTOS COMERCIAIS

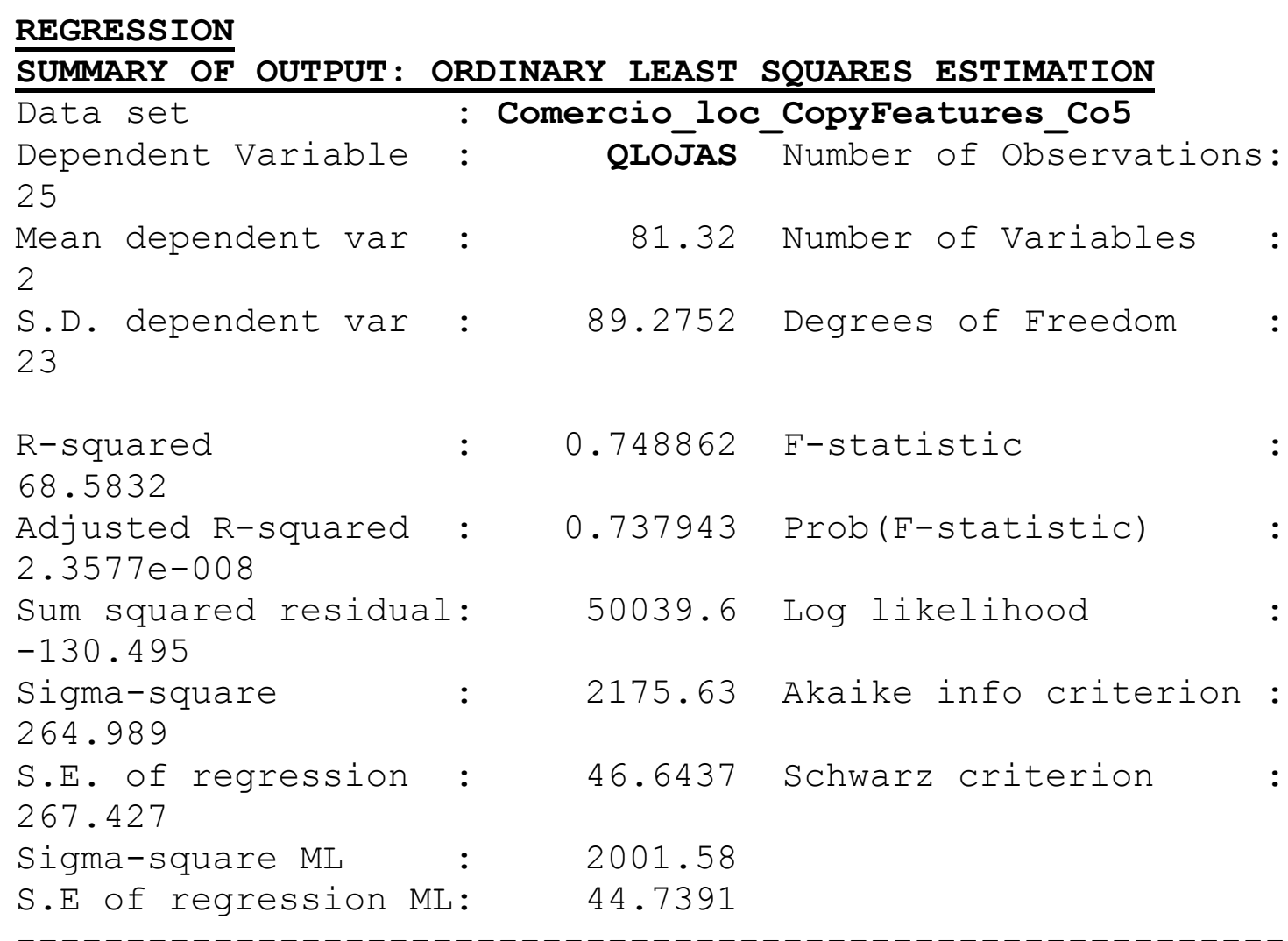

Variable Coefficient Std.Error t-Statistic
Probability

CONSTANT

0.3858151

ONIBUS

0.0000000
11.14174

5.115033

12.60301

0.8840543

0.6176461

8.281496 
Apêndice G 
Apêndice G - QUANTIDADE DE ESTABELECIMENTOS COMERCIAIS E LINHAS DE ÔNIBUS

\begin{tabular}{|c|c|c|c|}
\hline \multicolumn{4}{|c|}{ QUANTIDADE DE LOJAS E LINHAS DE ÔNIBUS } \\
\hline NOME DA RUA & BAIRRO & $\begin{array}{c}\text { QUANTIDADE DE LOJAS NA } \\
\text { REGIÃO }\end{array}$ & LINHA DE ÔNIBUS \\
\hline Largo 13 de Maio & Santo Amaro & 387 & 75 \\
\hline R. Antonio do Campo & V. Aparecida & 26 & 4 \\
\hline Estrada do Alvarenga & $\begin{array}{l}\text { Balneário Mar } \\
\text { Paulista }\end{array}$ & 75 & 22 \\
\hline R. Alice dos Santos Peixe & Jardim Selma & 30 & 7 \\
\hline R.. Papa Gregório Magno & V. Missionária & 21 & 7 \\
\hline R. Wilson Cantoni & Parque Primavera & 22 & 13 \\
\hline Av. Eduardo Pereira Ramos & Parque São Jorge & 31 & 8 \\
\hline Av. Yervant Kissajikian & Cidade Ademar & 214 & 16 \\
\hline $\begin{array}{l}\text { Av. Nossa Senhora do } \\
\text { Sabará }\end{array}$ & Campo Grande & 116 & 32 \\
\hline R. Davide Perez & Jardim Apurá & 29 & 6 \\
\hline R.Vicente Strichalsky & Jardim Rubilene & 22 & 4 \\
\hline R.Carlos de Rezende Enout & Jardim Rubilene & 27 & 7 \\
\hline R. Prof. Cardozo de Mello & $\begin{array}{l}\text { Jardim Rubilene/ } \\
\text { Favela do Pantanal }\end{array}$ & 51 & 9 \\
\hline R. Apiaris & Parque Santa Amélia & 9 & 1 \\
\hline R. Guaicuri & Parque Primavera & 39 & 3 \\
\hline Av. Alda & $\begin{array}{l}\text { Eldorado (Jardim do } \\
\text { Castelo) }\end{array}$ & 19 & 3 \\
\hline Estrada da Água Santa & $\begin{array}{l}\text { Eldorado (Mata } \\
\text { Virgem) }\end{array}$ & 11 & 1 \\
\hline $\begin{array}{l}\text { R. Dr. José Silvio de } \\
\text { Camargo }\end{array}$ & Monte Líbano & 33 & 1 \\
\hline $\begin{array}{l}\text { Av. Interlagos (Shopping } \\
\text { Interlagos) }\end{array}$ & Campo Grande & 247 & 33 \\
\hline $\begin{array}{l}\text { Av. das Nações Unidas } \\
\text { (Shopping SPMarket) }\end{array}$ & Campo Grande & 156 & 17 \\
\hline Av. Cupecê & Americanópolis & 68 & 21 \\
\hline Centro de Diadema & Diadema & 170 & 17 \\
\hline Av. Rotary & Serraria - Diadema & 117 & 7 \\
\hline $\begin{array}{c}\text { Av. Nossa Senhora dos } \\
\text { Navegantes } \\
\end{array}$ & $\begin{array}{c}\text { Navegantes - } \\
\text { Diadema }\end{array}$ & 72 & 8 \\
\hline
\end{tabular}

Fonte: Pesquisa do autor 
Apêndice H 


\section{Apêndice H - SÍNTESE DA DISTRIBUIÇÃO DOS RAMOS DO COMÉRCIO POR REGIÃO}

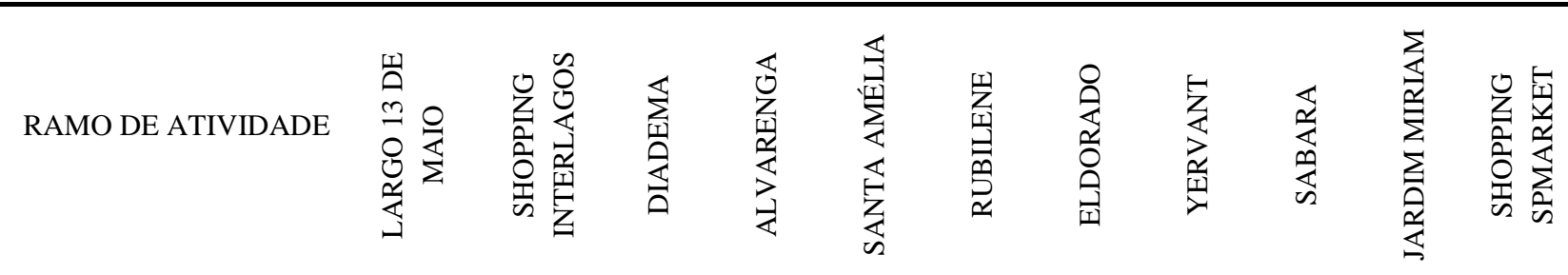

\begin{tabular}{|c|c|c|c|c|c|c|c|c|c|c|c|}
\hline Padaria & 0 & 0 & 0 & 20 & 7 & 16 & 13 & 4 & 3 & 2 & 0 \\
\hline Bazar e papelaria & 5 & 2 & 14 & 14 & 2 & 16 & 4 & 9 & 0 & 0 & 2 \\
\hline Farmácia & 8 & 4 & 10 & 11 & 3 & 3 & 12 & 12 & 11 & 5 & 1 \\
\hline Material de limpeza & 0 & 0 & 0 & 6 & 4 & 12 & 8 & 3 & 1 & 2 & 0 \\
\hline Açougue & 10 & 1 & 4 & 6 & 1 & 1 & 12 & 9 & 4 & 4 & 0 \\
\hline Casa do norte & 8 & 0 & 3 & 3 & 3 & 3 & 6 & 5 & 0 & 1 & 0 \\
\hline Avícola & 0 & 0 & 0 & 5 & 0 & 1 & 0 & 2 & 0 & 0 & 0 \\
\hline Alimentos de animais & 0 & 1 & 0 & 12 & 5 & 10 & 15 & 10 & 2 & 4 & 0 \\
\hline Vestuário & 128 & 91 & 55 & 19 & 5 & 8 & 36 & 34 & 19 & 7 & 61 \\
\hline Óptica & 21 & 9 & 11 & 5 & 2 & 0 & 3 & 4 & 5 & 1 & 7 \\
\hline Comércio de tintas & 0 & 0 & 3 & 2 & 0 & 0 & 0 & 2 & 1 & 1 & 0 \\
\hline Material de construção & 0 & 4 & 0 & 24 & 6 & 23 & 26 & 16 & 6 & 9 & 0 \\
\hline Diversos & 3 & 13 & 4 & 6 & 1 & 1 & 4 & 7 & 5 & 1 & 16 \\
\hline Mercearias & 1 & 0 & 2 & 27 & 3 & 30 & 22 & 11 & 2 & 1 & 0 \\
\hline Cosméticos & 17 & 6 & 6 & 4 & 0 & 2 & 6 & 5 & 3 & 1 & 11 \\
\hline Doces, bombons & 16 & 0 & 0 & 3 & 2 & 3 & 9 & 5 & 4 & 4 & 2 \\
\hline Hiper e supermercados & 0 & 2 & 2 & 7 & 3 & 3 & 8 & 6 & 2 & 4 & 2 \\
\hline Móveis & 14 & 29 & 9 & 2 & 1 & 1 & 6 & 10 & 14 & 1 & 1 \\
\hline Variedades & 20 & 1 & 4 & 11 & 11 & 4 & 22 & 23 & 18 & 6 & 0 \\
\hline Ferragens & 12 & 2 & 2 & 1 & 0 & 0 & 2 & 0 & 3 & 0 & 1 \\
\hline Hortifrutigranjeiros & 0 & 0 & 0 & 8 & 2 & 7 & 8 & 9 & 1 & 2 & 0 \\
\hline Calçados & 37 & 17 & 13 & 2 & 0 & 1 & 6 & 4 & 4 & 3 & 15 \\
\hline
\end{tabular}




\begin{tabular}{|c|c|c|c|c|c|c|c|c|c|c|c|}
\hline RAMO DE ATIVIDADE & 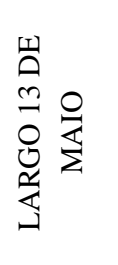 & 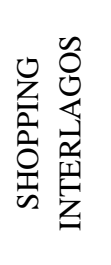 & 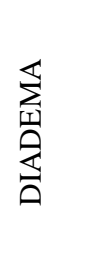 & 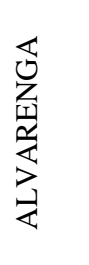 & 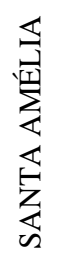 & 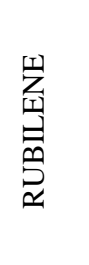 & 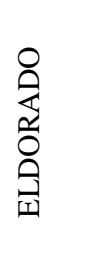 & 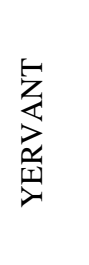 & 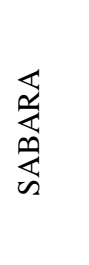 & 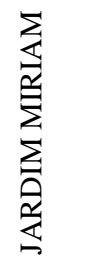 & 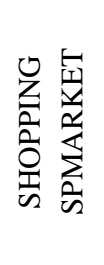 \\
\hline Cine e foto & 2 & 6 & 2 & 1 & 1 & 0 & 0 & 4 & 0 & 1 & 2 \\
\hline Bijuteria & 11 & 6 & 4 & 1 & 3 & 1 & 4 & 1 & 1 & 2 & 6 \\
\hline Artigos de viagem & 10 & 4 & 2 & 0 & 0 & 0 & 1 & 2 & 0 & 2 & 5 \\
\hline Cama, mesa e banho & 12 & 6 & 1 & 0 & 0 & 0 & 1 & 1 & 1 & 0 & 1 \\
\hline Eletrônica, Telefonia & 7 & 15 & 6 & 1 & 2 & 0 & 6 & 5 & 1 & 2 & 11 \\
\hline Discos, CDs e DVDs & 7 & 1 & 4 & 1 & 0 & 0 & 1 & 1 & 0 & 1 & 2 \\
\hline Eletrodoméstico & 10 & 12 & 3 & 0 & 0 & 0 & 1 & 0 & 0 & 0 & 2 \\
\hline Embalagem & 2 & 0 & 0 & 1 & 0 & 0 & 0 & 1 & 0 & 0 & 0 \\
\hline Colchões & 8 & 6 & 2 & 0 & 0 & 0 & 0 & 1 & 1 & 0 & 1 \\
\hline Armarinhos e fios & 4 & 0 & 0 & 0 & 0 & 0 & 3 & 2 & 1 & 0 & 0 \\
\hline Jóias e relógios & 5 & 8 & 3 & 0 & 0 & 0 & 3 & 2 & 0 & 1 & 7 \\
\hline Tecidos & 0 & 0 & 0 & 0 & 0 & 0 & 0 & 0 & 1 & 0 & 0 \\
\hline Magazines & 0 & 1 & 0 & 0 & 0 & 1 & 0 & 3 & 1 & 0 & 0 \\
\hline Bebidas & 0 & 0 & 0 & 2 & 3 & 1 & 7 & 1 & 1 & 0 & 0 \\
\hline TOTAL & 387 & 247 & 170 & 205 & 70 & 148 & 252 & 214 & 116 & 68 & 156 \\
\hline
\end{tabular}

conclusão

Obs.: Fazem parte da região de Eldorado, os centros comerciais dos bairros Vila Nossa Senhora da Aparecida, Vila Conceição, Serraria e Navegantes, todos em Diadema, sendo esses dois últimos apresentando padrões semelhantes da Avenida Yervant Kissajikian ou Avenida Nossa Senhora do Sabará.

Fonte: pesquisa do autor 
Apêndice I 
Apêndice I - SÍNTESE DOS RESULTADOS DA REDE SOCIAL E DA ESTATÍSTICA ESPACIAL

\begin{tabular}{|c|c|c|c|c|c|c|}
\hline \multirow[b]{2}{*}{ LOCAIS } & \multicolumn{3}{|c|}{ MEDIDAS - REDE SOCIAL } & \multicolumn{2}{|c|}{$\begin{array}{l}\text { ESTATÍSTICA } \\
\text { LOCAL }\end{array}$} & \multirow[b]{2}{*}{$\begin{array}{c}\text { DISTÂN- } \\
\text { CIA EM } \\
\text { LINHA } \\
\text { RETA - } \\
\text { km * }\end{array}$} \\
\hline & GRAU & $\begin{array}{c}\text { POSICIO- } \\
\text { NA- } \\
\text { MENTO }\end{array}$ & $\begin{array}{c}\text { PROXI- } \\
\text { MI- } \\
\text { DADE }\end{array}$ & MORAN'S I & $\begin{array}{c}\text { GETS } \\
\text { ORD } \\
\text { Gi* }\end{array}$ & \\
\hline Largo 13 de Maio & 25,16 & 3947 & 1617 & 0,28 & 0,91 & 7,4 \\
\hline $\begin{array}{l}\text { Shopping } \\
\text { Interlagos }\end{array}$ & 22,27 & 2493 & 1605 & 3,56 & 2,23 & 3,9 \\
\hline Diadema & 17,68 & 2104 & 1728 & 0,05 & $-0,31$ & 2,7 \\
\hline $\begin{array}{l}\text { Estr. do } \\
\text { Alvarenga }\end{array}$ & 3,34 & 78 & 1991 & 0,22 & $-0,53$ & 1,4 \\
\hline $\begin{array}{c}\text { Parque Santa } \\
\text { Amélia }\end{array}$ & 5,39 & 1194 & 1921 & 0,25 & $-0,68$ & 0,15 \\
\hline Jardim Rubilene & 2,47 & 231 & 1974 & 0,28 & $-0,68$ & 0,53 \\
\hline Eldorado & 1,80 & 76 & 2015 & 0,09 & $-0,34$ & 2,5 \\
\hline Jardim Miriam & 1,28 & 12 & 1960 & 0,11 & $-0,54$ & 1,8 \\
\hline Av. N. S. Sabará & 4,25 & 175 & 1960 & 0,02 & $-0,25$ & 4,3 \\
\hline $\begin{array}{l}\text { Av. Yervant } \\
\text { Kissakijian }\end{array}$ & 4,18 & 136 & 1906 & 0,07 & $-0,68$ & 2,8 \\
\hline $\begin{array}{l}\text { Shopping } \\
\text { SPMarket }\end{array}$ & 6,00 & 67 & 1755 & 4,04 & 3,4 & 5,7 \\
\hline
\end{tabular}

*Distância em linha reta a partir do centro médio dos moradores

Fonte: pesquisa do autor 
Apêndice J 


\section{Apêndice J - Cálculos da distância do vizinho mais próximo}

Executing (AverageNearestNeighbor_12): AverageNearestNeighbor

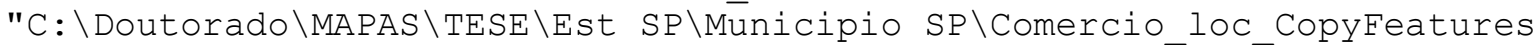
layer.lyr" "Euclidean Distance" false \# 00

Start Time: Tue Jan 20 19:42:15 2009

Running script AverageNearestNeighbor...

The input feature class does not appear to contain projected data. Building Lists...

Calculating results...

$$
\begin{array}{r}
20 \% \text { complete } \\
40 \% \text { complete } \\
60 \% \text { complete } \\
80 \% \text { complete } \\
100 \% \text { complete }
\end{array}
$$

Nearest Neighbor Observed Mean Distance $=0,000244$

Expected Mean Distance $=0,000995$

Nearest Neighbor Ratio $=0,244948$

Z Score $=-48,984256$ Standard Deviations

Completed script AverageNearestNeighbor...

Executed (AverageNearestNeighbor_12) successfully.

End Time: Tue Jan 20 19:42:29 2009 (Elapsed Time: 14,00 seconds)

Observed Mean Distance $/$ Expected Mean Distance $=0.24$

$\square$ Score $=-48,98$ standard deviations

Clustered
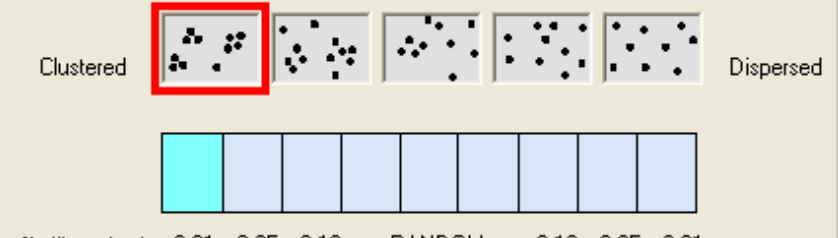

Significonce Level: Critical Value:

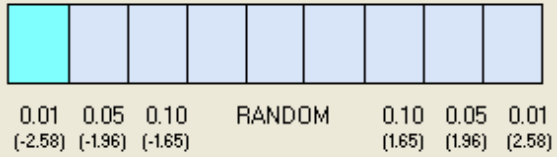

There is less than $1 \%$ likelihood that this clustered pattern could be the result of random chance.

Close 


\section{Apêndice J - Cálculo da estatísitica global Moran’s I}

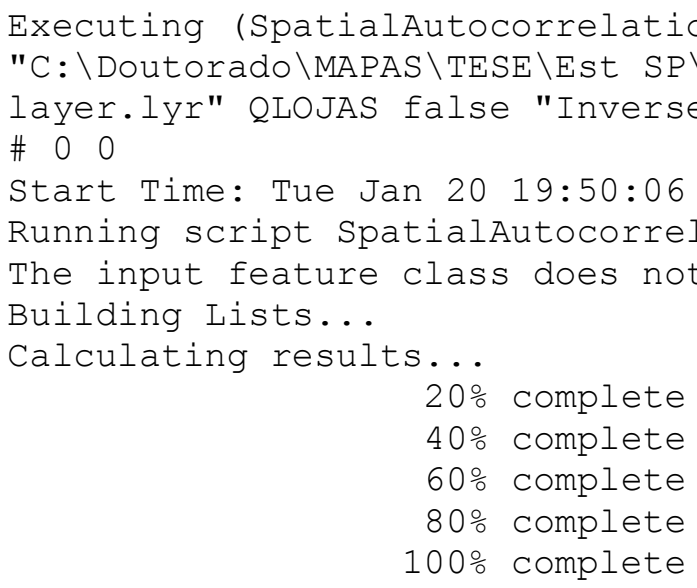

Calculations complete...

$$
\begin{aligned}
& 20 \% \text { complete } \\
& 40 \% \text { complete } \\
& 60 \% \text { complete } \\
& 80 \% \text { complete } \\
& 00 \% \text { complete }
\end{aligned}
$$

Moran's Index $=0,027295$

Expected Index $=-0,000870$

Variance $=0,000028$

Z Score $=5,337027$

Completed script SpatialAutocorrelation...

Executed (SpatialAutocorrelation 15) successfully.

End Time: Tue Jan 20 19:50:16 2009 (Elapsed Time: 10,00 seconds)

Moran's I Index $=0,03$

$Z$ Score $=5,34$ standard deviations

Dispersed
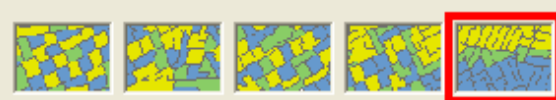

Clustered

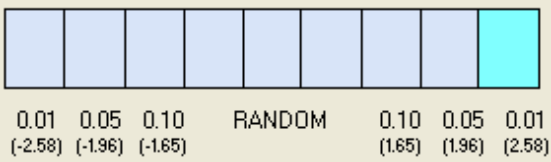

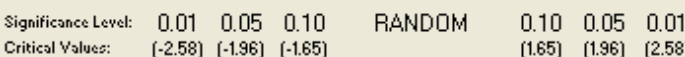

There is less than $1 \%$ likelihood that this clustered pattern could be the result of random chance. 


\section{Apêndice J - Cálculo da estatística global Getis Ord G}

Executing (HighLowClustering_2): HighLowClustering

"C: \Doutorado \MAPAS $\backslash T E S E \backslash E s t ~ S P \backslash M u n i c i p i o$ SP $\backslash$ Comercio_loc_CopyFeatures layer.lyr" QLOJAS false "Inverse Distance" "Euclidean Distance" None 0 \# 000

Start Time: Tue Jan 20 19:18:26 2009

Running script HighLowClustering...

The input feature class does not appear to contain projected data. Building Lists...

Calculating results...

$$
\begin{array}{r}
20 \% \text { complete } \\
40 \% \text { complete } \\
60 \% \text { complete } \\
80 \% \text { complete } \\
100 \% \text { complete }
\end{array}
$$

Calculations complete...

Observed General G $=100,077796$

Expected General G $=89,306489$

General G Variance $=17,758269$

Z Score $=2,556042$ Standard Deviations

Completed script HighLowClustering...

Executed (HighLowClustering_2) successfully.

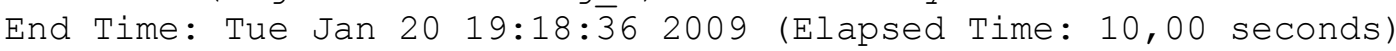

Gigh/Low Clustering (Getis-0rd General G)

General G Index $=100,08$

$Z$ Score $=2,56$ standard deviations

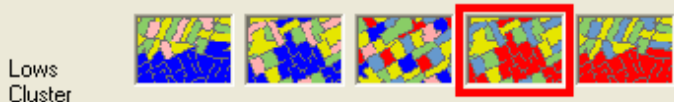

Cluster

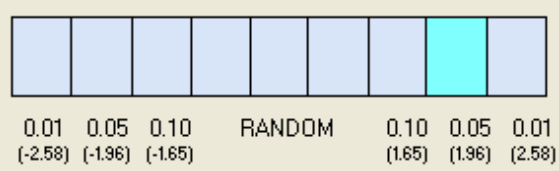

Highs

Cluster

There is less than $5 \%$ likelihood that the clustering of high values is the result of random chance.

Close 
Apêndice K 
SETOR CENSITÁRIO

ENDEREÇO

1)COMPRAS DE FREQÜÊNCIA DIÁRIA

\begin{tabular}{|l|l|l|l|}
\hline PRODUTO & & ESTABELECIMENTO & ENDEREÇO \\
\hline Padaria & & & \\
\hline Bar & & & \\
\hline Mercearia & & & \\
\hline Quitanda & & & \\
\hline Açougue & & & \\
\hline Outros & & & \\
\hline & & & \\
\hline & & & \\
\hline & & & \\
\hline & & & \\
\hline
\end{tabular}

2)COMPRAS DE FREQÜÊNCIA SEMANAL

\begin{tabular}{|l|l|l|l|l|}
\hline & & ESTABELEC. & BAIRRO & ENDEREÇO \\
\hline $\begin{array}{l}\text { Supermercado } \\
\text { Local }\end{array}$ & & & & \\
\hline $\begin{array}{l}\text { Supermercado } \\
\text { Grande }\end{array}$ & & & & \\
\hline Hipermercado & & & & \\
\hline Atacadista & & & & \\
\hline Shopping Center & & & & \\
\hline Feira & & & & \\
\hline Pet Shop & & & & \\
\hline Outros & & & & \\
\hline & & & & \\
\hline
\end{tabular}

4)SERVIÇOS DE SAÚDE

\begin{tabular}{|l|l|l|l|l|}
\hline & & ESTABELEC. & BAIRRO & ENDEREÇO \\
\hline Dentista & & & & \\
\hline Médico & & & & \\
\hline Hospital & & & & \\
\hline Posto de saúde & & & & \\
\hline & & & & \\
\hline & & & & \\
\hline
\end{tabular}


3)COMPRAS DE FREQÜÊNCIA MENSAL OU DE PERIODICIADE MAIOR

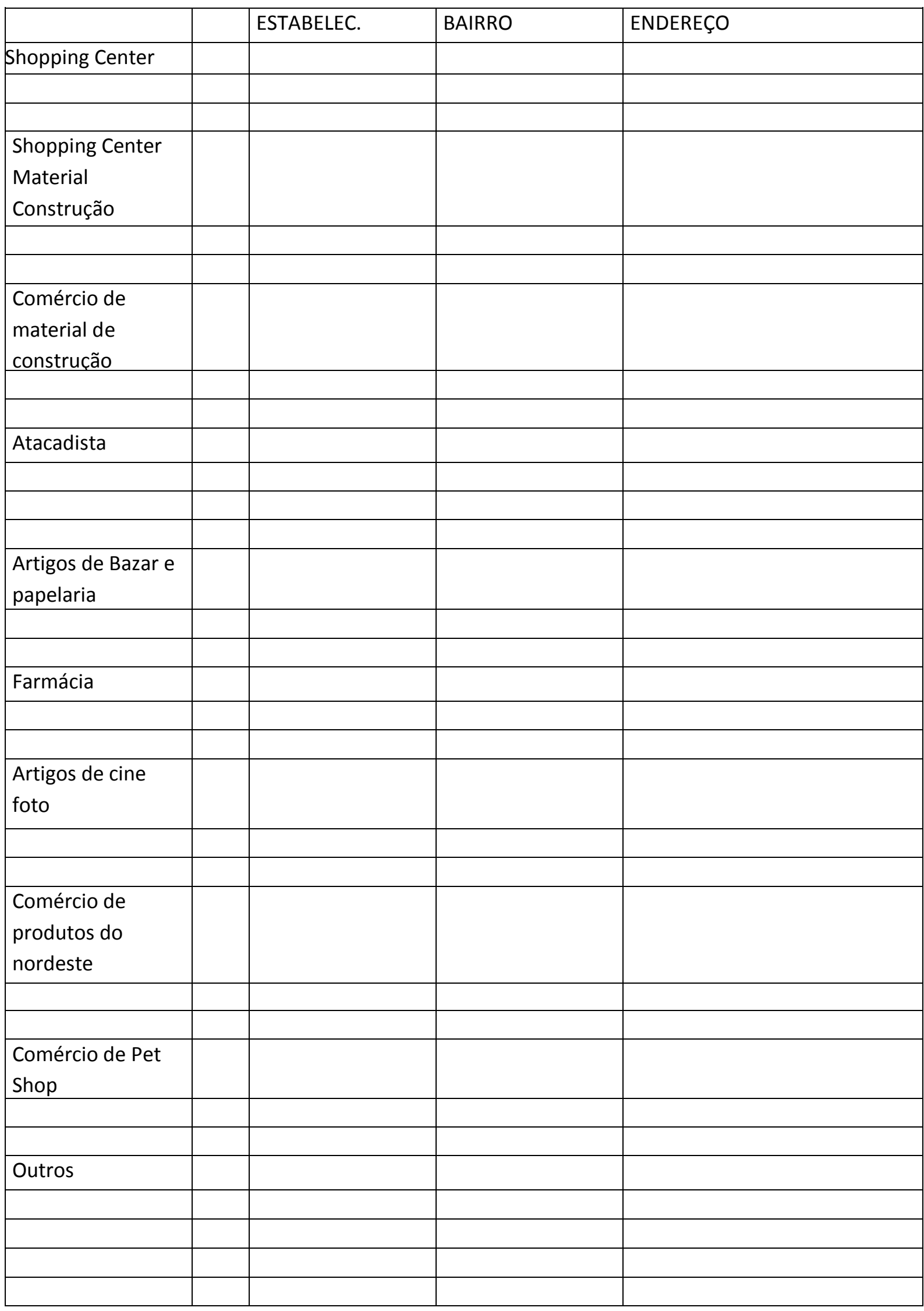


3)COMPRAS DE FREQÜÊNCIA MENSAL OU DE PERIODICIADE MAIOR

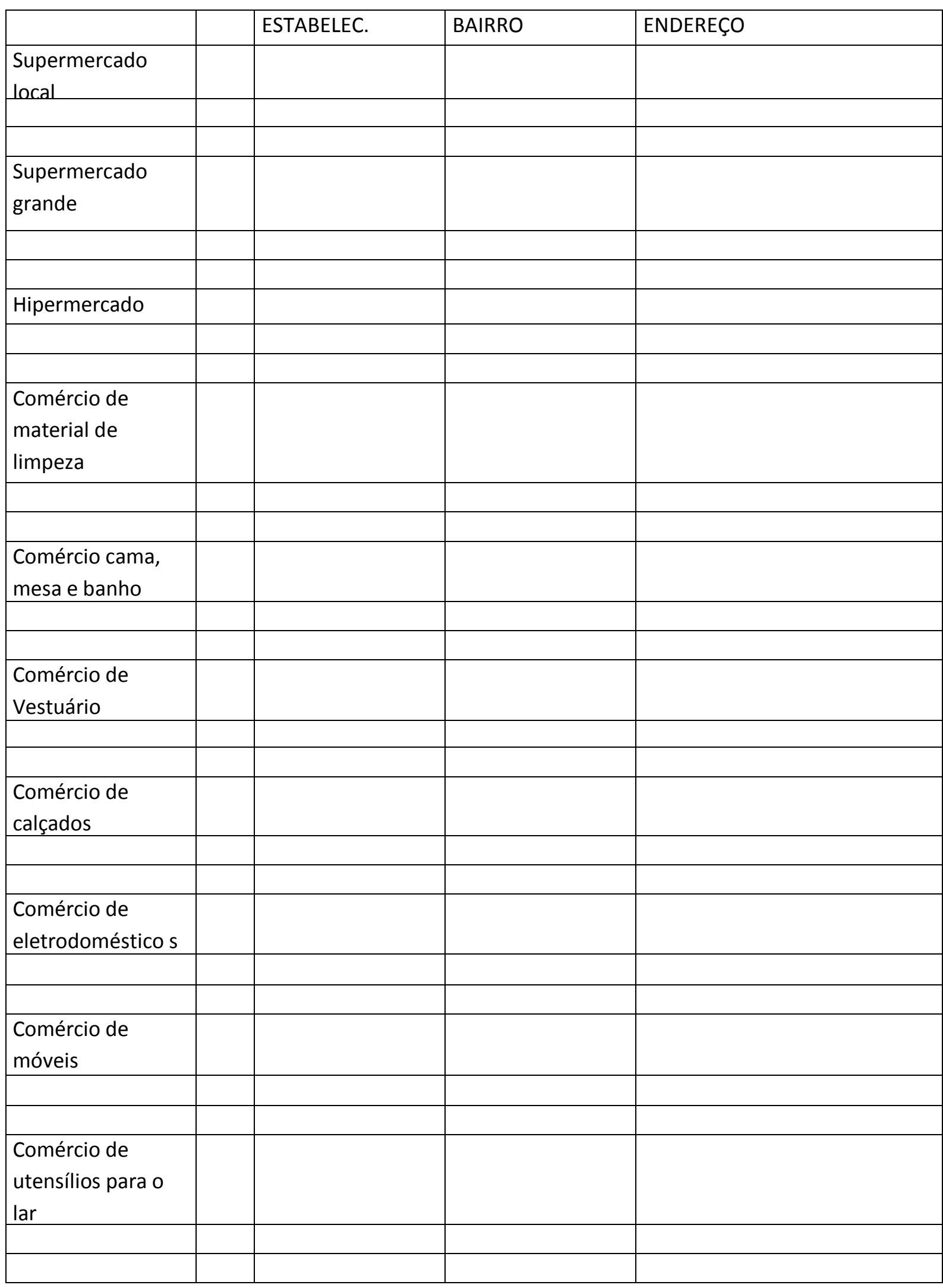


Apêndice L 
RUA PRINCIPAL:

\begin{tabular}{|c|c|c|c|c|c|c|c|}
\hline & HIpermercados & & & & & & \\
\hline C2-4711302 & Supermercados & & & & & & \\
\hline $\mathrm{C} 2-4712100$ & Mercearias/armazéns & & & & & & \\
\hline C2-4713001 & Magazines & & & & & & \\
\hline C2-4713002 & Loias de variedades & & & & & & \\
\hline C2-4721101 & Padaria e confeitaria & & & & & & \\
\hline C2-4721103 & Laticínios e frios & & & & & & \\
\hline C2-4721104 & Doces.bombons & & & & & & \\
\hline C2-4722901 & Acouques & & & & & & \\
\hline C2-4722902 & Peixaria & & & & & & \\
\hline C2-4723700 & Bebidas & & & & & & \\
\hline C2-4724500 & Hortifrutigranieiros & & & & & & \\
\hline C2-4729601 & Tabacaria & & & & & & \\
\hline C2-4741500 & Tintas, mat para pintura & & & & & & \\
\hline C2-4742300 & Material elétrico & & & & & & \\
\hline C2-4743100 & Vidros & & & & & & \\
\hline $\mathrm{C} 2-4744001$ & Ferragens e ferramentas & & & & & & \\
\hline C2-4744002 & Madeira e artefatos & & & & & & \\
\hline C2-4744003 & Materiais hidráulicos & & & & & & \\
\hline C2-4744004 & Cal,areia,tiiolos e telhas & & & & & & \\
\hline C2-4744099 & Materiais construcão & & & & & & \\
\hline C2-4751200 & Supr.informática & & & & & & \\
\hline C2-4752100 & Eq.telef.comunicacão & & & & & & \\
\hline C2-4753900 & Eletrodomésticos & & & & & & \\
\hline C2-4754701 & Móveis & & & & & & \\
\hline C2-4754702 & Artigos de colchoaria & & & & & & \\
\hline C2-4754703 & Artiqos de iluminacão & & & & & & \\
\hline C2-4755501 & Tecidos & & & & & & \\
\hline C2-4755502 & Artigos de armarinho & & & & & & \\
\hline C2-4755503 & Cama, mesa e banho & & & & & & \\
\hline C2-4756300 & Instr.musicais e aces. & & & & & & \\
\hline C2-4759801 & Tapecaria, cortinas & & & & & & \\
\hline C2-4761001 & Livros & & & & & & \\
\hline C2-4761002 & Jornais e revistas & & & & & & \\
\hline C2-4761003 & Artigos de papelaria & & & & & & \\
\hline C2-4762800 & Discos. CDs & & & & & & \\
\hline C2-4763601 & Brinquedos & & & & & & \\
\hline $\mathrm{C} 2-4763602$ & Artigos esportivos & & & & & & \\
\hline C2-4771701 & Farmacêuticos. s.m.f. & & & & & & \\
\hline C2-4771702 & Farmacêuticos, c.m.f. & & & & & & \\
\hline C2-4772500 & Cosméticos.perf.,hiq.pes. & & & & & & \\
\hline C2-4774100 & Artigos de óptica & & & & & & \\
\hline C2-4781400 & Vestuário e acessórios & & & & & & \\
\hline C2-4782201 & Calcados & & & & & & \\
\hline C2-4782202 & Artigos de viagem & & & & & & \\
\hline C2-4783101 & Artigos de joalheria & & & & & & \\
\hline C2-4783102 & Artigos de relojoaria & & & & & & \\
\hline C2-4789001 & Biiuterias,artesanatos & & & & & & \\
\hline C2-4789002 & Plantas e flores & & & & & & \\
\hline C2-4789004 & Animais vivos,alim.anim. & & & & & & \\
\hline C2-4789005 & Saneantes domissan. & & & & & & \\
\hline C2-4789008 & Fotográficos,filmagem & & & & & & \\
\hline
\end{tabular}


Anexo A 


\begin{tabular}{|c|c|c|c|c|c|}
\hline \multicolumn{2}{|r|}{ CNAE 2.0 рои. . } & \multicolumn{3}{|r|}{ CNAE $1.0_{\text {mants }}$ mate } & \multirow{2}{*}{$\begin{array}{l}\text { Oberrvaçoes } \\
\text { (Junho/2007) }\end{array}$} \\
\hline codlgo & denominaça & codlgo & & denominaçao & \\
\hline $46.89-3$ & 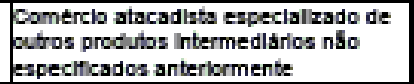 & $\$ 1.52-7$ & & $\begin{array}{l}\text { Comerclo atacadista de produtos } \\
\text { extrativos de orlgem mineral }\end{array}$ & \\
\hline $46.89-3$ & 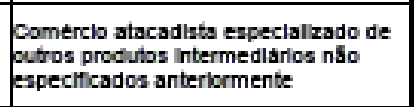 & $51.59-4$ & - & $\begin{array}{l}\text { Comerclo atacadlata de outros } \\
\text { erodubos intemedistios niso- } \\
\text { soropecuarioa, ndo especificados } \\
\text { anteriomente }\end{array}$ & $\begin{array}{l}\text { Excebo combrclo atscadiata de } \\
\text { Elderüralcos e metalurgicos, papel e } \\
\text { papelâ }\end{array}$ \\
\hline 16.89-3 & 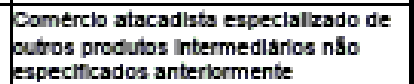 & $\$ 1.92-6$ & - & $\begin{array}{l}\text { Comerclo atacadlats especialzado em } \\
\text { mercadorias nío especilicadas } \\
\text { anteriormente }\end{array}$ & 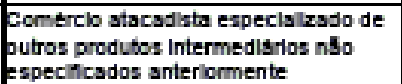 \\
\hline $16.91-5$ & $\begin{array}{l}\text { Comerelo atacadlata de mercadorlas } \\
\text { emm geral, com presominsncis de } \\
\text { erodutos almenticios }\end{array}$ & $\$ 1.91-8$ & - & $\begin{array}{l}\text { Comerclo atacadlats de mercadorlss } \\
\text { em geral (nIto especiallzado) }\end{array}$ & $\begin{array}{l}\text { Comberclo stacaslata de mercadorias } \\
\text { em geral, com predoominsncia de } \\
\text { produtos simenticlos }\end{array}$ \\
\hline $16.92-3$ & $\begin{array}{l}\text { Comerclo atacadlata de mercadorias } \\
\text { em peral, com predominsncla de } \\
\text { insumos spropecuatrios }\end{array}$ & $\$ 1.91-8$ & - & $\begin{array}{l}\text { Comerclo atacadlata de mercadorlas } \\
\text { em peral (n\$\$ especlallzado) }\end{array}$ & $\begin{array}{l}\text { Eombrclo stacsilata de mercadorias } \\
\text { em geral, com predominsncla de } \\
\text { nasumos apropecuatrios }\end{array}$ \\
\hline 16.93-1 & $\begin{array}{l}\text { Comerclo atacadlata de mercadorlas } \\
\text { em oeral, sem presominsncla de } \\
\text { allmentos ou de insumos } \\
\text { ggropecuatrios }\end{array}$ & \$1.91-8 & • & $\begin{array}{l}\text { Comerclo atacadlata de mercadorlas } \\
\text { em peral (n\$o especiallzado) }\end{array}$ & $\begin{array}{l}\text { Exceto comberclo stacadlata de insumoe } \\
\text { bgropecubrios }\end{array}$ \\
\hline 47.11-3 & $\begin{array}{l}\text { Comerclo varejlata de mercadorlas em } \\
\text { peral, com predomindncla de produtos } \\
\text { allmenticlos - hlpermercados e } \\
\text { aupermercados }\end{array}$ & $\$ 2.11-6$ & & 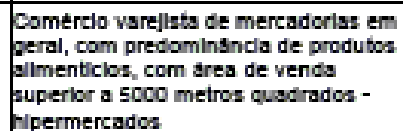 & \\
\hline $77.11-3$ & $\begin{array}{l}\text { Comerclo varejlata de mercadorisa em } \\
\text { peral, com predomindncla de produtos } \\
\text { alimenticlos - hlpermercados e } \\
\text { supermercados }\end{array}$ & $=2.12-4$ & & 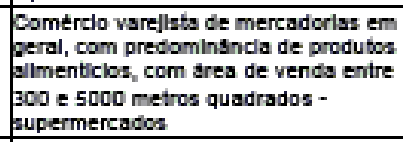 & \\
\hline 47.12-1 & 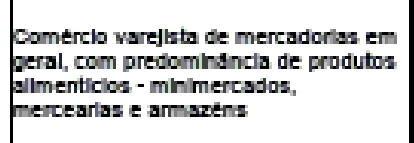 & $\$ 2.13-2$ & & 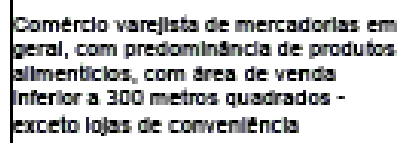 & \\
\hline 47.13-0 & $\begin{array}{l}\text { Comerclo varelata de mercadorisa em } \\
\text { geral, semm predominsncia de produtos } \\
\text { allmenticios }\end{array}$ & \$2.15-9 & & $\begin{array}{l}\text { Comerclo varelista nSo especialzzado, } \\
\text { sem predominancis de produtos } \\
\text { allmenticlos }\end{array}$ & \\
\hline $47.21-1$ & $\begin{array}{l}\text { Comerclo vareflata de produtos de } \\
\text { padaria, laticinlo, doces, balas e } \\
\text { gemelhantes }\end{array}$ & $15.81-4$ & - & $\begin{array}{l}\text { Fabricaç̧ıo de produtos de padaria, } \\
\text { Eonfeltarisa e pastelaris }\end{array}$ & $\begin{array}{l}\text { Produtos de padaria com venda no } \\
\text { pcal (padarla) }\end{array}$ \\
\hline 17.21-1 & $\begin{array}{l}\text { Comerclo vareflata de produtos de } \\
\text { podisra, isticinio, doces, balas e } \\
\text { gemelhantes }\end{array}$ & $=2.21-3$ & & $\begin{array}{l}\text { Comerclo vareflats de produtas de } \\
\text { padarita, de isticinib, trlos e conservas }\end{array}$ & \\
\hline 77.21-1 & $\begin{array}{l}\text { Comérclo vareflata de produtos de } \\
\text { podsaria, isticinio, doces, balas e } \\
\text { gemelhantes }\end{array}$ & $\$ 2.22-1$ & & $\begin{array}{l}\text { Comerclo varelista de balss, bombons } \\
\text { e semehantes }\end{array}$ & \\
\hline $17.22-9$ & $\begin{array}{l}\text { Comerclo varelata de carnes e } \\
\text { eescados - agoupues e peixarisa }\end{array}$ & $\$ 2.23-0$ & & $\begin{array}{l}\text { Comerclo vareflata de carnes - } \\
\text { acoupues }\end{array}$ & \\
\hline $47.22-9$ & $\begin{array}{l}\text { Comerclo varelata de carnes e } \\
\text { pescados - açougues e pelkarisa }\end{array}$ & $=2.29-9$ & - & $\begin{array}{l}\text { Comerclo varelista de outros produtos } \\
\text { allmenticios niso especiflcados } \\
\text { anterlormente e de produtos do tumo }\end{array}$ & Comerclo varejsta de pescados \\
\hline $47.23-7$ & Comerclo vareflata de bebidas & $52.24-8$ & & Comerclo varejlata de bebldas & \\
\hline $47.24-5$ & $\begin{array}{l}\text { Comerclo varelasta de } \\
\text { hortitiutigranvelros }\end{array}$ & $\$ 2.29-9$ & ${ }^{\circ}$ & 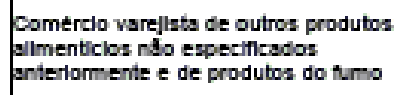 & $\begin{array}{l}\text { Comberclo varefsta de } \\
\text { hortitrutlopranjelios }\end{array}$ \\
\hline 47.29-6 & 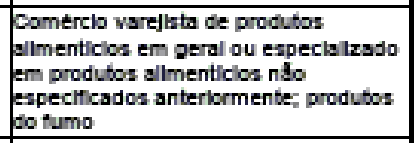 & $\$ 2.14-0$ & & 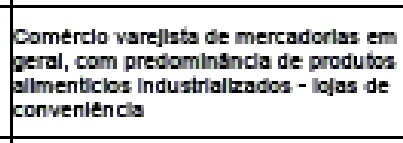 & \\
\hline 17.29-6 & 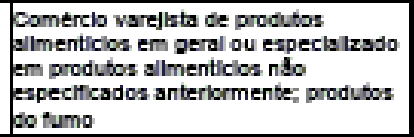 & $\$ 2.29-9$ & - & 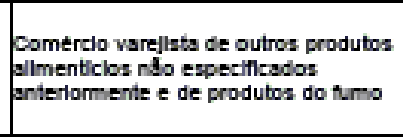 & $\begin{array}{l}\text { Excebo Comencio varellsta de } \\
\text { horithutipranjelros e pescados }\end{array}$ \\
\hline $47.31-8$ & $\begin{array}{l}\text { Comerclo vareflata de combuativels } \\
\text { para velculos aubomotores }\end{array}$ & $50.50-4$ & $\cdot$ & Comerclo a varejo de combustivels & $\begin{array}{l}\text { ExceboComerclo varejlata de } \\
\text { ubrifleantes }\end{array}$ \\
\hline $47.32-6$ & Comerclo varejlata de lubril'cantes & $50.50-4$ & $\cdot$ & Comerclo a varejo de combustivels & Comerclo varejsta de lubrincantes \\
\hline $17,41-5$ & $\begin{array}{l}\text { Comerclo varejata de tintas e materials } \\
\text { para pinturas }\end{array}$ & $52.44-2$ & • & $\begin{array}{l}\text { Comerclo vareflats de material de } \\
\text { construçdo, ferrajens e ferramentas } \\
\text { manuals; vilios, espelhos e vitrals; } \\
\text { intas e madelras }\end{array}$ & $\begin{array}{l}\text { Comberclo varejsta de tintas e materials } \\
\text { para pintura }\end{array}$ \\
\hline $47,42-3$ & Comerclo varejata de material eletrico & $\$ 2.44-2$ & - & 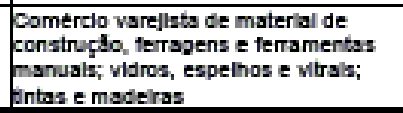 & Combrclo varejsta de materisl eletrico \\
\hline
\end{tabular}




\begin{tabular}{|c|c|c|c|c|c|}
\hline \multicolumn{2}{|r|}{ CNAE 2.0 pau wewswat } & \multicolumn{3}{|r|}{ CNAE $1.0_{\text {manks what }}$} & \multirow{2}{*}{$\begin{array}{l}\text { Obeervaç0es } \\
\text { (Junho/2007) }\end{array}$} \\
\hline codigo & denominaçaso & codlgo & & denominaça & \\
\hline $47,43-1$ & Comerclo varejlata de vidros & $52.44-2$ & $\cdot$ & $\begin{array}{l}\text { Comerclo varejlsta de material de } \\
\text { construçdo, ferragens e ferramentas } \\
\text { manuals; vidros, espelhos e vitrala; } \\
\text { intas e madelras }\end{array}$ & Comerclo varejlsta de vidros \\
\hline $47.44-0$ & $\begin{array}{l}\text { Comerclo varejlata de ferrajens, } \\
\text { madeira e materisla de construçăbo }\end{array}$ & $52.44-2$ & 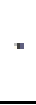 & $\begin{array}{l}\text { Comerclo varejlata de material de } \\
\text { construçdo, ferragens e ferramentas } \\
\text { manuals; vidros, espelhos e vitrala; } \\
\text { intas e madelras }\end{array}$ & $\begin{array}{l}\text { Excebo Comerclo varejlata de tintas, } \\
\text { materials para pintura, material eletrico } \\
\text { vidros }\end{array}$ \\
\hline $47.51-2$ & $\begin{array}{l}\text { Comerclo varejlata especislzado de } \\
\text { equipamentos e suprimentos de } \\
\text { Informatica }\end{array}$ & $52.45-0$ & $\cdot$ & $\begin{array}{l}\text { Comerclo varejlata de equipamentos } \\
\text { para eacritorio; Informstica e } \\
\text { comuricaçSo, inclushe suprimentos }\end{array}$ & $\begin{array}{l}\text { Comerclo varejlsta de equipamentos e } \\
\text { Euprimentoa de informatica }\end{array}$ \\
\hline $47.52-1$ & $\begin{array}{l}\text { Comerclo varejlata especialzado de } \\
\text { equipamentos de telefonis e } \\
\text { gomunicaçdo }\end{array}$ & $52.45-0$ & $\cdot$ & $\begin{array}{l}\text { Comerclo varejlsta de equlpamentos } \\
\text { gara eacritorio; Informstica e } \\
\text { comunicaçSo, inclushe suprimentos }\end{array}$ & $\begin{array}{l}\text { Combrclo varejsta de equipamentos de } \\
\text { eiefonia e comunicaçdo }\end{array}$ \\
\hline $47.53-9$ & $\begin{array}{l}\text { Comerclo varejlata especislzado de } \\
\text { eietrodomesticos e equipamentos de } \\
\text { sudio e video }\end{array}$ & $52.42-6$ & • & $\begin{array}{l}\text { Comerclo varejlsta de maquinas e } \\
\text { spareilhos de usos domestico e } \\
\text { pessoal, discos e inatrumentoas } \\
\text { mualicals }\end{array}$ & $\begin{array}{l}\text { Combrcio varejsta de eletrodomesticos } \\
\text { E equipamentos de sudlo e video }\end{array}$ \\
\hline $47.54-7$ & $\begin{array}{l}\text { Comerclo varejlata especisizsdo de } \\
\text { movels, colchoarla e artipos de } \\
\text { llumingça }\end{array}$ & $52.43-4$ & * & $\begin{array}{l}\text { Comerclo varejlata de movels, artigos } \\
\text { de liuminaç\$so e outros artigos para } \\
\text { fesidencla }\end{array}$ & $\begin{array}{l}\text { Comerclo varejsta de movels, } \\
\text { folkhoaris e artigos de lluminsçalo }\end{array}$ \\
\hline $47.55-5$ & $\begin{array}{l}\text { Comerclo varejlata especislzado de } \\
\text { eecidos e artigos de cama, mesa e } \\
\text { panho }\end{array}$ & $52.31-0$ & & $\begin{array}{l}\text { Comerclo varejlata de tecldos e artigos } \\
\text { de armarinho }\end{array}$ & \\
\hline $47.56-3$ & $\begin{array}{l}\text { Comerclo varejlata especlalzsodo de } \\
\text { instrumentos musicals e acessorios }\end{array}$ & $52.42-6$ & • & $\begin{array}{l}\text { Comercio vareflata de maquinas e } \\
\text { aparelhos de usos domestico e } \\
\text { pessoal, discos e inatrumentos } \\
\text { musicala }\end{array}$ & $\begin{array}{l}\text { Comerclo varejlsta de Instrumentos } \\
\text { musicals e acessorios }\end{array}$ \\
\hline $47.57-1$ & $\begin{array}{l}\text { Comerclo vareflata especislzado de } \\
\text { peças e acessorios para aparelhos } \\
\text { eietroeletronicos para uso domestico, } \\
\text { exceto Informatica e comunicaça }\end{array}$ & $52.49-3$ & • & $\begin{array}{l}\text { Comerclo varejlata de outros produtoa } \\
\text { hlo especincados anteriomnente }\end{array}$ & $\begin{array}{l}\text { Comercio varejlsta de peças e } \\
\text { acesscrios para aparelhos } \\
\text { eletroeletronicos para uso domestico, } \\
\text { exceto informatica e comunicaça }\end{array}$ \\
\hline $47.59-8$ & $\begin{array}{l}\text { Comerclo varejlata de artigos de uso } \\
\text { domtatico nSo eapeclicados } \\
\text { anterlomente }\end{array}$ & $52.42-6$ & • & $\begin{array}{l}\text { Comerclo varejlata de maquinas e } \\
\text { sparelhos de usos domestico e } \\
\text { pessoal, discos e inatrumentos } \\
\text { musicala }\end{array}$ & $\begin{array}{l}\text { Comerclo varejsta de slatemas de } \\
\text { Eegurança residencial }\end{array}$ \\
\hline $47.59-8$ & $\begin{array}{l}\text { Comerclo varejlata de artigos de uso } \\
\text { domestico nSo eapecificados } \\
\text { anterlorments }\end{array}$ & $52.43-4$ & $\cdot$ & $\begin{array}{l}\text { Comerclo varejlata de movels, artigos } \\
\text { de lluminaç\$so e outros artigos para } \\
\text { residencla }\end{array}$ & $\begin{array}{l}\text { Excebo comerclo varejsta de movels, } \\
\text { Folchoarla e artigos de lluminsçdo }\end{array}$ \\
\hline $47.61-0$ & $\begin{array}{l}\text { Comerclo varejlata de Ivros, Jornals, } \\
\text { Eevistas e papelaria }\end{array}$ & $52.46-9$ & & $\begin{array}{l}\text { Comerclo varejlata de livros, Jornals, } \\
\text { evilstas e papelaria }\end{array}$ & \\
\hline $47.62-8$ & $\begin{array}{l}\text { Comerclo vareflata de dlacos, CDs, } \\
\text { pvids e fltas }\end{array}$ & $52.42-6$ & $\cdot$ & $\begin{array}{l}\text { Comerclo varejlata de maquinas e } \\
\text { aparelhos de usos domestico e } \\
\text { pessoal, discos e instrumentos } \\
\text { musicala }\end{array}$ & $\begin{array}{l}\text { Comerclo varejsta de discos, CDs, } \\
\text { Pvids e flas }\end{array}$ \\
\hline $47.63-6$ & $\begin{array}{l}\text { Comerclo varejasta de artigos } \\
\text { fecreattvos e esportivos }\end{array}$ & $52.49-3$ & 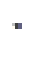 & $\begin{array}{l}\text { Comerclo varejlata de outros produtos } \\
\text { hlo especincados anteriomnente }\end{array}$ & $\begin{array}{l}\text { Eomerclo varejsta de artigos } \\
\text { fecreativos e esportivos }\end{array}$ \\
\hline $47.71-7$ & $\begin{array}{l}\text { Comerclo varejlata de produtos } \\
\text { tarmactuticos para uso humano e } \\
\text { veterindirlo }\end{array}$ & $52.41-8$ & • & $\begin{array}{l}\text { Comerclo varejlsta de produtos } \\
\text { farmaceuticos, artipos medicos e } \\
\text { ortopedlicos, de perfumaria e } \\
\text { cosmeticos }\end{array}$ & $\begin{array}{l}\text { Comitrclo varejsta de produtos } \\
\text { farmsctuticos para uso humano e } \\
\text { veterinarlo }\end{array}$ \\
\hline $47.72-5$ & $\begin{array}{l}\text { Comerclo varejlata de coameticos, } \\
\text { produtos de perfumarla e de higlene } \\
\text { pessoal }\end{array}$ & $52.41-8$ & - & $\begin{array}{l}\text { Comerclo varejlata de produlos } \\
\text { gamaceuticos, artigos medicos e } \\
\text { ortopedlcos, de perfumaria e } \\
\text { cosmettcos }\end{array}$ & $\begin{array}{l}\text { Combrelo varejsta de cosmeticos, } \\
\text { produlos de perfumaria e de higlene } \\
\text { pessosl }\end{array}$ \\
\hline $47.73-3$ & $\begin{array}{l}\text { Comerclo varejlata de artigos medicos } \\
\text { E ortopedicos }\end{array}$ & $52.41-8$ & - & $\begin{array}{l}\text { Comerclo varejlata de produlos } \\
\text { amaceutlcos, artipos medicos e } \\
\text { ortopedicos, de perfumaria e } \\
\text { cosmettcos }\end{array}$ & $\begin{array}{l}\text { Combrcio varejsta de artipos medicos } \\
\text { = ortopedicos }\end{array}$ \\
\hline $47.74-1$ & Comerclo varejata de artigos de optica & $52.49-3$ & $\cdot$ & $\begin{array}{l}\text { Comerclo varejlata de outros produtos } \\
\text { hlo especincados anteriomnente }\end{array}$ & Comerclo varejsta de artigos de optica \\
\hline $47.81-4$ & $\begin{array}{l}\text { Comerclo vareflata de artigos do } \\
\text { vestuario e acessorios }\end{array}$ & $52.32-9$ & & $\begin{array}{l}\text { Comerclo varejlata de artigos do } \\
\text { vestuarlo e complementos }\end{array}$ & \\
\hline $47.82-2$ & $\begin{array}{l}\text { Comerclo varejlata de calçados e } \\
\text { artipos de vlagem }\end{array}$ & $52.33-7$ & & $\begin{array}{l}\text { Comerclo varejlata de calçados, artigos } \\
\text { de couro e de vlagem }\end{array}$ & \\
\hline $47.83-1$ & Comerclo varejlata de jolas e reloglos & $52.49-3$ & $\cdot$ & $\begin{array}{l}\text { Comerclo varejlata de outros produtos } \\
\text { n\$o especincados anteriomente }\end{array}$ & Comerclo varejlsta de jolss e reloglos \\
\hline $47.84-9$ & $\begin{array}{l}\text { Comerclo varejlata de gts lquefelto de } \\
\text { petroleo (GLF) }\end{array}$ & $52.47-7$ & & $\begin{array}{l}\text { Comerclo varejlata de gts llquefelto de } \\
\text { Eetroleo (GLP) }\end{array}$ & \\
\hline $47.85-7$ & Comerclo vareflata de artipos usados & $52.50-7$ & & Comerclo varellata de artigos usados & \\
\hline $47.89-0$ & $\begin{array}{l}\text { Comerclo varejlata de outros produtos } \\
\text { novos ndo espechicados anteriormente }\end{array}$ & $52.42-6$ & $\cdot$ & $\begin{array}{l}\text { Comerclo varejlata de maquinas e } \\
\text { sparelhos de usos domestico e } \\
\text { pessoal, discos e inatrumentos } \\
\text { muasicala }\end{array}$ & $\begin{array}{l}\text { Combrcio varejlsta de artipos } \\
\text { fotograflicos e para inmspem }\end{array}$ \\
\hline
\end{tabular}




\begin{tabular}{|c|c|c|c|c|c|}
\hline \multicolumn{2}{|r|}{ CNAE 2.0 pou. wewsom } & \multicolumn{3}{|r|}{ CNAE $1.0_{\text {mants }}$ mate } & \multirow{2}{*}{$\begin{array}{l}\text { Oberrvaçoes } \\
\text { (Junho/2007) }\end{array}$} \\
\hline codlgo & denominaçáso & codlgo & & denominaça & \\
\hline 77.89-0 & $\begin{array}{l}\text { Comerclo vareflata de outros produlos } \\
\text { povos nîo especlilicados anterlormente }\end{array}$ & $52.44-2$ & - & $\begin{array}{l}\text { Comerclo vareflata de material de } \\
\text { construçdo, ferrajens e ferramentas } \\
\text { manuals; vidros, espelhos e vitrals; } \\
\text { entas e madelras }\end{array}$ & Comerclo varejsta de molduras \\
\hline 47.89-0 & $\begin{array}{l}\text { Comerclo vare/lata de outros produlos } \\
\text { novos nố eapechlicados anterlormente }\end{array}$ & $\$ 2.45-0$ & - & 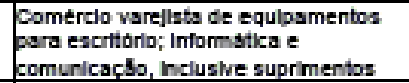 & $\begin{array}{l}\text { Combrclo varejsta de moquinas e } \\
\text { =quipamentos para escritiorio }\end{array}$ \\
\hline 77.89-0 & 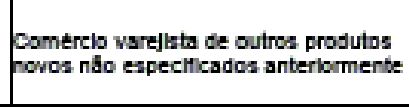 & $52.49-3$ & - & $\begin{array}{l}\text { Comerclo vare/lats de outros produtos } \\
\text { ilo especincados anteriomente }\end{array}$ & $\begin{array}{l}\text { Exceto comtercio varejsta de artipos de } \\
\text { bptica, esportivos e recreativos, jolas e } \\
\text { elogilos e peças e acessiorioa para } \\
\text { Equipamentos domesticos }\end{array}$ \\
\hline $47.90-3$ & $\begin{array}{l}\text { Camerclo ambulante e outros tipos de } \\
\text { sommenclo varelsta }\end{array}$ & $\$ 2.62-0$ & & $\begin{array}{l}\text { Comerclo em viss publicas, exceto em } \\
\text { gulosques fruos }\end{array}$ & \\
\hline $19.11-6$ & Tranaporte ferrovitsrio de carga & $30.10-0$ & . & Transporte ferrovisrio interurbano & Transporte ferroviario de carpa \\
\hline $49.12-4$ & $\begin{array}{l}\text { Tranaporte metroterrovilario de } \\
\text { passapelros }\end{array}$ & $50.10-0$ & $\cdot$ & Tranaporte ferrovisrio interurbano & $\begin{array}{l}\text { Transporte ferroviario Interurtano de } \\
\text { passapelios }\end{array}$ \\
\hline $49.12-4$ & $\begin{array}{l}\text { Tranaporte metroferrovilario de } \\
\text { passaperos }\end{array}$ & $50.21-6$ & & $\begin{array}{l}\text { Tranaporte ferrovistoro de passsgeliros, } \\
\text { arbano }\end{array}$ & \\
\hline $49.12-4$ & $\begin{array}{l}\text { Tranaporte metrolerrovilario de } \\
\text { passapeliros }\end{array}$ & $50.22-4$ & & Transporte metroviario & \\
\hline $19.12-4$ & $\begin{array}{l}\text { Tranaporte metroferrovitario de } \\
\text { passapeiros }\end{array}$ & 50.29-1 & - & $\begin{array}{l}\text { Tranaporte regular em bondes, } \\
\text { euniculares, teiefericos ou trens } \\
\text { eroprios pars exploraç\$o de pontos } \\
\text { auristicos }\end{array}$ & Fransporte regular de bondes \\
\hline $19.21-3$ & 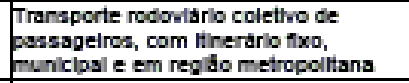 & $50.23-2$ & & $\begin{array}{l}\text { Transporte rodoviario de passageiros, } \\
\text { regular, untoano }\end{array}$ & \\
\hline $19.21-3$ & $\begin{array}{l}\text { Tranaporte rodowitrio colettivo de } \\
\text { gassageiros, com linerario fixo, } \\
\text { Funiclosi e em reg bo metropolitana }\end{array}$ & 50.24-0 & - & $\begin{array}{l}\text { Transporte rodoviario de passageiros, } \\
\text { regular, nlo urtano }\end{array}$ & $\begin{array}{l}\text { Transporte rodovitario de passageiros, } \\
\text { regular, municipal, ndo urbano }\end{array}$ \\
\hline $19.22-1$ & 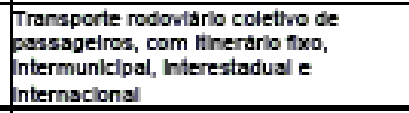 & 50.24-0 & - & $\begin{array}{l}\text { Transporte rodoviario de passageiros, } \\
\text { fegular, nlo urtano }\end{array}$ & $\begin{array}{l}\text { Excebo transporte rodovitario de } \\
\text { passapelros, regular, municipal, nâo } \\
\text { urbano }\end{array}$ \\
\hline $49.23-0$ & Tranaporte rodoviario de tari & $50.25-9$ & $\cdot$ & $\begin{array}{l}\text { Transporte rosoviario de passageros, } \\
\text { ho repular }\end{array}$ & Berviços de tsari \\
\hline $49.24-8$ & Transporte escolar & $50.25-9$ & * & $\begin{array}{l}\text { Transporte rodoviario de passageinos, } \\
\text { hlo regular }\end{array}$ & Transporte escolar \\
\hline $19.29-9$ & 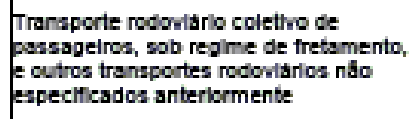 & $50.25-9$ & - & $\begin{array}{l}\text { Tranuporte rodoviario de passageiros, } \\
\text { to regular }\end{array}$ & $\begin{array}{l}\text { Excebo serviços de taxl, de locaçăo de } \\
\text { sutombovel com motorista municioal e } \\
\text { fransporte escolar }\end{array}$ \\
\hline $49.30-2$ & Tranaporte rodovitario de carga & $0.26-7$ & & $\begin{array}{l}\text { Tranaporte rodoviario de cargas, em } \\
\text { geral }\end{array}$ & \\
\hline $19.30-2$ & Tranaporte rodoviario de carga & $50.27-5$ & & $\begin{array}{l}\text { Transporte rosoviario de produlos } \\
\text { Eeripovos }\end{array}$ & \\
\hline $49.30-2$ & Tranaporte rodowitrio de carpa & $50.28-3$ & $\cdot$ & Transporte rodoviario de mudanças & Transporte rodovistilo de mudanças \\
\hline $19.40-0$ & Tranaporte dutovistio & $30.30-5$ & & Transporte dutovisisio & \\
\hline $49.50-7$ & Trena turisticos, teleftericos e simliares & $50.29-1$ & - & 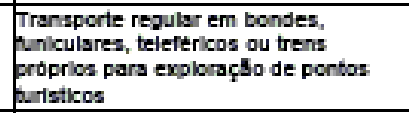 & Exceto bondes regulares \\
\hline $50.11-4$ & Tranaporte maritimo de cabotagem & $51.11-5$ & - & Transporte maritimo de cabotagem & $\begin{array}{l}\text { Excebo fransporite para passelo turistico } \\
\text { Eostero em embarcaçbes de menor } \\
\text { porte }\end{array}$ \\
\hline $0.12-2$ & Tranaporte maritimo de lonjo curso & $51.12-3$ & & Transporte maritinso de longo curso & \\
\hline $50.21-1$ & $\begin{array}{l}\text { Tranaporte por navejaç̧o interior de } \\
\text { cargs }\end{array}$ & $51.22-0$ & & $\begin{array}{l}\text { Transporte por navegaçso interior de } \\
\text { earga }\end{array}$ & \\
\hline$=0.22-0$ & $\begin{array}{l}\text { Tranaporte por navejaçso intertor de } \\
\text { passapeiros em linhas regulares }\end{array}$ & $\$ 1.21-2$ & - & $\begin{array}{l}\text { Transporte por navegaçso interior de } \\
\text { passageiros }\end{array}$ & 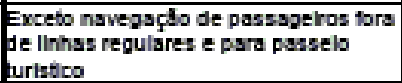 \\
\hline $0.30-1$ & Navegsç̧o de apolo & $3.22-3$ & $\cdot$ & $\begin{array}{l}\text { Movididsdes survillares sos transportes } \\
\text { squsviarion }\end{array}$ & Athidades de navegaçấo de apolo \\
\hline $0.91-2$ & Tramaporte por navegsç̧o de travessis & $51.23-9$ & & Transporte aquavistio urbano & \\
\hline \$0.99-8 & $\begin{array}{l}\text { Tranaportes squavisrios ndo } \\
\text { eapecifleados anteriormente }\end{array}$ & $\$ 1.11-5$ & - & Transporte martimo de cabotagem & $\begin{array}{l}\text { Transporte para passelo turistico } \\
\text { Eostero em embarcaçbes de menor } \\
\text { porte }\end{array}$ \\
\hline $50.99-8$ & $\begin{array}{l}\text { Tranaportes squavilsrios ndo } \\
\text { eapecifleados anterlormente }\end{array}$ & $51.21-2$ & $\cdot$ & $\begin{array}{l}\text { Transporte por navegaçso interior de } \\
\text { passageiros }\end{array}$ & $\begin{array}{l}\text { Transporte para passelo turistico e fora } \\
\text { ge linhas regulares }\end{array}$ \\
\hline $1.11-1$ & $\begin{array}{l}\text { Tranaporte aetreo de passajeliros } \\
\text { Teqular }\end{array}$ & $\$ 2.10-3$ & - & Transporte aereo, regular & $\begin{array}{l}\text { Transporte sereo de passageliros } \\
\text { Teqular }\end{array}$ \\
\hline 51.12-9 & $\begin{array}{l}\text { Tranaporte aereo de passapelios nbo- } \\
\text { reqular }\end{array}$ & $52.20-0$ & $\cdot$ & Transporte aereo, ndo regular & $\begin{array}{l}\text { Transporte sereo de passogeliros nSo- } \\
\text { fepular }\end{array}$ \\
\hline $51.20-0$ & Tranaporte aereo de carga & $52.10-3$ & $\cdot$ & Transporte atereo, regular & Fransporte streo de carpa \\
\hline $1.20-0$ & Tranaporte aereo de carga & $32.20-0$ & 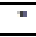 & Transperte aetreo, ndo regular & Fransporte streo de carpa \\
\hline $51.30-7$ & Franaporte espacial & $52.30-8$ & & Transporte espacial & \\
\hline
\end{tabular}

